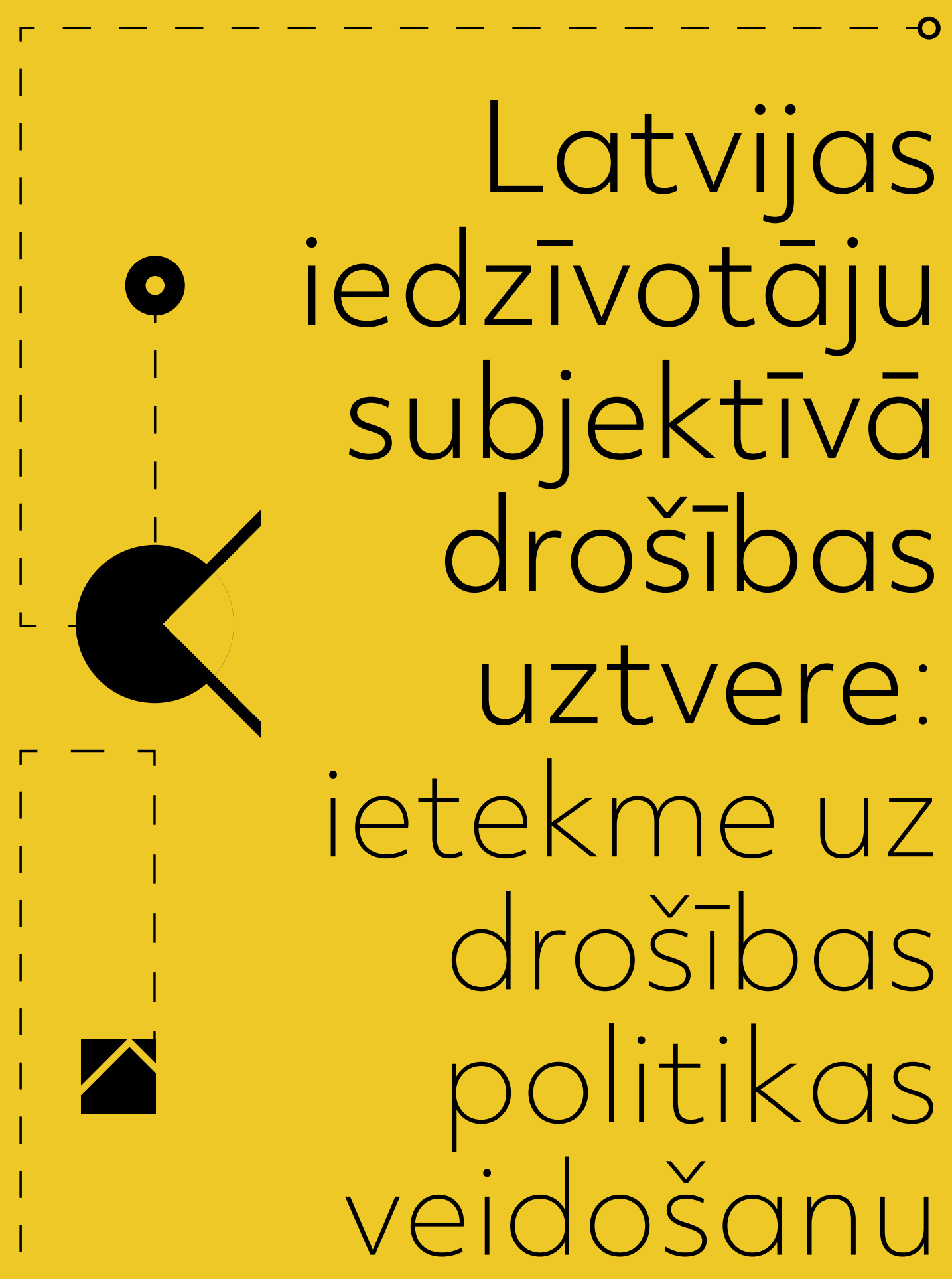




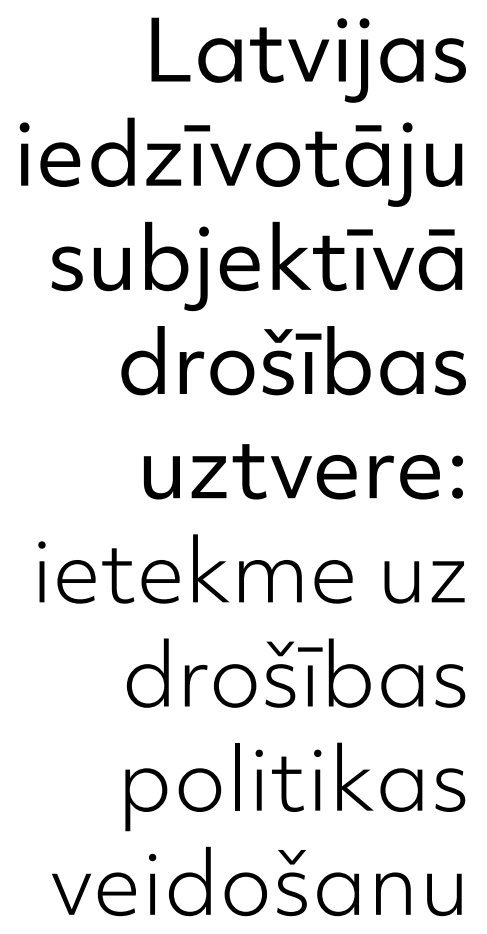

LU Akadēmiskais apgāds 
Latvijas iedzīvotāju subjektīvā drošības uztvere: ietekme uz drošības politikas veidošanu. Rìga: LU Akadēmiskais apgāds, 2021. 272 lpp.
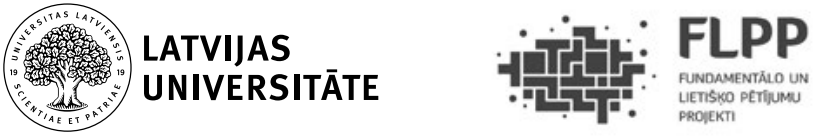

Zinātniskās redaktores:

Dr. paed. prof. Žaneta Ozoliņa

Dr. sc. pol. prof. Iveta Reinholde

Mg. sc. pol. Sigita Struberga

\section{Recenzenti:}

Ph.D. asoc. prof. Juris Pupčenoks, Marist College, ASV

Dr. sc. pol. asoc. prof. Ieva Bērziṇa, Latvijas Nacionālās aizsardzības akadēmijas

Drošibas un stratēgiskās pētniecības centra vadošā pētniece, Vidzemes Augstskolas asociētā profesore

Kolektīvā monogrāfija apstiprināta publicēšanai ar LU Humanitāro un sociālo zinātṇu padomes 08.09.2021. lēmumu (protokola Nr. 10).

Projektu "Latvijas iedzīvotāju subjektīvā drošības uztvere: ietekme uz drošības politikas veidošanu” (lzp-2018/1-0480) finansējusi Latvijas Zinātnes padome.

Literārā redaktore Ruta Puriņa

Angḷu tekstu literārā redaktore Katrīna Baltmane

Maketu un vāka dizainu veidojusi Baiba Lazdina

(C) Rovena Berga, Kristaps Celmiņš, Ruta Ceple, Harijs Kārkliņš, Aleksandra Kjakste, Valdis Otzulis, Žaneta Ozoliņa, Iveta Reinholde, Sigita Struberga, Malvīne Stučka, Gunārs Valdmanis, 2021

(C) Latvijas Universitāte, 2021 


\section{Saturs}

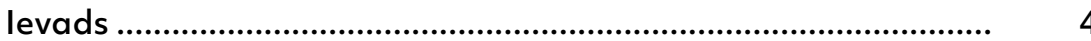

Žaneta Ozoliņa, Iveta Reinholde, Sigita Struberga

Subjektīvā drošības uztvere - izpētes ietvara konstruēšana

8

Žaneta Ozoliņa, Iveta Reinholde, Sigita Struberga

Ekonomiskā drošība

Harijs Kārkliņ̌̌, Gunārs Valdmanis

Politiskā drošība

Malvīne Stučka, Valdis Otzulis

Vides drošỉba

Malvīne Stučka, Harijs Kārkliṇš

Sabiedrības drošǐba

Aleksandra Kjakste, Sigita Struberga

Personiskā drošība

Aleksandra Kjakste, Ruta Ceple

Hibrīddraudi

Sigita Struberga, Ruta Ceple

Militārā drošība

Ruta Ceple, Valdis Otzulis

Krīzes komunikācija: sabiedrības iespējošana vai drauds subjektīvai drošības uztverei

Kristaps Celmiņš, Rovena Berga

Secinājumi

Rekomendācijas

Bibliogrāfija

Par autoriem 


\section{levads}

Latvijas politikas zinātnē drošỉbas pētniecībai ir bijusi ierādīta nozīmīga vieta. Kopš pagājušā gadsimta 90. gadu sākuma lielāka interese ir pievērsta starptautiskajam kontekstam un Latvijas iekḷūšanai pasaules politikas augstākajā līgā - Eiropas Savienībā un Ziemel̦atlantijas līguma organizācijā. Savukārt iekšējās drošības jautājumi aktualizējušies pēc iestāšanās abās organizācijās un jo īpaši pēc 2014. gada notikumiem Ukrainā. Apgalvojums, ka iekšèjā un ārējā drošība ir savstarpēji saistītas, pēdējos 10 gados ir kḷuvis jau par aksiomu, kuras ignorēšana var dārgi maksāt valstu neatkarībai un sabiedrību pastāvēšanai.

Pētỉjums "Latvijas iedzīvotāju subjektīvā drošîbas uztvere: ietekme uz drošîbas politikas veidošanu" ir viens no mēginājumiem aplūkot drošỉbu tās daudzveidībā, galveno uzmanību pievēršot tam, vai tās bažas un apdraudējumi, kurus izjūt cilvēki, atspoguḷjojas politiskajos lēmumos un vai nepastāv atšķirīibas drošîbas uztverē individuālā un nacionālā līmenī. Respektīvi, vai tie draudi, kuri ir nozīmīgi iedzīvotājiem, tiek apzināti un identificēti kā draudi arī rīcíbpolitikas veidošanas līmenī - ministrijās un iestādēs. Šādas pieejas izvēle balstījās uz iepriekš veikto pētijumu par cilvēkdrošîbu un sabiedrības drošību kopš 2002. gada, kad pētnieki vairākkārtīgi aicināja pievērst uzmanību indivīdu un valsts (nacionāla līmeņa drošỉba) ciešas sasaistes nepieciešamïbai, jo krīzes vai pat vardarbīga konflikta gadījumā bez sabiedrības atbalsta un iesaistes, kas balstīti drošỉbas politikas izpratnē un tās legitimizācijā, nav iespējama operatīva un sekmīga rīcỉba apdraudējuma novēršanā. Ja nacionālā drošîba tiek îstenota atrauti no sabiedrības bažām, tad var izrādīties, ka krīzes situācijā valstij pietrūkst nepieciešamo cilvēkresursu neatkarības saglabāšanai. Pētỉjuma pieteikuma sagatavošana notika vēl pirms Latvijas Aizsardzības ministrijas ierosinātās 
visaptverošās valsts aizsardzības sistēmas izveides. Taču tā pētījuma dažādos posmos nācās secināt, ka gan metodologiija, gan iegūtie rezultāti vistiešāk palīdz identificēt tās iespējas un problēmas, kas rodas indivīda-pašvaldībasvalsts daudzveidīgajā attiecību spektrā. Tādējādi paveiktais var lieti noderēt ikvienai struktūrai - valsts vai nevalstiskajai, kura iesaistīta visaptverošās valsts aizsardzības koncepcijas ieviešanā un Latvijas drošības politikas īstenošanā.

Projekta īstenošana norisinājās vairākos posmos. Sākotnēji uzmanība bija pievērsta Latvijā iepriekš veikto pētijumu par drošību izzināšanai, piegriežot pastiprinātu vērību indivīdu un sabiedrības drošǐbas dažādiem aspektiem, tai skaitā sabiedriskās domas aptauju rezultātiem. Balstoties uz teorētiskām atziņām un iegūtiem empīriskiem rezultātiem, tika izveidots analītiskais ietvars tieši drošības subjektīvās uztveres izpētei. Šì pētījuma posma izstrādē, kas atspoguḷota grāmatas pirmajā rakstā, piedalījās Latvijas Universitātes Politikas zinātnes nodaļas docētājas un Sociālo un politisko pētỉjumu institūta pētnieces Iveta Reinholde, Sigita Struberga un Žaneta Ozoliņa. Galvenie drošības sektori, kuriem pētnieki pievērsa uzmanību empīriskā pētījuma gaitā, bija ekonomiskā, politiskā, sabiedrības, vides, personiskā, hibrīdā un militārā drošỉba.

Tālākajā gaitā, kombinējot pilotprojektā un iepriekšèjās sabiedriskās domas aptaujās identificētos svarīgākos apdraudējumus, autori sagatavoja jautājumus fokusa grupu intervijām, kuras veiktas Aizkrauklē, Ādažos, Daugavpilī, Gulbenē, Jaunjelgavā, Liepājā, L̦audonā, Madonā, Rīgā, Talsos, Valmierā. Fokusa grupu veidošanā ievērotas fokusa grupu interviju organizēšanas labas prakses principi, nodrošinot dzimumu pārstāvniecības līdzsvaru, iekḷaujot dažādu sociālo grupu un vecumgrupu pārstāvjus - gan studējošos, gan seniorus. Rezultātā fokusa grupu intervijas l̦āva apzināt iedzīvotāju skatījumu uz drošību, tai skaitā bailes, raizes, noskaņojumus un pat stereotipus. Emociju izklāsta un daudzveidīgo viedokḷu interpretācija nav pamats, lai veidotu vispārinātus secinājumus vai precīzi noteiktu baiḷu cēloṇus, tomēr tas ḷauj gūt priekšstatu par subjektīvās drošības uztveres dažādiem aspektiem sabiedrības griezumā. Savukārt, lai noskaidrotu sabiedrības drošỉbas uztveres pārnesi politikas veidošanas līmenī un identificētu, vai drošības uztveres ir līdzīgas vai atškịīgas, par intervējamiem kḷuva attiecīgo (t. i., pašvaldību, kur notika fokusa grupu intervijas) pašvaldību darbinieki. Empīrisko pētijumu veica Latvijas Universitātes Politikas zinātnes nodaḷas doktoranti Aleksandra Kjakste, Harijs Kārkliņš, Malvīne Stučka, Ruta Ceple, Sigita Struberga, Valdis Otzulis un eksperts Gunārs Valdmanis. Kad projekta empīisko datu ieguve un apstrāde bija noslēgušās, valsti pāršalca Covid-19 pandēmija un tās radītās sekas. Pētijumu nevarētu uzskatīt par pilnvērtīgu, ja neatspogulotu šì ievērojamā apdraudējuma ietekmi uz sabiedrību. Tādēḷ projekta komandai pievienojās Politikas zinātnes 
nodaļas studenti Rovena Berga un Kristaps Celmiņš, kuri apskatīja valdības krīzes komunikāciju, kas tika realizēta pandēmijas izplatības sākuma posmā 2020. gada pavasarī. N̦emot vērā vienu no projekta uzdevumiem, - izpētīt ietekmi uz politikas veidošanu, svarīgi bija noskaidrot, vai pašvaldību reakcija uz iedzìvotāju paustajām bažām atbilst labas pārvaldības principiem. Apzinoties, ka labas pārvaldības indikatori attīstās līdzi laikam, Iveta Reinholde izstrādāja indikatorus katram pētāmajam drošîbas sektoram un novērtēja empīrisko datu atbilstību labai pārvaldībai. Pārvaldības sistēmas stabilitāte, reformu pamatojums, caurskatāmība, attīstības scenāriju redzējums ir tikai daži no pārvaldības indikatoriem, kas atspoguḷojas gan iedzīvotāju viedokḷıs, gan arī pašvaldību rīcībā. Salīdzinot šos indikatorus, iedzīvotāju un pašvaldỉbas darbinieku uztverē varēja apjaust saiknes starp individuālo un nacionālo drošības lìmeni.

Pētījumu noslēdz secinājumu un rekomendāciju nodal̦a, kas izstrādāta, apvienojot pètījuma rezultātus ar diskusiju rezultātiem, kuri savukārt iegūti sadarbībā ar projekta partneriem. Lai arī rekomendāciju ieviešana ir katras institūcijas labās gribas izpausme, tomēr pēc pašvaldību reformas Latvijas pašvaldības uzsāks darbu pie jaunizveidoto pašvaldību attīstības plānošanas dokumentu izstrādes, kur līdzās mobilitātes un jaunatnes politikas un mājokḷu jautājumiem, cerams, būs arī vietējās politikas sabiedrības drošìbas palielināšanai.

Projekta īstenošana būtu ievērojami sarežğìtāka un tvēruma ziņā ierobežotāka, ja tā īstenošanā nepiedalītos plašs sadarbības partneru tīkls. Starp nozīmīgākajiem partneriem minama Latvijas Aizsardzības ministrija, Latvijas Iekšlietu ministrija, Latvijas Pašvaldību savienība, Latvijas Politologu biedrība, Latvijas Transatlantiskā organizācija.

Dažādos projekta posmos pētnieki iepazīstināja ar iegūtajiem rezultātiem lekcijās, prezentācijās konferencēs un zinātniskām un populārām publikācijām. No šādām aktivitātēm minamas, piemēram, projekta dalībnieku piedalīšanās ikgadējās Latvijas Universitātes starptautiskajās zinātniskajās konferencēs 2019.-2021. gadā, projekta vadītājas prof. Žanetas Ozoliṇas uzstāšanās un valsts pārvaldes augstāko amatpersonu iepazisstināšana ar pētījuma rezultātiem valsts aizsardzības seminārā 2020. gada janvārī, projekta dalībnieku uzstāšanās starptautiskās zinātniskās un praktiskās konferencēs Apvienotajā Karalistē, Dānijā, Igaunijā, Lietuvā, Ķīnā, Spānijā, Ukrainā.

Subjektīvās drošîbas izpētes teorētiskā analīzes ietvara inovatīvais raksturs un iegūtie empīriskie dati ir ieinteresējuši citus sadarbïbas partnerus, un rezultātā sagatavoti divi starptautiski projekti: "Vienotu studiju kursu izveide sabiedrības drošỉbas jomā" (Needs-based education and studies in societal 
security - 2020-1-SE01-KA203-078013), kuru apstiprinājusi Zviedrijas Augstākās izglītības padome un kur koordinējošā institūcija ir Baltijas jūras valstu padome, un Latvijas Zinātnes padomes apstiprinātais projekts "Perspektīvās tehnoloǵijas noturīgiem un drošiem servisiem" (VPP-COVID-2020/1-0009), kur koordinējošā institūcija ir Rīgas Tehniskā universitāte.

Pētījums "Latvijas iedzīvotāju subjektīvā drošības uztvere: ietekme uz drošỉbas politikas veidošanu” veikts Latvijas Zinātnes padomes atbalstītā projekta LZP-2018/1-0480 ietvaros.

Žaneta Ozolinga Iveta Reinholde Sigita Struberga 


\section{Subjektīvā drošības uztvere - izpētes ietvara konstruēšana}

ŽANETA OZOLIN,A, IVETA REINHOLDE, SIGITA STRUBERGA

Nodaḷā atspoguḷoti drošības subjektīvās uztveres izpētes svarīgākie metodolog̣iskie aspekti, kuri izmantoti Latvijas iedzīvotāju viedokḷu noskaidrošanai empīrisko datu ieguvē. Drošības izzināšanai Latvijā ir senas tradīcijas, tomēr tās subjektīvie aspekti nav pietiekami apzināti. Tiem ir īpaša loma laikā, kad valstī tiek ieviesta visaptverošā valsts aizsardzība, kurā iedzīvotāji ir ne tikai drošîbas patērētāji, bet arī radītāji. Izpētes metodologisko rāmējumu veido šādi secīgi soḷi: sabiedriskās domas apaujas rezultātu analīze, kas liecina par iedzīvotāju dominējošām attieksmēm pret drošību valstī, pētāmo drošības sektoru identificēšana, attiecīgu indikatoru izvēle katram no tiem, pārvaldības indikatoru noteikšana kopumā un atbilstoši katram sektoram, fokusa grupu interviju veikšanas ietvars, pašvaldības darbinieku intervēšana atbilstoši iegūtajiem datiem par subjektīvo uztveri attiecīgajā kopienā un rekomendāciju izstrāde, kas balstīta pētījumu rezultātos. Izstrādātais un lietotais Latvijas iedzīvotāju drošîbas subjektīvās uztveres metodologiskais rāmējums l̦auj iegūt dažādus datus indivīda, grupas, kopienas un valsts līmenī, tādējādi veidojot politiku, kura atbilst iedzīvotāju vajadzībām un rada nosacījumus iesaistei visaptverošā valsts aizsardzībā.

Atslēgvārdi: drošỉbas indikatori, metodologiija, pārvaldības indikatori, subjektīvā drošība, subjektīvā drošības uztvere.

The article focuses on the main elements of methodology applied in analysis of the subjective perception of security that is prevailing among the inhabitants of Latvia and discusses the subsequent collection of empirical data. The concept of security has been widely studied in Latvia and has longstanding traditions, while the subjective perspective of security has not been investigated and analysed. The subjective aspects of security are of particular importance at the present time when the government is introducing a comprehensive defence concept. This comprehensive defence concept presupposes that society acts not only as a consumer but also as a provider of security. 
The methodological framework consists of the following components: 1) analysis of existing public opinion polls that serve as a source of information on the dominant attitudes towards security in the country, 2) identification of the most relevant security sectors, 3) elaboration of indicators relevant in each of the sectors, 4) focus group interviews based on the set of indicators in selected municipalities, 5) further interviews with municipal employees based on the results of the focus group interviews, thus comparing whether local governments are aware of the subjective perceptions of security and whether adequate policy measures are being employed, and 6) recommendations based on the results of the study. The proposed methodological framework allows to collect rich data on the subjective perception of security at the individual, group, community, and national levels; this data can then be used for policy making that responds to the needs of inhabitants and engages them in the comprehensive defence of the country.

Keywords: governance indicators, methodology, security indicators, subjective security, subjective security perception.

\section{levads}

Latvijas iedzīvotāju drošības subjektīvās uztveres izpēte nav iespējama bez teorētiskā analīzes ietvara izstrādes, jo tas rada nosacījumus autoru pašu individuālo priekšstatu un zināšanu norobežošanai no iegūtajiem datiem un patvaḷịgas interpretācijas. Tādēḷ šìs nodaḷas mērķis ir secīgi konstruēt tādu metodolog̣isko rāmējumu, kas kalpotu visa projekta vajadzībām un būtu izmantojams empīrisko datu ieguvei un atlasei, uz kura pamata izstrādātu secinājumus un rekomendācijas. Pētījuma centrālais koncepts ir drošiba. Tādēl raksta pirmā daḷa ir veltīta šì jēdziena izpētes īpatnībām Latvijā un tā definējuma pamatojumam, kas izmantots visa pētījuma gaitā. Otrajā daḷā uzmanība pievērsta drošỉbas subjektīvās uztveres dažādiem aspektiem, kuri ir pētīti starptautiskās politikas jomā, un noteikti tie elementi, kuri nozīmīgi Latvijas gadījuma izpētē. Savukārt trešā raksta daḷa izskaidro galvenos izpētes soḷus, kas l̦auj nonākt līdz Latvijas iedzīvotāju drošības subjektīvās uztveres analīzes galvenajiem elementiem un to sasaistei ar drošības politikas veidošanu, ìpašu uzmanību pievēršot pašvaldību attiecībām ar kopienām. 


\section{Drošības jēdziena izpēte Latvijā starptautisko diskusiju kontekstā}

Drošības jēdziena izpēte Latvijā ir ar salīdzinoši senām tradīcijām. Tā ir viena no visvairāk pētītajām jomām starptautiskās politikas disciplīnā. Drošîbas dažādo sektoru izzināšanai uzmanību ir veltijuši, piemēram, vēstures, ${ }^{1}$ ekonomikas, ${ }^{2}$ starptautisko tiesību ${ }^{3}$ nozares pārstāvji. Taču tieši starptautiskās politikas disciplīnā ir vērojams visbagātākais pētijumu klāsts, un tam ir savi skaidri redzami objektīvi nosacijumi. Latvijas neatkarības atgūšana 1990.-1991. gadā bija primāri saistīta ar Krievijas karaspēka izvešanu, trauslā miera nodrošināšanu, pārejot uz demokrātisku politisko režīmu un Latvijas drošības un aizsardzības sistēmas veidošanu, tai skaitā dibinot Latvijas bruņotos spēkus no nulles punkta. Praktiski risināmie jautājumi, kuros nebija uzkrāts bagāts zināšanu kopums, veicināja pētījumu par drošîbu un drošības politiku nacionālā, regionālā un starptautiskā līmenī.

Salīdzinājumā ar drošỉbas pētījumiem pasaulē Latvijas pieredze un attīstības posmi neatbilst tai dinamikai, kas bija vērojama šajā nozarē pasaulē, kurā 1990. gada sākumā jau valdīja visdažādāko skolu konkurence par "vislabāko piedāvājumu" drošības skaidrojumu tirgū, sākot ar reālistu cinnu par intelektuālu izdzīvošanu pēc aukstā kara līdz konstruktīvistu piedāvājumam radīt jaunas drošības identitātes un skaidrot "runas aktus"'. Latvijas gadījumā

1 Skatīt, piemēram, Feldmanis, I., Stranga, A., Virsis., M. (1993). Latvijas ārpolitika un starptautiskais stāvoklis: 30. gadu otrā puse. Rīga: Latvijas Ārpolitikas institūts; Stranga, A. (2010). Vēsturnieki par Latvijas drošības problēmas risinājumiem starpkaru periodā. Latvijas Vēsture: jaunie un jaunākie laiki, Nr. 2, 22.-36. lpp.

2 Skatīt, piemēram, Šumilo, E., Baumane, I. (2007). Some Negative Aspects of Social Capital: The Case of Undeclared Work in Latvia. Humanities and Social Science in Latvia, No. 2(51). Riga: Institute of Economics; Sauka, A., Rivža, B. (red.) (2014). Latvijas ekonomikas un uzñēmējdarbības izaicinājumi. Ventspils: Ventspils Augstskolas Uzṇēmējdarbības, inovāciju un reǵionālās attīstības centrs.

3 Ziemele, I. (2004). Latvijas loma drošības un miera tiesiskā nostiprināšanā. Vai starptautiskām tiesībām un organizācijām ir nozīme? No: Latvija Eiropā: nākotnes vīzijas. Jundzis, T. (red.) Rīga: Latvijas Zinātṇu akadēmijas Baltijas stratēgisko pētījumu centrs, 31.-55. lpp.

4 Skatit: Wolfer, A. (1962). Discord and Collaboration: Esseys on International Politics. Baltimore: John Hopkins University; Morgenthau, H. J. (1967). Politics Among Nations. New York: Knopf; Bull, H. (1977). The Anarchical Society: A Study of Orderi $n$ World Politics. New York: Columbia University Press; Waltz, K. N. (1979). Theory of International Politics. New York: Random House; Ullman, R. H. (1983). Redifining Security. International Security, Vol. 8(1); Mearsheimer, J. (2001). The Tragedy of Great Power Politics. New York: Norton.

5 Buzan, B., Waever, O., de Wilde, J. (1998). Security: A New Framework for Analysis. Boulder Co: Lynne Rienner; Weldes, J. et al. (1999). Cultures of Insecurity: States, Communities, and the Production of Danger. Minneapolis: University of Minnesota Press; Jone, R. W. (1999). Security, Strategy and Critical Theory. Boulder Co: Lynne Rienner; McSweeney, B. (1999). Security, Identity and Interests. Sociology of International Relations. Cambridge: Cambridge University Press; Booth, K. (2005). Critical Security Studies and World Politics. Boulder Co: Lynne Rienner. 
pētniecību drošības jomā virzīja nevis globālās pārmaiṇas pasaules politikā un starptautiskajā spēku līdzsvarā, bet ikdienas praktiskie jautājumi, kas bija nozīmīgi Latvijas atgūtās neatkarības nostiprināšanai un tās neatgriezeniskuma nodrošināšanai, - drošības jēdziena skaidrojumi un nacionālās drošības politikas izveides aspekti, ${ }^{6}$ alianšu teorija, NATO būtỉba un paplašināšanos kavējošie un veicinošie nosacījumi, ${ }^{7}$ reǵionālā drošỉba kā Baltijas valstu un Baltijas jūras reg̣iona rīcība, ${ }^{8}$ un pāri šīm tēmām kā vienojošais izpētes objekts bija Krievijas rīcỉba pasaulē un reǵionālajā telpā. ${ }^{9}$

Latvijas drošības un aizsardzības politikas veidošana atstāja iespaidu uz pieaugošām atšķirībām drošības jēdziena teorētiskajos un empīiskajos pētỉjumos. Pēc aukstā kara beigām starptautiskās drošības pētijumos dominēja tā saucamie "visaptverošie drošības" aspekti - migrācija, atbruṇošanās, nevienlīdzības un nabadzības pieaugums, drošîba kā emancipācija un citi (atsauce uz 90. gadu sākuma pētijumiem), bet Latvijā šo tematu izpēte nesniegtu atbildes uz tūlītējiem jautājumiem par tradicionāliem drošỉbas sektoriem: nacionālo un militāro drošību, drošības politikas stratēǵiju - no neitralitātes līdz līdzsvarošanas politikai. Pētniecībā skatījums uz drošības politiku izlīdzinājās ap gadsimtu miju, kad no ES un NATO tika saṇemta skaidra atbilde par abu organizāciju paplašināšanās procesa uzsākšanu Baltijas valstīs. Līdz ar to Latvijas iekḷaušanai organizācijās, kuras bija valsts ārējās un drošības politikas mērḳis, bija nepieciešams pastiprināti pētìt drošību tās daudzveidībā, jo sarunu

6 Jundzis, T. (1995). Latvijas drošība un aizsardzība. Rīga: Junda; Lejiņš, A. (1995). The Baltic Security Dilemma: How to Secure Independence. In: Berry, Ch. (Ed.) The Search for Peace in Europe. Institute for National Strategic Studies and the George C. Marshall European Center for Strategic Studies, Garmisch-Partenkirchen; Lejinšs, A., Apinis, P. (Ed.) (1995). The Baltic States on Their Way to the European Union/Security Aspects. Riga: Latvian Institute of Foreign Affairs; Jundzis, T. (1996). Defence Models and Strategies in the Baltic States. The International Spectator, 31(1), pp. 25-37, DOI: 10.1080/03932729608456728

7 Ozoliņš, A. (1996). Estonia, Latvia and Lithuania in the European Security Architecture: Limits and Opportunities. Lejiņš, A., Bleiere, D. (1996). The Baltic States: Search for Security. Riga: LIA, pp. 76-93; Lejinš, A. (1999). Baltic Security Prospects at the Turns of the 21st Century. Helsinki: Kikimora Publications; Bleijere, D. et al. (1999). The Impact of European Integration Processes on Baltic Security. NATO Fellowship Programme; Lejiņš, A. (red.) (2003). NATO un Eiropas Savienības sadarbība drošîbas jomā: atšķirīgi viedokḷi un kopēji risinājumi. Rīga: Latvijas Ārpolitikas institūts.

8 Lejin̄š, A., Bleiere, D. (1996). The Baltic States: Search for Security. Rīga: LIA; Ozoliṇa, Ž. (2000). Latvijas drošîbas politikas reǵionālie aspekti. Rịga: Izglìtiba; Arteus, G., Lejiņš, A. (1997). The Baltic Security. Looking towards the 21st Century. Stockholm: Forsvarhogskolan / Riga: Latvian Institute of International Affairs.

9 Stranga, A. (1996). Russia and security of the Baltic States 1991-1996. In: Lejiņš, A., Bleiere, D. (eds.) The Baltic States: Search for Security. Riga: LIA, pp. 141-185; Stranga, A. (1997). Baltic Russian relations: 1995 - beginning of 1997. In: Lejin̦š, A., Ozolin̦a, Ž. (eds.) Small States in Turbulent Environement: The Baltic Perspective. Rīga: LIA, pp. 184-238; Ozoliṇa, Ž. (1998). Latvia. In: Mouritzen, H. (ed.) Bordering Russia. Theory and Prospects for Europe's Baltic Rim. London: Ashgate, pp. 131-164; Bleiere, D., Stranga, A. (2000). The Latvian Russian Crisis of 1998. In: Stern, K. E., Hansen, D. (eds.) Crisis Management in a Transitional Society: The Latvian Experience. Stockholm: Försvagshögskolan, pp. 216-259. 
vešana ar ES un NATO notika ne tikai par militārām vai iekšlietu sistēmas spējām, bet par visu drošǐbas politikas spektru.

Sākot ar 2000.-2002. gadu, pieaug pētijumu skaits "visaptverošās drošības" laukā, pievēršoties cilvēkdrošības, ${ }^{10}$ sabiedrības drošības, ${ }^{11}$ ekonomikas drošības un citiem drošības sektoriem. Vēl jo vairāk šo pētijumu paplašināšanas tendenci ietekmēja globālās finanšu un tai sekojošā ekonomikas krīze pasaulē un Latvijā, kas skāra gandrīz ikvienu mājsaimniecību valstī, mazinot tās drošumspēju. Taču nebūtu korekti apgalvot, ka drošības pētījumi koncentrējās tikai uz iekšpolitiskās situācijas apzināšanu. Šajā pašā laikā sākās diskusijas Eiropas Savienībā par tās lielāku lomu pasaules politikā un Kopējās ārējās un drošības politikas (KĀDP) aktīvāku lietošanu. Rezultātā ES, gatavojot jauno Lisabonas līgumu, ${ }^{12}$ kuru pieṇēma 2009. gadā, liela dalïbvalstu uzmanība tika vērsta šis politikas virzienā, kas vienlaicīgi veicināja pētnieku kopienas darbību, apzinot ES potenciālu un vājos posmus. Tādējādi arī Latvijā drošîbas pētỉjumos uzmanība pievērsta ES starptautiskās darbības izvērtējumam. ${ }^{13}$ Īpašu vietu ieṇem analīze par Krieviju kā ES kaimiņvalsti.

Būtisks pavērsiens drošības pētniecībā Latvijā sākas pēc 2014. gada notikumiem Ukrainā, kuri liecina par to valstu pārākumu konfliktu situācijās, kuras spēj savienot militāros ar nemilitāriem līdzekḷiem un kuras mērḳtiecīgi lieto hibrīddraudus savu ieceru sasniegšanai. Militārais konflikts Ukrainā un Krimas teritorijas aneksija būtiski ietekmēja drošības jēdziena izpētes virzienu, kurā vienlīdz svarīgas ir "cietās" un "maigās" drošỉbas komponentes un kurā vienlīdz nozīmīgi ir pētỉjumi par valstu aizsardzības doktrīnām un militārajām spējām, kā arī par sabiedrības, kopienu un indivīdu spēju piemēroties jauniem apstākḷiem, būt noturīgiem pret hibrīddraudu radītajiem izaicinājumiem

10 Skatīt, piemēram, Tautas attīstības pārskats. Cilvēkdrošība. Latvija. (2003). Rīga: UNDP; Ozoliṇa, Ž. (Ed.) (2010). Rethinking Security. Rīga: Zinātne; Ozoliṇa, Ž. (red.) (2012). Cilvēkdrošǐba Latvijā un pasaulē: no idejas lìdz praksei. Rīga: Zinātne; Ozolina, Ž. (Ed.) (2015). Gender and Human Security. A view from the Baltic Sea Region. Rīga: Zinātne.

11 Ozolin̦a, Ž. (Ed.) (2016). Societal Security. Inclusion-Exclusion Dilemma. A Portrait of the Russian Speaking Community in Latvia. Rīga: Zinātne; Aatola, M. et al. (2018). Societal Security in the Baltic Sea Region. Riga: Latvian Institute of Foreign Affairs.

12 Lisabonas līgums. Pieejams: mfa.gov.lv

13 Auers, D., Bukovskis, K. (2006). Eiropas Parlaments un Eiropas kopējā ārējā un drošības politika. No: Ozoliṇa, Ž. (red.) Eiropas Parlaments: ārējās un drošîbas politikas ìstenotājs. Rīga: Zinātne, 15.-40. lpp.; Ozoliņa, Ž., Rostoks, T. (2006). Latvian Outlook on the European Union Common Foreign and Security Policy. In: Tiirma-Klaar, H., Marques, T. (eds.) Global and Regional Security Challenges: A Baltic Outlook. Tallinn: Tallinn University Press; Lejin̦š, A. (red.) (2007). Pastiprināta Eiropas Savienības austrumu kaimiņu politika: jautājumi un izaicinājumi. Rīga: Latvijas Ārpolitikas institūts; Bungs, Dz. et al. (2007). Eiropas Savienības Kopējā ārējā un drošîbas politika vērtību un interešu krustugunīs (bet ne krustcelēs). No: Ozoliṇa, Ž. (red.) Latvijas skatījums uz Eiropas Savienības nākotni. Rīga: Zinātne, 214.-262. lpp.; Ozoliṇa, Ž. (2007). European Security and Defence Policy: the Latvian perspective. In: Archer, Cl. (ed.) New Security Issues in Northern Europe. The Nordic and Baltic states and the ESDP. London: Routledge, pp. 115-138. 
un par līdzatbildību valsts drošỉbas uzturēšanā. ${ }^{14}$ Jēdzieni, kuri šobrīd tiek izmantoti drošības politikā, kā, piemēram, izturētspēja/noturīgums (resilience), ir sinonīmi jau 2003. gadā publicētajam tautas attīstības pārskatā par cilvēkdrošību lietotajam drošumspējas jēdzienam. ${ }^{15}$ Savukārt vairākos pētījumos liktais uzsvars uz nepieciešamību iesaistìt sabiedrību drošības un aizsardzības politikas veidošanā ir vainagojies ar Latvijas valdības akceptēto informatīvo ziņojumu "Par visaptverošas valsts aizsardzības sistēmas ieviešanu Latvijā"16.

90. gadu sākumā bija vērojama atšķirība drošības definējumā, kuru izmantoja Rietumu tradīcijā sakņoti starptautiskās politikas eksperti un Latvijas pētnieki, bet ap 2000. gadu šìs atšķirības samazinājās, lielāku uzmanību pievēršot daudzpusējam šì fenomena skatījumam. Savukārt pēc 2014. gada vienprātība par konvencionālo un hibrīdo apdraudējumu drošības interpretējumā ir tikai pieaugusi.

Diez vai šobrīd atgriešanās pie aukstā kara mēginājumiem paplašināt drošìbas jēdziena interpretāciju vairs ir nepieciešama, jo situācija pēc aukstā kara ir pierādījusi, ka domāšana "vai - vai" kategorijās ir vairāk izdevīga un piemērota akadēmiskām diskusijām, kamēr drošỉbas politika ir spiesta vienlaicīgi risināt šaurās (politiskās un militārās) un paplašinātās (sabiedrības, vides, energêetikas, ekonomikas) drošības jautājumus, ko nosaka pieaugošais apdraudējuma daudzveidīgums un cilvēku pieprasijums pēc atbilstošām politikām. Diskusija par šauro un plašo drošǐbas interpretējumu ir savā ziṇā kḷuvusi bezjēdzīga. Minēto draudu daudzveidības pieauguma dẹl aktuālāks ir jautājums par drošîbas politikas veidotāju un drošības patērētāju spēju - abām pusēm saskatīt draudus, abām pusēm sadarboties to novēršanā, abām pusēm būt spējīgām lietot atbilstošākos līdzekḷus draudu izcelšanās novēršanai un pieaugošas intensitātes apstākḷ̆os to mazināšanai. Šāda mijiedarbỉba var izrādīties visai sarežǧìta, jo nedz valdība ar definēto drošỉbas un aizsardzības politiku, nedz

14 Kudors, A. (red.) (2014). Krievijas publiskā diplomātija Latvijā: mediji un nevalstiskais sektors. Rīga: LU Akadēmiskais apgāds; Internet trolling as a hybrid warfare tool: the case of Latvia. (2016). Riga: NATO Strategic Communications Centre of Excellence; Redefining Euro-Atlantic values and Russia's strategic communication in the Euro-Atlantic space. (2016). Riga: NATO Strategic Communications Centre of Excellence; StratCom Laughs: In search of an analytical framework. (2017). Riga: NATO Strategic Communications Centre of Excellence; Rostoks, T., Vanaga, N. (eds.) (2019). Deterring Russia in Europe. Defence Strategies for Neighbouring States. London: Routledge; Bērzin̦a, I. (red.) (2016). Sabiedrības destabilizācijas iespējamība Latvijā: potenciālie nacionālās drošības apdraudējumi. Rīga: Latvijas Nacionālā aizsardzības akadēmija; Bērziṇa, I. (2020). From 'total' to 'comprehensive' national defence: the development of the concept in Europe. Journal of Baltic Security, 6(2), pp. 1-9; Bērziña, I., Zupa, U. (2020). Latvijas sabiedrības griba aizstāvēt valsti: veicinošie un kavējošie faktori. Rīga: Latvijas Nacionālā aizsardzības akadēmija.

15 Tautas attīstības pārskats. Cilvēkdrošîba. Latvija. (2003). Rīga: UNDP.

16 Latvijas Aizsardzības ministrija. Par visaptverošas valsts aizsardzības sistēmas ieviešanu Latvijā. (2019). Pieejams: Informativais zinojums_VVA ieviesana_2018.pdf (mod.gov.lv) 
indivīdi un sabiedrība ir konstantas vienības. Tās atrodas pastāvīgā mainībā, kas atbilstoši var pārdefinēt, adaptēt vai radìt jaunas izpratnes par apdraudējumu un atbilstošām politiku izvēlēm. Viens no redzamākajiem drošības pētniekiem Bils Maksvīnijs (Bill McSweeney) norādīja, ka drošības politikas nevajadzētu formulēt kā vienkāršu indivīdu vajadzību apkopošanu un to pierakstîšanu valstij, bet uz tām jāskatās kā uz procesu, kurš dinamiski attīstās un kurā sociālie aǵenti, meklējot jaunas identitātes un intereses, rada un piedāvā drošības risinājumus. Šo procesu viņš nosauc par "sociālās kārtības refleksīvo teoriju", piešķirot drošības radītāja statusu indivīdiem un kopienām. ${ }^{17}$ Tieši minētā Maksvīnija atziṇa ir būtiski iespaidojusi grāmatā atspoguḷotā pētijuma gaitu, kas padara tālāk atspoguḷotos rezultātus unikālus un inovatīvus, jo fokusa grupu interviju apkopotie rezultāti ir samēroti ar attiecīgo pašvaldỉbu darbinieku/vadītāju aptaujās iegūto skatījumu par drošības situāciju kopienā. Viens no pētijjumu soḷiem bija noskaidrot, vai pašvaldību darbinieki kā drošības radītāji un labas pārvaldības nodrošinātāji ir informēti par kopienā pastāvošajām bažām un vai viņiem ir sasaiste ar drošỉbas politikas dinamiskajām norisēm nacionālā līmenī.

Šajā pètījumā izmantotais definējums arī pieder pie minētā dominējošà strāvojuma. Tas balstīts pieņēmumā, ka "drošîba ir stāvoklis bez draudiem, .. kā arī valstu un sabiedrības spēja saglabāt neatkarīgu identitāti un to funkcionālu vienotību"18. Berija Buzana (Barry Buzan) piedāvātā definīcija akcentē sabiedrības līdzdalību drošîbas politikas veidošanā, kas ir būtiska subjektīvās uztveres analīzē, kā arī uzsver identitātes un valsts un sabiedrības funkcionēšanu, kuras ir īpaši nozīmīgas hibrīddraudu dominēšanas apstākḷos.

\section{Drošības subjektīvā uztvere}

Neraugoties uz pieaugošu interesi par daudzveidīgu drošîbas aspektu izpēti pēdējo gadu laikā, tomēr ir vairāki aspekti, kuriem nav pievērsta pienācīga uzmanība, bet kuriem ir īpaša nozīme situācijās, kad valstis un sabiedrības var kḷūt par hibrīduzbrukuma objektiem un kad nepietiek ar militāro spēju klātbūtni un efektivitāti, bet nacionālās drošỉbas stiprināšanā un pat aizsardzībā indivīds, grupas un sabiedrība kopumā sadarbojas ar bruṇotajiem spēkiem. Koordinēta visu iesaistīto dalïbnieku rīcība iespējama ar nosacìjumu, ka indivīds

17 McSweeney, B. (1999). Security, Identity and Interests. Sociology of International Relations. Cambridge: Cambridge University Press.

18 Buzan, B. (1991). People, States and Fear. An Agenda for International Security Studies in the PostCold War Era. London: Harvester Wheatsheaf, pp. 18-19. 
vai grupas gūst apstiprinājumu tam, ka viņu subjektīvais drošības redzējums atbalsojas valsts līmeņa prioritāro risku un apdraudējumu sarakstā un valdības rīcỉbpolitikās. Tādējādi veidojas attiecības starp drošǐbas politikas veidotājiem un šĩs politikas patērētājiem, kuri, redzot savu bažu un baiḷu atspogulojumu valsts īstenotajās darbībās, kḷūst par tās līdzīstenotājiem.

Tādēḷ projekta izstrādes gaitā uzmanība pievērsta drošības subjektīvajam uztveres definējumam. Drošỉbas objektīvos un subjektīvos aspektus vēl aukstā kara posmā akcentējis Arnolda Volfers (Arnold Wolfer), rakstot, ka "Drošỉba tās objektīvā nozīmē tiek mērīta ar apdraudējuma trūkumu pastāvošajām vērtībām, subjektīvā drošỉba ar baiļu neesamību, ka šādām vērtībām tiks uzbrukts"19. Drošības uztveri visbiežāk pēta no kvantitatīvā aspekta, noskaidrojot, kādus apdraudējumus dažādas sabiedrības grupas identificē kā prioritārus. Ja pieņem to, ka cilvēki savā apziņā konstruē realitāti tā, lai tā atbilstu pieṇēmumam, kādai tai jābūt vai vajadzētu būt, tad apdraudējumi parāda, cik atšķirīgi un daudzveidīgi ir iedzīvotāju pieṇēmumi par drošību un cik lielā mērā apdraudējumi tiek identificēti un saistìti ar konkrēto kontekstu. Retāk uzmanība pievērsta iemesliem, kāpēc tieši vieni vai otri draudi tiek prioritizēti un kā šis subjektīvais skatījums atspoguḷojas attiecīgās valsts drošības politikā. Draudu identifikācijā un prioritizācijā svarīga ir gan sociālā pieredze, gan sociālā atmiņa. Ārkārtas situāciju vadībā tiek lietots jēdziens "sociālā ievainojamība", kas apzīmē to kontekstuālo faktoru kopumu (piemēram, politisko, sociālo, kultūras), kas iezīmē kādas kopienas lielāku "uzṇēmību" vai reakciju uz draudiem, kamēr citas kopienas, saskaroties ar šiem pašiem draudiem, reaǵe citādāk. ${ }^{20}$

Bobijs Dafijs (Bobby Duffy) norāda, ka ir maz tādu subjektīvās uztveres pētījumu, kas pievēršas maldīgas uztveres skaidrojumiem. Viṇš to skaidro ar nepietiekamiem empīriskiem pierādījumiem. Sabiedriskās domas aptaujas par sociālās realitātes uztveri ir sāktas tikai salīdzinoši nesen - pagājušā gadsimta vidū, un arī pēc tam sekojis tikai salīdzinoši neliels to skaits. ${ }^{21}$

Tikai pēdējos gados piedzìvots šādu pētījumu pieaugums, ${ }^{22}$ ko veicinājusi tehnolog̣iju attīstība, sociālo mediju izplatība un drošîbas elementu klātbūtne

$$
\text { Books, pp. 7-8. }
$$

22 Skatit: Escriba-Folch, A. (2013). Repression, Political Threats, and Survival under Autocracy. International Political Science Review, 34(5), pp. 543-560; Farnham, B. (2003). The Theory of Democratic Peace and Threat Perception. International Studies Quarterly, 47(3), pp. 393-415; Rousseau, D., Garcia-Retamero, R. (2007). Identity, Power, and Threat Perception: A Cross-National Experimental Study. Journal of Conflict Resolution, 51(5), pp. 744-771; Siegrist, M., Gustcher, H., Earle, T. C. (2005). Perception of Risk: The Influence of General Trust, and General Confidence. Journal of Risk Research, 8(2), pp. 145-156; Stein, J. G. (2013). Threat Perception in International 
visās politikās. Kā vienu no šādiem inovatīviem pètījumiem jāmin lietuviešu zinātnieku veikums, lai noskaidrotu vēsturiskās atmiņas ietekmi uz militāro draudu uztveri Lietuvā pagātnē, tagadnē un nākotnē. ${ }^{23}$ Autori secina, ka sabiedrības uzticēšanās institūcijām ietekmē arī indivīdu savstarpējo uzticēšanos, kam ir īpaši liela nozīme apdraudējumu situācijās. Savukārt drošība par nākotni veicina personisko drošumspēju un pārliecību par savu spēju rīkoties. Pandēmijas apstākḷ̆os pieaugošā neapmierinātība un pat dusmas var būt draudu un risku nenovērtēšanas un uz riskiem vērstas uzvedības (piemēram, nepaḳ̣aušanās mājsēdes noteikumiem, sejas aizsargmasku nevalkāšanas u. c.) cēlonis. ${ }^{24}$

Drošības subjektīvā uztvere ne tikai palīdz labāk izprast iedzivotāju skatỉjumu uz apdraudējumiem, kas var atškịirties no valsts rīcibpolitikās definētajiem, bet arī veidot drošỉbas un aizsardzỉbas politiku, kas atspoguḷo sinerğiju starp objektīvi pastāvošajiem izaicinājumiem, par kuriem indivīdi dažādu apsvērumu dēl var nebūt informēti, un vienlaicīgi iekḷauj rīcības, kuras reageè uz iedzīvotāju pastāvošajām bažām. Šādas sinerǵijas pastāvēšana ir nosacijums cilvēku attieksmes un arī uzvedības maiņai, kas palielina iedzīvotāju spēju sevi pasargāt. Uz šādu secinājumu norāda arī Rafaels Prjeto Kurjels (Rafael Prieto Curiel) un Stīvens Ričards Bišops (Steven Richard Bishop), kuri, pētot drošības un viktimizācijas attiecības, secina, ka "Drošǐbas vai nedrošības uztvere var radìt cilvēkos nepieciešamību mainīt savu uzvedību"25.

Arī šie autori norāda uz politikas veidotāju un sabiedrības grupu draudu uztveres interpretācijas savietojamību, kas novērš uztveres un maldīgas uztveres (misperception) iespējamās negatīvās sekas. Viens no pirmajiem par šiem jautājumiem starptautiskās politikas disciplīnā rakstīja Roberts Džerviss (Robert Jervis), uzsverot, ka valstis un politikas veidotāji nereti piel̦auj kḷūdas lēmumu pieņemšanā, jo aplami kalkulē oponenta nolūkus un iespējamās rīcības. Viņš raksta: ja deg māja, tas nenozīmē, ka visi skries uz izeju identisku motīvu vadīti. ${ }^{26}$ Lai arī Džerviss galvenokārt analizē valstu un lēmumu pieñēmēju savstarpèjās uztveres īpatnības, daudzas atziņas iespējams ekstrapolēt uz indivīdu un grupu rīcību. Tà minētais piemērs par ugunsgrēku ir izmantojams,

Relations. In: Huddy, L., Sear, D. O., Levy, J. S. (eds.) The Oxford Handbook Political Psychology. Oxford: Oxford University Press, pp. 364-394.

23 Lašas, A., Matonite, I., Jankauskaite, M. (2020). Facing past, present and future: the role of historical beliefs and experiences in the Lithuanian public perception of military threats. Journal of Baltic studies, 51(2), pp. 199-222.

24 Ibid., pp. 204-207.

25 Curiel, R. P., Bishop, St. R. (2016). A metric of the diference between perception of security and victimisation rates. Crime Science, 5(12), p. 1.

26 Jervis, R. (1976). Perception and Misperception in International Politics. Princeton, New Jersey: Princeton University Press, p. 19. 
skaidrojot Latvijas iedzīvotāju dažādo subjektīvo attieksmi pret valsts dalību NATO, kuru kopumā atbalsta vairākums iedzīvotāju, bet militāro bāzu klātbūtni savās kopienās interpretē atšķirīgi (skatīt Valda Otzuḷa rakstu grāmatā). Atgādinājums, ka spēlētājs A spriež par spēètāju B, balstoties uz tā sūtītajiem signāliem, var izrādīties maldīgas uztveres rezultāts. Lai izprastu B iespējamās rīcības, jānoskaidro tā tradīcijas, nacionālais stils, iekšējie konflikti, viṇa paša izkalkulētās potenciālās rīcības sekas. ${ }^{27}$

Latvijas iedzīvotāju subjektīvās drošības uztveres metodoloǵiskā ietvara konstruēšanai svarīgi ir divi koncepti, kuri l̦auj pievērst uzmanību indivīdu un grupu lomai. Tas ir cilvēkdrošības un sabiedrības drošỉbas jēdziens. Cilvēkdrošības koncepcijā uzmanība pievērsta katra indivīda pamatvajadzību nodrošināšanai, kas tiek raksturota kā "brīvība no bailēm un brīvība no trūkuma"28. Pie tam šajā konceptā tiek izšķirti tādi drošības sektori, kuri parasti trūkst tradicionālajās drošỉbas studijās. Tie ir: veselības drošība, ekonomiskā, personiskā, ekolog̣iskā, kopienas, politiskā drošība un uzturdrošība. Šie ir tieši tie drošības aspekti, kuri aktualizējas krīzes apstākḷ̆os un demonstrē valdības spēju veidot iekḷaujošu un ilgtermiṇa drošibas politiku, kas rada priekšnoteikumus institūciju un indivīdu savstarpējai uzticíbai. Tādēḷ arī šajā pētījumā ir izmantoti minētie drošỉbas sektori, papildinot tos ar militāro un hibrīddraudu sektoru.

Savukārt sabiedrības drošības jēdziens raksturo grupu un visas sabiedrības spēju izturēt un saglabāt savu patību pastāvīgi mainīgos apstākḷos vai apdraudējuma situācijās, kā arī tādu savu tradicionālu modeḷu kā valoda, kultūra, reliǵija un nacionālā identitāte ilgtspēju..$^{29}$ N̦emot vērā 21. gadsimta izaicinājumus, kas saistīti ar tādiem tradicionāliem (cietās drošîbas / šaurā interpretējuma) apdraudējumiem cilvēka un grupu eksistencei kā robežu pārskatī̌̌ana, teritoriju okupēšana, vardarbīgu konfliktu izraisīšana, terorisms, kā arī iepriekš nepieredzēti un masveida raksturu ieguvušie riski, kas izriet no pandēmijas, hibrīddraudu, klimata pārmaiņu, nekontrolētas migrācijas un citiem apdraudējumiem, gan valstis, gan sabiedrïbas, gan indivīdi ir vienlïdz pakḷauti eksistenciālām bailēm un satraukti par identitātes saglabāšanu. Pastāvošo dažādo draudu kombinācijas vēl jo vairāk rada nosacījumus un arī nepieciešamību apzināt objektīvu pastāvošo un subjektīvo drošỉbas uztveri, kas padara indivīdus un grupas par drošības politikas līdzdarbīgām vienībām. Princeton University Press, pp. 21-22.

28 Human Development Report 1994. Oxford: Oxford University Press, pp. 22-24.

29 Buzan, B. et al. (1993). The European Security Order Recast. Scenarios for the Post-Cold War Era. London, New York: Pinter Publisher, p. 4. 
Sabiedrības drošìba ir nozīmīgs nacionālās un starptautiskās drošības nosacijjums, jo tas raksturo attiecības starp dažādām sabiedrībā pastāvošām grupām, kurām ir raksturīgas miermīlīgas un uz savstarpēju sadarbỉbu balstītas attiecibas, kas vairo stabilitāti, savukārt spriedze vai pat konflikti ir nestabilitātes avots un negatīvi ietekmē starptautisko vidi. Attiecības starp grupām, kuras sakṇotas subjektīvā drošìbas uztverē, jo tās skar identitātes aspektus, var būtiski iespaidot grupu uzvedību. Jo īpaši tam ir nozīme, ja pieaug dažādu grupu atšķirības - diskriminācija, favorītisms grupās, vienas grupas pārākums pār citu grupu, tas vairo spriedzi. Drošības subjektīvo aspektu analīzē ir svarīga sevis, savas grupas (in-group) un citas grupas (out-group) savstarpējā uztvere, ${ }^{30}$ kā arī pastāvošo atš̌kirību raksturs (naidīgs-draudzịgs-neitrāls). Ja starp grupām pastāvošās atškiriības subjektīivi netiek uztvertas kā apdraudošas, tad ir lielākas iespējas ilgstošai stabilitātei. Savukārt, ja pastāvošās atšķirības pārvēršas apdraudējumā, tad sabiedrība kḷūst par risku avotu, kas sarežğì nacionālās drošības mērḳu sasniegšanu.

Zinātniskās literatūras klāstā atrodami pētījumi par faktoriem, kas ietekmē subjektīvo uztveri. Tā jau pieminētie Kurjels un Bišops izšķir faktorus, kas ietekmē noziedzības uztveres līmeni. Tas var noderēt arī plašākā draudu analīzē. Piemēram, viens no tiem ir iepriekšèjā pieredze saskarsmē ar attiecīgo draudu; starptautiskā, nacionālā un lokālā vide, kura veicina vai samazina attiecīga drauda pastāvēšanu un izplatību; grupas, pie kuras pieder indivīds, pieredze un piedāvātie risinājumi; mediji un sociālie mediji draudu atspoguļošanā var situāciju saasināt un ietekmēt gan uztveri, gan uzvedību. ${ }^{31}$ Iepriekšèja saskare ar draudu var palielināt bailı sajūtu. Pēc terorisma uzbrukumiem 2001. gada 11. septembrī sabiedriskās domas aptaujas ASV tūlīt demonstrēja, cik lielas bailes amerikāṇu sabiedrības pārstāvji bija pārdzìvojuši. Tās emocionālā reakcija krietni pārsniedza reālos riskus. Saskaṇā ar Hārvarda Universitātes profesores Dženiferas Lerneres (Jeniffer Lerner) sniegto informāciju intervijā pēc 11. septembra teroraktiem, 30\% aptaujāto piel̦āva iespējamību, ka viṇi varētu kḷūt par teroristu upuriem tuvākajos 12 mēnešos. ${ }^{32}$

Pie līdzīgiem secinājumiem nonākuši Daniels Stīvens (Daniel Stevens) un Niks Vons-Viljams (Nick Vaughan-Wiljams). Viṇi apgalvo, ka vide vai tiešāk konteksts, kurā persona ir sastapusies ar draudiem, nosaka, vai nākamo reizi

30 Hogg, M., Abrams, D. (1988). Social Identifications: A Social Psychology of Intergroup Relations and Group Processes. London: Routledge, p. 23.

31 Curiel, R. P., Bishop, St. R. (2016). A metric of the diference between perception of security and victimisation rates. Crime Science, 5(12), pp. 1-2.

32 Vedantam, S. How Emotional Responses To Terrorism Shape Attitudes Toward Policies. 22.12.2015. Radio NPR. Pieejams: https:/www.npr.org/2015/12/22/460656763/how-emotional-responses-toterrorism-shape-attitudes-toward-policies 
situācija tiks uztverta kā draudīga vai ne. Tā, piemēram, imigrācijas draudi vai vides piesārņojums vistiešākā veidā tiek saistīts ar kontekstu un sociālo pieredzi, kur, trūkstot sociālajai pieredzei, faktors (piem., vides piesārņojums) var nelikties tik draudīgs vai, gluži pretēji, var kḷūt draudīgs, ja persona šo faktoru "ieliek" sev zināmā kontekstā, kā, piemēram, piesārṇojums tuvu manai mājai. ${ }^{33}$ Arī noziedzības gadījumā indivīds var uztvert savu tiešo vidi kā nedrošu, bet tajā paša laikā nebaidīties, ka viņš varētu kḷūt par upuri, vai arī nebaidīties tāpēc, ka viņš ir veicis pasākumus, lai nekḷūtu par upuri. ${ }^{34}$

Vēl viena psihologiska reakcija, kas var ietekmēt subjektīvo uztveri, ir dusmas. Lernere norāda, ka uz traǵiskiem un šķietami lieliem apdraudējumiem, kā, piemēram, terorisma uzbrukums, sievietes biežāk reagè ar bailēm, bet vīrieši ar dusmām. Dusmas mazina riska izjūtu. Cilvēkiem, kas izjūt šīs emocijas, retāk sajūtas kā upuri. Turklāt tie ir gatavi paši uzṇemties papildu riskus, pateicoties iespējamai vēlmei rīkoties agresīvi, un var veidoties vienkāršošanās mehānismi. ${ }^{35}$ Zìmīgi, ka citi pētỉjumi ASV pierāda, ka ziņas par ekonomiskiem draudiem iedzīvotājos drīzāk izraisa dusmas, nevis bailes. Tādējādi ar emociju starpniecību indivīdi nosaka to, kāda nozīme tiek piešķirta tam vai citam draudu veidam. ${ }^{36}$

Šis atziņas daḷēji sakrīt ar Dafija aprakstītajām draudu uztveres īpatnībām. Viņš norāda, ka attiecībā uz noziedzības uztveri pētījumi daudzu valstu sabiedrībās pierāda, ka neatkarīgi no tā, vai patiesais noziedzības un vardarbïbas līmenis krīt vai ne, kopējais apdraudējuma sajūtas līmenis tomēr saglabājas. Turklāt to nav iespējams tieši saistīt tikai un vienīgi ar noziedzības atainojuma intensitāti medijos, kas vienmēr būs salīdzinoši augsta. Dafijs savos un kolēgu pètījumos to galvenokārt saistījis ar indivīdu uztveres un "maldīgās" uztveres ipatnībām, kas piemīt ikvienam indivīdam. To ilgtermiņā ietekmē dažāda rakstura negatīvas informācijas lielais apjoms publiskajā telpā, kā arī ieradums dot priekšroku tieši šāda veida informācijai. Politiķu un pazīstamu cilvēku radītas dramatiskas ainas un runas sabiedrībai šķiet interesantākas un pievilcīgākas. Rezultātā neatkarīgi no objektīvās realitātes, piemēram,

33 Stevens, D., Vaughan-Williams, N. (2014). Citizens and Security Threats: Issues, Perceptions and Consequences Beyond the National Frame. British Journal of Political Science, 46, pp. 149-175, DOI: 10.1017/S0007123414000143

34 Curiel, R. P., Bishop, St. R. (2016). A metric of the diference between perception of security and victimisation rates. Crime Science, 5(12), p. 2.

35 Vedantam, S. How Emotional Responses To Terrorism Shape Attitudes Toward Policies. 22.12.2015. Radio NPR. Pieejams: https://www.npr.org/2015/12/22/460656763/how-emotional-responses-to-terrorism-shape-attitudes-toward-policies

36 Coan, Travis G. et al. Emotional Responses to Human Security Threats: Evidence from a National Experiment. 31.10.2012. Pieejams: www.travisgcoan.com/replication-materials.html. 
fakta, ka kopumā kriminogēnā situācija vēsturiski kḷūst arvien labāka, mums piemìt tendence domāt pretēji, secina Dafijs. ${ }^{37}$

Situācijās, kad indivīds ilgstoši pārdzīvo spēcīgas bažas, tam rodas nopietnas grūtîbas novērst savu uzmanību uz kaut ko citu, ${ }^{38}$ kā arī potenciāli var rasties citi kognitīvās kontroles traucējumi, piemēram, uztverot informāciju par iespējamo apdraudējumu. ${ }^{39}$ "Draudi mūsu smadzenēs kḷūst arvien lielāki un lielāki, ${ }^{\prime 40}$ raksta Dafijs. Cita pētnieku grupa - Leonijas Hadijas (Leonie Huddy) vadībā - norāda, ka, pieaugot apdraudējuma sajūtai, samazinās politiskā tolerance, pieaug aizspriedumi un etnocentrisms, ${ }^{41}$ kas var novest pie drošíbas situācijas pasliktināšanās.

Paralēli iedzīvotāju subjektīvajai draudu uztverei svarīgi aplūkot arī draudu intensitāti un to prioritāro uztveri. Nosacīti sadalot draudus divās grupās - personīgajos un sociotropiskajos draudos -, vērojama savdabīga aina. Hadija $^{42}$ norāda, ka nacionāla līmeņa draudi visbiežāk atspoguḷojas cilvēku uztverē saistībā ar ekonomiskajām sekām, kamēr personīgā līmeņa draudi veicina personīgo paradumu maiņu, lai mazinātu potenciālos draudus. No uztveres perspektīvas sociotropiskie draudi tiek uztverti kā tālāki no indivīda ikdienas gaitām, tomēr pētījumi parāda, ka indivīds daudz biežāk savā apziṇā veido konstrukciju "sabiedrības apstākḷi un valdība" nekā konstrukciju "paša apstākḷi un publisko amatpersonu rīcība" ${ }^{\text {”3 }}$. Šāda konstrukcija liecina, ka visbiežāk arī medijos sociotropiskie draudi tiek asociēti ar nacionālo līmeni un mazāka uzmanība pievērsta personiskajiem draudiem.

Šì pētījuma mērḳis ir noskaidrot, vai Latvijas iedzīvotāju subjektīvais skatījums uz apdraudējumiem atbalsojas politikas veidotāju piedāvātajos rīcībpolitiku risinājumos. Tādēḷ no plašajām teorētiskajām atziṇām par drošîbas subjektīvo uztveri empīisko datu ieguvei īpaši svarīgas ir šādas atziṇas: baiḷu līmenis dažādos drošîbas sektoros, kas var rezultēties pasivāa reakcijā uz

37 Duffy, B. (2018). The Perils of Perceptions. Why We're Wrong About Nearly Everything. Atlantic Books, pp. 121-129.

38 De Raedt, R., Koster, E. H. W. (2010). Understanding vulnerability for depression from a cognitive neuroscience perspective: Areappraisal of attentional factors and a new conceptual model. Cognitive, Affective, \& Behavioral Neuroscience, 10, pp. 50-70.

39 Beckwe, M. (ed.) (2013). Worrying and Rumination are Both Associated with Reduced Cognitive Control. Psychological Research, 9, p. 2, DOI: 10.1007/s00426-013-0517-5

40 Duffy, B. (2018). The Perils of Perceptions. Why We're Wrong About Nearly Everything. Atlantic Books, p. 125.

41 Huddy, L. et al. (2002). The Consequences of Terrorism: Disentangling the Effects of Personal and National Threat. Political Psychology, 23(3), p. 486. Pieejams: https://cpb-us-el.wpmucdn.com/ you.stonybrook.edu/dist/f/1052/files/2018/03/Huddy-Feldman-Capelos-and-Provost-2002-TheConsequences-of-Terrorism-rpyn7l.pdf

42 Ibid.

43 Ibid. 
notiekošo un mazināt līdzdalību visaptverošas aizsardzības sistēmas veidošanā; dusmu pastāvēšana sabiedrības grupās, kas savukārt var radīt priekšnoteikumus radikalizācijai un agresijai; pārliecība par nākotnes attīstību kā savas drošumspējas/noturīguma rādītājs; uzticēšanās institūcijām/valdībai, kas veicina sadarbību starp drošības veidotājiem, tai skaitā pašu sabiedrību.

\section{ledzīvotāju subjektīvā drošības uztvere un drošības politikas veidošana: pētījuma rāmējums}

Mūsdienās ikviena rīcībpolitikas veidošana ir saistīta gandrīz ar visa plašā apdraudējuma spektra apzināšanu un ietekmes uz sabiedrību prognozēšanu. Šajā daudzveidīgajā un sarežgìitajā situācijā sabiedrība ir viens no nozīmīgākajiem partneriem eksistējošo un potenciālo draudu novēršanā. Taču šie dažādie draudi un riski sabiedrỉbā tiek atšķirīgi uztverti un prioritizēti. Dạ̦ā indivīdu tie izraisa bailes, citos dusmas, vēl citos neuzticību politikas veidotājiem un to pieṇemtajiem lēmumiem un rīcībpolitikām. Attiecīgi arī sabiedrības pārstāvju drošỉbas izjūtas un labsajūtas nodrošināšana neaprobežojas ar valsts ārējo robežu sargāšanu vai indivīdu fiziskās drošîbas garantēšanu. Drošības politikas veidotājiem līdz ar to jālieto kompleksa pieeja iedzīvotāju drošumspējas veidošanā, kurā vienlīdz liela nozīme ir gan valsts neatkarības nodrošināšanai, gan arī privātumam un datu drošỉbai kibertelpā, sabiedrības veselībai, personiskai drošībai, emocionālai un garīgai labklājỉbai u. c. Lìdz ar to mūsdienās var tikt uzdoti pamata jautājumi, lai uzzinātu, kā sabiedrība formulē stāvokli, kurā jūtas droši; kāda veida draudus mēs uzskatām par primāriem; vai politikas veidotāji apzinās un spēj reagêêt uz sabiedrības pārstāvju vajadzībām.

Lai rastu atbildes uz jautājumiem, vai un kā cilvēku drošîbas uztvere atspoguḷojas drošǐbas politikā, kādus un, galvenais, kāpēc viṇi identificē vienus vai otrus draudu veidus un vai pašvaldỉbas reagee uz cilvēku bailēm/bažām, tās mazinot, vai rodas saikne starp drošîbas politikas veidotāju un patērētāju, izveidota vairāku posmu izpētes darba metodolog̣ija, kas atspoguḷota attēlā.

Pirmkārt, projekta atskaites punkts bija daudzās Latvijā veiktās sabiedriskās domas aptaujas, kuras iezīmē iedzīvotāju attieksmi pret drošîbas situāciju valstī un galvenajiem draudu veidiem. Tas savukārt palīdzēja veidot jautājumus fokusa grupu intervijām šì projekta mērḳu sasniegšanai. Pētījumā izmantoti to Latvijas un starptautisko sabiedriskās domas aptauju rezultāti, kas atainoja Latvijas iedzīvotāju viedokḷus un noskaņojumus, kuri bija apkopoti laika posmā no 2014. gada līdz 2019. gada sākumam. Saskaṇā ar tiem Latvijas iedzīvotāji pamatā kā nozīmīgus saskata draudus, kuru avots ir valstī, nevis 


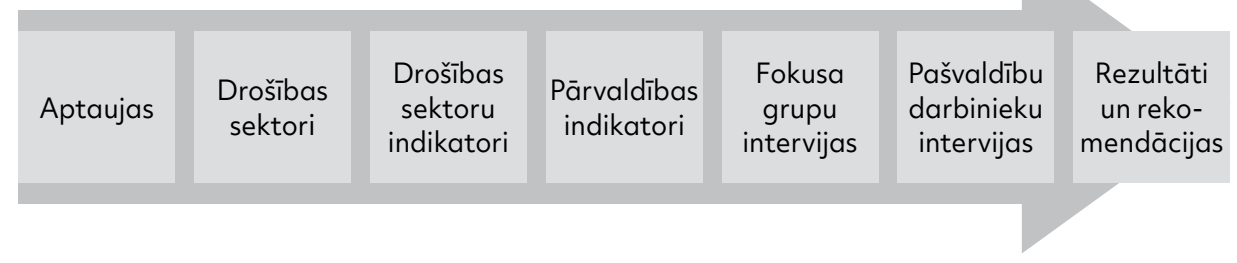

Pētijuma īstenošanas posmi

ārējus draudus. ${ }^{44}$ Starp nozīmīgākajiem apdraudējumiem Latvijas iedzīvotāji identificējuši sociālus draudus, piemēram, zemas algas, bezdarbs, nepietiekamas sociālās garantijas. ${ }^{45}$ Iedzīvotāju neapmierinātība ar valsts pārvaldes darbu, neuzticēšanās politiskajai elitei veicinājusi situāciju, kad vairāk nekā puse Latvijas iedzīvotāju dažādās sabiedriskās domas aptaujās paudusi pilnīgu vai daḷēju neuzticēšanos nacionāla līmeņa valsts pārvaldes iestādēm, galvenokārt valdībai un Saeimai, ${ }^{46}$ un to darbību skatījusi kā iespējamu apdraudējumu. ${ }^{47}$ Līdzās šim bieži atzīmēta arī korupcija kā nozīmīgs apdraudējums. ${ }^{48}$ Aptauju dati norāda uz to, ka Latvijas iedzīvotājus satrauc arī demogrāfiskie jautājumi, piemēram, sabiedrības novecošana, zema dzimstība, ekonomiskā situācija valstî. ${ }^{49}$ Lai arī retāk nekā iepriekšêjās draudu grupas, tomēr aptaujās parādījušies arī tādi iedzīvotāju identificētie draudu veidi kā Latvijas integrācijas problēmas un divkopienu sabiedrības esamība, imigrācija, ekolog̣iskās problēmas un

44 Nacionālā Aizsardzības akadēmija (2016). Sabiedrības destabilizācijas iespējamība Latvijā: potenciālie nacionālās drošības apdraudējumi. Rīga: Nacionālā Aizsardzības akadēmija; SKDS. Latvijas Barometrs, 19.06.2016.; Eurobarometer, Special Eurobarometer 464b. Security, June 2017; Eurobarometer, Autumn 2018; SKDS, 02.2018.; SKDS. Latvijas Barometrs, 10.2018.

45 Nacionālā Aizsardzības akadēmija (2016). Sabiedrības destabilizācijas iespējamība Latvijā: potenciālie nacionālās drošības apdraudējumi. Rīga: Nacionālā Aizsardzības akadēmija; SKDS. Latvijas Barometrs, 06.2016.; Eurobarometer, Autumn 2018; SKDS. Latvijas Barometrs, 10.2018.

46 Salīdzinoši - pašvaldībām iedzīvotāji uzticas ievērojami vairāk. Piemēram, SKDS 2018. gada februārī veiktā aptauja rādīja, ka vairāk nekā puse Latvijas iedzīvotāju ir pilnībā vai daḷēji apmierināti ar savas pašvaldības darbu.

47 SKDS. Latvijas Barometrs, 12.2016.; SKDS, 07.2017.; Pew Research. Ethnic Russians in Some Former Soviet Republics Feel a Close Connetion to Russia. 24.07.2017. Pew Resarch. Pieejams: http://www. pewresearch.org/fact-tank/2017/07/24/ethnic-russians-in-some-former-soviet-republics-feel-aclose-connection-to-russia/; SKDS. Latvijas Barometrs, 10.2017.; SKDS, 02.2018.; SKDS, 07.2018.; SKDS, 11.2018.; Eurobarometer, 09.2018.

48 Nacionālā Aizsardzības akadēmija (2016). Sabiedrības destabilizācijas iespējamība Latvijā: potenciālie nacionālās drošības apdraudējumi. Rīga: Nacionālā Aizsardzības akadēmija; SKDS. Latvijas Barometrs, 12.2016.; SKDS. Latvijas Barometrs, 10.2017.

49 Nacionālā Aizsardzības akadēmija (2015). Aktuālās drošības problēmas Latvijā. Rīga: Nacionālā Aizsardzības akadēmija; SKDS. Latvijas Barometrs, 06.2016.; SKDS. Latvijas Barometrs, 10.2017.; SKDS, 06.2018.; SKDS. Latvijas Barometrs, 12.2018. 
dabas katastrofas, kiberdraudi personiskā un nacionālā līmenīi. ${ }^{50}$ Attiecībā uz iekšējiem draudiem nepastāv ievērojamas atšķirības starp Latvijas iedzīvotāju viedokḷiem atkarībā no to etniskās vai lingvistiskās piederības. Tiesa, krievvalodīgie Latvijas iedzīvotāji biežāk Latvijas valsti skata kā svešu un naidīgu, kā apdraudējuma avotu to personiskajai drošībai. ${ }^{51}$ Kā nozīmīgāko ārējo apdraudējuma avotu Latvijas iedzīvotāji galvenokārt minējuši Krievijas Federācijās ārpolitiku. Un te pastāv ievērojamas atšķirības starp divām lingvistiskās piederības grupām. Latviešu vidū šāda viedokḷa atbalstītāju īpatsvars bija salīdzinoši liels un aptaujās sasniedza vairāk nekā pusi no kopējā aptaujāto skaita, bet starp krievvalodīgajiem respondentiem šāda viedokḷa atbalstītāju skaits aptaujās nesasniedza pat 1/5. Krievijas Federācijas aktivitātes drīzāk viṇi skatījuši kā tādas, kas līdzsvaro Rietumu realizētās politikas un/vai aizstāv krievvalodīgos ārpus tās robežām..$^{52}$ Aptaujās iezīmējās arī Latvijas iedzīvotāju bažas par NATO spēku klātbūtni kā iespējamo to apdraudējuma avotu. ${ }^{53}$

Otrais pētijuma solis bija saistīts ar drošìbas sektoru noteikšanu. Tajos notiktu apdraudējumu identificēšana ar izvēlētu indikatoru palīdzību. Šajā gadījumā autori izmantoja gan Barija Buzana klasisko iedalïjumu ekonomiskajos, politiskajos, militārajos, vides, sabiedrības un strukturālajos sektoros, ${ }^{54}$ gan Apvienoto Nāciju Organizācijas Attīstības programmas ietvarā izstrādātos cilvēkdrošības jēdzienu skaidrojošos sektorus - veselību, personisko, kopienas, vides, politisko. ${ }^{55}$ N̦emot vērā pēdējos gados pieaugošo un Latvijas situācijai īpaši nozīmīgo hibrīdapdraudējumu, tad arī tie iekḷauti kopējā sarakstā. Tieši hibrīddraudi un riski indivīdam un sabiedrībai rada apstākḷus personiskiem kognitīvi emocionāliem konfliktiem, kuriem raksturīgas tādas pazīmes

50 Nacionālā Aizsardzības akadēmija (2016). Sabiedrības destabilizācijas iespējamība Latvijā: potenciālie nacionālās drošîbas apdraudējumi. Rīga: Nacionālā Aizsardzības akadēmija; SKDS. Latvijas Barometrs, 06.2016; Eurobarometer, 11.-12.2016; SKDS. Latvijas Barometrs, 12.2016.; Pew Resarch. Pieejams: http://www.pewresearch.org/fact-tank/2017/07/24/ethnic-russians-in-someformer-soviet-republics-feel-a-close-connection-to-russia/; SKDS. Latvijas Barometrs, 10.2017; SKDS, 11.2017.; SKDS, 04.2018.; SKDS, 05.2018.; Eurobarometer, Autumn 2018; SKDS, 10.2018.; SKDS, 12.2018 .

51 Ozoliņa, Ž. (Ed.) (2016). Societal Security. Inclusion-Exclusion Dilemma. A Portrait of the Russian Speaking Community in Latvia. Rīga: Zinātne.

52 Nacionālā Aizsardzības akadēmija (2016). Sabiedrības destabilizācijas iespējamība Latvijā: potenciālie nacionālās drošîbas apdraudējumi. Rīga: Nacionālā Aizsardzības akadēmija; Pew Research. Ethnic Russians in Some Former Soviet Republics Feel a Close Connetion to Russia. 24.07.2017. Pew Resarch. Pieejams: http://www.pewresearch.org/fact-tank/2017/07/24/ethnic-russiansin-some-former-soviet-republics-feel-a-close-connection-to-russia/

53 Nacionālā Aizsardzības akadēmija (2016). Sabiedrības destabilizācijas iespējamība Latvijā: potenciālie nacionālās drošības apdraudējumi. Rīga: Nacionālā Aizsardzības akadēmija.

54 Buzan, B. (1991). People, States and Fear. An Agenda for International Security Studies in the PostCold War Era. London: Harvester Wheatsheaf, pp. 116-134.

55 Tautas attīstības pārskats. Cilvēkdrošība. Latvija. (2003). Rīga: UNDP, 30. lpp. 
kā apjukums, dezorientācija, motivācijas zaudēšana, depresija, noliegums, saiknes zaudēšana ar realitāti, vājums, bailes vai pārspīlēta kāda apbrīnošana un citas, kas norāda uzbrukuma vektorus potenciālajam ienaidniekam, lai ietekmētu un pakḷautu izvēlēto indivīdu vai grupu sev vēlamā virzienā un veidā. Šādās situācijās cilvēks pats vairs nav savas izvēles noteicējs, bet pakḷaujas citu kontrolei. Jo īpaši šādi kognitīvie konflikti tiek izmantoti "kritiskos laikos" (vēlēšanas, gatavošanās militārām operācijām, sabiedriskās domas atbalsta iegūšanas kampaṇās). ${ }^{56}$

Treškārt, balstoties uz vairākām sabiedriskās domas aptaujām, kas veiktas Latvijā un veltītas iedzīvotāju attieksmes pret drošỉbas situāciju (Latvijā, Eiropā un pasaulē) apkopošanai un cilvēkdrošības pētījumu izvērtēšanai, tika izveidots Latvijai nozimmīgāko drošības sektoru saraksts un atbilstoši tam atlasīti indikatori, kas bijuši lietoti un pārbaudīti iepriekšējos pētījumos. ${ }^{57}$ Drošības sektoru un attiecīgo indikatoru saraksts atspogulots 1. tabulā.

Ceturtais solis bija saistīts ar pārvaldības jēdziena un tādu pārvaldības indikatoru definēšanu un atlasi, kuri būtu piemērojami dažādiem drošības sektoriem. Draudu sekas ir gan politiskās uzvedības maiṇa, gan arī valdības reakcijas un pārvaldības efektivizācija. ${ }^{58}$

Labas pārvaldības jēdziens visbiežāk tiek lietots, lai aprakstìtu procesus politiskajā un administratīvajā sistēmā, kur iesaistās institūcijas un privātie uzņēmēji, indivīdi un nevalstiskās organizācijas, lai panāktu labāku valsts pārvaldes darbību un operatīvāku reakciju uz sabiedrības problēmām un izaicinājumiem. Lai arī mēdz runāt par labo pārvaldību (good governance) un viedo pārvaldību (smart governance), ${ }^{59}$ šajā pētijumā tika izmantotas Pasaules Veselības organizācijas piedāvātie kritēriji viedajai pārvaldība (smart governance), saucot to par labu pārvaldību, jo tieši termins "laba pārvaldība" ir akceptèts Latvijas sabiedrībā.

Sākotnēji labas pārvaldības jēdziens tika saistīts ar piecām pārvaldes vērtībām - atvērtība, līdzdalība, atbildīgums, efektivitāte un saskaņotība, ko

56 Skatīt: Wells II, L. (2017). Cognitive-Emotional Conflict - Adversary Will and Social Resilience. PRISM, 7(2). Pieejams: Cognitive-Emotional Conflict - Adversary Will and Social Resilience > PRISM | National Defense University > News (ndu.edu); Studeman, W. O. (02.2017). Tutorial on Managing the Overlap Between and Alignment of Cyber, Information Warfare/Conflict/Operations and Intelligence (including all forms of security), p. 27.

57 Ozoliṇa, Ž. (red.) (2012). Cilvēkdrošỉba Latvijā un pasaulē: no idejas lìdz praksei. Rīga: Zinātne; Ozolina, Ž. (red.) (2016). Societal Security. Inclusion-Exclusion Dilemma. A Portrait of the Russian Speaking Community in Latvia. Rịga: Zinātne; Nacionālā Aizsardzības akadēmija (2015). Aktuālās drošǐbas problēmas Latvijā. Rīga: Nacionālā Aizsardzības akadēmija un citi.

58 Stevens, D., Vaughan-Williams, N. (2014). Citizens and Security Threats: Issues, Perceptions and Consequences Beyond the National Frame. British Journal of Political Science, 46, pp. 149-175, DOI: $10.1017 /$ S0007123414000143

59 World Health Organization. Governance for health in the 21st century. 2012. 
1. tabula. Drošības sektori

\begin{tabular}{|c|c|}
\hline Drošības sektori & Indikatori \\
\hline $\begin{array}{l}\text { Ekonomikas } \\
\text { sektors }\end{array}$ & $\begin{array}{l}\text { Pirktspēja } \\
\text { Spēja veidot uzkrājumus } \\
\text { lenākumu stabilitāte } \\
\text { Pieeja finansiālam atbalstam nepieciešamības gadījumā } \\
\text { Uzṇēmējdarbības vides stabilitāte un prognozējamība } \\
\text { Ekonomikas noturība pret globālās ekonomikas svārstībām un eksporta } \\
\text { tirgu diversitāte } \\
\text { Administratīvais slogs uzṇēmējdarbībai un uzṇēmējdarbības uzsākšanai }\end{array}$ \\
\hline $\begin{array}{l}\text { Politikas } \\
\text { sektors }\end{array}$ & $\begin{array}{l}\text { Valdības stabilitāte } \\
\text { Pienemto lēmumu leǵitimitāte } \\
\text { Politiskais atbalsts drošības situācijas uzlabošanai valstī } \\
\text { Attiecību raksturs starp nacionālo un lokālo/pašvaldību līmeni } \\
\text { Sabiedrības līdzdalība vēlešanās } \\
\text { Uzticība politiskiem institūtiem }\end{array}$ \\
\hline $\begin{array}{l}\text { Sabiedrības } \\
\text { drošîbas } \\
\text { sektors }\end{array}$ & $\begin{array}{l}\text { Grupu identitāte un tās saglabāšanas iespējas } \\
\text { Izglîtības pieejamība } \\
\text { Sabiedrības līdzdalība } \\
\text { Ticības brīvība } \\
\text { Kultūras daudzveidība } \\
\text { Kopienas pašizpausmes iespējas } \\
\text { Psiholoǵiskais noturīgums }\end{array}$ \\
\hline $\begin{array}{l}\text { Vides } \\
\text { sektors }\end{array}$ & $\begin{array}{l}\text { Apdraudēto resursu aizsargāšana } \\
\text { Rīcībspēja dabas katastrofu radīto seku pārvarēěanā } \\
\text { Likumdošana vides piesārṇojuma mazināšanai } \\
\text { Iniciatīvas klimata pārmainu mazināšanai } \\
\text { Vides resursu kvalitāte }\end{array}$ \\
\hline $\begin{array}{l}\text { Militārais } \\
\text { sektors }\end{array}$ & $\begin{array}{l}\text { Valsts robežu drošība } \\
\text { Spēja nepielaut citas valsts iebrukumu } \\
\text { Spēja aizsargāt valsti iebrukuma gadījumā (bruṇoto spēku gatavība, } \\
\text { spējas, iedzīvotāju griba un gatavība) } \\
\text { Finansiālais nodrošinājums NBS spēju attīstībai } \\
\text { Sabiedrības iesaiste valsts aizsardzībā - dalība Zemessardzē, } \\
\text { jaunsardzē vai iestāšanās profesionālajā dienestā }\end{array}$ \\
\hline $\begin{array}{l}\text { Hibrīddraudu } \\
\text { sektors }\end{array}$ & $\begin{array}{l}\text { Fiziskā drošība un aizsardzība pret dabas katastrofām } \\
\text { Informācijas drošība - viltus zinnas, mediju brīvība, vide un patība } \\
\text { Citu valstu iejaukšanās iekšējās lietās un to ietekme } \\
\text { Kiberuzbrukumi } \\
\text { Kritiskās infrastruktūras apdraudētība }\end{array}$ \\
\hline $\begin{array}{l}\text { Personiskās } \\
\text { drošības sektors }\end{array}$ & $\begin{array}{l}\text { Veselība } \\
\text { Sociālā aizsardzība } \\
\text { Labklājība } \\
\text { Fiziskā drošība } \\
\text { Emocionālā drošība } \\
\text { Noziedzības līmenis }\end{array}$ \\
\hline
\end{tabular}


Eiropas Savienība definēja 2001. gadā. Taču, tā kā valsts pārvaldei un pašvaldībām risināmie jautājumi kḷuva arvien sarežg̀itāki, bija nepieciešama "kopējā risinājuma meklēšanas stratēégija”, kur publiskās pārvaldes iestādes kopā ar sabiedrību un politiķiem konstruktīvi sadarbojas. Taču ne visiem pārvaldības dalïbniekiem ir kopīgas vērtības un, vēl jo vairāk, kopīga izpratne par to, kas ir vērtības un kādām jābūt vērtỉbām, uz kuru bāzes tiek veidota sadarbība, lai risinātu sarežğìtas sociālekonomiskas vai apstākḷu izraisītas ārkārtas situācijas. Tādēl vēlāk pārvaldības definējumi atspoguḷo nosacỉjumus "labākā risinājuma meklēšanas stratēǵija" ${ }^{\prime 60}$, kas ietver virkni nosacijumu. Tā pārvaldības pamatā ir pieṇēmums, ka, jau veidojot rīcībpolitikas, normatīvos aktus un jebkādu administratīvo regulējumu, ir jāṇem vērā paredzamais iegūstamais rezultāts, ko iegūst iedzīvotājs, nevis citas pārvaldes institūcijas. ${ }^{61}$ No labas pārvaldības perspektīvas jebkura valsts veidotā rīcíbpolitika ietver tālredzīgu, uz nākotni vērstu skatījumu un rīcībpolitikas izstrāde ir balstīta uz pierādījumiem. Šajā kontekstā iedzīvotāju draudu uztvere, to intensitāte ir nozīmīgs drošỉbas politikas pilnveides pierādījums. Labas pārvaldības kontekstā daudz uzmanības tiek pievērsts iestāžu savstarpējai koordinācijai un spējai vienoties par koordinētu rīcỉbu ārkārtas situācijās. ${ }^{62}$

Vienlaikus labas pārvaldības elementi pētījumā tika uzlūkoti kā netiešie/ fona indikatori, kas ir saistīti ar drošības vidi un var iedarboties uz personas neapmierinātîbu un diskomfortu (piem., normatīvo aktu izmaiṇu biežums). ${ }^{63}$ Pārvaldības indikatori kā netiešie vai fona indikatori, ilgstošā periodā negatīvi iedarbojoties, var ietekmēt drošības uztveri. Tajā pašā laikā drošîbu tieši ietekmējošie indikatori (piem., drošība uz ielas vai bailes palikt bez darba) ir saistīti ar drošību un pastāvīgi iedarbojas uz drošības uztveri.

Tādējādi, balstoties uz teorētiskām nostādnēm par labu pārvaldỉbu, pētījumā sākumā tika noteikti nozīmīgākie labas pārvaldības elementi, kas atspoguḷo visu plašo pārvaldības jautājumu spektru:

- pārvaldības sistēmas stabilitāte, prognozējamība, pēctecība;

- plānošanas ilgtermiņa pieeja - ilgtermiņa redzējums;

- reformu jēgpilnums - ieviešanas efektivitāte;

- caurskatāmība;

- normatīvo aktu izmaiņas un to biežums;

- ierēdṇu profesionalitāte;

60 World Health Organization. Governance for health in the 21st century. 2012.

61 Ibid

62 Ibid.

63 Cole, G. A. (1997). Personnel Management: Theory and Practice. London: Greener Books, p. 78. 
- informētîba, kā rīkoties X stundā, preventīvās rīcībpolitikas veidošana;

- iestāžu darbības koordinācija.

Tālākajā izpētē šie pārvaldības elementi tika piemēroti drošỉbas sektoriem, kas savukārt secīgi veidoja pamatojumu interviju jautājumiem sarunās ar pašvaldību darbiniekiem un iegūto datu analīzei, salīdzinot ar iedzīvotāju drošỉbas uztveres rezultātiem. 2. tabulā atspoguḷoti pārvaldības indikatori atbilstoši dažādiem drošǐbas sektoriem.

Piektajā solĩ izvēlētas pašvaldības, kurās tika veiktas fokusa grupu intervijas. Fokusa grupu intervijas tika realizētas Ādažos, Daugavpilī, Gulbenē, Jaunjelgavā, Liepājā, L,audonā, Madonā, Rīgā (divas), Rēzeknē, Talsos. Fokusa grupu norises vietas bija izvēlētas tā, lai nodrošinātu plašu reǵionālo pārstāvniecību, kā arī bija nodrošināti dažādi geoogrāfiskie, sociālpolitiskie un ekonomiskie konteksti. Starp izvēlētajām apdzīvotajām vietām ir gan galvaspilsēta, gan republikas pilsētas ar pilsētu domēm un mazpilsētas ar novadu domēm, gan ciems, kurā darbojas pagasta pārvalde. Fokusa grupu diskusiju mērķauditorijas bija veidotas tā, lai maksimāli tiktu nodrošināta dažādu sabiedrības pārstāvju klātbūtne kā demogrāfiskā, tā arī ekonomiskā, sociālā un citās dimensijās. Tajās piedalijās visu vecumgrupu (sākot no 18 gadu vecuma) dažādu dzimumu pārstāvji ar atšķirīgu izglìtības līmeni, sociālo statusu un nodarbošanos, etnisko un religisko piederību. Katrā grupā bija ne mazāk kā astoṇi un ne vairāk kā 15 dalībnieki. Fokusa grupas moderēja šîs monogrāfijas autori, stingri sekojot pētijumā noteiktajam analīiskajam ietvaram un no tā izrietošajai pētnieciskajai log̣ikai. Fokusa grupu intervijas ilga ne vairāk kā pusotru-divas stundas un ne mazāk kā stundu.

Sestajā solī, balstoties uz iepriekš pamatotiem un izvēlētiem labas pārvaldỉbas elementiem un drošǐbas sektoriem atbilstošiem indikatoriem, veiktas intervijas ar visu to pašvaldību darbiniekiem, kurās iepriekš veiktas fokusa grupu intervijas ar iedzīvotājiem. Lai iegūtu salīdzināmus rezultātus, sākotnēji analizēti fokusa grupu dati katrā no pašvaldībām, izceḷot katrā no tām trīs nozīmīgākos draudu veidus, kurus nosaukuši un apsprieduši iedzìvotāji. Šie prioritārie apdraudējumi bija atskaites punkts, vērtējot pašvaldības darbinieku attieksmi pret tiem. Izpētes gaitā svarīgi konstatēt, vai pašvaldības darbinieku minētie riski un apdraudējumi sakrīt ar iedzīvotāju subjektīvi uztvertajiem. Pēc šìs informācijas ieguves pētỉjumā jānoskaidro, vai pašvaldības līmenī tiek veiktas darbības cilvēkiem svarīgajos sektoros un vai tiek vairota vai mazināta viṇu drošumspēja. Pašvaldības pārstāvju attieksme tika mērìta, realizējot padzị̣inātās, daḷēii strukturētās intervijas. Interviju laikā tika uzdoti jautājumi, kas ḷāva identificēt pašvaldības darbinieku skatījumu uz iespējamiem apdraudējumiem lokālajām kopienām, kas dzīvo pašvaldībās, to attieksmes pret katru 
2. tabula. Pārvaldības indikatori drošības sektoros

\begin{tabular}{|c|c|c|c|c|c|c|c|c|}
\hline 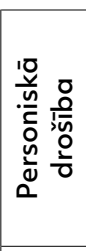 & 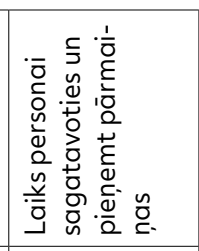 & 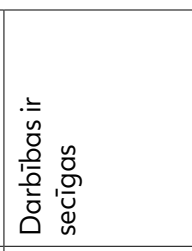 & 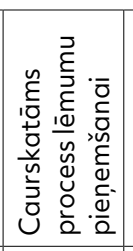 & 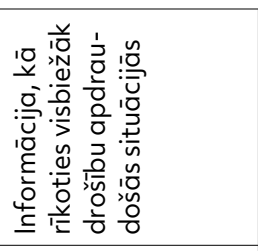 & 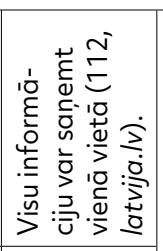 & \multirow{7}{*}{ 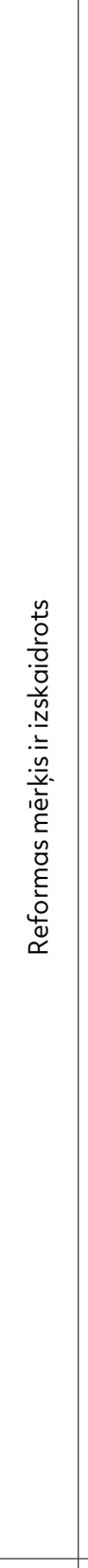 } & \multirow{7}{*}{ 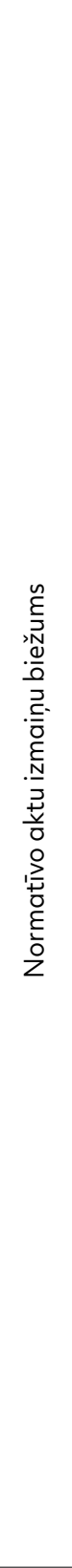 } & \multirow{7}{*}{ 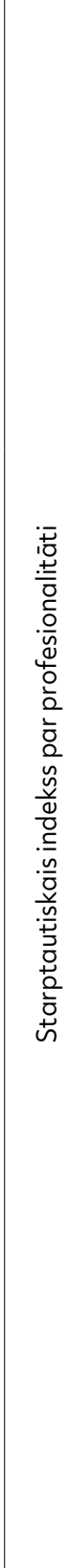 } \\
\hline 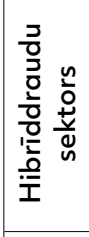 & 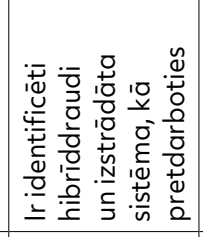 & 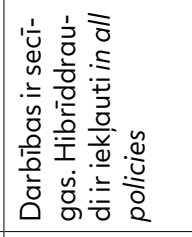 & 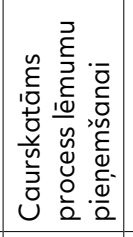 & 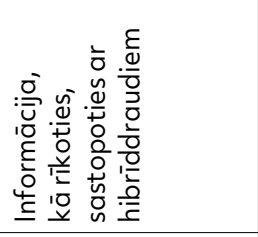 & 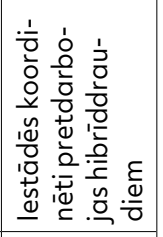 & & & \\
\hline 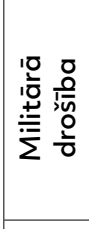 & 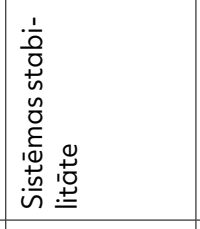 & 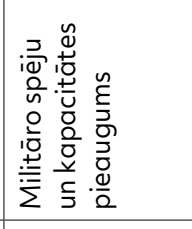 & 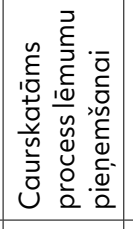 & 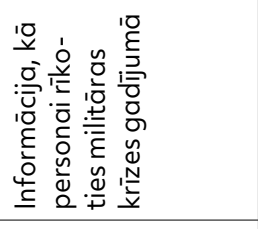 & 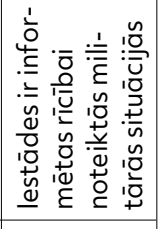 & & & \\
\hline 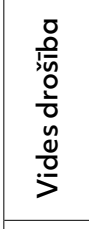 & 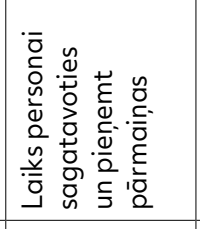 & 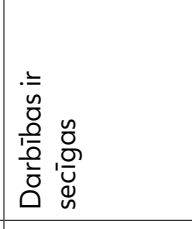 & 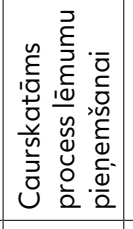 & 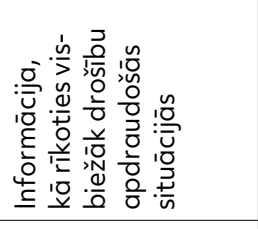 & 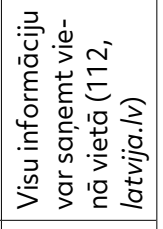 & & & \\
\hline 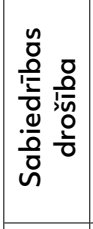 & 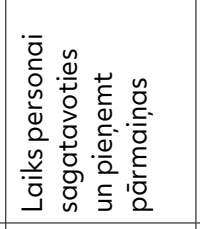 & 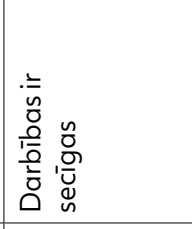 & 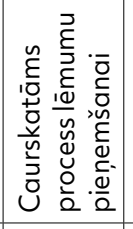 & 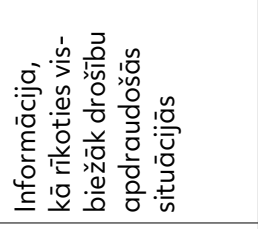 & 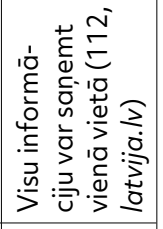 & & & \\
\hline 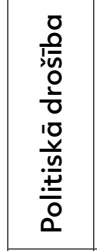 & 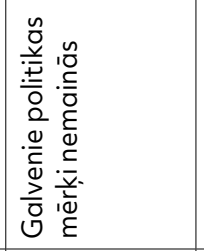 & 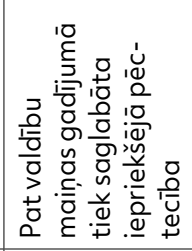 & 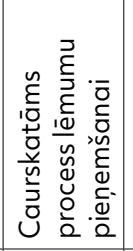 & 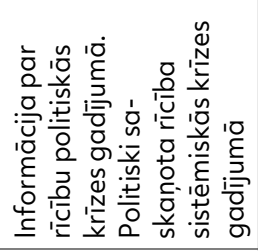 & 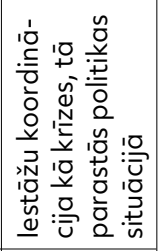 & & & \\
\hline 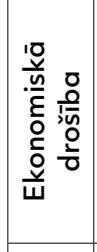 & 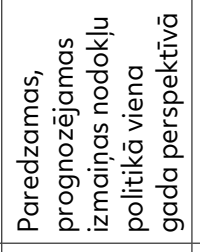 & 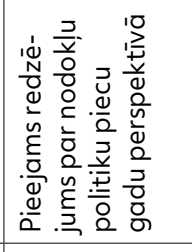 & 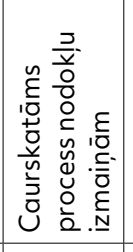 & 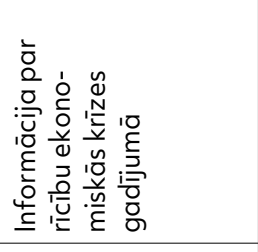 & 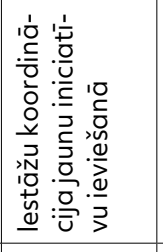 & & & \\
\hline & 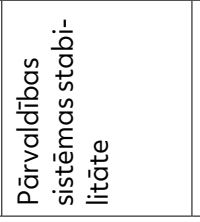 & 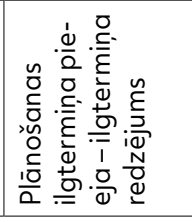 & 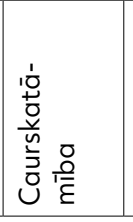 & 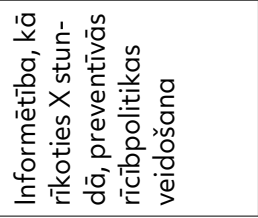 & 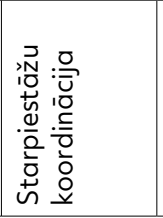 & 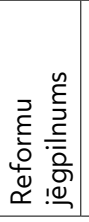 & 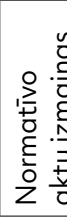 & 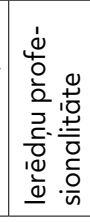 \\
\hline
\end{tabular}


no iedzīvotāju prioritizētajiem draudu veidiem fokusa grupu interviju laikā. Tāpat arī intervijās tika noteikts, vai pašvaldības darbinieki pieškirir vietējai pašvaldībai lomu draudu novēršanā un kāda tā ir, kā arī tika noskaidrots, kā tie vērtē vietējo un nacionāla līmeņa pārvaldes institūciju sadarbību. Lìdzās intervijām tika analizēti pašvaldības stratēgiskās plānošanas dokumenti un normatīvie akti, kas l̦āva ieskatīties pašvaldību realizētajās rīcībpolitikās draudu novēršanas kontekstā.

Pētījuma sestais un noslēdzošais solis ir saistīts ar secinājumu un rekomendāciju izstrādi, kuru veidošanā ir piedalījušies visi iesaistītie monogrāfijas autori.

\section{Secinājumi}

Lai arī drošîbas teorētisko un praktisko aspektu pētī̌sanai Latvijā un pasaulē ir senas tradīcijas, pēdējās desmitgadēs pieaugušo apdraudējumu un risku klāsts turpina piegādāt zinātniekiem un politikas veidotājiem arvien jaunus izziņas laukus. Spēju veikt visaptverošu un teorētiski pamatotu drošības situācijas analīzi ietekmē un arī kavē apdraudējumu avotu savstarpēja pārklāšanās un dinamiska transformācija. Piemēram, kādas sabiedrības grupas šķietami īslaicīga neapmierinātîba ar politisku lēmumu var pāraugt dusmās, kas izpaužas nemieru ierosināšanā, ko uzkurina sociālie mediji, un rezultātā šo situāciju izmanto nedraudzīgi ārvalstu spēètēàji. Šo situāciju varētu raksturot kā hibrīddraudu tālāku "hibridizāciju". Cilvēku emocijas, kas veidojas drošības uztveres rezultātā, atstāj iespaidu uz rīcībpolitiku formulējumu, pieņemšanu un ieviešanu pašvaldību un nacionālā līmenī, kā arī uz indivīdu personisko stratēǵiju un noturīguma izstrādi un lietošanu. Jo lielākā mērā valsts un kopienu līmeņa pārvalde reagêe uz iedzīvotāju bažām un bailēm, jo lielāka iespēja izveidot partnerības un sadarbības modeli ikdienas izaicinājumu risināšanā, kurš krīzes un ārēja apdraudējuma apstākḷos kalpo visaptverošās aizsardzības mērķiem. N̦emot vērā, ka drošỉbas subjektīvā uztvere raksturo sabiedrībā pastāvošo attieksmju daudzveidỉbu, tieši fokusa grupu intervijas ir viena no metodēm, kura atklāj iedzīvotājos valdošo emociju spektru. Apkopotie rezultāti un datu puduri no dažādiem Latvijas novadiem var sekmēt tādu rīcībpolitiku ieviešanu, kas atbilstu konkrētās kopienas vajadzībām. Rakstā piedāvātais metodologiskais rāmējums ir izmantots empīiskā pētỉjuma veikšanai un ir nodrošinājis rekomendāciju izstrādei bagātīgu informācijas klāstu, kas atspoguḷots grāmatas noslēgumā. 


\section{Ekonomiskā drošǐba}

HARIJS KĀRKLINŠ, GUNĀRS VALDMANIS

Raksta mērķis ir analizēt Latvijas iedzīvotāju ekonomiskās drošības uztveri. Tradicionāli ar to tiek izprasta indivīda spēja piekḷūt nepieciešamajiem resursiem izdzīvošanai un pilnvērtīgai funkcionēšanai sabiedrībā. Apskatot gan kvantitatīvos datus, gan iegūtos kvalitatīvos fokusa grupu rezultātus šajā pētījumā, redzams, ka ekonomiskās drošības sektoru Latvijas iedzīvotāji uztver dažādi. Viena no visbiežāk minētajām problēmām ir prognozējamība. Par to liecina tas, ka viskritiskāk tiek vērtēta nodokḷu politika. Sabiedrību satrauc ne tikai lielais nodokḷu slogs, bet arī biežās nodokḷu politikas izmaiṇas. Ekonomiskā drošība tiek uztverta primāri kā ekonomiskā stabilitāte - spēja veidot uzkrājumu, iegūt nepieciešamos finanšu resursus izdzīvošanai, pensijas sistēmas uzticamība. Saistībā ar pēdējo respondenti iezīmēja neticību pietiekamu finanšu līdzekḷu iegūšanai vecumdienās. Rakstā atzīmēts, ka vērojamas būtiskas atšķirības starp fokusa grupu un pašvaldību pārstāvju viedokḷiem. Pašvaldībās ar zemāku bezdarba līmeni iedzīvotāji starp būtiskākajām problēmām minēja nodokḷu sistēmu, uzṇēmējdarbības vidi, nestabilu finanšu sistēmu, savukārt pašvaldībās ar augstāku bezdarba līmeni - transporta nozari, darba vietu skaitu, kā arī zemu minimālo algu. Savukārt pašvaldību pārstāvji intervijās norādīja uz izaicinājumiem, kas saistās ar ES fondu iespējām/finansējumu un mājokḷu pieejamības nodrošinājumu, kamēr fokusa grupās šie jautājumi parādās reti vai neparādās vispār.

Atslēgvārdi: darba tirgus, ekonomiskās drošības uztvere, nodokḷu politika, pabalsti, pensiju sistēma, uzṇēmējdarbība.

The goal of the article is to analyse the economic security perception of Latvia's inhabitants. Traditionally, economic security perception is understood as the ability of individuals to access resources needed for physical survival and for wholesome functioning within society. Analysis of both quantitative and qualitative data obtained during the study revealed that strong differences in the perception of economic security are displayed 
among societal groups. In line with the opinions voiced by the majority of the interviewed respondents, the most acute problems (with the most significant detrimental effect on the economic security perception of society) in Latvia are the low predictability of economic policy, the relatively high burden of taxes on income, the frequent changes in tax policy, and the low reliability of the pension system. Most point out that their economic security perception is closely related to their economic stability specifically, the individual's ability to obtain economic means for survival, the ability to make savings, and to have access to sufficient financial resources after retirement. The interviews involved representatives from municipalities and societal groups in municipalities with distinct differences in economic and social development, and they suggest significantly divisive opinions among residents of economically stronger versus weaker municipalities. In municipalities with higher overall economic activity, residents identify the priority issues to be the stability of tax/financial systems and a strong entrepreneurial environment, while residents of municipalities with lower economic activity point out the accessibility of public transport, creation of jobs and guaranteed minimum income for workers. Meanwhile, municipal representatives outlined the main economic issues to be the availability of housing and access to state budget support and European Union funds for investments.

Keywords: labour market, economic security perception, tax policy, social benefits, pension system, entrepreneurship.

\section{levads}

Ekonomiskā drošība politikas pētỉjumos tradicionāli tiek izprasta kā indivīda spēja piekḷūt un sevi nodrošināt ar resursiem, kas nepieciešami indivīda izdzīvošanai, kā arī pilnvērtīgai funkcionēšanai sabiedrībā. ${ }^{1}$ Valsts gadījumā tā ir valsts spēja nodrošināt resursus ekonomiskās politikas īstenošanai, veicinot valsts iedzīvotāju ekonomisko un kopējo drošību. ${ }^{2}$ Ekonomiskā drošība ir cieši saistīta ar visām citām drošības jomām, piemēram, sociālo drošîbu, militāro drošību, kiberdrošību, jo daudzos gadijumos tieši primāro ekonomisko resursu pieejamība pasākumu veikšanai citās jomās ir izškiriroša tam, lai valsts spētu stiprināt savas militārās spējas, veicināt sociālo drošību, sekmīgi ierobežot un samazināt dabas katastrofu un citu līdzīgu drošības draudu sekas. ${ }^{3}$

1 Buzan, B. (1991). People, States and Fear: An Agenda for International Security Studies in the PostCold War Era. London: Harvester Wheatsheaf.

2 Stone, M. (2009). Security According to Buzan: A Comprehensive Security Analysis. Security Discussion Papers, 11.

3 Suarez, Marcial A. \& Acacio, I. (2014). Reflections on Virtual to Real: Modern Technique, International Security Studies and Cyber Security Environment. 10.1007/978-3-642-37481-4_15. 
Kā būtiskākie ekonomiskie resursi jeb faktori, kuru pieejamība visvairāk nosaka indivīda un valsts ekonomisko drošỉbu un ilgtermiṇā arī atstāj ietekmi uz valsts makroekonomisko attīstỉbu, ir jāmin šādi ekonomiskie resursi: brīvība nodarboties ar uzṇēmējdarbību un izvēlēties nodarbinātības jomu; stabila un uzticama monetārā sistēma; finanšu un kapitāla tirgus sistēma, kas nodrošina nepieciešamos aizṇēmumus indivīdiem un uzṇēmumiem, kā arī nodrošina iespēju veikt drošus uzkrājumus; prognozējama un attīstīta nodokḷu sistēma. ${ }^{4}$ Ir būtiski atzīmēt, ka ievērojama ietekme uz ekonomikas attīstību un ar to saistīto ekonomisko drošîbu ir ne tikai uzskaitītajiem faktoriem, bet arī iedzīvotāju subjektīvajai uztverei un attieksmei pret minētajiem ekonomiskajiem resursiem - piemēram, ja sabiedrībā valda viedoklis, ka konkrētas valsts nodokḷu slogs ir augsts un netaisnīgs, tas būtiski ietekmē sabiedrības uzņēmējdarbības aktivitāti, ēnu ekonomikas īpatsvaru un iedzīvotāju mobilitāti darba tirgū, un tā iespaidā ir iespējama situācija, ka valstīs ar līdzīgu uzṇēmējdarbības vispārējo regulējumu un līdzīgu nodokḷu slogu uz ekonomiku sabiedrības kopējā ekonomiskā aktivitāte būtiski atškiriras. ${ }^{5}$ Svarīgi arī atzīmēt, ka ekonomiskā drošība visos gadījumos ir cieši saistīta arī ar citām drošỉbas jomam un, piemēram, sabiedrības ekonomiskās drošības uztvere var būtiski mainīties arī citu drošības aspektu pārmaiṇu rezultātā, kā arī ietekmēt sabiedrības drošības uztveri citās drošības jomās.

Šì raksta mērkịis ir, balstoties uz iedzīvotāju fokusa grupās veiktajām intervijām, iegūt priekšstatu par Latvijas iedzīvotāju ekonomiskās drošības uztveri un par to, cik no ekonomiskās drošības viedokḷa droši jūtas dažādu Latvijas pilsētu iedzīvotāìi, identificējot problēmas, kuras Latvijas iedzīvotāju skatījumā ekonomiskās drošỉbas jomā ir vērtējamas kā aktuālākās, un cik lielu nozīmi šo ekonomiskās drošîbas problēmu risināšanā iedzīvotāji pieškir valstij un pašvaldībai, kā arī aprakstìt atškirības un to iespējamos cēloṇus, kas vērojamas dažādu Latvijas pašvaldību iedzīvotāju ekonomiskās drošỉbas uztverē.

\section{Kas paveikts ekonomiskās drošības izpētē?}

Ekonomiskā drošība ir viena no jomām, kurā tiek veikti gan regulāri sabiedrïbas attieksmes mērījumi, gan arī ekonomisko indikatoru apkopošana un analīze, kas nepieciešamas, lai izprastu indivīda drošības subjektīvo uztveri.

4 Tamošiūnienè, R. \& Munteanu, C. (2015). Current research approaches to economic security, pp. 62-65. 10.4995/ICBM.2015.1537.

5 Roberto Dell'Anno (2009). Tax evasion, tax morale and policy maker's effectiveness. The Journal of Socio-Economics, 38(6), pp. 988-997. Pieejams: https://doi.org/10.1016/j.socec.2009.06.005. 
Ar augstu regularitāti un pēc vienotas metodologijas iedzīvotāju un uzņēmēju viedokḷa aptaujas un noskaņojuma mērïjumi tiek veikti visā Eiropas Savienībā (ES). Tas ļauj šajā pētỉjumā iegūtos datus un viedokḷus salīdzināt ar līdzīgu pētījumu datiem. Šajā pētījumā par būtisku atskaites punktu var uzskatīt 2019. gada rudenī Eirobarometra (Eurobarometer) veikto ES iedzīvotāju aptauju par nozīmīgākajiem draudiem, ar kuriem saskaras ES un tās dalībvalstis. ${ }^{6}$ Aptaujā ES iedzīvotājiem tradicionāli tikai uzdoti jautājumi par ekonomisko situāciju un diviem lielākajiem draudiem, ar ko nākas saskarties ES kopumā un dalībvalstīs atseviški.

1. attēlā ir redzams, ka Latvijas iedzīvotāji savu personisko situāciju vērtē līdzvērtīgi kā visi ES dalībvalstu pilsoṇi (darba jomā pat nedaudz augstāk), tomēr kopējo valsts situāciju vērtē negatīvāk.

Ja salīdzina aptaujā norādītās atbildes un jautājumiem par galvenajām problēmām, ar ko saskaras ES kopumā un attiecīgā dalībvalsts, redzams, ka Latvijas iedzīvotāji ekonomikas jomas problēmas uztver prioritārāk nekā ES iedzīvotāji, ja jautājums ir par pašu dalībvalsti, nevis ES kopumā. Aptaujā tika piedāvāti 13 dažādi atbilžu varianti par aktuālāko ES problēmu, un seši no tiem ir saistìti ar ekonomisko drošību plašākā izpratnē (ekonomiskā situācija, dalībvalstu publisko finanšu stāvoklis, nodarbinātība, inflācija / augošās izmaksas, pensijas, nodoklii).

2. attēlā redzams, ka, salīdzinot ar ES valstīm kopumā, Latvijā iedzīvotāju viedoklis par problemātiskākajiem jautājumiem ekonomiskās drošības jomā būtiski neatšḳiras no ES dalībvalstu iedzīvotāju viedokḷa vidēji, - tādu iedzīvotāju skaits, kuri ar ekonomiku saistìtus jautājumus min starp ES nozīmīgām problēmām, ir bijis līdzīgs un nedaudz zemāks nekā Eiropas Savienībā kopumā, vienlaikus nedaudz pesimistiskāk vinii vērtē nodokḷu sistēmas problēmas, bet nedaudz optimistiskāk - nodarbinātības situāciju.

3. attēlā atspoguḷoti ES dalībvalstu lokālie kritiskie jautājumi, kuri, pēc iedzīvotāju domām, ir visnozīmīgākie un ir saistīti ar ekonomikas jomu. Ja salīdzina ar ES vidējo situāciju, tad redzams, ka jautājumi, kas saistīti ar ekonomiku un finansēm, vairāk satrauc Latvijas, nevis citu valstu iedzīvotājus. Kā galveno kritisko problēmu Latvijā 43\% tās iedzīvotāju norādījuši "Veselību un sociālo drošîbu”. Kā otru galveno - inflāciju / augošās izmaksas (29\%), savukārt 3. vietā ir nodokḷi (24\%, tas ir 2. augstākais rādītājs ES aiz Lietuvas, ar kuru kopā Latvija ir vienīgās dalībvalstis, kuru iedzīvotāii norādīja uz nodoklịem kā starp trim galvenajiem problemātiskajiem jautājumiem). Analogas

6 European Commission (2018). Europeans' attitudes towards cyber security. Pieejams: https://op. europa.eu/en/publication-detail/-/publication/468848fa-49bb-11ea-8aa5-01aa75ed71a1 


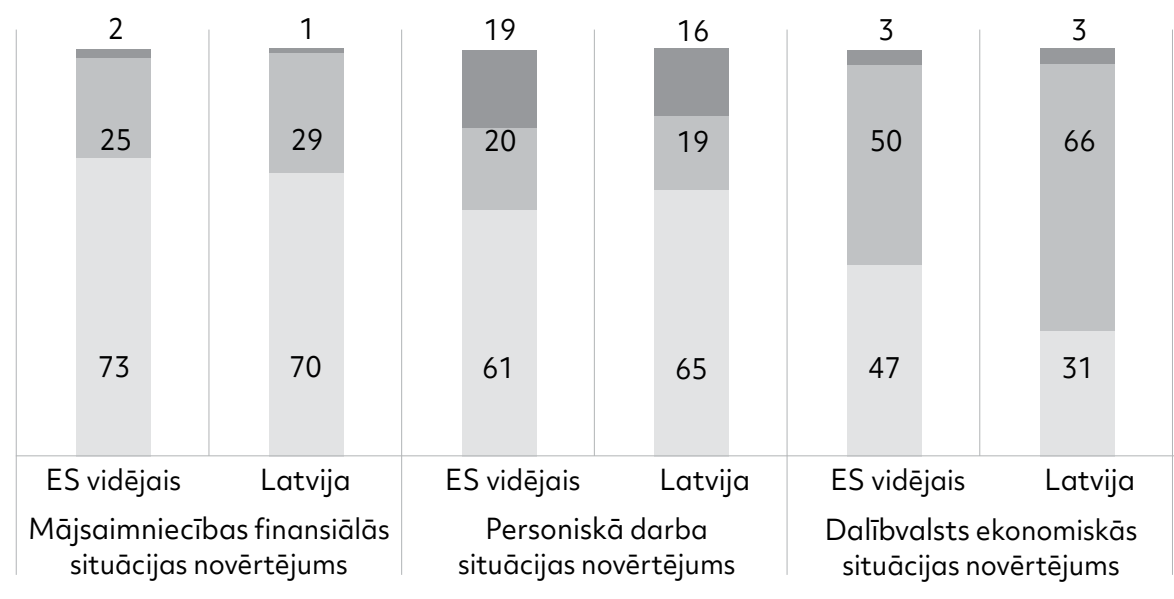

Labi Slikti $\quad$ Nezinu

1. attēls. ledzìvotāju ekonomiskās situācijas novērtējuma salīdzinājums starp ES dalībvalstu vidējo un Latviju, \%

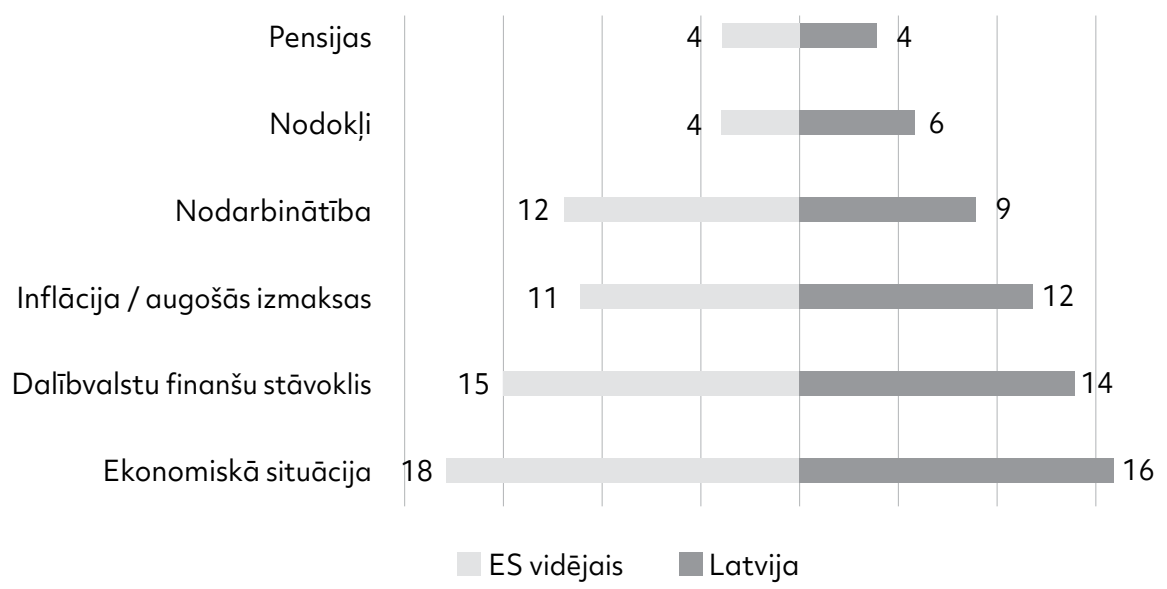

2. attēls. Ekonomikas jomas galvenie jautājumi, ar ko pašlaik saskaras Eiropas Savienība kopumā, iedzīvotāju vērtējumāā, \%

būtiskākās problēmas Latvijas iedzīvotāji bija minējuši arī 2019. gada pavasara Eirobarometra aptaujās, turklāt nodokḷu sistēma kā problēma 2019. gada pavasarī Latvijā, salīdzinot ar citām ES dalībvalstīm, tika minēta visbiežāk. ${ }^{7}$

7 Eurobarometer 91 (2019. gada pavasaris). Pieejams: https://data.europa.eu/euodp/lv/data/dataset/ S2253_91_5_STD91_ENG 


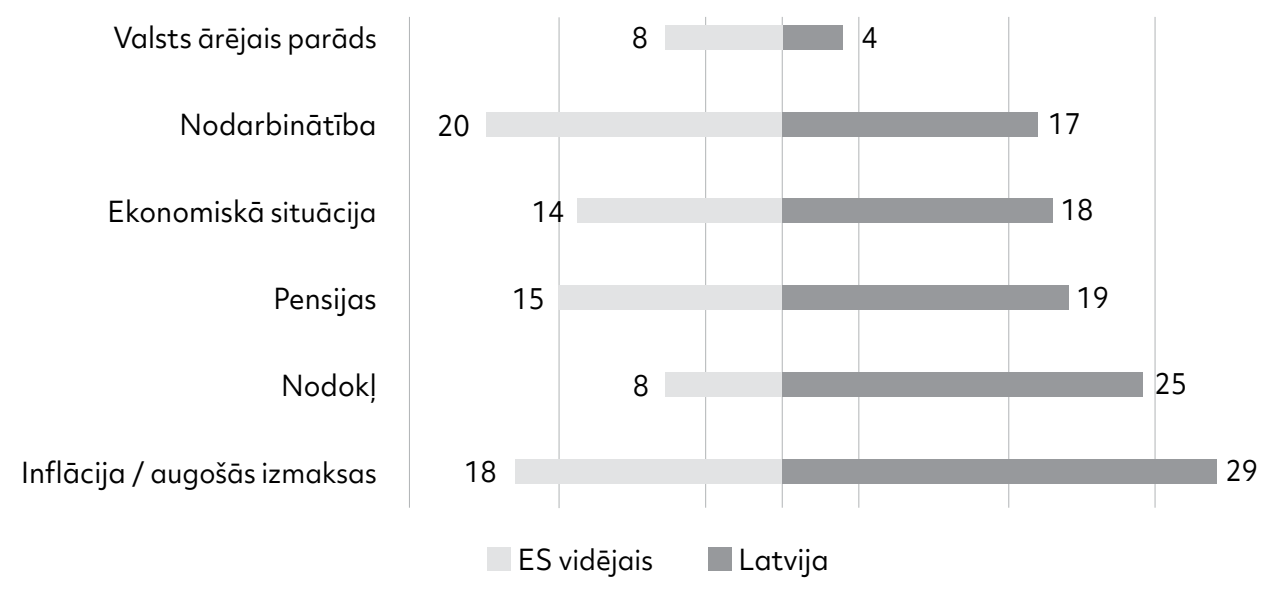

3. attēls. Ekonomikas jomas galvenie jautājumi, ar ko pašlaik saskaras ES dalībvalstis, to iedzivotāju vērtējumā, \%

Padziḷinātāku ieskatu apsvērumos, kuri Latvijas iedzīvotājus mudina ekonomiskās drošības problēmas uzskatīt par kopumā sev nozīmīgākām, nekā uzskata citu ES valstu iedzīvotāji, sniedz arī vairāki Latvijā veikti pētỉjumi un sabiedriskās domas aptaujas, kur norādīts, ka, gan pēc pašu iedzīvotāju, gan arī pēc ekonomistu vērtējuma, Latvijā ir salīdzinoši augsts iedzīvotāju nabadzības risks un ienākumu nevienlīdzība. 2019. gada aprīlī publicētais Centrālās statistikas pārvaldes pārskats par ienākumiem apliecina, ka, par spīti vidējās algas pieaugumam tautsaimniecībā, aug arī to iedzīvotāju skaits, kas ir pakḷauti nabadzības riskam, - šis rādītājs 2019. gadā sasniedzis 23,3\% pretstatā 19\% 2010. gadā. Lai gan 2020. gada janvārī publicētie analoǵiskie pētỉjuma dati uzrāda nelielu uzlabojumu un nabadzības riskam pakḷauto iedzīvotāju skaita samazināšanos līdz 22,9\%, rādītājs joprojām ir vērtējams kā augsts.

Nabadzības riskam pakḷauto iedzīvotāju grupu padzilināăta analīze norāda uz to, ka šādu iedzīvotāju īpatsvars visstraujāk palielinās pensijas vecumu sasniegušu cilvēku vidū, savukārt tas samazinās gados jauniem cilvēkiem ar bērniem un vienas personas mājsaimniecībām darbspējīgajā vecumā. Kā būtiskas nabadzības risku raksturojošas pazìmes pētỉjumā var identificēt augstu sociālo transfertu īpatsvaru mājsaimniecību ieṇēmumu grozā, jo kopumā sociālo transfertu apjoma pieaugums ir lēnāks nekā daudzu citu makroekonomisko rādìtāju pieaugums, piemēram, vidējo darba algu pieaugums un patēriņa cenu pieaugums, starpības palielināšanās starp vienam mājsaimniecības loceklim nepieciešamo un faktiski pieejamo ienākumu apjomu (555 EUR pretstatā 488 EUR) ḷoti būtiskā skaitā mājsaimniecību (aptuveni $70 \%$ no visām 
mājsaimniecībām). Tāpat arī jāmin pazīme, kas ir raksturīga augstam nabadzības riskam, - iedzīvotāju nespēja segt neparedzētus izdevumus un finansēt ilglietojamo patēriņa preču iegādi, piemēram, mēbel̦u iegādi. ${ }^{8}$

Veiktie pētījumi par nabadzības riskam pakḷauto iedzīvotāju skaitu ir būtiski, jo, pirmkārt, tie ḷauj precizēt iedzīvotājiem aktuālās problēmas un iegūt vispārīgu ieskatu par iedzīvotāju attieksmi pret tām un, otrkārt, tie ḷauj arī identificēt un nodalìt vairākas atsevišķas iedzīvotāju grupas, kurām ir atšķirīgas ekonomikas drošības problēmas, un padzilinināti novērtēt šo sabiedrības grupu atbildes jau tālākajā pētījuma gaitā. Iepriekšējie pētījumi par nabadzības risku ḷauj izcelt divas būtiski atšķirīgas iedzīvotāju grupas, kurām aktuālie ekonomiskās drošības izaicinājumi ievērojami atšķiras, - ekonomiski aktīvos iedzīvotājus darbspējīgā vecumā, kā arī ekonomiski mazāk aktīvo sabiedrības dalıu, piemēram, pensiju saņēmējus un atsevišķos gadījumos mājsaimniecības ar bērniem, kurās ir tikai viens pieaugušais, kā arī iedzīotājus ar zemāku izglìtības un profesionālās sagatavotības līmeni. Atsevišķi ir vērtējams apstāklis, ka atbilstoši pētỉjumu rezultātiem joprojām satraucoši augsts ir arī tādu iedzīvotāju īpatsvars, kuru mājsaimniecības, par spīti aktīvai dalībai darba tirgū, gūst ieņēmumus tikai minimāli nepieciešamajā apjomā uz vienu mājsaimniecíbas locekli vai pat zem šì apjoma.

\section{Ekonomiskās drošības jēdziens}

Ekonomisko drošỉbu kā vienu no drošỉbas politikas aspektiem plašāk un padziḷinātāk ir definējis angḷu politologs, drošības jautājumu pētnieks Barijs Buzans (Barry Buzan), kurš zināmā mērā pārskatijja tradicionālo pieeju ekonomiskās drošỉbas izpratnei par to, ka ekonomiskā drošỉba ir, pirmkārt, valsts ekonomiskā kapacitāte nodrošināt nepieciešamo finansējumu aizsardzības spējām un militārajam sektoram. Buzans ekonomisko drošību saista ar pieeju svarīgākajiem resursiem, finansēm un tirgiem, kuri ir nepieciešami, lai valstī nodrošinātu pieņemamu labklājības un varas līmeni. ${ }^{9}$ Vienlaikus autors atzīmē ekonomiskās drošības abstrakto un nekonkrēto raksturu, uzsverot, ka ekonomiskās drošības izpratnes definēšanu konkrētā valstī var ietekmēt gan atsevišķu iesaistīto pušu attiecības ar tirgu, gan individuālās vēlmes, gan arī dialogs starp iesaistītajām pusēm, politikas veidotājiem, piemēram, valsts pārvaldes

8 Vairāk nekā trešdaḷa mājsaimniecību nemaina mēbeles, kad tās ir nolietotas, ap 60\% mājsaimniecību 2018. gadā nevarēja atḷauties segt neparedzētus izdevumus līdz 320 eiro.

9 Buzan, B. (1991a). People, States, and Fear: The National Security Problem in International Relations. Wheatsheaf Books Ltd. 
struktūrām un politiskajām organizācijām, un ekonomiski aktīvo sabiedrības daḷu, darba devējiem un ñēmējiem. ${ }^{10}$

Savukārt Amerikas Universitātes Starptautiskā dienesta skolas docents Mamuka Ceretelli (Mamuka Tsereteli) uzsver ekonomisko drošības ilgtspējas nozīmi un pasvītro, ka valstu ekonomiskā drošỉba ir ilgtermiņa pieeja ekonomiskajām iespējām tirgū un nepieciešamajiem resursiem, ieskaitot cilvēkus, kapitālu, enerǵiju, ūdeni, tehnoloǵijas un izglîtību. ${ }^{11}$ Vienlaikus pētnieks lielu nozīmi piešķir arī ekonomiskajai brīvībai, proti, sabiedrības locekḷu tiesībai un iespējām brīvi izvēlēties savas ekonomiskās aktivitātes, kā arī valsts spējai îstenot politiku, kas stabilizē ekonomiku un labklājību. Treškārt, Ceretelli kā būtisku ekonomiskās drošības aspektu saskata arī valsts spēju aizstāvēt savas un tās iedzìvotāju un uzṇēmēju ekonomiskās intereses attiecībās ar citām valstīm. Tāpat pētnieku, piemēram, Brendas Horiganas (Brenda L. Horrigan) un Teodora Karasika (Theodore Karasik), darbos ekonomiskā drošiba tiek cieši saistīta arī ar citu drošības politikas jomu veiksmīgu isstenošanu - tiek uzsvērts, ka ekonomiskās drošības samazinājums negatīvi ietekmē, piemēram, sociālo drošỉbu, samazina sabiedrības uzticēšanos valsts pārvaldei un vēlētajiem politiķiem, kā arī var pamudināt sabiedrību mazāk aktīvi atbalstīt valsts īstenoto politiku ārējās drošības jomā (var būt spiediens samazināt aizsardzības izdevumus vai pārskatīt valsts īstenoto ārpolitiku attiecībās ar ārpolitiskajiem partneriem).

Tāpēc šajā pētijumā ekonomiskās drošỉbas uztveres analīzei, balstoties uz iepriekš aprakstìtajiem datiem un teorētiskajiem pètījumiem, ir izvēèèti šādi sabiedrības ekonomiskās drošības uztveres aspekti ar attiecīgajiem pamatojumiem:

1) iespējas brīvi iesaistīties darba tirgū un nodarboties ar uzṇēmējdarbību - liecina par iedzīvotāju ekonomisko pratību, tautsaimniecības spēju pielāgoties iekšējām un ārējām pārmaiṇām, kā arī valsts ekonomisko izaugsmi un iedzīvotāju ienākumu līmeni;

2) tautsaimniecības struktūras ilgtspēja un spēja pielāgoties lokālām un globālām pārmaiṇām - diversificētām valstu ekonomikām ir ievērojami augstāka spēja pārvarēt krīzes, jo būtiskākā daḷa no tām parasti smagāk skar atsevišķas tautsaimniecỉbas nozares. Piemēram,

10 Buzan, B., Waever, O. and de Wilde, J. (1998). Security: A New Framework for Analysis, Lynne Rienner Publishers, Inc, Boulder, Colorado.

11 Tsereteli, M. (2008). Economic and Energy Security: Connecting Europe and the Black Sea-Caspian Region. Central Asia-Caucasus Institute and Silk Road Studies Program, Singapore. Pieejams: http://www.silkroadstudies.org/resources/pdf/SilkRoadPapers/2008_03_SRP_Tsereteli_EnergyBlack- Sea.pdf [Skatīts 30.04.2020.] 
lauksaimniecības nozari proporcionāli būtiskāk skar tieši dabas apstākḷi, savukārt tūrisma un naftas ieguves nozares - drošības situācijas pasliktināšanās, tāpēc no valstu ekonomiskās stabilitātes viedokḷa ir būtiski, lai tās lielāko daļu nodarbinātības un ieṇēmumu neveidotu viena šauri specifiska ekonomiskā aktivitāte;

3) valsts spēja ierobežot globālu ekonomisko norišu negatĩvo ietekmi uz tautsaimniecību un spēja gūt pēc iespējas lielāku labumu no pozitīvām globālām ekonomiskām norisēm - raksturo kopējo ekonomiskās politikas efektivitāti un elastību, piemēram, spēja un gatavība novērtēt ārējo konkurētspēju noteicošos faktorus un veikt tiem atbilstošas korekcijas normatīvo aktu bāzē un faktiskajā valstu rīcībpolitikā, piemēram, veicinot ārējo tirdzniecỉbu ar jauniem ārējās tirdzniecības partneriem;

4) nodokḷu sistēmas un publiskās pārvaldes ietekme uz uzṇēmējdarbỉbu un ekonomisko aktivitāti - priekšnosacijums tam, lai valstī veidotos uzņēmējdarbībai labvēlīga vide un lai iedzìvotāju vērtējumā nodokḷu slogs un tiesiskais regulējums motivētu indivīdus sākt patstāvīgu uzṇēmējdarbību vai profesionālo darbību augsti atalgotā tautsaimniecības jomā;

5) valsts sociālo transfertu sistēma - pensija un pabalsts sociāli neaizsargātākajai daḷai ir galvenais vai nereti vienīgais ienākumu avots. Šīs sistēmas efektīva funkcionalitāte veicina iedzīvotāju daḷas izkḷūšanu no nabadzības riska zonas;

6) finanšu sistēmas drošība un spēja iegūt finanšu aizdevumu, uzkrājumus - kredītiestāžu sistēmu drošība ir būtiska, lai garantētu iedzīvotājiem drošỉbu. Savukārt informācija par finanšu aizdevumu pieejamību ilgtermiṇa lietošanas preču un mājokḷu iegādei sniedz salīdzinoši objektīvāku ieskatu par to, cik stabili, prognozējami un pietiekami primāro vajadzību apmierināšanai ir iedzīvotāju ienākumi. Turklāt spēja saṇemt finanšu aizdevumu mājokḷa iegādei būtiski ietekmē arī indivīda nākotnes ekonomiskās drošības novērtējumu, jo mājokḷa iegādi ar finanšu aizdevumu palīdzību var uzskatīt par iespēju vairot ekonomisko labklājību, savukārt mājokḷa īre lielākajā dạ̦ā gadījumu tikai apmierina indivīda primārās vajadzības, nenodrošinot ekonomisko resursu uzkrāšanas iespēju. 


\section{Latvijas iedzivotāji par ekonomisko drošību}

Pētỉjuma gaitā fokusa grupās iegūtie iedzīvotāju viedokḷi apstiprināja citos pētỉjumos gūtos novērojumus par to, ka Latvijas iedzīvotāji ekonomisko drošîbu uzskata par vienu no nozīmīgākajiem drošības aspektiem un kopumā dažādās fokusa grupās iegūtie iedzīvotāju viedokḷi norāda, ka ekonomiskās drošības uztveres atšķirības iedzīvotāju vidū dažādās pašvaldībās un reǵionos ir nebūtiskas. Praktiski visās fokusa grupās uz jautājumu "Ko jums nozīmē drošība?" bieži tika saṇemtas tādas atbildes kā "ekonomiskā stabilitāte", "finansiālā drošība", "materiālā stabilitāte un fiziskā drošība". Ekonomiskā stabilitāte kā drošỉba tika minēta astoṇās no 12 fokusa grupām, ${ }^{12}$ kḷūdama par vienu no visbiežāk sastopamajām frāzēm.

Iedzīvotāji izsaka neapmierinātību ar algām, pensijām, pabalstiem, nodokḷu politiku un citiem faktoriem. Turklāt ekonomiskā sektora nozīmīgums parādās arī, vērtējot situāciju citu jomu drošībā, piemēram, sociālajā drošîbai, vides drošībā, militārajā drošībā, jo tiek uzsvērts, ka ekonomiskā drošība ir būtiskākais priekšnosacījums tam, lai sabiedrība un valsts pārvaldes struktūras spētu veikt nepieciešamos pasākumus vides un dabas katastrofu apdraudējumu novēršanai, militāro draudu samazināšanai un sociālās drošības instrumentu stiprināšanai.

Vīrietis, Aizkraukle: Klimata pārmaiņas neuztveru kā draudu savai personiskajai drošizai. Nešksiet, ka tas uz mani attiecas, un neuzskatu, ka tā būtu Latvijā ḷoti milzīga problēma. Latvijai tas drīzāk noteiktās jomās nāktu par labu. Palielināsies ražība, pazemināsies cilvēku slimošana ar ziemas perioda slimībām. Mazāki rēkini par apkuri.

Vīrietis, Jaunjelgava: Cilvēk' iestājas NBS dēl naudas.

Neskatoties uz ekonomiskās drošības jautājumu augsto prioritāti praktiski visās pašvaldībās, kurās tika veikts pētījums, dažās ievērojami atšķīās izpratne par nozīmīgākajām problēmām un resursu pieejamību to risināšanai pašvaldībās ar augstākiem vidējiem ienākumiem un zemāku bezdarba līmeni (Aizkraukle, Rīga) iedzīvotāji starp būtiskākajām problēmām minēja nodokḷu sistēmu, uzṇēmējdarbības vidi, stabilu finanšu sistēmu, kā arī darbaspēka emigrāciju, savukārt pašvaldībās ar salīdzinoši augstāku bezdarba līmeni (Rēzekne, Daugavpils) būtiskas problēmas bija atsevišķu ekonomikas sektoru darbības rezultāti (piemēram, transporta nozare), darba vietu skaits, iedzīvotāju emigrācija, kā arī zema minimālā alga. 
Tālāk tiek sīkāk aprakstīti iegūtie rezultāti pa dažādām ekonomikas jomām, kuras iedzīvotāji fokusa grupās minējuši visbiežāk, - finanšu un banku sistēma, darba tirgus, nodokḷ sistēma un administratīvais slogs, publiskās investīcijas, reǵionālās attīstības politika, kā arī sociālās apdrošināšanas sistēmas darbiba.

\section{Ekonomiskā stabilitāte - ienākumi un uzkrājumi}

Kā atsevišķs ekonomiskās drošības riska faktors, kuru salīdzinoši bieži pieminējuši iedzīvotāji lielākajā dạ̦ā pašvaldību, ir ekonomiskā stabilitāte, kas tiek saistīta gan ar iedzīvotāju un uzṇēmēju iespējām veikt aizṇēmumus un veidot uzkrājumus, gan ar iedzīvotāju iespējām izpildīt uzņemtās saistības. Kopumā finanšu sektora stabilitāte iedzīvotāju skatījumā ir apmierinoša. Lai gan finanšu sektorā ir vērojami skandāli un ekonomiskās grūtības, iedzīvotāji riskus, kas ir saistīti ar kredītiestāžu darbu, vērtē kā iespējamus, tomēr maz ticamus. Kredītiestāžu darbības satricinājumu risks iedzīvotāju vērtējumā ir uzskatāms par zemu galvenokārt tāpēc, ka finanšu sektors daḷēji tiek uzraudzìts arī Eiropas Savienības līmenī, turklāt valsts noguldïjumu garantiju sistēma būtiski samazina iedzīvotāju riskus saistībā ar uzkrājumu drošību kredītiestādēs.

Savukārt par kritisku problēmu tiek uzskatìta iedzīvotāju nespēja pildīt savas saistības, it īpaši īstermiņa kredītu gadījumā, un, pēc aptaujāto domām, salīdzinoši liberāla valsts un uzṇēmēju politika ir veicinājusi nesamērīgi dārgu un pārāk viegli pieejamu kredītu izsniegšanu iedzīvotājiem, šādi apdraudot sabiedrības ekonomisko drošību, veicinot mazāk turīgo sabiedrības locekḷu maksātnespēju un sekojošu emigrāciju. Iedzīvotāji nereti norāda uz to, ka ekonomiskā stabilitāte ir galvenā problēma, jo

a) ja nebūs līdzeklu, cilvēkus vieglāk pamudināt uz kaut kādām darbībām;

b) tie, kas aizbrauc [strādāt uz ārzemēm], negrib mainìt ekonomisko stabilitāti pret dzimtenes mīlestību.

Vairākās fokusa grupās (piemēram, Ādažos, Jaunjelgavā un Aizkrauklē) pensijas vecuma iedzīvotāji norādīja, ka kopumā ilgtermiṇā neuzticas valsts pensiju sistēmai, jo prognozēe, ka, migrācijas rezultātā pakāpeniski samazinoties darbspējīgo iedzīvotāju skaitam valstī, budžeta ieņēmumi kḷūs nepietiekami, lai nodrošinātu pensiju sistēmas tālāko darbību. Tāpat atsevišḳās fokusa grupās (piemēram, Aizkrauklē) tika kritizēta pansionātu kvalitāte. Bez tam četrās fokusa grupās respondenti arī norādīja, ka nākotnē būtiski nepaḷaujas uz iespēju, ka iztikai nepieciešamos līdzekḷıs vecumdienās varētu nodrošināt tuvinieku, piemēram, bērnu, atbalsts. Atsevišķ̧os gadījumos iedzīvotāji atzīst, ka ilgtermiṇā ekonomisko drošību veicinātu arī uzkrājumu veidošana, tomēr, 
viņuprāt, nepietiekamu ienākumu dēl šobrīd šādas iespējas ir ierobežotas lielai dal̦ai sabiedrības. Kopumā pašvaldībās arī izskan iedzīvotāju viedoklis, ka minēto iemeslu dẹl kopumā iedzīvotāju labklājỉba var pasliktināties, - kā norāda kāda intervēta sieviete no Talsiem, nabadzība plauks. Vienlaikus pietiekami bieži izskan iedzīvotāju viedokḷi arī par to, ka ekonomiskās drošības nodrošināšana lielā mērā ir arī viṇu pašu atbildība un par savu ekonomisko labklājỉbu un ienākumiem iedzīvotājiem ir jārūpējas, plānojot savu nākotnes karjeru un izvēloties arī dzīvesvietu. Piemēram, vīrietis no Madonas uzsver, ka dą̧a iedzīvotāju, ņemot vērā atalgojuma apsvērumus, labprāt iestājas Nacionālajos bruṇotajos spēkos.

Ir vērojams arī, ka pašvaldībās ar augstāku dzīves līmeni un zemāku bezdarbu iedzīvotāji biežāk uzskata, ka ekonomiskā labklājība un ekonomiskā drošība primāri ir uzskatāmas par indivīda atbildību, ieskaitot uzņēmējdarbību, darba vietu radīšanu, noteikta ienākumu līmeņa uzturēšanu, savukārt valstij un pašvaldībai ir jānodrošina nepieciešamie priekšnosacijumi, lai indivīds spētu sevi ekonomiski realizēt, veicinot iedzīvotāju iesaistīšanos uzṇēmējdarbībā vai arī augstas profesionālas kvalifikācijas iegūšanu.

Savukārt pašvaldībās ar zemāku ienākumu līmeni un augstāku bezdarba līmeni iedzīvotāji salīdzinoši biežāk ir pauduši viedokli, ka viņu ekonomiskā labklājỉba un uzṇēmējdarbības attīstìba ir primāri valsts un pašvaldību atbildība, kurām ideālā gadījumā būtu jāgarantē iedzīvotāju spējām un prasmēm atbilstošu darba vietu pieejamība. Pamanāmas bija arī atšķirības, kā iedzīvotāji izprot uzṇēmējdarbības nozīmi ekonomikas drošības veicināšanā, - pašvaldībās ar augstu ienākumu līmeni un zemu bezdarbu uzṇēmējdarbība tika primāri uztverta kā nozīmīgākais ekonomiskās labklājības un drošības dzinējspēks un neatṇemama kopējās saimnieciskās dzīves sastāvdaḷa, turpretī pašvaldībās ar augstāku bezdarbu biežāk vērojama pretrunīga un duāla attieksme, uzṇēmēji nereti tiek pretnostatìti darba ņēmējiem, tiek uzsvērts īpašs uzn̦ēmēju pienākums rūpēties par pārējo sabiedrību līdzīgi kā valstij un pašvaldībām un netieši pausts viedoklis, ka valstij un pašvaldībām ir jāuzrauga, lai uzṇēmēji šo pienākumu pildītu.

Respondenti no Gulbenes: Darbu nevar atrast, tāpēc padomju laiks bija mierīgāks.

Jädomā pašvaldībām, valstìm, kā taisìt darba vietas, nevis izklaides vietas.

Finanšu sektors ir visnestabilākais. Privāto firmu aiztaisa ciet - darbinieki zaudē darbu. Valsts darbinieku sektorā situācija it kā ir stabilāka/drošāka.

Pretrunīgāks viedoklis ir par pabalstiem, kas tiek izmaksāti nenodarbinātām personām. Lai gan tiek kritizēta indivīdu ienākumu un uzkrāšanas 
iespējas kopumā valsts līmenī, tieši pabalstu izmaksāšana tiek kritizēta kā pārāk dāsna un izškēèdīga, jo neveicina nodarbinātību, tieši pretēji - motivē cilvēkus nestrādāt, jo finansiālais papildu ieguvums strādājot ir salīdzinoši neliels. Tāpat tiek veltìta kritika dažādu kursu rīkošanai, kuru primārais mērķis - samazināt bezdarbu - netiek sasniegts. Tos uztver kā pabalsta iegūšanas veidu. Turklāt šo kursu rīkotāji/pasūtītāji nepēta, kādas prasmes kursos var apgūt un kāds ir to pieprasijums darba tirgū. Šāds viedoklis ir novērojams tieši mazākās pašvaldībās - Ādažos, Gulbenē, Madonā, Rēzeknē.

Nepamatotas pabalsta izmaksas. Saņems cilvēks 100 EUR un nestrādās!

Kāpēc man strādāt par 400 EUR, ja es varu saņemt pabalstus par 200-300 EUR. Neatbalstu 9 mēnešu ierobežojumus.

\section{Valsts pārvalde un nodokli}

Savukārt salīdzinoši vienota izpratne iedzìvotāju vidū ir bijusi par nodokḷu sistēmu un uzṇēmējdarbības vidi, kuras visās pašvaldībās ir novērtētas kā ekonomisko un sociālo drošību apdraudošs faktors. Fokusa grupās nodokḷ sistēmas kritizēšana bija visregulārāk sastopama, tā tika kritizēta lielākajā daḷā pašvaldību. Lai gan iedzīvotāji uzskata, ka Latvijā nodokḷu likmes ir augstas un tās kavē gan iedzīvotāju labklājības uzlabošanos, gan arī uzṇēmējdarbības attīstību, vairāk tika kritizēta nodokḷ politikas nestabilitāte un regulārās izmaiṇas. Balstoties uz šo viedokli, iedzīvotāji visos Latvijas reǵionos uzskata, ka ekonomiskās drošîbas veicināšanai nodokḷu likmes būtu samazināmas un būtu jāizvairās no biežām nodokḷu likmju izmaiṇām.

Sieviete darbspējas vecumā: Latvijā ir liela dārdzība (nodokḷi, pārtika, komunālie). Tas apdraud personīgo drošību.

Respondents, Jaunjelgava: Būtu forši, ja grozìtu nodokl̦us tikai piecos gados reizi. Sieviete darbspējas vecumā, Talsi: Lielus nodokḷus maksāt tagad es neredzu jēgu, jo valstī ir nestabila nodokḷ sistēma. Reforma pēc reformas, es viniem neuzticos pilnībā. Nav ticības nodokḷu un pensiju sistēmai. Katram savā zeķēe.

Pensionārs, Talsi: Nodokliem nav perspektīvas. Nāks jauna reforma un atkal nodokḷu politiku mainīs.

Uzṇēmēja, Rìga: Valstī kopumā nav paredzamības un plānveidības. Nevienā no lìmeniem nevar paredzēt, kas notiks.

Savukārt uzṇēmējdarbības vides jomā ekonomisko drošību lielākajā dậa pašvaldību negatīvi ietekmē administratīvais slogs un birokrātija. Turklāt uzñēmējs no Talsiem norāda, ka mazinās iedzīvotāju vēlme pildīt nodokḷu saistības: 
Valsts lìmeña korupcija ir milzīgs apdraudējums. Käda jēga mums visiem maksāt nodoklus - pilnīgs bezcers. It kā tiek apsūdzētas personas, bet nekas nenotiek. Korupcija grauj vēlmi maksāt nodokḷıs.

\section{Banku sektors un to pakalpojumu pieejamība}

Kā atsevišks ekonomiskās drošỉbas riska faktors vairāku iedzīvotāju atbildēs minēts arī finanšu sektors - kredītiestādes un to darbība. Vairāki iedzīvotāji uzsver, ka finanšu sektorā iepriekš vērotie skandāli un arī kredītiestāžu maksātnespējas gadījumi risku, ka Latvijas ekonomisko stabilitāti un iedzīvotāju ekonomisko drošỉbu var apdraudēt satricinājumi banku sektorā, vērtē kā ticamu. Tomēr vienlaikus iedzīvotāji atzīst, ka kopumā riski, kas ir saistīti ar kredītiestāžu un finanšu sistēmu, ir samazinājušies Eiropas Savienības līmeņa kredītiestāžu uzraudzības ieviešanas, kā arī vienotās valūtas - eiro - ieviešanas dēḷ. Tāpat atzinīgi tiek vērtēti garantiju fonds un nerezidentu naudas samazinājums.

Vairāku pašvaldību iedzīvotāju vērtējumā savukārt par risku finanšu un kredītiestāžu sistēmu darbībai tiek uzskatīts fakts, ka lielākā daļa Latvijas kredītiestāžu pieder ārvalstu investoriem, - izskan viedoklis par to, ka ārvalstu kapitāla klātbūtne kredītiestādēs ierobežo valsts pārvaldes institūciju iespējas ietekmēt un kontrolēt to darbību sabiedrības interesēs, piemēram, ārkārtas gadījumos, kad iedzīvotājiem masveidā var rasties nepieciešamība pēc skaidras naudas. No tā var secināt, ka kopumā iedzīvotāju vērtējumā valsts ekonomisko drošību veicinātu arī ciešāka valsts kontrole pār kredītiestāžu darbību vai pat valstij piederošas kredītiestādes darbības atjaunošana. Vienlaikus atsevišķi iedzīvotāji atzīst, ka kopumā kā pozitīvu, ekonomisko drošību veicinošu apstākli vērtē to, ka Latvijas lielākās bankas pieder investoriem no Skandināvijas valstìm.

Vīrietis, Ādaži: Banku darbïbas apdraudējums ir pieredzēts, jo nevar izņemt naudu. Ir bijuši tādi gadījumi. Sapratām, ka jebkurā mirklī var pazust nauda. Bezskaidras naudas norēkini ir drauds.

Vīrietis, Gulbene: Lielākās bankas ir apdraudējums, jo tās nav Latvijas bankas. Finansiālās drošỉbas nav, ja to skatìtu no banku sektora.

Sieviete, Ādaži: Es uzskatu, ka skandināvu bankas ir pozitīivi, jo 2008. gadā pārstäja dot kredìtus, bet tomēr SEB banka deva.

Kā papildu risks tiek atzīmēta banku filiāḷu darbību apturēšana/samazināšana mazajās pašvaldībās un neapmierinātība ar bankomātu pieejamību. Kopumā vērtējams, ka iedzīvotājiem ir būtiska kontrole pār iespēju tikt pie skaidras naudas līdzekḷiem. 
Vīrietis, Gulbene: Bankomāti ir, bet SEB filiāle no 5 dienām pārgāja uz 3 dienām.

Citadele tikai vien̄̄gā palikusi. Bet šāda samazināšanās ir visur reǵionā.

\section{Eiropas Savienības fondi}

Pretrunīgu vērtējumu lielākajā dạ̧ā fokusa grupu ir guvušas valsts un ES investīcijas uzņēmējdarbībā un ekonomikā. Lielākā daḷa aptaujāto uzsver ES investīciju nozīmīgumu, norādot, ka tās ir būtiski veicinājušas infrastruktūras attīstību un nodrošinājušas iedzīvotāju un uzṇēmumu ieņēmumus. Tomēr vienlaikus ES investīcijas tiek vērtētas arī kā potenciāls ekonomiskās drošỉbas drauds, jo iedzīvotājos valda viedoklis, ka, mainoties ES politiskajai un ekonomiskajai situācijai un samazinoties ES investīciju apjomam, Latvijas ekonomikas izaugsme var piedzīvot strauju kritumu un iedzīvotāju labklājība var samazināties. Tāpat situāciju var ietekmēt ne tikai ar ES saistīti ārpolitiskie jautājumi, kā to norādījis vīrietis no Madonas:

Ekonomiskā situācija ir stabilāka. Lìdz ko problēmas ar Krimu, tā samazinājās eksports uz Krieviju. Trūkst darbaspēks.

[Brexit] kaut vai pastarpināti atstās iespaidu uz Latvijas procesiem. Lìdz ko ES vājāka, tā tas negatīvi ietekmē mūs. ES fondi kḷ ūst mazāki.

\section{Ekonomiskā drošība pašvaldībās}

Intervijās ar pašvaldību vadītājiem bija novērojama tendence, ka vairāku pašvaldību pārstāvji kā nozīmīgus izcēluši arī jautājumus, kurus iedzīvotāji retāk minējuši fokusa grupās. Piemēram, pretstatā iedzīvotāju biežāk pieminētajām bažām par nodokḷu sistēmas, atalgojuma, valsts pārvaldes politikas un nodokļu sistēmas prognozējamību un banku sektora ietekmi uz ekonomisko drošību, pašvaldību pārstāvji ievērojami biežāk ekonomiskās drošỉbas jomā par prioritāti uzskata jaunu uzņēmumu veidošanu, darba vietu skaita pieaugumu, ekonomisko un sociālo atšķirību starp reǵioniem izlīdzināšanu, pieeju ES fondiem, kā arī mājokḷu jautājumu risināšanu.

Pašvaldību pārstāvju sniegtajās atbildēs par būtiskākajiem ekonomiskās drošības izaicinājumiem bija vērojama tendence, ka pēc iedzīvotāju skaita mazāko pašvaldību pārstāvji kā būtisku ekonomiskās drošības problēmu min neapmierinošu pakalpojumu pieejamību un ierobežotas ekonomiskās aktivitātes iespējas iedzīvotājiem. Tas veicina iedzīvotāju neaizsargātību un migrāciju. Mazākās pašvaldībās ir mazāk iespēju un līdz ar to cilvēki ir neaizsargātāki, tāpēc biežāk izvēlas migrēt uz ārvalstīm vai citu pašvaldību - tā situāciju raksturo pašvaldību pārstāvji. Piemēram, Gulbenes pārstāvis norāda, ka Gulbene pēc iedzìvotāju skaita un ekonomiskās attīstības rādītājiem atpaliek no tādām 
reg̣ionu pilsētām kā Valmiera, tāpēc pašvaldībai ir mazākas iespējas, piemēram, ieviest tādus uzñēmējdarbību veicinošus instrumentus kā biznesa inkubatori vai arī nodrošināt augstākās izglîtības iegūšanu Gulbenē. Šie faktori pašvaldības pārstāvja vērtējumā kopumā veicina gados jaunu cilvēku aizplūšanu no mazām pašvaldībām, ko vēl vairāk veicina arī iedzīvotāju atalgojuma līmeņa atš̌kirības dažādās pašvaldībās. Kopējā labklājības līmeņa izteikto atšķirību izjūt arī pašas pašvaldỉbas, cenšoties piesaistìt sev darbiniekus.

Algas lìmenis zems, bet ne administrācijā. Bet pat pašvaldïbu darbiniekiem ir zems algas lìmenis salīdzinājumā ar citām pašvaldībām..$^{13}$

Lielāku un ekonomiski attīstītāku pašvaldību priekšrocības, kas veicina sabiedrības ekonomisko drošību, atzīst arī vairāku lielo pašvaldību, piemēram, Daugavpils, Liepājas un Valmieras, pārstāvji. Pēc Valmieras pašvaldības pārstāvju teiktā, lielākām pašvaldībām ir vieglāk veicināt iedzīvotāju ekonomisko drošîbu un novērst to migrāciju, kā arī piesaistìt darbaspēku un uzṇēmējus, arī pateicoties infrastruktūrai un pakalpojumu pieejamībai, piemēram, slimnīcām.

Slimnīca ir baigais pluss. Cilvēki izvēlas Valmieru [dzīvošanai], jo slimnīca blakus. $^{14}$

\section{Ekonomiskā stabilitāte - ienākumi un uzkrājumi}

Intervijas ar pašvaldību pārstāvjiem arī apliecina, ka kopumā viṇi ir salīdzinoši labi informēti par to, kādi ekonomiskās drošības izaicinājumi ir nozīmīgākie iedzīvotāju vērtējumā, tomēr daudzos gadījumos pašvaldību redzējums par iespējamajiem problēmu risinājumiem atšķiras no iedzīvotāju viedokḷa. Pretstatā iedzīvotājiem, kuri par būtisku problēmu uzskata to, ka trūkst labi atalgotu darba vietu, vairāku pašvaldību pārstāvji sabiedrības ekonomiskās drošības izaicinājumus saista ar neapmierinošu uzñēmējdarbības aktivitāti un darbaspēka trūkumu, kā arī dažos gadījumos pašvaldības ekonomiskās labklājības atkarību no ierobežota skaita uzn̦ēmumu. Vairāku pašvaldību, piemēram, Aizkraukles, Gulbenes un Talsu, pārstāvji uzsver - pašvaldība par savu nozīmīgāko uzdevumu uzskata piemērotas infrastruktūras izveidi pašvaldības teritorijā, lai ar tās palīdzību radītu labvēlīgus apstākḷus uzṇēmējdarbības attīstỉbai, tomēr pašvaldỉbai pieejamie atbalsta pasākumi nav garantija jaunu uzṇēmumu izveidei, - ja sabiedrībai nav intereses par uzņēmējdarbỉbas uzsākšanu vai attīstību, tad pašvaldíba to nevar tai uzspiest. 
Nav novērojama industrijas attīstība. Gulbenes vājība ir 2-3 spēcīgi uzņēmumi, bet vairāk nekā. Tas atsaucas arī uz citu cilvēku izvēli dzīvot vai nedzīvot Gulbenē. Pašvaldība sper nozīmīgus soḷus. Daudz izdarìts infrastruktūras, īpaši ceḷu sakārtošanai. Labs, saistošs piedāvājums jauniem uzn̄èmējiem ir grantu konkurss katru gadu. Konkursa ietvaros turklāt summa cēlās no 3000 EUR atbalsta uz 5000 EUR. Konkrēta pašvaldības iniciatīva. ${ }^{15}$

Pašvaldība var jau sakārtot infrastruktūru, bet uzņēmumiem ir jāveido šis darba vietas. Talsu geogräfiskais novietojums ir plus punkts, infrastruktūra ir sakārtota, pozitìva situācija ir, ka Talsu novadā atrodas biznesa inkubators. Uzn̄ēmēju kopums tiekas ar pašvaldību. ${ }^{16}$

Savukārt Aizkraukles pašvaldības pārstāvis atzīst: neskatoties uz to, ka kopējā uzṇēmējdarbības aktivitāte pilsētā ir vērtējama kā salīdzinoši laba, ne visos gadījumos uzṇēmēji ir ieinteresēti pietiekami aktīvi sadarboties ar pašvaldību un censties izmantot visas tās piedāvātās atbalsta iniciatīvas.

Vairums pašvaldību uzsver, ka par ekonomisko drošību veicinošu faktoru uzskata arī pašvaldības teritorijā esošās uzṇēmējdarbības daudzveidību, un uzsver nepieciešamību panākt mazo un vidējo uzṇēmēju skaita pieaugumu, šādi sekmējot kopējo pašvaldības iedzīvotāju ekonomisko drošumu. Liepājas pašvaldības pārstāvis norāda, ka pilsētas attīstības vēsturē jau ir pierādījies, ka l,oti lieli, šauri specifiskā uzṇēmējdarbības jomā strādājoši uzṇēmumi var kḷūt arī par sociālekonomiskās drošības risku.

Metalurgs bankrotēja 1. reizi, 1500 darbinieki zaudēja darbu. 2. reizi bankrotēja800 cilvēki. Atrada Liepājā citus uzn,ēmumus. Pārkvalificējās, meklē darbu ārpus Liepājas, pēc tam - Latvijas. Strādājošo skaits pieaudzis no 28000 lìdz 30000 tagad. Bankrota krīze pārvarēta. Negribam degradētu vidi un primitìvu produktu ražošanu. Modernas, zal̦as idejas gribam. Negribam šāda monstra atgriešanos, bet gan vidējus uzņēmumus - maksimums lìdz 500 darbiniekiem [vairāki uzṇēmumi ir apvienojušies koncernā].

Savukārt Valmieras pārstāvis norāda, ka, veicinot uzṇēmējdarbībai labvēlīgas vides attīstību pašvaldības teritorijā, pilsētai ir iespējams panākt ievērojamu ekonomiskās drošỉbas pieaugumu visai sabiedrībai un, piemēram, būtiski samazināt bezdarba līmeni.

Valmierā darba vietas ir ievērojami vairāk kā darbspējas vecumā cilvēki. Inženiertehniskā infrastruktūra balstīta uz uznēemējiem, ražotājiem. Gāzes, elektrības 
infrastruktūra piemērota 19000 darba vietām, bet iedzīvotāji darba spējas vecumā ir virs $15000 .^{17}$

Pašvaldības pārstāvis uzsver, ka Valmierai, pateicoties tās izvēlētajai ekonomiskās attīstības politikai un uzñēmējdarbības atbalsta pasākumiem, ir izdevies ne tikai ievērojami uzlabot pilsētas iedzīvotāju nodarbinātības rādītājus, bet arī piesaistìt pilsētā strādājošajiem uzṇēmumiem darbaspēku no citiem reǵioniem. Raksturojot šo tendenci, pašvaldības pārstāvis uzsver, ka, pēc CSP datiem, Valmierā ir 23000 iedzīvotāju, bet pie Valmieras gimenes ārstiem ir reg̣istrējušies 33000 iedzīvotāju. Tas norāda uz to, ka savu ikdienu ar Valmieru, visticamāk, saista ievērojami lielāks skaits iedzīvotāju, kuri dzīvo citās pašvaldībās un kurus ir piesaistijušas darba tirgus iespējas. Valmiera savu pilsētplānošanu līdz ar to ir paredzējusi 30000 iedzìvotāju, ņemot vērā abus šos informācijas avotus.

3\% bezdarbs - tie ir cilvēki, kuri dzìvē nekad nav strādājuši tā kārtīgi. Ik pa brīdim atnāk kāds jauns uzñēmums... No apkārtējiem novadiem ap 40\% brauc strādāt uz Valmieru. Apsekojumi rāda, ka 30-50 km rādiusā cilvēki ir gatavi braukt uz Valmieru. ${ }^{18}$

\section{Pabalsti un sociālais nodrošinājums}

Raksturojot situāciju ar sociālo aprūpi un pabalstiem, pašvaldību pārstāvji uzsver, ka kopumā pašvaldību iespējas sniegt atbalstu iedzìvotājiem, attīstot sociālo infrastruktūru un nodrošinot atbalstu krīzes situācijās, uzlabojas un ka, piemēram, notiek investīcijas sociālās aprūpes centros, lai sniegtu atbalstu pensijas vecuma cilvēkiem. Madonas pašvaldības pārstāvis norāda: lai gan trūcīgo iedzīvotāju skaits samazinās, pašvaldības sociālais budžets un pabalstu apjoms tiek palielināts. Piemēram, pašvaldība ir radusi iespēju palielināt bērna piedzimšanas pabalstu līdz 150 EUR un arī sniegt pabalstu gimenēm skolas mācību līdzekḷu iegādei.

Tomēr vienlaikus pašvaldību pārstāvji atzīst, ka citu sociālās palīdzības instrumentu darbība ne vienmēr ir apmierinoša, piemēram, nodarbinātības veicināšanai paredzētās apmācības un bez darba esošo iedzivotāju pārkvalificēšanās pasākumi dažkārt ir raksturojami kā nepietiekami efektīvi, jo netiek kontrolēta šo apmācību un kvalifikācijas paaugstināšanas pasākumu efektivitāte un atbilstība tautsaimniecības un uzṇēmēju pieprasijumam. $\mathrm{Ne}$ reti darba meklētājs pat pēc vairāku apmācību kursu beigšanas tomēr neatrod 
piemērotu darbu un nesniedz atbilstošu pienesumu tautsaimniecībai, uzsver pašvaldībās.

\section{Valsts pārvalde un nodokli}

Vairākās pašvaldībās to pārstāvji, vērtējot kopējo valsts pārvaldes un nodokḷu sistēmas ietekmi uz ekonomisko drošibu, pauda kritisku viedokli par valsts un pašvaldību reformu plānošanas procesu, norādot, ka bieži vien reformas tiek plānotas, nepietiekami ņemot vērā reǵionos vērojamās attīstības tendences un arī nepietiekami izvērtējot to ietekmi uz dažādām ekonomiskajām norisēm regionos. Kā vienu no problēmām reg̣ionu attīstỉbas plānošanā pašvaldību pārstāvji minēja faktu, ka transporta infrastruktūras un atjaunošanas plānošanā nepietiekami tiek ņemti vērā iedzìvotāju apsvērumi par mobilitāti un plānošanas process netiek pietiekami piesaistīts demogrāfiskās un ekonomiskās aktivitātes tendencēm un prognozēm.

Savukārt, komentējot nodokḷu sistēmas efektivitāti, pašvaldību pārstāvji ir atzinuši, ka kopumā pašvaldībām ir salīdzinoši neliela ietekme uz kopējo nodokḷ sistēmu un ka pašvaldíbas kompetencē neietilpst nodokḷ sistēmas kopējās efektivitātes kvalitatīvs novērtējums. Tomēr kopumā pašvaldības netiešā veidā izjūt to, ka nodokḷu sistēmā ir neapmierinoša ilgtermiņa plānošana.

Pašvaldībai nav ilgtermina nodokḷ viżija. Manuprāt, jābūt piecgades plānam.

Vērtējot līdzekḷu izlietojuma caurspīingumu un pamatotỉbu valsts pārvaldē, pašvaldību pārstāvji pauduši viedokli, ka nodokḷu politika un rīkotie iepirkuma konkursi kopumā ir pietiekami caurspīiñgi, tomēr daḷai sabiedrības kopumā pietrūkstot kompetences, lai to novērtētu.

\section{Banku sektors un to pakalpojumu pieejamība}

Mazākās pašvaldībās satraukumu rada bankomātu trūkums un filiāḷu slēgšana, kas ievērojami ierobežo pakalpojumu pieejamību iedzīvotājiem. Pašvaldības uzsver, ka šādos gadījumos notiek pārrunas ar bankām, lai nodrošinātu pakalpojumu nepārtrauktību.

Aizkrauklē ir tikai viens bankomāts, kurš pieejams uz ielas. Jaunjelgavā vispār tikai viens - tas pats aiz slēgtām durvīm. ${ }^{19}$

Tomēr pašvaldību pārstāvji apzinās, ka, ņemot vērā demogrāfiskās tendences, bankām nav izdevīgi uzturēt filiāles nerentablās apkaimēs. Madonas pārstāvis norādīja, ka trūkst valstiska mehānisma šai problēmai. Pašvaldību

19 Padzilinātā intervija ar Aizkraukles novada pašvaldības darbinieku. 
vērtējumā iespējamie šìs problēmas risinājumi varētu būt valstij piederošas kredītiestādes vai finanšu pakalpojuma tîkla izveide vai arī normatīvais regulējums, kurš motivētu finanšu pakalpojumu sniedzējus uzturēt šādu infrastruktūru. Gulbenes pārstāvis stāstīja, ko dara pašvaldība, lai pensijas vecuma iedzīvotāji iegūtu skaidrību par banku darbību.

Bibliotēkās daudz dara, lai izglìtotu sabiedrības vecāko daḷu saistībā ar izmainām banku darbībā. Degvielas cenas ir nozīmīgs ekonomikas drauds, jo cilvēkiem ir nepieciešams pārvietoties. ${ }^{20}$

\section{Eiropas Savienības fondi un ārpolitika}

Salīdzinot ar iedzīvotāju fokusa grupās pausto viedokli, pašvaldību pārstāvji ekonomiskās drošības kontekstā ievērojami lielāku nozīmi pieškir atbalsta un investīciju līdzekḷu pieejamībai no ES fondiem. Kā norāda pašvaldības, ES kohēzijas politikas ietvaros realizētie projekti tām ir vieni no nozīmīgākajiem instrumentiem attīstības veicināšanai, jo dažos gadījumos tie veido vairāk nekā $66 \%$ no pieejamā finansējuma visiem attīstības projektiem. Pašvaldību pārstāvji atzīst, ka, lai gan iedzīvotāji nereti ilgtermiņa budžeta plānošanai un investīciju pieejamībai pievērš maz uzmanības, tomēr kopumā pieejamie līdzekḷ pašvaldības attīstībai ir ḷoti būtisks priekšnosacījums tās ekonomiskās attīstîbas veicināšanai, un šì brīža situāciju pašvaldības vērtē ar bažām, norādot uz iespējamo pieejamo līdzekḷu samazinājumu nākamajā ES finansējuma plānošanas periodā.

Tiek norādīts, ka, samazinoties šim finansējumam, var apstāties lielākie infrastruktūras projekti, piemēram, ēku atjaunošanas, èku siltināšanas aktivitātes. Turklāt šobrīd pašvaldībām nav iespēju aizṇemties līdzekḷus Valsts kasē, un līdz ar to ES kohēzijas politikas projekti ir būtiskākais finanšu instruments pašvaldību attīstībai. Vienlaikus pašvaldību pārstāvji līdz šim sasniegto ES fondu finansējuma ietekmi uz ekonomisko drošỉbu vērtē atzinīgi, uzsverot, ka līdzšinējo projektu realizācijas gaitā ir sekmīgi izdevies iesaistît arī uzņēmējus un nevalstiskās organizācijas, šādi nodrošinot sabiedrības līdzdalību. Papildus jāatzīmē Rēzeknes pārstāvja paustais par finansiālām atškirīiām starp novadiem, sasaistot to ar ārpolitisko jautājumu.

Latgale dara nepareizi, veidojot labas attiecības ar kaimiņvalstìm. Tas arī ekonomiskajā politikā ir atspoguḷots, ka Latgale saņem mazāko finansiālo atbalstu [visiem jau zināms fakts] salīdzinājumā ar citiem reǵioniem. Un, protams, $k a$ 
ši informācija ir pieejama un cilvēki to loti labi saprot, un nekas nenotiek pretējā virziena. ${ }^{21}$

\section{Mājoklu pieejamība}

Kā īpaši būtisku problēmu, kas apdraud sabiedrības ekonomisko drošǐbu un attīstības perspektīvas daudzās pašvaldībās, pašvaldību pārstāvji min mājoklu pieejamību, kas ir saistīta gan ar īrei pieejamo mājokḷu trūkumu, gan iegādei pieejamo mājokḷu skaitu un jaunu mājokḷ būvniecības aktivitāti. Mazās pašvaldības norāda, ka nevar aṭ̦auties finansēt jaunu mājokḷu celtniecību. Savukārt Valmierā, kurā ir nodarbināts arī relatīvi liels skaits iedzīvotāju no citām pašvaldībām, secināts, ka liela dạ̦a no pilsētas infrastruktūras ir pietiekama, lai pilsētā strādājošos iedzīvotājus izmitinātu arī pašā Valmierā, tomēr nepietiekams ir tieši mājokḷu skaits.

Cilvēki fiziski nevar atrast mājokli Valmierā - skolas ir, darbs ir, slimnīca, izklaide ir. Bankas un valsts negrib finansēt mājoklı jautājumus... Fiziski to iedzìvotājus varētu pie sevis dabüt.22

Pašvaldību pārstāvji sagaida aktīvāku valsts iesaisti šĩ jautājuma risināšanā un uzsver, ka šobrīd dzīvokḷi tiek piešķirti tikai atsevišķām sociālajām grupām, tomēr būtu nepieciešams valsts atbalsts tādām programmām, kas veicina plašāku mājokḷu pieejamību visai sabiedrībai, un arī dzīvojamā fonda uzturēšanai.

Pirmkārt, noveco dzīvojamais fonds, kas nozīmē, ka iziet no aprites gan dzīvokl̦i, gan mājas, un ar kaut ko vajag aizvietot. Un ja mēs plānojam, bet plāni tādi ir - apturēt cilvēku aizplūšanu un sākt palielināt iedzīvotāju skaitu. Tas nozīmēe, ka vajag organizēt tādas programmas, kas būtu saistītas ar daudzdzīvokḷ māju būvniecību. Mès pagaidām plānojam piesaistìt privāto kapitālu, un tā konjunktūra ir tāda, ka arì Rēzekne var sev aţ̦auties būvēt, un tad tā nomas maksa būs atbilstoša, lai cilvēki spētu maksāt, un tā maksa arì segtu visus saistītos izdevumus ar mājas būvniecību un uzturēšanu tālāk. Noteikti šeit ir jābüt valsts politikai, kas stimulēs to. ${ }^{23}$

Savukārt, analizējot pašvaldību attīstības plānošanas dokumentus, secināms, ka kopumā pašvaldību pārstāvju intervijās paustie viedokḷi lielā mērā ir bijuši atbilstoši arī plānošanas dokumentos izvirzìtajām prioritātēm. 
Tā, piemēram, Aizkraukles pašvaldības izstrādātajā attīstības dokumentā "Aizkraukles novada integrētās attīstîbas programma 2013.-2020. gadam"24 par prioritāti ekonomikas jomā teikts: "Daudzpusīgas ekonomikas, kas vērsta uz ražošanas un pakalpojumu attīstību un pievienotās vērtības palielināšanu, veicināšana, sekmējot gan pilsētvides, gan lauku izaugsmi.” Kopumā iecerētās aktivitātes prioritātes veicināšanai pašvaldība ir izvirzỉjusi sasniedzamā apjomā un lielāko daļu no tām arī ir sekmīgi ìstenojusi, tostarp ielu tīkla optimizāciju, inženierkomunikāciju izbūvi un pilnveidi rūpnieciskajās zonās, uzṇēmējdarbībai paredzēto teritoriju attīstīšanu un iekḷaušanu pilsētvidē, inženiertehniskās infrastruktūras un ceḷu uzlabošanu u. c. Pašvaldība atbilstoši savām izvirzịtajām prioritātēm būtisku uzmanību pievērsusi un ìstenojusi atbilstošus pasākumus arī darbaspēka pieejamības veicināšanai tās teritorijā, uzsverot, ka sasniegts ir arī rezultatīivais rādītājs pieejamo mācību programmu skaita palielināšanai novadā, galvenokārt nodrošinot mācību programmu skaita palielināšanos Aizkraukles Pieaugušo izglìtỉbas un inovāciju atbalsta centrā, kas piedāvā 36 mācību programmas galvenokārt uzṇēmēju pieprasìtajām specialitātēm darba tirgū.

Savukārt Madonas novadā pašvaldības attīstības plānošanas dokumentā 2013.-2038. gadam ${ }^{25}$ būtiskākās ekonomiskās attīstības prioritātes ir formulētas atšķirīgi, paredzot mazāk intensīvas aktivitātes uzṇēmējdarbības piesaistei tiešā veidā un lielāku atbalstu transporta infrastruktūras attīstīšanai. Šādu attīstības politikas izvēli lielā mērā nosaka arì Madonas novada formulētās uzṇēmējdarbības prioritātes. Novads sevi saredz kā teritoriju, kurā augsta prioritāte piešķirta dabas vērtību saglabāšanai un ar dabas resursu apguvi un izmantošanu saistìtu nozaru attīstībai, piemēram, mežizstrādei, lauksaimniecībai un tūrismam. Dokumentā gan nav sniegtas tiešas atsauces uz iespējamajiem pašvaldības plāniem aktīvi iesaistīties tādu pasākumu īstenošanā, kuri veicina uzņēmējdarbībai nepieciešamā darbaspēka atrašanu.

Valmieras pašvaldības sagatavotajā dokumentā "Valmieras pilsētas ilgtspējìgas attīstības stratēgiija 2015.-2030. gadam"26, līdzīgi Aizkraukles attīstības plānam, liela nozīme ir pieškirirta pilsētas uzṇēmējdarbỉbas attīstības vēsturisko tendenču saglabāšanai un jaunu ražošanas uzņēmumu plašai piesaistei. Arī šajā gadījumā pašvaldība savu prioritāšu veicināšanai ir izraudzījusi konkrētu aktivitāšu kopumu, tostarp pilsētā pieejamo industriālo teritoriju saglabāšanu

24 Pieejams: http://aizkraukle.lv/wp-content/uploads/2018/01/ap_1_dala.pdf

25 Madonas novada ilgtspējigas attīstìbas stratēgija 2013.-2038. gadam. Pieejams: https://madona.lv/ lat/box/files/PlanosanasDokumenti/attstbas_stratija.pdf

26 Pieejams: https://www.valmiera.lv/dokumenti/valmieras-pilsetas-ilgtspejigas-attistibas-strategija2015-2030-gadam/ 
un jaunu iespējamo attīstîbas teritoriju plānošanu, kā arī bijušo industriālo teritoriju revitalizāciju. Uz uzņēmējdarbības atbalstu vērsta pieeja Valmieras pilsētas pašvaldības attīstības plānā ir vērojama arī citās attīstības jomās, piemēram, mājokḷu politikā. Pašvaldības plānošanas dokumentā pašvaldība arī pilsētas ekonomikas attīstību, iekḷaujošu pilsētvidi un sociālo infrastruktūru cieši saista ar iedzīvotāju drošỉbu, minot tās kā vienlaicīgi îstenojamus stratēgiskus mērķus.

Savukārt Gulbenes novada attīstības plānošanas dokumentā 2018.2024. gadam ${ }^{27}$ formulētās prioritātes ekonomiskās drošỉbas veicināšanas jomā ir bijušas līdzīgas Madonas novada prioritātēm, un kā perspektīvāko savas tālākās ekonomiskās attīstības virzienu novads saredz jau esošās ekonomiskās struktūras saglabāšanu, par prioritāriem uzskatot ar dabas resursu apgūšanu un izmantošanu saistîtu uzņēmējdarbỉbas nozaru attīstību (piemēram, lauksaimniecību, mežizstrādi un tūrismu). Lìdz ar to galvenās novada prioritātes ir transporta infrastruktūras saglabāšana un attīstǐšana, tūrisma infrastruktūras attīstība, vides aizsardzība, savukārt kā novada vājās vietas novada pašvaldība identificējusi ierobežotu teritoriju pieejamību industriālajai apbūvei.

Kopumā, salīdzinot minēto un arī citu pašvaldību attīstîbas plānošanas dokumentus, ir vērojama tendence, ka pašvaldības lielākajā daḷā gadījumu plānošanas procesā ir n̦ēmušas vērā pilsētu un novadu vēsturiskās attīstības tendences un tām raksturīgo sociālekonomisko struktūru. Lielākā daḷa to plānoto aktivitāšu ir vērstas uz šī pašvaldības vēsturiskās attīstības virziena saglabāšanu. Pašvaldībām, kuru vēsturisko attīstību ir būtiski ietekmējusi industriālā attīstība, kopumā ir raksturīga lielāka interese par industriālo investīciju piesaisti un ražošanas attīstībai nepieciešamās infrastruktūras nodrošināšanu, bez tam arī prioritātes citās jomās, piemēram, mājokḷu politikā un izglìtībā, šajās pašvaldībās tiek formulētas, vairāk balstoties uz uzṇēmējdarbības un nodarbinātības veicināšanas apsvērumiem. Savukārt pašvaldībās ar zemāku vēsturisko industrializāciju un augstāku lauksaimniecības un mežrūpniecības ìpatsvaru ievērojami lielāks uzsvars likts uz vides saglabāšanu, tūrisma veicināšanu, iedzīvotāju dzīves vides pilnveidošanu un vispārējās izglīīibas kvalitātes paaugstināšanu, bet mazāks uzsvars - uz ekonomiskās aktivitātes veicināšanu.

27 Gulbenes novada attīstības programma 2018.-2024. gadam. Pieejams: https://www.gulbene.lv/lv/ doks/pld/313-gulbenes-novada-attistibas-programma-2018-2024-gadam 


\section{Secinājumi}

Apkopojot būtiskākos secinājumus par pētijumā veiktajām intervijām ar iedzīvotājiem un pašvaldībām, apstiprinās iepriekš veikto aptauju iegūtais rezultāts, ka kopumā ekonomiskās drošības draudi Latvijas sabiedrībā tiek uzskatīiti par vieni no nozīmīgākajiem, ar kuriem jāsaskaras Latvijas sabiedrībai, un tie ir vērtējami kā būtiskāki nekā, piemēram, militārie draudi, dabas katastrofas vai vides piesārņojums, sociālie izaicinājumi. Vienlaikus sabiedrībā nepārprotami dominē arī viedoklis par to, ka ekonomisko draudu novēršana (labklājỉbas un ekonomiskās ilgtspējas veicināšana) ḷautu būtiski samazināt draudus arī citās sabiedrības dzìves jomās. Praktiski visās pašvaldībās iedzīvotāji fokusa grupas intervijās ir pauduši viedokli, ka pietiekams ekonomiskās labklājỉbas līmenis ir obligāts priekšnosacỉjums tam, lai valsts varētu stiprināt savas militārās spējas, aktīvāk iesaistīties vides piesārņojuma un klimata pārmaiṇu problēmu risināšanā un risināt citus līdzīgus uzdevumus, kas saistīti ar draudu novēršanu. Iedzīvotāji uzsver, ka, pirmkārt, valstij ir jābūt pietiekami turīgai, lai tā varētu aț̣auties sniegt ieguldījumu savu militāro spēju stiprināšanā, kā arī vides problēmu risināšanā, un, otrkārt, tikai pietiekami augsts iedzīvotāju labklājības līmenis attaisno valsts aktivitātes šajā jomā. Var secināt: kamēr iedzivotājus neapmierina viṇu labklājības līmenis, valstij, pēc iedzīvotāju domām, ir jāiegulda līdzekḷi militāro spēku attīstỉbā tikai ierobežotā, minimālā apjomā. Arī valsts tēriṇi vides un klimata politikas jautājumu risināšanai un draudu samazināšanai apstākḷos, kad iedzīvotājus neapmierina viṇu labklājības līmenis, drīzāk tiek vērtēti kā nevēlami.

Aptaujās tika norādīts, ka Latvijā aktuālākās ekonomiskās problēmas ir dārdzība un augošās cenas, tomēr fokusa grupās iegūtā informācija par to neliecināja. Apstiprinājās gan, ka Latvijas iedzīvotāji par salīdzinoši lielāku problēmu uzskata nodokḷu sistēmu, bet, fokusa grupās apspriežot šo problemātiku, var secināt, ka šì problēma nav saistīta ar nodokḷu apjomu, bet gan ar nodokḷu sistēmas nestabilitāti un neprognozējamību. Turklāt korupcijas gadījumi samazina vēlmi godīgi pildìt nodokḷu maksātāja pienākumus.

Iedzīvotājiem ir raksturīgs viedoklis par to, ka Latvijas ekonomisko drošību būtiski apdraud arī ārējie ekonomiskie draudi: potenciālā nedrošība banku sektora piederībai ārvalstu investoriem, atkarība no Eiropas Savienības finanšu atbalsta un investīcijām, liels ārvalstu kapitāla īpatsvars Latvijas ekonomikā, liela globālu ekonomisko krī̌̌u ietekme uz Latvijas ekonomiku. Tomēr iedzīvotāju vērtējumos vērojamas arī zināmas pretrunas, jo vienlaikus iedzīvotāji ir atzinīgi novērtējuši to, ka ES finansējums ir ḷāvis palielināt Latvijas labklājību, tāpat arī par būtisku tiek uzskatìta Latvijas uzṇēmēju konkurētspēja ārvalstu tirgos un spēja eksportēt Latvijā ražotas preces un pakalpojumus. Iedzīvotāji 
atzinīgi izteikušies arī par to, ka ārvalstu uzņēmumu investīcijas Latvijas ekonomikā veicina jaunu darba vietu radīšanu.

Tāpat fokusa grupu rezultāti apliecina to, ka ekonomiskās drošības draudi, pēc iedzīvotāju domām, ir īpaši cieši saistīti ar sociālo drošību. Nereti atsevišķās pašvaldībās to jēdzieniskais saturs praktiski saplūst, proti, ar ekonomisko un sociālo drošību tiek saprasta valsts un uzṇēmēju spēja praktiski visiem iedzīvotājiem garantēt darba vietas, kuras nodrošina minimālos ienākumus, kas ir pietiekami indivīda primāro vajadzību apmierināšanai. Šie ekonomiskās drošības draudi atklāj acīmredzamas pretrunas, jo, neskatoties uz plašas iedzīvotāju daļas vēlmi saṇemt lielu ekonomiskā un sociālā atbalsta pakalpojumu klāstu, iedzīvotāji uzskata, ka valstij no uzņēmējiem un strādājošajiem būtu jāiekasē pēc iespējas mazāki nodokḷi, kā arī jācenšas samazināt pašvaldībās un valsts iestādēs strādājošo skaitu. Tai pašā laikā novērojams, ka pašvaldību pārstāvji, runājot par ekonomisko drošību, biežāk min atkarību no ES fondu līdzfinansējuma.

Tāpat iedzīvotāju vērtējumā Latvijai ir raksturīgs nesamērīgi augsts valsts pārvaldes un pašvaldību administratīvais slogs un pārlieku liels, dārgs birokrātiskais aparāts, kura uzturēšana Latvijas iedzīvotājiem izmaksā nepamatoti dārgi un liedz ḷoti lielus līdzekḷus novirzìt dažādām citām vajadzībām, piemēram, infrastruktūras attīstībai, veselības aprūpei, sociālajām vajadzībām. Iedzīvotāji kopumā kritiski novērtējuši arī salīdzinoši biežas izmaiņas likumdošanā un nodokḷ sistēmā. Plašāk un intensīvāk komunicējot ar Latvijas iedzīvotājiem, var tikt sniegts iedzīvotājiem precīzāks priekšstats par nodokḷu slogu un valsts pārvaldes izmaksām citās ES valstīs, tādējādi veicinot kopējo iedzīvotāju izpratni par Latvijas nodokḷu sistēmas un valsts pārvaldes sistēmas konkurētspēju Eiropas Savienībā.

Papildus veiktajām fokusa grupu intervijām ar iedzivotājiem būtisku ieskatu par iedzīvotāju ekonomiskās drošības uztveri sniedza arī intervijas ar pašvaldību pārstāvjiem. Kopējā tendence liecināja, ka pašvaldībās ar salīdzinoši zemāku iedzīvotāju ienākumu līmeni un augstāku bezdarbu pašvaldību pārstāvji ir vairāk akcentējuši valsts un pašvaldību uzdevumu garantēt noteiktu sociālās un ekonomiskās labklājības līmeni iedzīvotājiem, savukārt pašvaldībās ar augstāku ienākumu līmeni un zemāku bezdarbu lielāks uzsvars likts uz pašvaldības pienākumu nodrošināt uzṇēmējdarbībai un iedzīvotāju ekonomiskajai aktivitātei stimulējošus apstākḷus. Jāuzsver, ka, salīdzinot ar iedzīvotājiem, pašvaldību pārstāvju vidū viedokḷu polarizācija starp reǵioniem ar augstāku un zemāku labklājības līmeni ir bijusi zemāka. Pašvaldību pārstāvju vidū dominē viedoklis, ka būtiskākais faktors, kas veicina ekonomisko drošību un izaugsmi, gan pašvaldībā, gan valstī kopumā ir tieši iedzīvotāju ekonomiskā 
aktivitāte. Pašvaldību pārstāvji par mazāk nozīmīgu ir uzskatījuši pašvaldību vai valsts realizēto ekonomisko politiku.

Interesanti, ka, pēc iedzīvotāju domām, pašvaldību loma ekonomiskās drošības veicināšanā ir manāmi mazāka, nekā to vērtē paši pašvaldību pārstāvji. Iedzìvotāji uzskata, ka pašvaldību rīcībā ir salīdzinoši neliels ekonomiku stimulējošu instrumentu klāsts un galvenokārt tas ir paredzēts iedzīvotāju atbalstam un infrastruktūras nodrošināšanai. Daļēji šĩ vērtējuma iespaidā lielākajā dạ̦ā aptaujāto pašvaldību (neskaitot Rīgu) iedzīvotāji ekonomikas drošības jomā pašvaldībām ir pauduši pat lielāku uzticēšanos nekā valsts centrālajai varai. Savukārt pašu pašvaldību pārstāvji, it īpaši pašvaldībās ar augstu ekonomiskās labklājības līmeni, savu lomu ekonomikas stimulēšanā ir novērtējuši kā ievērojami lielāku, uzsverot, ka daudzas pašvaldību nodrošinātās vai iespējamās funkcijas ir būtiskas, lai konkrētā pašvaldībā piesaistītu investīcijas un veicinātu darbaspēka rašanos. Tiek minēta ceḷu infrastruktūra, ùdensapgāde, izglītỉbas sistēma, sabiedriskā kārtība, kultūras pasākumi, atpūtas iespējas iedzīvotājiem, kā arī atsevišķos gadījumos mājokḷu attīstība.

Apkopojot būtiskākos secinājumus, jāsecina, ka sekmīga valsts ekonomikas politika ir vērtējama kā vitāli nozīmīgs priekšnosacỉjums valsts kopējās drošības stiprināšanai un ka viens no būtiskākajiem Latvijas valsts pārvaldes rīcībpolitikas uzdevumiem ir konkurētspējīgas uzņēmējdarbības vides un iedzīvotāju ekonomiskās aktivitātes veicināšana, uzlabojot to uzticēšanos Latvijas nodokḷu sistēmai un tiesiskajai videi, jo kopumā iedzivotājos valda viedoklis, ka ekonomikas izaugsme un iedzīvotāju labklājības pieaugums būtiski veicinās arī citu nozīmīgāko drošības apdraudējumu risinājumu, jo ekonomiskā labklājība stiprinās iedzīvotāju gatavību iesaistīties un finansēt, piemēram, militāro spēju stiprināšanu, sociālo problēmu samazināšanu, vides problēmu risināšanu. Labklājības pieaugums var sniegt arī tiešu ieguldījumu, lai veicinātu iedzīvotāju lojalitāti pret valsts pārvaldes institūcijām un drošỉbas institūcijām, šādi samazinot iespēju, ka iedzīvotāju viedokli un attieksmi pret valsts institūcijām var ietekmēt hibrīddraudi, piemēram, nedraudzīgu valstu izplatīta dezinformācija vai centieni iejaukties masu saziṇas līdzekḷu darbībā. 


\title{
Politiskā drošība
}

\author{
MALVĪNE STUČKA, VALDIS OTZULIS
}

Politiskās drošības jēdziens ir saistīts ar valsts pārvaldes institūciju darbības stabilitāti, to legitimitāti un ideologisko noturību, kā arī ar varas līmeṇu attiecībām un to atzīšanu/vērtēšanu. Politiskās drošības subjektīvā drošības uztvere liecina par iedzīvotāju un varas attiecībām, kuras var vairot stabilitāti un veicināt cilvēku līdzdalību vai, tieši pretēji, - radìt spriedzi un pat vardarbības pieaugumu. Rakstā analizēts, cik lielā mērā iedzīvotājus uztrauc politiskā drošỉba, kā vērtēta valsts institūciju stabilitāte, ievēlēto amatpersonu (deputātu) darbs, kā arī pašvaldību darbs un kāda ir kopējā Latvijas iedzīvotāju subjektīvā uztvere par politisko drošîbu. Pētījuma laikā noskaidrots, ka politiskā drošība ir viens no svarīgākajiem aspektiem Latvijas iedzīvotājiem un viṇus satrauc ar to saistītās problēmas.

Atslēgvārdi: politiskā drošība, politiskie draudi, Latvijas pašvaldības.

The concept of political security includes the stability of public administration institutions, the legitimacy and ideological persistence of these institutions, and the relationship among the different levels of government, including mutual recognition and evaluation. Political security demonstrates the character of the relationship between political institutions and society, which can increase stability and participation or do just the opposite provoke tensions and even spread violence. The article defines the subjective perception of political security in Latvia and brings light to the population's concerns regarding political security, the stability of public institutions, the work of elected deputies and the work of local governments. The article suggests that political security is one of the most important aspects for the residents of Latvia and that they are deeply concerned with the problems associated with political security.

Keywords: political security, political threats, Latvian municipalities. 


\section{levads}

Politiskās drošības jēdziens ir saistìts ar valsts pārvaldes institūciju darbỉbas stabilitāti, to leğitimitāti un ideolog̣isko noturību, kā arī ar varas līmeņu attiecībām un to atzī̌anu/vērtēšanu. Politiskās drošìbas kontekstā nozīmīga ir valsts institūciju stabilitāte un pārvaldes sistēmas darbības leǵitimitāte. ${ }^{1}$ Tādi politiskie apdraudējumi kā pārvaldes sistēmas kapacitātes trūkums, korupcijas novājināta pārvalde un politiskā sistēma, kā arī neregulēta privātuma politika mūsdienu digitālajā pasaulē rada jaunus izaicinājumus un nedrošību valstij un tās iedzīvotājiem. ${ }^{2}$ Politiskā drošîba iezīmē to problēmjautājumu loku, kas jārisina valstij, piemēram, valdības spēju pieņemt atbildīgus un izskaidrotus lēmumus, kas atbilstu sabiedrības interesēm un gaidām. Politiskās drošības subjektīvā uztvere liecina par iedzīvotāju un varas attiecībām, cik lielā mērā iedzīvotājus uztrauc politiskā drošība, kā tiek vērtēta valsts institūciju stabilitāte un uztverts ievēlēto amatpersonu (deputātu) un pašvaldību darbs.

Lai nonāktu pie secinājumiem par to, cik lielā mērā iedzīvotājus uztrauc politiskā drošība, tika vērtēta valsts institūciju stabilitāte, ievēelēto amatpersonu (deputātu) darbs, kā arī pašvaldību darbs. Raksts ir sadalīts šādās daḷās: pirmkārt, aplūkoti iepriekš veiktie pētijjumi politiskās drošības jomā. Otrkārt, ir analizēts politiskās drošǐbas jēdziens un identificētas tā būtiskākās pazīmes. Treškārt, analizēti fokusa grupu intervijās iegūtie rezultāti, kuri atspoguḷo Latvijas iedzīvotāju subjektīvās bažas politiskās drošības jomā.

\section{Kas paveikts politiskās drošības izpētē?}

Latvijā ir ievērojams skaits gan kvalitatīvu, gan kvantitatīvu pētījumu par atsevišķiem politiskās drošības elementiem, kā, piemēram, korupciju, iedzīvotāju līdzdalību vēlēšanās, valdības stabilitāti un tās pieṇemtajiem lēmumiem un cilvēktiesībām.

Politiskā drošība no subjektīvās uztveres viedokḷa Latvijā pirmo reizi pētīta ap 2002. gadu, kad Māras Sīmanes redakcijā iznāk ANO Attīstības programmas izdevums "Latvija. Pārskats par tautas attīstību 2002/2003. Cilvēkdrošība”. Šajā pārskatā uzsvars likts uz cilvēkdrošību, kuras ietvaros skatīta politiskā drošỉba, definējot tādus elementus kā cilvēku pamattiesību un pamatbrīvību

Buzan, B. (2007). People, states \& fear: an agenda for international security in the post-cold war era. Colchester, England: European Consortium for Political Research Press.

2 Costa, T. G. (2008). Political Security, an Uncertain Concept with Expanding Concerns, p. 8. Pieejams: https://link.springer.com/chapter/10.1007/978-3-540-75977-5_42 
ievērošana, uzticēšanās valdībai, valdības darbībspēja, korupcijas izjūtamība un iesaiste politiskajā dzīvē. ${ }^{3}$

Atsevišķi politiskās drošības sektora elementi atspoguḷoti tautas attīstības pārskatos, sākot jau ar 1995. gadu, - uzticēšanās valsts pārvaldei, attiecības starp iedzīvotājiem, pašvaldību un centrālo varu, ombuda institūcijas ieviešana u. c. ${ }^{4}$ Pētijumi par korupciju kā vienu no politiskās drošības elementiem Latvijā sāk parādīties līdz ar "Sabiedrības par atklātību - Delna" dibināšanu 1998. gadā. "Delnas" pirmais pètījums par korupciju Latvijā izdots 2000. gadā, akcentējot nepieciešamību pēc sabiedrību integrējošas programmas, kas veicinātu nacionāli valstiskās identitātes pieaugumu, samazinātu cilvēku atsvešināšanos, sekmētu sabiedrības tiesisko un pilsonisko izglītošanu. ${ }^{5}$

Lìdz ar korupcijas aktualizāciju akadēmiskajā vidē parādās virkne pētỉjumu, pievēršoties tādiem jautājumiem kā korupcijas riski veselības aprūpes sistēmā, ${ }^{6}$ publiskajos iepirkumos, ${ }^{7}$ valsts pārvaldēe. ${ }^{8}$

Vienlaikus Latvijā tiek veikti regulāri kvantitatīvi pētijumi par iedzīvotāju uzticēšanos valdībai, iestādēm un pašvaldībām. Tā, piemēram, no 2002. gada SIA "Latvijas Fakti" un pētijumu centrs SKDS regulāri veic sabiedriskās domas aptaujas. ${ }^{9}$

Latvijā ir veikti vairums pētījumu par iedzīvotāju līdzdalību politiskajās norisēs, piemēram, 2015. gada pētỉjumā par mazākumtautību līdzdalību demokrātiskajos procesos Latvijā tiek norādīts, ka mazākumtautībām ir salīdzinoši augsta interese iesaistīties politiskajos procesos, taču tajā pašā laikā cittautiešos ir zema pārliecība, ka kaut kas mainīsies Saeimas, valdības vai pašvaldību līmenī. ${ }^{10}$ Arī pētỉjumā par jauniešu politisko līdzdalību Latvijā tiek secināts, ka jauniešu interese par politiku ir izteikti zema, to priekšstats par politiku ir

3 Sīmane, M. (ed.) (2003). Latvija. Pārskats par tautas attīstību 2002/2003. Cilvēkdrošība, 30. lpp. Pieejams: http://providus.lv/article_files/920/original/UNDP2003_ful_lv.pdf?1326366357

4 Tautas attīstības pārskati. Pieejams: https://www.lu.lv/zinatne/zinatniskas-publikacijas/tautasattistibas-parskati/

5 Putniņa, A., Sedlnieks, K. (2000). Korupcijas seja Latvijā. Rīga: Sabiedrība par atklātību Delna, 104. lpp.

6 Mangule, I. (2015). Korupcija veselības sektorā: izaicinājumi un labās prakses piemēri Latvijā. Rīga: Sabiedriskās politikas centrs PROVIDUS.

7 Skatīt arī: Kriviņš, A. (2015). Korupcijas novēršana un apkarošana publisko iepirkumu jomā. Rīga: Drukātava.

8 SKDS. Pētījums par korupciju valsts iestādēs. Pieejams: https://www.mercell.com/lv-lv/31549912/ skds_petijums_par_korupciju_valsts_iestades.aspx [skatīts 10.09.2020.]

9 Kaktiņš, A. No sabiedrības uzticības krīzes līdz valsts drošībai: riski lēmumos, komunikācijā vai kur citur? Pieejams: https://www.pkc.gov.lv/sites/default/files/inline-files/15-40\%20Arnis\%20Kaktins.pdf

10 Pētījums "Mazākumtautību lìdzdalība demokrātiskajos procesos Latvijā" (2015). Rīga: Baltic Institute of Social Science, 51. lpp. 
negatīvs, turklāt jauniešu vidū nav viedokḷu līdera. ${ }^{11}$ Pašvaldību līmenī ir veikts pētijjums, izvēloties Ķekavas novada gadījuma analīzi un secinot, ka pašvaldību līmenī iedzīvotāju viedokḷi un priekšlikumi netiek iekḷauti attīstības plānošanas dokumentos vai to dalíba nav radijusi redzamas izmaiņas. ${ }^{12}$

Līdzīgi kā citi politiskās drošības elementu pètījumi, arī pētījumi par cilvēktiesībām Latvijā ir veikti regulāri, un pamatā tos veic Tiesībsarga birojs, Labklājības ministrija, Latvijas Cilvēktiesību centrs. Veiktas arī atsevišķas sabiedriskās aptaujas. 2006. gadā Providus veica pētījumu par cilvēktiesībām Latvijā, kur secināja, ka lielākā daḷa iedzīvotāju par svarīgām uzskata tiesības uz izglìtîbu un tiesības uz sociālo garantiju nodrošinājumu, tiesības uz darbu un taisnīgiem, labvēlīgiem darba apstākḷiem. ${ }^{13}$ Šajā pašā pētijumā secināts, ka apmierinātība ar cilvēktiesību ievērošanu iedzīvotāju vidū nav viennozīmīga, daļa uzskata, ka cilvēktiesību ievērošana Latvijā ir pozitīva, savukārt otra daļa norāda, ka pastāv trūkumi politiskajā un ekonomiskajā vidē. ${ }^{14}$

Tomēr tieši pēdējos divos gados (2019. un 2020. gadā) ir sagatavoti vairāki nozīmīgi pētījumi, kas skar politiskās drošības jomu. Ievas Bērziņas un Ulda Zupas 2020. gada pētījumā par Latvijas sabiedrības gribu aizstāvēt valsti secināts, ka $50 \%$ respondentu uzticas savai pašvaldībai, bet $30 \%$ valdībai. Pētījumā atklāts, ka uzticēšanās pašvaldībām ir augstāka nekā valdībai, jo pašvaldības vadītāji ir tuvāk iedzīvotājiem, vieglāk sasniedzami un ikdienā ir redzami sasniegtie rezultāti pilsētas attīstības veidolā. ${ }^{15}$

Valdỉbas darbībspēja ${ }^{16}$ jeb tās kapacitāte veikt tai noteiktos uzdevumus ir pētīta Turības biznesa indeksā, kur SKDS, aptaujājot uzṇēmējus, secināja, ka valdības darbības ietekme uz uzṇēmējdarbību drīzāk traucē. Tas pamatots ar uzṇēmējdarbību saistìtas likumdošanas mainību, lielu administratīvo slogu un neprognozējamību pieņemtajos lēmumos. ${ }^{17}$ Tāpat arī 2019. gada decembrī SKDS veica iedzīvotāju aptauju par Latvijas valdības darbu, kur iedzīvotāji

11 Exocol Latvia (2015). Jauniešu politiskā lìdzdalība Latvijā: situācijas raksturojums un lìdzdalības faktoru (determinantu) analize. Riga: Latvijas Jaunatnes padome, 31. lpp.

12 Lukjanska, R. (2017). Pilsoniskās iesaistes veicināšana pašvaldībās: Ķekavas novada piemērs. Rīga: Latvijas Pilsoniskā alianse, 18. lpp.

13 Baltijas sociālo zinātṇu institūts (2006). Pētījums par cilvēktiesībām Latvijāa. Rīga: Sabiedriskās politikas centrs PROVIDUS, 3. lpp.

14 Turpat.

15 Bērziṇa, I., Zupa, U. (2020). Latvijas sabiedrības griba aizstāvēt valsti: veicinošie un kavējošie faktori. Rīga: Nacionālās aizsardzības akadēmijas Drošības un stratēǵiskās pētniecības centrs, 14. lpp.

16 Darbībspēja jeb kapacitāte (angḷu val. capacity) - darbības resursu pietiekamỉba, t. i., darbinieku, tehniskā aprīkojuma un finanšu daudzums un piemērotība. Zobena, A. (red.) (2006). Latvijas pārskats par tautas attīstību. Rīga: Sociālo un politisko pētījumu institūts, 14. lpp.

17 SKDS (2020). Turības Biznesa Indekss. Pieejams: https://www.turiba.lv/lv/augstskola/turibas-biznesa-indekss [skatìts 10.09.2020.] 
norādīja, ka ir neapmierināti ar valdības darbu, tādējādi pastāvošās valdības darbspējas vērtējums iedzīvotāju vidū turpina kristies. ${ }^{18}$

Tiesībsarga birojs arī pēdējos gados ir veicis nozīmīgus pètījumus, kuros ir aplūkoti citi politiskās drošības elementi. Pētijumā par nodokḷu reformu secināts, ka netiek izpildīti pamatprincipi attiecībā uz vienlīdzību, neitralitāti, stabilitāti un vienkāršību. ${ }^{19}$ Veicot pētījumu par labas pārvaldības principiem pašvaldībās, Tiesībsarga birojs secināja, ka valsts un pašvaldību iestādēs pastāv atklātības trūkums, korupcijas riski, savukārt pieklājīga un pretimnākoša attieksme pašvaldībās ir uzlabojusies. ${ }^{20} 2020$. gadā tika veikts pētijums par diskrimināciju darba vidē, secinot, ka diskriminācija samazinās, bet joprojām darba tirgū ar diskrimināciju saskaras jaunieši un pirmspensijas vecuma iedzīvotāji. ${ }^{21}$

Pārskatot pieejamo akadēmisko literatūru un sabiedriskās domas aptaujas, var secināt, ka Latvijā pētỉjumi par politisko drošîbu ir sadrumstaloti un sadalīti pa tās elementiem. Tikai skatot katru elementu kopā ar citu elementu, var veidot pilnīgu ainu par politisko drošỉbu Latvijā.

\section{Politiskās drošības jēdziens}

Viens no drošības pētniekiem ir Barijs Buzans (Barry Buzan), kurš piedāvāja plašāku drošības jēdziena skatījumu, kas atspoguḷots 1982. gadā grāmatā "Cilvēki, valstis un bailes" (People, States and Fear), ${ }^{22}$ tai skaitā definējot politisko drošību. Vēlākajos darbos drošības pētnieki Barijs Buzans, Ole Vēvers, Jāps de Vilde (Barry Buzan, Ole Woever, Jaap de Wilde), kuri pārstāv Kopenhāgenas skolu, norāda, ka politiskā drošỉba ir saistìta ar sociālās kārtības organizēšanu un stabilitātes nodrošināšanu. Tādējādi politiskās drošỉbas sektors savos pamatos aplūko iespējamos draudus valsts suverenitātes ilgtspējai..$^{23}$ Politisko

18 Leta. Aptauja: Turpina kristies Kariṇa vadītās valdības darba vērtējums. Diena, 19.01.2020. Pieejams: https://www.diena.lv/raksts/latvija/zinas/aptauja-turpina-kristies-karina-vaditas-valdibas-darbavertejums-14234000 [skatìts 10.09.2020.]

19 Koṇušveskis, R. u. c. (2019). Nodokḷu reforma neapliekamā minimuma, atvieglojumu un attaisnoto izdevumu piemērošanas problēmu, efektivitātes un risinājumu izvērtējumā. Rìga: Latvijas Republikas tiesībsargs, 199. lpp.

20 Arklone, I. (2017). Labas pārvaldības ievērošana valsts un pašvaldības iestādēs Rīga: Latvijas Republikas tiesibsargs, 46.-47. lpp.

21 Norstat (2020). Diskriminācijas izplatība nodarbinātības vidē Latvijā. Rīga: Latvijas Republikas tiesibsargs.

22 Buzan, B. (2007). People, states \& fear: an agenda for international security in the post-cold war era. Colchester, England: European Consortium for Political Research Press.

23 Buzan, B., Wæver, O., Wilde, J. de (1998). Security: A new framework for analysis. Lynne Rienner Publishers, p. 141. 
drošỉbu saista ar valsts pārvaldes institūciju darbības stabilitāti, to leg̣itimitāti un ideoloğisko noturību, varas līmeṇu attiecỉbām, pārvaldes statusu un tās atzišanu/vērtēšanu. ${ }^{24}$

Jāṇem vērā, ka līdz ar Kopenhāgenas skolas pārstāvjiem arī citi pētnieki attīstijja politiskās drošỉbas jēdziena izpratni. Viens no virzieniem, kur attīstijās politiskās drošỉbas jēdziena izpratne, ir cilvēkdrošība (human security). Cilvēkdrošības pētījumos tiek iekḷauta politiskā (valstiskā) drošība (state security). ${ }^{25}$ Politiskie draudi no cilvēkdrošības perspektīvas ir civiltiesību un cilvēktiesību neievērošana, ierēdṇu bezatbildība, korupcija, valsts pārvaldes nestabilitāte un tiesu sistēmas nepilnības. ${ }^{26} \mathrm{Līdz}$ ar to cilvēkdrošības ietvaros politisko drošību nosaka valdības stabilitāte, legitīms likumdošanas process, skaidra lēmumu pieṇemšanas procedūra, efektīva valsts pārvalde, līdzdalība vēlēšanās un lēmumpieņemšanas procesos un cilvēktiesību ievērošana. ${ }^{27}$

Pētnieks Jorgs Nefs (Jorge Nef) norāda, ka politiskajā drošībā ietilpst pārstāvniecība, autonomija (brīiiba), līdzdalība un iespēja paust atškirīigu viedokli, kas ietver juridisku brīvību, tiesu sistēmas drošību un stabilitāti. ${ }^{28}$ Līdzīgi 1994. gadā norādīja arī Paza Butdāla (Paz Buttedahl), ka politiskā drošỉba ietver tiesisko drošību, individuālo un kolektīvo piekḷuvi tiesai, kā arī aizsardzību pret vardarbību. ${ }^{29}$ Bjorns Molers (Bjorn Moller) uzskata, ka politiskā drošība ir saistīta ar attiecībām starp valsti un tās iedzīvotāju. ${ }^{30}$

UNESCO pētijumā par Austrumeiropu politisko nedrošibu saista ar demokrātijas konsolidācijas problēmām, uzticības trūkumu institūcijām un

24 Filimon, L. M. (2016). An Overview of the Copenhagen School's Approach to Security Studies: Constructing (In)Security through Performative Power, p. 54. Pieejams: https://www.academia. edu/38227272/An_Overview_of_the_Copenhagen_School_s_Approach_to_Security_Studies_ Constructing_In_Security_Through_Performative_Power

25 Hassan, O. (2015). Political security: from the 1990s to the Arab Spring. Contemporary Politics, 21 (1), pp. 86-99. Pieejams: https:/www.tandfonline.com/doi/full/10.1080/13569775.2014.993907?scroll=top\&need Access $=$ true

26 Tadjbakhsh, S., \& Chenoy, A. (2007). Human security: Concepts and implications. Routledge. ISBN 9780415473385.

27 Ozoliṇa, Ž. (2014). Ziņojums par cilvēkdrošības koncepcijas ieviešanu kopienu lìmenī. Pieejams: https://nvo.lv/uploads/201910181603026858.pdf

28 Nef, J. (1999). Human Security and Mutual Vulnerability: The Global Political Economy of Development and Underdevelopment. Pieejams: https://idl-bnc-idrc.dspacedirect.org/bitstream/handle/ 10625/21995/IDL-21995.pdf?sequence=5\&isAllowed $=\mathrm{y}$

29 Buttedahl, P. (1994). Viewpoint: True Measures of Human Security. Ottawa: IRDC. Pieejams: http:// www.nzdl.org/cgi-bin/library?e=d-00000-00---off-0cdl--00-0----0-10-0---0---0direct-10---4-----0-11--11-en-50---20-about---00-0-1-00-0-0-11----0-0-\&cl=CL1.129\&d=HASH0115fbc366ca719a$9 \mathrm{~b} 468 \mathrm{ad} 8.7 .7 \& \mathrm{x}=1$

30 Bjorn, M. (2000). The Concept of Security, p. 7. Pieejams: https://www.peacepalacelibrary.nl/ebooks/ files/370659244.pdf 
pieaugošo korupciju. ${ }^{31}$ Iepriekš apskatīitie pētijumi par politisko drošǐbu norāda, ka drošỉba tiek skatīta kopienu un indivìda līmenī, valstij nodrošinot, ka tiek ievērotas iedzīvotāju tiesības, intereses un tie tiek pasargāti, kā arī pieņemtie lēmumi ir leǵitīmi, tādā veidā nodrošinot iedzìvotāju drošîbu.

Par pamatu pētījuma analìtiskā ietvara izveidei ir izmantots politiskās drošības sektora definējums, kas izriet no cilvēkdrošỉbas pētijumiem. Atbilstoši tam noteiktas šādas draudu grupas, kas saistītas ar politisko drošỉbu: neleǵitīmu politikas lēmumu pieņemšana, sarežğìtas vai pat neesošas attiecības starp centru un reǵioniem, iedzīvotāju neiesaistǐšanās lēmumu pieṇemšanā, nepārraudzītas vēelěšanas.

Lai izzinātu iedzīvotāju subjektīvo drošības uztveri politiskās drošības sektorā un noskaidrotu, vai noteiktos politiskās drošības draudus iedzīvotāji vērtē kā nozīmīgus, fokusa grupu intervijās tika izvirzītas šādas jomas:

- vai iedzīvotājiem ir saprotami valdības pieñemtie lèmumi;

- kā politiskā pēctecība ietekmē iedzīvotāju drošỉbu, ar to saprotot, vai jaunā valdība turpina iesākto politisko kursu vai arī to pārtrauc, uzstājot uz to, ka tas ir bijis nepareizs;

- vai, pēc iedzīvotāju domām, politiķi spēj piedāvāt saprotamu ilgtermiņa attīstības plānu, lai samazinātu biežas likumdošanas izmaiņas, piemēram, nodokḷu politikā;

- vai politiskās attiecības starp centru un regioniem ir lïdzsvarā vai pastāv būtiskas atšḳirības, kas ietekmē iedzivotāju politiskās drošības uztveri;

- vai pašvaldības darbība un lèmumu pieñemšanas process ir caurspīdīgs un iedzīvotājiem saprotams, turklāt tāds, kurā būtu atspoguḷotas iedzīvotāju vēlmes par sociālo aprūpi, infrastruktūru utt.;

- vai iedzīvotāji uzskata, ka vēlēšanas ir legitīimas, ar to saprotot, ka iedzīvotāji uzticas vēelěšanu norisei;

- vai, pēc iedzīvotāju domām, korupcija ir problēma un to var identificēt gan valsts, gan pašvaldību līmenī kā problēmu, kas ietekmē viṇu politiskās drošības uztveri.

31 Tadjbakshs, Sh., Tomescu-Hatto, O. (2007). Promoting human secuirty: ethical, normative and educational frameworks in Eastern Europe, p. 52. Pieejams: https://unesdoc.unesco.org/ark:/48223/ pf0000151145? posInSet=1\&queryId=e7e86a89-64bc-4890-8737-d7985bb43043 


\section{Latvijas iedzīvotāji par politisko drošību}

Fokusa grupu intervijās primārais uzdevums bija noskaidrot, ko iedzīvotājiem nozīmē politiskās drošības elementi katram personīgi un kuri no tiem viṇus satrauc un rada bažas par politisko drošību. Iegūtie rezultāti tālāk izklāstīti detalizētāk, lai iegūtu padziļinātāku izpratni par iedzīvotāju politiskās drošības uztveri, t. sk. aplūkojot iepriekš noteiktās jomas.

\section{Valdības pieṇemtie lēmumi}

Iedzīvotāju ieskatā, valdības stabilitāte ir l, loti būtiska, ${ }^{32}$ jo no valdības ir atkarīga lēmumu paredzamība. Valdības stabilitāte ir ne tikai politisko partiju spēja vienoties par attīstības virzieniem un pieejamo finansējumu attīstības iniciatīvām, bet tā arī iekḷauj iedzīvotāju līdziesaisti un atbalstu pieṇemtajiem lēmumiem.

Vīrietis darbspējas vecumā, Liepāja: Nepieciešams apzināties, jo tas, ko dari šodien, būs derīgs arī rītdien.

Arī Jaunjelgavā diskusijas laikā iedzīvotāji uzsvēra, ka stabilitātes trūkums mazina motivāciju iedzīvotājiem iesaistīties valdības pieṇemto lēmumu îstenošanā vai atsevišķu iniciatīvu atbalstīšanā, jo viņu prioritāte ir savas sociālās labklājības nodrošināšana.

Jauniete, Jaunjelgava: Nestabilitāte nemotivē iesaistīties iedzīvotājiem, jo cilvēki ir pārāk aizṇemti, lai nodrošinātu savu sociālo labklājību.

Tas liecina: lai gan iedzīvotājus uztrauc valdības stabilitāte un tās ietekme uz tiešiem gimenes labklājības rādītājiem, valdības stabilitāte tiek aplūkota caur indivīda labklājības veicināšanas prizmu. Respektīvi, vai lēmumu rezultātā uzlabojas individuālā labklājība vai ne. Tomēr diskusijās izkristalizējās, ka iedzīvotājiem trūkst izpratnes par saikni starp individuālajām vajadzībām un valdības stabilitāti. Tas veido apburto loku, kur bez valdības nav iespējama ilgtspējīga labklājība indivīda līmenī, savukārt bez iedzīvotāju iesaistes valdības lēmumu pieņemšanā un pieņemto lēmumu izpildē ir apdraudēta valdības stabilitāte.

Sieviete darbspējas vecumā, Valmiera: Politikiem ir jālauj strādāt, un nevar viņus tik bieži mainìt. Jo stabilāka valdība, jo lielāka drošîba. 


\section{Politiskā pēctecība}

Fokusa grupu interviju laikā bija iespējams secināt, ka iedzīvotājus vairāk uztrauc politiskā pēctecība jeb valdības iesākto darbu kontinuitāte. Proti, jau uzsākto politisko iniciatīvu pabeigšana. Šobrīd iedzīvotāju subjektīvajā drošības uztverē dominē viedoklis par situāciju, kad netiek panākts politiskais kompromiss kādā jautājumā, valdība ir spiesta demisionēt, bet jaunā valdība noraida visas iepriekšējās uzsāktās iniciatīvas kā aplamas, tādējādi ne tikai nelietderīgi tērējot valsts finanšu resursus, bet arī graujot uzticību valsts pārvaldei kopumā.

Vīrietis darbspējas vecumā: Politiķi sēj nedrošỉbas sajūtu, viṇi nomainās ik pēc četriem gadiem un nenes nekādu atbildību. Nav atbildības - nav drošỉbas.

Atsaucoties uz Ministru kabineta iekārtas likumu, kur 4. pantā ir noteikta politiķu atbildība, ${ }^{33}$ arī Valsts kanceleja 2020. gadā sagatavoja un publicēja vadlīnijas izpildvaras politisko un pārvaldes amatpersonu sadarbībai, ${ }^{34} \mathrm{kur}$, lai gan vispārīgi, bet tomēr tiek noteikta politisko amatpersonu atbildība. Turklāt ministri ir atbildīgi Saeimas priekšā par pieņemtajiem lēmumiem. Šobrīd iedzīvotāju skatījumā ši sistēma nav sevi attaisnojusi kā efektīvu līdzekli, lai sniegtu drošību un stabilitāti par pieņemtajiem lēmumiem valdības līmenī. Iedzīvotāju ieskatā, atbildīguma sistēmu par politiķu pieņemtajiem lēmumiem būtu nepieciešams pilnveidot, to attiecinot ne tikai uz valdỉbu, bet arī uz Saeimu.

Respondents, Rīga: Valdībai ir daudz neprofesionalitātes, politika ir zemā profesionālā lìmenī, kam trūkst pieredzes, un tiek lemts par lietām, par kurām nav ne mazākās sajēgas.

Savukārt citās fokusa grupas interviju norises vietās, piemēram, Aizkrauklē, norādīja, ka valdības stabilitāte ir uzlabojusies, jo valdības vairs nemainās tik bieži, līdz ar to iespējams panākt politikas plānošanu garākā termiṇā. Tomēr iedzīvotāji kā problēmu uzsver partiju stabilitātes trūkumus jeb nespēju ilglaicīgi pastāvēt - gandrīz visas partijas saskaras ar organizatoriskām problēmām, tādējādi ierobežojot to spēju strādāt vairākas desmitgades. Rezultātā norisinās pārgrupēšanās, kas cilvēkos ir radījusi neuzticîbu politikai.

33 Saeima (01.07.2008.). Ministru kabineta iekārtas likums. Pieejams: http://m.likumi.lv/doc.php? id=175919 [skatìts 05.05.2020.]

34 Valsts kanceleja (17.02.2020.). Vadlīnijas izpildvaras politisko un pārvaldes amatpersonu sadarbībai. Pieejams: https://www.google.com/url?sa=t\&rct=j\&q=\&esrc=s\&source=web \&cd=5\&cad=rja\& uact=8\&ved=2ahUKEwjT3pvPxZzpAhVu2aYKHarqC6YQFjAEegQIBhAB\&url=https\%3A\%2F\% 2Fwww.mk.gov.lv\%2Fsites\%2Fdefault\%2Ffiles\%2Fpage\%2Fattachments\%2Fgreco_vadlinijas_ 17.02.2020_gala.pdf\&usg=AOvVawljhhCuhOeQyUTdJd7kxsFT [skatīts 05.05.2020.] 
Jaunietis, Aizkraukle: Nav attīstījušās stabilas partijas, iznฺemot vienu, Saskaņa. Savukārt pārējās ir organizatoriski vājākas, kuras spētu strādāt vairākus desmitus gadus. Notiek pārgrupēšanās, un tas ir radījis cilvēkos neuzticību. Tiek bìdītas ìsterminga intereses, un nav stabilas vizijas.

\section{Ilgtermiṇa redzējums}

Kā nozīmīgu draudu politiskās drošības uztverē iedzīvotāji visās fokusa grupu interviju norises vietās uzskata valdības un politiķu nespēju piedāvāt ilgtermiņa attīstības redzējumu. Piemēram, Ādažos un Liepājā norādīja, ka nepastāv kopīgs redzējums par valsts attīstìbu divdesmit un trīsdesmit gadu perspektīvā. Arī Jaunjelgavā iedzīvotāji izteica vēlmi un nepieciešamību pēc ilgtermiṇa plāna. Valmierā akcentēja nepieciešamību pēc plānošanas vismaz desmit gadu perspektīvā, bez kā nav iespējams runāt par attīstîbu. Arī Gulbenē, Daugavpilī un Rēzeknē iedzīvotājiem šķita, ka normatīvie akti pārāk ātri mainās.

Vĩrietis darbspējas vecumā, Jaunjelgava: Šobrīd Latvijā nestrādā ilgtermiña un pat vidējā termina plānošana, visa tiek darìta ìsterminnā.

Respondents, Talsi: Man drošība nozìmē drošība par rìtdienu, ka varēs uzturēt ǵ imeni un būs droša vide.

Sieviete darbspējas vecumā, Rēzekne: Vairāk tas ir darba jautājumos, būvniecībā, ja nāk jauni likumi un biežas izmainas, pēdējo piecu gadu laikā viss kḷusts sarežğìtāk, lìdz ar to nav pārliecības par nākotni. Jauni ministri daudz ko maina, taču ar mainīgām sekmēm. Vai tas būs ilgterminnā, tas nav skaidrs.

Jauniete, Gulbene: Neskatās ilgtermiņā, domā tikai istermiņā, un katrs cīnās, ka četros gados paveic to un to [..] cinnās par to, ko varēs parädìt nākošās vēlēšanās.

Lai gan ātru lēmumu pieņemšanu uztver kā pozitīvu aspektu, tas nes sev līdzi negatīvas tendences, īpaši ietekmējot uzṇēmējdarbību. Tā, piemēram, uzn̦ēmēji Valmierā un Ādažos norāda, ka lēmumi par nodokḷu politiku ir pārāk mainīgi, līdz ar to grūti prognozējami, tāpēc šādu īstermiņa lēmumu pieņemšanu vērtē kā draudu. Šobrīd saskaṇā ar 2018. gada Latvijas ziņojumu Apvienoto Nāciju Organizācijai par ilgtspējīgu attīstības mērķu ieviešanu norādīts, ka Latvijas plānošanas sistēma ir decentralizēta un akūti risināmo problēmu uzṇemas tas valsts pārvaldes līmenis, kurš visefektīvāk spēj ar to tikt galā. N̦emot vērā interviju laikā identificētās problēmas attiecībā uz ilgtermiņa plānošanu valdības līmenī, jāsecina, ka ilgtermiṇa plānošanas funkcijas kaut kādā mērā ir nodotas pašvaldībām. Taču arī pašvaldībās tiek norādīts, ka to ilgtermiṇa plānošana ir atkarīga no nozares ministrijām. 
Pārresoru koordinācijas centrs ziņojumā norāda, ka valsts risina tikai to, ko pašvaldība, kopiena vai indivīds nespēj atrisināt. ${ }^{35}$ Latvijai nozīmīgi attīstības mērḳi ir definēti Latvijas Nacionālajā attīstības plānā 2021.-2027. gadam (NAP), kurš ir ilgtermiṇa plānošanas dokuments un kurā nospraustie mērķi ir saistīti ar valsts budžetu. Šajā plānošanas sistēmā pašvaldības savas vajadzības pamato ar vietējām prioritātēm un pieejamiem resursiem, kur sabiedrības līdzdalība šāda plānošanas dokumenta izstrādē ir brīvprātīga. Valmieras pašvaldības pārstāvis norādỉja, ka Valmierā, Gulbenē un Talsos ilgtermiņa plānošana tiek veikta formāli, kam neseko citas iniciatīvas, jo trūkst finansējuma.

Pašvaldības pārstāvis, Valmiera: Tik tālu, cik to nosaka likumdošana.

Pašvaldības pārstāvis, Gulbene: Lielākā daḷa no drošības draudiem ir risināmi tikai un vienīgi valdības lìmenī, jo pašvaldībà viss ir kārtìbā, bet valstiskā lìmenē nepietiek resursu.

Pašvaldības pārstāvis, Talsi: Novada attīstību būtu jādomā stratēgiskās plānošanas kategorijā, tomèr šobrīd novadam nav šādas plānošanas.

Pašvaldības pārstāvis, Talsi: Piecu līdz desmit gadu plānošanas perspektīva virzītu pašvaldību iestāžu, kapitālsabiedrību un izpildvaru darbu uz priekšu.

\section{Centra-reǵiona attiecības}

Centra-regiona ${ }^{36}$ attiecības vienmēr ir ien̦ēmušas būtisku vietu Latvijas politiḳu dienaskārtībā, diskutējot par valsts dotācijām un atbalstu nabadzīgākiem reǵioniem, jaunām iniciatīvām reǵionu investīciju piesaistei vai akcentējot regiona īpašās kultūras iezīmes. Reǵionu attīstîba ir būtiska politikas sastāvdaļa, kura ir uzsvērta un kurai pievērsta uzmanība arī valdības prioritātēs. ${ }^{37}$ Turklāt Valsts reg̣ionālās attīstības aǵentūra regulāri pasūta pētījumus par Latvija regionu attīstību, lai uzraudzìtu vispārējās reǵionu attīstības tendences. Tā, piemēram, Nacionālajā attīstības plānā 2021.-2027. gadam reǵionu attīstība ir iekḷauta kā viena no prioritātēm, kas ietver reǵionu ekonomiskās nevienlīdzības mazināšanu, to spēju veicināšanu un konkurētspējas palielināšanu. ${ }^{38}$ Vienlaicīgi plānošanas reǵioni pilda arī pašpārvaldes funkcijas. Pašpārvaldes procesa gaitā, nodrošinot reǵiona attīstības plānošanu, koordināciju, pašvaldību

35 Pārresoru koordinācijas centrs. Latvija, ziņojums Apvienoto Nāciju Organizācijai par ilgtspējīgas attīstības mērk, ieviešanu, 10.-11. lpp.

36 Šajā pētījumā centra-regiona attiecības tiek izprastas kā valdības un pašvaldību savstarpējās attiecības.

37 Skatīt: Ministru kabinets. Deklarācija par Artura Krišjāņa Kariņa vadìtā Ministru kabineta iecerēto darbību. 07.05.2019.

38 Pārresoru koordinācijas centrs. Nacionālais attīstības plāns 2027. gadam. Pieejams: https://www. pkc.gov.lv/lv/nap-2027/atbalsti-prioritates [skatīts 09.05.2020.] 
un citu valsts pārvaldes iestāžu sadarbību, rodas domstarpības starp centru un regioniem par jaunām iniciatīvām un finansējumu, tādējādi arī veidojot iedzīvotāju viedokli un to politiskās drošîbas uztveri par valdības kopējo politiku attiecībā pret reǵioniem, pašvaldībām, un otrādi.

No fokusa grupu intervijās iegūtajiem datiem ir iespējams secināt, ka regionu iedzīvotājiem ir raksturīgs stingrs nošķīums "mēs reǵionā - viṇi centrā". İpaši spēcīgi tas izpaužas Latgalē, kur iedzīvotāji uzskata, ka Rīga ir tālu un nepievērš pietiekami daudz uzmanības šì reǵiona problēmām. Šo piemēru vispārinot, šādu secinājumu var attiecināt arī uz citiem Latvijas reǵioniem.

Vīrietis darbspējas vecumā, Liepāja: Rīga un Liepāja ir tik atrauti viens no otra, ka valdìbas, Saeimas un Rīgas domes lēmumi un politika tiek jaukti.

Sieviete darbspējas vecumā, Daugavpils: Latgale kā reǵions ir attāls, un to neņem par pilnu, turklāt pastāv valodas problēmas.

Šĩ nošķīiruma dēḷ pastāv atsvešinātība no centrālās varas lēmumiem, jo tie neatspoguḷo iedzīvotāju vajadzības, līdz ar to iedzīvotāji vairāk uzticas pašvaldībām, jo tās ir tuvāk un spēj efektīvāk risināt viṇu problēmas. Šì iemesla dēḷ iedzīvotāji ir gatavi atbalstīt un piedalīties pašvaldību vēlēšanās. Vieni no iemesliem apmierinātībai ar pašvaldības darbu ir pabalstu izmaksa, atbalsts uzṇēmējiem vai Eiropas Savienības fondu apguve infrastruktūras labiekārtošanai. Tie veido kopējo subjektīvo uztveri. Pašvaldības vairāk pievēršas iedzīvotāju vajadzībām un tās īsteno.

Sieviete darbspējas vecumā, Rēzekne: Apmēram puse iedzìvotāju neuzticas pašvaldībai, bet uzticas valdībai. Savukārt ir cilvēki, kuri ir apmierināti ar pašvaldību. Pensionārs, Rēzekne: Pašvaldība cenšas vairāk nekā centrālā valdība. Strādā labāk, savukārt Rìgà vairāk runā.

Būtiskākā problēma, ko saskata iedzīvotāiji, ir finansējuma trūkums pašvaldību iniciatīvu realizēšanai, tādēl nepieciešams valdības līdzfinansējums. Arī Ādažos iedzīvotāji uzskata, ka valsts nespēj sadarboties ar pašvaldību, lai uzlabotu infrastruktūru. Tāpat iedzīvotāji intervijā norāda, ka institucionālā ziṇā pašvaldībās viss ir kārtībā, taču pašvaldību komunikācija ar sabiedrību ir slikta.

Sieviete darbspējas vecumā, Rēzekne: Rēzeknes pašvaldība cenšas apgūt ES fondus infrastruktürai, ražošanai, uzbūvèt viesnīcu, bet ir problēmas, ka šos lïdzekļus nevar dabüt, tādèl vajag subsìdijas no valdības.

Pensionāre, Liepāja: Valdība melo un manipulē, tajā skaitā arī Liepājas pašvaldìba, turklāt valdībai trūkst atgriezeniskās saiknes ar tautu. Tās vienīgā saikne ir vēelěšanas. 
Pensionāre, Jaunjelgava: Ja nevar palīdzèt, tad lai netraucē, jo reǵionos dzīvo savu dzīvi, ir savs ritms, kuru Rīga cenšas izjaukt. Turklāt valsts tiešās pārvaldes centralizācija šobrìd nodara vairāk ḷaunu nekā labu un nav izprotams, kādēl visām ministrijām jāatrodas Rìgā. Kāpèc nevarētu decentralizèt, lai varētu attīstìt regionus?

Vīrietis darbspējas vecumā, L̦audona: Mazo pagastu nākotne ir apdraudēta, jo pastāvīgi jācīnās, lai nodrošinātu finansiālu atbalstu, un Latvijas lauku attīstība nākotnē šobrìd tiek uzskatìta par draudu.

Centra-reǵiona attiecībās kā problēma uzsvērta ekonomiskā nevienlīdzība, kur atalgojums vienā un tajā pašā iestādē ir atškirīgs, piemēram, Rīgā tas ir lielāks nekā Valmierā.

Bezdarbniece, Valmiera: Rīgā vienas iestādes ietvaros ir lielākas algas nekā Valmierā, tajā pašā laikā pašvaldībā tiek pien,emti izsvērtāki lēmumi un vairāk tiek domāts par cilvēkiem.

Iedzīvotāju vērtējumā Valmiera ir Vidzemes reǵiona centrs, kas piesaista cilvēkus no apkārtējām apdzīvotajām vietām. Turklāt iedzīvotāji uzskata, ka valdība nespēj ieklausīties iedzīvotāju vajadzībās, tādējādi pašvaldība ir tā institūcija, kura klausās un cenšas īstenot identificētās vajadzības, veicinot reǵiona izaugsmi un kopējo drošìbu.

Saskaṇā ar Valsts reǵionālās attīstības aǵentūras 2018. gada teritorijas attīstības indeksa vērtību Latgales reǵions ieņem piekto vietu, ${ }^{39}$ būtiski atpaliekot no Rīgas, Vidzemes, Zemgales un Kurzemes reǵiona. Neskatoties uz centra centieniem atbalstīt Latgales reǵiona attīstību, regulāri pieņemot lēmumus par rīcības plānu ekonomikas veicināšanai ${ }^{40}$ un 2016. gadā izveidojot Latgales specializētās ekonomiskās zonu, ${ }^{41}$ līdz šim brīdim nav vērojami būtiski uzlabojumi reǵiona attīstībā, kas arī ietekmē iedzīvotāju drošìbas uztveri par centra un reǵiona attiecībām.

Problēmas ar centra (t. i., nacionālās valdības) spēju pieṇemt konsekventus lēmumus par ilgtermiņa attīstību ir viens no faktoriem iedzīvotāju drošỉbas uztverē, jo jaunas valdības prioritātes un politiḳu ambīcijas var mainīt šo attiecību līdzsvaru, ko uzskata par draudu. Lai mazinātu centra lēmumu negatìvo

39 VRAA. Teritorijas attīstības indeksa vērtības pēc 2018. gada datiem. Pieejams: http://www.vraa.gov. lv/lv/publikacijas/attistibas_indekss/ [skatits 09.05.2020.]

40 Skatīt: Ministru kabinets. Par Rīcības plānu Latgales reǵiona izaugsmei 2015.-2017. gadam. 29.04.2015. rīkojums Nr. 230. Pieejams: https:/likumi.lv/ta/id/273813-par-ricibas-planu-latgalesregiona-izaugsmei-2015-2017gadam; Ministru kabinets. Par Rīcības plānu Latgales reǵiona izaugsmei 2018.-2021. gadam. 19.09.2018. rīkojums Nr. 447. Pieejams: https://likumi.lv/ta/id/301764-parricibas-planu-latgales-regiona-ekonomiskajai-izaugsmei-2018-2021-gadam

41 Saeima (19.05.2016.). Latgales speciālās ekonomiskās zonas likums. Pieejams: https://likumi.lv/ta/ id/282586-latgales-specialas-ekonomiskas-zonas-likums 
ietekmi indivīda līmenī, iedzīvotāji pašvaldībām uzticas vairāk. Neskatoties uz komunikācijas trūkumu ar iedzīvotājiem reǵionālā līmenī, pašvaldību politikas veidotāji pārzina iedzīvotāju vajadzības un spēj saglabāt lēmumu izpildes pēctecību. Šādu tendenci pierāda arī Rīgā veiktās fokusa grupas intervijas rezultāti.

Respondents, Rīga: Pašvaldības ir tuvāk iedzìvotājiem, lìdz ar to saprot iedzīvotāju vajadzības labāk, atšksirìbā no valdības.

\section{Pašvaldības}

Pašvaldības iedzīvotājiem atrodas vistuvāk un nodrošina plašu klāstu ar dažāda veida pakalpojumiem. Pašvaldībām nepieciešams sadarboties ar vietējiem iedzīvotājiem, un otrādāk - lai spētu ātrāk identificēt draudus pašvaldībā, veicinātu iedzīvotāju uzticību pašvaldỉbai un kvalitatīvāk sniegtu pakalpojumus. Nozīmīgi elementi politiskās drošỉbas nodrošināšanai un tās uzturēšanai ir ievēelētie pašvaldības deputāti un viņu skatiijums uz pašvaldības vēlamo attīstību. Svarīga nozīme politiskās drošības ietvarā ir ievēlēto deputātu vēlmei noskaidrot jautājumus, kas uztrauc vietējos iedzivotājus.

Tomēr pastāv zināms strupcẹ̣š komunikācijas nodrošināšanai starp pašvaldību un iedzīvotājiem, jo iedzīvotāji uzskata, ka trešdaļa pētijumā iekḷauto pašvaldību pietiekami nekomunicē ar iedzīvotājiem. Šādu uzskatu pauž Liepājas, Jaunjelgavas, L̦audonas iedzīvotāji.

Respondents, Liepāja: Novadā darbiniekiem ir augstprätības deva saskarsmē ar iedzīvotājiem.

Šādi izteikumi liecina par komunikācijas problēmām un veicina neuzticību pašvaldībai, tās pieṇemto lēmumu kvalitātei un nepieciešamībai. Pašvaldības norāda, ka iedzīvotāji ir pasivi un neierodas uz rīkotajiem pasākumiem, sapulcēm, tajā pašā laikā iedzīvotāji atzīmēe ka, viṇuprāt, pastāv publisko apspriešanu problēmas. Pašvaldības sagaida no iedzīvotājiem lielāku aktivitāti un iesaisti lēmumu pieņemšanas procesā, savukārt iedzivotāji sagaida labāku atgriezenisko saiti un redzamus rezultātus no iesaistes lēmumu pieņemšanas procesā.

Respondents, Liepāja: Sabiedriskās apspriešanas ir formālas.

Pašvaldību priekšrocība, ko iedzīvotāji arī novērtē, ir esība "tuvāk cilvēkiem" un iedzīvotāju interešu pārstāvniecība.

Respondents, Valmiera: Pašvaldība ir sakopta un strādā iedzīvotāju interesēs.

Respondents, Valmiera: Pašvaldība klausās, un tās vajadzības, ko uzņēmēji norāda, tiek ņemtas vērā. 
Pašvaldībām iedzìvotāji uzticas visvairāk - reǵionāla vai vietēja līmeṇa institūcijām uzticas pat $50 \%$ iedzīvotāju. ${ }^{42}$ Starptautiskie pētijumi liecina, ka efektīvāka situācijas pārraudzība veicina arī iedzīvotāju uzticību un tieši mazajās pilsētās, piepilsētās un lauku reǵionos uzticība institūcijām ir augstāka nekā lielajās pilsētās ${ }^{43}$ kur efektīva pārraudzība un kvalitatīvu pakalpojumu sniegšana ir sarežg̀îtāk īstenojama. Iedzīvotāju ieskatā, mazās pašvaldībās ir iespējama efektīvāka situācijas pārraudzība nekā lielās pašvaldībās.

Tiesa, ir iedzīvotāji, kuri uzskata, ka pašvaldības lēmumi ir nepamatoti, nesabalansēti un tās darbs nav efektīvs, minot, ka sportam pašvaldības sniedz daudz plašāku atbalstu nekā kultūrai. Šādi iedzīvotāju uzskati par pieṇemtajiem lēmumiem pašvaldībā un to nesabalansētība var būt nozīmīgs drauds politiskajai drošībai.

Respondents, Valmiera: Valmierā prioritāte ir sports, taču vajag sabalansēt to ar citām vajadzībām, piemēram, kultūru.

\section{Vēlēšanas}

Godīgas un brīvas vēelěšanas ir viens no svarīgākajiem demokrātijas stūrakmeņiem. Būtiska ir ne tikai vēlēšanu organizēšana, bet arī iedzīvotāju līdzdalība un apmierinātība ar vēlēšanu rezultātiem.

Rịgā iedzīvotāji uzskata, ka vēlēšanu rīkošanas un balsu skaitīšanas process notiek atbilstoši normatīvajiem aktiem. Iedzīvotāji norāda, ka uzticas Centrālajai vēlēšanu komisijai (CVK), tas ir nozīmīgi politiskās drošības ietvarā. Šie argumenti atbilst arī CVK veiktajiem pētijumiem, kur vairums respondentu norādīja, ka 13. Saeimas vēelěšanās nesaskārās ar problēmām iecirkṇa darbā, un uzskatīja, ka vēlēšanu rezultāti tika saskaitīti godīgi. ${ }^{44}$ CVK pētījumā $78 \%$ aptaujāto respondentu uzskatiija, ka 2017. gada pašvaldību vēlēšanās balsis noteikti saskaitītas godīgi. Savukārt 2018. gada Saeimas vēlēšanās šādi uzskatīja 70,5\%. Abos gadījumos tikai nedaudz virs 5\% iedzīvotāju norādīja, ka ir lielāka varbūtība, ka balsis nesaskaitija godīgi un noteikti nesaskaitīja godīgi. Lìdz ar to var secināt, ka vēlēšanu process ir uzticams un iedzīvotāji nesatraucas, ka varētu būt piel̦autas ḷaunprātības. Nenoliedzami ir būtiski, ka vēlētāji uzticas vēlēšanu organizatoriem un uzskata, ka vēlēšanas ir bijušas brīvas un

42 Eurobarometer 92 (2019. gada rudens), 5. lpp.

43 European Commission (2015). Trust, local governance and quality of public service in EU regions and cities, p. 23. Pieejams: https://publications.jrc.ec.europa.eu/repository/bitstream/JRC92655/ kjna27195enn.pdf

44 Centrālās vēlēšanu komisijas publiskais pārskats (2018). 37. lpp. Pieejams: https://www.cvk.lv/ uploads/files/P\%C4\%81rskati/Publiskais\%20p\%C4\%81rskats\%202018.pdf 
godīgas, jo, kā atzīst pētnieki, tad iedzīvotāji var būt spēcīgs katalizators labākai pārvaldībai un lielākai drošības nodrošināšanai. ${ }^{45}$

Par vienu no politiskās drošības elementiem, kas saistīts ar vēlēšanām, ir uzskatāma iedzìvotāju zemā uzticība vēlētām amatpersonām. Lai gan šì problēma pētỉjumos ${ }^{46}$ par vēlēšanām un viedokḷu līeru komentāros par tām ir akcentēta regulāri ${ }^{47}$ tā tiek uzsvērta arī fokusa grupas intervijās.

Sieviete, Jaunjelgava: Nepilda solijumus, ja padomātu, to, ko sola, patiesībā realizēt nemaz nevar.

Vīrietis, Rīga: Tikai dažas politiskās partijas (viena vai divas) isteno savus solījumus. Lai gan piedalos vēlēšanās, taču cerība, ka kaut kas mainīsies, samazinās.

Iedzīvotāji uzskata, ka bez uzticības politiskajiem solījumiem Saeimas vēlēšanās nav vērts piedalīties, jo viss ir noteikts un izlemts bez vinuu iesaistes. Taču tajā pašā laikā pastāv uzskats, ka nepiedalīšanos Saeimas vēlēšanās uztver kā nosacìtu draudu, jo, neaizejot nobalsot par vēlamo kandidātu, balsi atdod kādam citam, kurš nav tīkams un kurš varētu izjaukt ierasto vidi. Fokusa grupu intervijās iedzīvotāji vairāk pauda neapmierinātību ar Saeimas vēlēšanām. Tas sasaucas arī ar 2021. gada sākumā domnīcas Providus veikto pētījumu, ka 55\% Latvijas iedzīvotāju uzskata, ka viṇu balsij ir nozīme pašvaldībā, savukārt mazāk par pusi (47\%) tic savai ietekmei Latvijā. ${ }^{48}$

Sieviete pensijas vecumā, Jaunjelgava: Drošǐbu ietekmē, jo izvēlamies cilvēkus, kam uzticamies.

Jauniete, Gulbenes: Uz vēelēšanām neeju, jo viss jau ir sadalìts, nav jēgas iet.

Pensionāre, Liepāja: Politiki domā vairāk par savu labklājību, un viņiem nav laika domāt par kaut ko citu, lìdz ar to nav pamats ticēt, ka kaut kas varētu mainìties.

Viens no iemesliem, kādēl iedzīvotāji nepiedalās vēlēšanās, ir uzskats, ka nacionālie politiķi lielākoties ir korumpēti un rūpējas vien par savu personīgo labklājību. Tā, piemēram, Eirobarometra 2019. gada rudens aptaujas rezultāti liecina, ka tikai 6\% Latvijas iedzīvotāju drīzāk uzticas politiskajām partijām,

45 Global Commission on Elections, Democracy \& Security (22.06.2014.). Pieejams: https://www. kofiannanfoundation.org/supporting-democracy-and-elections-with-integrity/global-commissionon-elections-democracy-security-2/

46 Skatìt: Eiropas Parlamenta vēlētāju gaidu pètījums 2019.

47 Zanders, M. Diagnoze - solījumu nepildī̌sanas. Latvijas Avīze, 24.01.2019. Pieejams: https://www. la.lv/piegade-ar-100-prieksapmaksu

48 Kažoka, I. (29.01.2021.) Latvija - joprojām zemas uzticēšanās sabiedrība; iedzīvotāji vēlētos plašākas iesaistes iespējas. Pieejams: https://www.lsm.lv/raksts/zinas/latvija/latvija--joprojam-zemas-uzticesanas-sabiedriba-iedzivotaji-veletos-plasakas-iesaistes-iespejas.a390701/ 
kā arī tikai 37\% uzticas Latvijas tieslietu sistēmai un tiesai. Latvijas valdībai uzticas vairāk iedzīvotāju (28\%) nekā Latvijas Republikas Saeimai (19\%). ${ }^{49}$

\section{Korupcija}

Korupcijas uztveres indeksā 2019. gadā Latvija ierindojās 44. vietā no 180 valstīm ar 56 punktiem no 100 (0 - augsts korupcijas risks, 100 - zems korupcijas risks). ${ }^{50}$ Šis rādītājs ir zemāks nekā iepriekšèjā gadā, un tā iemeslus KNAB izvērtē padziḷinātāk, lai sekmētu tā uzlabošanos. ${ }^{51}$ Kopš 2012. gada līdz 2017. gadam korupcijas uztveres indekss uzlabojās, taču šobrīd redzama tā pasliktināšanās. Viens no izskaidrojumiem varētu būt nelikumīgi iegūtu līdzekḷu legalizācijas problēmas un atvērto datu un politiskā integritāte Ziemeḷu reǵionā..$^{52,53}$ Nozīmīgi, ka korupcija publiskajā sektorā var veicināt demokrātisko institūciju, kā arī demokrātisko vērtību vājināšanos. ${ }^{54}$

Saskaņā ar iegūtajiem rezultātiem var secināt, ka iedzīvotāji korupciju joprojām saskata kā vienu no draudiem. Attiecīgi korupcijas pazīmes visvairāk tiek saskatītas procesos, kas saistīti ar politiku. Mazāk citās jomās - veselības aprūpē, pašvaldību darbībā vai būvniecībā.

Jaunā māmiña: Ir korupcija veselības aprūpes jomā. Manuprāt, tauta pati ir pieradinājusi àrstus pie šìm aploksnēm [..] bet tas nav normāli. Ja es gulēšu uz nāves gultas, pienāks ārsts un paskatīsies macin̄ā, un tikai tad ar mani runās. Tas nav normāli. Ir jābùt cilvēeìibai.

Vīrietis darbspējas vecumā: Ir korupcija, un valsts politika nav stabila. Konkursi ir nepārskatāmi.

Jaunā uzṇēmēja: Pašvaldību lìmenī ir šì problēma, t. i., korupcija, jo īpaši būvniecìbas jomā.

Respondents: Austrumu pierobežā lika žogu, un tur jau ir identificēta korupcija.

Respondents: Bezdarbs, korupcija ir galvenie draudi un nelaimju cēlonis.

49 Eurobarometer 92. 2019. gada rudens, 5. lpp.

50 Corruption Perceptions Index. Pieejams: https://beta.transparency.org/en/cpi/2019/results/lva

51 Korupcijas novērošanas un apkarošanas birojs (23.01.2020.). KNAB analizē Korupcijas uztveres indeksa 2019. gada rezultātus. Pieejams: https://vportals.lv/dienaskartiba/312485-knab-analize-korupcijas-uztveres-indeksa-2019-gada-rezultatus-2020

52 Open data and political integrity in the Nordic region (26.11.2019.). Pieejams: https://delna.lv/en/ 2019/11/26/new-publication-open-data-and-political-integrity-in-the-nordic-region/

5325 corruption scandals that shook the world (05.07.2019.). Pieejams: https://beta.transparency.org/ en/news/25-corruption-scandals

54 2018. gada korupcijas uztveres indeksa rezultāti liecina par Latvijas nespēju mazinät korupciju (29.11.2019.). Pieejams: https://delna.lv/lv/2019/01/29/2018-gada-korupcijas-uztveres-indeksa-rezultati-liecina-par-latvijas-nespeju-mazinat-korupciju/ 
Fokusa grupu intervijās novērojams, ka uzticība ievēlētajām amatpersonām un viņu pieṇemtajiem lēmumiem ir zema, tas apdraud uzticību valsts institūcijām un vājina demokrātiskās institūcijas.

\section{Politiskā drošība pašvaldībās}

Šajā apakšnodaḷā analizēti pārvaldības rādītāii politiskās drošības sektorā četrās Latvijas pašvaldībās - Liepājā, Daugavpilī, Rīgā un Jaunjelgavā -, kur fokusa grupu intervijās politiskā drošības sektora draudi identificēti kā vieni no trim nozīmīgākajiem. Katras pašvaldības sniegums pārvaldības rādītāju atbilstībai politiskās drošỉbas sektoram tiks analizēts atbilstoši pētijuma gaitā izstrādātai labas pārvaldības matricai.

Labas pārvaldības rādītāji politiskās drošîbas sektorā analizēti, izmantojot intervijas ar lēmumu pieņēmējiem pašvaldībās un kvalitatīvo plānošanas dokumentu analīzi (pašvaldību attīstības plānošanas dokumenti, attīstības pārskati un citi publiski pieejami dati).

\section{Liepājas pilsētas pašvaldība}

Intervijā ar Liepājas pilsētas pašvaldības darbinieku aktualizēti politiskās drošîbas jautājumi. Intervējamais stāstīja, ka pašvaldība regulāri aptaujā iedzīvotājus, lai noskaidrotu viṇu viedokḷus par pašvaldībai aktuāliem jautājumiem, un vienlaikus norādīja uz problēmu saistībā ar iedzīvotāju niecīgo atsaucību un neaktivitāti.

Mēs Liepājā arī veicam iedzīvotāju aptaujas, un mēs redzam, ka iedzīvotāju aktīvā daḷa ir neliela. Tikuši veikti dažādi pētījumi, lai noteiktu aktualitātes Liepājā. Pēdējais pētījums, ko veica Liepājas domes (LD) Attīistības pārvalde saistībāa ar Attīstības plānu 2020.-2027. gadam. Iedzīvotāju atsaucība niecīga - piedalījās nepilni 300 respondenti. Mudinām iedzīvotājus aktīvāk iesaistīties, un attiecīgi tā aktìvā iedzīvotāju daḷa jūt, ka viņi vairāk var ietekmèt procesus gan pašvaldībā, gan valstī. Savukārt tā neaktìvā daļa - tiem šķiet, ka vinus neviens nedzird, neuzklausa, bet tie arī paši nav aktìvi savus jautājumus risināt.

Pašvaldības darbinieks norāda arī uz iedzivotāju uzticēšanos (pašvaldībai uzticas vairāk nekā valdībai) un to skaidro līdzīgi kā iedzīvotāji fokusa grupu intervijās.

Pēdējie sociolog̣iskie pētījumi jau ilgstoši parāda, ka uzticēšanās pašvaldībām Latvijā ir lielāka kā valdībai. Jautājums - kāpēc? Konkrēti Liepājas piemēers: tādēl, ka varas mainība pašvaldībās ir mazäka nekā valsts (centrälās valdības) mērogā. Liepājā varas maiña notika gadu atpakaḷ. Šì pārmaina, kas arī nenotiek bieži, saglabāja konsekvenci, jo tika respektēti iepriekšējie lēmumi un turpināti iesāktie procesi. 
Intervējamais norāda, ka pašvaldība veido sadarbību ar valsts iestādēm un strādā kopā ar tām, līdz ar to nevar uzskatīt, ka pašvaldība nesadarbojas un centrs ir tālu prom no reğiona.

Izglìtības ministrijas pārraudzībā ir Jūrniecības koledža un Valsts tehnikums, kaut kādā mèrā arī augstskolas, bet tās ir lielā mērā suverēnas, savukārt Kultūras ministrijas pārziñā ir Mūzikas, mākslas un dizaina skola, kas ir faktiski tehnikums. Mès veidojam sadarbību ar šìm iestādēm gan vertikāli, gan horizontāli. Un, to darot, ir jāatceras, ka cilvēki loti reti saprot, kas ir kura kompetence.

Apkopojot iegūtās atziņas no padziḷinātās intervijas, pašvaldības pārstāvis daudz negatīvāk vērtē iedzīvotāju iesaisti lēmumpien̦emšanas procesos, bet pozitīvāks vērtējums ir par sadarbību ar centru un iedzìvotāju uzticību. Pašvaldỉbas plānošanas dokumentos - Liepājas pilsētas attīstības programma 2015.2020. gadam, Liepājas pilsētas ilgtspējīgas attīstības stratēgija līdz 2030. gadam un Liepājas pilsētas politisko vadlīniju uzdevumi 2017.-2021. gadam - politiskās drošības draudi visizteiktāk noteikti politisko vadlīniju uzdevumos. ${ }^{55}$ Plānošanas dokumentos nav ietverti rādītāji par to, kādā veidā samazināt politiskos draudus, piemēram, zemo līdzdalību vēlēšanās, rādītāji par iedzīvotāju aktivitātes samazināšanos, taču politisko vadlīniju uzdevumos noteikts, ka dome nodrošinās brīvo amatu vakanču aizpildīšanu visās struktūrvienībās atklātos konkursos, vērtējot potenciālo darbinieku profesionalitāti. Tas saistìts ar korupcijas riska samazināšanu un pašvaldības darbības caurskatāmību.

Analizējot Liepājas pilsētas pašvaldības Uzraudzības ziņojumu (2018) par Liepājas pilsētas attīstības programmu 2015.-2020. gadam, secināts, ka rīcībpolitikas izpildē par efektīvas pilsētas pārvaldību, līdzdarbojoties pilsētas iedzīvotājiem, 90\% noteikto uzdevumu ir sasniegti. Tomēr iedzīvotāju vērtējums par pašvaldību darbu netiek veikts ikgadēji, ${ }^{56}$ tāpēc ir sarežğiti izvērtēt pilsētas iedzīvotāju līdzdarbošanos apmēru.

Attiecībā uz preventīvo rīcībpolitiku izstrādi politiskās drošības sektorā, piemēram, Liepājas speciālās ekonomiskās zonas pārvalde ir izstrādājusi dokumentu "Korupcijas un interešu konflikta riska novēršanas politika", kurā izskaidroti riski, kā rīkoties, un uz valsts amatpersonām attiecināmie speciālie

55 Liepājas pilsētas politisko vadliniju uzdevumi 2017.-2021. gadam. Pieejams: https://faili.liepaja.lv/ Dokumenti/Dokumentu-biblioteka/Strat\%C4\%93\%C4\%A3ijas-nozaru-pl\%C4\%81ni/Politisko_ vadliniju_uzdevumi_2017_2021_aktualisets_22_08_2019.pdf

56 Liepājas pilsētas attīstības programma 2015.-2020. gadam. Uzraudzības ziņojums par 2018. gadu. Pieejams: https://faili.liepaja.lv/Dokumenti/Dokumentu-biblioteka/Strat\%C4\%93\%C4\%A3ijas-nozaru-pl\%C4\%81ni/Uzraudzibas_zinojums_par_2018_gadu.pdf 
noteikumi. ${ }^{57}$ Liepājas pilsētas pašvaldības nolikumā ir noteikti korupcijas riska draudi, tātad ir veiktas preventīvas darbības, ${ }^{58}$ bet atsevišķa rīcībpolitikas dokumenta, kas apskatītu politiskās drošỉbas sektoru draudu novēršanas iespējas, nav.

\section{Daugavpils pilsētas pašvaldība}

Pašvaldības pārstāvis norāda, ka teritoriālā izvietojuma dēḷ pastāv gan nošķirtỉba starp centru un reǵioniem, gan finansējuma sadalijuma problēma. Viņaprāt, valstij būtu jāievieš atbilstoši kompensācijas mehānismi, lai nodrošinātu arī līdzvērtīgus apstākḷus kā galvaspilsētā, tā reǵionos.

Cita lieta, vai ir pietiekoši domāts un vai vispār tiek darîts kaut kas, lai atrastu kompensējošus mehānismus.

Protams, atkarīgs no tā, kur dzīvo, var būt dažādas iespējas.

Apkopojot iegūtās atziņas no padziḷinātās intervijas, politiskā drošības sektora izvērtējums ir daudz negatīvāks iedzīvotāju iesaistes procesos, bet pozitīvāks sadarbībā ar centru un iedzīvotāju uzticības jautājumā. Pašvaldības plānošanas dokumentos - Daugavpils pilsētas attīstības programmā 2014.-2020. gadam, ${ }^{59}$ Daugavpils pilsētas ilgtspējīgas attīstības stratēóija līdz 2030. gadam - ir noteikts, kas ir politiskās drošỉbas draudi. ${ }^{60}$ Piemēram, stratēgijā noteikts, ka nepieciešams uzturēt ārējās funkcionālās saites ar nacionālas nozīmes centriem. ${ }^{61}$ Laika posmam līdz 2030. gadam Daugavpils pilsētas pašvaldība izvirza šādu galveno stratēgisko mērḳi: "Daugavpils pilsēta - pievilcīgākā vieta dzīvei un uzṇēmējdarbībai Austrumbaltijā”ø2. Plānošanas dokumentos nav ietverti rādītāii par to, kādā veidā samazināt politiskos draudus.

Analizējot Daugavpils pilsētas attīstības programmas "Mana pils Daugavpils" 2014-2020. gadam īstenošanas uzraudzības un novērtēšanas kārtību, norādīts, ka uzraudzības ziṇojumi ietverti pilsētas publiskajos

57 Liepājas speciālās ekonomiskās zonas pārvalde (16.10.2019.). Korupcijas un interešu konflikta riska novēršanas politika. Pieejams: https://liepaja-sez.lv/uploads/assetDocument/source/5e09bdla64ae8.pdf

58 Liepājas pilsētas dome (2017). Liepājas pilsētas pašvaldības nolikums Nr. 14. Pieejams: http://dvs.liepaja.lv/public/passport/31431/print

59 Daugavpils pilsētas attīstības programma "Mana Pils-Daugavpils" 2014.-2020. gadam. Pieejams: https://www.daugavpils.lv/assets/upload/dokumenti/4_Istenosanas-uzraudziba-novert-kartiba_ 2020_1.pdf

60 Daugavpils pilsētas ilgtspējīgas attīstības stratēgija 2014.-2030. gadam. Pieejams: https://www.daugavpils.lv/assets/upload/attistiba/2018/Strategija2014-2030_.pdf

61 Turpat, 38. lpp.

62 Turpat, 30. lpp. 
pārskatos. $^{63}$ 2019. gada publiskajā pārskatā ir iekḷauta informācija par komunikāciju ar sabiedrību un par pasākumiem, kas veikti sabiedrības informēšanai par pašvaldības darbību, piemēram, regulāras preses relīzes, preses konferences divas reizes mēnesī, domes sēžu translācijas, reklāmas kampaņas ${ }^{64}$ tādā veidā īstenojot iedzīvotāju iesaisti un izpratni par pašvaldības paveikto.

Attiecībā uz preventīvo rīcỉbpolitiku izstrādi - politiskās drošîbas sektorā nav atsevišķa rīcībpolitikas dokumenta, kas apskatītu politiskās drošības sektoru draudu novēršanas iespējas.

\section{Rīgas pilsētas pašvaldība}

Rīgas pilsētas pašvaldības pārstāvis norādīja uz šādu problēmu - kapitālsabiedrībās tiek ieceltas personas, kas ir cieši saistītas ar politiku, tas savukārt var tikt saistīts ar korupciju politiskās drošǐbas sektora skatījumā.

Vispār vajadzētu lototi nopietni skatīties uz valsts un pašvaldību kapitālsabiedrībām. Varbüt es esmu viens no tiem cilvēkiem, kas uzskata, ka nevajag daudz kapitālsabiedrību, lai valsts var nodot privātās rokās. Tāpēc ka padomju laiku domāšana, ja kaut kas nepieder man, tad es varu zagt zemā, vidējā un augstā lìmenī, ja tas būtu privātais, tad neḷautu zagt. Diemžēl tas ir. To vajadzētu publiski stāstìt, kas notiek, publiski pamatoti, lai visi procesi ir caurspìdīgi.

Apkopojot padziḷinātajā intervijā iegūtās atziņas, var secināt, ka politiskās drošības sektora izvērtējums ir negatīvāks nekā reālā sasaiste ar labas pārvaldības indikatoriem. Rīgas pilsētas plānošanas dokumenti izstrādāti, pamatojoties uz likumu "Par pašvaldībām", Teritorijas attīstības plānošanas likumu, Ministru kabineta 16.10.2012. noteikumiem Nr. 711 "Noteikumi par pašvaldību teritorijas attīstỉbas plānošanas dokumentiem" un Rīgas domes 05.07.2011. lēmumu Nr. 3385 "Par Rìgas attīstības programmas 2014.-2020. gadam un Rịgas ilgtspējīgas attīstības stratēgijas līdz 2030. gadam izstrādi”. Rīgas ilgtspējīgas attīstîbas stratēgijā noteikts, ka "Rìgas pilsētas pašvaldỉbas virsuzdevums ir pilsētas iedzīvotāju dzīves kvalitātes uzlabošana"65. Savukārt saistībā ar politiskās drošîbas draudiem Rīgas ilgtspèjīgas attīstības stratēǵijā ir iekḷauti četri ilgtermiṇa attīstības mērḳi, no kuriem viens ir "prasmīga,

63 Daugavpils pilsētas attīstības programma "Mana Pils-Daugavpils" 2014.-2020. gadam, 270. 1pp. Pieejams: https://www.daugavpils.lv/assets/upload/dokumenti/4_Istenosanas-uzraudziba-novert-kartiba_2020_1.pdf

64 Daugavpils pilsētas 2019. gada Publiskais pārskats, 92.-93. lpp. Pieejams: https://www.daugavpils. lv/assets/upload/dokumenti/2020/Publiskais_parskats_2019.pdf

65 Rīgas domes Pilsētas attīstības departaments (2014). Rīgas ilgtspējīgas attīstības stratēóija lìdz 2030. gadam. Piejams: https://www.rdpad.lv/wp-content/uploads/2014/11/STRATEGIJA_WEB.pdf 
nodrošināta un aktīva sabiedrība" ${ }^{\prime 6}$, līdz ar to identificēts viens no politiskās drošỉbas sektora elementiem - aktīivi iedzìvotāii, kas veicina līdzdalību, piedalās lēmumu pieņemšanā. Tāpat arī šĩ mērḳa sasniegšanai noteikti šādi rezultatīvie rādìtāji - vēlētāju aktivitāte pašvaldību vēlēšanās, iedzīvotāju apmierinātìba ar pašvaldības darbu kopumā, un šie rādìtāji arī ir pastarpināti nozīmīgi politiskās drošỉbas sektorā.

Rīgas pilsētas pašvaldības publiskajā pārskatā par 2019. gadu ir ietverta informācija par īstenotajiem pasākumiem iedzīvotāju informēšanai un izglìtošanai. Atgriezeniskās saites uzturēšanai starp pašvaldību un sabiedrību 2019. gadā veiktas četras sabiedriskās aptaujas, un aptauju rezultāti ietekmē gan pašvaldības lēmumus, gan projektu tapšanu un virzību, taču iegūtie rezultāti nav publiskoti vai nav norādìts, kur tie būtu atrodami. ${ }^{67} \mathrm{Lìdz}$ ar to var secināt, ka ir apzināti politiskās drošỉbas draudi, taču par tiem būtu nepieciešama detalizētākā informācija.

Saistībā ar preventīvās rīcībpolitikas izstrādi politiskās drošības sektorā ir norādīts, ka Rīgas pilsētas pašvaldības publiskajā pārskatā par 2019. gadu ietverta informācija par Rīgas pilsētas pašvaldības vadības un darbības pilnveidošanu efektīvas darbības nodrošināšanai, iekšējo auditu, korupcijas novēršanu. Rīgas domes Birokrātijas apkarošanas centrs nodrošina korupcijas risku novēršanas sistēmas pārvaldību, kā arī sagatavo pretkorupcijas stratēgiju nākamajiem periodiem. ${ }^{68}$

\section{Jaunjelgavas pašvaldība}

No izveidotās labas pārvaldības matricas un padziḷinātajām intervijām ar Jaunjelgavas pašvaldības darbinieku var secināt, ka pārvaldības sistēma ir visnotal stabila, ņemot vērā faktu, ka Jaunjelgavas domes priekšsēdētājs amatā atrodas jau trešo termiṇu. Lai gan vadošo amatpersonu maiṇa šajā pašvaldībā nenotiek bieži, pašvaldības darbinieka ieskatā, iedzīvotāji, nebalsojot par “jauniem" cilvēkiem, mazina draudus, kas rodas, nonākot pie varas jaunai amatpersonai un mainoties ierastajai dzīves videi. Tomēr, no otras puses, iedzīvotāji alkst pēc pārmaiṇām, kuras varētu radìt jauns politiskais spēks pašvaldībā.

66 Rīgas domes Pilsētas attīstības departaments (2014). Rīgas ilgtspējīgas attīstības stratēgija lìdz 2030. gadam. Pieejams: https://www.rdpad.lv/wp-content/uploads/2014/11/STRATEGIJA_WEB. pdf, 61. lpp.

67 Rīgas pilsētas pašvaldības publiskais pārskats 2019, 29. lpp. Pieejams: https://www.riga.lv/lv/publiskais-parskats/rigas-pilsetas-pasvaldibas-publiskais-parskats-2019.pdf

68 Rīgas pilsētas pašvaldības publiskais pārskats 2019. Pieejams: https://www.riga.lv/lv/publiskais-parskats/rigas-pilsetas-pasvaldibas-publiskais-parskats-2019.pdf 
Kā apdraudējums no politiskās vides ir. Pirmo vietu pašvaldību vēlēšanās ieguva KPV LV. Tas bija bezatbildìgs protesta balsojums. Esmu trīs reizes ievēlèts, lìdz ar to baigās pārmainas iedzìvotāji nealkst.

Pašvaldībai ir sagatavota ilgtspējīgas attīstības stratēgija līdz 2033. gadam, kas ir pamats turpmākai plānošanas dokumentu izstrādei, - novada attīstības programma, novada teritorijas plānojums, nozaru plānošanas dokumenti vidējam termiņam (3-5 gadi) un īstermiṇa plānošanai. ${ }^{69}$ Tajā pašā laikā izvirzītie mērķi, kā norāda pašvaldības darbinieks, ir teorētiski un nav reāli sasniedzami. Intervijā izskan neapmierinātība ar Vides aizsardzības un reǵionālās ministrijas veidoto politiku attiecībā uz pašvaldībām. Tā ne tikai negatīvi ietekmē centra-reǵiona attiecību modeli, bet arī mazina reformu ieviešanas efektivitāti.

Ir teorētiski noformulēti mērķi, bieži vien nav reāli, un tad ir saraksts ar pasākumiem, kas jāveic. Attīstības programma ir derīga lìdz 2020. gadam, ministrija [VARAM] aizliegusi izstrādāt jaunus ilgtermiņa plānus.

Pašvaldībā ir regulāri nodrošināta caurskatāmība, izmantojot tādus instrumentus kā ikgadējie pārskati par paveikto, ${ }^{70}$ kuros sniegti revidentu ziṇojumi par iepriekšējo finanšu periodu un veicamajiem pasākumiem iedzīvotāju informēšanai, pašvaldības darbību un viṇu iespējām lēmumu pieṇemšanā. Pārskatā atspoguḷots, ka 2019. gadā iedzīvotājiem bija regulāra iespēja tikties ar amatpersonu pieņemšanas laikos, kā arī iepazīties ar domes pieņemtajiem lēmumiem, izņemot tiem, kas satur sensitīvu informāciju. Iepriekšèjā gadā ir notikusi vismaz viena tikšanās ar iedzīvotājiem Jaunjelgavā un katrā šì novada pagastā. ${ }^{71}$ Tāpat 2019. gadā ir apstiprināts korupcijas risku analīzes un pretkorupcijas pasākumu plāns 2019.-2021. gadam, ${ }^{72}$ kurā ir noteikti pasākumi korupcijas riska mazināšanai.

Kā vienu no draudiem Jaunjelgavas pašvaldības darbinieks saskata centra-regiona attiecības, jo līdzfinansējums ir būtisks šīs pašvaldības noteikto mērķu izpildei. Viņš uzskata, ka finanšu izlīdzināšana starp pašvaldībām nav taisnīga, tāpēc pastāv arī risks zaudēt dotācijas Jaunjelgavai.

69 Jaunjelgavas novada dome (2013). Jaunjelgavas novada ilgtspējīgas attīstības stratēǵija 2013.2033. gadam. Pieejams: https://www.jaunjelgava.lv/novads/novada-attistiba/ilgtspejigas-attistibasstrategija/ [skatīts 15.09.2020.]

70 Jaunjelgavas novada dome (2019). Jaunjelgavas novada pašvaldības novada publiskais pārskats. Pieejams: https://www.jaunjelgava.lv/pasvaldiba/publikacijas/publiskie-parskati/ [skatïts 15.09.2020.]

71 Turpat.

72 Jaunjelgavas novada dome (2019). Jaunjelgavas novada pašvaldības korupcijas risku analizzes un pretkorupcijas pasākumu plāns 2019.-2021. gadam. Pieejams: https://www.jaunjelgava.lv/ pasvaldiba/dokumenti/jaunjelgavas-novada-pasvaldibas-korupcijas-risku-analizes-un-pretkorupcijas-pasakumu-plans-2019-2021-gadam/ [skatīts 15.09.2020.] 
Finansējuma sadalījums Pierīgas pašvaldībās [..] finanšu izlīdzināšana starp pašvaldībām nav taisnīga - potenciāls apdraudējums pašvaldībai - [bailes] no valsts dotāciju zaudēšanas Jaunjelgavai. Tā ir 1/3 budžeta, par kuru iespējams uzturēt skolas, bèrnudārzus, teritorijas uzturēšana un sociālā palīdzība.

Kopumā var secināt, ka Jaunjelgavas pašvaldība cenšas nodrošināt labas pārvaldības praksi ar caurskatāmību un pārvaldības sistēmas stabilitāti. Taču tajā pašā laikā ir nepieciešami uzlabojumi preventīvajā rīcībpolitikā, jo Jaunjelgavā publiski nav pieejami algoritmi rīcībai krīzes situācijā un nav pašvaldības apstiprināta aktuāla civilās aizsardzības plāna. Nepieciešams paaugstināt ierēdṇu profesionalitāti, jo sarežğitāku pakalpojumu gadījumā ierēdṇi nespēj palīdzēt, tādēḷ iedzīvotājiem jādodas uz Rīgu. Tāpat jāpārskata plānošanas ilgtermiṇa redzējums, izvirzot reālus un sasniedzamus mērķus.

\section{Secinājumi}

Latvijas iedzīvotājus satrauc politiskā drošỉba un ar to saistītās problēmas. Piemēram, valsts resursu pārvaldība, ilgtermiṇa plānošana, kā arī iedzīvotājiem skaidrs ilgtermiņa redzējums ir vieni no svarīgākajiem aspektiem, lai viņi varētu apgalvot, ka politiskā drošỉba pastāv. Diemžēl ne tikai iedzīvotāji un arī ne visi politikas veidotāji uzskata, ka šobrīd trūkst ilgtermiṇa plānošanas, kurā vaino valdības veidoto politiku vai tās neesamību/neskaidrību.

Iedzīvotāju uztverē politika ietver ḷoti plašu sfēru kopumu, iekḷaujot tajā apkārtējos notikumus sabiedrībā. Līdz ar to arī visās neveiksmēs un problēmās iedzīvotāji vaino valsti kā kopumu, nevis atsevišķas amatpersonas vai institūcijas, piemēram, neefektīvā valsts resursu pārvaldībā un ilgtermiņa plānošanas neesamībā.

Interviju laikā iezīmējās vairāki būtiski aspekti gan iedzīvotāju subjektīvajā drošības uztverēe, gan politikas veidotāju redzējumā par politiskajiem draudiem. Būtiskākais no tiem ir ilgtermiṇa plānošanas vai ilgtermiṇa redzējuma trūkums, uz ko norādīja gan iedzīvotāji, gan arī lielākā dą̧a pašvaldību darbinieku. Šāda viedokḷa veidošanos ir veicinājusi pārāk biežā valdības politikas maiṇa galvenokārt attiecỉbā uz nodokḷiem, līdz ar to iedzīvotājiem trūkst stabilitātes un aug nenoteiktība par nākotni. Arī politikas veidotāji norāda uz ilgtermiņa plānošanas trūkumu, pirmkārt, jau no valdības puses un atzīst, ka pašu pārvaldītajā pašvaldībā nav ilgtermiņa plāna, jo tam neesot resursu. İpaši tas ir vērojams mazākās pašvaldībās, kā Jaunjelgava vai Talsi. Otrs subjektīvās uztveres aspekts ir cieši saistīts ar valdības stabilitāti, kur iedzīvotāji norādīja, ka tieši valdības stabilitāte veicina drošības sajūtu. Stabila valdība spēj pieņemt 
lēmumus un tos īstenot ilgākā termiņā, jo pārāk bieža valdību maiņa neveicina iesāktās politikas īstenošanu, bet gan sekmē regresu kopējā attīstībā, turklāt lieki tiek tērēti finanšu resursi. Nestabilas valdības raisa iedzīvotājos, privātajā sektorā vēl lielāku neuzticību tām, jo nav iespējams paredzēt turpmākās izmaiņas, kas var rezultēties ekonomiskā nestabilitātē. Treškārt, iedzīvotāju ieskatā, draudus stabilitātei rada politiķu nesodāmība jeb politiskās atbildības neesamība. Lai gan pastāv kārtība, kādā valdības ministri atskaitās Saeimas priekšā, tomēr šì kārtība ir pārāk vispārīga, atrauta no reālās dzīves un neuzliek līdzatbildību par pieņemtajiem lēmumiem.

Kopumā subjektīvajā drošỉbas uztverē būtiska nozīme ir komunikācijai, kur centram nepieciešams skaidrot pieņemto lēmumu nozīmi ne tikai iedzīvotājiem, bet arī reǵionos izvietotajām institūcijām, jo centra pieņemtie lēmumi ietekmē visus iedzīvotājus, kamēr pašvaldību lēmumi ir saistoši tikai tās iedzīvotājiem. Turklāt iedzīvotājiem nepieciešams skaidrot institucionālo atbildību, jo viņu uztverē atsevišķas funkcijas (visbiežāk tās, kuras pašvaldỉba nepilda vai nespēj izpildīt), kuras būtu jāpilda, pašvaldībām tiek novirzìtas kā centra atbildība, tādējādi arī veidojot centru kā draudu subjektīvajā drošỉbas uztverē. Tajā pašā laikā atseviškāās pašvaldībās iedzìvotāji uztver centru kā kaut ko tālu un grūti aizsniedzamu, tāpēc tur notiekošie procesi viņiem nešķiet aktuāli, turklāt pastāv uzskats, ka kopējā procesā viṇi nespēj neko ietekmēt. Rezultātā iedzīvotājos veidojas pretestîba centra veidotajai politikai. Tã izpaužas ne tika kā pasivitāte vēlēšanās, bet arī kā vāja iesaiste sabiedriskās apspriešanās un jaunās politikas iniciatīvās.

Lai gan iedzīvotāji lielākoties uzticas pašvaldībām un vērtē to darbu pietiekami augstu, tomēr pētījumā parādās norādes uz nepieciešamìbu pēc kvalitatīvākas savstarpējās komunikācijas. Iedzīvotājiem trūkst informācijas par iespējām iesaistīties lēmumu pieņemšanā, lai arī pašvaldības regulāri publicē informāciju vietnēs, informatīvajos izdevumos un sociālo tīklu kontos. Iespējams, ka iedzīvotāju pārmetums par ierobežotām iespējam līdzdarboties pašvaldību darbā ir saistāms ar iedzīvotāju gaidām pēc jaunām un interaktīvām iesaistes formām.

Latvijas iedzīvotāji uzticas vēlēšanu norisei, neraugoties uz to, ka uzticība politiķiem un institūcijām nav pārāk augsta. Vēlētāji paļaujas uz Centrālo vēlēšanu komisiju un apzinās, ka vēlēšanas tiek organizētas korekti un kvalitatīvi, līdz ar to nav pamata bažìties par vēlēšanu procesa pārkāpumiem.

Pašvaldībās (Liepājā, Daugavpilī, Rīgā, Jaunjelgavā), kurās fokusa grupu intervijās politiskās drošības sektora draudi identificēti starp trim nozīmīgākajiem draudiem, pašvaldỉbu plānošanas dokumentos nav apskatīti visi pašvaldībām nozīmīgie politiskās drošîbas draudi. Tā, piemēram, pašvaldības bieži 
nav aplūkojušas iedzīvotāju zemo iesaisti lēmumpieņemšanas procesos vai korupcijas risku novēršanu, jo attīstības plānošanas dokumenti tiek izstrādāti ilgākam laika posmam un pašvaldības cenšas iekḷaut gan esošās, gan arī iespējamās problēmas. Šeit saduras divas atšķirīgas subjektīvās perspektīvas, kur iedzīvotāji, iespējams, raizējas par vietējās varas atvērtību, bet vietējā vara kopējās politiskās drošíbas problēmu - korupciju - uztver kā nacionālā līmeṇa parādỉbu un neattiecina uz sevi. 


\section{Vides drošỉba}

MALVĪNE STUČKA, HARIJS KĀRKLINŠ

Mūsdienās vides draudus vairs neuzskata par dabisku apstākḷu sakritību, bet gan par cēloṇsakarību, kas izriet no cilvēku ekonomisko aktivitāšu pieauguma. Lai veiksmīgi atjaunotu resursus un rastu stratēgisku redzējumu vides drošíbas jautājumu risināšanai, nepieciešama visas sabiedrības iesaiste. Iedzīvotāju subjektīvā vides drošibas uztvere var gan veicināt, gan kavēt iespējamo risku novēršanu. Rakstā identificēti līdz šim Latvijā veiktie nozīmīgākie pētījumi par vides drošības sektoru, operacionalizēti vides draudi atbilstoši pētijuma vajadzībām un atspoguḷota fokusa grupās gūtā informācija par to, kā iedzīvotāji subjektīvi uztver vides draudus. Vides jautājumi, līdzīgi kā sabiedriskās domu aptaujās, netiek izcelti kā nozīmīgākie un primārie drošības aspekti.

Atslēgvārdi: vides drošība, vides problēmas, riski videi, Latvijas pašvaldības.

Nowadays, environmental threats are no longer regarded as a coincidence of natural conditions, but they are viewed as a causal link resulting from the increase of human economic activities. Therefore, it is essential to draw attention to the subjective perception of the population in order to be more successful in tackling the issue of renewable resources and to find a strategic vision for addressing environmental security issues. The article looks at studies carried out in Latvia regarding the environmental security sector and the operationalisation of environmental threats, and it reflects the information obtained from focus groups regarding the subjective perception about environmental threats. Environmental issues are not highlighted as the major and primary security aspect in Latvia.

Keywords: environmental security, environmental problems, environmental risks, Latvian municipalities. 


\section{levads}

Apkārtējās vides jautājumi ${ }^{1}$ ir saistīti ar drošìbu, jo tādas problēmas kā dabas piesārņojums, dzeramā ūdens un pārtikas trūkums var destabilizēt situāciju reg̣ionālajā un nacionālajā līmeni. ${ }^{2}$ Vides jautājumi raisījuši plašas diskusijas jau kopš pagājušā gadsimta 70. gadiem, taču to interpretējums strauji mainās. Šobrīd tos skata no dabas resursu un ekologijas atjaunošanas perspektīvas, kur vienlīdz svarīgi ir atjaunot resursus un rast stratēgisku redzējumu vides ilgtspējai.

Lìdz šim ir veikti pētijjumi par vides drošỉbas sektoru, bet ne kopsakarā ar iedzīvotāju draudu uztveri Latvijā, tāpēc mērḳis ir identificēt tos vides draudu veidus, kurus Latvijas iedzīvotāji vērtē kā nozīmīgus. Pirmkārt, rakstā identificēti līdz šim Latvijā veiktie nozīmīgākie pētỉjumi par vides drošības sektoru un tā elementiem. Otrkārt, vides draudi operacionalizēti atbilstoši pētỉjuma vajadzībām, un, treškārt, sniegta pētījumā iegūto rezultātu analīze un secinājumi.

\section{Kas paveikts vides drošîbas izpētē?}

Latvijā ir veikti nozīmīgi pētỉjumi par vides drošības sektoru un tā elementiem, ko var izmantot par atskaites punktu tālākajai Latvijas iedzīvotāju subjektīvās drošības analīzei.

Valsts pētijumu programma "Klimata maiņas ietekme uz Latvijas ūdeņu vidi” (KALME), kas īstenota no 2006. gada līdz 2009. gadam, ir uzskatāma par vienu no apjomīgākajiem pētỉjumiem par klimata pārmaiṇām Latvijā. Tajā pētnieki analizēja klimata pārmaiņu ietekmi uz Latvijas ezeru, upju, Baltijas jūras un tās piekrastes vidi un ekosistēmu. Pētijumā secināts, ka valsts un pašvaldību iestādes apzinās klimata pārmaiṇu izraisītās sekas, taču seku novēršanas stratēgijas un plāni vēl nebija atspogul̦oti likumdošanā. ${ }^{3}$ Papildus šai programmai ik gadu pētnieki uzsāk jaunus projektus, kuros pēta klimata pārmaiņas un ekosistēmas daudzveidības izmaiņas. Būtiski, ka valsts pētijumu programmā prioritārajos virzienos ir iekḷauti tādi virzieni, kas saistīti ar klimata pārmaiņām un dabas aizsardzību, līdz ar to vides problēmu risināšana ir atzìta par svarīgu izaicinājumu. ${ }^{4}$

Šajā rakstā vides jautājumi tiek saistīti ar vidi tās ekologiskajā izpratnē.

2 Zurlini, G., Muller, F. (06.08.2006.) Environmental Security. Pieejams: https://www.sciencedirect. com/topics/earth-and-planetary-sciences/environmental-security

3 KALME. Climate change impact on water environment in Latvia. Pieejams: http://kalme.daba.lv/en/

4 Valsts pētījumu programmas. Pieejams: https://lzp.gov.lv/programmas/valsts-petijumu-programmas/ 
Latvijā ir veikti plaši pētỉjumi par klimata pārmaiṇu iespējamo ietekmi uz lauksaimniecības nozari, virszemes ūdeṇu kvalitāti, Latvijas piekrastes teritorijām, Baltijas jūras un Rīgas jūras līča ekosistēmu un ūdens kvalitāti. ${ }^{5}$ Pètniece L. Apine ir pētījusi Latvijas piekrastes zonas eroziju un to, kā erozijas novēršanas stratēǵijas vērtē piekrastes teritoriju iedzivotāji. Pētijumā tika secināts, ka preterozijas pasākumu ieviešanu atbalstītu puse aptaujāto iedzīvotāju, savukārt otra puse neatbalstìtu šādu pieeju, jo uzskata to par neefektīvu vai norāda citus iemeslus, kāpēc to nevajadzētu istenot. ${ }^{6}$

2011. gadā publicēta kolektīvā monogrāfija "Klimata pārmaiṇas Latvijā un pielāgošanās tām" (Climate change in Latvia and Adaptation to it), kurā tika apkopoti pètijumi par klimata pārmaiņām un to mainīgumu Latvijā, par klimata pārmaiņu nozīmi nākotnē un par to, ar kādiem instrumentiem iespējams efektīvāk tās novērst vai tām sagatavoties. ${ }^{7}$

Klimata mainība, globālās sasilšanas ietekme, klimatisko faktoru ietekme, klimata politika un ilgtspējīgas attīstïbas nozīmība ir apskatìtas kolektīvajā monogrāfijā "Klimats un ilgtspējīga attīstība". Valsts pētijumu programmas īstenošanas rezultātā tika publicēta grāmata "Latvijas ekosistēmu dinamika klimata ietekmē” (2018). Tajā apskatītas ūdens un mežu ekosistēmas, kā arī izstrādāti modeḷi dabas aizsardzībai, vides plānošanas un vides problēmu risināšanai. ${ }^{9}$ 2020. gadā izdota kolektīvā zinātniskā monogrāfija Dagnijas Blumbergas redakcijā "Klimata inženierija un politika", kurā aplūkoti enerḡêtikas un klimata problēmu aspekti, - viedā uzskaite un klimata pārmaiņas, globālā klimata scenāriju ietekme uz Latvijas politikas mērķiem un energètiskā drošỉba. ${ }^{10}$ Līdz ar to par vides drošības draudiem Latvijā - klimata pārmaiṇām, ekosistēmas daudzveidības samazināšanos, ūdens kvalitātes pasliktināšanos - ir veikti plaši un detalizēti pētỉjumi.

5 Kḷaviņš, M. (2010). Klimata pārmaiṇas un to iespējamās ietekmes Latvijā. Akadēmiskā Dzīve, Nr. 47, 33.-42., 153. lpp.

6 Apine, L. (2011). Residents' attitude towards possible adaptation measures to the sea coast erosion in Latvia. International Journal of Climate Change Strategies and Management, 3(3), pp. 238-249. Pieejams: https://doi.org/10.1108/17568691111153393

7 Kḷaviņš, M., Briede, A. (red.) (2011). Climate Change in Latvia and Adaptation to it. Rìga: University of Latvia Press. Pieejams: https://edu.lu.lv/pluginfile.php/150753/mod_resource/content/1/Climat_ Change-makets\%5B1\%5D.pdf

8 Kḷaviņš, M., Zalıksnis J. (red.) (2016). Klimats un ilgtspējīga attīstība. Rīga: LU Akadēmiskais apgāds. Pieejams: https://www.zalabriviba.lv/wp-content/uploads/Klimats-un-ilgtsp\%C4\%93j\%C4\%ABgaatt\%C4\%ABst\%C4\%ABba.pdf

9 Aigars, J. (red.) (2018). Latvijas ekosistēmu dinamika klimata ietekmē. Rīga: Daugavpils Universitātes ağentūra "Latvijas Hidroekologijas institūts". Pieejams: http://lhei.lv/attachments/article/572/ Latvijas-ekosistemu-dinamika-klimata-ietekme.pdf

10 Āboltiņš, R. u. c. (2020). Klimata inženierija un politika. Rīga: RTU Izdevniecība. Pieejams: https:// ortus.rtu.lv/science/lv/publications/30901 
Vides aizsardzības un reǵionālās attīstības ministrijā 2014. gadā apzināja vides riskus, lai identificētu atbalstāmās aktivitātes Latvijas pašvaldībās 2014.2020. gada ES fondu finanšu plānošanas periodam. Šajā ziṇojumā apskatīti tādi vides riski, kas saistīti ar pazemes, virszemes, jūras piekrastes ūdeṇu situāciju Latvijas pašvaldībās, t. sk. dažādi pasākumu plāni, lai novērstu applūšanas draudus. ${ }^{11}$

Latvijā vides drošības aspekti plaši skatīti arī dažādās sabiedriskās domas aptaujās. Piemēram, Eiropas Savienībā reizi pusgadā veiktas Eirobarometra aptaujas, kurās noskaidroti dalībvalstu iedzīvotāju viedokḷi par to, kādas problēmas ir aktuālākas Eiropas Savienībā kopumā un dalībvalstī atsevišķi. Katrs aptaujas dalībnieks norāda vienu vai divas aktuālākās problēmas. ${ }^{12}$ Aptaujas dalībniekiem piedāvāja 13 izvēles variantus par aktuālākajām ES problēmām. Vides un klimata izmaiņas bija otra biežākā atbilde visā ES - 28\% ES respondentu norādīja to kā galveno problēmu (tikai imigrācija uzrādīja augstāku rezultātu - 36\%). Latvija ir viena no sešām dalībvalstīm, kur šì problēma nebija starp trīs biežāk minētajām. 18\% Latvijas respondentu vides problēmas un klimata pārmaiṇas bija tikai ceturtā biežāk minētā problēma ES. ${ }^{13}$ Aptaujas dalībniekiem piedāvāja 14 problēmas, kuras, viṇuprāt, ir būtiskākās attiecīgajā dalībvalstī. Arī šajā gadījumā vides un klimata izmaiņas jautājumi bija 2. pozīcijā (vidēji ES 21\%) tūlīt aiz veselības un sociālās drošîbas jomas. Tomēr Latvijas gadījumā tikai $2 \%$ aptaujāto norādīja, ka vides un klimata izmaiṇas ir viena no galvenajām problēmām Latvijā, - tas ir zemākais rādītājs visā ES. ${ }^{14}$ Šos datus var aplūko arī 1. attēlā, kur ir redzams salīdzinājums arī ar pārējām Baltijas valstīm. Igaunijas iedzīvotāji vairākkārt norādījuši, ka klimata pārmaiṇas ir drauds pašiem. Turklāt Latvija starp ES dalībvalstīm izceḷas ar lielāko relatīvo atšķirīibu vides un klimata izmaiņu novērtējumā. 18\% Latvijas iedzìvotāju uzskata, ka klimata un vides problēmas ir starp nozīmīgākajām ES pretstatā iepriekš minētajiem $2 \%$ respondentu. Tas norāda, ka Latvijai klimata un vides problēmas ir svarīgas. Šāda relatīvā atšķiiniba ir vispārliecinošākā starp visām ES dalïbvalstīm.

11 Būtisku vides risku apzināšana Latvijas pašvaldībās 2014.-2020. gada finanšu plānošanas perioda atbalstāmo aktivitāšu identificēěanai. Noslēguma ziņojums. Pieejams: https://www.varam.gov.lv/ sites/varam/files/content/files/nosleguma_zinojums_gala_ver_26_08_2014.pdf

12 Eurobarometer 92. 2019. gada rudens. Pieejams: https://ec.europa.eu/commfrontoffice/publicopinionmobile/index.cfm/Survey/getSurveyDetail/surveyKy/2255

13 Biežāk Latvijas respondenti minēja imigrāciju, ekonomisko situāciju, terorismu.

14 Vēl zemāku rādijjumu ieguva tikai terorisms. Pārējie 11 atbilžu varianti bija biežāk minēti, t. sk. veselība un sociālā drošība, augošās cenas, nodokḷi, nodarbinātība u. c. Turpretī Austrijas, Dānijas, Nìderlandes un Vācijas iedzīvotāji to uzskata par galveno problēmu. 


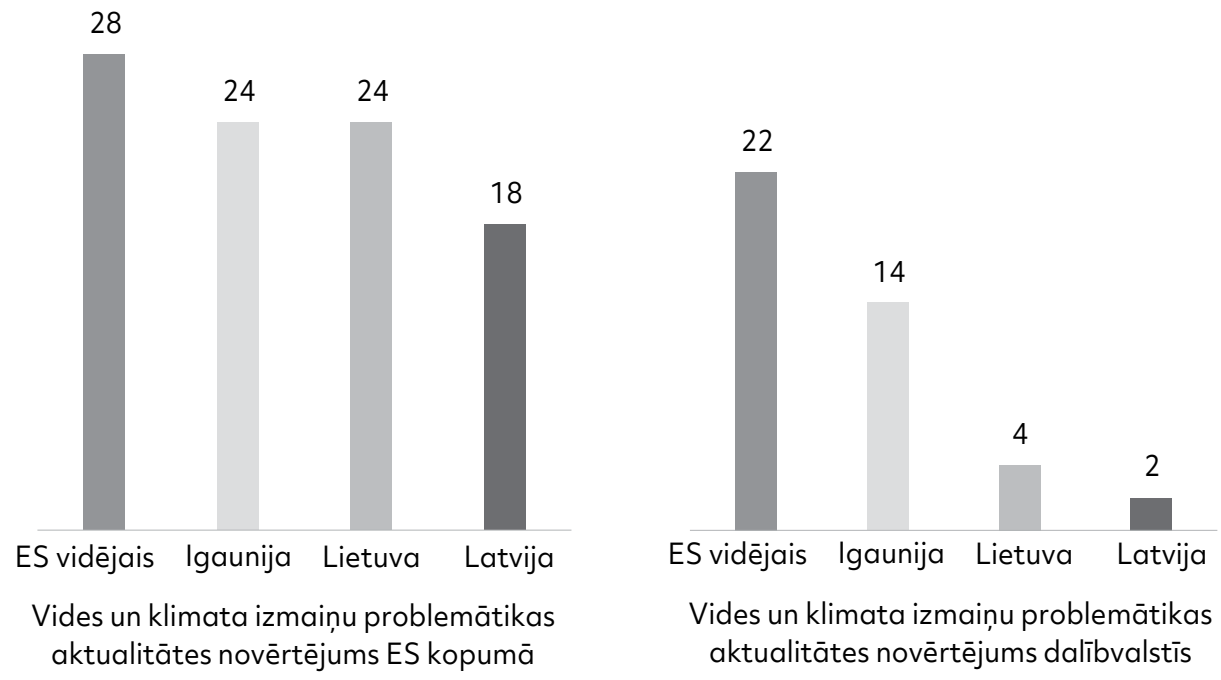

1. attēls. Vides un klimata izmainu problemātikas aktualitātes novērtējums starp ES dalībvalstu respondentiem. Eirobarometra dati, \%

Lai gan šajā pētījumā iezīmējas aina, ka Latvijas iedzīvotājiem vides un klimata izmaiṇu jautājumi nav tie būtiskākie, citi aptauju dati uzrāda, ka tie tomēr nav Latvijas iedzīvotājiem vienaldzīgi. Piemēram, 2019. gada decembra Eirobarometra specializētājā pētijumā apskatīta Eiropas iedzīvotāju attieksme pret vides problēmām. Rezultāti norāda, ka 36\% Latvijas iedzīvotāju vides aizsardzība ir ḷoti svarīga un $54 \%$ - diezgan svarīga, ${ }^{15}$ turklāt $39 \%$ iedzīvotāju uzskata, ka vides jautājumiem ir tieša ietekme uz viņu ikdienas dzīvi un veselību. ${ }^{16}$ 2019. gadā arī Latvijas Dabas fonds sadarbībā ar SKDS ìstenoja aptauju, ar kuras palīdzību noskaidroja, ka 77\% aptaujāto Latvijas iedzīvotāju uztrauc dabas daudzveidības samazināšanās Latvijā. Savukārt iepriekš SKDS veiktajā aptaujā (2018) konstatēts, ka 49\% Latvijas iedzīvotāju satrauc globālā sasilšana, bet $45 \%$ iedzīvotāju tā nesatrauc. ${ }^{17}$

15 Eurobarometer 501. 2019. Pieejams: https://ec.europa.eu/commfrontoffice/publicopinion/index. cfm/Survey/getSurveyDetail/instruments/SPECIAL/surveyKy/2257

16 Ibid

17 Ziņu ag̣entūra LETA (2018). Aptauja. Globālā sasilšana satrauc katru otro Latvijas iedzīvotāju. 


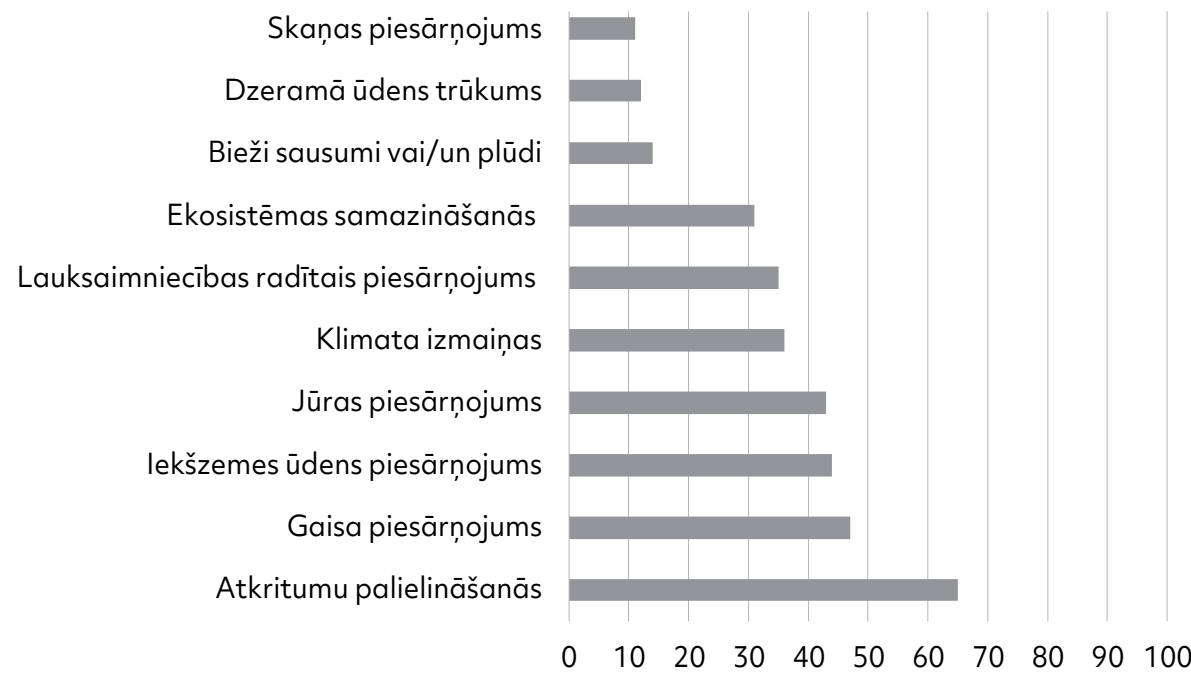

2. attēls. Nozīmīgākās vides problēmas Latvijas iedzīvotāju vērtējumā. Eirobarometrs 501, 201918

Eirobarometra specializētajā pētỉjumā arī apskatītas problēmas, kuras vides jautājumos tiek uzskatītas par būtiskākajām (2. attēls). Visvairāk - nepilnas divas trešdaḷas - iedzīvotāju satrauc atkritumu palielināšanās, bet pārējās vides problēmas nesatrauc pat $50 \%$ respondentu. Klimata pārmaiñas ir tikai piektā aktuālākā vides problēma, to nosaukuši 36\% iedzīvotāju. Šajos pētījumos aplūkotās nozīmīgākās problēmas atšḳiras, jo, piemēram, iepriekš minētajā SKDS pētījumā svarīgākā problēma bija dabas daudzveidības samazināšanās, savukārt Eirobarometra aptaujā novērojams, ka iedzīvotājus šī problēma (ekosistēmas samazināšanās) tik l̦oti nemaz nesatrauc. Dabas daudzveidība var nebūt saistīta ar klimata pārmaiņām. Vides problēmas ir daudzveidīgas un kompleksas, jo, piemēram, atkritumu palielināšanos cilvēki var attiecināt nevis uz klimata pārmaiṇām, bet gan uz savu rīcību.

Lai risinātu vides problēmas, Latvijas iedzīvotāji uzskata, ka efektīvas būtu šādas darbības:

1) patēriṇa paradumu maiņa (36\%);

2) plašāka informācijas izplatîšana un izglìtošana (35\%);

18 Eurobarometer 501. 2019. Pieejams: https://ec.europa.eu/commfrontoffice/publicopinion/index. cfm/Survey/getSurveyDetail/instruments/SPECIAL/surveyKy/2257 (p. 1). Atzīmēt varēja ne vairāk kā 4 atbilžu variantus. 
3) finansiālo stimulu ieviešana vai palielināšana uzṇēmumiem un personām, kas īsteno vides aizsardzības pasākumus (33\%);

4) stingrāku nosacījumu un ierobežojumu ieviešana vides regulējumā $(28 \%){ }^{19}$

Iedzīvotāju uzskatos var identificēt atšķirības - 78\% iedzīvotāju domā, ka lēmumi vides aizsardzības jomā būtu jāpien,em Eiropas Savienībai kopīgi, ${ }^{20}$ un tikai 19\% - ka dalībvalsts līmenī. Tādējādi iedzīvotāji ir raduši uzskatīt, ka vides problēmas ir nevis valsts vai pašvaldïbas līmeņa problēma, bet gan reǵionāla un pat starptautiska problēma. Bet tai pašà laikā pretrunīgumu rada apstāklis, ka tikai 54\% iedzīvotāju norāda, ka ES šajā jomā nedara pietiekami daudz, salīdzinājumā ar 72\% respondentu, kas uzskata, ka Latvijas valsts nedara pietiekami daudz. Visvairāk - 76\% - domā, ka paši iedzīvotāji nedara pietiekami daudz vides aizsardzībai. ${ }^{21}$

Aptaujas par vidi, tās saglabāšanu, biologiisko daudzveidíbu ir veiktas, un iegūtie dati liecina, ka iedzīvotājus satrauc klimata pārmaiņas, ekosistēmas samazināšanās, atkritumu palielināšanās. Tādēḷ svarīgi noskaidrot, kādas ir atškirỉbas un kāda ir iedzīvotāju subjektīvā drošỉbas izpratne par vides drošîbu valstī.

\section{Vides drošības jēdziens}

Vides drošìba ir daudz pētīts jēdziens. Pastāv daudzveidīgi interpretējumi, kuri liecina par apņemšanos izstrādāt visaptverošu definējumu, kas atspoguļotu laikam atbilstošu un iekḷaujošu skaidrojumu. Tā kā vides drošỉba ir cieši saistìta ar politiku, tad uzmanība pievērsta rīcībpolitikas nozīmei gan problēmas definēšanā, gan risinājumu meklēšanā. Pētnieki Sverre Lodgārds (Sverre Lodgaard) un Arturs H. Vestings (Arthur H. Westing) uzskata, ka vides sasaiste ar drošību un līdz ar to arī ar "augsto politiku" (high politics) ir veicinājusi politiķos problēmas apzināšanos un mudinājusi viņus steidzami rīkoties, lai risinātu vides problēmas un uzlabotu drošību. Lai gan vides drošību iekḷauj politikas dienaskārtībā, Barijs Buzans (Barrry Buzan), Ole Vēvers (Ole Wover) un Jāps de Vilde (Jaap de Wilde) brīdina, ka vides iekḷaušana dienaskārtībā ir nevēlama vides problēmu "pārvēršana papīros", kas ierobežo pieejamo līdzekḷu un

19 Eurobarometer 501. 2019. Pieejams: https://ec.europa.eu/commfrontoffice/publicopinion/index. cfm/Survey/getSurveyDetail/instruments/SPECIAL/surveyKy/2257 (p. 2). Varēja norādìt ne vairāk par 3 atbildēm.

20 Ibid., p. 4.

21 Ibid., p. 3. 
instrumentu klāstu vides problēmu risināšanai. Tomēr ilgtermiņā vides drošības uzlabošanu drīzāk var sasniegt, ja tā ir daļa no politiskās dienaskārtības. ${ }^{22}$

Pēc Buzana domām, vides draudi var ietekmēt arī valsts materiālo pamatu, kas savukārt var apdraudēt valsts institūciju darbību. Tādēl institūcijas šos jautājumus cenšas neignorēt un regulāri iekḷaut savā darba kārtībā. Tomēr mūsdienās vides draudus vairs neuzskata par dabisku apstākḷu sakritību, bet gan par cēloṇsakarību, kas izriet no cilvēku ekonomisko aktivitāšu pieauguma. Piemēram, siltumnīcas efektu izraisošās gāzes, ozona slāni noārdošie ķīmiskie elementi ir cilvēku īstenoto darbību sekas. ${ }^{23}$

Buzans uzskata, ka viena no būtiskākajām atbalsta sistēmām vides drošỉbas nodrošināšanai ir saistīta ar reǵionālās un planētas biosfēras un dabas daudzveidības saglabāšanu, no kuras ir atkarīgas cilvēku spējas īstenot ikdienas darbības un rīcības (human enterprises). ${ }^{24}$

Vide skatīta arī cilvēkdrošības perspektīvā. Cilvēkdrošỉbu saista ar cilvēku iespējām piekḷūt dabas resursiem un viṇu neaizsargātību no vides pārmaiṇām, jo lielākā dạ̣a vides izmaiṇu tieši vai netieši ietekmē cilvēku ikdienas darbības, piemēram, ūdens trūkums var neizraisīt karu, bet ietekmēt iedzìvotāju veselību un dzīves kvalitāti. No cilvēkdrošības perspektīvas vides drošības draudus saista ar to vispārējo ietekmi uz cilvēku dzīvi, labklājību, veselību un produktivitāti. ${ }^{25}$

Līdz ar to vides drošỉba iekḷauj planētas ekosistēmas saglabāšanu atbilstoši regioniem, cilvēku radīto ekolog̣ijas problēmu seku samazināšanu un biosfēras saglabāšanu. Šie faktori veicina sabiedrības drošîbu no vides katastrofām, kuras rada dabiskas problēmas vai problēmas nepietiekamu zināšanu dēl, - dabas resursu trūkums, neveselīga vide, vides degradācija, sociālās problēmas un konflikti. ${ }^{26}$

Tādējādi vides drošība ir jāsaista ar problēmām, kuras var grupēt trīs vispārīgās kategorijās:

1) bažas par cilvēku darbības nelabvēlīgo ietekmi uz vidi;

343396033001008. Pieejams: https://www.researchgate.net/publication/2581 55432_Environmental_Security

23 Buzan, B. (1983). People, states, and fear: The national security problem in international relations. Brighton, Sussex: Wheatsheaf Books.

24 Buzan, B. (1991). New Patterns of Global Security in the Twenty-First Century. International Affairs (Royal Institute of International Affairs 1944-), 67(3), pp. 431-451, DOI:10.2307/2621945. Pieejams: https://pdfs.semanticscholar.org/7e80/1a412aec847eb67e464852c0d6319388266e.pdf (p. 4).

25 Khagram, S., Clark, W., \& Raad, D. F. (2003). From the environment and human security to sustainable security and development. Journal of Human Development, 4(2), pp. 289-313. Pieejams: https://www.researchgate.net/profile/William_Clark3/publication/44836193_From_the_Environment_and_Human_Security_to_Sustainable_Security_and_Development/links/09e4150ac0da $26 \mathrm{c} 23 \mathrm{~b} 000000 . \mathrm{pdf}$

26 Ibid. 
2) bažas par dažādu vides izmaiņu formu tiešo un netiešo ietekmi, kas var būt dabiska vai cilvēku radīta, uz valsts un regionālo drošỉbu;

3) bažas par indivīdu un grupu nedrošỉbu, kas rodas tādu vides izmaiṇu dēl kā ūdens trūkums, gaisa piesārṇojums, globālā sasilšana u. c. ${ }^{27}$

Savukārt Džovanni Dzurlīni (Giovanni Zurlini) un Fēlikss Millers (Felix Müller) uzskata, ka vides drošības problēmas var iedalīt trīs citās kategorijās:

1) vides drošìba;

2) aizsardzība no vides izmaiņām/pārmaiņām, kas var izraisìt nestabilitāti un konfliktus valstīi;

3) aizsardzība no vides izmaiṇām/pārmaiņām (piemēram, no ūdens trūkuma, gaisa piesārn,ojuma u. c.). ${ }^{28}$

Apvienojot visas minētās kategorijas, var secināt, ka vides drošību var garantēt, ja visiem indivīdiem ir taisnīga un saprātīga pieeja videi, kā arī ir ieviesti mehānismi vides problēmu un konfliktu risināšanai. ${ }^{29}$

N̦emot vērā iepriekš aprakstīto, šajā pētījumā izvirzìtas trīs pamatkategorijas, kuras apskatītas fokusa grupu intervijās, lai noskaidrotu Latvijas iedzīvotāju subjektīvo vides drošības uztveri:

1) klimata pārmaiņas - šajā kategorijā tiek apskatīti jautājumi par vides mainīgumu un prasmi pielāgoties šiem apstākḷiem, t. sk. tiek apskatīts klimata pārmaiṇu jautājums;

2) vides katastrofu un dabas stihiju seku pārvaldība - šajā kategorijā tiek apskatīi jautājumi par to, cik augsti riski ir saistīti ar dažādu dabas stihiju vai katastrofu varbūtību un sekām, kā arī par to, kādas ir rīcíbas, lai iespējamos riskus novērstu, prognozētu un spētu pilnvērtīgi neitralizēt negatīvās sekas;

3) vides pārvaldība - šajā kategorijā tiek apskatīi jautājumi par iedzīvotāju un valsts rīcību un par tās sekām attiecībā uz vidi un tās saglabāšanu.

\section{Latvijas iedzīvotāji par vides drošību}

Fokusa grupu intervijās primārais uzdevums bija noskaidrot, ko iedzīvotājiem nozīmē vides drošỉba katram personīgi un kādi draudi rada bažas. Galvenais secinājums ir, ka vides jautājumi, līdzīgi kā veiktajās Eirobarometra aptaujās,

27 AC/UNU Millennium Project - United Nations Doctrine for Managing Environmental Security (2000). Pieejams: https://apps.dtic.mil/dtic/tr/fulltext/u2/a572501.pdf

28 Zurlini, G., Muller, F. (06.08.2006.) Environmental Security. Pieejams: https://www.sciencedirect. com/topics/earth-and-planetary-sciences/environmental-security

29 Ibid. 


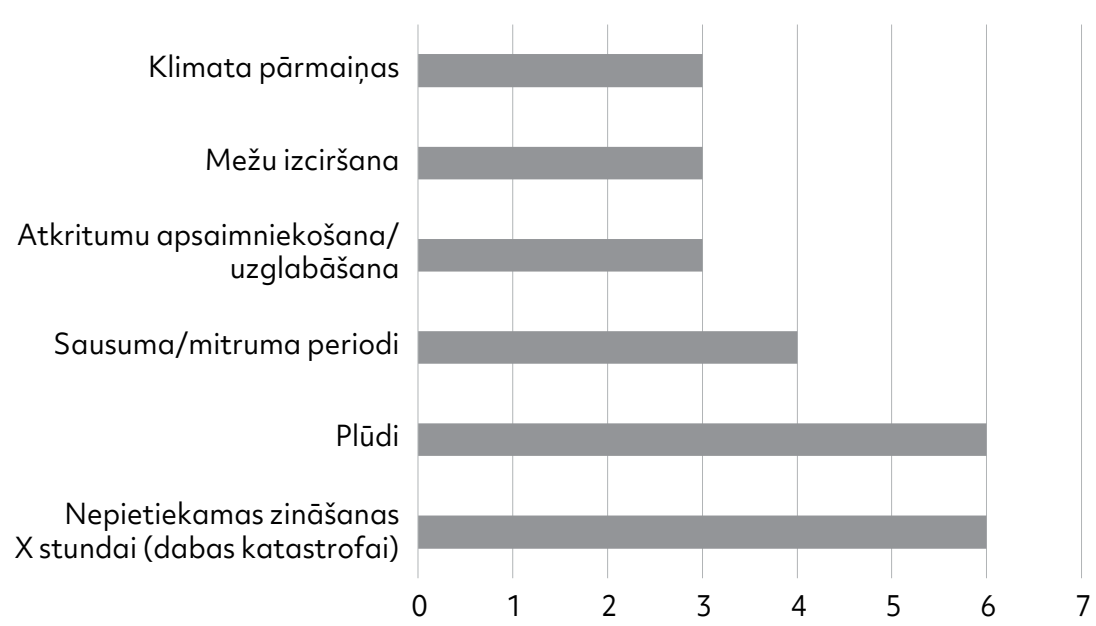

3. attēls. Fokusa grupu skaits, kurās tika minēts draudu veids

netiek izcelti kā nozīmīgākie drošības aspekti. Aicinot respondentus brīvi izteikties par faktoriem, kas liek justies nedroši, biežāk minēti ekonomiskie apsvērumi un fiziskā drošība, bet retos gadījumos piemin jautājumus, kas saistīti ar vidi.

Noskaidrojot respondentu viedokḷus, iegūta aina par galvenajiem draudiem arī šajā jomā. 3. attēlā ir redzams, cik bieži pašvaldībās tika pieminēti (vismaz 3 fokusa grupās) konkrētie vides draudu veidi.

Iedzīvotāju skatījumā biežākie apdraudējuma veidi ir plūdu iespējamība, kā arī zināšanu un gatavības trūkums atbilstoši rīkoties gadījumā, ja notiek katastrofa (iestājas X stunda). Savu vērtējumu par gatavību X stundai respondenti sniedza pēc grupu intervētāju jautājuma, savukārt ar plūdiem saistītā tematika pieminēta biežāk pēc pašiniciatīvas. Fokusa grupu intervijās satraukums par klimata pārmaiņām un no tām izrietošajām sekām neparādās biežāk kā par cita veida draudiem - meža izciršanu, sausuma periodiem u. c. Lai iegūtu padziḷinātāku izpratni par iedzīvotāju vides drošības uztveri, iegūtie rezultāti tālāk izklāstīti detalizētāk un aplūkotas atsevišķas tēmas.

\section{Klimata pārmainas}

Vairākās fokusa grupās respondenti sniedza savu viedokli par klimata pārmaiṇām. Respondentu atbildes uz jautājumu par klimata pārmaiṇu pašreizējām un potenciālām ietekmēm Latvijā intervētāji sadalīja trijās dạ̣ās: pesimistiskajās, neitrālajās un optimistiskajās. Tie, kuru atbildes bija pesimistiskas, 
norādīja, ka klimata pārmaiṇas viṇus satrauc, jo šo pārmaiṇu dēḷ Latvijas vides situācija pasliktinās vai var pasliktināsies:

Sieviete vidējā vecumā, Rìga: Lìdz šim es domāju, ka pārāk nopietni tas nav Latvijai. Bet šogad 1. oktobrī uz Daugavpils ielas ieraudziju kastani, un vēl tagad bišķu zied. Tà gan ir problēma, jo viņš zied un tūlìt būs sals. Tätad visa tā biosistēma ar siltumu ir izjukusi. Tà visa mūsu sistèma, tā daba ir vienkārši apjukusi, jo tagad ir silts un dzen àrā pumpurus. Un ar laiku tur, nezinu, labi nebūs. Tas ir viss, ko mès èdam.

Neitrāla viedokḷa paudēji bija skeptiski par to, ka klimata pārmaiṇas negatīvi ietekmēs Latviju. Negatīiās nostājas iemesli atškiras starp respondentiem. Viens no tiem ir, ka Latvijas geogrāfiskā pozīcija un klimats nav nelabvēlīgs šim apstāklim.

Jaunietis, Rīga: Uzskatu, ka cilvēce ir sasniegusi, bezmaz vai pārkāpusi neatgriezeniskam slieksnim. Un situācija pašlaik ir tik drastiski slikta, ka ir jāveic kardinālas pārmainnas. Protams, ka mēs Latvijā to tik lototi neizjutīsim, jo mūsu ǵeogrāfiskā lokācija aţ̦auj dažădi šiss sekas vienkārši neizbaudìt. Bet kopējā līmenì tai bütu jābüt cilvēces vienai no galvenajām prioritātēm.

Savukārt cits neitrālas pozīcijas iemesls ir skepticisms par cilvēku radīto ietekmi uz klimata pārmaiṇām, jo klimata pārmaiṇas ir bijušas arī pagātnē, kā arī norādes uz to, ka vēl trūkst pietiekami daudz informācijas, lai varētu viennozīmīgi noteikt, ka klimata pārmaiņas izraisījusi cilvēku darbība. Klimata pārmaiņas, visticamāk, notiek, bet nav pietiekamas informācijas, lai vērtētu to ietekmi.

Vïrietis, Madona: Es personīgi neizjūtu nekādus draudus, jo mēs [cilvēki] te dzīvojam tikai mazu laiku, un varbūt šajā laikā ir kaut kādas pārmaiņas, bet ilgā laikā tas varbūt ir normāli. Varbūt tā ir jābūt. Tāpēe - kāpēc mums baidìties no tā, kas ir normāli. Varbūt meklējam problèmu, kur tās nav.

Intervijās viena respondentu daḷa - optimisti - klimata pārmaiņas uztver nevis kā draudu, bet gan kā iespēju un potenciālu Latvijas ekonomikai, norādot uz siltāka klimata pozitīvajiem faktoriem.

Vïrietis, Aizkraukle: Neuztveru kā draudu savai personiskajai drošïbai. Nešķiet, ka tas uz mani attiecas, un neuzskatu, ka tā bùtu Latvijā loti milzìga problèma. Latvijai tas drīzāk noteiktās jomās nāktu par labu. Palielināsies ražība, pazemināsies cilvēku slimošana ar ziemas perioda slimībām. Mazāki rēķini par apkuri. 
Pēdējais piemērs iezīmē vēl kādu būtisku apstākli - fokusa grupas dalībnieki savu vērtējumu par to, vai klimata izmaiņas apdraud drošỉbu, pārsvarā sniedz no ekonomiskā viedokḷa, - proti, kā temperatūras svārstības var ietekmēt lauksaimniecību, rēķinu lielumu u. tml., tādā veidā sasaistot ekonomisko drošības sektoru ar vides drošỉbas sektoru.

Optimistus un neitrālu viedokḷu paudējus var uzlūkot arī kā respondentus, kuri neuzskata, ka klimata pārmaiņas rada draudus Latvijai. Ja šis grupas salīdzina ar respondentiem-pesimistiem, kuri uzskata, ka klimata pārmaiņas rada draudus Latvijai, ir vērojams skaitlisks optimistu pārsvars starp fokusa grupu dalībniekiem. Kopumā tikai trijās fokusa grupās - Gulbenē, Rīgā, Talsos - bija pesimistiskā viedokḷa paudēji. Bet neitrālā vai pat optimistiskā viedokḷa paudēji bija gan šajās pašās, gan arī citās pašvaldībās - Aizkrauklē, Jaunjelgavā, Madonā. Līdzvērtīgi arī Daugavpilī, Liepājā, Rēzeknē iezīmējās viedoklis, ka dabas katastrofas nav augsts drauds. Līdz ar to kopumā tas radīja asimetrisku situāciju - proti, pesimistiskā viedokḷa paudējiem nācās sastapties ar atšķirīgu/opozicionāru viedokli, ko izteica citi iedzīvotāji, savukārt neitrālā/optimistiskā viedokḷa paudējiem nenācās sastapties ar atšķirīgu/opozicionāru viedokli. Tai pašā laikā, lai gan pesimistisks viedoklis parādās trīsreiz retāk nekā neitrāls/optimistisks viedoklis, nozīmīgas teritoriālās atšķirības, kas iezīmētu kādu dalījumu starp pašvaldībām vai reǵioniem, šajā jautājumā nav identificētas.

Novērojama arī tendence, ka pesimistisku viedokli biežāk izsaka jaunieši, savukārt vecāka gadagājuma cilvēkiem biežāk ir optimistisks/neitrāls viedoklis, jo viṇi savas dzīves laikā pieredzējuši daudzus un dažādus laikus un notikumus.

Sieviete, Rìga: Vēsture rāda, ka ir arī agrāk bijis līdzīgi. Diez vai tas šodien tik ḷoti ietekmē. Esmu redzējusi fotogräfiju, 1932. gada 29. vai 28. novembra, kur mana mamma ir nofotografējusies ar ziedošu avenุu zaru un gatavām avenēm.

Kopumā iegūtie rezultāti atbilst Eirobarometra uzrādītajiem datiem, ka Latvijas sabiedrība neuztver klimata pārmaiņas kā nozīmīgāko vai primāro draudu.

\section{Katastrofas, dabas stihijas un to pārvaldība}

Kopumā fokusa grupās aptaujātie Latvijas iedzīvotāji uzskata, ka dabas katastrofas viņus neapdraud. Katastrofu draudu neesamība bija viena no biežāk sastopamajām tēzēm - kopumā uz to norādija sešās fokusa grupās. ${ }^{30}$ Šis viedoklis 
balstās uzskatā, ka Latvijas geogrāfiskais novietojums ir gana veiksmīgs, lai izvairītos no dabas kataklizmām ar spēcīgu ietekmi.

Vīrietis, Rīga: Vienīgais, kas ilgtermiñā draudētu, - konkrētas laika apstāklu maiņas, paildzināti mitruma vai siltuma periodi, kas atstātu ietekmi uz zemkopību.

Šis piemērs iezīmēja to, ka biežāk cilvēki kā iespējamo risku min sausuma vai mitruma periodu un ka dabas radītie apdraudējumi ir lielāki draudi tieši lauksaimniekiem, bet šie apdraudējumi netiek uztverti kā vispārīgi draudi sabiedrībai. Turklāt tas apstiprina iepriekš secināto, ka vides problēmas uztver caur ekonomikas prizmu. To papildina fakts, ka par dažādām iespējamām problēmām vairāk satraucas iedzīvotāji, kuri uzturas lauku teritorijā un, iespējams, atrodas nedrošā ekonomiskā situācijā:

Vīrietis, L̦audona: Mani apdraud laika apstākḷi - applūdīšu, ja būs lieli vēji un lietus.

Sieviete, Alūksne: Man ir dārziņ̌ korporatīvā "Ziedos", dārzkopības korporatīvā.. siltās ziemas dèl jau ir izdīguši kịploki, kas nozīmēe, ka raža varētu arī nebūt kiplokiem.

Sausums pēdējo gadu laikā skar l̦oti daudzus lauku reǵionu iedzīvotājus, kuriem ir jārisina gan ūdens trūkuma, gan sausuma izraisìtās vides izmaiņas problēmas un no tām izrietošās finansiālo zaudējumu problēmas lauksaimniekiem. Liels sausums bija novērots 2018. gadā, kas izraisīja vairākus meža un purvu ugunsgrēkus. ${ }^{31}$ 2019. gads bija vissiltākais gads novērojumu vēsturē, kad pieturējās liels sausums, kā arī tika novēroti pērkona negaisi un virpuḷviesu1i. ${ }^{32}$ 2020. gada vasarā Ministru kabinets pieņēma noteikumus "Valsts atbalsta piešķiršanas kārtība apdrošinātājam sausuma radīto zaudējumu atlīdzības izmaksu kompensēšanai”, nosakot, kādā veidā kompensēs izmaksāto atlīizību par sausuma radītajiem zaudējumiem sējumu platībām. ${ }^{33}$

Sieviete darbspējas vecumā, Talsi: Laukos ir sausums, un tā ir lototi liela problēma. Arī mūsu novadā ūdens ir jāved kannās cilvēkiem.

31 2018. gads-sausākais novērojumu vēsturē. Pieejams: https://www.meteo.lv/lapas/laika-apstakli/klimatiska-informacija/laika-apstaklu-raksturojums/2018/gads/gads-2018-meteo?id=2374\&nid=1177

32 2019. gada laikapstākḷu raksturojums. Pieejams: https://www.meteo.lv/lapas/laika-apstakli/klimatiskainformacija/laika-apstaklu-raksturojums/2019/gads/gads-2019?id=2468\&nid=1215

33 Ministru kabineta 2019. gada 18. jūnija noteikumi Nr. 263 "Valsts atbalsta piešķiršanas kārtība apdrošinātājamsausumaradītozaudējumuatlìdzībasizmaksukompensēšanai”. Pieejams: https://likumi. lv/ta/id/307671-valsts-atbalsta-pieskirsanas-kartiba-apdrosinatajam-sausuma-radito-zaudejumuatlidzibas-izmaksu-kompensesanai 
Bieži par potenciālu draudu uzskatīja plūdu iespējamību vairākās pašvaldībās - Aizkrauklē, Ādažos, Daugavpilī, Jaunjelgavā, Madonā, Valmierā. Respondenti atsaucās arī uz jau iepriekš notikušiem plūdiem ar negatīvu ietekmi, bet kopumā uzskatīja, ka, lai gan draudi pastāv, tie nav vērtējami kā augsti, jo tiek veikti preventīvi pasākumi un plūdu iespējamību var prognozēt.

Respondents, Ādaži: Gaujas dambis ir drošībā, jo ir piedzīvoti baigie plūdi.

Vīrietis, Daugavpils: Mēs astoņus metrus spējam izturēt.

Vïrietis, Valmiera: Pilsēta pie Gaujas no plūdiem nebaidās.

Runājot par katastrofu pārvaldību, iedzīvotāji fokusa grupu intervijās norādīja, ka atzīst paveikto, bet nepieciešams ievērot līdzsvaru ziņojumos par bīstamiem dabas apstākḷiem.

Respondents: 2005. gadā, kad bija milzīgà vētra, bija loti minimāli kaut kas zināms. Šodien ir atkal tā, ka pie katra vēja plūsmas brïdina par oranžajiem/sarkanajiem orkāniem. Tā ir labāk.

Iedzīvotāju uzskati par to, kā rīkoties krīzes/katastrofas gadījumā (X stundā), ir l̦oti atšķirīgi. Lielākā daļa aptaujāto respondentu atzina, ka zinātu, kā jārīkojas X stundā, piemēram, dzirdot sirēnas, būtu jāieslēdz televizors vai radio (to lielākoties visās pašvaldībās atzīmē pensionāri), tomēr kopumā viņiem trūkst papildu zināšanas, lai darbotos pareizi. Būtiski, ka jauniešiem ir bijušas civilās aizsardzības apmācības.

Skolniece, Rìga: Man skolā pastāstīja, ko darìt krīzes situācijās, it īpaši, ja ir zemestrīce. Mums pat bija īpašas apmācības.

Respondents: Baigi maz ir informācija, kā rīkoties konkrētā stihijā. Jā, ir jāslēdz iekšā radio. Bet tā droši viens pats uz savu galvu domātu.

Madonā min, ka trauksmes sirēnas atskaņo pāāāk bieži, tāpēc cilvēki tās vairs neuztver nopietni. Savukārt citās fokusa grupās atzina, ka ir veiktas mācỉbas, bet tās nav pietiekamas, jo, lai būtu efektīvas, tām jānotiek regulāri un jāliek cilvēkiem atkārtot un atjaunot savas zināšanas.

Sieviete, Rēzekne: Mums augstskolā bija [apmācības], bet es jau aizmirsu.

Sieviete, Valmiera: Mūs apmāca, mès pēc tam aizmirstam.

2016. gadā Saeima pieṇēma "Civilās aizsardzības un katastrofas pārvaldī̌anas likumu”34, un 2020. gada 25. augustā Ministru kabinetā apstiprināja

34 Saeima. Civilās aizsardzības un katastrofas pārvaldī̌anas likums (stājās spēkā 01.10.2016.). Pieejams: https://likumi.lv/ta/id/282333-civilas-aizsardzibas-un-katastrofas-parvaldisanas-likums 
Valsts civilās aizsardzības plānu. ${ }^{35}$ Likums izšḳir divu veidu katastrofas (dabas un cilvēku izraisītās) un nosaka gan kārtību, kā rīkoties, gan arī atbildīgās institūcijas, kam jābūt iesaistītām katastrofas pārvaldībā. ${ }^{36}$

Respondenti piedāvāja arī savu redzējumu par to, kādā veidā vajadzētu uzlabot iedzīvotāju informēšanu par krīzes situācijām valstī.

Sieviete, Aizkraukle: Man draudzene dzìvo Holandē. Un viniem, kā tuvojas vētra, kā nu ir lielāki riski, katram iedzīvotājam uz telefonu tiek atsūtīts SMS, brīdinājums par draudošajām briesmām un arī ieteikumi, vai ir labāk palikt mājās vai $k \bar{a}$. Nu tādā veidā. Es domāju, ka mums lìdz tam vēl augt un augt.

Vīrietis, Aizkraukle: Tā ir lieta [par iepriekš minētās sievietes pieminēto SMS brīdinājumu sistēmu Holandē], ko Latvijā jāievieš, beznosacījuma uzstādījums.

Šāda risinājuma ieviešanu atbalstiija visu grupu dalībnieki, norādot, ka nav nozīmes, kurš un kādā veidā sniedz šāda veida informāciju nepieciešamības gadījumā. Rēzeknē iedzīvotāji novērtē valsts akciju sabiedrības darbu - viņus informē par to, kad atslēgs elektrību un kad atjaunos tās pieslēgumu. Arī pensionāri novērtē to, ka uz viṇu zvaniem tiek atbildēts un sniegta informācija par viņus interesējošiem jautājumiem. 2018. gadā Eiropas Parlaments atbalstija direktīvu, kurā iekḷauti noteikumi par publisku brīdinājumu sistēmas izveidošanu ārkārtas gadījumos un zvanītāja atrašanās vietas noteikšanu. Noteikumi ir saistoši visām dalībvalstīm. ${ }^{37}$ Grozījumi Elektronisko sakaru likumā stājās spēkā 2020. gada 2. oktobrī, nosakot, ka elektronisko sakaru komersantiem pēc iespējas ātrāk jānosūta informācija sakaru lietotājiem..$^{38}$

Iedzīvotājos nav vienprātības par uzticību atbildīgajiem dienestiem, kuri monitorē dažādu katastrofu iespējamību un vides kvalitāti.

Nevienprātība skaidrojama ar to, ka respondenti personīgi nav saskārušies ar atbildīgajiem dienestiem, tāpēc ir dažādi vērtējumi un dažāda pieredze. Kopumā cilvēki uzskata, ka uzraudzība/monitorings no valsts puses notiek, bet tas nav pietiekošs. Novērojams arī, ka nepastāv korelācija starp respondentu viedokli par zināšanām, kā rīkoties $\mathrm{X}$ stundā, un uzticību atbildīgo dienestu veiktajam monitoringa procesam.

35 Plāna projekts "Valsts civilās aizsardzības plāns". Pieejams: http://tap.mk.gov.lv/lv/mk/tap/?pid= 40480284\&mode $=$ mk\&date $=2020-08-25$

36 Saeima. Civilās aizsardzības un katastrofas pārvaldīšanas likums (stājās spēkā 01.10.2016.). Pieejams: https://likumi.lv/ta/id/282333-civilas-aizsardzibas-un-katastrofas-parvaldisanas-likums;

37 Šveicars, R. (07.02.2019.) Drīz par katastrofām brīdinās ar SMS. Pieejams: https://www.la.lv/ driz-par-katastrofam-bridinas-ar-sms

38 N̦ikona, L. (21.09.2020.) Kas ir valsts agrīnās brīdināšanas sistēma. Pieejams: https://lvportals.lv/ skaidrojumi/320034-kas-ir-valsts-agrinas-bridinasanas-sistema-2020 
Sieviete, Rīga: Neesmu saskārusies ar to, ka iedomātos, ka kāds nav ko izdarījis. Vīrietis, Aizkraukle: Man ir grūti novērtēt, jo es neesmu piedzīvojis situāciju, kad man būtu reāli kritiska situācija un varētu redzèt, kā viņi reagèe.

Respondents, Gulbene: It kā jau PVD pārbauda. Bet nav Latvijai kārtīga saimnieka, kurš to visu uzrauga.

Respondents: Problēma nav, ka ir informācija pēc jaunākajām tehnologiijām, bet gan ka ir informācija pēc vecākajām tehnoloğijām.

\section{Vides pārvaldība}

Fokusa grupu dalībnieki, izklāstot savu viedokli par vides pārvaldību, būtiski izcel̦ Latvijas mežu nozīmi vides drošības nodrošināšanai. Pāris fokusa grupās parādās iedzīvotāju satraukums par mežu izciršanu, jo ar to tiek saistīta vides kvalitātes samazināšanās. Risku saskata arī mežu teritorijas pārdošanā (Gulbenes pašvaldībā, kur tika norādīts, ka nekustamā īpašuma mežu teritorija pārdota Zviedrijas pilsoņiem Jaungulbenes pagasta teritorijā 142 ha platībā ${ }^{39}$ ), jo tādā veidā zūd potenciālā kontrole pār teritoriju un var veikt darbības, kas nelabvēlīgi ietekmē kopējo Latvijas vidi. Turklāt Ādažu fokusa grupā mežu izciršana atzīmēta kā viena no pirmajām problēmām, apskatot visus drošības sektorus vienkopus. Līdz ar to iedzīvotāji uzskata, ka mežu apsaimniekošana ir apdraudējums, un iedzīvotāji neuzticas lēmumu pieṇēmējiem, jo viṇi var pieņemt neatbilstošus lēmumus.

Respondents, Ādaži: Mežu izciršana ir apdraudējums Latvijas dabai. Virpuḷiesuḷi sākas, neekoloğiska domāšana.

Respondents, Gulbene: Kas Latvijā ietekmē gaisu? Mēs apzināti izcērtam visus mežus.

Studente, Daugavpils: Lìdz ar laiku mums var beigties meži. Latvijā ir daudz mežu, bet neizmanto to savām vajadzībām.

Respondents: Priekš novada vajadzībām nepieciešami finanšu līdzekl̦i. Nedod aizdevumu, tādēl pārdeva, Jaungulbenē 140 ha pārdeva zviedriem. Cilvēkiem ḷoti liela ažiotāža - ko tagad darīs? Zviedri mūs ien̦em tādā veidā! Ir cilvēki, kam tas arī ir sava veida apdraudējums. Tas ir pašvaldības lèmums. Bija cilvēki, kas vāca parakstus, - 800 paraksti. Paraksti nelìdzēja. Visi 5 deputāti nolèma par-pret 800 .

39 Zute, L. (2019). Gulbenes novada iedzīvotāji iebilst pret vietvaras ieceri pārdot 142 hektārus meža. Pieejams: https://www.lsm.lv/raksts/zinas/latvija/gulbenes-novada-iedzivotaji-iebilst-pret-vietvarasieceri-pardot-142-hektarus-meza.a330218/?fbclid=IwAR2NAkSdLxnEI224FtC0aBmxDR70p0po gOYY69w_0bGhO98CP_97e2BNXgo 
Eirobarometra veiktajā aptaujā norādīts, ka atkritumu pārvaldība ir galvenā vides problēma. Aptaujātie respondenti atkritumu pārvaldību saskatīja kā risku, kas ietekmē apkārt esošo vidi. Tie respondenti, kuri minēja šo problēmu, atzīmēja to kā potenciāli augstu risku, tomēr pašvaldību vairākumā atkritumu pārvaldība nav novērtēta kā drauds.

Sieviete (jaunā māmiņa), Daugavpili: Satrauc tas, ka pirms 8 gadiem Daugavpilī tika aprakti atkritumi un tie piesārnoja gruntsūdenus. Bet kopumā ūdens mums pilsētà ir tìrs.

Iedzīvotāji norādīja, ka aizvien biežāk stāsta/ziṇo par atkritumu šķirošanas iespējām. Cilvēkiem ir informācija, kur var nodot lielāko dal̦u atkritumu, bet ne visu veidu atkritumus. Grupas dalībnieki atzina: lai biežāk šķirotu atkritumus, tiem ir nepieciešamas papildu iespējas, kur tos nodot un škirot. Intervijās iedzīvotāji stāstīja, cik svarīgi viṇiem ir šķirot atkritumus pie mājas. Viņuprāt, pašvaldībām kopā ar atkritumu apsaimniekotāju vajadzētu nodrošināt atkritumu šķirošanas punktu pēc iespējas tuvāk iedzīvotāju dzīvesvietai. Interviju laikā identificēta reǵioniem raksturīga problēma, ka atkritumu šķirošanas konteineri atrodas tālu no dzīvesvietas.

Vīrietis darbspējas vecumā: Lokācija krietni apgrūtina parastam ikdienas cilvēkam tam pieķerties... Cilvēki to nedara, jo cilvēki ir pārāk slinki.

Respondents: Es gribu škirot atkritumus, tad man jāved viņi daudzu kilometru uz attiecīgo vietu. Un arī tad tikai dalı, jo nav kur mest organiskos atkritumus.

Atkritumu šķirošanas nozīme atzīmēta arī Gulbenē, kur to sasaistīja ar klimata pārmaiṇu novēršanas iespējām un kur iezīmējās atšķirīgie viedoklıi par šķirošanas ietekmi. Iedzīvotāji uzskata, ka atkritumu šķirošana ir pirmais solis (kopā ar mežu izciršanas samazināšanu), lai uzlabotu klimatu. Tomēr šādu viedokli citi iedzīvotāji apstrīdēja, norādot, ka nevar ietekmēt tādas dabas stihijas kā vētras un viesuḷvētras.

Fokusa grupās respondentus nesatrauca biodažādība un kopèjā vides draudu ietekme uz dabu, kura tiešā veidā nesaistās ar viṇu personisko drošîbu. Vienā no fokusa grupu intervijām parādijāas viedoklis, ka "ekonomiski produktīvu" sugu ieviešanās būtu ieguvums.

Iedzīvotāji norāda, ka viṇu aktuālās problēmas attiecas arī uz klimata pārmaiņām un iespaido pārtikas kvalitāti, savukārt klimata pārmaiņas ietekmē iedzìvotāju iespējas nodrošināt sev pārtiku.

Sieviete, Gulbene: Termiņ̧̌s - trīs mēneši. Normāli, ka pienam termiņš trīs mèneši? Kas tas par pienu vispār? Vai gaḷai. Atver vakuuma galu - vinai ir specifiska smarža. Tā arī ir piesārņotība ar visādām ķìmijām. 


\section{Vides drošība pašvaldībās}

Šajā apakšnodaḷā analizēti vides drošības sektora pārvaldības rādītāji divās Latvijas pašvaldībās - Rīgā un Madonā. Šajās pašvaldībās fokusa grupu intervijās vides drošības sektora draudi identificēti kā vieni no trim nozīmīgākajiem draudiem. Katras pašvaldības sniegums tiks analizēts atbilstoši pētījuma gaitā izstrādātajai labas pārvaldības matricai.

Vides drošības sektora labas pārvaldības rādītāji analizēti, izmantojot intervijas ar lēmumu pieñēmējiem pašvaldībās un plānošanas dokumentu kvalitatīvo analīzi (pašvaldību attīstības plānošanas dokumenti, attīstības pārskati un citi publiski pieejami dati).

\section{Rīgas pilsētas pašvaldība}

Rīgas pilsētas pašvaldības pārstāvis padziḷinātajā intervijā, atškirībā no iedzīvotājiem, nepievērš lielu uzmanību tiešiem vides draudiem, kā arī vides ilgtspējai, bet apspriež rīcību krīzes situācijās.

Rìgas pilsētas pašvaldības pārstāvis: Civilās aizsardzības plāns ir palicis no padomju laikiem birokrātiskā lìmenì. Apšaubu spējas X stundā. Zvanìtu kādam pa draugam primāri, nevis pēc saraksta.

Rīgas pilsētas plānošanas dokumenti izstrādāti, pamatojoties uz likumu "Par pašvaldībām", Teritorijas attīstības plānošanas likumu, Ministru kabineta 16.10.2012. noteikumiem Nr. 711 "Noteikumi par pašvaldību teritorijas attīstỉbas plānošanas dokumentiem" un Rìgas domes 05.07.2011. lēmumu Nr. 3385 "Par Rīgas attīstības programmas 2014.-2020. gadam izstrādes uzsākšanu un Rīgas ilgtermiṇa attīstības stratēóijas līdz 2025. gadam aktualizāciju”. Rīgas ilgtspējīgas attīstības stratēgijā noteikts, ka "Rìgas pilsētas pašvaldības virsuzdevums ir pilsētas iedzīvotāju dzīves kvalitātes uzlabošana" ${ }^{\text {"40 }}$. Vides drošỉbas draudu dēḷ Rìgas ilgtspējīgas attīstības stratēgijā ir iekḷautas stratēǵiskās nostādnes pilsētvides attīstībai. Viena stratēgijas sadaļa veltīta dabas mantojuma un vides kvalitātes nodrošināšanai, minot gaisa attīî̌šanas nozìmīgumu, trokšņa piesārṇojumu, dabas teritoriju saglabāšanu, apkārtējai videi nekaitīgu atkritumu apsaimniekošanas sistēmu, plūdu riska samazināšanu un dabas resursu lietderīgu izmantošanu (lietusūdeṇu atkārtotu izmantošanu). ${ }^{41}$ Lìdzīgi kā stratēǵijā 2030, arī Rìgas “Attīstības programmā 2014-2020” viens no

40 Rīgas ilgtspējīgas attīstības stratēgija lìdz 2030. gadam (2014). Pieejams: https://www.rdpad.lv/ wp-content/uploads/2014/11/STRATEGIJA_WEB.pdf (16.lpp.)

41 Turpat, 80.-81. lpp. 
rīcības virzieniem ilgtermiņa mērķu sasniegšanai ir labas vides kvalitātes saglabāšana, nosakot detalizēti priekšrocības un trūkumus pilsētā. ${ }^{42}$

No labas pārvaldības perspektīvas nav konstatēti trūkumi secības un savstarpējās pamatotības ievērošanā, plānošanas dokumentu izstrādē vides drošības sektora draudu mazināšanai. Apskatītajos dokumentos identificēti visi apskatītie vides draudi un iespējas tos mazināt. Par normatīvo aktu izmaiṇām var secināt, ka ievērota konsekvence.

Rīgas pilsētas pašvaldības publiskajā pārskatā par 2019. gadu ir ietverta informācija par paveikto vides aizsardzības jomā. Kopumā 2019. gadā iztērēti apmēram 3 miljoni eiro vides aizsardzības nodrošināšanai - atkritumu apsaimniekošanai, notekūdeņu apsaimniekošanai, vides piesārṇojuma novēršanai un samazināšanai, biologiiskās daudzveidības un ainavas aizsardzỉbai, kā arī pārējai citur neklasificētai vides aizsardzībai. ${ }^{43}$ Tātad ir novērsti tie vides drošības draudi, kas noteikti plānošanas dokumentos.

Runājot par preventìvo rīcībpolitikas izstrādi vides drošỉbas sektorā, pētījumā secināts, ka Rīgas pilsētas pašvaldībai ir izstrādāts Rīgas pilsētas Civilās aizsardzības plāns, kurā ir iekḷauta informācija par to, kā sabiedrībai rīkoties, sastopoties ar tādiem vides drošỉbas draudiem kā, piemēram, vides piesārṇojums, pārtikas un dzeramā ūdens apgādes katastrofa, bīstamo atkritumu noplūšana, dabas katastrofa, kā arī ar tādām katastrofām, kuras izraisa cilvēki un kuras ietekmē vides drošỉbu.

\section{Madonas novada pašvaldība}

Intervijā Madonas novada pašvaldības pārstāvis norādīja, ka klimata pārmaiņas 2019./2020. gada ziemā atstājušas negatīvu iespaidu uz tūrisma jomu novadā, jo viena no pašvaldības tūrisma jomas prioritātēm ir ziemas sporta aktivitātes. Pašvaldības domes vadītājs norādīja uz negatīvajām ekonomiskajām sekām, ko var radīt šādas klimata svārstības.

Novadam kā ziemas galvaspilsētai traucē ziemas neesamība. Finansiāli traucē ziemas orientēšanas čempionāta nenotikšana.

Apkopojot padziḷinātajā intervijā iegūtās atziṇas, var secināt, ka vides drošîbas sektora izvērtējums ir daudz pozitīvāks nekā reālā sasaiste ar labas pārvaldības indikatoriem. Madonas novada ilgtspējīgas attīstības stratēgiija 2013.-2038. gadam ir izstrādāta, pamatojoties uz Attīstības plānošanas

42 Rīgas Attīstības programma 2014-2020 (2014). Pieejams: https://www.rdpad.lv/strategija/attistibasprogramma/

43 Rīgas pilsētas pašvaldības publiskais pārskats 2019 (2020). Pieejams: https://www.riga.lv/lv/publiskaisparskats/rigas-pilsetas-pasvaldibas-publiskais-parskats-2019.pdf (23.lpp.) 
sistēmas likumu, Teritorijas attīstības plānošanas likumu, Latvijas Republikas MK noteikumu Nr. 711 "Noteikumi par pašvaldību teritorijas attīstības plānošanas dokumentiem" prasībām un Madonas novada 2012. gada 27. septembra domes sēdes lēmumu (sēdes protokols Nr. 21) "Par Madonas novada ilgtspējīgas attīstības stratēgijas izstrādes uzsākšanu"44 . Tāpat arī ir izstrādāta Madonas novada attīstības programma 2013.-2020. gadam ${ }^{45}$ un Madonas novada teritorijas plānojums 2013.-2025. gadam. ${ }^{46}$ Madonas novada ilgtspèjīgas attīstỉbas stratēgijas vīzija ir "Madonas novads: zeme, kur piedzimt un dzīvot, atgriezties isstenot sapṇus un ieceres, kur daba, darbs un latviskā kultūra ikkatru veido par turīgu, stipru un radošu personību" ${ }^{\text {"77 }}$. Un viens no stratēǵiskajiem mērķiem iekḷauj arī vides drošības draudu novēršanu - "dabiska, droša dzīves vide ir balstīta uz gudru, ilgtspējīgu dabas un dabas resursu apsaimniekošanu, saglabājot tās unikalitāti un daudzveidību"48. Attīstības stratēǵijā un attīstības plānā nav tieši minēti vides drošības draudi, taču ir noteiktas darbības un mērķi, lai tos mazinātu, piemēram, vides un dabas aizsardzības aizsargjoslu noteikšana. ${ }^{49}$

Nav identificēti atkritumu apsaimniekošanas, plūdu iespējamības draudi. Par normatīvo aktu izmaiņām kā vienu no labas pārvaldības indikatoriem gan dokumentu analīzes gaitā, gan padzilịnātās intervijas analīzē secināts, ka Madonas novadā nenotiek bieža jaunu normatīvo aktu apstiprināšana un tiek ievērota konsekvence normatīvo aktu izmaiņās.

Madonas novada pašvaldības mājaslapā 2020. gada 25. augustā ir apstiprināts Madonas novada attīstības programmas 2013.-2020. gadam isstenošanas uzraudzības ziņojums, kur vidēja termiņa prioritātēe "Dzīves vides drošǐba" rīcỉbas plāns izpildīts par 77\%, jo īstenots, ievērojot Madonas novada teritorijas plānojumu 2013.-2020. gadam un citus valstī noteiktos normatîvos aktus. Ziṇojumā norādīts, ka saglabātas un attīstîtas dabas takas un cita vides izziņas infrastruktūra. Vidēja termiṇa prioritātē "Dabas kapitāla veidošana" rīcības plāns izpildīts par 54\%. Visa aktuāā informācija par tūrismu un dabas objektiem ir sistemātiski uzturēta un atjaunota mājaslapā, kā arī Madonas

44 Madonas novada ilgtspējīgas attīstības stratēgija 2013.-2038. gadam (2013). Pieejams: http://www. madona.lv/lat/box/files/PlanosanasDokumenti/attstbas_stratija.pdf

45 Madonas novada attīstības programma 2013.-2020. gadam (2013). Pieejams: http://www.madona. lv/lat/box/files/PlanosanasDokumenti/attstbas_stratija.pdf

46 Madonas novada teritorijas plānojums 2013.-2025. gadam (2013). Pieejams: https://www.madona. lv/lat/madonas-novada-teritorijas-planojums-2013-2025gada

47 Madonas novada ilgtspējīgas attīstības stratēǵija 2013.-2038. gadam (2013). Pieejams: http://www. madona.lv/lat/box/files/PlanosanasDokumenti/attstbas_stratija.pdf (10.1pp.)

48 Turpat, 10. lpp.

49 Turpat, 29. lpp. 
novada pašvaldības Tūrisma informācijas centrā, Lubāna mitrāja informācijas centrā un Bērzaunes Tūrisma informācijas punktā. ${ }^{50}$ İstenojot projektus Eiropas Regionālās attīstîbas fonda aktivitāšu ietvaros, Madonas novadā uzlabota ūdensapgādes un notekūdeņu savākšanas un attīrīšanas kvalitāte, ievērojami paplašināta ūdenssaimniecības pakalpojumu pieejamība, nodrošinot kvalitatīvu dzīves vidi, samazinot vides piesārņojumu un ūdenstilpju eitrofikāciju, sekmējot ūdens resursu un energoresursu racionālu izmantošanu. ${ }^{51}$

Runājot par preventīvo rīcībpolitikas izstrādi vides drošības sektorā, pētijuma rezultātā secināts, ka Madonas novada pašvaldībā ir Civilās aizsardzības komisija, taču 2019. gadā tā nav sanākusi ne uz vienu sēdi, ${ }^{52}$ savukārt 2018. gadā tai bija četras sēdes. ${ }^{53}$ Nemot vērā, ka Madonas novadā ir vairāki dabas parki, tad Dabas aizsardzības pārvalde ir izstrādājusi šo dabas parku aizsardzības plānus, piemēram, "Dabas parka "Aiviekstes paliene" dabas aizsardzības plānu" ${ }^{\prime 4}$.

Kas attiecas uz katastrofu novēršanu, tad iedzīvotāji uzskata, ka pastāv vāja katastrofu seku novēršana, un to pārvaldību vērtē kā darboties nespējīgu / neefektīvu, jo, viņuprāt, par katastrofu seku novēršanu netiek ziņots pienācīgi. Tomēr pašvaldību vadītāji ir informēti par vides problēmām un to novēršanu, piemēram, Madonas novada domes priekšsēdētājs uzsver, ka

pašvaldība aktīvi seko Lubānas ezeram. Bija risks, ka dambis lüztu. Bija avārija slūžās (tas bija bistams risks).

\section{Secinājumi}

Pētijumā iegūtie rezultāti lauj secināt, ka vides problēmas Latvijas iedzīvotāji neuztver kā galvenos draudus un apšauba arī klimata pārmaiņu negatīvo ietekmi uz Latvijas teritoriju. Lielāka nozīme tiek piešķirta ekonomiskajai drošîbai, tādēl vides problēmas tiek biežāk uztvertas no tautsaimniecības skatpunkta. Tajā pašā laikā fokusa grupu interviju rezultāti liecina, kuras no vides

50 Madonas novada attīstības programma 2013.-2020. gadam. İstenošanas uzraudzības ziņojums (2016). Pieejams: https://www.madona.lv/lat/box/files/PlanosanasDokumenti/uzraudzbasziojums 30062016.pdf (12. lpp.)

51 Turpat, 14. lpp.

52 Madonas novada pašvaldības 2019. gada publiskais pārskats (2020). Pieejams: http://www.madona. lv/lat/get.php?o=1\&f=filelists/1593762728-gadaparskatsmadona2019publicesanai2.pdf (9. lpp.)

53 Madonas novada pašvaldības 2018. gada publiskais pārskats (2019). Pieejams: http://www.madona. lv/lat/get.php?o=1\&f=filelists/1562231317-publiskaisparskats2018.pdf (7. lpp.)

54 Paziņojums par dabas parka "Aiviekstes paliene” dabas aizsardzības plāna sabiedrisko apspriešanu (18.10.2019.). Pieejams: https://madona.lv/lat/aktualitates-novada?fu=read\&id=9047 
jomām nav nozīmīgas iedzīvotāju skatījumā. Piemēram, sabiedriskās domas aptaujās biežāk minētā tēma - atkritumi - parādījās tikai dažās fokusa grupās. Nākamās biežāk minētās problēmas - gaisa, iekšzemes un jūras ūdens piesārṇojums - minētas reti vai nav minētas vispār. Tāpat vides pārvaldības jomā iedzīvotājus nesatrauc biodažādība un kopējā ietekme uz dabu, jo tā tiešã veidā nesaistās ar viṇu personisko drošỉbu.

Diskusijas ar iedzīvotājiem atspoguḷo iedzīvotāju daudzveidīgo skatījumu uz vidi. Kādam vide asociējās ar globālā klimata pārmaiņām, vēl kādam - ar nesavāktiem atkritumiem, ikgadējo talku un veselīgiem produktiem. Cauri vijas pieredzē balstītais vides skatījums - svarīgs ir tas, ko persona ir pieredzējusi vai piedzīvojusi. Līdz ar to iedzīvotāju prioritāšu sarakstā globālā sasilšana nevar konkurēt ar izmestām riepām vietējā mežà vai ar vietējā karjera negatīvo ietekmi uz gruntsūdeniem.

Fokusa grupās atspoguḷojās viedoklis, ka valstij ir nepieciešams uzlabot veicamos pasākumus mežu apsaimniekošanā, atkritumu pārvaldī̌anā, informētībā par katastrofu pārvaldību.

Iedzīvotāji uzskata, ka vides katastrofu un dabas stihiju seku pārvaldības jomā uzraudzība no valsts puses notiek, bet tā nav pietiekoša. Pètījumā secināts, ka iedzīvotāji apzinās, kā rīkoties $\mathrm{X}$ stundā, bet neuzticas atbildīgajiem dienestiem, kam efektīvi jānovērš dabas stihiju sekas. Lielākoties iedzīvotāji uzskata, ka Latvijas geogrāfiskais novietojums ḷauj izvairīties no dabas kataklizmu spēcīgās ietekmes, tāpēc tās, viṇuprāt, nav liels apdraudējums vides drošībai.

Vides pārvaldības jomā iedzīvotājus nesatrauc biodažādība un kopējā ietekme uz dabu, jo tā tiešā veidā nesaistās ar viṇu personisko drošību. Interviju laikā identificēta reǵioniem raksturīga problēma, ka atkritumu šķirošanas konteineri atrodas tālu no dzīvesvietas, tāpēc iedzīvotāji izvēlas nešķirirot atkritumus. Tādu iedzīvotāju, kuri aicina aktīvāk rīkoties klimata pārmaiṇu novēršanai vai atkritumu apsaimniekošanas politikas uzlabošanai, ir mazāk nekā to, kas ir skeptiski noskaņoti pret klimata pārmaiņām.

Iedzīvotāju bažas daḷēji atspoguḷojas pašvaldību darbinieku intervijās, kā arī pašvaldību plānos un stratēgijās. Tajās pastiprināta uzmanība pievērsta atkritumu apsaimniekošanai, dabas vērtību saglabāšanai un dabas struktūru apsaimniekošanai, lai iedzīvotājiem novērstu, piemēram, upju plūdu draudus. Savukārt mazāka uzmanība ir pievērsta katastrofu pārvaldībai, kā arī klimata pārmaiņu radīto seku samazināšanai. 


\title{
Sabiedrības drošība
}

\author{
ALEKSANDRA KJAKSTE, SIGITA STRUBERGA
}

Sabiedrības drošība apskata apdraudējumus sabiedrības vai tās daḷu tradicionālajiem dzīvesveidiem, paražām, reliǵiskajām praksēm, etniskajām un nacionālajām īpatnībām. Sabiedrības drošỉbas dimensija pēdējā desmitgadē ir bijusi gan politiskajā, gan akadēmiskajā dienaskārtībā, tomēr līdz šim nav ticis veikts pètījums, kas l̦autu integrēt indivīdu identificētos draudus to identitātei kopējā Latvijas iedzīvotāju draudu uztveres skatījumā un vērtēt iespējamās cēloṇsakarības, kuras pastāv starp uztvertajiem draudiem un atbilstošām rīcībpolitikām kā atbildēm uz tiem. Šajā grāmatas nodaḷā identificēti tie sabiedrības draudu veidi, kurus Latvijas iedzìvotāji uzskata par nozīmīgiem, kā arī apskatīts, vai un kā vietējās pašvaldības reagē uz iedzīvotāju bažām par apdraudējumiem sabiedrības drošības dimensijā. Analīzes rezultātā secināts, ka Latvijas iedzìvotāji identificē draudus to unikālajai patībai un atzīst tos kā būtisku izaicinājumu savai drošībai. Visbiežāk tos satrauc imigrācija kā potenciālais apdraudējums viṇu subjektīvā vērtējumā. Kopumā Latvijas sabiedrība tiek raksturota kā slēgta, uz tradicionālām vērtībām orientēta. Savukārt reǵionos iedzìvotāji izjūt plaisu starp reǵionu un galvaspilsētu un uzsver, ka pastāv atsevišķa, nošķirta dzìve un dienaskārtība un līdz ar to divas atšķirīgas kopienas. Rezultātā kā nozīmīgākos iekšējos apdraudējuma avotus sabiedrības drošības sektorā Latvijas iedzīvotāji nosaukuši citus iedzīvotājus vai to grupas, kā arī valsts pārvaldes iestādes. Savukārt pašvaldības bauda lielāku uzticēšanos. Kā ārējais apdraudējuma avots galvenokārt minēta Krievijas Federācija. Pašvaldību darbỉbas analīze liecina, ka kopumā pašvaldības reti un ierobežotā apjomā saredz savu lomu drošîbas stiprināšanā sabiedrības drošības sektorā. No iegūtajiem rezultātiem secināms, ka sabiedrības pārstāvju, kā arī pašvaldību darbinieku iesaiste plašākās diskusijās par drošỉbu, pilsonisko audzināšanu un iekḷaušanu ir būtisks faktors sabiedrības drošības stiprināšanā ar noteikumu, ka šāda veida aktivitātes būtu domātas visu sabiedrības grupu iekḷaušanai, nevis kādas grupas izslēgšanai, identitātes apdraudēšanai vai tās nozīmīguma noliegšanai.

Atslēgvārdi: sabiedrības drošỉba; identitāte; izslēgšana; imigrācija; kopiena. 
Societal security addresses threats to the traditional lifestyles, customs, religious practices, and ethnic and national characteristics of a society or part of it. The dimension of societal security has been on the political and academic agenda for the last decade, but so far, no research has been conducted to integrate the threats identified by individuals into their overall view on the threat perception of Latvia's population and to assess the possible causal link between the perceived threats and policy-making processes that respond to them. This section of the book identifies those types of societal threats that inhabitants of Latvia consider significant and explores whether and how local governments respond to inhabitants' concerns about threats to societal security. The analysis demonstrates that the inhabitants of Latvia identify threats to their unique identity and recognise them as a significant challenge. In general, Latvian society is characterised as closed and oriented towards traditional values. In the regions, on the other hand, people feel a gap between the capital city and their concerns, emphasising the disparity in lives and agendas, and thus - the existence of two different communities. As a result, inhabitants of Latvia have named other residents and groups, as well as national public administration institutions, as the most significant internal sources of threat when it comes to the dimension of societal security. Municipalities, on the other hand, enjoy greater trust. The Russian Federation is mainly mentioned as an external source of societal threats. In general, analysis of the activities of local governments demonstrates that they rarely (and to a limited extent) see their role in strengthening security in the societal security sector. It can be concluded from the obtained results that the involvement of public and municipal representatives in wider discussions on security, civic education, and inclusion is an important factor in strengthening societal security. Such discussions should involve all societal groups, should not exclude any group (even if their identity is perceived as threatening), and should not deny the significance of any group.

Keywords: societal security, identity, exclusion, immigration, community.

\section{levads}

Sabiedrības drošỉba apskata apdraudējumus sabiedrības vai tās daḷu tradicionālajiem dzīvesveidiem, paražām, relig̣iskajām praksēm, etniskajām un nacionālajām īpatnībām. Iepretī personiskajai drošībai, kur dominē cilvēka un valsts attiecības, sabiedriskā drošība raksturo attiecíbas starp dažādām sociālām grupām. Tātad uzmanības centrā ir sabiedrības vai atsevišḳu tās grupu identitātes izturētspēja, kas ḷauj sabiedrības drošǐbu interpretēt kā dienaskārtību, veidu, kā valsts tiek pārvaldīta sabiedrības tradicionālās patības saglabāšanai. N̦emot vērā Latvijas valsts vēsturisko pieredzi un šì briža izaicinājumus, sabiedrības drošỉba līdzās militārajai, politiskajai un ekonomiskajai drošîbai ir kḷuvusi par nozīmīgu dimensiju debatēs par Latvijas drošỉbu. Šāda pieeja 
ḷāvusi pakḷaut analīzei tos riskus un apdraudējumus, ko valsts sabiedrïbas grupas vai iedzīvotāiji kopumā identificē kā būtiskus to identitātei, kā arī integrēt tos plašākā redzējumā par pastāvošās sociālās struktūras noturīgumu attiecībā uz ārējiem un iekšējiem destabilizācijas mēóginājumiem.

Lai arī sabiedrības drošība pēdējā desmitgadē ir bijusi gan politiskajā, gan akadēmiskajā dienaskārtībā, līdz šim nav ticis veikts pētījumus, kas l̦autu integrēt indivīdu identificētos draudus to identitātei kopējā Latvijas iedzīvotāju draudu uztveres skatījumā un vērtēt iespējamo korelāciju, kas pastāv starp uztvertajiem draudiem un atbilstošām rīcībpolitikām kā atbildēm uz tiem. Tāpèc nodaļas mērḳis ir identificēt tos sabiedrïbas draudu veidus, ko Latvijas iedzīvotāji vērtē kā svarīgus. Vispirms tiks apskatīti līdz šim veiktie nozīmīgākie pētijumi par sabiedrības drošības sektoru. Tam sekos sabiedrības draudu operacionalizācija atbilstoši pētījuma vajadzībām, kā arī pētījuma rezultāti un secinājumi.

\section{Kas paveikts sabiedrības drošības izpētē?}

Latvijā drošības pētniecības jomā ir uzkrātas ievērojamas zināšanas par sabiedrības drošības dimensiju. Pēc neatkarības atjaunošanas tika izstrādāti vairāki pētijumi, kuru mērḳis bija sniegt paplašinātu izpratni par drošību, īpaši izcel̦ot cilvēkdrošības dimensiju, ${ }^{1}$ kas cita starpā skāra atsevišķ us ar identitāti saistītos jautājumus, ko iespējams plašāk vispārināt arī sabiedrības drošības aspektā. Tas nav pārsteidzoši, ņemot vērā Latvijas valsts vēsturisko mantojumu un mūsdienu aktuālos drošỉbas izaicinājumus.

Piemēram, 2003. g. Māras Sīmanes redakcijā tika izdots ANO pārskats par tautas attīstību "Latvija. Pārskats par tautas attīstību. Cilvēkdrošība 2002-2003” (Sīmane, M. (red.) (2003). Latvija. Pārskats par tautas attīstību. Cilvēkdrošîba 2002-2003. Rīga: ANO, 154 lpp. ISBN: 9984-684-19-9). Pārskatā uzmanība vērsta uz izpratnes par cilvēkdrošibu padziḷināšanu, apskatot Latvijas iedzīvotāju galveno bažu iemeslus un pakārtojot tos septiņiem cilvēkdrošibas aspektiem. 2012. g. Žanetas Ozolin̦as redakcijā tika publicēta monogrāfija "Cilvēkdrošība Latvijā un pasaulē: no idejas līdz praksei”, kuras mērḳis ir izstrādāt cilvēkdrošỉbas un drošībspējas teorētisko konceptu, kurš lietojams dažāda attīstības līmeņa valstīs un uz kura pamata radìt zināšanu kopumu par risinājumiem individuālā un nacionālā līmenī risku novēršanai un nedrošibas mazināšanai (Ozoliṇa, Ž. (red.) (2012). Cilvēkdrošỉba Latvijā un pasaulē: no idejas līdz praksei. Rīga: Zinātne, 8. lpp.). 2015. g. Žanetas Ozoliņas redakcijā tika publicēts pētījums "Dzimums un cilvēkdrošība: Baltijas jūras regiona skatījums" (Ozolina, Ž. (red.) (2015). Gender and Human Security: A View from the Baltic Sea Region. Riga: Zinātne, 272 lpp.), kas fokusējās ne tikai uz identificētiem riskiem un draudiem, bet arī uz sieviešu līdztiesības veicināšanu Baltijas jūras valstu reg̣ionā. Nozīmīgu ieguldījumu Latvijas drošîbas studiju pētniecībā sniedza arī 2019. g. aizstāvētā Riharda Bambala doktora disertācija "Cilvēkdrošỉba kā nacionālā interese ārpolitikā: Japānas, Kanādas un Norvēgijas gadījumu analīze”. Šis promocijas darbs līdztekus citiem pētījumiem sniedz paplašinātu izpratni par drošību, teoretizējot tādus jēdzienus kā cilvēkdrošỉba un dzīvotspēja/noturība (resilience). 
2016. gadā Žanetas Ozoliṇas redakcijā tika publicēta grāmata "Sabiedrības drošība. Iekḷaušanas - izslēgšanas dilemma. Krievvalodīgo kopienas portrets Latvijā" (Societal Security: Inclusion- Exclusion Dilemma. A portrait of Russian-speaking community in Latvia). Pētijuma mērḳis bija apskatìt tos potenciālos draudus un riskus, ko identificē Latvijas krievvalodīgo kopiena, un to, kā šie draudi un riski var veicināt drošỉbas sistēmas destabilizāciju valstī. No sabiedrības drošíbas perspektīvas šis pētījums sniedz vienas kopienas krievvalodīgo - subjektīvās drošỉbas uztveres atspogulıjumu.

Otrs pētījums, kurā aplūkota sabiedrības drošība Baltijas jūras regiona valstīs, ir 2018. gadā Mikas Āltolas (Mika Aaltola), Borisa Kuzṇecova, Andra Sprūda un Elizabetes Vizgunovas redakcijā publicētais kopdarbs "Sabiedrības drošỉba Baltijas jūras reǵionā: ekspertīzes kartēšana un rīcībpolitikas attīstîbas veicināšana" (Societal Security in the Baltic Sea Region: Expertise Mapping and Raising Policy Relevance). ${ }^{2}$ Tas apvieno autoru kolektīvu, kas sniedz skatijumu uz sabiedrības drošību Dānijā, Somijā, Islandē, Norvēǵijā, Zviedrijā, Igaunijā, Latvijā, Lietuvā, Polijā, Baltkrievijā un Krievijā.

Dažādi sabiedrības drošības aspekti Latvijas situācijas kontekstā daudz plašāk apskatīti dažādās sabiedriskās domas aptaujās. Apkopojot publicēto aptauju datus, iespējams noškịt trīs visbiežāk minētās draudu grupas iedzivotāju subjektīvajā sabiedrības draudu uztverē. Saskaņā ar tiem Latvijas sabiedrības subjektīvās drošības uztveres novērtējumā visbiežāk parādās jautājumi par nacionālo identitāti, reliǵisko identitāti un lingvistisko piederību, bet nedaudz retāk - par etnisko identitāti. Latviskās identitātes saglabāšanas indikators aptaujās tiek skatīts caur vairāku faktoru prizmu, piemēram, nāciju, tradīcijām un kultūru. Reliǵiskā brīvība tiek vērtēta kā gimenes atvērtỉba citu relig̣iju pārstāvjiem un viṇu religiiskajām praksēm. Savukārt etniskā patība kā sabiedrības drošỉbas garants aptaujās tiek skatīta, novērtējot attieksmes un orientāciju un biežāk reflektējot par lingvistisko, nevis šauri etnisko piederību.

Piemēram, saskaṇā ar SKDS 2019. gadā publicētiem datiem " $42 \%$ no respondentiem norādījuši satraukumu par to, ka norisinās latviešu kultūras amerikanizācija”’3. Turklāt, saskaṇā ar domnīcas Pew Research Center rīkotās 2018. gada aptaujas datiem, "38\% aptaujāto Latvijas iedzīvotāju pauduši uzskatu, ka viṇu nācijas kultūra ir ìpašāka nekā citas”’. Bet kā nozìmīgu faktoru

2 Aatola, M. et al. (2018). Societal Security in the Baltic Sea Region: Expertise Mapping and Raising Policy Relevance. Rīga: Latvijas Ārpolitikas institūts, p. 270.

3 Ziṇu ag̉entūra LETA (2019). Kultūras amerikanizācija Latvijas iedzīvotājus lielākoties nesatrauc. Pieejams: https://lat.bb.lv/raksts/sabiedriba/2019/07/07/kulturas-amerikanizacija-latvijas-iedzivotajus-lielakoties-nesatrauc

4 Pew Research Centre (2018). Eastern and Western Europeans Differ on Importance of Religion, Views of Minorities, and Key Social Issues. Pieejams: https://www.pewforum.org/2018/10/29/ 
identitātes saglabāšanā respondenti ir minējuši piederības sajūtu Latvijai: "71\% respondentu uzskatīja, ka, lai būtu īsti piederīgs Latvijai, te jāpiedzimst, bet $61 \%$ aptaujāto norādīja, ka gimenes saknēm ir jābūt no šĩs valsts"s.

Attiecībā uz apdraudējumiem reliǵiskajai piederībai šāda ievērojama subjektīvā draudu uztvere aptaujās nav novērojama, jo Latvijas iedzīvotāju pašidentifikācijai reliǵija nav tik nozīmīga. Saskaṇā ar Pew Research Center datiem tikai $10 \%$ Latvijas iedzīvotāju reliǵija ir ļoti svarīga vinuu dzīvē, lai gan $71 \%$ respondentu atzinuši, ka tic Dievam. ${ }^{6}$ Vienlaikus Latvijas sabiedrība raksturojama kā konservatīva un noslēgta, ar ierobežotu spēju pieņemt citu reliǵiju pārstāvjus: "19\% respondentu būtu gatavi pien̦emt ǵimenē musulmani un 53\% - ebreju”.

Apdraudējums lingvistiskajai patībai Latvijas publiskajā dienaskārtībā ir viens no visbiežāk aktualizētajiem sabiedriskās drošības draudiem. İpaši tiek izcelta plaisa starp latviešu un krievu valodā runājošiem, uzsverot sabiedrības sašḳeltību divās lingvistiski atškirīgās kopienās. Lai arī šis aspekts dažkārt gan apzināti, gan neapzināti tiek jaukts ar etnisko piederību, tomēr tas ir stingri nošķirams.

Runājot par iedzīvotāju subjektīvo drošỉbas uztveri saistībā ar etnisko piederību, aptauju dati parāda divas nozīmīgas tendences. Saskaņā ar Pew Research Center 2018. gada datiem, $61 \%$ etnisko krievu un 45\% pārējo aptaujāto Latvijas iedzīvotāju uzskata, ka ir labāk, ja sabiedrību veido cilvēki ar dažādu nacionālu un kultūras piederību. ${ }^{8}$ Tas liecina, ka aptuveni puse Latvijas iedzīvotāju ir gatavi dzìvot heterogēnā sabiedrībā, bet "24\% respondentu, kas sevi ir uzskatījuši par etniskiem krieviem, neidentificē sevi ar valsti, kurā tie dzīvo"'.

Līdzīgas tendences uzrāda pētījumi, kas pievērsušies krievvalodīgo kopienas uzskatu analīzei. No tiem secināma ne tikai lielas šo iedzīvotāju daļas atsvešinātība no pastāvošās politiskās sistēmas, bet arī ciešas saiknes izjūta ar Krievijas Federāciju. Piemēram, taujāti, vai Krievijai būtu pienākums aizsargāt krievvalodīgo intereses un tiesības Latvijā, tie atbildējuši apstiprinoši. ${ }^{10}$ Šādas nostājas ievērojamā daļā Latvijas sabiedrības negatīvi ietekmē sabiedrības drošîbu, kā arī potenciāli var kḷūt par iemeslu politiskās drošības situācijas pasliktināšanai.

eastern-and-western-europeans-differ-on-importance-of-religion-views-of-minorities-andkey-social-issues/?fbclid=IwAR0Af1zqir6iRYBAYd_dZ1hsDOoMOhMJUc4qxgpqD6Q6XdDF4ZulqXUlLp4\#fn-30843-1

5 Ibid.

6 Ibid.

7 Ibid.

8 Pew Research Centre (2017). Ethnic Russians in some former Soviet republics feel a close connection to Russia. Pieejams: http://www.pewresearch.org/fact-tank/2017/07/24/ethnic-russians-in-some-former-soviet-republics-feel-a-close-connection-to-russia/

9 Ibid.

10 Ibid. 


\section{Sabiedrības drošības jēdziens}

Sabiedrïbas drošỉbas (societal security) konceptu 20. gadsimta 80. gados ieviesis viens no spilgtākajiem Kopenhāgenas skolas (Copenhagen School) pārstāvjiem Barijs Buzans (Barry Buzan). Savā darbā "Cilvēki, valstis un bailes" (People, States \& Fear: The National Security Problem in International Relations) Buzans, paužot uzskatu, ka "mūsdienu drošîbas izpratni veido ne tikai militārā drošība, bet arī (indivīdu) politiskā, ekonomiskā, ekolog̣iskā un sabiedrības (kopienas) drošîba"11. Tādējādi viņš kḷuva par vienu no pirmajiem pētniekiem, kas paplašināja drošỉbas uztveri no valsts līmeṇa līdz sabiedrības un indivīda līmenim. ${ }^{12}$

Barija Buzana izpratnē sabiedrības drošība nozīmē sabiedrības tradicionālo valodas un kultūras modeḷu, tradīciju, relig̣iskās un etniskās identitātes ilgtspēju un piel̦aujamo attīstîbas nosacỉjumu nodrošinājumu un ilgtspēju. ${ }^{13}$ No tā secināms, ka sabiedrības drošỉba ir stāvoklis, kurā netiek apdraudēta sabiedrības ilgtspēja, valoda, kultūra un indivīdu reliǵiskā un etniskā identitāte un tiek uzsvērta sabiedrības kā vienotas kopienas pastāvēšana. Praksē tas nozīmē uzskatu, ka indivīdu un sabiedrības drošìba ir atkarīga ne tikai no valsts spējām nosargāt teritoriju un kopienu no ārējiem draudiem. Barijs Buzans pieņēma, ka indivīdu un sabiedrības drošîbu var apdraudēt arī iekšêjie draudi. Tā sabiedrības drošîbu Buzans saistīja ar piel̦aujamiem nosacījumiem tradicionālu, sabiedrībai raksturīgu dzīvesveidu, kultūras, valodas un citu identitātes ipatnibu saglabāšanai.

Paplašinot Barija Buzana izvirzītās tēzes par sabiedrības drošības definējumu, 1993. gadā Oles Vēvera (Ole Wrever) redakcijā tika publicēts pētījums "Identitāte, migrācija un jaunā drošības dienaskārtība Eiropā" (Identity, Migration and the New Security Agenda in Europe), kurā tika rekonceptualizētas Buzana idejas par drošības uztveres paplašināšanu. Saskaņā ar šì pētījuma autoru atzin̄ām sabiedrības drošība ir neatñemama valsts drošības sastāvdaļa. "Ja valsts drošības garants ir suverenitāte (zaudējot suverenitāti, valsts neizdzīvos kā valsts (struktūras ziņā)), tad sabiedrības drošỉbas garants ir identitāte (zaudējot identitāti, sabiedrība neizdzīvos)." ${ }^{4}$ Tādējādi arī Vēvers, līdzịgi kā

11 Buzan, B. (1983). People, States \& Fear: The National Security Problem in International Relations. London: Wheatsheaf Books, p. 10.

12 Ibid., p. 33.

13 Buzan, B. (1991). People, States and Fear: An Agenda for International Security Studies in the PostCold War Era (2nd ed.). London: Harvester Wheatsheaf, p. 123.

14 Weawer, O. et al. (1993). Identity, Migration and the New Security Agenda in Europe. London: Pinter, p. 23. 
Buzans, sabiedrības drošību sākotnēji drīzāk skatīja nacionālās drošības paplašinātā perspektīiā.

Ole Vēvers uzsvēris: lai gan sabiedrības drošỉba ir cieši saistìta ar politisko drošību, kas ir par valsts pārvaldes organizacionālo, legitimitātes un ideologisko stabilitāti, tomēr tā ir nošķirama kā atsevišķa vienība. Lìdzīgi kā Buzans, viņš uzsvēris identitātes saglabāšanas nozīmi un piedāvājis šādu sabiedrības drošỉbas definīciju: "sabiedrības drošība ir definējama kā identitātes aizsardzība pret uztvertiem draudiem vai, precīzāk, kopienas aizsardzība pret tās uztvertiem draudiem identitātei"15. Šādā koncentrētā definīijā Vēvers iekḷauj plašu identitātes dimensiju klāstu. Viņš uzskata, ka tas skar bailes par kultūras īpatnību saglabāšanu, kopienas, nācijas, reliǵijas, dzimuma tradicionālo uzvedības modelıu un citu līdzīgu individuālo, grupu un visas sabiedrības skatījumu uz savas identitātes ilgtspēju. ${ }^{16}$ Vienlaikus Ole Vēvers arī norādījis uz nepieciešamību diferencēt dažādu indivīdu grupu intereses vienā sabiedrībā, tādējādi pieḷaujot, ka noteiktos apstākḷ̆os tās var savstarpēji konfliktēt un radìt apdraudējumu cita citai.

Buzans, Vēvers un Vilde (1998) savā kopdarbā uzsvēruši, ka kopienas definē apdraudējumus to identitātei dažādos veidos, izceḷot trīs nozīmīgākās faktoru grupas, kas to ietekmē. Tās ir: migrācija, vertikālā sāncensība un horizontālā sāncensỉba. Autori piel̦auj, ka draudu avoti var būt gan iekšèji, gan ārēji, gan iepriekš plānoti un apzināti, gan strukturāli, gan arī neplānoti un neapzināti. Šādā skatijjumā imigranti tiek identificēti kā tādi, kam piemīt potenciāls mainīt sabiedrības izkārtojumu un kohēziju. Horizontālā sāncensība apskata tos draudus, kas potenciāli var rasties no blakām esošas kultūras dominances, un rezultātā var mainīties pastāvošā kultūra. Savukārt vertikālā sāncensība kā drauds tiek skatīta, ja izmaiņas sabiedrības kultūrā tiek projicētas "no augšas", lai mainītu sabiedrības pašidentifikāciju, integrējot to "pārnacionālos" identitātes projektos (piem., eiropeiskā identitāte, ES pilsonība u. tml.). ${ }^{17}$

Līdzīgs skatījums uz sabiedrības drošību ir arī, piemēram, Juliānam Čifu (Iulian Chifu). Viṇš sabiedrības drošỉbu skata kā visaptverošu jēdzienu, kas apkopo daudzveidīgus mūsdienīgos draudus sabiedrībai. Čifu ieskatā, kā nozīmīgi te apskatāmi sociālās identitātes un sociālās saliedētības nestabilitātes fenomeni. Viņš secina, ka sabiedrības drošības sektorā apskatāms viss, kas saistīts ar sabiedrības locekḷu identitātes un saliedētības/sadarbības saglabāšanu,

15 Wæver, O. (2008). The Changing Agenda of Societal Security. In: Brauch H. G. et al. (eds.) Globalization and Environmental Challenges. Hexagon Series on Human and Environmental Security and Peace. Springer, Berlin, Heidelberg. p. 581.

16 Ibid.

17 Buzan, B., Wæver, O., de Wilde, J. (1998). Security: A New Framework for Analysis. Lynne Rienner Publishers United Kingdom, pp. 239. 
ņemot vērā konkrētas sabiedrības īpatnības. ${ }^{18}$ No tā izriet, ka sabiedrības drošỉbas izpētē uzmanība tiek pievērsta tam, kā tiek nodrošināta sabiedrības un tās dalıu identitātes īpatnību, t. sk. valodas, kultūras, tradīciju, paražu, ilgtspēja. Par draudiem tie tiek uzskatīti tad, kad tie radušies valsts institūciju vai citu valsts iekšējo aktoru darbības rezultātā un apdraud sabiedrības dzìves ilgtspēju. Tādējādi mūsdienu sabiedrības drošības izpratne iekḷauj indivīdu drošības sajūtu (safety) gan attiecībā uz iekšējiem, gan ārējiem draudiem. ${ }^{19}$

Pētijuma analītiskā ietvara izveidei šìs nodal̦as izstrādē ņemti vērā ne tikai sabiedrības kopumā uztvertie draudi tās identitātei neatkarīgi no iedzīvotāju piederības pie kādas sabiedrības grupas, bet izcelti arī tie subjektīvi uztvertie apdraudējumi, kas attiecināmi uz minoritāšu grupu pārstāvjiem. Atbilstoši minētajam noteiktas šādas draudu grupas, kas saistītas ar sabiedrības drošību: grupas identitāte; izglīīiba; grupas pārstāvniecība (sabiedrības un politiskā līdzdalība); kultūra un reliǵija; izmaiṇas kopienas lielumā un ietekmes apjomā; rasisms un nacionālisms; vairākuma dominance (psiholog̣isks spiediens, iejaukšanās grupas iekšêjās lietās).

Lai analizētu pārvaldes spēju reagèt uz izaicinājumiem sabiedrības drošībai un apzinātu aktivitātes, kas vērstas uz Latvijas sabiedrības tradicionālās patības saglabāšanu, izmantota labas pārvaldības rādītāju matrica, kas iekḷauj šādus rādītājus: pārvaldības sistēmas stabilitāte/prognozējamība/pēctecība; plānošanas ilgtermiņa pieeja - ilgtermiņa redzējums; reformu jēgpilnums - ieviešanas efektivitāte, caurskatāmība; normatīvo aktu izmaiṇas; ierēdṇu profesionalitāte; informētība, kā rīkoties X stundā; preventīvās rīcībpolitikas veidošana; iestāžu koordinācija.

Piedāvātās matricas aizpildīšanai katrā sabiedrības draudu grupā tika izvēlēti jautājumi intervijām ar vietējo pašvaldību pārstāvjiem. Tie palīdzēja noskaidrot vietējo pašpārvalžu pārstāvju informētību par iedzìvotāju bažām un uztvertajiem draudiem identitātei, ar ko tie saskaras savā ikdienā. Pēc tam tika apskatītas analizējamo pašvaldību realizētās aktivitātes sabiedrības drošības draudu novēršanai. Šāda pieeja sniedza iespēju izcelt gan tos faktorus, kas tieši saistīti ar apdraudējuma radīšanu sabiedrības drošībai un kas pastāvīgi negatīvi ietekmē drošības sajūtu, gan arī netiešos jeb fona rādītājus, kas ir saistīti ar drošỉbas vidi un kas var potenciāli negatīi ietekmēt personas drošības uztveri un veicināt tās neapmierinātību un diskomfortu (piem., normatīvo aktu izmaiņu biežums vai ierēdṇu profesionalitātes līmenis).

18 pdfs/societal_security.pdf

19 Laegried, P., Rykkja, L. H. (ed.) (2019). Societal Security and Crisis Management. Governance Capacity and Legitimacy. London: Palgrave Macmillian, p. 5. 


\section{Latvijas iedzīvotāji par sabiedrības drošību}

Veiktās fokusa grupu intervijas atklāj, ka Latvijas iedzīvotāji draudus sabiedrības drošībai uztver kā nozīmīgus, tomēr ne prioritārus kopējā drošības redzējumā. Lai arī visās pašvaldībās apdraudējumi sabiedrības drošỉbai tika minēti, tomēr tikai trijās no divpadsmit - Aizkrauklē, Liepājā, Rēzeknē - iedzīvotāji tos nosauca starp trīs nozīmīgākajiem draudu veidiem. Nevienā pašvaldībā respondenti sabiedrības draudus neizcēla kā svarīgākos.

\section{Krievija}

Kā būtiskākais ārējais draudu avots sabiedrības drošībai visos reǵionos tika minēta Krievijas Federācija. Atsevišķās fokusa grupās, piemēram, Rīgā, respondenti nosauca iespējamo migrācijas vilni no musulmaṇu valstīm kā ievērojamu potenciālo apdraudējumu sabiedrības drošỉbai Latvijā. Visbiežāk tas tika asociēts ar svešu tradīciju un nepieņemamu reliğisko paražu ieviešanu, kas varētu negatīvi ietekmēt Latvijas iedzīvotāju tradicionālo dzīvesveidu. Vēl vienā pašvaldībā kā potenciāls apdraudējums tika minēta Ķīnas Tautas Republikas pilsoṇu vēlme nākotnē meklēt jaunas, brīvas teritorijas dzīvesvietu ierīkošanai. Šis un atsevišḳi citi naratīvi, kas iekḷauti iedzīvotāju pārdomās par apdraudējumiem to identitātei, norādīja uz bailēm no eiropeizācijas, globalizācijas un plašākas mijiedarbības ar starptautiski dominējošām kultūrām, t. sk., piemēram, no amerikanizācijas.

\section{Sabiedrības šḳelšana}

No iekšējiem draudu avotiem galvenokārt tika minēta sabiedrības šḳelšanās latviski runājošo un krievvalodīgo kopienās, kā arī atsevišķu iedzīvotāju grupu atsvešinātība no Latvijas valsts un naidīgums pret to. Reǵionos kā draudu avotus ne tikai politiskajai, bet arī sabiedrības drošỉbai respondenti atzīmēja reǵionālo reformu un depopulāciju lauku apvidos. Tika nosaukta arī Rīgas un Pierīgas iedzīvotāju arogantā attieksme pret "lauciniekiem” kā profesionālās, tā sadzīves jomās.

\section{Identitāte}

Pētījuma gaitā tika izgaismotas vairākas grupu identitātes, kuru kontekstā iespējams runāt par iedzīvotāju subjektīvo draudu izjūtu. Kā nozīmīgākā minama piederība latviešu vai krievvalodīgo lingvistiskai kopienai. Piederība latviešu valodā runājošai kopienai vairumā gadījumu pārklājas arī ar etnisko piederību, bet krievvalodīgo grupas gadījumā šāda pārklāšanās nav tik izteikta. Zīmīgi, ka latviešu valodā runājošie fokusa grupu interviju dalībnieki 
izteica vienlīdz lielas bažas par apdraudējumiem to etniskajai identitātei un valodai kā krievvalodīgie iedzīvotāii.

Šis un arī citi pētījumi atklāj, ka plaisa starp latviešu un krievvalodīgo kopienu galvenokārt ir aktuāla grupu un plašākā sabiedrības līmenī, bet ne indivīdu līmenī. Tomēr dažkārt tika izteiktas bažas par abu kopienu pārstāvju līdzāspastāvēšanu bez konflikta individuālā līmenī.

Sieviete darbspējas vecumā, Talsi: Ja divas tautības satiekas gimenes dzīvei, tad tie ir potenciālie psihoterapeita pacienti, jo ir ḷoti grūti savienot šìs abas atšķirīgas mentalitātes.

Nesaskaņu pamatcēlonis latviešu respondentu skatijumā galvenokārt ir vēsturiskā pieredze.

Respondente, Talsi: Mums nekas nav pret cittautiešiem, mums vienkārši ir rūgta pieredze par tiem cittautiešiem, kas ir gājuši pie mums un mācījuši, kā mums dzīvot. ${ }^{20}$ Tãpēc ir grūti pieñemt, ka krievi ir labi Latvijā.

Savukārt krievvalodīgo kopienas pārstāvji atsevišķās fokusa grupas intervijās norādījuši uz aizspriedumiem, kas, viṇuprāt, pastāv latviešu vidū. Pamatā aizspriedumi ir par valodas zināšanām, piederības izjūtu valstij un patriotismu.

Jauniete, Daugavpils: Ir stereotips, ka, ja tu dzìvo Daugavpilī, tad automātiski nezināsi valodu, bet tā nav.

Abu lingvistisko kopienu gadījumos arī tika minēti atsevišş̧i piemēri par indivīda subjektīvi uztvertu diskrimināciju uz etniskās piederības pamata.

Sieviete darbspējas vecumā, Rēzekne: .. man ir krievu vārds un uzvārds, es pati jūtos kà latviete, bet, mācoties Rīgā, viena pasniedzēja mani ienīda tikai par to, ka man ir krievu vārds un uzvārds. [.] Ja tu strādà valsts amatā - tavs vārds un uzvārds spēlē l̦oti lielu lomu. Ja tevi sauc Ivans Ivanovs, tev nedos augstu amatu.

Secināms, ka abu lingvistisko kopienu pārstāvjiem ir raksturīgas negatīvas emocijas, kas dažkārt ir saistītas arī ar apdraudējuma sajūtu no citas kopienas pārstāvju puses. Tas zināmā mērā skaidrojams ar sabiedrības drošības dilemmas izpratni. ${ }^{21}$ Tomēr drīzāk šādas bažas nav saistāmas ar izteiktām bailēm vai sajūtu par tūlītēju apdraudējumu. Latviešu kopienas pārstāvji ar bažām

21 Plašāk skatît: Societal Security: Inclusion-Exclusion Dilemma. A portrait of Russian-speaking community in Latvia (2016). Ed. Ozoliṇa, Ž. Rīga: Zinātne. 
raugās uz krievvalodīgo kopienas pārstāvju attieksmi pret šo valsti iespējamo uzvedību krīzes situācijās.

Pensionēts vīrietis, Talsi: Talsu krieviem ir loti liels naids pret pastāvošo valdību, Latviju. [..] Viņi redz tā - ak, nolādètā Latvija!

Krievvalodīgo kopienas pārstāvji drīzāk ar aizvainojumu raugās uz, viņuprāt, nevienlīdzīgu attieksmi un vairākuma dominanci. İpaši šis aizvainojums atainojas ne tik daudz attieksmē pret latviešu kopienu, cik pret pastāvošo politisko režīmu, skatot to kā drīzāk naidīgu. Rezultātā secināms, ka krievvalodīgo kopienas pārstāvjiem raksturīga apdraudējuma un psiholog̣iska spiediena subjektīva uztvere, kas būtiski ierobežo šìs sabiedrības daḷas iekḷaušanās procesu.

Ar nacionālo identitāti šajā pētījumā tika izprasta Latvijas sabiedrība kā vienotas kopienas patība un iedzīvotāju subjektīvi uztvertie draudi pret Latvijas sabiedrību kopumā. Citu reliǵisko, etnisko vai citas identitātes grupas pārstāvju iekḷaušana Latvijas sabiedrībā ir sarežğìts un izaicinošs process, jo struktūras ziṇā Latvijas sabiedrība tiek raksturota kā slēgta sabiedrība. Daudzi Latvijas iedzīvotāji citu reliǵisko, etnisko vai citu identitāšu pārstāvju iekḷaušanu sabiedrībā saskata kā apdraudējumu savai identitātei.

Fokusa grupas intervijas dalïbnieks, Talsi: Citu reliǵisko pārstāvju pieņemšana savā ǵimenē ir lototi sarežğìta. Ar lielu sajūsmu es to neuztvēru.

Tiesa, reǵionos aptaujātie iedzīvotāji biežāk ārvalstnieku klātbūtni skata kā potenciālu apdraudējumu sabiedrības drošībai nākotnē, kamēr Rīgā, viņuprāt, tā jau ir būtiska problēma.

Respondents, Daugavpils: Imigranti mums nav problèma. Mès viniem esam lauki. Ja nu kāds cilvēks parādās, tad tā nav problèma. Jā, Rīgā gan ir grüti pat nopirkt kebabu, ja tu nezini anglu valodu, bet pie mums nē.

Izṇēmums šajā ziņā bija respondenti fokusa grupā Jaunjelgavā, kuri intervijas laikā norādīja, ka, viņuprāt, patvēruma meklētāji no musulmaṇu valstīm ir reāls šĩ brīža apdraudējums nacionālai un kultūras identitātei un ka Latvija nav gatava stāties pretim šim izaicinājumam. Savukārt Rīgā kāds respondents uzskatīja, ka, viṇa ieskatā, nākamās paaudzes pārstāvji reageēs asāk uz imigrantiem un "noliks viņus pie vietas".

Rīgā notikušu fokusa grupu interviju rezultāti apliecināja, ka iedzīvotāji imigrantu klātbūtni saskata kā draudu. İpaši tas attiecināms uz ieceḷotājiem no musulmaņu valstīm. Plašāka musulmaņu klātbūtne vai, piemēram, iespējama mošeju parādīšanās Rīgā, fokusa grupu interviju dalībnieku ieskatā, negatīvi ietekmētu Latvijai raksturīgās kultūrtelpas ìpatnības. Respondenti interviju 
laikā norādīja uz nopietnām bailēm par Latvijas nācijas izdzīvošanu gadījumā, ja tā pārdzīvotu ievērojamu musulmaṇu imigrācijas vilni. Tāpēc ES patvēruma politika tika interpretēta galvenokārt negatīvi. Zīmīgi, ka iedzīvotāju izglìtības līmenis vai cel̦ošanas biežums nekorelē ar aizspriedumu mazināšanos pret ieceḷotājiem.

Kā nozīmīgākos draudus šajā sakarā aptaujātie Latvijas iedzīvotāji minēja tradicionālajam dzīvesveidam svešu vērtību ienākšanu un svešu uzskatu paušanu. Šāda veida apdraudētības sajūta īpaši raksturīga vecāko paaudžu pārstāvjiem. Piemēram, šajā sakarā bažas rada draudi tradicionālam gimenes institūtam.

Pensionāre, Ādaži: Nopietnu nedrošību rada giimenes institūcijas graušana ar visādu praidu ${ }^{22}$ aț̦aušanu.

Līdzīgi vecākās paaudzes pārstāvju uzskati atainojušies arī, kad runa ir par kultūras amerikanizāciju un Rietumu popkultūras dominanci. Izteikti gados vecāko cilvēku vidū novērojama arī nedrošība, kas tiek izjusta, vienkārši sastopoties ar citu nacionalitāšu pārstāvjiem.

Jauniete, Rēzekne: .. manai paaudzei problēmu nav. Bet manam tētim ir aizspriedumi pret citām nacionalitätēm. Vecāki cilvēki nesaprot, ka mès visi esam vienādi.

Jaunieši atzīst, ka svešu kultūru pārstāvji, atšḳirīgas ādas krāsas vai Latvijas sabiedrībai svešas etniskās piederības pārstāvji var tikt un tiek diskriminēti. Jauno cilvēku ieskatā, zemais tolerances līmenis ir saistīts galvenokārt ar vēsturisko mantojumu, vājām zināšanām par citām kultūrām un līdz šim nenotikušu plašu mijiedarbību ar citu kultūru pārstāvjiem, īpaši lauku reǵionos.

\section{Patriotisms}

Cits aspekts, ko saistībā ar nacionālās identitātes problemātiku identificējuši aptaujātie Latvijas iedzīvotāji, ir patriotisma trūkums sabiedrībā. Piemēram, Rēzeknē fokusa grupas dalībnieki norādīja, ka šis ir patiesi nopietns izaicinājums, ar ko sastopas Latvijas valsts. Rezultātā nacionālisms ir vairāk izteikta iezīme, bet patriotisma trūkums subjektīivi drīzāk tiek interpretēts kā protestu (pret notiekošajiem politiskajiem procesiem un zemas uzticēšanās politikiiem) rezultāts.

Tradicionāli ir pieņemts uzskatīt, ka krievvalodīgo kopienai patriotisma trūkums ir raksturīgāks nekā latviešu kopienai. Tomēr ši pētijuma fokusa

22 Praids - seksuālo minoritāšu pārstāvju organizēts publisks pasākums, lai veicinātu šo marginalizēto grupu tiesību ievērošanu, atbalstītu tās un mazinātu homofobiju un neiecietību. 
grupu interviju rezultāti liecina, ka šāds uzskats neprecīzi ataino reālo situāciju. Krievvalodīgo kopienas pārstāvji, neskatoties uz rūgtumu par politiskajiem procesiem, bieži sevi vienlaikus identificē ar valsti, tiesa, vairāk uztverot teritoriālo piederību un piederību lokālai kopienai.

\section{Lokālā identitāte}

Iedzīvotāji dažādos regionos fokusa grupu interviju laikā norādīja uz piederību noteiktai vietai, reg̣ionam kā nozīmīgu pašidentifikācijas aspektu. Tāpēc subjektīvi uztverti apdraudējumi šajā kontekstā tiek uztverti kā nozīmīgāki. Īpaši tas attiecas uz depopulāciju.

Respondents, L,audona: Latvijas lauku nākotne, Latvijas mazo apdzīvoto vietu izdzìvošana ir loti, l̦oti apdraudēta.

Respondentu diskurss liecina par to, ka lauku iedzìvotāju uztverē Latvijā norisinās divas atškirīgas sabiedriski politiskās dzīves - viena Rīgā, kurai piederīgi viṇi nejūtas, un otra - reǵionos. Reǵionu iedzīvotāji, ìpaši Latgalē, norādījuši arī uz negatīvu attieksmi vai diskriminējošām situācijām, ko izjutuši no Rīgas un Pierīgas iedzīvotājiem. Šāda veida subjektīvās izjūtas paplašina plaisu starp centra un reǵionu iedzīvotājiem.

Respondents, Daugavpils: Mēs viniem esam lauki. Viss, kas ir ärpus Rïgas 30 kilometru attālumā, tie ir lauki.

Fokusa grupas dalībniece, Daugavpils: Esmu saskārusies ar negatìvu attieksmi, jo esmu no Latgales. Latgali, teiksim tā, apspiež. To es esmu izjutusi, pati nē, bet uz bèrniem jā, noteikti.

Šāda subjektīvi uztverta plaisa un atsvešināšanās no valsts pārvaldes regionu iedzīvotājos rada rūgtumu un vilšanos. Turklāt, ņemot vērā fokusa grupām raksturīgos diskursus, secināms, ka atsvešināšanās un vilšanās sajūtai drīzāk ir raksturīgs pieaugums - īpaši reǵionālās reformas dēḷ. Šādas orientācijas var potenciāli negatîvi ietekmēt sabiedrības vienotību un solidaritāti. Tās izgaismo sabiedrības izturētspējas iespējamos vājos posmus, kas krīzes situācijās var negatīvi ietekmēt valsts spēju reageèt uz potenciāliem apdraudējumiem.

\section{Sabiedrības drošība pašvaldībās}

Šajā apakšnodaḷā analizēti pārvaldības rādītāii sabiedrības drošības sektorā trīs Latvijas pašvaldībās - Liepājā, Rēzeknē un Aizkrauklē. Tās ir pašvaldības, kurās draudus sabiedrības drošỉbai fokusa grupu dalïbnieki identificēja kā vienus no trim nozīmīgākajiem draudu veidiem. Katras pašvaldības sniegums tiks analizēts atbilstoši pētījuma gaitā izstrādātai labas pārvaldības matricai. Labas 
pārvaldības rādītāji sabiedrības drošības sektorā analizēti, izmantojot intervijas ar lēmumu pieṇēmējiem pašvaldībās un kvalitatīvo plānošanas dokumentu analīzi (pašvaldību attīstības plānošanas dokumenti, attīstības pārskati un cita publiski pieejama informācija).

\section{Liepājas pilsētas pašvaldība}

Iedzīvotāju etniskais sastāvs Liepājas pilsētas pašvaldībā ir multietnisks. 2018.2019. gadā tika reg̣istrēti "68 945 iedzīvotāji, no kuriem 59\% ir latvieši, 28\% ir krievi, $4 \%$ ir ukraiņi, $3 \%$ ir lietuvieši, $3 \%$ ir baltkrievi un $3 \%$ ir pārējo tautību pārstāvji"23. Šāda diversitāte, kā arī Karostas vēsturiskais mantojums raisa jautājumus par starpetniskajām attiecībām, dažādu etnisko grupu izpratni par apdraudējumiem, ar ko tās sastopas, kā arī pašvaldības spēju reagêèt uz kopienas pārstāvju subjektīvo draudu izjūtu.

Padziḷinātā intervija ar Liepājas pilsētas pašvaldības darbinieku apliecināja, ka vietējās pārvaldes pārstāvji apzinās sabiedrības drošības draudu aktualitāti. Vienlaikus tie netiek identificēti kā prioritāri, salīdzinot ar, piemēram, personiskiem vai politiskiem draudiem. Pašvaldības darbinieks intervijas laikā arī pauda uzskatu, ka, neskatoties uz pastāvošajiem izaicinājumiem, Liepājā nav būtiski apdraudēta nevienas etniskās grupas identitāte un ka visas etniskās grupas spēj mierīgi pastāvēt līdzās, respektējot citu grupu kultūru.

Liepājas pašvaldības pārstāvis: .. mès pilsētā esam spējuši, mācējuši iesaistìt mazākumtautību kopienas, un tās ir kḷuvušas l̦oti lokālpatriotiskas. Jūs neatradīsiet nevienu, kas nav Liepājas patriots. Neatkarīgi no dzimtās valodas, arī krievi. [..] Pilsētā arvien vairāk tiek lietota latviešu valoda. Ja arī pasākums ir krievu valodā, tas tūdal tiek tulkots uz latviešu valodu, ar cieņu un respektu pret valsti un kultūru. ${ }^{24}$

Intervijas laikā pašvaldības pārstāvis arī secināja, ka pašvaldībā nav iespējams runāt par negatīvajām nacionālisma izpausmēm vai izteiktu etniskā vairākuma (latviešu) dominanci. Savukārt kā vienu no sabiedrības drošîbas sektora apdraudējumiem, kas ir aktuāli, respondents norādīja bilingvālās izglīīibas nodrošinājumu Latvijā.

Liepājas pašvaldības pārstāvis: .. tā ir valstiska nolaidība, ka vēl joprojām bērnudārzos nav valsts valoda kā vienīgà apmācību valoda. Tikai tagad vidusskolas gada-publiskais-parskats/

24 Padziḷinātā intervija ar Liepājas pilsētas pašvaldības darbinieku Rīgā, Liepājas pārstāvniecībā, 2020. gada 22. janvārī. 
8.-9. klase pāries uz valodas proporciju par labu valsts valodai. Tā ir nolaidība pēc 30 gadu neatkarības, nolaidība roku rokā ar glèevvulïbu, jo mūs vairāk uztrauc reitingi, nevis valsts attīstība. ${ }^{25}$

Analizējot pastāvošo situāciju sabiedrības drošības kontekstā, cita starpā respondents norādījis arī uz to, ka, viņaprāt, iedzīvotāji vairāk uzticas tieši pašvaldībām, nevis nacionālā līmeṇa valdībai. Sabiedrības uzticēšanos intervējamais cieši saista gan ar to, ka pašvaldībās ir vērojama konsekvence lēmumu pien,emšanas procesos, gan ar to, ka pašvaldỉba ar savu rīcibu mazina apdraudējumus dažāàos drošîbas sektoros.

Liepājas pašvaldības pārstāvis: .. uzticēšanās pašvaldībām Latvijā ir lielāka kā valdībai. Jautājums - kāpēc? Konkrēti Liepājas piemēers parāda iemeslus. Tas ir tädēl, ka varas mainība pašvaldībās ir mazāka nekà centrālās valdības mērogā. Liepājā varas maiña notika pirms gada. Šis izmaiñas, kas arī nenotiek bieži, saglabāja konsekvenci, jo tika respektēti iepriekšējie lèmumi un turpināti iesāktie procesi. [..] Pašvaldību iedzīvotājiem vēelěšanās neinteresē skaistas frāzes, bet interesēe, $k \bar{a}$ tiek renovētas skolas un remontētas ielas, kādas ir personības un kāda ir to reputācija. ${ }^{26}$

Apkopojot intervijas rezultātus, secināms, ka pašvaldības pārstāvja sniegtais vērtējums ir visai optimistisks un neiezīmē būtiskus izaicinājumus sabiedrības drošības sektorā. Tas daḷeji atšḳiras no iedzīvotāju redzējuma, ņemot vērā, ka saskaṇā ar to šāda veida draudi pastāv.

Liepājas pilsētas pašvaldības attīstība saskaņā ar Liepājas domes lēmumu Nr. $1^{27}$ ir nostiprināta divos pašvaldības attīstības plānošanas dokumentos Liepājas pilsētas ilgtspējīgas attīstības stratēgijiā līdz 2030. gadam (turpmāk Stratēóija 2030) un Liepājas pilsētas attīstības programmā 2015.-2020. gadam. Stratēǵijas 2030 virsmērķis ir "stiprināt Liepājas lomu un atpazīstamību starptautiskā mērogā, piesaistot pilsētai zinošus un radošus cilvēkus, investīcijas, tūristus"28. Šì stratēóija tiešā veidā neidentificē apdraudējumus sabiedrības drošībai. Bet tie tiek minēti pastarpināti stratēgijas attīstības virzienā "Liepājnieki un viṇu labklājỉba"29. Šîs prioritātes aprakstā ir apkopotas kultūras un izglīiības apdraudējumu novēršanas rīcíbas. Lìdzịgi kā Stratēgijā

25 Padzị̣inātā intervija ar Liepājas pilsētas pašvaldības darbinieku Rīgā, Liepājas pārstāvniecībā, 2020. gada 22. janvārī.

26 Turpat.

27 Liepājas pilsētas pašvaldība (2015). Domes lēmums Nr. 1. Pieejams: https://www.liepaja.lv/dokumenti/ ?page $=1 \&$ dokumenti_veidi $=$ strategijas

28 Liepājas pilsētas pašvaldība (2017). Liepāja 2030. Pieejams: https://faili.liepaja.lv/liepaja_strategija_ 2030.pdf

29 Turpat. 
2030, Liepājas pilsētas attīstības programmā 2015.-2020. gadam starp aprakstītajām darbības prioritātēm nav tiešā veidā minēta to izaicinājumu novēršana. Tomēr sabiedrības drošības problemātika ir apskatīta pastarpināti, uzskaitot darbības virzienus iespējamo apdraudējumu mazināšanai kultūras un izglīîibas jomā.

No labas pārvaldības perspektīvas raugoties, nav konstatējami trūkumi secības un savstarpējās pamatotības ievērošanā un pašvaldību attīstības plānošanas dokumentu izstrādē sabiedrības drošìbas sektora draudu mazināšanai. Tomēr pētījuma gaitā ir atklājies, ka iespējams konstatēt nepilnības sabiedrības drošības sektora draudu vispārējā/tiešā definēšanā un risku mazināšanas stratēǵiju izstrādē. Netiek identificēti draudi, kas ir saistīti ar grupu identitāti, religiju, izmaiņām kopienas lielumā, ${ }^{30}$ rasismu, nacionālismu un dažādu sabiedrības grupu pārstāvju psiholog̣isko spiedienu.

Izvērtējot normatīvo aktu izmaiṇu izstrādi labas pārvaldības kontekstā, secināms, ka gan dokumentu analīze, gan arī padzị̣inātās, daḷeji strukturētās intervijas ar pašvaldības pārstāvi parāda, ka šis process vērtējams pozitīvi. Izmaiṇas normatīvajos aktos nenotiek bieži, tiek ievērota konsekvence, t. i., rīcība tiek turpināta vai pārcelta no viena normatīvā akta uz otru normatīvo aktu.

Vēl viens nozīmīgs pašvaldības attīstības plānošanas dokuments ir Liepājas pilsētas pašvaldības Uzraudzības ziņojums. Apskatot 2018. gada ziṇojuma attīstības programmas prioritāti "Liepājnieki un viṇu labklājība", iespējams ieraudzìt, ka kultūras un izglìtības apdraudējumi novērsti " $74 \%-90 \%$ apmēră”31. Laika posmā no 2015. gada līdz 2017. gadam veiksmīgi realizētas vairākas prioritāras rīcības, kas saistītas ar sabiedrības drošības stiprināšanu tiešā vai pastarpinātā veidā. Ir vairota pieejamība pirmsskolas izglītības iestādēm, renovētas sporta bāzes un skolas pašvaldības teritorijā, pieaudzis pašvaldības finansējums kultūras aktivitātēm. ${ }^{32}$

Analizējot preventīvo rīcībpolitiku izstrādi sabiedrības drošības kontekstā, var secināt, ka pašvaldībā nav izstrādāta neviena preventīvā rīcíbpolitika, kas veicinātu sabiedrības informètību par to, kā rìkoties, sastopoties ar draudiem, kuri asociējami ar dažādām sabiedrības drošības dimensijām. Līdzịga situācija ir novērojama starpiestāžu koordinācijā. Pašvaldība nav ieviesusi saistošos noteikumus par sabiedrības drošỉbas draudu novēršanu. No tā secināms,

30 Ar izmaiṇām kopienas lielumā tiek saprastas ne vien demogrāfiskas problēmas, bet arī kopienas locekḷu migrācija un iespējamā integrācija.

31 Liepājas pilsētas pašvaldība (2018). Uzraudzības ziņojums par 2018. gadu. Pieejams: https://faili. liepaja.lv/Dokumenti/Dokumentu-biblioteka/Stratēgijas-nozaru-plāni/Uzraudzibas_zinojums_ par_2018_gadu.pdf

32 Turpat. 
ka, iespējams, viens no šāda rīcības trūkuma galvenajiem iemesliem ir fakts, ka pašvaldības pārstāvji nesaskata problēmu, un tāpēc neseko arī rīcība. Tomēr, zinot, ka sabiedrības drošības apdraudējumus iedzīvotāji ir identificējuši, pašvaldības pārstāvjiem nepieciešams pievērst lielāku uzmanību komunikācijai ar vietējās kopienas pārstāvjiem, skaidrojošajam darbam un atgriezeniskās saites saṇemšanai, tādējādi veicinot labāku pārvaldību, kas balstās uz savstarpējo izpratni un koordinētu rīcību. Ne vienmēr tas noteikti nozīmē, ka nepieciešams izdot normatìvos aktus. Ir iespējams rast arī citus risinājumus. Visnozīmīgākā gan ir pašvaldības reakcija uz iedzīvotāju subjektīvo draudu izjūtu un iespēja to mazināt.

\section{Rēzeknes pilsētas pašvaldība}

Rēzeknē iedzīvotāji, līdzīgi kā Liepājā, par nozīmīgiem uzskata sabiedrības drošības sektora draudus. Apskatot Rēzeknes iedzīvotāju etnisko sastāvu, secināms, ka vietējo kopienu veido divas lielas etniskās grupas - latvieši un krievi. Saskaņā ar statistikas datiem 2019. gadā Rēzeknes pilsētas pašvaldībā bija reg̣istrēti 27820 pastāvīgie iedzīvotāji, no kuriem 47\% ir latvieši, 42,5\% krievi, 2,2\% poḷi, 1,4\% baltkrievu, 1,2\% ukraiṇu un 5,6\% citu tautību pārstāvji ${ }^{33}$. No fokusa grupas intervijas rezultātiem, kā arī citiem pētījumiem un aptaujām secināms, ka tieši etniskais sastāvs, etnisko grupu savstarpējās attiecỉbas, kā arī vēsturiskais mantojums ir pamatfaktori, kas ietekmē subjektīvo drošības uztveri pilsētā, tāpēc draudi sabiedrības drošībai ir jāuzskata par nozīmīgiem.

Intervijas rezultāti ar pašvaldības pārstāvi norāda, ka ne tikai iedzīvotāji, bet arī vietējā pašpārvalde apdraudējumus sabiedrības drošỉbai atzīst par svarīgiem. Kā viens no šāda veida draudu determinējošiem faktoriem tika minēts Rēzeknes géogrāfiskais novietojums - tās atrašanās tuvu Krievijas Federācijas robežām. Tiesa, kā draudu avots tika minēta nevis Krievija, bet gan citu Latvijas iedzīvotāju attieksme pret pierobežā dzīvojošajiem.

Intervijas laikā Rēzeknes pilsētas vietējās pārvaldes pārstāvis norādīja, ka nozīmīgākie sabiedrības drošības draudi Rēzeknē ir dažādu etnisko grupu piederības sajūta - piederība Latvijai, reǵionam - Latgalei, kā arī atsevišķu grupu sociālās piederības izjūta. Attiecībā uz kopējo reǵiona piederību Latvijai respondents norādīja, ka pastāv liela atstumtības izjūta, ko izjūt ne tikai Rēzeknes, bet visas Latgales iedzīvotāji. Arī Latgales pārvaldes darbinieki uzskata, ka valstiskā līmenī pastāv dalījums starp Latgali un Latviju. Intervējamais

33 Rēzeknes pilsētas pašvaldība (2019). Rēzeknes pilsētas pašvaldības 2018. gada publiskais pārskats. Pieejams: https://rezekne.lv/wp-content/uploads/2019/06/rezeknes-pilsetas-publiskais-gada-parskats2018.pdf 
norādīja, ka Latvijas sabiedrībā ir daudz cilvēku, kas Latgali skata kā marginalizētu reǵionu ar valsts attīstībai nevēlamām tendencēm.

Rēzeknes pilsētas pašvaldības pārstāvis: Latvija ir normāla, bet Daugavpils un Rèzekne ir nenormāla - tur nedzìvo uzticamas personas, tur cilvēki ir vinu valsts ienaidnieki apriori. [..] Balstoties uz šādiem uzskatiem, notiek mēǵinājumi dalīt Latviju vairākās daḷās. Lai tà saškeltìiba būtu vēl lielāka Latvijā, tiek apgalvots, $k a$ Latgale ir tāda riska vieta, no kuras var sākties kaut kādi apvērsumi. ${ }^{34}$

Apskatot Rēzeknes pilsētas pašvaldības attiecỉbas ar Krievijas valsts un pašvaldību institūcijām, respondents intervijā norādīja, ka pašvaldība kā pārvaldes struktūra veido draudzīgas saiknes, tomēr pašvaldības darbības negūst sabiedrības atbalstu. Rezultātā, viņaprāt, sabiedrībā tiek vairoti mīti par to, ka dzīvot Krievijas tuvumā nozīmē "mīlēt Krieviju un Putinu".

Rēzeknes pašvaldības pārstāvis: Tikai daži cilvēki uzskata, ka tas [Krievijas tuvums un Krievijas realizētā ārpolitika] var apdraudēt viņu drošību. [..] Es domāju, ka šāda veida viedokḷus iespaido tas, ko mēs lasām presē un skatāmies TV, jo tiešā saskarsmē vai personīgas pieredzes [negatīvas pieredzes] nav cilvēkam šajā saistībā. Cilvēks tikai uztver ārējo informāciju, un tad veidojas tāds vai citäds viedoklis. ${ }^{35}$

Interesanti, ka politiskiem draudiem, kas, pēc aptaujātā Rēzeknes pašvaldības pārstāvja uzskatiem, rodas nacionālās valdības un Latgales reǵiona vietējo pašvaldību saspīlēto attiecību rezultātā, viņš saskata tālākas sekas, kas ietekmē citas dzīves sfēras, t. sk. sabiedrības drošību. Intervijas laikā viņš pauda uzskatu, ka nacionālās politikas un nacionāla līmeņa lēmumu pieņēmēju darbības rezultātā veidojas plaisa starp reǵiona iedzīvotājiem un valsti, citu reǵionu iedzīvotājiem un Latgalē dzīvojošajiem.

Rēzeknes pašvaldības pārstāvis: .. nesen tika publicēts pētījums par Daugavpili un Rèzekni. Tajā tika teikts, ka pašvaldība piekopj tādu draudzīgu politiku attiecìbā uz Krieviju, un tas tika traktēts kā nedraudzīga politika attiecībā uz Latviju [ja pašvaldība aktīvi sadarbojas ar Krievijas pierobežu pašvaldībām]. Tie visiem zināmie postulāti - ar kaiminiem visos laikos vajag labāk draudzēties nekā gatavoties karam. Tas būtu pareizais virziens. Bet pētījums bija pasūtìts no valsts puses - tas neveicina [kopīgas piederības sajūtas veidošanu]. Mums ir visādas attiecības. Mēs mēéginām nodibināt labas attiecības ar kaimiņiem, ar pašvaldībām, 
kas nav nekas pretlikumīgs. Ja mēs realizējam kopīgus projektus, izmantojot pārrobežu instrumentus, kas ir noteikts likumos. ${ }^{36}$

Apskatot iedzīvotāju noskaņojumus, pašvaldības pārstāvis norādīja uz Rēzeknes iedzīvotāju, viņaprāt, augsto piederības izjūtu vietējai kopienai, kā arī uz to, ka pašvaldība ir ieguldījusi ievērojamu darbu, lai veicinātu šādu lokālu lojalitāti un atbildīgumu.

Rēzeknes pašvaldības pārstāvis: Jā, sociālā piederība ir loti svarīga, un mums tiek veikti daži pētījumi par šo tēmu. Viss sākas no savas mājas. Es dzīvoju daudzdzīvoklı mājā, un mums ir piederības sajūta pie šìs kopienas kā iedzìvotājam. Tas, protams, ar dažădiem instrumentiem var veidoties - sapulces, kopigi lèmumi, kas tiek pieņemti attiecībā uz savu māju. Parādās soliņ̌s mājas pagalmāan, un tas jau ir moments, ar kuru mēs varam sākt vienas kopienas veidošanu. [..] Mums ir jādzīvo drošībā, un mēs katrs esam atbildīgs par to drošǐbu, nevis nozimēetāa atbildīgā persona. ${ }^{37}$

Intervējot Rēzeknes pašvaldības pārstāvi, uzzinām, ka, līdzīgi kā Liepājā, vietējā līmeņa amatpersonas uz draudiem, kas pastāv sabiedrības drošîbas sektorā, skatās daudz optimistiskāk nekā iedzīvotāji. Iespējams, ka šāds optimistisks skatījums ir viens no nozīmīgākajiem iemesliem, kāpēc pašvaldības attīstības plānošanas dokumentos nav atrodams draudu novērtējums un atbilstošu risinājumu meklējumi.

Pašvaldības attīstības plānošanas dokumentos - Rēzeknes pilsētas ilgtspējīgas attīstības stratēgijā līdz 2030. gadam, Rēzeknes pilsētas attīstības programmā 2014.-2020. gadam un Rēzeknes pilsētas pašvaldības jaunatnes politikas plānošanas dokumentā 2020.-230. gadam ${ }^{38}$ - sabiedrības drošības draudi tiek minēti pastarpināti. Tomēr, atšķirībā no Liepājas pilsētas pašvaldības attīstības plānošanas dokumentiem, Rēzeknes pašvaldība uzsver nepieciešamību stiprināt "latgaliešu kultūru, vērtības un tradīcijas, kas balstās valodā, ražošanā un izdevīgā geogrāfiskā novietojumā"39.

Raugoties no labas pārvaldes perspektīvas, visas trīs analizētās rīcíbpolitikas stratēǵijas ir savstarpēji pamatotas un iesaistītas pašvaldības attīstības plānošanas dokumentu izstrādē. Darbības, kas ir iekḷautas pašvaldības attīstības

36 Padziḷinātā, daḷēji strukturētā intervija ar Rēzeknes pilsētas pašvaldības pārstāvi Rēzeknē 2020. gada 21. janvārī.

37 Turpat.

38 Rēzeknes pilsētas pašvaldība (2020). Pilsētas plānošanas dokumenti. Pieejams: https://rezekne.lv/ pilsetas-attistibas-dokumenti/

39 Rēzeknes pilsētas dome (2014). Rēzeknes pilsētas ilgtspējīgas attīstības stratēǵija 2030. Pieejams: https://rezekne.lv/wp-content/uploads/2017/08/rezeknes-pilsetas-ilgtspejigas-attistibas-strategijalidz-2030-gadam.pdf 
plānošanas dokumentos, ir secīgas un pamatotas, ir ievērots pēctecības princips. Savukārt, vērtējot praktisko pienesumu, secināms, ka konstatējamas nepilnības sabiedrības drošības sektora draudu definēšanā un iekḷaušanā rīcībpolitikās. Nav ietverti virzienrādītāji sabiedrības drošības draudu mazināšanā, nav arī skaidrs, kā, īstenojot pasākumu kopumu, kas ir iekḷauts pašvaldības attīstības plānošanas dokumentos, ${ }^{40,}{ }^{41}$ tiks mazināta plaisa piederības veicināšanā starp mēs - Latvija $v s$ jūs - Latgale. Nav noteikti rīcības virzieni un rezultativitātes rādītāji.

Apskatot preventīvo rīcībpolitiku izstrādi, secināms, ka pašvaldībā nav izstrādāta neviena preventīvā rīcībpolitika, kuras mērḳis būtu informēt sabiedrību par rīcību, reagéjot uz sabiedrības drošības draudiem. Papildus, saskaņā ar publiski pieejamo informāciju, Rēzeknes pilsētas pašvaldībā nav izstrādāts atsevišḳs civilās aizsardzības plāns. Civilā aizsardzības plāna funkciju pašvaldībā pilda izstrādātais Rēzeknes pilsētas teritorijas plānojums 2018.-2030. gadam, ${ }^{42}$ kurā iekḷauta informācija par stratēgiski nozīmīgiem objektiem pašvaldībā, un vides pārskats, ${ }^{43}$ kas ir šis rīcībpolitikas neatṇemama sastāvdaḷa. Informācija par sabiedrības drošības apdraudējumu un rīcỉbas virzieniem to mazināšanai šajos dokumentos nav iekḷauta. Izvērtējot starpiestāžu koordināciju, secināms, ka tā tiek īstenota daliēji. ${ }^{44}$

40 Analizējot Rēzeknes pilsētas plānošanas dokumentus, pētījumā tika secināts, ka "Rēzeknes pilsētas ilgtspējīgas attīstības stratēǵijas 2030” (turpmāk arī - Stratēǵija 2030) vīzija ir cieši saistīta ar rēzekniešu kultūras un tradīciju stiprināšanu. Stratēgijā divi rīcības virzieni - "Sekmēt Rēzeknes kā Austrumlatvijas izglītības, pētniecības un sporta centra attīstību"; "Veidot Rēzekni kā cilvēkam un videi draudzīgu, drošu un mūsdienīgu pilsētu Eiropas Savienības Austrumu pierobežā” - pastarpināti definē sabiedrības drošības sektora draudus, kas ir saistīti ar izglītības kvalitātes celšanu, kultūras un etniskās daudzveidības saglabāšanu, stiprinot sabiedrības integrāciju. Attīstības programmas 2014.-2020. gadam viens no darbības virzieniem ir kvalitatīvas dzīves telpas nodrošināšana pilsētas iedzīvotājiem. Pastarpinātā veidā šis darbības virziens iezīmē potenciālos draudus sabiedrības drošībā. Saskaṇā ar SVID (SVID - stiprās puses, vājās puses, iespējas, draudi) analīzi, kas tika iekḷauta attīstības programmā, potenciālie draudi ir sasaistes trūkums starp dažādiem plānošanas līmeņiem un nepietiekams kultūras pasākumu apmeklētāju skaits (tāpēc mazināsies piederība Latvijas kultūrai). Jaunatnes politikas pamatnostādnes, atškirīibā no Stratēǵijas 2030 un attīstības programmas, iekḷauj rezultativitātes rādītājus. Viens no tās darbības virzieniem ir cieši saistīts ar jauniešu integrāciju un piederības sajūtas stiprināšanu Latvijai.

${ }^{41}$ Rēzeknes pilsētas dome (2014). Rēzeknes pilsētas ilgtspējīgas attīstības stratēǵija 2030. Pieejams: https://rezekne.lv/wp-content/uploads/2017/08/rezeknes-pilsetas-ilgtspejigas-attistibas-strategijalidz-2030-gadam.pdf; Rēzeknes pilsētas dome (2020). Rēzeknes pilsētas jaunatnes politikas attīstības programma 2020.-2023. gadam. Pieejams: https://rezekne.lv/wp-content/uploads/2020/05/1198_ jaunatnes-strategija-2020-2023.pdf

42 Metrium (2017). Rēzeknes pilsētas teritorijas plānojums 2018.-2030. gadam. Pieejams: https:// rezekne.lv/wp-content/uploads/2018/04/paskaidrojuma_raksts.pdf

43 Turpat.

44 Starpiestāžu koordinācijas daḷēja īstenošana tika konstatēta, analizējot jaunatnes politikas attīstības programmu, kurā bija skaidrs, definēts atbildīgo iestāžu loks. 


\section{Aizkraukles novada pašvaldība}

Aizkrauklē veiktās fokusa grupas intervijas rezultāti norādīja uz to, ka arī šajā pilsētā iedzīvotāji sabiedrības drošỉbas draudus uzskata par nozīmīgiem. Saskaṇā ar Centrālās statistikas pārvaldes datiem Aizkraukles novadā 2018. gadā bija reǵistrēti 8687 iedzīvotāji, no tiem - 68,3\% latvieši, 21,2\% krievi, 3,2\% baltkrievi, 2,3\% ukraini,i, 1,5\% poḷi un 3,6\% pārējie ${ }^{45}$. No etniskā izkārtojuma redzams, ka, lai arī kopumā vietējā kopiena raksturojama kā multietniska, pastāv vienas etniskās grupas dominance. Tomēr intervijas laikā pašvaldības pārstāvis norādīja, ka dominējošā loma lokālās identitātes veidošanā Aizkrauklē ir nevis etnisko īpatnību izjūtai, bet gan piederības izjūtai savai pilsētai. Tas gan neesot, viņaprāt, stipri izteikts, jo lielākā daḷa iedzīvotāju ir iebraucēji. ${ }^{46}$

Aizkraukles novada pašvaldības pārstāvis: Aizkrauklē nav izteikta kādas etniskās grupas dominēšana. Visi sadzìvo mierīgi un respektē viens otru. [..] Kā jau mazā pilsētā, visi visus pazīst. ${ }^{47}$

Intervijas laikā respondents arī norādīja uz Aizkraukles vēsturisko mantojumu ${ }^{48}$ un tā saglabāšanu iedzīvotāju vēsturiskajā atmiņā, kas, viņaprāt, ir viens no nozīmīgākajiem aspektiem sabiedrības drošības kontekstā. Respondents norādīja, ka šādas kolektīvās vēsturiskās atmiņas trūkums liecina par to, ka trūkst sajūtas, ka piederi pie vietējās kopienas.

Salīdzinājumā ar citām analizētajām pašvaldībām Aizkraukles novada pašvaldībā ir izstrādāti vairāki attīstības plānošanas dokumenti - Aizkraukles novada ilgtspējīgas attīstības stratēǵija 2014.-2025. gadam, Energettikas rīcības plāns, Aizkraukles novada Daugavas ūdenskrātuves ainavu koncepcija, Aizkraukles novada teritorijas plānojums 2014.-2026. gadam, Aizkraukles novada ilgtspējīgas attīstības programma 2014.-2020. gadam. ${ }^{49}$ Tomēr, analizējot kvalitatīvos dokumentus, tika secināts, ka tikai divos no tiem pastarpinātā veidā definēti rīcības virzieni sabiedrības drošǐbas sektora draudu mazināšanai. Atšķirībā no Rēzeknes un Liepājas attīstības dokumentiem, Aizkrauklē nevienā plānošanas dokumentā nav uzsvērta nepieciešamība stiprināt piederības sajūtu pašvaldỉbai.

45 Aizkraukles novada dome (2019). Publiskais pārskats par 2018. gadu. Pieejams: http://www. aizkraukle.lv/wp-content/uploads/2019/09/29.08.2019._217_Publiskais_pārskats.pdf

46 Padziļinātā intervija ar Aizkraukles novada pašvaldības darbinieku 2020. gadā.

47 Turpat.

48 Aizkraukle kā energètiķu pilsēta Padomju Savienības laikā.

49 Aizkraukles novada pašvaldība (2020). Attīstības plānošanas dokumenti. Pieejams: http://www. aizkraukle.lv/lv/pasvaldiba/attistibas-planosanas-dokumenti/attistibas-programma/ 
No labas pārvaldības principu ieviešanas perspektīvas raugoties, secināms, ka visas analizētās rīcibpolitikas ir savstarpēji pamatotas. To izstrādē ir vērojama pēctecỉba un konsekvence. Līdzīgi kā Rēzeknes un Liepājas pilsētu pašvaldību gadījumā, arī Aizkraukles novada pašvaldības plānošanas dokumentos konstatējamas nepilnības sabiedrības drošības sektora draudu definēšanā un to integrācijā rīcibpolitikas iniciatīvās. Atšķirīibā no Liepājas, kurā ir izstrādāts civilās aizsardzības plāns, un Rēzeknes, kurā civilās aizsardzības plāns ir daļa no vides pārskata, Aizkrauklē ir nodibināta Aizkraukles sadarbības teritorijas civilās aizsardzības komisija un 2018. gadā apstiprināts tās darbības nolikums. Nolikumā atrunāts komisijas sastāvs, funkcijas un apziṇošanas kārtība krīzes situācijās. Saskaņā ar to notiek apziṇošanas kārtības pārbaudes divas reizes gadā..$^{50}$ Tomēr, līdzīgi kā citās analizētajās pašvaldībās, Aizkraukles sadarbības teritorijas civilās aizsardzības komisija neaktualizē sabiedrības drošības draudus, kas arī nav ne pārsteidzoši, ne nepareizi. Civilās aizsardzības plānam ir citi mērķi un sabiedrības drošības apdraudējumi, kā arī to novēršanas mehānismi atrunājami citos dokumentos. Tiesa, aplūkojot citus publiski pieejamus normatīvos aktus, secināms, ka sabiedrības informētîba par to, kā rīkoties, sastopoties ar sabiedrības drošîbas apdraudējumiem, veicināta drīzāk netiek. Līdzīgi kā citās pašvaldībās, Aizkraukles novadā nav izstrādāta atbilstoša rīcībpolitika.

Apkopojot iegūtos datus par visām pašvaldībām, var secināt, ka pašvaldības un lēmumu pieņēmēji identificē sabiedrības drošības sektora draudus. Un, lai arī lēmumu pieņēmēju un pašvaldības iedzìvotāju skatījums uz sabiedrības drošību nav krasi atšķirīgs, tomēr atšķiras skatījums uz šo draudu intensitātes pakāpi. Pašvaldības plānošanas dokumentu analīze atklāj, ka reakcija uz sabiedrības drošibas apdraudējumiem ir visai ierobežota un nepilnīga.

Analizējot pašvaldību reakcijas uz sabiedrības drošỉbas sektora draudiem un izmantojot labas pārvaldības matricu, nākas secināt, ka, no vienas puses, visās trijās analizētajās pašvaldībās ir nodrošināta pārvaldības sistēmas stabilitāte un ilgtermiṇa plānošanas redzējums, pieṇemtās rīcībpolitikas ir pamatotas un secīgas. Tomēr šis redzējums par sabiedrības drošības sektoru ir drīzāk nepilnīgi atrunāts plānošanas dokumentos. Tajos draudi sabiedrības drošībai tiek identificēti pastarpināti.

Attiecībā uz caurskatāmību kā labas pārvaldības indikatoru secināms, ka Liepājas un Rēzeknes pilsētas un Aizkraukles novada pašvaldībās lēmumu 
pieṇemšanas process ir caurskatāms. To nosaka likuma "Par pašvaldībām" 26. pants, atrunājot, ka "domes sēdes ir atklātas, ja likumos nav noteikts citādi. [..] Domes lēmumi un domes sēžu protokoli ir publiski pieejami" ${ }^{2}$. Visi pieṇemtie domes lēmumi ir publiski pieejami visās pašvaldību mājaslapās. Tas veicina caurskatāmību un informācijas pieejamību. Turklāt visās analizētajās pašvaldībās tiek izmantoti alternatīvie sabiedrības informēšanas kanāli - pilsētas/novada avīzes, mājaslapas un sociālie tīkli.

Analizējot normatīvo aktu izmaiņu biežumu, secināms, ka nevienā analizējamā pašvaldībā nav novērojamas pašvaldības normatīvo aktu dinamiskas vai krasas, neprognozējamas izmaiņas. Tas vērtējams pozitīivi. Bet, izvērtējot ierēdṇu profesionalitāti, pētījuma gaitā tika ṇemti vērā starptautiski atzīta InCiSE indeksa (International Civil Service Effectiveness (InCiSE) Index, starptautisks ierēdṇu efektivitātes indekss) dati, kur Latvija gan centrālā pārvaldes līmenī, gan pašvaldību līmenī tiek atzinīgi novērtēta un ierindota 23 . vietā. ${ }^{53}$ Tas, no vienas puses, uzskatāms par pozitīvu rādītāju, tomēr, no otras, joprojām norāda uz nepieciešamību pēc izaugsmes.

Attiecībā uz sabiedrības informētỉbu par iespējamiem rīcības modeliem, sastopoties ar sabiedrības drošības draudiem, secināms, ka visās analizētajās pašvaldībās - Rēzeknē, Liepājā un Aizkraukles novadā - tika identificēta šì labas pārvaldes kritērija nepietiekama izpilde. Nevienā analizētajā pašvaldībā nav izstrādātas konkrētas vadlīnijas, kā var atpazìt un kā būtu jārīkojas, sastopoties ar sabiedrības drošîbas draudiem, kā arī nav viennozīmīgi vērtējama starpiestāžu koordinācijas spēja. Konkrēts rīcības plāns ar pasākumiem sabiedrības drošỉbas apdraudējumu mazināšanai daļēji tika īstenots tikai Rēzeknes pilsētas pašvaldībā. Citās pašvaldībās šādu rīcības plānu izstrāde netika konstatēta. Lai arī ne vienmēr jaunu rīcībpolitikas dokumentu izstrāde ir vienīgais cel̦š problēmas risināšanā un arī šajā gadījumā, iespējams, tas nav obligāts priekšnosacījums iedzīvotāju subjektīvās draudu uztveres mazināšanai, tomēr ir arī citi faktori, kas norāda uz pašvaldību nepietiekamo uzmanību šim draudu veidam. Intervijas ar pašvaldību pārstāvjiem apliecina, ka iemesls, kāpēc plānošanas dokumentos netiek minēti sabiedrības drošības draudi, drīzāk ir nepietiekama draudu aktualitātes izpratne, nevis tas, ka ir praktiski risinājumi to mazināšanai.

51 Latvijas Republikas Saeima (1994). Likums “Par pašvaldībām”. Pieṇemts 19.05.1994. Spēkā no 09.06.1994. Pieejams: https://likumi.lv/ta/id/57255-par-pasvaldibam

52 Turpat.

53 Blavatnik school of Government, Oxford University (2019). International Civil Service Effectiveness Index, p. 79. 
Otrs būtisks aspekts - sabiedrības drošỉbas izpratne neattiecas tikai uz etnisko sadalījumu un etniskās identitātes saglabāšanu. Tā var tikt attiecināta arī uz reliǵisko piederību un citiem sociālās identitātes aspektiem. Problēma ir tā, ka gan vietējo kopienu locekḷi, gan arī pašvaldību pārstāvji galveno uzmanību pievērš etniskai identitātei un tās iespējamai ietekmei uz piederības sajūtu valstij un meklē risinājumus, kā veicināt piederības sajūtu konkrētai vietai - pašvaldības teritorijai. Tomēr, pirmkārt, piederības veicināšana kādai konkrētai vietai vai lokālai kopienai ne vienmēr veicina piederības izjūtu valstij. Otrkārt, sabiedrībā visos līmeņos joprojām noklusēti un neizdiskutēti paliek jautājumi par citām identitātēm un cita veida sociālo grupu drošîbu un iekḷaušanos sabiedrībā.

\section{Secinājumi}

Pētijuma rezultāti sabiedrības drošības sektorā atklāj, ka Latvijas iedzīvotāji identificē draudus to unikālajai patîbai un atzīst tos kā būtiskus izaicinājumus savai drošībai. Visbiežāk respondentus satrauc imigrācija un, viṇuprāt, līdz ar to nenovēršama nacionālās identitātes zaudēšana. İpaši Latvijas iedzīvotājus biedē potenciālie migrācijas viḷni no musulmaṇu valstīm. Musulmaņi tiek uztverti kā nozīmīgs svešais. Rezultātā secināms, ka Latvijas sabiedrībai kopumā - neatkarīgi no iedzīvotāju izvietojuma pilsētās vai lauku apvidos, to izglītîbas pakāpes vai sociālā statusa - ir raksturīga neuzticēšanās un izteikti aizspriedumi pret islāmticīgajiem vai jebkuriem citiem svešu kultūru pārstāvjiem, vai pret jebko citu, kas būtiski atškiras no tradicionālajiem uzskatiem par indivīdam atbilstošu uzvedību, gimenes modeli vai sabiedrības funkcionēšanu.

Analizējot negatīvās attieksmes pret atšķirīgo Latvijas sabiedrībā, t. sk., piemēram, pret seksuālajām minoritātēm, secināms, ka tā ir orientēta uz tradicionālām vērtībām, drīzāk slēgta sabiedrība, kas atšḳirīgo uztver kā nopietnu apdraudējumu nācijas izdzīvošanai. Rezultātā minoritāšu grupas tiek marginalizētas, izjūt nozīmīgu psiholog̣isku spiedienu un to jebkāda veida pārstāvniecibai dominējošā sabiedrības daḷa liek ievērojamus šķērš̌lus.

Klaji negatīvā attieksme pret atšķirīgo vieno citkārt savstarpēji nošķirtās latviešu un krievvalodīgo kopienas. Šo kopienu pārstāvji atzīst savstarpējo nošķīrumu un lūkojas ar aizdomām uz pretējās puses pārstāvjiem, tomēr šķelšanos pēc lingvistiskās piederības tie reti uzskata par nozīmīgākajiem draudiem savai drošībai. Drīzāk tas tiek skatīts kā kaut kas sekundārs vai potenciāli bīstams nākotnē nelabvēlīgu valsts attīstības scenāriju vai konfliktu gadījumā. 
Izceḷams ir iedzīvotāju negatīvais patriotisma vērtējums. Intervijas atklāj, ka daḷa sabiedrības patriotisma trūkumu saredz kā nopietnu izaicinājumu valstij. Tomēr, izzinot tuvāk iedzīvotāju uzskatus, biežāk ar to tika asociēts uzticēšanās trūkums Latvijas valdībai un valsts pārvaldes institūcijām, atsvešināšanās no politiskās varas. Nedaudz atšķirīga situācija ir dạ̦ā krievvalodīgo kopienu, kas politisko režīmu saskata kā tai naidīgu un subjektīvi uztver psiholoğisku spiedienu.

Runājot par atsvešināšanos no politiskās varas, īpaši atzīmējama arī Latvijas regionu subjektīivi uztvertā plaisa starp Rīgu un reǵiona iedzīvotājiem. Tiek uzsvērts, ka pastāv divas atšķirīgas sabiedriski politiskās dienaskārtības. Viena Rīgā, otra - reǵionos. Rezultātā reǵionu iedzīvotāji izjūt ne tikai psihologisku spiedienu un subjektīvi vērtē to kā diskrimināciju, bet arī nopietnas bažas par lokālo kopienu izdzīvošanas iespējām. Šāda veida bailes būtiski negatīvi ietekmē Latvijas sabiedrības vienotību un solidaritāti.

Kā nozīmīgākos iekšêjos apdraudējuma avotus sabiedrības drošības sektorā Latvijas iedzīvotāji nosaukuši citu valstu iedzīvotājus (iebraucējus) vai to grupas, kā arī valsts pārvaldes iestādes, bet ne pašvaldības. Pašvaldības arī šajā jomā bauda iedzīvotāju lielāku uzticēšanos. Pa nozīmīgāko ārējo draudu avotu sabiedrības drošībai iedzīvotāji uzskata Krievijas Federāciju, uzsverot tās iespējas negatīvi ietekmēt sabiedrības stabilitāti.

Padzilịnātās intervijas ar pašvaldību pārstāvjiem atklāj, ka tie galvenokārt atpazīst sabiedrības drošības draudus, tomēr saredz minimālu pašvaldības lomu vai to nesaredz vispār drošības stiprināšanā šajā jomā, jo uzskata, ka tas ir nacionālā pārvaldes līmeņa institūciju pienākums. Tiesa, pašvaldību ikdienas prakses pierāda, ka bieži vien tiek sniegts zināms ieguldījums vietējo kopienu stiprināšanā, etnisko minoritāšu patības saglabāšanā un citās aktivitātēs sabiedrības drošỉbas pilnveidē. Tas liecina par to, ka trūkst vienotas izpratnes par sabiedrības drošỉbas daudzdimensionālo dabu un savstarpējām cēloṇsakarībām starp kultūras īpatnību saglabāšanu un nacionālās izturētspējas stiprināšanu.

Pētỉjuma rezultāti arī norāda uz to, ka pastāv plaisa starp nacionālā un vietējā līmeņa pārvaldes institūcijām. Šis un arī citi faktori nosaka to, ka vietējā līmeņa pārvaldes institūcijas bieži vien savu neizdarību, pieņemot lēmumus sabiedrības drošības stiprināšanai, pamato ar to, ka tas ir nevis pašvaldību, bet gan nacionālā līmeṇa pārvaldes institūciju pienākums. Tomēr tā gluži nav. Bieži vien sabiedrības drošǐbas draudu mazināšana ir tieši saistìta nevis ar nacionālā līmeņa institūciju kompetencēm, bet gan tieši ar pašvaldību kompetencēm. Jāatzīst, ka nav novērojama arī interese par abu - nacionālā un lokālā līmeņu sadarbību iedzīvotāju draudu uztveres mazināšanai. Tāpēc iedzīvotāji 
netiek sadzirdēti un sabiedrības drošỉbas sektorā netiek sperti soḷi identificēto apdraudējumu mazināšanā. Ieteicams veicināt gan ciešāku mijiedarbību ar iedzīvotājiem, lai apzinātu tiem aktuālos apdraudējumus un atbilstoši reageètu, gan arī lokālā un nacionālā mēroga institūciju sadarbību reaǵěšanas mehānismu izstrādē.

Vēl viens nozīmīgs aspekts, kam nepieciešams pievērst uzmanību, ir patriotisma jautājums. Lai arī nacionālā un vietējā mērogā pārvaldes institūcijas veic ievērojamu darbu patriotisma izjūtas stiprināšanā, tomēr iedzīvotāju apdraudējuma subjektīvo uztveri, iespējams, varētu mazināt vēl papildu informatīvie pasākumi un pasākumi pilsoniskās iesaistes veicināšanai pašvaldībās. Pilsoniskā iesaiste paredz ne tikai sabiedrības informēšanu par dažādām pilsoniskās iesaistes formām pašvaldībā, bet arī NVO un interešu grupu atbalstu. To darbība ir orientēta uz pilsonisko audzināšanu. Ir svarīgi, lai pilsoniskā iesaiste veicinātu visu grupu iekḷaušanu, nevis kādas grupas izslēgšanu vai identitātes apdraudēšanu. 


\title{
Personiskā drošība
}

\author{
ALEKSANDRA KJAKSTE, RUTA CEPLE
}

Subjektīvās drošỉbas uztveres analīzē īpaša nozīme ir personiskajai drošībai, jo tā vistiešāk atspoguḷo cilvēka primārās vajadzības, intereses un izjūtas un tajā atspoguḷojas citi drošỉbas sektori - militārais, politiskais un ekonomiskais. Šìs nodaḷas mērḳis ir identificēt personiskās drošỉbas draudus, kas Latvijas iedzīvotājiem ir nozīmīgi, un noteikt iespējamo korelāciju, kas pastāv starp uztvertajiem draudiem un atbilstošām vietējā līmeṇa rīcībpolitikām kā atbildes reakciju uz tiem. Pētijuma gaitā tika identificēti četri intensitātes ziṇā visspilgtākie personiskās drošības apdraudējumi Latvijas iedzīvotājiem. Tie ir: indivīdu fiziskā drošība, izglìtîbas sistēmas pakalpojumu pieejamība, veselïbas aprūpes pakalpojumu pieejamība un sociālā aizsardzỉba. Identificējot galvenos apdraudējumus personiskās drošỉbas jomā, gan iedzīvotāju, gan pašvaldību darbinieku skatījums uz subjektīviem apdraudējumiem sakrìt. Atšķirības tika novērotas pašvaldỉbas rīcības novērtēšanā - vērtējot pašvaldības darbību, iedzīvotāji personiskās drošības apdraudējumu vērtēja kritiskāk nekā pašvaldību darbinieki.

Atslēgvārdi: personiskā drošỉba, fiziskā drošǐba, izglitīibas pakalpojumu pieejamība, veselības aprūpe, sociālā aizsardzība.

In analysis of subjective security, particular attention is paid to personal security because it is intertwined with such important security sectors as military, political and economic security. This study identifies the personal security threats that are considered the most relevant. Subsequently, the possible correlation between the perception of threat and the respective responses and action plans from the local authorities are identified and analysed. These four most intense and important threats to personal security for Latvian people were identified in the study: 1) an individual's physical security, 2) the availability and accessibility of education, 3) the availability of medical care services and 4) social security. With opinions from both sides, the people who were interviewed in the focus groups and the local administration officials of 
different municipalities identified the same crucial threats to the personal security of people in Latvia. The only difference of opinion was identified when people and officials were asked to assess and evaluate the results and outcome of actions and measures taken by local municipalities towards the protection of people against threats to personal security. The people were more critical than administrative officials of the respective local authorities.

Keywords: personal security, physical security, access to education system, health care, social protection.

\section{levads}

Drošības subjektīvās uztveres analīzē īpaša nozīme ir personiskajai drošìbai, jo tā vistiešāk atspoguḷo cilvēka primārās vajadzības, intereses un izjūtas. Latvijas gadījumā tā ir jāpēta ciešà sasaistē ar militāro, politisko un ekonomisko drošību, jo iedzīvotāji ir vienlīdz pakḷauti potenciālajiem riskiem no ārpasaules un iekšpolitiskās situācijas. Līdz šim nav ticis veikts atsevišşs pētījums par indivīdu personiskās drošības draudiem, kam pievēršas šìs nodaļas autores. Nodaļas mērḳis ir identificēt personiskās drošības draudus, kas Latvijas iedzīvotājiem ir nozīmīgi, un noteikt iespējamo korelāciju, kas pastāv starp subjektīvi uztvertajiem draudiem un vietējā līmeņa rīcībpolitikām kā atbildes reakcija uz cilvēku bailēm un bažām.

Nodaḷas struktūra paredz personiskās drošības definējumu, atziṇu apkopojumu par līdz šim veikto nozīmīgāko pētījumu par personiskās drošības sektoru Latvijā. Pētījuma gaitā autores pētījuma vajadzībām operacionalizēja personiskos draudus un apkopoja pētỉjuma rezultātus un secinājumus. Pētỉjuma rezultātā personiskās drošības draudi Latvijas iedzīvotājiem tika sarindoti hierarhiskā kārtībā, ṇemot vērā identificēto draudu intensitāti iedzīvotāju vidū.

\section{Kas paveikts personiskās drošības izpētē?}

Latvijā ir veikti vairāki nozīmīgi pètījumi, kuri sniedz ieguldījumu personiskās drošības jēdziena izpratnē. Kā viens no pirmajiem minams Māras Sīmanes redakcijā iznākušais pārskats "Latvija. Pārskats par tautas attīstību 2002/2003. Cilvēkdrošība”. Šî pārskata mērḳis "ir rosināt uz pasākumiem, kas mazinātu augsto nedrošības sajūtu, ar kādu dienā dzīvo liela daḷa Latvijas iedzīvotāju, un paaugstinātu visas sabiedrības kopējo drošumspēju. [..] Pārskata ietvaros tika sniegti galvenie Latvijas iedzīvotāju bažu iemesli 2002.-2003. gadā, 
kas ir pakārtoti septiniem cilvēkdrošības aspektiem. Personiskās drošības jomā tika identificētas sekojošas iedzīvotāju bažas - gūt ievainojumu, iet bojā satiksmes negadījumā un piedzīvot vardarbību uz ielas"'. Apkopojot minētos draudus, var secināt, ka viens no galvenajiem apdraudējumiem personiskās drošības jomā ir fiziskā drošîba. Fiziskā drošỉba ir cieši saistīta ar bailēm par savu fizisko veselïbu.

Savukārt 2012. gadā Žanetas Ozoliņas redakcijā tika publicēta monogrāfija "Cilvēkdrošība Latvijā un pasaulē: no idejas līdz praksei", kuras mērķis bija "izstrādāt cilvēkdrošības un drošībspējas teorētisko konceptu, kas lietojams dažāda attīstības līmeņa valstīs, uz kura pamata radīt zināšanu kopumu par risinājumiem individuālā un nacionālā līmenī risku novēršanai un nedrošîbas mazināšanai"'. Personiskās drošības jautājumi šajā pētijumā bija aktuāli trim piektdaļām respondentu: "salīdzinošā perspektīvā ir augusi cilvēku drošỉbas sajūta policijas un sabiedrības attiecībās, ir saglabājušãs bailes no iespējām ciest nelaimes gadījumā." ${ }^{3}$ Atšķirībā no 2002.-2003. gada pētījuma par cilvēkdrošību, šo personīgo bailı/draudu pamatā tika definēts vēl viens apdraudējums, kas ir saistìts ar indivīdu ekonomisko labklājību.

Līdzīgi kā 2012. gadā publicētā pētījumā par cilvēkdrošību, 2014. gadā publicētajā darbā "Praktiskās vadlīnijas cilvēkdrošîbas koncepcijas ieviešanai kopienu līmenī, tajā skaitā nevalstiskajās organizācijās”’4 personīgās drošības jomas pētišanai tika iezīmētas šādas bažas - "cietîšu nelaimes gadījumā; cietǐšu no autovadītāju agresīvās braukšanas; mani var apzagt, cietī̌u no fiziskās

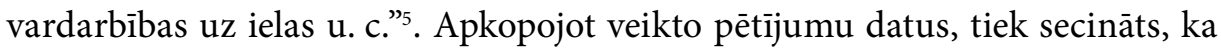
personiskās drošības sektora galvenie apdraudējumi Latvijas iedzīvotājiem ir saistīti ar fizisko drošību un ekonomisko labklājību. Tomēr no teorētiskās perspektīvas indivīdu personiskā drošỉba nav tikai fiziskā vai ekonomiskā drošỉba. Plašāku skatījums uz personiskās dažādiem drošības aspektiem Latvijas kontekstā sniedz sabiedriskās domas aptaujas.

Analizējot sabiedriskās domas aptaujas, kas tika veiktas Latvijā no 2016. līdz 2018. gadam, tika secināts, ka personiskās drošības draudu sektorā visvairāk cilvēkus satrauc gimenes finansiālā labklājība / sociālā aizsardzība (bailes zaudēt darbu un līdz ar to iztikas līdzekḷ̂us un iespēju uzturēt gimeni),

Sīmane, M. (red.) (2003). Latvija. Pārskats par tautas attīstību 2002/2003. Cilvēkdrošǐba. Rīga: ANO, 154. lpp.

2 Ozoliņa, Ž. (red.) (2012). Cilvēkdrošǐba Latvijā un pasaulē: no idejas līdz praksei. Rīga: Zinātne, 8. lpp.

3 Turpat, 70. lpp.

4 Ozoliṇa, Ž., Reinholde, I., Rudzīte, L. (2014). Praktiskās vadlīnijas cilvēkdrošïbas koncepcijas ieviešanai kopienu lìmenī, tajā skaitā nevalstiskajās organizācijās. Pieejams: https://www.sif.gov.lv/nodevumi/nodevumi/5985/Nodevums3_Vadlinijas.pdf

5 Turpat, 38. lpp. 
izglītỉba, veselība, indivīdu fiziskā drošỉba un vardarbība gimenē. Piemēram, 2018. gada septembrī publicētajā Latvijas Barometra aptaujā ("Latvijas iedzīvotāju noskaņojuma vērtējums"), atbildot uz jautājumu "Kā Jūs novērtētu savu / savas ğimenes pašreizējo finansiālo stāvokli? Vai, Jūsuprāt, tas ir ...", 58,54\% aptaujāto novērtē to kā viduvēju, 23,24\% - kā drīzāk sliktu, 5,5\% - kā ḷoti sliktu un tikai 11,13\% - kā drīzāk labu. ${ }^{6}$ Šos datus var papildināt ar Baltic International Bank veikto aptauju, kurā respondentiem vajadzēja atbildēt uz jautājumu "Kādas, Jūsuprāt, Latvijā ir iespējas atrast darbu?". "1\% aptaujāto uzskata, ka Latvijā ir ḷoti labas iespējas atrast labu darbu; 8\% - ka drīzāk labas; "viduvējas" - 30\%; $35 \%$ - drīzāk sliktas; $20 \%$ - l̦oti sliktas; 6\% - grūti pateikt."”

Kā otro apdraudējumu personiskajai drošībai, pēc aptauju datiem, var nosaukt bažas par izglïtîbas un veselības sistēmas pakalpojumu kvalitāti un pieejamību. " $28 \%$ no respondentiem ir atzīmējuši, ka [Latvijā] ir vērojama izglīiības kvalitātes pasliktināšanās.” Tas rada negatīvu efektu uz indivīdu personīgo attīstîbu nākotnē. Kas attiecas uz bažām veselības jomā, tad trīs vadošās pozīcijas ien̦em bažas par medikamentu un medicinas pakalpojumu sadārdzinājumu un nepietiekamo finansējumu veselības aprūpes sistēmai - to aptaujās atzīmē $62-67 \%$ respondentu. ${ }^{9}$

Fiziskās drošības un vardarbības jomā indivīdiem joprojām saglabājas augsts draudu/bažu līmenis. Saskaṇā ar 2017. gadā veikto SKDS aptauju " $28 \%$ no respondentiem apgalvo, ka viṇu dzīvesvietas tuvumā ir vietas, kur viņiem vieniem naktī bail atrasties, $12 \%$ no respondentiem ir grūti pateikt un $60 \%$ no respondentiem atzīmē, ka šādu vietu viṇu dzīvesvietu tuvumā nav"10. Savukārt situācija ar indivīdu bažām par vardarbību ir vēl dramatiskāka, par to liecina 2016. gadā publicētie Eirobarometra dati. "11\% respondentu uzskata, ka Latvijā vardarbỉba gimenē pret sievietēm ir l̦oti izplatīta, 47\% uzskata, ka ir diezgan izplatīta, 29\% domā, ka ne pārāk izplatīta, un tikai 2\% domā, ka tā nav vispār izplatīta."

Apkopojot iegūto informāciju, var secināt, ka indivīdu personiskā drošỉba nevar tikt skatīta atrauti no vispārējās drošības uztveres. Teorētiski - indivīdu

6 SKDS (2018). Latvijas Barometra aptauja. Latvijas iedzīvotāju nosakñojuma novērtējums. Pieejams: https://www.skds.lv/docs/1414/2016-2017/Latvijas_barometrs_120__092018_.pdf

7 Baltic International Bank (2018). Mājdzīvnieki un ekologija, Nr. 116. Pieejams: https://www.bib.eu/ uploads/2017/02/Baltic-International-Bank-Latvijas-barometrs-majdzivnieki-ekologija-10.2018.pdf

8 SKDS (2017). Latvijas Barometra aptauja. Latvijas iedzīvotāju noskaņojuma novērtējums (jūnijs). Pieejams: https://www.skds.lv/jaunumi?gads=2019\&pp=

9 Baltic International Bank (2017). Veselība. Pieejams: https://www.bib.eu/uploads/2017/02/Baltic-International-Bank-Latvijas-barometrs-veseliba-08.2017.pdf

10 SKDS (2017). Latvijas Barometra aptauja. Latvijas iedzīvotāju noskaņojuma novērtējums (jūlijs). Pieejams: https://www.skds.lv/jaunumi?gads=2019\&pp=

11 European Comission (2016). Gender-based Violence, p. 102. 
personiskā drošỉba ir daļa no cilvēkdrošības koncepta. Savukārt praktiski tā iezīmē galvenās indivīdu bažas un draudus. Identificētie draudi, ņemot vērā to dažādo intensitāti, ir nozīmīgi ne tikai sabiedrībai, bet arī valstij kopumā. Apzinot personiskās drošǐbas sektora izplatītākās bažas, ir iespējams laicīgi tās novērst un mudināt lēmumu pieṇēmējus stiprināt sabiedrības vispārējo drošības uztveri.

\section{Personiskās drošības jēdziens}

Personiskā drošība literatūrā tiek apskatīta no dažādiem skatpunktiem. Pastāv vairāki savstarpēji saistīti jēdzieni, kuri atspoguḷo personiskās drošības būtību. Barijs Buzans jau pagājušā gadsimta 80. gadu sākumā ievieš indivīda drošības jēdzienu, kurš raksturo cilvēka attiecības ar valsti. Saskaņā ar Buzanu šāda drošības izpratne ir saistīta ar valsts spēju radìt apdraudējumu citiem un novērst ienaidnieku iebrukumu, balstoties uz militāro konfrontāciju un materiālo labklājību. ${ }^{12}$ Otrs ir cilvēkdrošības jēdziens, kura pētniecībā nozīmīgu ieguldījumu sniedza ANO 1994. gadā publicētais "Pārskats par tautas attīstību" (Human Development Report). No teorētiskās perspektīvas "cilvēkdrošībai tiek nošķirtas divas, savstarpēji saistītas dimensijas - drošība (fiziskā) (security) un drošības sajūta (sense of security)"'13. Lìdz ar to var secināt, ka personiskā drošība nav tikai indivīdu fiziskā drošìba, bet arī to sajūtas vai stāvoklis, kurā indivīdi jūtas droši.

Šaurākā izpratnē personiskā drošība raksturo indivīda fizisko drošību drošỉbu uz ielām, gimenē, grupā u. c. Tomēr nav pamatoti personisko drošỉbu reducēt līdz fiziskajai, ignorējot cilvēku izjūtas attiecỉbā uz viņiem nepieciešamajiem izdzīvošanas un dzìves kvalitātes aspektiem. Tādē šajā pētỉjumā ir izvēèta paplašināta personiskās drošības izpratne, kurā tiek iekḷauti cilvēkdrošìbas konceptam raksturīgie parametri - indivīdu fiziskā drošîba (uz ielām, mājās), indivīdu sociālā aizsardzība (vai indivīdi jūtas droši par valsts/pašvaldības sniegto atbalstu, nonākot ekonomiskās grūtībās - zaudējot darbu u.c.), veselības aprūpes pakalpojumu pieejamība un kvalitāte, kā arī izglìtības sistēmas pakalpojumu pieejamība un kvalitāte. Minētās parametru grupas, pēc autoru domām, palīdz izprast Latvijā dzīvojošo indivīdu subjektīvo drošības uztveri caur personisko draudu prizmu.

12 Buzan, B., Hansen, L. (2009). The Evolution of International Security Studies. Cambridge: Cambridge University Press, pp. 383, 402.

13 Sīmane, M. (red.) (2003). Latvija. Pārskats par tautas attīstību 2002/2003. Cilvēkdrošîba. Rīga: ANO, 20. lpp. 
Raksta mērḳis ir identificēt personiskās drošības draudus, kas Latvijas iedzīvotājiem ir nozīmīgi, un noteikt iespējamo korelāciju, kas pastāv starp uztvertajiem draudiem un atbilstošām vietējā līmeņa rīcībpolitikām kā atbildes reakcija uz tiem. Nodạ̦ā personiskās drošîbas sektora draudi tiks strukturēti hierarhiskā kārtībā, pamatojoties uz fokusa grupu interviju laikā identificēto draudu biežumu. Visbiežāk minētie draudi tika identificēti kā visintensīvākie draudi, savukārt visretāk minētie - kā mazāk intensīvi/svarīgi iedzīvotājiem.

Lai sniegtu skatỉjumu, kā pašvaldības reagèe/nereagèe uz iedzīvotāju bažām/draudiem, tika veikta pašvaldỉbu attīstības plānošanas dokumentu kvalitatīvā analīze, balstoties uz pārvaldības indikatoru matricu.

Pētijuma pirmajā dạ̦ā Latvijas plānošanas reǵionos tika rỉkotas fokusa grupu intervijas, kurās iedzīvotājiem tika lūgts nosaukt galvenās savas subjektīvās bažas/draudus par personisko drošību. Apkopojot iegūtos rezultātus, personiskās drošības draudi tika sarindoti hierarhiskā kārtībā, ņemot vērā draudu intensitāti. Otrajā pètijuma dạ̦ā tika veiktas intervijas ar pašvaldību vietēja līmeņa lēmumu pieṇēmējiem, lai noskaidrotu, vai viṇu viedoklis par personiskās drošības sektora draudu identificeešanu sakrīt ar sabiedrības viedokli par galvenajiem apdraudējumiem personiskās drošības sektorā. Trešajā pētījuma etapā pašvaldībās, kurās personiskās drošîbas apdraudējumi tika identificēti kā intensīvi apdraudējumi, tika veikta pašvaldību plānošanas dokumentu padziḷinātā analīze, balstoties uz labas pārvaldības indikatoru matricu, kas ietver astoṇus indikatorus - pārvaldības sistēmas stabilitāti (pēctecību), plānošanas ilgtermiņa redzējumu, reformu ieviešanas efektivitāti, ${ }^{14}$ lēmumu pieņemšanas procesa caurskatāmību, ${ }^{15}$ normatīvo aktu izmaiņas biežumu, ierēdṇu profesionalitāti, ${ }^{16}$ preventīvās rīcībpolitikas veidošanu un starpiestāžu koordināciju (skatīt pielikumu "Latvijas iedzīvotāju identificētie nozīmīgākie draudi (hierarhiskais izkārtojums)").

Reformu ieviešanas efektivitāte šajā pētijjumā tiek analizēta no lēmumu pieņēmēju skatpunkta.

15 Caurskatāmības indikators kā labas pārvaldības rādìtājs pêtijuma gaitā tika attiecināts uz visām analizētajām pašvaldībām. Latvijas gadījumā lēmumu pieņemšanas procesa caurskatāmība tiek nostiprināta ar likuma "Par pašvaldībām" 26. pantu, kas noteic, ka domes sēdes ir atklātas, tās lēmumi un domes sēžu protokoli ir publiski pieejami. Otrkārt, visas analizētās pašvaldības, izstrādājot attīstības plānošanas dokumentus, piesaista sabiedrību. Treškārt, visās analizētajās pašvaldībās tiek izmantoti alternatīvie sabiedrības informēšanas kanāli (par pieṇemtajiem lēmumiem) gan pilsētas/novada lokālās avīzes, gan mājaslapas, gan sociālie tīkli.

16 Ierēdṇu profesionalitātes indikators kā labas pārvaldības indikators pētỉjuma gaitā tiek attiecināts uz visām pašvaldībām. Par pamatu indikatora attiecināšanai tika ņemti vērā starptautiski atzìta InCiSE indeksa (starptautisks ierēdņu efektivitätes indekss) dati, kur Latvija gan centrālā pārvaldes līmenī, gan pašvaldību līmenī tiek atzinīgi novērtēta un ierindota 23. vietā. Pieejams: Blavatnik school of Government, Oxford University (2019). International Civil Service Effectiveness Index, p. 79. 


\section{Latvijas iedzīvotāji par personisko drošību}

Veiktās fokusa grupu intervijas demonstrē, ka Latvijas iedzīvotāji draudus personiskajai drošībai uztver kā l̦oti svarīgus un piešķir tiem l̦oti lielu nozīmi savā kopējā drošỉbas redzējumā. Desmit no 13 pašvaldībām (Liepājā, Talsos, Daugavpilī, Rēzeknē, Jaunjelgavā, Valmierā, L,audonā, Gulbenē, Aizkrauklē un Madonā), kurās tika veiktas fokusa grupu intervijas, iedzīvotāji personiskās drošības draudus ierindoja starp trim nozīmīgākajiem draudu veidiem savā subjektīvajā drošības uztverē. Apkopojot rezultātus, pašvaldībās, kurās personiskās drošỉbas draudi tika identificēti kā nozīmīgi, minētie apdraudējumi tika sarindoti hierarhiskā kārtībā, ņemot vērā to intensitāti. Intensitātes ziṇā augstākais ir indivīdu sociālās aizsardzības apdraudējums, tad seko veselības aprūpes sistēmas pakalpojumu pieejamības un kvalitātes apdraudējums un izglītības sistēmas pakalpojumu pieejamības un kvalitātes apdraudējums. Savukārt draudu intensitātes ziṇā hierarhiski zemākais personiskās drošības sektorā ir indivīdu fiziskās drošības apdraudējums.

\section{Indivīdu fiziskā drošība}

Viens no jautājumiem, kas tika uzdots visās fokusa grupās, ir "Ko Jūs saprotat ar jēdzienu "drošība"?”. Lielākā daḷa respondentu, kas piedalìjās fokusa grupu diskusijās, ar jēdzienu "drošỉba" saprot savu un savas gimenes fizisko drošību.

Strādājoša sieviete darbspējas vecumā, Talsi: Ikdienā Talsi ir drošākāa (fiziski) un latviskākā pilsēta.

Pensionārs, Rēzekne: Fiziski pašvaldībā jūtas droši. Drošỉbu mazina tas, ka nav pašvaldības policijas.

Strādājošs vīrietis darbspējas vecumā, Daugavpils: Drošība ir plašāks jēdziens. [..] Daugavpils ir tā pilsēta, kur viss caurmēeā ir labi [t. i., fiziski respondents jūtas droši], bet vienmēr var gribēties labāk.

Apkopojot iegūtās atziņas par indivīdu fizisko drošību kā par vienu no personiskās drošības sektora apdraudējumiem, var secināt, ka Latvijas iedzīvotājiem viṇu fiziskā drošība ir svarīga. Izvērtējot šì indikatora intensitāti, jāatzīst, ka fiziskā drošība netiek uztverta kā drauds un nerada bažas indivīdiem, bet - tieši pretēji - lielākā daḷa respondentu atzinīgi vērtē fizisko drošību Latvijā. Atzin̄igi tika novērtēts pašvaldību policiju darbs pašvaldībās. ${ }^{17}$ Nacionālo bruṇoto spēku klātbūtne Liepājā šis pašvaldības iedzìvotājiem rada papildu

17 Izṇēmuma gadījums bija Rēzeknes pašvaldībā, kur nav pašvaldības policijas. Vairāki fokusa grupu dalībnieki atzīmēja, ka (fiziski) nejūtas droši vakaros uz ielām, jo nav pašvaldỉbas policijas. 
fiziskās drošības garantu, savukārt Vidzemes un Latgales pašvaldību iedzīvotājiem rada papildu militāros apdraudējumus, bet to intensitāte ir samērā zema, jo šie draudi fokusa grupu interviju laikā netika identificēti Kurzemē un Zemgalē. Respondentu atbildēs par fizisko drošību visā Latvijā vērojams, ka vidèjā un vecākā gadagājuma cilvēki vērtē to pēc savas pieredzes, salīdzinot ar to, kā bijis 90. gados un jaunās tūkstošgades sākumā. Kopumā visās pašvaldībās, izņemot Ļaudonu un Rēzekni, respondenti atzina, ka jūtas pasargāti un var palauties uz valsts un pašvaldības klātbūtni fiziska apdraudējuma gadỉjumā.

Strādājošs vīrietis darbspējas vecumā, L̦audona: Ja notiek dzērāju kautiņ̌̌ vai kāds piedzēries brauc pa ciematu, policija ieradīsies pēc izsaukšanas, ātrākais, 20 minūtès, ja vispār ieradīsies. Bet pa to laiku jau kāds var būt nosists vai nobraukts. Nav nedz pašvaldïbas policijas, ne regulāras valsts policijas klātbütnes. Policija uz vietas ir reizi divās nedēlās trešdienās uz stundu.

Liepājā un Valmierā respondenti norādīja, ka fiziskā drošiba var tikt apdraudēta arī infrastruktūras nolietojuma dēḷ, proti, lielākais apdraudējums ir padomju laikā būvētie daudzstāvu nami, kas šobrīd atrodas ḷoti sliktā stāvoklī. Fokusa grupu diskusijās respondenti ir atzīmējuši, ka viņu fizisko drošîbu apdraud sliktā ceḷu infrastruktūra un ceḷu kvalitāte, kas sekmē daudzus ceḷu satiksmes negadijumus ar letālu iznākumu. Bez šaubām tika norādīts, ka nevar visu "novelt uz sliktajiem cel̦iem", jo augsta atbildība par šiem negadijumiem gulst uz to autovadītāju pleciem, kas piekopj agresīvu braukšanas stilu.

\section{Izglìīiba}

Intensitātes ziņā otrs zemākais personiskās drošības draudu sektora apdraudējums ir izglìtỉba - izglìtības sistēmas pakalpojumu pieejamība un kvalitāte. Ierobežota izglītîbas sistēmas pakalpojumu pieejamība un skolu reforma, ${ }^{18}$ pēc respondentu domām, viṇu subjektīvā drošības uztverē ir nopietns drauds. Jaunāka gadagājuma respondenti diskusiju gaitā ir atzīmējuši, ka izglīî̉ba ir jebkura indivīda personiskās drošības garants, - ja tev ir laba izglìīiba, tev ir atvērtas visas durvis. Viņu vērtējums par izglìtïbas sistēmas pakalpojumu pieejamību un skolu reformu bija daudz mērenāks nekā to respondentu vērtējums, kuru atvases apmeklē skolas vai mācās augstskolās.

Pašnodarbināts vīrietis darbspējas vecumā, Gulbene: Mūsu bērniem absolūti nav pieejama izglìtības sistēma. Manam bèrnam, lai dotos uz skolu, ir jābrauc pus stunda. Skolas apvieno, kvalitāte krìt. Ne vienmēr "lielās gimnäzijas" ir

18 Latvijas Republikas Izglīīibas un zinātnes ministrija (2014). Izglītības attīstības pamatnostādnes 2014.2020. gadam. Pieejams: https://izm.gov.lv/lv/normativie-akti/96-attistibas-planosanas-dokumenti 
rezultativitätes rādītājs. [..] Ja man kaut kas notiks, es nebūšsu spējīgs izskolot savu bèrnu, jo viňs fiziski uz to netiks.

Jaunietis, skolēns darbspējas vecumā, L,audona: Skolas Latvijā ir pieejamas, bet $k a \bar{d} a$ ir izglìtības kvalitāte. Nav nopietni, ka mācìbu stundu laikā tiek pildìtas tikai darba lapas, no kurām neko nevar iemācīties.

\section{Veselības aprūpe}

Lielākā dal̦a respondentu atzīmēja, ka personiskā drošîba viṇiem ir cieši saistìta ar savu veselības stāvokli un veselības aprūpes pieejamību, un sniegto pakalpojumu kvalitāti. Fokusa grupu intervijās gan sievietes, gan vīrieši atzīmēja, ka fiziskā veselība neatkarīgi no vecuma ir viṇu personiskās drošības garants. Analizējot datus reǵionu griezumā, tika secināts, ka respondentu veselības stāvoklis (fiziskā veselība), bailes saslimt ar kādu slimību intensitātes ziṇā ir viens no intensīvākiem draudiem. Diskusijā respondenti novērtēja ne tikai savu veselības stāvokli un tā saistību ar personisko drošìbu, bet arī vispārējo veselības aprūpes pakalpojumu kvalitāti un pieejamību, kas, viṇuprāt, ir vēl viens drauds personiskajai drošibai.

Strādājoša sieviete pirmspensijas vecumā, Talsi: Lielākais apdraudējums, bailes no smagas slimības. Kvalitatīva medicīniskā palīdzìba kā apdraudējums (nespēj noteikt diagnozi).

Vīrietis bezdarbnieks darbspējas vecumā, Gulbene: Latvijā, kamēr tu esi vesels, tu esi vajadzīgs sabiedrïbai. Tikko esi saslims - tevi var norakstīt.

Jauna sieviete bērna kopšanas atvaḷinājumā, Rēzekne: .. ir korupcija veselības aprūpes jomā. Manuprāt, tauta pati ir pieradinājusi ärstus pie šìm aploksnēm .., bet tas nav normāli. Ja es gulēšu uz nāves gultas, pienāks ārsts un paskatīsies macin̄ā, un tikai tad ar mani runās.

Veselības aprūpes pieejamība Latvijas iedzīvotājiem ir ļoti jūtīgs jautājums, īpaši n̦emot vērā notiekošo reǵionālo slimnīcu apvienošanas procesu. ${ }^{19}$ Reǵionos respondenti šim draudam piešķir augstāku intensitāti. ${ }^{20}$ Respondenti diskusijas laikā ir izteikuši bažas par to, ka kvalificētais medicīniskais personāls aizplūst uz Rīgu. Līdz ar to, lai tiktu pie augsti kvalificēta ārsta, iedzīvotāji

19 Latvijā jau vairākus gadus ilgst reǵionālo slimnīcu apvienošanas process, ko sabiedrība uztver l̦oti pretrunīgi. Plašāk par slimnīcu apvienošanu skatīt: Latvijas Republikas Veselibas ministrija (2017). Konceptuālais ziņojums "Par veselības aprūpes sistēmas reformu”. Pieejams: http://www.vm.gov.lv/ lv/nozare/veselibas_aprupes_sistemas_reforma/

208 no 10 pašvaldībām šis drauds tika minēts kā otrais visbiežāk minētais personiskās drošības apdraudējums. 
ir spiesti braukt uz reǵionālām slimnīcām vai gaidīt garā rindā, lai pierakstītos pie Rīgas ārstiem.

Runājot par veselïbas aprūpes pakalpojumu pieejamību visos regionos, respondenti bija kritiski un atzīmēja, ka pašvaldỉbas nenodrošina pietiekamu atbalstu un veselības aprūpe ir pieejama minimālā apjomā un ir formāla. Veselỉbas aprūpes pieejamība (rindas uz pakalpojumiem, pieraksta sistēmas organizēšana), kvalitāte un maksa par medicīnas pakalpojumiem ir galvenie faktori, kas satrauc iedzīvotājus. Arī korupcija (kukuḷdošana ārstiem) medicīnas aprūpē ir būtisks drauds, taču Rēzeknē respondente atzīst, ka cilvēki paši pie tā ir vainīgi, jo pieradinājuši mediḳus pie pateicībām aploksnēs.

Pensionārs, Talsi: Mums saka, ka veselïbas aprūpe ir par velti, bet mēs visur maksājam, tikko pārkāp slieksni pie ǵimenes àrsta, ir jāmaksā [..] Mums paveicās, ǵimenes ārsts ir labs, bet citās pašvaldībās tā nav un cilvēkiem ir jābrauc uz reǵgioniem. Tas taču nav nopietni, ja vajag acu ārstu, ir jāmēro $40 \mathrm{~km}$.

Bezdarbniece pirmspensijas vecumā, Daugavpils: Veselības ministrija mūsu valstī ir lamu vārds. Trūkst ārsti, un pieejamība ir loti ierobežota.

Uzṇēmējs darbspējas vecumā, Daugavpils: Rigga, protams, var ḷoti labi teikt, $k a$ Daugavpils ir reǵionālā slimnīca, bet trūkst personāla. [..] Slimot ir diezgan bailīgi. Kvalitäte ir loti zema. [..] Pierakstī̌anas sistēma ir absurda.

\section{Sociālā aizsardzība}

Intensitātes ziṇā lielākais apdraudējums, kas tika identificēts fokusa grupu diskusiju laikā, ir indivīdu sociālā aizsardzība, kas bija viens no draudiem, kurš tika identificēts lielākajā daḷā visu regionu, kuros norisinājās fokusa grupu diskusijas. Šajā pētījumā ar sociālo aizsardzību tiek saprasta indivīdu spēja strādāt algotu darbu, pelnīt iztiku (uzturēt savu gimeni) un saņemt pabalstu darba zaudēšanas vai slimības dēḷ.

Pēc respondentu domām, sociālā aizsardzība Latvijā rada bažas. Cilvēkiem nav drošîbas par savu rītdienu, tāpēc zūd pārliecỉba ne tikai par savu nākotni, bet arī par savas ğimenes drošỉbu un nākotni. Piemēram, Valmieras fokusa grupas respondenti vienbalsīgi piekrita kāda respondenta viedoklim, ka "sabiedrības sociālais nodrošinājums ir primāra vajadzība, lai justos droši". Talsos un Gulbenē respondenti sociālo aizsardzỉbu pielīdzināja Maslova vajadzību piramīdas ${ }^{21}$ pirmajam pakāpienam, kas ir eksistenciāli svarīgs faktors cilvēces izdzīvošanai gan individuālā, gan kopienas līmenī.

21 Gun, N. (2014). Maslows Hierarchy of Needs. Pieejams: https://www.incentivesolutions.com/ employee-engagement-hierarchy-needs/ 
Uzṇēmējs darbspējas vecumā, Talsi: Būt drošam nav tikai drošîba uz ielas. Drošība par rìtdienu [tā ir īstā drošības izpratne] - es zinu, ka man būs darbs un es varēšu uzturēt savu ǵimeni, pelnìt iztiku.

Strādājoša sieviete darbspējas vecumā, Liepāja: Drošība ir tad, ja mani bèrni un mazbērni ir drošībā, tad, ja man ir darbs nodrošināts. Un tad ir tālāk, lai ir valsts drošiba.

Strādājoša sieviete pirmspensijas vecumā, Talsi: Man nav laba izglītība, un es nejūtos droši. Darba stāžs man ir, bet nodokḷi nav maksāti, lìdz ar to es zinu, ka pensija man nav un man ir jāstrādā, kamēr varēšu pastrādāt.

Pensionāre, Rēzekne: Tagad Latvijā jūtos droši, bet nav drošỉba par saviem bērniem un mazbērniem [..] Vai viņiem pienākas pensija? Sociālā aizsardzība? Pabalsti? [..] Domāju, ka šādas iespējas maniem bērniem un mazbērniem nebūs.

Neskatoties uz to, ka sociālā aizsardzība tiek identificēts kā viens no spilgtākajiem apdraudējumiem personiskās drošības sektorā, Vidzemes un Kurzemes reg̣ionā respondenti par draudu ir identificējuši sociālās aizsardzības pabalstu izšḳērdēšanu. Vecākā gadagājuma respondenti šim draudam ir piešķīruši lielāku intensitāti nekā gados jaunāki respondenti. Sociālo pabalstu piešķiršana, jo īpaši gados jauniem cilvēkiem, pēc šo respondentu domām, ir izšķērdība un milzīgs slogs valsts/pašvaldības budžetam. Viņuprāt, sociālo pabalstu piešķiršanas kārtībai ir jābūt stingri limitētai un reglamentētai. Interesanta tendence bija vērojama divu regionu fokusa grupu diskusijās, kur sociālo pabalstu izškēêrdēšana tika saistīta ar "cilvēktiesībām”. Abos gadījumos respondenti jēdzienam "cilvēktiesības" piešķīra negatīvu vai pat noniecinošu nokrāsu, kas, viṇuprāt, attaisno cilvēkus, kas dzīvo uz godīgu pilsoṇu rēḳina. Jaunjelgavā, Valmierā un Rēzeknē iedzīvotājus satrauc valsts politika un pašvaldības amatpersonu līdzdarbība kārtības noteikšanā, kā un kam tiek pieškiriti tā saucamie bezdarbnieku kursi. Pirmkārt, kursu pieejamība nav visiem vienāda, jo kursi tiek Nodarbinātības valsts aǵentūras filiālı un pašvaldības darbinieku pazin̄ām, draugiem pirmspensijas vecumā, nevis jauniem cilvēkiem, kam vēl visa darba dzīve ir priekšā. Īpaši tas attiecas uz angḷu valodas, grāmatvedības un datoru kursu prasmju uzlabošanas mācībām. Bezdarbnieku mācību pabalstu pieškirš̌anas sistēma tiek uzskatīta par negodīgu un nepareizu.

Strādājoša sieviete darbspējas vecumā, Gulbene: [..] Latvijā ir pārprastas cilvēktiesības, kad ikviens no mums var nodzerties, slinkot vai nesträdāt, bet var pretendèt uz valsts/pašvaldïbas garantētiem pabalstiem, kas apdraud godīgi strädājošos pilsonus, tos, kas maksā nodokḷus.

Pensionārs, Talsi: Jo labāk cilvēki dzīvo, jo vairāk rodas izlaidība un sākas visatl̦autība. Eiropas cilvēktiesības - tās mūs novedīs, jau daudz kur ir novedušas 
[parāda noniecinošu attieksmi pret vārdu salikumu "Eiropas cilvēktiesības", paskaidro, ka cilvēktiesības l̦auj cilvēkiem nodzerties vai lietot narkotikas un nedomāt par rītdienu, jo valsts/pašvaldỉba kalpo kā garants indivīdu iztikai - tiek izšķērdēti sociālie pabalsti].

Sieviete darbspējas vecumā, Jaunjelgava: Mēs taču redzam, kurš kādus kursus izsitis. Vinšs iziet tos kursus un nākošă dienā aizbrauc uz Angliju vai citur strādāt. Bet tas, kurš paliktu uz vietas Latvijā, pie tiem kursiem netiek.

Apkopojot iegūtos datus par galvenajiem draudiem personiskās drošỉbas sektorā, var secināt, ka intensitātes ziṇā draudu sarindojums (no vismazāk intensīviem uz visintensīvākiem draudiem) ir šāds: indivīdu fiziskā drošība, izglītības sistēmas pakalpojumu pieejamība un kvalitāte, veselïbas aprūpes pieejamība un kvalitāte un indivìdu sociālā aizsardzība. Kopumā fokusa grupu interviju laikā tika secināts, ka Latvijas iedzīvotāji personiskās drošỉbas ziṇā nejūtas droši.

Reǵionu griezumā - Latgalē un Vidzemē - indivīdiem prevalē sociālā aizsardzība, savukārt Kurzemē - fiziskās veselības drošība un veselības pakalpojumu pieejamība. Veselības sistēmas pakalpojumu pieejamības un aprūpes kvalitātes izvērtēšanā fokusa grupās tika identificēti trīs apdraudējumi - pieraksta sistēma stacionāros uz izmeklējumiem, garās rindas, kuru gaidīšanas laikā veselība pasliktinās vēl vairāk, attālums līdz slimnīcai un pakalpojumu pieejamība (finansiālais aspekts). Piemēram, Talsos vīrietis stāsta, ka, lai tiktu pie acu ārsta, ir jābrauc 40 kilometri. Minētās datu atšḳirības var tikt pamatotas ar atškirīigiem ienākumiem. Piemēram, saskaṇā ar Centrālās statistikas pārvaldes datiem par 2018. gadu vidējie ienākumi uz vienu mājsaimniecību "Rīgā sastāda - 669 EUR, Pierīgā - 591 EUR, Zemgalē - 501 EUR, Kurzemē 467 EUR, Vidzemē - 431 EUR un Latgalē - 376 EUR”22.

\section{Personiskā drošība pašvaldībās}

Intervijās ar pašvaldību darbiniekiem pētỉjuma gaitā tika secināts, ka draudu identificēšana personiskās drošības sektorā gan individuālā līmenī, gan pašvaldību līmenī sakrīt. Visi pašvaldību darbinieki interviju laikā identificēja tos pašus draudus, ko identificēja iedzīvotāji fokusa grupu diskusiju laikā. Arī identificēto draudu intensitāte un hierarhiskais izkārtojums bija līdzīgs. Kopumā pašvaldību darbinieki bija nedaudz optimistiskāk noskaņoti nekā to iedzīvotāji. Lēmumu pieņēmējiem intervijās bija atzinīgāks vērtējums par pašvaldības darbu personiskās drošības draudu mazināšanā.

22 Centrālā statistikas pārvalde (2008). 2018. gadā mājsaimniecību rīcībā esošie ienākumi pieauga par 11,7\%. Pieejams: https://www.csb.gov.lv/lv/statistika/statistikas-temas/socialie-procesi/nabadziba/ meklet-tema/2567-majsaimniecibu-riciba-esosie-ienakumi-2018 


\section{Indivīdu fiziskā drošība}

Gan indivīdi, gan pašvaldību darbinieki ir norādījuši, ka fiziski viṇi jūtas droši pašvaldības teritorijā, tāpēc šis drauds tiek identificēts kā vismazāk intensīvs. Visu pašvaldību pārstāvji norādīja, ka Latvijā nav deviņdesmitie, tāpēc uz ielām ir droši. Piemēram, intervijā ar Valmieras pašvaldības darbinieku tika atzìmēts, ka

drošǐba pilsētà (fiziskā drošỉba), lai paši jūtas droši, lai bērnus var droši palaist uz skolu, ir augstā lìmenī. Pastiprināta policijas klātbūtne. Pašvaldības policija, attìstìta video novērošana, kas reǵgistrē iebraucošās un izbraucošās mašinas. Saskaņā ar policijas datiem Valmiera ir drošākā pilsēta, un, pèc apsardzes kompāniju aptaujām, Valmiera ir droša. Veido drošu pilsētu, lai cilvēki varētu droši strādāt un palaist bērnus. Bērniem ir bezmaksas transports, lai pārvietotos starp mācību iestādēm un mājām.

\section{Izglìtība}

Izvērtējot izglìtības sistēmas pieejamību un to kvalitāti reǵionos, pašvaldību darbinieku nostāja salīdzinājumā ar iedzīvotāju attieksmi ir nedaudz mērenāka. Identificējot šo personiskās drošības sektora draudu, atbildēs parādijīās pašvaldību nevēlēšanās uzņemties atbildību un norādes uz ministriju un valsts atbildību lēmumu pien̦emšanā. Intervijā ar Gulbenes pašvaldỉbas darbinieku viņš pauda, ka "izglìtîbas sistēmas pieejamība, pašvaldības līmenī tiek risināta, bet skolu optimizācija ir valstiska līmeņa problēma, kuru mēs nevaram ietekmēt”". Intervējamais norādīja, ka pašvaldībā tiek īstenoti visi nepieciešamie mehānismi (transports līdz skolai, celtas/renovētas pirmsskolas izglìtības iestādes), lai izglītîbas sistēmas pieejamība neapdraudētu pašvaldību iedzīvotāju personīgo drošìbu. Talsu novada pašvaldības darbinieks savā intervijā arī ir apliecinājis, ka "Talsu novada pašvaldībā izglītība ir pieejama. Nav ne vidusskolu problēmu, ne pirmsskolas izglītības iestāžu problēmu”. Liepājas pilsētas pašvaldības darbinieks, atškiriībā no Rēzeknes pilsētas un Daugavpils pilsētas pašvaldību darbiniekiem, intervijā akcentēja Liepājas Universitātes lielo nozīmi pilsētas un visa Kurzemes regiona kopējā izaugsmē un attīstībā, tai skaitā iedzīvotāju noturēšanā un piesaistē.

Kopumā var secināt: pašvaldību darbinieki apzinās, ka izglìtības sistēmas nepietiekamā pieejamība varētu būt iedzīvotāju personiskās drošības apdraudējums, tomēr šì drauda intensitāte ir zemāka nekā fokusa grupu diskusijās. Sabiedrības negatīvo vērtējumu par izglìtỉbas pieejamību un kvalitāti pašvaldību darbinieki sasaista ar valsts normatīvajiem aktiem, kas noteic, ka pašvaldība nodrošina tikai pamatizglitiỉbu. 


\section{Veselība}

Pašvaldību darbinieku intervijās biežāk tika identificēts nevis indivīdu fiziskās drošības drauds, bet gan veselības aprūpes pakalpojumu pieejamības drauds. Lìdzīgi kā fokusa grupās šì drauda intensitāte ir augstāka tajās Latvijas pašvaldībās, kurās nav regionālās slimnīcas. Tomēr pašvaldību darbinieki šo problēmu vairāk aktualizē nevis kā personiskās drošỉbas problēmu, bet gan kā valstisku problēmu. Viņuprāt, pašvaldībām nav pietiekoši daudz resursu un varas mehānismu, lai vietējā līmenī varētu šo problēmu atrisināt. Piemēram, intervējamais no Talsu novada pašvaldības atklāj, ka

tas [veselības aprūpes pakalpojumu pieejamība] ir drauds. Novadā ir veselības centri, kas sniedz pakalpojumus, un mums ir viena reǵionālà slimnīca [Kurzemes reǵionālā slimnīca], kas sniedz pakalpojumus, bet tā nepieder pašvaldībai. Mès $k \bar{a}$ novads saņemam daudz sūdzības, bet ietekmèt to nevaram, jo ietekmètājs ir Ventspils pašvaldība. Kā rezultātā viens no tiešajiem draudiem ir tas, ka mēs kā liels spèlètājs nevaram ietekmēt slimnìcu darbību.

Savukārt intervējamais no Valmieras pašvaldības atzīmē, ka

Valmierā slimnīca dod pozitìvu devumu, jo tās tuvums piesaista iedzìvotājus. Taču cilvēkiem reǵionā tas ir vairāk risks, vai paspēs atbraukt, vai tiks uz slimnīcu.

Papildus vairāku pašvaldību darbinieki (Rēzeknē, Daugavpilī) intervijās atzīmēja, ka veselības aprūpes pakalpojumu pieejamību būtiski ietekmē privātie medicīnas centri. Privātie medicinas pakalpojumu centri, no vienas puses, uzlabo pakalpojumu pieejamību, bet, no otras puses, n̦emot vērā pakalpojumu augstās cenas, nav spējīgi atrisināt samilzušo problēmu veselības aprūpes pakalpojumu pieejamībā reǵionos. Liepājas pašvaldības darbinieks uzsvēra, ka pašvaldība diemžēl nevar ietekmēt nedz kvotas, nedz rindas, nedz speciālistu pieejamību Kurzemes reg̣ionālajā slimnīcā. Kritiska situācija ir ar bērnu un valsts apmaksātajiem zobārstniecības pakalpojumiem - to pieejamība ir nepietiekoša, bet pašvaldība maz ko var ietekmēt. Liepājas pašvaldība saņem iedzīvotāju sūdzības un lūgumus risināt veselības aprūpes pieejamības jautājumus, jo iedzīvotāji nezina, kas šajā jomā ir valsts un kas pašvaldības kompetencē.

\section{Sociālā aizsardzība}

Sociālo aizsardzību, kurai fokusa grupu diskusiju laikā tika piešķirta visaugstākā intensitāte, pašvaldību darbinieki savās intervijās vērtēja pozitīvāk. Viņuprāt, ar indivīdu sociālo aizsardzību pašvaldībās viss ir kārtībā. Nav jāmeklē draudi tur, kur viṇu nav. Proti, intervijā Talsu novada pašvaldības darbinieks 
norādīja, ka "sociālā aizsardzība Talsu novadā ir pietiekama. Ir gan Sarkanais Krusts, gan nakts mītnes un pabalsti, bet, vai tas ir tik ideāli, man grūti spriest”. Jaunjelgavas pašvaldības darbinieks intervijā stāsta, ka "Jaunjelgavā pamatvajadzības ir nodrošinātas, dzīvesvietas ir pieejamas, ko vilkt mugurā ir un ko ēst arī. Trīs ārsti uz tik mazu iedzīvotāju skaitu ir samērā ekskluzīvi”.

Vairāki pašvaldību darbinieki savās intervijās ir iezīmējuši skaidru nošķīumu starp valsts līmeṇa un vietējā līmeṇa pārvaldi indivīdu sociālās aizsardzības stiprināšanā. Piemēram, intervijā ar Liepājas pašvaldības darbinieku viņš atklāja, ka "pašvaldība gribētu darìt un rūpēties vairāk par saviem iedzīvotājiem, bet ir likuma norma, kuru nedrīkst pārkāpt". Savukārt intervējamais no Gulbenes novada pašvaldības atzīmēja, ka "Latvijā ir skaidrs dalījums starp varas līmeņiem - valdība un pašvaldība. Lielākā daļa no draudiem - indivīdu sociālā aizsardzība, veselības aprūpes pieejamība, ir draudi, kas risināmi tikai un vienīgi valstiskā līmenī (nodokḷi, dzīvokḷi, infrastruktūra, izglìtība, veselības aprūpe). Pašvaldībā jau viss ir kārtībā, bet valstiskā līmenī jau nepietiek resursu".

Apkopojot iegūtos datus, tika secināts, ka pašvaldību iedzīvotāju un lēmumu pieņēmēju skatījums uz galvenajiem apdraudējumiem personiskās drošìbas sektorā sakrīt. Atšķkirības ir vērojamas subjektīvā draudu uztverē starp iedzīvotājiem un lēmumu pieņēmējiem. Iedzīvotāji ir daudz kritiskāki pret pašvaldības darbu un sniegto atbalstu identificēto apdraudējumu minimizēšanā. Piemēram, fokusa grupu diskusiju laikā respondenti ir atzīmējuši, ka uz drošìbu kā kompleksu parādību ir jāskatās no Maslova vajadzību piramīdas skatpunkta. Ja tiek apmierinātas pirmā līmeņa jeb eksistenciālās vajadzības, indivīds var tiekties pēc nākamo līmeṇu vajadzību apmierināšanas.

Uzṇēmējs darbspējas vecumā, Rēzekne: Mēs Latgalē neesam tik atbalstīti [gan no valsts, gan no pašvaldības puses], cik vajadzētu, lai mēs justos droši.

Respondentu skatījumā galvenā problēma, kāpēc šis atbalsts ir nepietiekams, ir saistìta ar valsts, nevis pašvaldību darbỉbas virzienu neefektīvu plānošanu. Šādam viedoklim piekrita arī lielākā daļa lēmumu pieņēmēju, kas atzīmēja, ka vairākas problēmas (personiskās drošības draudu minimizēěana) ir iespējams atrisināt tikai valstiskā līmenī.

Pensionāre, Rēzekne: Pašvaldība par mums rūpējas tik, cik viniiem ir tās naudiņas, un mums iedod to. Kaut kas nav pareizi tur augšā [domā valdības ministrus]. Vietējās pašvaldības cenšas vairāk nekā tur auǧ̌ă. Vietējie vairāk pārzina, kas te darās, vairāk raksta projektus. Viñi vairāk saprot mūsu vajadzības. 
Nodarbināts vīrietis darbspējas vecumā, Jaunjelgava: Pašsaldība nekomunicē ar iedzìvotājiem cieņpilni, bet, neskatoties uz to, pašvaldība tiek vērtēta pozitìvi salìdzinājumā ar Saeimu un valdību.

Tomēr ne visi respondenti diskusiju laikā ir bijuši tik optimistiski noskaņoti par pašvaldības darbu personiskās drošības jomā. Vairāki respondenti ir atzīmējuši, ka pašvaldības kā vietējās varas institūcijas nedara neko, lai stiprinātu indivīdu personisko drošību, vai arī pašvaldības darbs aprobežojas tikai ar noteiktu sociālu labumu pārdali. Lielāka pašvaldības iesaiste indivīdu personiskās drošības jomā tika atzīmēta pirmsvēelěšanu laikā.

Nodarbināta sieviete darbspējas vecumā, Gulbene: Pašvaldība nedara neko, lai pasargātu mūsu privāto dzīvi, t. i., ir lıoti zema uzticība vietējā līmeña politikikiem. Uzņēmējs darbspējas vecumā, Talsi: Pašvaldībai mēs esam interesanti tikai vēlēšanās - katrus četrus gadus.

Pamatojoties uz datiem, kas iegūti interviju laikā, tika secināts: lēmumu pieṇēmēji pašvaldībās tam nepiekrīt un uzskata, ka pašvaldības dara pietiekoši, lai minimizētu personiskā drošības sektora apdraudējumus. Līdz ar to, lai izvērtētu katras pašvaldības rīcību personiskās drošības sektora draudu minimizēšanā, balstoties uz izstrādāto labas pārvaldes matricu, tika veikta katras pašvaldības kvalitatīvā attīstības plānošanas dokumentu analīze.

\section{Talsu novada pašvaldība}

Talsu novada pašvaldības attīstîba ir nostiprināta trīs savstarpēji saistītos plānošanas dokumentos: Talsu novada ilgtspējīgas attīstības stratēgija 2030. gadam, Talsu novada attīstības programma 2014-2020. gadam un Talsu novada pašvaldības mājokḷu politikas vadlīnijas 2020.-2022. gadam. ${ }^{23}$ No labas pārvaldes perspektīvas visas trīs analizētās rīcībpolitikas ir savstarpēji pamatotas un saistìtas plānošanas dokumentu izstrādē. Attīstības dokumentu izstrādē ir ievērots pēctecỉbas princips un dokumentu izstrādes hierarhija gan nacionālā līmenī (sasaiste ar Latvijas ilgtspèjīgas attīstības stratēǵiju līdz 2030. gadam (Latvija 2030), Latvijas Nacionālo attīstības plānu (NAP 2020), Regionālās politikas pamatnostādnēm 2013.-2019. gadam), gan reǵionālā līmenī (sasaiste ar Kurzemes plānošanas reǵiona ilgtspējiggas attīstības stratēǵiju 2015.-2030. gadam, Kurzemes plānošanas reǵiona Attīstības programmu 2015.-2020. gadam, nozaru plānošanas dokumentiem).

Hierarhiski augstākais vietējā līmeņa plānošanas dokuments ir Talsu novada pašvaldības attīstības stratēǵija 2030. gadam. Attīstības stratēǵijas uzbūve 
tiek koncentrēta ap apdzīvojuma struktūras telpiskiem izkārtojumiem, kam tiek pakārtoti vides aspekti, sociālie aspekti (drošỉba, sociālie pakalpojumi, sociālais darbs, izglītība, sports un aktīvā atpūta, kultūra, veselība, iedzīvotāju informēšana) un ekonomiskie aspekti (uzṇēmējdarbỉba, inženierapgāde, tūrisma infrastruktūra). Stratēǵijas vīzija ir "ekonomiski attīstìts novads Ziemel̦kurzemē ar reğiona centru Talsos, ar konkurētspējīgiem un inovatīviem uzṇēmumiem, ar drošu un pievilcīgu dzìves vidi, bagāts ar izglìtotiem, radošiem un pilsoniski aktīviem cilvēkiem, kuri veido veselīgu, gimenisku un pārtikušu sabiedrību; efektīvi pārvaldīts novads, kurā katrai pilsētai un pagastam ir sava dabas un kultūras pievilcība"24. Definētās vīzijas sasniegšanai tiek pakārtoti četri stratēǵiskie mērḳi - "1. Izglītota, radoša un pilsoniski aktīva, veselīga, gimeniska un pārtikusi sabiedrỉba; 2 . Vides resursos balstīta progresīva un attīstīta daudznozaru ekonomika; 3. Talsu pilsētas izcilība, novada nozīmība un atpazīstamība - novada svītrukods; 4. Iedzìvotājiem tuva pašvaldība, stipra un efektīva pārvaldība" ${ }^{\prime 2}$.

Pirmais stratēgiskais mērķis "izglītota, radoša un pilsoniski aktīva, veselīga, gimeniska un pārtikusi sabiedrība" ${ }^{26}$ tiešā veidā iekḷauj rīcības virzienus, kas ir vērsti uz personisko draudu novēršanu vai mazināšanu. Saskaņā ar mērḳi Talsu novada pašvaldībā personiskās drošības sektora draudu mazināšanai ir paredzēta novada izglìtības sistēmas pārvaldība (kas paredz visu līmeṇu pirmsskolas, vispārējās, interešu, profesionālās un augstākās - izglītības pieejamības un kvalitātes uzlabošanu), veselības aprūpes sistēmas pieejamības attīstība un sociālais atbalsts (nodarbinātības veicināšana, dažādu sociālo atbalsta pasākumu ieviešana). ${ }^{27}$

Saskaṇā ar fokusa grupās identificētiem draudiem personiskās drošības sektorā indivìdu fiziskā drošìba, sociālā aizsardzība, indivīdu fiziskā veselība un izglìtības pieejamība Talsu novada pašvaldības attīstības plānošanas dokumentos ir iekḷautas tieši, nevis pastarpināti. No labas pārvaldes perspektīvas var secināt, ka personiskās drošỉbas draudi un to mazināšanas iespējas ir iekḷauti visās novada izstrādātās rīcíbpolitikās. Lai gan intervijā ar Talsu novada pašvaldības darbinieku tika konstatēts, ka, viṇaprāt, "novadā pietrūkst ilgtermiņa redzējums (konkrēti - rīcībpolitiku izstrādēe)", tomēr kvalitatīvā dokumentu

Talsu novada pašvaldỉba (2019). Talsu novada pašvaldības attīstības stratēǵija 2030. gadam. Pieejams: https://talsi.lv/wp-content/uploads/2019/07/stategija_apstiprinats_2030.pdf

Turpat.

Turpat.

Talsu novada pašvaldība (2016). Talsu novada attìstības programma 2014.-2020. gadam. Rìcības plāns 2016.-2020. gadam. Pieejams: https://talsunovads.lv/wp-content/uploads/2019/08/06_2pielikums_ rcbuplns_projekts_precizets.pdf 
analīze atspoguḷo to, ka rīcībpolitiku izstrādes gaitā tiek ņemts vērā ilgtermiṇa redzējums. Pašvaldība adekvāti reaǵē uz personiskās drošības apdraudējumu izmaiņām. ${ }^{28}$ Analizētajos attīstības plānošanas dokumentos tiek iekḷautas konkrētas rīcības personiskās drošîbas draudu minimizēšanai.

Runājot par preventīvo rīcībpolitiku izstrādi personiskās drošības sektorā, pētījuma gaitā tika secināts, ka pašvaldībā nav izstrādāta neviena preventīvā rīcībpolitika, kas informētu sabiedrību, kā rīkoties, sastopoties ar personiskās drošības draudiem. Pretstatā tam ir izstrādāta virkne saistošo noteikumu par to, kādu atbalstu pašvaldība sniedz saviem iedzīvotājiem personiskās drošības draudu mazināšanā. Piemēram, saistošie noteikumi Nr. 12 "Par materiālo palīdzību Talsu novadā”, Nr. 59 "Par sociālajiem pakalpojumiem Talsu novada pašvaldībā", Nr. 17 "Par veselības aprūpes pabalstu Talsu novadā"29. Papildus 2011. gada jūnijā tika apstiprināts apvienotais Dundagas, Mērsraga, Rojas un Talsu novada civilās aizsardzības plāns. ${ }^{30}$ Šis plāns netieši jeb pastarpināti iekḷauj pašvaldības rīcību personiskās drošības draudu mazināšanai. Civilās aizsardzības plāns nosaka kārtību, kādā pašvaldība "sniegs palīdzību iedzīvotājiem un, ja nepieciešams, evakuēs iedzīvotājus no katastrofas apdraudētajām vai skartajām teritorijām, nodrošinot iedzīvotāju uzskaiti, pagaidu izmitināšanu, èdināšanu, sociālo aprūpi un medicīniskās palīdzības sniegšanu" ${ }^{31}$.

Izvērtējot starpiestāžu koordināciju Talsu novada pašvaldībā, pētījuma gaitā tika secināts, ka personiskās drošỉbas sektorā tā ir efektīva. Pašvaldíbai ir vienots redzējums uz savu iedzīvotāju personisko drošību. Tiek nodrošināta sadarbība starp iestādēm, kas ir atbildīgas par fizisko drošỉbu (policija, probācijas dienests), sociālo aizsardzību (sociālais dienests), veselības un izglìitības pieejamību.

\section{Rēzeknes pilsētas pašvaldība}

Līdzīgi kā Talsu novada pašvaldības gadījumā, Rēzeknes pilsētas pašvaldības attīstỉba ir nostiprināta divos stratēgiski saistìtos un pakārtotos plānošanas

28 Ar to autores saprot pašvaldỉbas spēju reagēt uz Covid-19 infekcijas izplatības apdraudējumu Talsu novada pašvaldībā. Covid-19 infekcijas izplatība ir tiešā veidā saistīta ar personisko drošibu gan fiziskās veselības nodrošināšanā, gan izglītības sistēmas pieejamībā, gan indivīdu sociālajā aizsardzības sfērā. Sākot ar pandēmijas izsludināšanu, Talsu novada pašvaldībā ir izstrādāti visu pirmsskolas izglītības iestāžu "kārtība, kādā tiek nodrošināti epidemiologiskās drošības pasākumi Covid-19 infekcijas izplatības ierobežošanai 2020./2021. mācību gadā”. Tika pieṇemta kārtība, kādā tiks sniegta palīdzība grūtībās nonākušajiem novada iedzīvotājiem.

29 Talsu novada pašvaldỉba (2014). Pašvaldības saistošie noteikumi. Pieejams: https://talsi.lv/dokumenti/? document-subject $\% 5 \mathrm{~B} \% 5 \mathrm{D}=$ izglitiba\&document-subject $\% 5 \mathrm{~B} \% 5 \mathrm{D}=$ sociala-palidziba\&documentsubject $\% 5 \mathrm{~B} \% 5 \mathrm{D}=$ veseliba\&s=

30 Dundagas novada dome, Mērsraga novada dome, Rojas novada dome, Talsu novada dome (2011). Apvienotais Dundagas, Mērsraga, Rojas un Talsu novadu civilās aizsardzības plāns, 73. lpp.

31 Turpat. 
dokumentos - Rēzeknes pilsētas ilgtspējīgas attīstības stratēgijā līdz 2030. gadam un Rēzeknes pilsētas attīstības programmā 2014.-2020. gadam. ${ }^{32}$ Dokumentu izstrādē ir ievērots pēctecības princips un dokumentu izstrādes hierarhija. Abi plānošanas dokumenti ir pakārtoti gan nacionālā, gan reǵionālā līmeņa attīstības plānošanas dokumentiem (Latgales stratēgija 2030). ${ }^{33}$ No labas pārvaldes perspektīvas var secināt, ka Rēzeknes pilsētas pašvaldībā plānošanas dokumentu izstrādē tiek ievērots pēctecības princips.

Hierarhiski augstākais Rēzeknes pilsētas pašvaldības plānošanas dokuments ir Rēzeknes pilsētas ilgtspējīgas attīstības stratēǵija līdz 2030. gadam. Atšķirībā no Talsu novada attīstības stratēégijas, Rēzeknes pilsētas stratēégijā personiskās drošības draudi, kas tika identificēti fokusa grupu interviju laikā, ir iekḷauti pastarpināti (izņemot izglìtības sistēmas pieejamību un indivīdu fizisko drošību). Saturiski stratēgija ietver četrus attīstības mērķus - "1. Nodrošināt Rēzeknes kā starptautiski konkurētspējīga nacionālās nozīmes ekonomiskās attīstības centra attīstîbu; 2. Attīstīt Rēzekni kā Eiropas kultūras un tūrisma pilsētu; 3. Sekmēt Rēzeknes kā Austrumlatvijas izglìtības, pētniecības un sporta centra attīstību; 4. Veidot Rēzekni kā cilvēkam un videi draudzīgu, drošu un mūsdienīgu pilsētu Eiropas Savienības Austrumu pierobežă” ${ }^{34}$. Diviem no šiem stratēgiskās plānošanas mērķiem pastarpināti ir pakārtoti pasākumi personiskās drošības sektora draudu mazināšanai. Piemēram, lai nodrošinātu ekonomiskās attīstîbas centra attīstîbu, viens no darbības virzieniem (lielo ražošanas investīciju piesaistīšana, kas ap sevi rada uzṇēmējdarbības vidi maziem un vidējiem uzñēmumiem ${ }^{35}$ ) ir bezdarba līmeņa mazināšana, kas savukārt netieši ir saistīta ar fokusa grupās minēto - indivīdu sociālo aizsardzību.

No labas pārvaldes perspektīvas Rēzeknes pilsētas attīstības programmā 2014.-2020. gadam $^{36}$ iekḷautās vidējā termiṇa darbības prioritātes ${ }^{37}$ (tā

32 Rēzeknes novada pašvaldība (2020). Pilsētas plānošanas dokumenti. Pieejams: https://rezekne.lv/ pilsetas-attistibas-dokumenti/

33 Latgales plānošanas reǵions (2011). Latgales stratēgija 2030. Pieejams: https://lpr.gov.lv/wp-content/ uploads/2011/lpr-planosanas-dokumenti/Latgales_strategija_2030_apstiprinata_01.12.2010.pdf

34 Rēzeknes pilsētas pašvaldība (2014). Rēzeknes pilsētas ilgtspējīgas attīstības stratēgija. Pieejams: https://rezekne.lv/wp-content/uploads/2017/08/rezeknes-pilsetas-ilgtspejigas-attistibas-strategijalidz-2030-gadam.pdf

35 Turpat.

36 Rēzeknes pilsētas pašvaldība (2014). Rēzeknes pilsētas attīstības programma 2014.-2020. gadam. Pieejams: https://rezekne.lv/wp-content/uploads/2017/08/rezeknes-pilsetas-attistibas-programma2014-2020-gadam.pdf

37 Rēzeknē ir šādas vidējā termiņa darbības prioritātes: 1. Uzṇēmējdarbību un investīcijas atbalstoša vide; 2. Iedzīvotājiem un tūristiem interesanta, daudzveidīga kultūras dzìve, radošās industrijas un konkurētspējīgs tūrisma piedāvājums; 3. Latgales reǵiona ekonomikā integrēta izglītība un pētniecība; 4. Sports; 5. Kvalitatīva dzìves telpa. Pieejams: https://rezekne.lv/wp-content/uploads/2017/08/ rezeknes-pilsetas-attistibas-programma-2014-2020-gadam.pdf 
pastarpināti ir paredzēta personiskās drošības sektora draudu mazināšanai) mērḳu kaskadēšanā ir ievērots pēctecības princips. Papildus katram rīcības virzienam ir noteikti kvalitatīvi izmērāmi indikatori. N̦emot vērā fokusa grupās raksturotos draudus personiskās drošības sektorā, abos Rēzeknes pilsētas pašvaldības attīstības plānošanas dokumentos tie ir iekl̦auti tikai daḷeji un pastarpināti. Galvenais attīstības plānošanas dokumentu mērkisis ir uzñēmējdarbības veicināšana, izglītības kvalitātes uzlabošana un kultūrvides saglabāšana. Tiešã veidā šie attīstības plānošanas dokumenti nav domāti personiskās drošības sektora draudu mazināšanai. Analizētos attīstības plānošanas dokumentos netika iekḷauti darbības virzieni, kas būtu paredzēti indivīdu fiziskās drošības situācijas uzlabošanai, veicinātu veselības aprūpes pieejamību un radītu drošuma sajūtu sociālā aizsardzības jomā.

Atšķirībā no Talsu novada pašvaldības, Rēzeknes pilsētas pašvaldībai nav izstrādāts civilās aizsardzības plāns, ${ }^{38}$ kas vismaz pastarpināti iekḷauj rīcỉbas virzienus draudu mazināšanai personiskās drošîbas sektorā. Savukārt, līdzīgi kā Talsu novada pašvaldībā, Rēzeknes pilsētas pašvaldībā nav izstrādāta preventīva rīcībpolitika, kas informētu sabiedrību, kā rīkoties personiskās drošības draudu gadījumā. Draudu mazināšanai pašvaldībā ir izstrādāta virkne saistošo noteikumu par personiskās drošîbas draudu mazināšanu. Piemēram, saistošie noteikumi Nr. 22 "Sabiedriskās kārtības noteikumi Rēzeknē”, Nr. 28 "Par sociālajiem pakalpojumiem Rēzeknes pilsētas pašvaldībä", Nr. 15 "Par papildu materiālo palīdzību Rēzeknes pilsētas pašvaldỉbā", Nr. 5 "Par gimenes vai atseviṣ̌̌i dzìvojošas personas atzī̌anu par trūcīgu vai maznodrošinātu un sociālās palīdzības pabalstiem Rēzeknes pilsētas pašvaldībā"39. Tomēr pētijuma rezultātā tika secināts, ka arī šie saistošie noteikumi tikai daḷēji ataino pašvaldības rīcības virzienus personiskās drošības sektora draudu mazināšanā. Piemēram, pašvaldībā nav izstrādāti saistošie noteikumi (vai citi dokumenti, plāni un stratēgíijas) ${ }^{40}$ par veselības sistēmas pakalpojumu pieejamību.

Pētijuma gaitā tika secināts, ka Rēzeknes pilsētas pašvaldībā normatīvo aktu izmaiņas biežums, reageējot uz personiskās drošỉbas apdraudējumiem, nav optimāls, jo jaunākie attīstības plānošanas dokumenti un saistošie noteikumi neataino draudus, kas ir būtiski pašvaldības iedzīvotājiem, bet atspoguḷo tikai

38 2018. gadā ir izstrādāts apvienots civilās aizsardzības plāns Rēzeknes un Viḷānu novadu pašvaldībām. Rēzeknes pilsētas pašvaldībai šāds plāns netika izstrādāts. Rēzeknes pašvaldībai civilās aizsardzības plāns ir daḷa no vides pārskata.

39 Rēzeknes pilsētas pašvaldība (2020). Saistošie noteikumi. Pieejams: https://rezekne.lv/saistosienoteikumi/\#

40 Dokumenti vai noteikumi, kas atainotu to, kādu atbalstu pašvaldība sniedz saviem iedzīvotājiem personiskās drošíbas draudu mazināšanas jomā. 
izvirzìtās darbības prioritātes, kas tika definētas 2014. gadā. Izvērtējot starpiestāžu koordināciju Rēzeknes pilsētas pašvaldībā, pētījuma gaitā tika secināts, ka tā nav efektīva. No personiskās drošības sektora draudu perspektīvas Rēzeknes pilsētas pašvaldībā ir skaidri nošķirtas iestāžu atbildības jomas. Piemēram, par iedzīvotāju sociālo aizsardzību ir atbildīga pārvalde "Sociālais dienests", par izglītîbas sistēmas pilnveidošanu un pieejamību ir atbildīga Izglìtỉbas pārvalde. Tomēr no nosaukto personiskās drošības draudu (indivīdu fiziskā drošība un veselības sistēmas pieejamība) perspektīvas Rēzeknes pilsētas pašvaldībā atbildīgo iestāžu nav. 2014. gadā Rēzeknes pilsētā tika likvidēta pašvaldības policija. Kārtības uzturēšana pilsētā tika delegèèta Valsts policijai ${ }^{41}$ un nesen izveidotajai Administratīvajai inspekcijai. Pašvaldībā nav izveidota neviena iestāde, kas būtu atbildīga par veselības aprūpes sistēmas pieejamìbu.

\section{Daugavpils pilsētas pašvaldība}

Atšķirībā no Talsu novada un Rēzeknes pilsētas pašvaldībām Daugavpils pilsētas pašvaldības attīstìba ir nostiprināta divos stratēgiski saistītos un pakārtotos dokumentos - Daugavpils pilsētas ilgtspējīgas attīstības stratēǵija lìdz 2030. gadam un Daugavpils pilsētas attīstîbas programma "Mana pils - Daugavpils" 2014.-2020. gadam"42 - un katrai pilsētas pašvaldības attīstības prioritātei ir pakārtota atsevišķa stratēgiija. Stratēgiskās plānošanas dokumentu analīzes rezultātā tika secināts, ka pašvaldības definētās attīstības jomas ataino iedzīvotāju minētos personiskās drošības riskus.

Daugavpils pilsētas stratēǵijas vīzijas sasniegšanai ir izvirzìts viens stratēgiskais mērḳis - "Daugavpils pilsēta - pievilcīgākā vieta dzīvei un uzņēmējdarbībai Austrumbaltijā" ${ }^{3}$. Šì mērḳa īstenošanai tiek izraudzìti trīs darbības virzieni, un viens no tiem pastarpināti raksturo trīs no četriem personiskās drošîbas sektora apdraudējumiem. Šis virziens ir "sabiedrības līdzsvarotā attīstîba", kas ir orientēts uz kvalitatīvas izglìtības iegūšanas iespējām un kvalitatīvu publisko individuālo pakalpojumu groza ${ }^{44}$ paplašināšanu.

41 BNS (2015). Rēzeknes mērs: kopš pašvaldības policijas likvidēšanas situācija nav pasliktinājusies (intervija 2015. gada 16. februārī). Pieejams: https://www.la.lv/rezeknes-mers-kops-pasvaldibas-policijaslikvidesanas-situacija-nav-pasliktinajusies

42 Daugavpils pilsētas pašvaldība (2020). Pilsētas plānošanas dokumenti. Pieejams: https://www. daugavpils.lv/pilseta/pilsetas-attistiba/planosanas-dokumenti

43 Daugavpils pilsētas dome (2014). Daugavpils pilsētas ilgtspējīgas attīstības stratēgija. Pieejams: https://www.daugavpils.lv/assets/upload/attistiba/2018/Strategija2014-2030_.pdf

44 Saskaņā ar stratēgiju publiskie individuālie pakalpojumi, kas tiek nodrošināti Daugavpilī, ir primārie veselības pakalpojumi, medicīniskā aprūpe mājās, ambulatorie veselíbas aprūpes pakalpojumi, sociālie pakalpojumi, atbalsta pasākumi un konsultatīvā palīdzība, pilna apjoma sociālo pakalpojumu klāsts, sociālās rehabilitācijas pakalpojumi, pirmsskolas, sākumskolas, pamatskolas un vidusskolas pieejamība, mūžizglītỉbas veicināšana. 
Daugavpils pilsētas gadījumā personiskās drošības apdraudējumi ir iekḷauti visās pašvaldības attīstības plānošanas rīcībpolitikās. No labas pārvaldỉbas perspektīvas tas tiek vērtēts atzinīgi. Papildus pilsētas pašvaldỉbas plānošanas dokumentos katram draudam, kas tika identificēts personiskās drošības sektorā, ir izstrādāta atsevišķa rīcību stratēọija, kas ir attēlota atbildīgo iestāžu darbības un attīstības stratēgijās. Analīzes rezultātā tika secināts, ka attīstības plānošanas dokumentu izstrādes laikā tika ievērots pēctecỉbas un hierarhijas princips. Diemžēel preventīvā rīcībpolitika Daugavpils pilsētas pašvaldībā nav izstrādāta, tāpēc iedzīvotāji nav informēti, kā viṇiem rīkoties, sastopoties ar personiskās drošỉbas sektora draudiem.

Tāpat kā Madonas novada pašvaldībai, Daugavpils pilsētas pašvaldībai nav izstrādāts civilās aizsardzības plāns, kas vismaz pastarpināti iekḷautu pašvaldības un iedzīvotāju rīcības virzienus personiskās drošības draudu mazināšanai. Līdzīgi kā citās pašvaldībās, Daugavpils pilsētā ir pieņemta virkne saistošo noteikumu, kas pastarpināti regulē pašvaldības rīcību personiskās drošības draudu mazināšanā. Piemēram, saistošie noteikumi Nr. 6 "Par sabiedrisko kārtību", Nr. 46 "Daugavpils pilsētas pašvaldības materiālais atbalsts mazaizsargātajām personām”, Nr. 13 "Daugavpils pilsētas pašvaldības atbalsts ārkārtējā situācijā sakarā ar Covid-19 izplatību"45 u. c.

Daugavpils pilsētas pašvaldībai ir sniegts atzinīgs vērtējums par starpiestāžu koordināciju. Pētijuma gaitā tika secināts, ka tā tiek īstenota efektīvi. Katrai pašvaldības iestādei ir definēts savs atbildības lauks un iespējamās rīcības personiskās drošības draudu mazināšanai.

\section{Madonas novada pašvaldība}

Pētijuma gaitā fokusa grupu diskusijas tika veiktas gan ar Madonas pilsētas, gan ar L,audonas iedzīvotājiem. Savukārt pašvaldību rīcības kontekstā abas pašvaldības tika analizētas kopā kā Madonas novada pašvaldība. ${ }^{46}$ Madonas novada pašvaldības stratēgiskā attīstība, līdzīgi kā Talsu novada, Rēzeknes pilsētas un Daugavpils pilsētas pašvaldību attīstība, ir nostiprināta divos savstarpēji pakārtotos un saistītos dokumentos - Madonas novada ilgtspējīgas attīstības stratēgijā 2013.-2038. gadam un Madonas novada attīstības programmā 2013.-2020. gadam. ${ }^{47}$ Ilgtspējīgas attīstības stratēǵija 2013.-2038. gadam ir

45 Daugavpils pilsētas pašvaldība (2020). Saistošie noteikumi. Pieejams: https://www.daugavpils.lv/ pasvaldiba/dokumenti/normativie-akti?type=saistosie\&status-ok=true

46 Madonas novads tika izveidots 2009. gadā 6. jūnijā, un tajā ietilpst 14 pagasti, kā arī novada centrs Madona. Pieejams: https://www.madona.lv/lat/pagasti

47 Madonas novada pašvaldība (2020). Novada attīstības plānošanas dokumenti. Pieejams: https:// www.madona.lv/lat/attistibas-programma-un-strategija 
pakārtota gan nacionālā, gan regiionālā līmeņa attīstības plānošanas dokumentiem (Vidzemes plānošanas reǵiona ilgtspèjīgas attīstības stratēgija 2030 un Vidzemes plānošanas reǵiona teritorijas plānojums 2007.-2027. gadam ${ }^{48}$ ).

Madonas novada pašvaldỉbas ilgtspējīgas stratēgijas vīzija tiek pakārtota trīs stratēgiskiem mērķiem - "1. Madonas novads - pašpietiekams, ar attīstītu uzñēmējdarbību, kas sekmē produktu un pakalpojumu ar augstu pievienoto vērtību radīšanu, balstoties uz inovatīvām tehnologijām un savstarpējo sadarbību; 2. Mērķis ir vērsts uz iedzīvotāju, ipaši jauniešu palikšanu un atgriešanos novadā, nodrošinot augstu dzīves kvalitāti, kultūras, izglītības, sporta, atpūtas u. c. iespējas; 3. Dabiska, droša dzīves vide ir balstìta uz gudru, ilgtspējīgu dabas resursu un dabas resursu apsaimniekošanu, saglabājot tās unikalitāti un daudzveidību" ${ }^{\prime 9}$. Saskaṇā ar šiem mērḳiem pētījuma gaitā tika secināts, ka fokusa grupās raksturotie personiskās drošỉbas sektora draudi un rīcības virzieni to mazināšanai tiek daḷēji atspoguḷoti novada attīstības plānošanas dokumentos. Pastarpināti tiek raksturoti šādi pašvaldības rīcības virzieni personiskās drošības draudu mazināšanā: fiziskā drošība - ceḷu un infrastruktūras uzlabošana/uzturēšana, ${ }^{50}$ izglìtības sistēmas pieejamība - izglìtìbas kvalitātes attīstǐšana, ceḷot kopējo iedzīvotāju inteliǵenci, veselības sistēmas pieejamība un sociālā aizsardzība - augsta veselības aprūpes un sociālo pakalpojumu kvalitāte. ${ }^{51}$ Lìdz ar to var secināt, ka novada pašvaldības un iedzīvotāju skatījums uz galvenajiem personiskās drošības apdraudējumiem ir līdzīgs. Apdraudējumi ir konsekventi iekḷauti visos pašvaldības stratēgiskās attīstỉbas plānošanas dokumentos.

Madonas novada attīstìbas programmā 2013.-2020. gadam definēti kvalitatīvi izmērāmi rezultāti un rīcības virzieni fokusa grupu diskusiju laikā definētiem personiskās drošības draudiem. Indivīdu fiziskās drošības draudu mazināšanai, sabiedriskās kārtības uzlabošanai un drošas vides radīšanai pašvaldība plāno pilnveidot videonovērošanas sistēmas problemātiskajās pilsētas vietās un izstrādāt saistošos noteikumus videonovērošanas kamerās fiksēto

48 Vidzemes attīstības aǵentūra (2015). Vidzemes plānošanas régiona ilgtspèjīgas attīstības stratēǵija 2030. Pieejams: http://jauna.vidzeme.lv/upload/VIDZEMES_PLANOSANAS_REGIONA_ILGTSPEJIGAS_ATTISTIBAS_STRATEGIJA.pdf

49 Madonas novada pašvaldība (2013). Madonas novada pašvaldības ilgtspējīgas attīstības stratēgija 2013.-2038. gadam. Pieejams: https://www.madona.lv/lat/box/files/PlanosanasDokumenti/attstbas_ stratija.pdf

50 Šis pašvaldības rīcības virziens ir saistīts ar indivīdu fizisko drošỉbu uz ielām un pastarpinātā veidā veicinās uzṇēmējdarbību. Rezultātā pieaugs indivīdu drošuma sajūta par savu sociālo nodrošinājumu.

51 Madonas novada pašvaldība (2013). Madonas novada pašvaldības ilgtspējīgas attīstības stratēǵija 2013.-2038. gadam. Pieejams: https://www.madona.lv/lat/box/files/PlanosanasDokumenti/attstbas_ stratija.pdf 
pārkāpumu publiskošanai. Lai izglìtības sistēmas pakalpojumi būtu pieejami, pašvaldība plāno analizēt un optimizēt visu novada pašvaldību iestāžu pakalpojumus, paplašināt skolu un PII pakalpojumus (noteikt specializāciju), izveidot profesionālās ievirzes un interešu izglîtỉbas filiāles ārpus novada centra. Pašvaldībā ir izstrādāts Madonas novada izglīiības iestāžu tìkla attīstîbas plāns 2016.-2023. gadam, ${ }^{52}$ kurā raksturota pašvaldības izglìtības iestāžu tīkla attīstība. Šis plāns ir paredzēts fokusa grupu diskusiju laikā identificēto draudu (zema izglīīibas kvalitāte, skolu tīkla optimizācija) mazināšanai. Veselības aprūpes pakalpojumu pieejamības veicināšanai pašvaldība plāno izveidot pacientu viesnīcu, paplašināt Madonas slimnīcu, izveidot dienas stacionāru, atvērt diennakts aptieku. Savukārt novada iedzivotāju minēto sociālās aizsardzības draudu mazināšanai pašvaldība plāno ieviest sociālā darba pakalpojumu kvalitātes novērtēěanas sistēmu..$^{53}$

No labas pārvaldes perspektīvas var secināt, ka personiskās drošības draudi un rīcības virzieni to mazināšanai ir iekḷauti visās pašvaldības attīstības plānošanas rīcībpolitikās. Rīcībpolitiku izstrādes gaitā tiek ievērots pēctecības un hierarhijas princips. Iekḷautie rīcības virzieni personiskās drošỉbas draudu mazināšanai ir izmērāmi un atbilstoši situācijai. Pētījuma rezultātā tika secināts, ka pašvaldībā nav izstrādāta neviena preventìva rīcíbpolitika, kas informētu sabiedrību, kā rīkoties, sastopoties ar sabiedrības drošības draudiem.

Madonas novada pašvaldībā nav izstrādāts arì civilās aizsardzības plāns, kas vismaz pastarpināti iekḷautu rīcības virzienus personiskās drošības draudu minimizēšanai. Lìdzīgi kā citās pētỉjuma gaitā analizētajās pašvaldībās, Madonas novada pašvaldībā ir pieņemta virkne saistošo noteikumu, kas nosaka pašvaldības rīcību situācijās, kad tiek apdraudēta indivīdu personiskā drošība. Piemēram, uz indivīdu sociālo aizsardzību attiecas saistošie noteikumi Nr. 13 "Par sociāliem pakalpojumiem Madonas novadā" un Nr. 15 "Par Madonas novada pašvaldības sociālajiem pabalstiem”, uz indivīdu fizisko drošību - saistošie noteikumi Nr. 30 "Par sabiedrisko kārtību Madonas novadā"54 u. c. Izvērtējot starpiestāžu koordināciju, pētījuma gaitā tika secināts, ka tā tiek īstenota efektīivi. Katrai pašvaldības iestādei ir definēts savs atbildības lauks un iespējamās rīcības personiskās drošỉbas draudu mazināšanai.

52 Madonas novada pašvaldība (2016). Madonas novada izglītības iestāžu tīkla attīstības plāns 2016.2023. gadam. Pieejams: https://www.madona.lv/lat/get.php?o=1\&f=filelists/1459512792-izglitibas_ plans_2016.pdf

53 Madonas novada pašvaldība (2013). Madonas novada attīstības programma 2013.-2020. gadam. Rīcības plāna rezultatìvie rādìtāji. Pieejams: https://www.madona.lv/lat/box/files/Planosanas Dokumenti/ap_rcbas_plna_rezulttatvie_rdtji.pdf

54 Madonas novada pašvaldība (2020). Madonas novada pašvaldības saistošie noteikumi. Pieejams: https://www.madona.lv/lat/pasvaldibas-saistosie-noteikumi 


\section{Gulbenes novada pašvaldība}

Līdzīgi kā Madonas novada pašvaldībā, Gulbenes novada pašvaldỉbas stratēgiskā attīstîba ir nostiprināta divos savstarpēji saistìtos plānošanas dokumentos - Gulbenes novada ilgtspējīgas attīstïbas stratēgijā 2014.-2030. gadam un Gulbenes novada attīstības programmā 2018.-2024. gadam. ${ }^{55}$ Abas rīcībpolitikas ir pakārtotas gan nacionālā, gan reǵionālā līmeṇa attīstỉbas plānošanas dokumentiem. ${ }^{56}$ Rìcíbpolitiku kvalitatīvās analīzes rezultātā pētỉjuma gaitā tika secināts, ka Gulbenes novada attīstîbas stratēgiskā vīzija ir "sakopti lauki, daudzveidīga lauksaimnieciskā ražošana un pārstrāde, inovatīvi ražošanas uzņēmumi, kvalitatīvi pakalpojumi, uzturēta kultūrvide un vēstures pieminekḷi, pievilcīga lauku un pilsētvides ainava, aktīva sabiedriskā dzīve, sociālā iekḷaušana - pamats dzīvošanai, strādāšanai, atpūtai un dzìves līmeņa kvalitātes paaugstināšanai katrā gimenē un novadā kopumā”' ${ }^{57}$. Definētās vīzijas realizēšana tiek balstīta uz trim pīlāriem - 1) sabiedrība, 2) ekonomika un labklājība un 3) kultūrtelpa un dzīvesvide.

Pīlāri, kas veido novada attīstības vīziju, tiešā veidā atspoguḷo pašvaldības rīcības virzienus personiskās drošības draudu mazināšanā, kuri tika identificēti fokusa grupu diskusiju laikā. Indivīdu fiziskās drošības draudu mazināšanā pašvaldība veicina visu iedzīvotāju tiesisko drošǐbu, un izglitî̉bas sistēmas pieejamības draudu mazināšanā pašvaldība nodrošina pieejamu, kvalitatīvu vispārējo izglìtību, plašas interešu izglìtỉbas un tālākizglìtības iespējas. Savukārt veselības aprūpē pašvaldība nodrošina novada iedzīvotāju pieejamību kvalitatīvai veselības un sociālai aprūpei. ${ }^{58}$ Lai mazinātu personiskās drošības draudus, ko pašvaldība ir aktualizējusi Gulbenes novada attīstības programmā 2018.-2024. gadam, ir izstrādāts rīcības plāns, kas paredz konkrētus, kvalitatīvi izmērāmus rezultātus draudu minimizēěanā.

Saturiski attīstības programmas rīcības plāns tiek strukturēts atbilstoši definētiem pīlāriem, kuriem ir pakārtoti attiecīgi rīcības virzieni. Katram rīcības virzienam pašvaldības mērogā ir definēta atbildīgā institūcija un izmērāms rezultativitātes rādītājs. Lai mazinātu indivīdu fiziskās drošības draudus, pašvaldība pilnveido pašvaldības policijas darbỉbas un materiāltehnisko bāzi, īsteno preventīvus drošības pasākumus (dažādas izglītošanas kampaṇas)

55 Gulbenes novada pašvaldība (2020). Plānošanas dokumenti. Pieejams: https://www.gulbene.lv/ lv/doks/pld

56 Vidzemes plānošanas reǵiona ilgtspējīgas attīstības stratēǵija 2030 un Vidzemes plānošanas reǵiona teritorijas plānojums 2007.-2027. gadam

57 Gulbenes novada dome (2016). Gulbenes novada ilgtspējīgas attīstības stratēǵija 2014.-2030. gadam. Gala redakcija. Pieejams: https://www.gulbene.lv/images/att/pasv/dokum/pl/strat30-GalaIAS_2030_ uz23.03.2016_.pdf

58 Turpat. 
un sadarbību ar citām institūcijām (piem., Valsts policiju), kas ir atbildīgas par sabiedriskās kārtības nodrošināšanu. Lai veicinātu izglìtỉbas sistēmas pieejamību, pašvaldība izvērtē iestāžu tìklu un dažādo izglîtības programmas. Veselïbas aprūpes pakalpojumu pieejamības veicināšanai un draudu mazināšanai pašvaldībā tiek nodrošināta primārās veselības aprūpes pakalpojumu pieejamība un isstenots veselības profilakses projekts. Novada iedzīvotāju sociālās aizsardzības drošuma sajūtas veicināšanai pašvaldība attīsta daudzveidīgu sociālo pakalpojumu klāstu. ${ }^{59}$ Pašvaldības skatījums pilnībā sakrìt ar novada iedzīvotāju subjektīvo skatījumu uz personisko drošību un draudu definēšanu. Līdz ar to var secināt, ka personiskā drošỉba tiek aktualizēta kopienas līmenī.

Analizējot Gulbenes novada pašvaldības attīstības plānošanas dokumentus, pētijuma gaitā tika secināts, ka personiskās drošības draudi un pašvaldības rīcibas virzieni to mazināšanai ir definēti visās pašvaldības attīstības plānošanas rīcībpolitikās. Šo rīcībpolitiku izstrādes gaitā no labas pārvaldes perspektīvas ir ievērots pēctecības un hierarhijas princips. Salīdzinājumā ar citām pašvaldībām Gulbenes novada pašvaldībā ir vērojama biežāka rīcībpolitiku aktualizēšana, tāpēc tika secināts, ka personiskās drošỉbas apdraudējumi tiek laicīgi aktualizēti. Gulbenes novada pašvaldībā nav izstrādāta neviena preventīvā rīcībpolitika, kas informētu sabiedrību par tās rīcību, sastopoties ar personiskās drošības draudiem. Pozitīvi ir vērtējams Gulbenes novada pašvaldības civilās aizsardzības plāns, ${ }^{60}$ kas pastarpināti definē pašvaldības rīcību katastrofu vai draudu gadījumā. Tomēr šis plāns neinformē sabiedrību par rīcību personiskās drošības draudu gadījumā. Turklāt nav skaidrs, kad šis plāns tika pieņemts un aktualizēts pašvaldībā.

Informētību par rīcību, sastopoties ar personiskās drošîbas draudiem, līdzīgi kā citās pašvaldībās, Gulbenē regulē virkne saistošo noteikumu, piemēram, sociālās aizsardzības jomā - saistošie noteikumi Nr. 7 "Par sociālajiem pabalstiem”, Nr. 7 (2015) "Par materiālo palīdzību Gulbenes novadā”, Nr. 30 "Par veselïbas aprūpes pabalstu Gulbenes novadā”b1 u. c.

Izvērtējot starpiestāžu koordināciju, pētỉjuma gaitā tika secināts, ka tā tiek īstenota efektīivi. No labas pārvaldes perspektīvas atzinīgi tiek vērtēts tas, ka katrai pašvaldības iestādei ir definēts savs atbildības lauks un iespējamās rīcības personiskās drošības draudu mazināšanai.

59 Gulbenes novada dome (2018). Gulbenes novada attīstības programma 2018.-2024. gadam. Rīcības plāns 2018.-2024. gadam. Pieejams: https://www.gulbene.lv/images/att/pasv/dokum/Att_progr_1824/AP2018-2020Ricibas_plans.pdf

60 Gulbenes novada dome (n. d.). Gulbenes novada civilās aizsardzības plāns. Pieejams: https://www. gulbene.lv/images/att/pasv/dokum/ca/CA_plans.pdf

61 Gulbenes novada dome (2020). Sociālo atbalstu reglamentējošie saistošie noteikumi. Pieejams: https://www.gulbene.lv/lv/doks/snot/138-sa 


\section{Aizkraukles novada pašvaldība}

Aizkraukles novada pašvaldībā ir izstrādātas vairākas novada stratēgiskās attīstības rīcíbpolitikas, ${ }^{62}$ bet personiskās drošǐbas draudi un rīcības to mazināšanai ir definēti tikai Aizkraukles novada ilgtspējīgas attīstības stratēgijā 2014.-2025. gadam un Aizkraukles novada ilgtspèjīgas attīstības programmā 2014.-2020. gadam. ${ }^{63}$ Abi plānošanas dokumenti ir izstrādāti, ievērojot hierarhijas principu dokumentu izstrādē. Praksē tie ir pakārtoti gan nacionālā, gan reǵionālā līmeṇa attīstības plānošanas dokumentiem (Zemgales plānošanas regiona ilgtspējīgas attīstības stratēgija 2015-2030; Zemgales plānošanas reǵiona attīstibas programma 2015-2020). ${ }^{64}$

Ilgtspējīgas attīstības stratēgijas 2014.-2025. gadam vīzija ir "līdzsvarota un ilgtspējīga uz zināšanām balstīta sabiedrības attīstība, veicinot cilvēku dzīves kvalitātes pieaugumu un zinātņietilpīgas ekonomikas attīstību"65. Analīzes rezultātā tika secināts, ka stratēgijā personiskās drošỉbas sektora draudi tika identificēti pastarpināti un l̦oti virspusēji. Šai attīstības vĩzijai ir pakārtotas trīs vidējā termiṇa prioritātes - "1. Profesionālā un augsti kvalificēta darbaspēka un radošas pilsoniskās sabiedrības attīstǐšana; 2. Daudzpusīgas ekonomikas [..] veicināšana; 3. Dzīves kvalitātes uzlabošana, veicinot aktīvu un veselīgu dzīves veidu"66. Šîs prioritātes neaptver visus personiskās drošības sektora draudus, kas tika definēti fokusa grupu diskusiju laikā. ${ }^{67}$

Izvērtējot Aizkraukles novada stratēgiskās plānošanas dokumentus no labas pārvaldes perspektīvas, tika secināts, ka dokumentu izstrādes gaitā tiek ievērots pēctecības un hierarhijas princips. Attīstības plānošanas rīcībpolitikas ir pakārtotas gan nacionālā, gan reg̣ionālā līmeņa attīstības plānošanas dokumentiem. Rīcībpolitiku izstrādē ir vērojama pēctecība un konsekvence. Tomēr attīstības plānošanas dokumentos nav definēti visi personiskās drošības draudi, kas tika identificēti fokusa grupu diskusiju laikā. Normatīvo aktu izmaiṇas

62 Energétikas rīcības plāns (2018), Aizkraukles novada Daugavas ūdenskrātuves koncepcija (2018), kas neattiecas uz personiskās drošỉbas sektoru, līdz ar to šî pētījuma rezultātā šie plānošanas dokumenti netiek analizēti.

63 Aizkraukles novada pašvaldība (2020). Attīstības plānošanas dokumenti. Pieejams: http://www. aizkraukle.lv/lv/pasvaldiba/attistibas-planosanas-dokumenti/attistibas-programma/

64 Zemgales plānošanas reg̣ions (2020). Zemgales regiona plānošanas dokumenti. Pieejams: https:// www.zemgale.lv/attistibas-planosana/planosanas-dokumenti/category/32-zemgales-regiona-planosanas-dokumenti

65 Aizkraukles novada dome (2014). Aizkraukles novada ilgtspējīgas attīstības stratēǵija 2014.2025. gadam. Pieejams: http://aizkraukle.lv/wp-content/uploads/2018/01/aizkraukles_novada_ ilgtspejigas_attistibas_strategija.pdf

66 Turpat.

67 Aizkraukles novada dome (2014). Aizkraukles novada ilgtspējīgas attīstības programma 2014.2020. gadam. Pieejams: http://aizkraukle.lv/wp-content/uploads/2018/01/attistibas_programma 2014-2020.pdf 
biežums ir optimāls, to pamato pašvaldības un iedzīvotāju vienots skatījums uz personiskās drošỉbas draudiem.

Līdzīgi kā citās pašvaldībās, kurās personiskās drošỉbas draudi tika identificēti kā vieni no lielākiem (intensīvākiem) draudiem, Aizkraukles novadā nav izstrādāta neviena preventīva rīcỉbpolitika, kas informētu sabiedrību, kā rīkoties, sastopoties ar personiskās drošības draudiem. Pašvaldībā ir izstrādāta virkne saistošu noteikumu par to, kādu atbalstu sniedz pašvaldība, ja tās iedzīvotāji sastopas ar apdraudējumu personiskās drošības jomā. Tie ir: indivīdu fiziskās drošỉbas nodrošināšanā - saistošie noteikumi Nr. 306 "Aizkraukles novada sabiedriskās kārtības noteikumi”, sociālā aizsardzībā - saistošie noteikumi Nr. 2019/21 "Par Aizkraukles novada pašvaldỉbas sociālajiem pabalstiem", Nr. 2019/31 "Par materiālajiem pabalstiem Aizkraukles novadā", Nr. 2018/12 "Par sociālajiem pakalpojumiem Aizkraukles novadā”‘6 u. c. Salīdzinājumā ar pilsētu pašvaldībām (Rēzekni, Daugavpili) saistošo noteikumu skaits ir mazāks un paredz mazāk rīcību personiskās drošibas sektora draudu mazināšanai.

Līdzīgi kā Rēzeknes pilsētas pašvaldībā, Aizkraukles novadā nav izstrādāts civilās aizsardzības plāns, kur pašvaldība varētu pastarpināti aprakstīt tās rīcību, sastopoties ar personiskās drošības sektora draudiem. Tā vietā Aizkrauklē ir nodibināta Aizkraukles sadarbības teritorijas civilās aizsardzības komisija un 2018. gadā apstiprināts tās darbības nolikums. Nolikumā atrunāts komisijas sastāvs, funkcijas un apziṇošanas kārtība krīzes situācijās. Nolikums paredz, ka apziņošanas pārbaudes notiek divas reizes gadā. ${ }^{69}$ Savukārt, izvērtējot starpiestāžu koordināciju kā vienu no labas pārvaldes indikatoriem, Aizkraukles novada gadījumā tā tiek vērtēta apmierinoši. Visos plānošanas dokumentos ir definētas gan atbildīgās institūcijas, gan institūciju rīcība gadījumos, ja novada iedzīvotājs saskaras ar personiskās drošības sektorā definētiem draudiem.

\section{Valmieras pilsētas pašvaldība}

Valmieras pilsētas pašvaldības stratēgiskā attīstība ir nostiprināta divos savstarpēji pakārtotos attīstības plānošanas dokumentos - Valmieras pilsētas ilgtspējīgas attīstības stratēgijā 2015.-2030. gadam un Valmieras pilsētas attīstības programmā 2015.-2020. gadam..$^{70}$ Lìdzīgi kā Madonas novada pašvaldības gadījumā, Valmieras pašvaldības plānošanas dokumenti ir pakārtoti gan

68 Aizkraukles novada pašvaldība (2020). Saistošie noteikumi. Pieejams: http://www.aizkraukle.lv/lv/ pasvaldiba/dokumenti/saistosie-noteikumi/

69 Aizkraukles novada dome (2019). Aizkraukles sadarbības teritorijas civilās aizsardzības komisijas nolikums. Nr. 2018/2. 29.03.2019. Aizkraukles novada domes mājaslapa. Pieejams: http://www. aizkraukle.lv/wp-content/uploads/2018/04/29.03.2018._90_nolikums.pdf

70 Valmieras pilsētas pašvaldība (2020). Attīstība. Pieejams: https://www.valmiera.lv/lv/attistiba/ valmieras_pilsetas_attistibas_plans/attistibas_programma/ 
nacionālā, gan reǵionālā līmeņa (Vidzemes plānošanas regiona, skatīt sadal̦ā "Madonas novada pašvaldība") attīstības plānošanas dokumentiem.

Valmieras pilsētas ilgtspējīgas attīstības stratēgijas virsmērḳis ir iedzīvotāju labklājība. Šim virsmērḳim ir pakārtoti četri stratēgiskie mērḳi - "personības izaugsme, uzñēmējdarbības attīstība, funkcionāla, estētiska pilsētvide un iedzīvotāju sociālā un fiziskā drošība" ${ }^{\text {. }}$. Personiskās drošības sektora draudi un rīcības virzieni to mazināšanai tiek definēti divos no četriem mērḳiem "personības izaugsme, kas ilgtermiņa perspektīvā nodrošinās to, ka sabiedrība ir izglìtota, aktīva un radoša, un iedzìvotāju sociālā un fiziskā drošỉba - ilgtermiņā nodrošinās cieņu pret ğimeni kā vērtîbu, drošỉbu pilsētā, kvalitatīvu veselības aprūpi, sociālo pakalpojumu pieejamību, kā arī uz iedzivotāju vajadzībām un sadarbību vērstu pārvaldi" ${ }^{\prime 2}$. Praksē abi stratēgiskās plānošanas mērḳi iekḷauj rīcỉbas virzienus tādu personiskās drošības sektora draudu mazināšanai, kas tika identificēti fokusa grupu interviju laikā. Tie ir: indivīdu fiziskā drošỉba, izglītîbas sistēmas pieejamība un kvalitāte, veselības sistēmas pakalpojumu pieejamība un indivīdu sociālā aizsardzība.

Valmieras pilsētas attīstîbas programmas rīcības plāns paredz, ka personiskās drošỉbas draudu mazināšanai pašvaldības rūpēsies par "gimenēm atbilstošas vides nodrošināšanu, gimenes kā vērtības stiprināšanu; ${ }^{73}$ kvalitatīvas veselības aprūpes pieejamību un pilnveidi un atbilstošas infrastruktūras attīstību, ${ }^{74}$ sabiedriskās kārtības un drošības uzturēšanu pilsētā, ${ }^{75}$ sociālo aizsardzību - progresīviem un iekḷaujošiem sociāliem pakalpojumiem, preventīvo pasākumu organizēšanu un palīdzības sniegšanu krīzes situācijās"76, 77. Izvērtējot Valmieras pilsētas attīstības programmas Ikgadējo uzraudzības ziņojumu par 2019. gadu, var secināt, ka pašvaldība ne tikai definē rezultativitātes rādìtājus,

71 Valmieras pilsētas dome (2015). Valmieras pilsētas ilgtspējīgas attīstības stratēgija 2015.2030. gadam. Pieejams: https://www.valmiera.lv/sites/default/files/strategija_rl_1.40_0.pdf

72 Turpat.

73 Šis uzdevums paredz, ka pašvaldība veicinās pirmsskolas izglīīibas iestāžu pieejamību, informēs sabiedrību par ğimenes tiesību jautājumiem.

74 Šis uzdevums paredz, ka pašvaldība piesaistīs augsti kvalificētus medicīnas speciālistus, atbalstīs jaunu medicīnas pakalpojumu īstenošanu pašvaldībā, ieviesīs pacientu drošỉbas pasākumu plānu, nodrošinās Vidzemes slimnīcas telpu renovāciju un veicinās preventīvos veselības aprūpes pakalpojumus.

75 Šis uzdevums paredz, ka pašvaldība pilnveidos Valmieras pašvaldības policijas materiālo bāzi un darbỉbas, izveidos vienotu video novērošanas sistēmu, ieviesīs atskurbtuves pakalpojumus, izstrādās un periodiski aktualizēs civilās aizsardzības plānu.

76 Šis uzdevums paredz, ka pašvaldỉba sniegs kvalitativvu un uz klienta vajadzībām balstītu sociālo palīdzību un nodrošinās sociālos pakalpojumus visiem pašvaldỉbas iedzivotajiem, izveidos daudzfunkcionālu pakalpojumu centrus, veicinās jaunu sociālo pakalpojumu ieviešanu.

77 Valmieras pilsētas dome (2015). Valmieras pilsētas attīstības programmā 2015.-2020. gadam. Rīcības plāns. Pieejams: https://www.valmiera.lv/images/userfiles/Ricibas_plans_DM_5_aktualizets_ 28.01.2016.pdf 
bet arī nodrošina uzdevumu izpildi. Piemēram, 2019. gadā par 17\% ir augusi pašvaldības iedzīvotāju apmierinātỉba ar pašvaldībā pieejamiem veselības aprūpes pakalpojumiem - "iedzīvotāju vērtējums par veselíbas aprūpes pakalpojumu pieejamību 2019. gadā sastāda 53\% (2013. gadā 36\%)"78. No fiziskās drošîbas perspektīvas salīdzinājumā ar 2012. gadu Valmierā par 119 gadījumiem ir samazinājies noziedzīgo nodarījumu skaits. ${ }^{79}$ Negatīvi tiek vērtēta tikai sociālo pakalpojumu sniegšana - "salīdzinājumā ar 2013. gadu iedzīvotāju vērtējums par sociālās palīdzības pieejamību bija 49\%, šobrīd pēc pašvaldības aptaujas datiem ir 32\%" 80 .

No labas pārvaldes perspektīvas var secināt, ka personiskās drošības draudi un rīcíbas virzieni to mazināšanai ir iekḷauti visās pašvaldības attīstības plānošanas rīcībpolitikās. Dokumentu izstrādē ir ievērots pēctecības un hierarhijas princips. Līdzịgi kā citās pašvaldībās, kur personiskās drošības draudu intensitāte ir augsta, Valmierā nav izstrādāta neviena preventīva rīcỉbpolitika, ${ }^{81}$ kas informētu sabiedrību par rīcíbu personiskās drošības draudu gadījumā. Vienotas rīcībpolitikas vietā Valmierā ir pieņemti saistošie noteikumi, kas nosaka pašvaldības rīcību un iedzīvotājiem paredzēto palīdzības apjomu, saskaroties ar personiskās drošîbas draudiem. Tie ir saistošie noteikumi Nr. 334 "Valmieras pilsētas sabiedriskās kārtības noteikumi”, kas nosaka regulējumu, kā tiek nodrošināta dienestu darbỉba, lai iedzīvotāji justos fiziski droši pilsētā un pilsētas aktīvās atpūtas vietās. Saistošie noteikumi Nr. 268 "Par sociālajiem pakalpojumiem Valmieras pilsētā”, kas nosaka sociālās palīdzības saṇemšanas iespējas un apjomus iedzīvotājiem, kuri deklarēti Valmieras pilsētā. Seši saistošie noteikumi nosaka izglītības pieejamības un registrācijas kārtỉbu. ${ }^{82}$ Izvērtējot starpiestāžu koordināciju, pētījuma gaitā tika secināts, ka tā tiek ìstenota efektīvi. Katrai pašvaldības iestādei ir definēts savs atbildības lauks un iespējamās rīcības personiskās drošības draudu mazināšanai.

\section{Jaunjelgavas novada pašvaldība}

Jaunjelgavas novada pašvaldības stratēgiskā attīstība ir nostiprināta divos stratēgiski pamatotos dokumentos - Jaunjelgavas novada ilgtspèjīgas attīstības stratēóijā 2013.-2033. gadam un Jaunjelgavas novada attīstîbas programmā

78

Valmieras pašvaldības dome (2020). Valmieras pilsētas attīstības programmas ikgadèjās uzraudzībos zinojums par 2019. gadu. Pieejams: https://www.valmierasnovads.lv/dokumenti/valmieras- pilsetasattistibas-programma-2015-2020-gadam/

79 Turpat.

80 Turpat.

81 Nav izstrādāts arī civilās aizsardzības plāns.

82 Valmieras pilsētas dome (2020). Saistošie noteikumi. Pieejams: https://www.valmiera.lv/lv/pasvaldiba/ dokumenti/saistosie_noteikumi/ 
2013.-2020. gadam. Dokumentu izstrādes gaitā tika ņemts vēra gan nacionālais, gan reǵionālais konteksts. ${ }^{83}$ Jaunjelgavas novada ilgtspējīgas attīstības stratēgijijā ir izvirzịti trīs stratēgisiskie mērḳi ${ }^{84}$ kuri tikai daḷēji definē personiskās drošības draudus, kas tika identificēti fokusa grupu diskusijās. Attīstības plānošanas dokumentu analīzes rezultātā tika secināts, ka Jaunjelgavas novada pašvaldỉbas rīcỉba ir neatbilstoša laikam, dokumentu izstrādes gaitā nav ievērots pēctecības princips. Attīstības prioritātes, kurās izpaužas pašvaldības rīcība personiskās drošības draudu mazināšanā, netiek atjauninātas kopš Jaunjelgavas novada attīstības programmas 2010.-2017. gadam izdošanas. ${ }^{85}$ Piemēram, pašvaldības rīcības prioritāte "Pievilcīgu dzīves vides standartu nodrošināšana”, paredz pašvaldības rīcību sekojošu draudu mazināšanā - veselības un sociālas aprūpes pakalpojumu kvalitātes un pieejamības uzlabošanu un kvalitatīvas izglìtības iegūšanas iespēju nodrošināšanu. ${ }^{86} \mathrm{Lìdz}$ ar to tiek secināts, ka stratēgijā, kas ir hierarhiski augstākais pašvaldības plānošanas dokuments, netiek atrunātas pašvaldības rīcības indivīdu fiziskās drošības un sociālās aizsardzības veicināšanas jautājumos.

Izvērtējot Jaunjelgavas novada attīstības programmas 2013.-2020. gadam rīcības plānu, tika secināts, ka pašvaldība nav publiskojusi rezultativitātes rādītājus ${ }^{87}$ par personiskās drošības draudu mazināšanu. Attīstības programmā ir definētas tikai rīcības izglìtības sistēmas pakalpojumu pilnveidošanā "pilnveidot un regulāri atjaunot izglìtības un pirmsskolas izglìīibas iestāžu materiāltehnisko bāzi, nodrošināt izglìtības pakalpojumu pieejamību, pilnveidot esošo izglìtības programmu saturu, piesaistìt kvalificētus mācībspēkus un veicināt mūžizglìtỉbu novadā"s8. Lìdz ar to var uzskatīt, ka Jaunjelgavas

83 Abi Jaunjelgavas attīstîbas plānošanas dokumenti ir pakārtoti gan nacionālā līmeṇa, gan reǵionāla līmeṇa plānošanas dokumentiem (Zemgales plānošanas reğiona teritorijas plānojums 2006.2026. gadam).

84 1. mērḳis - izglïtotas, sociāli nodrošinātas un aktīvas sabiedrības veidošana; 2. mērḳis - konkurētspejīgas uzņēmējdarbības vides attīstība un daudzveidīgas ekonomikas veicināšana; 3. mērķis - dzīves kvalitātes uzlabošana, darba un atpūtas telpas veidošana un attīstība. Pieejams: Jaunjelgavas novada dome (2013). Jaunjelgavas novada ilgtspējīgas attīstības stratēgija 2033. Pieejams: http://jaunjelgava.lv/download/Novada_attistiba/JAUNJELGAVAS_NOVADA_ILGTSPJGAS_ ATTSTBAS_STRATIJA_2033.pdf

85 Rīcības virziena prioritāte "Pievilcīgu dzīves vides standartu nodrošināšana" kopš 2010. gada (kad tika publicēta Jaunjelgavas novada attīstības programma 2010.-2017. gadam) netiek atjaunināta, to pamato novada attīstības stratēǵija, kurā ir norādìts, ka prioritāte tika pilnībā pārṇemta no attīstības programmas.

86 Jaunjelgavas novada dome (2013). Jaunjelgavas novada ilgtspējīgas attīstības stratēǵija 2033. gadam Pieejams: http://jaunjelgava.lv/download/Novada_attistiba/JAUNJELGAVAS_NOVADA_ILGTSPJGAS_ATTSTBAS_STRATIJA_2033.pdf

87 Dati nav publiski pieejami.

88 Jaunjelgavas novada dome (2013). Jaunjelgavas novada attīstības programmas 2013.-2020. gadam. Rìcỉbu plāns. Pieejams: https://www.jaunjelgava.lv/wp-content/uploads/2020/07/Attistiibas_programma_2013.2020.pdf 
pašvaldības attīstības plānošanas dokumenti nepilnīgi atspoguḷo personiskās drošības draudus, tāpēc personiskās drošỉbas draudu mazināšana nav prioritāra pašvaldíbai.

No labas pārvaldes perspektīvas var secināt, ka personiskās drošỉbas draudi un rīcības virzieni to mazināšanai nav iekḷauti visās pašvaldības attīstības plānošanas rīcībpolitikās. Dokumentu izstrādē ir ievērots hierarhijas princips, bet nav ievērots pēctecības princips. Jaunjelgavas novadā nav izstrādāta preventīva rīcībpolitika, kas informētu sabiedrību, kā rīkoties, sastopoties ar personiskās drošības draudiem. ${ }^{89}$ Lìdzīgi ka citās pašvaldībās, arī Jaunjelgavas novada pašvaldībā ir pieņemti saistošie noteikumi, kas nosaka pašvaldības atbildības jomu personiskās drošības draudu mazināšanā. Piemēram, "Jaunjelgavas novada sabiedriskās kārtības noteikumi”, "Par Jaunjelgavas novada Sociālā dienesta sniegtajiem maksas pakalpojumiem”, saistošie noteikumi Nr. 12 "Par sociālo pakalpojumu sniegšanas kārtību Jaunjelgavas novadā” u. c. ${ }^{90}$ Izvērtējot starpiestāžu koordināciju, pètijuma gaitā tika secināts, ka Jaunjelgavas pašvaldībā tā tiek īstenota formāli. Salīdzinājumā ar citām pašvaldībām Jaunjelgavas pašvaldībā netika norādītas rīcỉbas virziena atbildīgās institūcijas. Atbildība par konkrētas rīcības īstenošanu tika vispārināta, par atbildīgo katras rīcības istenošanā tika uzskatīta pašvaldība, tāpēc nav iespējams noteikt starpiestāžu koordināciju personiskās drošîbas draudu mazināšanā.

\section{Liepājas pilsētas pašvaldība}

Liepājas pilsētas pašvaldības stratēgiskā attīstība ir nostiprināta divos attīstības plānošanas dokumentos - Liepājas pilsētas ilgtspējīgas attīstības stratēgíjā līdz 2030. gadam un Liepājas pilsētas attīstības programmā 2015.-2020. gadam. Abi dokumenti ir izstrādāti, ievērojot hierarhijas principu, papildus tie, tāpat kā citu pašvaldību gadījumā, ir pakārtoti gan nacionālā, gan reǵionālā līmeņa attīstības plānošanas dokumentiem (Kurzemes plānošanas reǵiona ilgtspējīgas attīstības stratēǵija 2015.-2030. gadam, Kurzemes plānošanas reǵiona attīstības programma 2015.-2020. gadam $^{91}$ ).

Liepājas pilsētas ilgtspējīgas attīstības stratēgijas virsmērķis ir "stiprināt Liepājas lomu un atpazīstamību starptautiskā mērogā, piesaistot pilsētai

89 Jaunjelgavā ir izstrādāts civilās aizsardzības plāns - DUS “Sērene”, bet tas nav saistošs personiskās drošības draudu mazināšanā. Papildus pētījuma gaitā tika secināts, ka pašvaldības mājaslapā šis plāns nav pieejams (skat.: https://www.jaunjelgava.lv/pasvaldiba/dokumenti/civilas-aizsardzibasplans-dus-serene/).

90 Jaunjelgavas novada dome (2020). Saistošie noteikumi. Pieejams: https://www.jaunjelgava.lv/pasvaldiba/dokumenti/saistosie-noteikumi/

91 Kurzemes plānošanas reǵions (2020). Reǵiona plānošanas dokumenti. Pieejams: https://www. kurzemesregions.lv/darbibas-nozares/attistibas-planosana/regiona-planosanas-dokumenti/ 
zinošus un radošus cilvēkus, investīcijas, tūristus" ${ }^{\prime 2}$. Virsmērḳim ir pakārtoti pieci pašvaldības rīcības virzieni. ${ }^{93}$ Pastarpināti rīcības personiskās drošības draudu mazināšanai ir definētas divos rīcības virzienos - "Liepājnieki un viṇu labklājība" un "Liepājas dzìvesvide". Šis rīcības virziens iezīmē pašvaldības darbības sfēras, kas ir domātas pašvaldības veselības aprūpes pakalpojumu pieejamības un kvalitātes uzlabošanai, izglītības sistēmas pakalpojumu pieejamības un kvalitātes uzlabošanai, indivīdu sociālās aizsardzības stiprināšanai un (fiziskās) drošības veicināšanai pašvaldībā.

Liepājas pilsētas attīstības programmas rīcību plāns ${ }^{94}$ paredz šādas pašvaldības rīcības personiskās drošības sektora draudu mazināšanai: izglìitibas sistēmas pakalpojumu kvalitātes uzlabošanai un pieejamībai - "kvalitatīvas pirmsskolas izglitības un vietu nodrošinājums PII, skolēnu prasmju attīstīšana un karjeras plānošana vispārizglïtojošās skolās, efektīva vispārizglītojošo skolu tīkla izveide, kvalificētu pedagogu piesaiste un starptautiski konkurētspējīgas augstākās izglìtības veicināšana" "95; veselības aprūpes pakalpojumu kvalitātes uzlabošanai un pieejamībai - "veselības aprūpes nodrošinājums, kas paredz gan kvalitatīva medicīniskā personāla piesaisti, gan Liepājas reğionālās slimnīcas kapacitātes stiprināšanu" "indivīdu fiziskās drošîbas un sociālās aizsardzības nodrošināšanai - "attīstīt starpnozaru profesionālo sadarbības pieeju sociālo pakalpojumu sniegšanas jomā, sekmēt iedzīvotāju drošỉbu uz ielām (ielu infrastruktūras atjaunošana)"97.

Izvērtējot Liepājas pilsētas attīstības programmas ikgadējo uzraudzības ziņojumu par 2019. gadu, līdzīgi kā Valmieras pilsētas pašvaldības gadījumā, tika secināts, ka pašvaldība ne tikai definē rezultativitātes rādītājus, bet arī nodrošina uzdevumu izpildi. Piemēram, 2019. gadā salīdzinājumā ar 2017. gadu, atbildot uz jauniem izaicinājumiem personiskās drošības jomā, tika paplašināts sociālo pakalpojumu klāsts (no 24 līdz 26 pakalpojumiem), par četriem darbiniekiem pieaug piesaistīto medicīnas darbinieku skaits. ${ }^{98}$ Saskaņā ar

92 Liepājas pilsētas pašvaldība (2017). Liepāja 2030. Pieejams: https://faili.liepaja.lv/liepaja_strategija_2030.pdf

93 Stratēǵijas virsmērķa sasniegšanai tiek izvirzītas četras pašvaldības rīcības stratēǵijas: 1. Liepājnieki un viņu labklājība; 2. Liepājas dzīvesvide; 3. Liepājas ekonomika; 4. Liepājas sasniedzamība un atpazīstamība; 5. Liepājas telpiskā perspektīva. Skatīt: Liepāja 2030. Pieejams: https://faili.liepaja.lv/liepaja_strategija_2030.pdf

94 Saskaṇā ar normatīviem aktiem rīcību plāns Liepājas pilsētas pašvaldībā tiek atjaunināts katru gadu.

95 Liepājas pilsētas dome (2015). Liepājas pilsētas attīstības programma 2015.-2020. gadam. Rīcību plāns. Pieejams: https://faili.liepaja.lv/strategiska_dala_23_01_2015.pdf

96 Turpat.

97 Turpat.

98 Liepājas pašvaldības dome (2020). Uzraudzības ziņojums. Pieejams: https://faili.liepaja.lv/Dokumenti/Dokumentu-biblioteka/Stratēgiijas-nozaru-plāni/Uzraudzibas-zinojums_par-2019_1.pdf 
aptaujas datiem " $80 \%$ no respondentiem pozitīivi vērtē sabiedrisko kārtību un drošỉbu pašvaldībā, $59 \%$ sniedz pozitīvu vērtējumu izglītîbas sistēmas pakalpojumiem pašvaldībā, savukārt, kritiskāks vērtējums no iedzīvotājiem tika saņemts par veselības aprūpes pakalpojumiem pašvaldībā, kur tikai $39 \%$ vērtē pozitīi un $55 \%$ kritiski un sociālo pakalpojumu pieejamību pozitīvi novērtēja tikai 42\%"99.

Liepājas pilsētas pašvaldībā nav izstrādāta neviena preventīva rīcībpolitika, kas informētu sabiedrību par rīcību personiskās drošības sektora draudu gadījumā. ${ }^{100}$ Lìdzīgi kā citās pašvaldībās, Liepājā ir pieņemta virkne saistošo noteikumu, kas satur informāciju par pašvaldíbas un iedzivotāju rīcību, sastopoties ar personiskās drošības sektora draudiem. Piemēram, saistošie noteikumi Nr. 30 "Liepājas pilsētas sabiedriskās kārtības saistošie noteikumi” nosaka regulējumu, lai iedzīvotāji justos fiziski droši pilsētās un pilsētas atpūtas vietās. Indivīdu sociālās aizsardzības jomā ir pieņemti 19 saistošie noteikumi, kas nosaka sociālās palīdzības veidu un apmēru pašvaldībā. Savukārt par izglìtības pakalpojumu sniegšanu (pieejamību) pašvaldībā ir atbildīga Izglìiības pārvalde, kas ik gadu izstrādā detalizētu rīcību plānu izglītỉbas sistēmas pakalpojumu kvalitātes uzlabošanai. Piemēram, Izglìtības pārvaldes rīcỉbu plāns 2020./2021. mācību gadam balstās uz četriem pīlāriem - "1. Izglītỉbas saturs, izglìtības kvalitātes izvērtēšana un pilnveidošana; 2. Pedagogu profesionālā kapacitāte; 3. Materiāltehniskās bāzes un finanšu resursu efektīva izmantošana; 4. Jēgpilnas sadarbïbas veicināšana"101. Veselības aprūpes jomā ir pieņemti saistošie noteikumi gan par pakalpojumu klāstu, gan par iedzīvotāju iespējām saņemt veselïbas aprūpes pabalstu - saistošie noteikumi Nr. 13 "Par pabalstu veselïbas aprūpē"102.

Izvērtējot starpiestāžu koordināciju kā vienu no labas pārvaldes indikatoriem, pētījuma gaitā tika secināts, ka Liepājas pilsētas pašvaldībā tā ir efektīva. Katrai personiskās drošības sektora draudu jomai ir izraudzītas atbildīgās iestādes, kuras darbojas, lai minimizētu draudus. Analīzes gaitā tika secināts,

99 Latvijas Fakti (2020). Sabiedriskās domas aptauja Liepājā. Pieejams: https://faili.liepaja.lv/Dokumenti/Dokumentu-biblioteka/Pārskati-publikācijas-ziṇojumi/Iedzivotaju_telefonaptauja_2020_ Latvijas_Fakti.pdf

100 Liepājā 2013. gadā ir publicēts civilās aizsardzības plāns, kura mērḳis ir "novērst vai mazināt katastrofu iespējamo apdraudējumu cilvēku dzīvībai un veselībai, kaitējumu īpašumam un videi”, tomēr rīcỉbas, kā rīkoties, sastopoties ar personiskās drošības apdraudējumiem, tas neiekḷauj (skatīt: Liepājas pilsētas pašvaldības civilās aizsardzības plāns. Pieejams: https://faili.liepaja.lv/Dokumenti/ Dokumentu-biblioteka/Pārskati-publikācijas-ziṇojumi/CA_PLans_2013.pdf

101 Izglīīibas pārvalde (2020). Liepājas pilsētas Izglītības pārvaldes darba plāns - rīcības 2020./2021. mācību gadam. Pieejams: https://faili.liepaja.lv/Dokumenti/Dokumentu-biblioteka/Stratēgijas-nozaru- plāni/Liepajas-izglitibas-parvaldes-darbaplans-ricibas-2020-2021.pdf

102 Liepājas pilsētas dome (2020). Saistošie noteikumi. Pieejams: https://www.liepaja.lv/veselibasaprupes-pabalsts/ 
ka katrai iestādei ir skaidri nošķirts tās atbildības lauks un darbības sfēra. Kopumā Liepājas pilsētas pašvaldības attīstības plānošanas dokumentu analīzes rezultātā tika secināts, ka personiskās drošības draudi un rīcības virzieni to mazināšanai ir iekḷauti visās pašvaldības attīstības plānošanas rīcībpolitikās. Dokumentu izstrādē ir ievērots pēctecības un hierarhijas princips. Normatīvo aktu izmaiṇas biežums ir atbilstošs situācijai un identificētiem draudiem.

\section{Secinājumi}

Apkopojot pētijuma gaitā iegūtās atziṇas par Latvijas iedzīvotāju personiskās drošības sektora draudiem, tika identificēti četri intensitātes ziņā visspilgtākie apdraudējumi. N̦emot vērā identificēto draudu intensitāti, draudi tika strukturēti hierarhiskā kārtībā (no zemākā uz augstāko): 1) indivīdu fiziskā drošība - vai var justies droši uz ielām un savā pašvaldībā; 2) izglìtības sistēmas pakalpojumu pieejamība un kvalitāte - cik kvalitatīvi ir izglîtības iestāžu sniegtie pakalpojumi, vai ir (fiziski) pieejamas skolas, pirmsskolas izglìtības iestādes un augstākās izglīīibas iestādes; 3) veselības aprūpes sistēmas pakalpojumu pieejamība un kvalitāte - vai ir bailes saslimt, vai ir pieejami veselības aprūpes pakalpojumi un to cenas; 4) indivīdu sociālā aizsardzība - vai ir iespēja nodrošināt sev un savai ğimenei iztiku, vai ir bailes zaudēt darbu, vai ir iespēja saṇemt pabalstu u.c.

Salīdzinot iegūtos datus ar pētījumiem, kas tika veikti līdz šim, ir vērojama neliela personiskās drošǐbas sektora identificēto draudu maiņa. Piemēram, Žanetas Ozoliṇas redakcijā publicētajā pētijumā (2012) visbiežāk minētie personīgās drošības sektora draudi bija indivīdu fiziskās drošības un sociālās aizsardzības draudi. ${ }^{103}$ Starp biežāk minētiem draudiem tika identificētas bailes no vardarbības. Šis apdraudējums tika identificēts arī sabiedriskās domas aptaujās. Savukārt šajā pētījumā nevienā fokusa grupu diskusijā bailes no vardarbības netika identificētas kā personiskās drošỉbas drauds.

Raksturojot galvenos personiskās drošības sektora draudus, gan iedzīvotājiem, gan pašvaldību darbiniekiem ir bijis kopējs skatijums uz subjektīiem apdraudējumiem. Atšķirīgi ir novērtēta pašvaldības rīcība personiskās drošības draudu mazināšanā. Iedzīvotāji fokusa grupu diskusijās kritiskāk vērtēja pašvaldības darbu draudu minimizēšanā. Savukārt pašvaldību darbinieki savu darbu vērtēja atzinīgāk un par efektīva pašvaldības darba galveno traucēkli

103 Ozoliṇa, Ž. (red.) (2012). Cilvēkdrošǐba Latvijā un pasaulē: no idejas lìdz praksei. Rīga: Zinātne, 63. lpp. 
minēja pašvaldību attiecỉbas ar valdību. Liepājas un Talsu pašvaldību amatpersonas uzsvēra, ka iedzīvotājiem nav skaidra priekšstata par to, kādu jautājumu risināšana ir pašvaldības (pilsētas domes - novada - reg̣iona) atbildībā un kompetencē un no kurienes tiek piesaistīts finansējums konkrētajai jomai. Tādẹl vietējās pašvaldībās bieži vien rodas spriedze, jo iedzīvotāji griežas pie tām, lūdzot palīdzēt risināt jautājumus, kas nav pašvaldību kompetencē. Analīzes rezultātā tika secināts, ka Kurzemes un Vidzemes reǵiona pašvaldību iedzīvotāji un lēmumu pieṇēmēji daudz vairāk paļaujas uz sevi, nevis uz pašvaldības "labumiem"/rīcībām. Savukārt Zemgalē un Latgalē izteiktāks bija viedoklis, ka iedzīvotājiem ir tiesības prasît un saņemt gan sociālo drošỉbu, gan izglìtîbu un citus pakalpojumus no valsts un pašvaldỉbas, neiedziļinoties, kuri pakalpojumi ir valsts kompetencē un kuri pašvaldỉbas kompetencē.

Pašvaldību darbinieki intervijās centās uzsvērt pašvaldību attīstībā pozitīvo un problēmjautājumus apiet vai ignorēt. Šāda rīcība var tikt pamatota ar to, ka ne visās analizētajās pašvaldībās rūpējas par personiskās drošības sektora draudu mazināšanu. Pētijuma gaitā tika secināts, ka ne visu pašvaldību attīstības plānošanas dokumentos ir iekḷauti personiskās drošỉbas sektora apdraudējumi un minētas rīcíbas to mazināšanai. Analizējot šos dokumentus, tika secināts, ka ir pašvaldību grupa (piemēram, Jaunjelgavā), kas attīstības programmu nevērtē regulāri, tāpēc attīstības plānošanas dokumenti netiek laicīgi atjaunināti. 


\title{
Hibrīddraudi
}

\author{
SIGITA STRUBERGA, RUTA CEPLE
}

Hibrīddraudu konceptam ir pieaugoša nozīme izpratnes veidošanā par drošỉbas fenomena daudzdimensionālo dabu mūsdienās. Pasaulē ir izstrādāta virkne pētỉjumu, kas pamatā raksturo hibrīddraudus kā arvien biežāk lietotu valsts un nevalstisku aktoru naidīgu, koordinētu rīcỉbu, kas ietver divus vai vairākus draudus vienlaikus un ir vērsta uz kaitējuma nodarīšanu mērḳa valstij. Latvijā līdz šim veiktā hibrīddraudu pētniecība galvenokārt tikusi koncentrēta uz Krievijas Federācijas realizētajām ietekmes aktivitātēm. Daudz mazāk uzmanības pievērsts hibrīddraudu uztveres īpatnībām un to ietekmei uz politiskajiem procesiem. Šajā nodaḷā analizēts Latvijas iedzīvotāju skatījums par viṇu apdraudētību šādās hibrīddraudu grupās: informācijas drošība; ārēja iejaukšanās valsts iekšêjās lietās; kiberuzbrukumi; infrastruktūras un energêtikas drošỉba; drošîba pret cilvēku izraisītiem apdraudējumiem/katastrofām. Līdzās iedzīvotāju subjektīvās uztveres analīzei apskatīts arì tas, kā un vai vietējās pašvaldības reagẹe uz iedzīvotāju bažām par hibrīdajiem apdraudējumiem. Analīzes rezultātā secināts, ka Latvijas iedzīvotāji identificē atsevišķas hibrīddraudu grupas kā būtiskus izaicinājumus savai drošìbai. İpaši tas attiecas uz informatīvajiem draudiem un kiberdraudiem, kā arī uz iespējamu iejaukšanos valsts iekšèjās lietās. Savukārt rīcībpolitikas analīze pašvaldỉbu līmenī liecina par to, ka tās reti saredz savu lomu drošibas stiprināšanā hibrīddraudu sektorā.

Atslēgvārdi: hibrīddraudi, civilā aizsardzība, propaganda, kiberdrošība, kritiskā infrastruktūra.

The concept of hybrid threats is playing an increasingly important role in raising awareness of the multidimensional nature of the security phenomenon. Several worldwide studies characterise hybrid threats as increasingly hostile, with actions being coordinated by governmental and non-governmental actors and consisting of the simultaneous use of two or more threats to the detriment of the target country. So far, the research on hybrid threats in Latvia has mainly focused on the activities carried out by the Russian 
Federation. Much less attention has been paid to the peculiarities in the perception of hybrid threats and their impact on political processes. This chapter of the book analyses the views of the Latvian population regarding their vulnerability in the following hybrid threat groups: information security, external interference in the internal affairs of the state, cyber-attacks, infrastructure and energy security, and safety against man-made hazards/disasters. In addition to analysis of the subjective perception of the population, this chapter also examines how and whether local governments respond to the population's concerns regarding hybrid threats. It is concluded that the population of Latvia identifies certain groups of hybrid threats as significant challenges to their security. This applies to information and cyber threats, as well as possible interference in internal affairs. On the other hand, analysis of policy-making processes at the local government level shows that local governments rarely identify their role in strengthening security in the sector of hybrid threats.

Keywords: hybrid threats, civil protection, propaganda, cyber security, critical infrastructure.

\section{levads}

Hibrīddraudi šobrīd tiek uzskatīti par vienu no visplašāk diskutētajiem draudu veidiem ne tikai drošības studijās, bet arī valstu politiskajās, mediju un sabiedrību dienaskārtībās. Šim konceptam piešḳirta pieaugoša nozīme izpratnes veidošanā par drošības fenomena daudzdimensionālo dabu. Hibrīddraudu dažādu formu identifikācija palīdz gūt ieskatu tajā, kā mūsdienās tiek apdraudēta starptautiskā, nacionālā, grupu vai pat atsevišku indivīdu drošỉba. Tomēr daudz mazāk sabiedrība un politiḳi runā par hibrīddraudu uztveres īpatnībām un to ietekmi uz politiskajiem procesiem.

Šobrīd ar hibrīddraudiem visbiežāk tiek saprasta valsts un nevalstisku aktoru naidīga, koordinēta rīcība, kas ietver divus vai vairākus draudus vienlaikus un ir vērsta uz kaitējuma nodarīšanu mērķa valstij, ietekmējot lēmumu pieņemšanu vietējā, reǵionālā, valsts vai starptautiskā institucionālā līmenī. Šādas aktivitātes var tikt realizētas kā politiskajā, ekonomiskajā, informācijas vidē, tā arī citās sabiedrības dzīves sfērās. Tām piemīt maskēts raksturs un mainīga intensitāte. ${ }^{1}$ Starp hibrīddraudu veidiem minēti, piemēram, informācijas draudi (tai skaitā propaganda un dezinformācija, un manipulācijas masu

Hybrid CoE. Brief Introduction to Hybrid Threats. Pieejams: https://www.hybridcoe.fi/what-is-hybridcoe/; Chivvis, S. C. Understanding Russian "Hybrid Warfare" and What Can be Done About It. The RAND Corporation; European Commision. Joint Communication to the European Parliament and the Council. Joint Framework on countering hybrid threats. A European Union response. Pieejams: https://eur-lex.europa.eu/legal-content/EN/TXT/?uri=CELEX\%3A52016JC0018 
medijos); stratēǵiski nozīmīgas informācijas nopludināšana; atbalsts nevalstiskām organizācijām, kas vēršas pret režīmu; atbalsts dumpiniekiem (tai skaitā masu protestu organizācijai); atbalsts paramilitārām organizācijām; kiberdraudi (tai skaitā kiberspiegošana, uzbrukumi, manipulācijas); ekonomiskie draudi; draudi finanšu sektoram; korupcija; politisko partiju finansēšana; diplomātiskā spiediena taktikas; atbalsts kaujiniekiem; terorisms, atbalsts teroristiem; nedrošības sēšana; diversijas; energètikas politika; sadarbība ar kriminālām organizācijām; vēlēšanu procesa ietekmēšana. ${ }^{2}$ Tātad būtībā divu vai vairāku jebkuru draudu veidu sajaukums potenciāli var veidot jaunu draudu jeb hibrīddraudu formu. Bet, apskatot šì brīža diskusijas par hibrīddraudu dažādību, secināms, ka mūsdienās ir mainījušās jau ilgstoši pazīstamu draudu lietojama kombinācijas un intensitāte. Jaunpienākuši ir vien tie, kas saistīti ar kibertelpu un digitālo vidi. ${ }^{3}$ Tiesa, mēgeinājumi konceptualizēt hibrīddraudus un hibrīdkaru, izceḷot to specifiku, ir salīdzinoši jauns virziens drošības studijās.

\section{Kas paveikts hibrīddraudu izpētē?}

Teorētiskie un praktiskie pētijumi, kas veikti no 21. gadsimta sākuma līdz mūsdienām, tapuši, galvenokārt reflektējot par Rietumu blokam radītajiem izaicinājumiem no salīdzinoši vājākiem pretiniekiem - Krievijas un dažādiem valstiskiem un nevalstiskiem aktoriem Tuvo Austrumu reǵionā. Pēdējā desmitgadē šim aktoru lokam pievienojusies arī Ķīnas Tautas Republika. Tomēr bieži tiek uzsvērts, ka diskusijas par hibrīddraudu nozīmi īpaši aktualizējās gan starptautiski, gan arī Latvijā pēc tam, kad Ukrainas krīzes agrīnajās fāzēs Krievijas Federācija bija aktīvi izmantojusi konvencionālos un plaša spektra nekonvencionālos līdzekḷus situācijas destabilizācijai., ${ }^{4}$

2 Treverton, G. et al. (2018). Addressing Hybrid Threats. Swedish Defence University; European Centre of Excellence for Countering Hybrid Threats. Countering Hybrid Threats. Web page of Hybrid CoE. Pieejams: https://www.hybridcoe.fi/wp-content/uploads/2020/07/Treverton-AddressingHybridThreats.pdf; Bajarūnas, E., Keršanskas, V. Hybrid Threats: Analysis of Content, Challanges Posed and Measures to Overcome. Lithuanian Annual Strategic Review, Vol. 16, 2017-2018. Vilnius: Military Academy of Lithuania. Pieejams: https:/content.sciendo.com/view/journals/lasr/16/1/ article-p123.xml?language $=$ en

3 Treverton, G. et al. (2018). Addressing Hybrid Threats. Swedish Defence University. p. 9.

4 Šajā sakarā bieži tiek piesaukta Gerasimova doktrīna, kas moderno karadarbību apraksta kā militāro un nemilitāro instrumentu lietojumu politisku mērḳu sasniegšanai. Par šīs doktrīnas attīstības pirmavotu tiek uzskatīts Krievijas Federācijas Bruņoto spēku (Вооружённые силь Российской Федерациน) G̦enerālštāba priekšnieka Valērija Gerasimova 2013. gadā piedāvātais raksts Krievijas armijas laikrakstā "Kara Rūpniecības Kurjers” (Военно-промышленный курьер). Tajā, analizējot 21. gs. sākumā notikušos konfliktus, viṇš secināja, ka ir ievērojami pieaugusi nekonvencionālo līdzekḷu izmantošanas loma politisku un stratēgisku mērḳu sasniegšanā. Viṇa ieskatā, tie pierādījuši, ka ir daudz efektīvāki nekā ieroču lietojums. Tāpat arī viņš norādīja uz tiem instrumentiem, 
Baltijas jūras reǵiona valstīs, apzinoties jaunos drošības izaicinājumus, līdzās atbilstošu rīcíbpolitiku veidošanai tika meklēti papildu instrumenti potenciālo apdraudējumu apzināšanai un to novēršanai. Tāpēc gadsimta otrajā desmitgadē aizsākās jaunu ekspertīzes un izcilības centru izveides process, un šobrīd ir iespējams runāt par vairākiem šādiem reǵionāli un starptautiski nozīmīgiem centriem, kas nodarbojas ar hibrīdapdraudējuma problemātiku. ${ }^{6}$ Rezultātā ir izstrādāts ievērojams apjoms pētỉjumu un dažāda rakstura ziņojumu, kas l̦āvis iespējot lēmumu pien̦ēmējus drošības stiprināšanai.

Latvijā hibrīddraudu pētniecība galvenokārt tikusi koncentrēta uz Krievijas lietotajiem ietekmes līdzekḷiem un stratēgijām. Tomēr dienaskārtībā ienāk arī jauni izaicinājumi, piemēram, Ķīnas radītie hibrīdapdraudējumi. Šobrīd ir uzkrāts ievērojams zināšanu apjoms par hibrīddraudu spektru, to darbïbas mehānismiem. Ir arī identificēti vairāki nozīmīgākie šo draudu avoti. Šāda veida hibrīddraudu izpēte ir sniegusi gan teorētisku ieguldījumu akadēmiskajās diskusijās par dažādiem drošỉbas aspektiem, gan arī praktisku ieguldijjumu atbilstošu rīcībpolitiku izstrādei un sabiedrības izturētspējas celšanai.

Sabiedriskās domas aptaujas liecina, ka Latvijas iedzīvotāji ir noraizējušies par to, ka karš un konflikti varētu apdraudēt viņu drošību. ${ }^{7}$ Par nozīmīgāko ārējo apdraudējumu Latvijas un Eiropas drošībai vairāk nekā puse Latvijas

kas šādā gadījumā izmantoti. To skaitā, viṇaprāt, minami politiskie, ekonomiskie, informatīvie, humanitārie un citi elementi, kam piemīt spēja veicināt iedzīvotāju protesta potenciālu. Savukārt konvencionālie līdzekḷi karadarbības vešanai šādā gadījumā darbojas tikai drīzāk kā papildinošs elements, visbiežāk slēptā veidā un konflikta noslēguma stadijās (Герасимов, В. Ценность науки в предвидении. Новые вызовы требуют переосмыслить формы и способы ведения боевых действий. Военно-промышленный курьер, 26.02.2013. Pieejams: https://www.vpk-news.ru/articles/14632)

5 Līdzīgas darbības tiek aprakstītas, skaidrojot tādus konceptus kā asimetriskie draudi, nelineāras operācijas, pilna spektra konflikts, neregulārā karadarbība, politiskā karadarbība, nekonvencionālā karadarbība, neierobežotā karadarbība vai 4. paaudzes karadarbība.

6 Baltijas valstīs darbojas trīs NATO akreditēti izcilības centri, katrs no tiem savu darbību koncentrē uz kādu no būtiskākajiem hibrīddraudu veidiem. Igaunijā 2012. gadā tika izveidots NATO Kiberaizsardzības izcilības centrs, Lietuvā 2013. gadā - Energētikas drošības centrs, bet Latvijā 2014. gadā - NATO Stratēgiskās komunikācijas centrs, Igaunijā - Kiberdrošības izcilības centrs, Lietuvā - Enerǵijas drošỉbas izcilības centrs, Latvijā - Stratēgiiskās komunikācijas izcilības centrs. Tie raksturojami kā zināšanu mezgli, domnīcas un mācību institūcijas. Savukārt Somijā kopš 2017. gada darbojas pirmā NATO un ES kopējā institūcija hibrīddraudu novēršanai un apkarošanai - Eiropas izcilības centrs cīņai ar hibrīdapdraudējumu. Tas pēta un analizē hibrīddraudus, kalpo par platformu valstu pieredžu apmaiņai un labo prakšu pārnesei, kā arī veicina ES un NATO sadarbību hibrīddraudu apkarošanai dalībvalstīs un veic dažādu līmeņu izglītojošo darbu. Līdzās šiem izcilības centriem Baltijas jūras reg̣iona valstīs darbojas vairākas reǵionāla un lokāla mēroga domnīcas un centri, kas nodarbojas ar pētnieciskām un sabiedrību izglītojošām aktivitātēm.

7 70\% Latvijas iedzīvotāju satrauc tas, ka karš un konflikti varētu negatīi ietekmēt valsti (Krumm, R. et al. (2019). Security Radar 2019. Wake -up Call for Europe. 2019. Vienna: FES Regional Office for Cooperationand Peace in Europe, pp. 44-45). 
iedzīvotāju uzskata Krievijas Federāciju. ${ }^{8}$ Latvijas sabiedrības izpratnē par būtiskiem apdraudējumiem hibrīddraudi ieņem nozīmīgu vietu. Īpaši iedzīvotājus satrauc hibrīddraudi informācijas vidē. Piemēram, tirgus izpētes uzṇēmuma "Latvijas Fakti" 2015. gada aptaujā Latvijas Nacionālās aizsardzības akadēmijas Drošības un stratēgiskās pētniecỉbas centra vajadzībām $61 \%$ aptaujāto Latvijas iedzīvotāju uzskatīja, ka viens no svarīgākajiem valsts drošỉbas stiprināšanas pasākumiem ir Latvijas mediju apraides nodrošināšana pierobežā. ${ }^{9}$ Bet, saskaņā ar Eirobarometra aptaujas 2018. gada datiem, 74\% aptaujāto Latvijas iedzīvotāju ir nobažījušies par dezinformāciju (disinformation and misinformation) interneta vidē. ${ }^{10}$

\section{Hibrīddraudu jēdziens}

Notikumi starptautiskajā vidē 21. gadsimta sākumā veicināja būtiskas izmaiņas draudu izpratnē, tāpēc lēmumu pieņēmēji pārskatīja savas drošības politikas stratēgijas un atbilstošos plānošanas dokumentus. Bet akadēmiskajā vidē jaunie teorētiskie un praktiskie izaicinājumi, ar ko sastapās ārējās un drošỉbas politikas veidotāji, kḷuva par pamatu jauniem konceptualizācijas un teoretizēšanas mēéginājumiem, un rezultātā tika izstrādāta jauna pieeja hibrīddraudiem.

Teorētisko un praktisko diskusiju transformācijas noteikušas to, ka šobrīd ne vienmēr hibrīdās karadarbības izpratnē konvencionāā karadarbība tiek uzskatīta par neatņemamu komponenti. Hibrīdā karadarbība var tikt potenciāli identificēta, tikai balstoties uz nekonvencionālās karadarbības elementu atpazīšanu. Šāda pieeja hibrīddraudu izpratnei paredz, ka pretinieks ofensīvā hibrīdā operācijā sākotnēji identificē sociālpolitisko kontekstu ${ }^{11}$ un tos mērḳa valsts nozīmīgos sektorus, kur iespējams atrast ievainojamību. Šādi sektori var būt, piemēram, valsts pārvaldes aparāts, starptautiskās sadarbības tìkli, nacionālās aizsardzības spējas, iekšējā drošîba, valsts ekonomikas un finanšu sektors,

8 Diamant, J. Ethnic Russians in Some Former Soviet Republics Feel a Close Connection to Russia. 24.07.2017. Pieejams: https://www.pewresearch.org/fact-tank/2017/07/24/ethnic-russians-in-someformer-soviet-republics-feel-a-close-connection-to-russia/; Krumm, R. et al. (2019). Security Radar 2019. Wake-up Call for Europe! Vienna: FES Regional Office for Cooperationand Peace in Europe, p. 44.

9 Bērziṇa, I. (red.) u. c. (2015). Sabiedrības destabilizācijas iespējamība Latvijā: potenciālie nacionālās drošỉbas apdraudējumi. Rīga: Latvijas Aizsardzības akadēmijas Drošỉbas un stratēgiskās pētniecības centrs, 19. lpp.

10 Eurobarometer 2018.

11 McCulloh, T., Johnson, R. (2013). Hybrid Warfare. Joint Special Operations University Report, No. 13-4, August 2013, pp. 14-17. Pieejams: https://www.socom.mil/JSOU/JSOUPublications/ JSOU\%2013-4_McCulloh\%2CJohnson_Hybrid\%20Warfare_final.pdf 
kibertelpa, infrastruktūra, iedzīvotāju veselība, labklājība un sociālā dzīve, ieskaitot kultūru un izglītību. Izvēloties šos mērḳus, tiek lietotas tādas pieejas, ko raksturo neparedzamība un dažādu elementu savienošana, maldināšanas un diversiju taktikas. ${ }^{12}$ Šāda paplašināta pieeja ḷauj ieraudzìt un skaidrāk nodalīt hibrīddraudus no hibrīdkara, piedāvājot divas savstarpēji saistītas, tomēr neidentiskas konceptuālās kategorijas.

Lai izvērtētu Latvijas iedzīvotāju hibrīddraudu subjektīvo uztveri, šajā nodạ̦ā ir operacionalizēts hibrīddraudu jēdziens un noteiktas pamatkategorijas, kas izmantotas empīrisko datu analīzē. Par vienu no darba definīcijām noderēs Eiropas izcilības centra cīṇai ar hibrīdapdraudējumu piedāvātais skaidrojums, ka hibrīddraudi ir apzināti un mērḳtiecīgi veiktas, koordinētas un sinhronizētas aktivitātes, kas vērstas pret demokrātisku valstu un institūciju vārīgumu, lai ietekmētu dažāda līmeņa lēmumu pieṇemšanu valsts augstākajā vai institucionālā līmenī realizētājam vēlamā virzienā, vienlaikus vājinot mērḳi. ${ }^{13}$ No šīs definīcijas izriet, ka hibrīddraudu avots vienmēr būs kāds konkrēts aktors, kam ir naidīgi nodomi pret mērksa valsti.

Savukārt plaši atzītu hibrīdā kara definīciju ir piedāvājis Frenks Hofmans (Frank Hoffman). Viņš noteicis, ka "hibrīdā karadarbība iekḷauj dažādas karadarbības formas, ieskaitot konvencionālo spēju lietojumu, neregulārās taktikas un formējumus, teroristiskos aktus, bezizvēles vardarbību un piespiešanu, kā arī kriminālās aktivitātes" ${ }^{\prime 4}$. Šajā definīcijā iekḷautā izpratne par hibrīdkaru, kas tiek vests, izmantojot dažādus hibrīddraudus mērḳa valstij, izmantota, uzdodot jautājumus fokusa grupu interviju dalībniekiem, lai uzzinātu iedzīvotāju domas par sabiedrības fizisko drošību potenciālās krīzes situācijās, kuras varētu būt izraisijusi mērḳtiecīga ārējo spēku rīcība. Autores apzinās šāda veida hibrīddraudu interpretācijas trūkumus, tai skaitā pastāvošās risku un draudu diversitātes analīzes ierobežojošo raksturu.

Apskatot divas piedāvātās, kā arī citas hibrīddraudu un hibrīdkara definīcijas, secināms, ka aktors, kas realizē hibrīdkaru, ar nodomu dzēš skaidras robežas starp kara un miera stāvokli. ${ }^{15}$ Tas ir spējīgs slēpt savu naidīgo rīcỉbu,

12 Cederberg, A., Eronen, P. (2015). How Can Societies be Defended Against Hybrid Threats? Strategic Security Analysis, No. 9. Geneva Centre for Security Policy, p. 3.

13 The European Centre of Excellence for Countering Hybrid Threats. Countering Hybrid Threats. Pieejams: https://www.hybridcoe.fi/hybrid-threats/

14 Hoffman, F. (2007). Conflict in the 21st Century: The Ryse of Hybrid Wars. Arlington: Potomac Institute for Policy Students, p. 14.

15 Cederberg, A., Eronen, P. (2015). How Can Societies be Defended Against Hybrid Threats? Strategic Security Analysis, No. 9. Geneva Centre for Security Policy, pp. 2, 4; Rostoks, T. (2019). The Evolution of Deterrance from the Cold War to Hybrid War. In: Dettering Russia in Europe. Defence Strategies for Neighbouring States. Ed. Rostoks, T., Vanaga, N. London and New York: Routledge and New York, p. 29. 
tāpēc ir grūtāk pamanāms gan draudu izcelsmes avots, gan dažkārt arī paši draudi. Tādējādi tiek radīti sarežğîti apstākḷi mērḳa valsts lēmumu pieņēmējiem šādu draudu novēršanai. ${ }^{16} \mathrm{Ne}$ mazākas grūtības identificēt hibrīddraudus ir arī valstu iedzīvotājiem, kas savā ikdienā reti interesējas par nacionālās drošības problemātiku vai politiku. Tādēl diskusija par hibrīddraudu uztveres īpatnībām un to ietekmi uz uzvedības stratēéijām ir nozīmīga sabiedrības izturētspējas veicināšanā.

Pētijuma analītiskā ietvara izveidei noteiktas šādas ar hibrīddraudiem saistītas drošîbas indikatoru grupas: informācijas drošība; iejaukšanās valsts iekšējās lietās / citu valstu ietekme uz valsts iekšējām lietām; kiberuzbrukumi; infrastruktūras un energeetikas drošība; drošība pret cilvēku izraisītiem apdraudējumiem/katastrofām. Draudi informācijas telpā apskatāmi vairākos līmeņos - sākot ar personisko līmeni, kur ir aktuāls jautājums par medijpratîbu un kritisko domāšanu, līdz pat nacionālajam līmenim. Tas nozīmē, ka, analizējot apdraudējumus informācijas telpā, tiks analizēta sabiedrības pārstāvju medijpratība, spēja izvērtēt piedāvāto argumentāciju, sabiedrības izturētspēja pret dezinformāciju un propagandu, uzticēšanās medijiem un citi aspekti, kas saistīti ar informācijas telpas drošîbu. Fokusa grupu intervijās respondentiem tika jautāts, kāds ir viṇu subjektīvais vērtējums par informācijas telpu, kā viṇi izprot iespējamos apdraudējumus nacionālajai drošîbai informācijas telpā.

Otrajā hibrīddraudu grupā ietverti draudi par iejaukšanos valsts iekšejās lietās, lai to destabilizētu, vājinātu vai iznīcinātu. Atbilstoši aplūkoti šādi indikatori: politiskās sistēmas destabilizācija, apšaubot pastāvošās politiskās iekārtas legitimitāti, stabilitāti, kā arī suverenitāti; plaisas starp iedzīvotājiem un valsti radīšana ar ārējo spēku organizētu grupu vai indivīdu starpniecību; uzņēmējdarbības un citu ekonomikas aktoru, kā arī finanšu sektora ietekmēšana ar ārēji atbalstītu vai kontrolētu specializētu grupējumu starpniecību; drošības situācijas destabilizācija ar slēpu ārēju un vietējas izcelsmes spēku atbalstītu militāru un paramilitāru grupējumu starpniecību. Tas nozīmē, ka šì sektora analīzei tiks izmantoti fokusa grupu intervijās paustie iedzīvotāju viedokḷi par iespējamu politisku, militāru iejaukšanos, kā arī iejaukšanos ekonomikā un subjektīvais vērtējums par to, vai un kā notikusi sastapšanās ar šādiem draudiem ikdienas dzivēe. Tātad iedzìvotājiem tiks jautāts, kā viṇi vērtē ārēju spēku vadìtu indivīdu vai grupu iespējamās aktivitātes pret pārvaldes aparātu,

16 Cederberg, A., Eronen, P. (2015). How Can Societies be Defended Against Hybrid Threats? Strategic Security Analysis, No. 9. Geneva Centre for Security Policy, pp. 2, 4; Rostoks, T. (2019). The Evolution of Deterrance from the Cold War to Hybrid War. In: Dettering Russia in Europe. Defence Strategies for Neighbouring States. Ed. Rostoks, T., Vanaga, N. London and New York: Routledge and New York, p. 3. 
etniskā naida kurināšanu un nemieru organizēšanu, vēlēšanu ietekmēšanu un balsu pirkšanu kādas trešās valsts interesēs.

Trešajā grupā iekḷauti hibrīddraudi, kas pastāv kibertelpā. Šo hibrīddraudu analīzei piemēroti šādi indikatori: ārēja avota izraisìta banku un maksājumu, citu finanšu sistēmu darbības pārtraukšana; stratēgiski nozīmīgas e-sarakstes nopludināšana; ārēja avota realizēti vai koordinēti kiberuzbrukumi valsts iestāžu mājaslapām vai kritiskiem valsts objektiem. Šajā gadījumā fokusa grupu interviju laikā pètijuma autores izvaicāja to dalïbniekus, lai noskaidrotu iedzīvotāju subjektīvo vērtējumu par drošību interneta vidē un šīs personiskās drošības saikni ar plašākām valsts un sabiedrības stratēgiskās drošības interesēm.

Ceturtajā grupā tika apkopoti tie hibrīddraudi, kas attiecas uz valsts kritisko infrastruktūru. N̦emot vērā Latvijas Republikas Nacionālās drošības likumā noteikto, ${ }^{17}$ par valsts kritisko infrastruktūru tiek uzskatīti šādi objekti: komunikāciju sektors; valsts aizsardzības objekti; neatliekamā palīdzība un sabiedrības veselības nodrošinājuma infrastruktūra kopumā; pārtikas piegāžu un lauksaimniecības sektors; finanšu pakalpojumu infrastruktūra; informācijas un tehnologiju infrastruktūra; ūdens piegāžu infrastruktūra; transporta infrastruktūra; enerǵêtikas infrastruktūra un piegāžu drošība. Tas nozīmē, ka šajā blokā skatīts iedzīvotāju subjektīvais vērtējums par valsts kritisko infrastruktūru kopumā vai par tās atsevišķu sektoru vārīgumu un ārējo apdraudējumu potenciālu.

Piektajā hibrīddraudu grupā ietverta sabiedrības fiziskā drošība pret ārējo spēku izraisītām katastrofām. Šajā jomā apskatīts iedzīvotāju subjektīvais vērtējums par to fizisko drošību potenciāli ārējo spēku izraisītu katastrofu kontekstā. Lai arī šis cieši sasaucas ar ceturtajā grupā ietvertajiem draudiem, tomēr te pamatā tiks skatīti iedzīvotāju uzskati par sabiedrības fizisko drošību potenciālās krīzes situācijās, kuras izraisijjusi mērḳtiecīga ārējo spēku rīcība.

Lai analizētu vietējās pārvaldes spēju reageèt uz hibrīddraudiem un apzinātu aktivitātes, ko tā realizējusi iedzivotāju izturētspējas pret hibrīddraudiem celšanai, izmantota labas pārvaldības rādītāju matrica, kas iekḷauj šādus rādītājus: pārvaldības sistēmas stabilitāte/prognozējamība/pēctecība; plānošanas ilgtermiṇa pieeja - ilgtermiṇa redzējums; reformu jēgpilnums - ieviešanas

17 Saskaņā ar Nacionālās drošības likumu ir noteikts, ka "kritiskā infrastruktūra ir Latvijas Republikā izvietoti objekti, sistēmas vai to daḷas, kuras ir būtiskas svarīgu sabiedrības funkciju īstenošanas, kā arī cilvēku veselības aizsardzības, drošỉbas, ekonomiskās vai sociālās labklājības nodrošināšanai un kuru iznīcināšana vai darbības traucējumi būtiski ietekmētu valsts funkciju īstenošanu (Latvijas Republikas Nacionālās drošības likums. 22. pants, 2. daḷa Pieejams: http://m.likumi.lv/doc. php?id=14011). 
efektivitāte, caurskatāmība; normatīvo aktu izmaiṇas; ierēdṇu profesionalitāte; informētîba par rīcību X stundā, preventīvās rīcībpolitikas veidošana; iestāžu koordinācija.

Lai apskatītu pārvaldības rādītājus atbilstoši piedāvātajai matricai, katrā hibrīddraudu grupā tika izraudzīti jautājumi intervijām, kas palīdzēja noskaidrot vietējo pašpārvalžu pārstāvju informētību par iedzivotāju bažām un hibrīdajiem apdraudējumiem, ar ko tie saskaras savā ikdienā. Tika pētītas analizējamo pašvaldību realizētās aktivitātes hibrīddraudu novēršanai. Šāda pieeja l̦āva izcelt gan tiešos ietekmējošos rādītājus, kas ir tieši saistīti ar drošību hibrīddraudu atpazišanā un novēršanā un kas pastāvīgi iedarbojas uz drošības uztveri, gan arī netiešos jeb fona rādītājus, kas ir saistīti ar drošîbas vidi un var ietekmēt personas neapmierinātību un diskomfortu (piemēram, normatīvo aktu izmaiṇu biežums vai ierēdṇu profesionalitāte).

\section{Latvijas iedzīvotāji par hibrīddraudiem}

Viens no nozīmīgākajiem pētījuma secinājumiem ir tas, ka Latvijas iedzīvotāji ir informēti par atsevišşu hibrīddraudu nozīmīgumu. Četrās pētītajās pašvaldībās - Aizkrauklē, Ādažos, Talsos, Daugavpilī - iedzīvotāji hibrīddraudus identificēja kā vienus no trim nozīmīgākajiem draudu veidiem, bet Latvijas sabiedrībai tie nav aktuālākie draudi. Kā nozīmīgākais hibrīdā apdraudējuma ārējais avots visos regionos tika minēta Krievijas Federācija. Atsevišķās fokusa grupās iedzīvotāji nosauca Ķinnas Tautas Republiku, tomēr nevienā gadījumā uz to netika norādīts kā uz būtisku, tūlītēju izaicinājumu Latvijas drošỉbai. Biežāk iedzīvotāji to asociēja kā svešu, ar pieaugošu starptautisko ietekmi apveltītu nezināmu aktoru, kura nodomi ir nezināmi un ilgtermiṇā varētu ap-

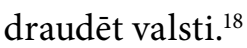

Fokusa grupu interviju laikā dalībnieki ļoti reti izmantoja vai nemaz neizmantoja jēdzienu "hibrīddraudi". Tā aprakstam tika lietoti citi apzīmējumi un dažādas izklāsta formas. Tas liecina par to, ka vairums Latvijas iedzīvotāju uzskata, ka specifiskas hibrīddraudu formas viniiem ir aktuālas. Tomēr te nav runa par visaptverošām zināšanām, kas ļautu to kontekstualizēt un skatìt izjustos apdraudējumus plašākā hibrīddraudu radìtā kaitējuma kopainā.

Vairākās fokusa grupu un pašvaldỉbu darbinieku vai amatpersonu intervijās izskanēja pārliecība par sabiedrisko mediju nozīmīgo lomu izpratnes par drošỉbu veidošanā. Tika uzskatīts: ja kādi draudi tiek aktualizēti medijos,

18 Fokusa grupu interviju rezultāti Talsos un Gulbenē. 
tas izraisa plašākas pārdomas un iedzīvotāju diskusijas, kā arī notiek izmaiņas pašvaldību dienaskārtībā - ne tikai politiskajā retorikā, bet arī atbilstošajā rīcībā.

Lai apskatītu iedzīvotāju subjektīvo drošības uztveri, uzmanība tiks vērsta uz dažādiem hibrīddraudu veidiem atbilstoši iepriekš izvirzītajām kategorijām. Uzmanības centrā bija sešas Latvijas pašvaldības, kurās aptaujātie iedzīvotāji hibrīddraudus identificējuši kā nozīmīgus. Balstoties uz pētỉjuma laikā veiktajām intervijām, tiks noteikts, vai pašvaldību pārstāvji pārzina tos draudu veidus, kas satrauc iedzìvotājus, un vai/kā tiek realizētas atbilstošas rīcībpolitikas. Analīzei tiek izmantota labas pārvaldības rādītāju matrica.

\section{Hibrīddraudi informācijas telpā}

Šo draudu veidu Latvijas iedzīvotāji atpazīst visbiežāk, identificējot tos galvenokārt ar Krievijas Federācijas izplatīto propagandu un dezinformāciju, īpaši izceḷot viltus ziņas.

Sieviete darbspējas vecumā, Valmiera: Informācijas karš jau notiek, bet nav nedz padoma, nedz lìdzekḷu, kā pret to cìnìties. Kä kontrolèt sociālo un digitālo telpu?

Tomēr atšķiras subjektīvais vērtējums par šo draudu aktualitāti individuālajā dzīvē un dažādos valsts reǵionos. Piemēram, Kurzemē, Rīgā un Pierīgā fokusa grupās aptaujātie iedzīvotāji uzskata, ka tādi informācijas draudi kā propaganda un dezinformācija attiecināmi galvenokārt uz Latgales reǵionu.

Sieviete darbspējas vecumā, Ādaži: Valsts nedara pietiekami drošības jomā. Latgalē nav valsts radio un televīzijas. Tas taču ir ideologiskais ierocis, kas skan päri robežām .. ir pat deputāti, kas to neapzinās.

Vïrietis, Liepāja: Krievijas propaganda un informācijas karš attiecas uz Latgali.

Latgalē iedzīvotāji saskatīja nozīmīgus, tomēr ne prioritārus draudus informatīvās telpas drošībai. Arī Vidzemes iedzīvotāji saskata draudus informatīvajai telpai. Aizkrauklē, Madonā un Valmierā tie tika atzīti par vieniem no nozīmīgākajiem, bet Gulbenē un Ļaudonā aptaujātie pasvītroja citu draudu sektoru lielāku aktualitāti. Lìdzīga situācija arī Zemgales reǵionā - Jaunjelgavā hibrīddraudiem piešķirta salīdzinoši mazāka nozīme.

Šādām subjektīvā vērtējuma atšķirībām starp regioniem var būt vairāki skaidrojumi. Pirmkārt, reg̣ionos ar sarežğìtāku sociālekonomisko situāciju iedzīvotāju uzmanība ir pievērsta citiem jautājumiem. Otrkārt, iedzīvotāju subjektīvajam pašvērtējumam par personisko medijpratību un noturību pret dažādām informatīvām manipulācijām Latvijā kopumā ir raksturīgs optimisms. 
Viņi uzskata, ka medijpratības vai kritiskās domāšanas izaicinājumi ir raksturīgi citiem - citai paaudzei, citu regionu, citu tautību pārstāvjiem. ${ }^{19}$

Studente, Daugavpils: Es ḷoti reti skatos televizziju, vairāk izmantoju datoru, tas ir pieejamāk. Tas ir, manuprāt, droši.

Vīrietis darbspējas vecumā, Valmiera: Informatìvais karš jau notiek visu laiku.

Un mēs kaut kādā ziṇā esam zaudējuši. Krievijas propaganda ir dažus sasniegusi.

Piemēram, vini noticējuši par to, ka neesam NATO vajadzīgi. Tas nav labi.

Savukārt citos reǵionos dzīvojošo vērtējumu par Latgales regiona iespējamo lielāko vārīgumu attiecībā uz informācijas draudiem nosaka izpratne par nacionālā sastāva īpatnībām reǵionā un fizisko atrašanos tuvāk Krievijas Federācijai, kā arī krievu valodā pārraidošo mediju piedāvātais diskurss.

Rēzeknē un Daugavpilī aptaujātie fokusa grupu dalībnieki norādījuši, ka apzinās Krievijas radītos apdraudējumus informācijas telpai, tai skaitā propagandas un viltus ziņu izplatī̌sanu.

Vīrietis darbspējas vecumā, Daugavpils: Gribētu nepiekrist, ka mūsu kaimiņam nav intereses par Latviju, jo tad uz robežas neviens neceltu televizijas torņus. Tas viss ir domäts mums un tāpēe liek aizdomäties, kāpēe kaut kas tāds ir vajadzīgs.

Tomēr vienlaikus abu pilsētu aptaujātie iedzīvotāji arī norādījuši uz Krievijas mediju telpas patēriņu, kas ir nozīmīgākais veids, kā var kḷūt par dezinformācijas un propagandas upuri.

Jaunā uzṇēmēja, Rēzekne: Pierobežas rajonos skatās krievu medijus un vairāk emocionāli jūtas piederīgi Krievijas mediju telpai.

Jaunā māminna, Daugavpils: Latvijā tas ir droši, jo nevienu reizi neesmu saskārusies ar fake news [viltus zin̄ām ${ }^{20}$. Savukārt esmu redzējusi vairākas saites uz krie$v u$ fake news un mums vajadzētu izglìtot cilvēkus par šo.

Vīrietis darbspējas vecumā, Rīga: Es nesen piecas dienas pavadīju Kijevā [..] Ko mums tie krievu mediji, ko skatos, stāsta, ka visur tur staigā fašisti, nacisti visus apzog, bezpajumtnieki dzīvo taisni uz ielas. Tie mediji biedē, ka nedrīkst runāt uz ielas krieviski, sāks sist. Nu nekā tur tāda nebija. Tie krievu mediji šādi destabilizè tavu iekšèjo drošǐbas izjūtu, biedē tevi.

19 Projektā realizēto fokusa grupu interviju rezultāti; Latvijas Fakti. Latvijas Iedzīvotāju medijpratība (2017). Latvijas Republikas Kultūras ministrijas mājaslapa. Pieejams: https://www.km.gov.lv/ uploads/ckeditor/files/mediju_politika/petijumi/Medijpratiba_petijuma\%20rezultati_Latvijas\%20 Fakti_18_07_2017.pdf

20 Tulkots no angḷu valodas. 
Latvijas medijiem iedzīvotāji piešķir svarīgu nozīmi informācijas iegūšanā. Kopumā tie bauda salīdzinoši lielāku sabiedrības uzticēšanos nekā citi sociāli vai politiski institūti. ${ }^{21}$ Tomēr atsevišksās fokusa grupās izskanējušas arī bažas par vietējo, sevišķi reǵionālo, mediju darbību un, aptaujāto ieskatā, kalpošanu kādām slēptām politiskām interesēm.

Vīrietis darbspējas vecumā, Daugavpils: Reǵionālā lìmenī mediji tiek izmantoti $k \bar{a}$ politisko spēku rupori, kas nomelno viens otru. Nacionālos medijus pie mums neizmanto.

Zīmīgi, ka atsevišḳi radikālāk noskaņoti fokusa grupu pārstāvji pauda pārliecíbu par mediju negatīvu un pat destruktīvu ietekmi uz sabiedrības drošības uztveri. Abās fokusa grupu intervijās Rīgà atsevišķi respondenti norādijja uz Latvijas mediju mēǵginājumiem, viņuprāt, apzināti veidot negatīvus iedzīvotāju uzskatus par kādiem specifiskiem notikumiem vai ārpolitiskajiem aktoriem. Viṇu minētie piemēri - kā Latvijas medijos kopumā tiek atainota migrācijas krīze Eiropā un cik intensīvas portālā "Delfi" ir negatīvās ziṇas par Krievijas agresiju, lai, viṇuprāt, iebiedētu iedzīvotājus. ${ }^{22}$ Savukārt Aizkrauklē aptaujātie norādīja uz šādiem uzskatiem kā sazvērestības teoriju izplatības rezultātiem, kas paši par sevi ir apdraudējums. Nevienā fokusa grupā citas informatīvas manipulācijas netika identificētas kā esošs vai potenciāls apdraudējums.

Hibrīddraudi informācijas vidē ir tas draudu veids, kas visās fokusa grupu intervijās tika atpazìts un pusē no tām arī tika interpretēts kā viens no nozīmīgākajiem izaicinājumiem Latvijas valstij. Par efektīvāko instrumentu propagandas un dezinformācijas ietekmes novēršanai aptaujātie visbiežāk uzskatija medijpratību un kritisko domāšanu. ${ }^{23}$ Pētijuma rezultāti apliecina, ka iedzīvotāji izprot šo divu kompetenču nozīmi drošỉbas stiprināšanā.

\section{Dažāda rakstura iejaukšanās valsts iekšējās lietās}

Fokusa grupu intervijās tie hibrīddraudi, kas vērsti uz politiskās sistēmas destabilizāciju valstī, apšaubot pastāvošās politiskās iekārtas leǵitimitāti, stabilitāti vai spēju pieņemt sabiedriski nozīmīgus lēmumus, tika vismazāk diskutēti. Lai gan mediju diskursā izskan bažas par ārējā spēka, šajā gadījumā - Krievijas -, iespējamiem mēǵinājumiem ar politisko partiju vai nevalstisku organizāciju atbalstu iedzīvotājos sēt neuzticēšanos valdībai vai citādi destabilizēt

21 Zelče, V. (2018). Latvijas mediju patēriṇa daudzveidība un ekspozīcija. No: Latvijas mediju vides daudzveidība. Zin. red. V. Zelče. Rīga: LU Akadēmiskais apgāds, 510. lpp.

22 Fokusa grupas intervija Nr. 1 Rīgā.

23 Fokusa grupas intervijas Talsos, Rēzeknē, L̦audonā, Rīgā. 
sociālpolitisko situāciju valstī, tomēr aptaujātie Latvijas iedzīvotāji nesaskata tūlītēju apdraudējumu valsts drošỉbai.

Vīrietis darbspējas vecumā, Aizkraukle: Ja partija "Saskaņa" līdz šim nav spējusi izveidot valdību, kas realizētu Krievijas interesēm atbilstošu politiku, tad diezin vai tas notiks arī nākotnē.

Vīrietis pensijas vecumā, Valmiera: Nu bet tas taču ir skaidri zināms, ka Krievija katru dienu mēgéina iejaukties Latvijas iekšèjās politiskās lietās. Tas notiek visu laiku. Bet tā nopietni mēs viņiem neesam bijuši vajadzīgi visus šos 20 gadus.

Fokusa grupu intervijās daudz tika spriests par korupciju un neskaidriem darījumiem pašvaldībās. Vēl biežāk respondenti atsaucās uz valdības nestabilitāti, kā arī minēto plaisu starp iedzīvotājiem un valdību vai centru un reǵioniem, kā arī citiem ar šo draudu grupu saistītiem izaicinājumiem. Tomēr nepieciešams pasvītrot, ka aptaujātiem iedzīvotājiem svarīga šķita galvenokārt valsts iekšējā problemātika, nevis iespējamo ārējo aktoru loma šādu problēmu izcelsmē. ${ }^{24}$ Faktiski nevienā gadijjumā fokusa grupu dalībnieki neminēja, ka korupcijas, politisko pasūtijumu vaininieki vai plaisas starp iedzīvotājiem un politiķiem vai reǵioniem un centru radītāji meklējami ārpus valsts robežām.

Savukārt fokusa grupā Rīgā vairākkārt izskanēja viedokḷi par Rietumvalstu, galvenokārt Amerikas Savienoto Valstu, spiedienu, kura rezultātā Latvijā tiek pieņemti nozīmīgi politiskie lēmumi un realizētas šĩ aktora interesēm atbilstošas rīcībpolitikas, piemēram, valsts finanšu sektorā. Vienlaikus tika norādīts arī uz politisko, un īpaši banku sektora, atkarību. ${ }^{25}$

Iejaukšanos valsts iekšèjās lietās, izmantojot ekonomikas vai finanšu instrumentus, kā potenciālu apdraudējumu minēja divās fokusa grupu intervijās - Talsos un Rēzeknē. Abos gadījumos kā šāda veida apdraudējuma avots tika minēta Krievijas Federācija.

Vīrietis darbspējas vecumā, Talsi: Krievija te ar karu nenāks. Krievi daudz investē Latvijā. Viñi ienāks savādāk - caur uznēmumiem, īpašumu nopirkšanu.

Vīrietis pensijas vecumā, Rēzekne: Varbūtība ir, ka varētu atkārtoties Ukrainas scenārijs, bet tas ir atkarīgs no iekšpolitikas, cik daudz Latgales attīstïbai no Rigas varētu sniegt atbalstu. Latgale nav atbalstīta tik daudz, lai justos droši finansiāli.

Savukārt trešais iejaukšanās veids - slēpta ārvalsts militārpersonu iejaukšanās valsts iekšējās lietās vai atbalsts bruṇotiem dumpiniekiem kā potenciāls 
apdraudējums - tika minēts vairākās fokusa grupu intervijās. Šo draudu iedzīvotāji atpazina kā "Ukrainas scenāriju", ar to saprotot Krievijas Federācijas realizēto Krimas aneksiju un agresiju Ukrainas austrumos, kad militarizētos formastērpos gèretbi bruṇoti cilvēki ar neskaidru vai slēptu valstspiederību realizēja uzbrukumus vai izdarīja spiedienu uz valsts pārvaldes iestādēm, tādējādi panākot varas gāšanu. Šāda "Ukrainas scenārija” atkārtošanos Latvijā kā iespējamu neizslēdza neviena no aptaujātajām fokusa grupām. Tomēr vairumā gadījumu respondenti piẹ̦āva, ka šāda iespējamība ir zema, pamatojot to ar Latvijas līdzdalību NATO kā drošỉbas garantu vai zemo Krievijas interesi.

\section{Kiberdraudi}

Fokusa grupu intervijas liecina, ka kopumā iedzīvotāji ir domājuši par drošības izaicinājumiem internetā. Visos Latvijas regiionos iedzīvotājus satrauc personas datu drošîba un neaizskaramība kibertelpā. Vairumam aptaujāto nav pārliecỉbas, ka viṇu dati nevar tikt ḷaunprātīgi iegūti un izmantoti. Respondenti arī izteica šaubas par to, vai banku sistēmas ir drošas pret kiberuzbrukumiem un vai individuālie neskaidras naudas uzkrājumi ir droši.

Kiberpratību, tai skaitā banku pakalpojumu nodrošinājumu ar interneta starpniecỉbu un personisko uzvedỉbu internetā, ipaši sociālajos medijos, aptaujātie Latvijas iedzīvotāji skata galvenokārt personisku draudu kontekstā. Kiberdraudus viṇi drīzāk saista ar noziedzīgiem nodarījumiem pret indivīdu, nevis ar ārējo, Latvijas valstij naidīgo spēku koordinētu rīcību, kas varētu būt vērsta uz nacionālās drošības apdraudējumu.

Sieviete darbspējas vecumā, Talsi: Banku drošība viennozīmīgi nav šajā sakarā aktuāla. Visvairāk skumdina, ka Latvijā iedzìvotājiem nav kritiskais prāts. It kāa gudrs cilvēks, bet šêro tādus rakstus. [..] Latvijā ir l̦oti izplatìta seksuālā vardarbība internetā.

Fokusa grupu interviju laikā aptaujātie arī pauda viedokḷ lus par tiešo mārketingu un personisko datu nepietiekamu aizsardzību, kā arī bezrūpīgu pieeju sociālo tìklu un citu interneta piedāvāto resursu lietojumā, kā arì par mākslīgā intelekta attīstîbas ietekmi uz informācijas telpas īpatnībām. ${ }^{26}$

Vĩrietis darbspējas vecumā, LLaudona: Māksligais intelekts ir noteikti tā problēma, ar ko jāstrādā valstiskā lìmenī, jo mēs neapzināmies, kā pakḷaujam riskam savas personiskās drošizas. 
Šie respondenti uzskatīja, ka kiberdraudi viņus apdraud potenciāli mazāk nekā citus, īpaši citu paaudžu, pārstāvjus. Par apdraudētāko sabiedrības daḷu vidējās un vecākās paaudzes pārstāvji visbiežāk nosaukuši pusaudžus un jauniešus vairāku iemeslu dēl - ilgais laiks, ko jaunieši pavada interneta vidē, medijpratības trūkums, dažāda veida kibernoziegumi (mobings, šantāža, izspiešana, seksuālā un emocionālā vardarbība). ${ }^{27}$

Sieviete pirmspensijas vecumā, Talsi: Cilvēkus, kam nav pieredzes, kas attiecas uz kritisko domāšanu interneta vidē, ir loti viegli apmuḷ̦ot. Krieva mūzikā ir slēptā reklāma, kas vedina bērnus uz kaitīgiem ieradumiem. Tã ir ḷoti liela ietekme.

Savukārt jaunākās paaudzes pārstāvji jūtas kompetenti, lietojot internetu, un norāda, ka vairāk apdraudēta ir gados vecākā sabiedrības daļa.

Jaunietis, Madona: Jaunie cilvēki jau zina, kā rīkoties internetā. Bet vecākā paaudze ir vairāk apdraudēta. Daudzi zina piemērus par vecāka gadagājuma [cilvēku] komunikāciju ar viltus Nigērijas prinčiem.

Neskatoties uz identificētajiem apdraudējumiem interneta vidē, visu vecumu respondenti atzina, ka salīdzinoši maz dara, lai sevi aizsargātu no tiem. Aptaujāto iedzìvotāju aprakstītās stratēǵijas savas personīgās drošības stiprināšanai drīzāk liecina par to, ka viṇi nepievērš pietiekamu uzmanību personisko datu drošībai un ir slikti informēti par negatīvām sekām, kādas varētu izraisìt bezrūpīga tīmekḷa lietošana.

Sieviete darbspējas vecumā, Valmiera: Täda kiberdraudu ${ }^{28}$ iespēja, protams, pastāv. Bet es par to negribu domät un satraukties.

Par jaunākās 5G mobilo sakaru tehnologijas ieviešanu kā vienu no iespējamiem izaicinājumiem Latvijas sabiedrības drošỉbai tika diskutēts trīs fokusa grupu intervijās - Aizkrauklē, Ādažos un Jaunjelgavā. Ādažos un Jaunjelgavā par tās iespējamo bīstamību daļai respondentu bija bažas - viṇi domāja, ka tā var kaitēt veselībai, bet Aizkrauklē uzskatīja, ka runas par potenciālo kaitīgumu rodas sazvērestības teorijas izplatības rezultātā. Respondentu sniegtās atbildes liecina, ka kvalitatīvas žurnālistikas materiāli, kas kliedē aplamos pieṇēmumus, kā arī oficiālo amatpersonu sniegtie skaidrojumi ir vairojuši sabiedrības informētîbu.

Kiberdrošỉbas problemātiku nevienā fokusa grupā respondenti neizcēla kā prioritāru izaicinājumu valsts un sabiedrības drošîbai. Potenciālie

28 Runājot par datu drošību internetā. 
kiberuzbrukumi valsts iestāžu mājaslapām, banku sistēmai vai kritiskās infrastruktūras objektiem netika minēti kā nozīmīgs apdraudējums valsts un sabiedrības drošỉbai.

Sieviete darbspējas vecumā, Valmiera: Es zinu, ka kiberdrošỉba iestāžu mājaslapām ir ikdienas jautājums. Arī manā darba vietā. Tomēr es par to neuztraucos, par to uztraucas citi algoti cilvēki.

Iespējams uzbrukums valsts institūcijām interneta vidē tika minēts tikai vienā fokusa grupā Talsos, raksturojot Krievijas agresijas potenciālo izpausmi Latvijā.

Vīrietis pensijas vecumā, Talsi: Krievija mūs iekaros ar interneta starpniecību.

Tātad iedzīvotājiem trūkst informācijas par to, ka ar kibervides instrumentu starpniecību var apdraudēt nacionālo drošību. Varbūt tās trūkums skaidrojams tādējādi, ka nenotiek plašākas publiskas diskusijas par draudiem ar interneta vides rīku starpniecību kā vienu no valsts nacionālās drošìbas lielākajiem izaicinājumiem.

\section{Valsts kritiskā infrastruktūra}

Ceturtais hibrīddraudu veids saistīts ar iespējamiem uzbrukumiem kritiskajai infrastruktūrai vai ar kritiskās infrastruktūras vārīguma izmantošanas potenciālu ārējā naidīgā spēka interesēs. Respondentu visbiežāk minētais kritiskās infrastruktūras elements bija transporta infrastruktūra, norādot uz ceḷu kvalitāti kā vienu no nozīmīgākajiem izaicinājumiem..$^{29}$

Vīrietis darbspējas vecumā, Daugavpils: Infrastruktūra Daugavpils pašvaldībā nav drošībā. Tilts pāri upei ir arī, piedodiet, drošǐba. Gribēšu redzēt, kā tanks var pārbraukt pāri mūsu tiltam.

Sieviete darbspējas vecumā, Gulbene: Ceḷi ir kritiskā stāvoklī. Nav iespējams izbraukt. Ne velti prezidents uz šejieni lidoja ar helikopteri, lai nebūtu jābrauc pa celiem.

Vienīgi Aizkraukles novadā respondenti pauda, ka ceḷu kvalitāte nodrošināta, pateicoties ne tikai valstij, bet arī ar pašvaldỉbai.

Starp citiem izaicinājumiem transporta sistēmā minēts arī degvielas uzpildes staciju tīklojums.

Vīrietis darbspējas vecumā, Jaunjelgava: Mums nav degvielas uzpildes stacijas. Degviela šeit cilvēkiem ir problēma. Ir tālu jābrauc, lai pie tās tiktu. 
Valsts aizsardzības objektu infrastruktūra tika pieminēta intervijās Ādažos un Liepājā - apdzīvotās vietās, kurā atrodas lielākās militārās bāzes valstī. Abos gadījumos iedzīvotāji atzina, ka to tuvums rosina aizdomāties par personisko drošību, tomēr uzskatīja, ka šo objektu klātesamība vienlaikus ir drošību veicinošs faktors. Nevienā gadījumā respondenti neizteica bažas par šo objektu vārīgumu. ${ }^{30}$

Kritiskās infrastruktūras objekts - Aizkraukles hidroelektrostacija - tika minēts divās fokusa grupās - Aizkrauklē un Jaunjelgavā. Aizkrauklē iedzīvotāji jūtas droši un atzīmēja augstu informētību kā vienu no nozīmīgākajiem faktoriem, kas ietekmējis to drošîbas uztveri.

Vīrietis darbspējas vecumā, Aizkraukle: Es paḷaujos uz atbildīgajām iestādēm, tās zina, kas jādara, noteikti ir plāns un drošǐba tiek nodrošināta.

Jaunjelgavā situācija ir atšķirīga, jo respondenti jau ilgstoši izjūt nozīmīgas bažas par savu drošíbu.

Vïrietis darbspējas vecumā, Jaunjelgava: Nozìmīga problēma, kas šeit mūs uztrauc no bērnības, ir Aizkraukles HES. Krïzes situācijā mēs būsim zem üdens. Padomju laika kartēs rakstìts, ka mūsu vieta ir diezgan nedroša.

Savukārt jautāti par to, vai ir pieejama informācija par atbilstošiem drošības pasākumiem krīzes situācijā, respondenti atbildēja visai nekonkrēti, uzsverot, ka pašvaldībā kaut kas tiekot darìts, un vienlaikus norādot, ka drīzāk tā ir valsts vadïbas kompetence.

Iespējamie apdraudējumi valsts robežām nevienā fokusa grupā netika uzskatīit par nozīmīgu šì brīža izaicinājumu valsts drošỉbai. Arī pilsētās, kas atrodas salīdzinoši tuvu valsts robežai, šis jautājums netika uzlūkots kā būtisks. Savukārt lokāla mēroga pārrobežu sadarbība drīzāk tika uzskatīta kā iespēja ekonomiskās attīstības veicināšanai, nevis sektors, kurā iespējami apdraudējumi. Aptaujātie Daugavpils iedzīvotāji norādīja, ka labprātāk redzētu centrālās varas neiejaukšanos šajā jomā. ${ }^{31}$

Izaicinājumi, kas saistīti ar pārtikas piegāžu un lauksaimniecības sektoru, fokusa grupu intervijās iedzīvotājiem nelikās nozīmīgi valsts drošîbai. Lai arī aptaujātie Rīgas iedzīvotāji pieskārās, viṇuprāt, pakāpeniskai lauksaimniecības iznīcināšanas politikai Latvijā, tomēr tā netika identificēta kā būtisks drauds sabiedrības drošỉbai.

Hibrīddraudi energeêtikas sektorā netika minēti starp nozīmīgākajiem draudiem. Latvijas energêetikas sistēmas vārīgumu respondenti uzskata par

30 Fokusa grupu intervijas Ādažos un Liepājā.

31 Fokusa grupas intervija Daugavpilì. 
izaicinājumu tikai Rīgas fokusa grupas intervijas laikā. Kopumā pētỉjumā atklājās, ka, lai gan iedzīvotājus satrauc iespējamais energoresursu piegādes pārtraukums, tomēr reālāks apdraudējums tiem šķiet energoresursu cenu kāpums, nevis kāda politiskā šantāža. Piemēram, Talsos respondenti norādīja, ka būtu jāmazina energoresursu atkarība no Krievijas ekonomisku apsvērumu dēl, nevis tādēl, ka Krievija to varētu instrumentalizēt geopolitisku mērķu sasniegšanai, lai gan diskusijas turpinājumā minēja Ukrainas piemēru, kur arī konflikta sākumā un vēlāk bija Ukrainas un Krievijas Federācijas domstarpības par naftas tranzīta cenām. Talsos minēja arī to, ka Latvijā uzmanīgi jāvēro Vācijas un Krievijas ekonomisko interešu tuvināšanās, jo Vācija ir stratēǵisks partneris un sabiedrotais Eiropas Savienības un NATO ietvaros un sadarbojas ar Krievijas Federāciju, un tas var nebūt mūsu interesēs. Paralēli citiem draudu sektoriem šis hibrīddraudu veids tiek asociēts ar valsts pārvaldes nacionālo līmeni, bet nevis ar pašvaldībām un indivīdiem.

\section{Fiziskā drošība ārējā spēka izraisītās humanitārās un dabas katastrofās}

Kopumā fokusa grupu interviju rezultāti liecina, ka iedzīvotājiem vinuu pašvērtējumā nav pietiekamu zināšanu par to, kā rīkoties krīzes situācijās, ${ }^{32}$ kā arī viņi nav tām gatavi.

Vīrietis darbspējas vecumā, Liepāja: Ja mēs kā sabiedrība neesam gatava mazākām krīzēm, vai mès bütu gatavi kaut kam lielākam? Šeit ir ḷoti daudz darāmā.

Respondenti nav saņēmuši pietiekamu informāciju par šāda veida potenciālajiem izaicinājumiem. ${ }^{33}$ Kā nozīmīgākais aktors šajā jautājumā minēta valsts pārvalde, nevis vietējā pārvalde. Lìdz ar to atbildība par komunikāciju tiek novelta uz valsts pārvaldes iestādēm.

Vīrietis darbspējas vecumā, Ādaži: Valstij nav skaidra redzējuma, ko tā vēlas no iedzìvotājiem krīzes situācijā.

Aptaujāto Valmieras un Aizkraukles iedzīvotāju noskaņojums ir pozitīvāks nekā citās pašvaldībās. Valmieras iedzīvotāji bija pārliecināti, ka justos visai droši iespējamo apdraudējumu gadījumā krīzes situācijās, jo pašvaldība, Zemessardze un citas atbildīgās puses ir piedalijjušās kopējās mācībās un guvušas zināšanas, kā rīkoties tehnogēnās katastrofas gadījumā. Aptaujātie

32 Piemēram, respondenti uz jautājumu, vai viņi zina, kur būs pieejams ūdens krīzes situācijā, nespēja atbildēt.

33 Fokusa grupu intervijas Ādažos, L̦audonā. 
Valmieras iedzīvotāji ir apmierināti arī ar novēroto pašvaldības darbību krīžu novēršanai (piemēram, Gaujas ūdens līmeņa mērỉjumu stacijas darbību).

Vīrietis darbspējas vecumā, Valmiera: Zinu, ka Valmierā Zemessardze darbojas Civilās aizsardzības padomè. Un padome visu laiku plāno un domā par iespējamām krìzēm.

Aizkraukles iedzīvotāji atzīmēja, ka zina, kur ir jāgriežas kāds nozīmīga apdraudējuma gadỉjumā. Tiesa, salīdzinot ar brīdinājuma sistēmām Rietumos, tika atzīmēta nepieciešamība pilnveidot Latvijā esošo kārtību un ieviest apziņošanu, izmantojot ìsziṇas, par tuvojošām briesmām un atbilstošām instrukcijām, kā rīkoties krīzes gadījumā. Respondenti uzskata, ka šādas komunikācijas formas ieviešana ir valsts, nevis pašvaldības ziṇā.

Interesanti, ka fokusa grupu interviju dalībnieki Talsos un Ļaudonā norādīja, ka kopumā justos droši arī iespējamu katastrofu gadijumā, jo Talsi ir droša pilsēta, kamēr l̦audonieši uzskatīja, ka pārējiem iedzīvotājiem ir zema interese par L,audonu.

Fokusa grupu interviju rezultāti rāda, ka iedzīvotāji ir salīdzinoši maz domājuši par iespējamiem izaicinājumiem un savas uzvedības modeḷiem vides katastrofas vai tehnogēnās krīzes situācijās. Vēl mazāk ticis domāts par to, ka šādas krīzes varētu būt ārējā naidīgi noskaņotā aktora apzinātas darbības rezultāts. No tā secināms, ka šāda veida iespējamie draudi nav apzināti. Respondenti ir maz informēti arī par valsts un pašvaldību funkcijām aprakstīto situāciju gadījumā. Pārsvarā nacionāla līmeņa valsts pārvaldes institūcijas tiek vainotas informācijas trūkumā un no tām tiek sagaidìta aktīva rīcība krīzes laikā.

\section{Hibrīddraudi pašvaldībās}

Šajā apakšnodaḷā apskatīti pārvaldības rādītāji hibrīddraudu novēršanas un apkarošanas jomā Aizkraukles, Ādažu, Daugavpils, Madonas un Talsu pašvaldībā, kur iedzīvotāji fokusa grupu interviju laikā šos draudus identificējuši kā vienus no trim nozīmīgākajiem draudiem. Situācijas analīzei izmantotas pašvaldību pārstāvju sniegtās intervijas pētījuma vajadzībām, pašvaldību attīstības plānošanas dokumenti, attīstîbas pārskati, civilās aizsardzības plāni un cita informācija, kas publiski pieejama pašvaldību mājaslapās.

\section{Aizkraukles novada pašvaldība}

Aizkraukles novada pašvaldības teritorijā atrodas kritiskās infrastruktūras objekti, to skaitā valsts nozīmes transporta infrastruktūra, kā arī hidroelektrostacija un magistrālais gāzesvads. Ir vairāki lieli ražošanas uzṇēmumi, kas 
potenciāli varētu radīt tehnogēno katastrofu riskus. Tomēr pēdējos septiņos gados nav vērojamas nozīmīgas izmaiņas normatīvajos aktos, kas liecinātu par pašvaldības reagêešanu uz hibrīddraudiem. Intervijas laikā pašvaldības pārstāvis norādīja, ka līdz šim pašvaldība nav saskārusies ar situācijām, kuras liktu pārskatīt normatīvos aktus. Viṇa ieskatā, kopumā pilsētā ir vērojams salīdzinoši zems nelabvēlīgu sociālo parādību, kriminālo aktivitāšu vai citu risku līmenis. Pašvaldības pārstāvis arī apliecināja izpratni par iespējamiem apdraudējumiem, kā arī norādīja uz vairākiem izaicinājumiem, ar ko saskārusies pašvaldība, mēgeinot stiprināt drošîbu reǵionā, tomēr to dēl nav bijis nepieciešams ieviest izmaiņas normatīvajā regulējumā.

Pašvaldības nozīmīgākajos stratēǵiskās plānošanas dokumentos ir identificēti daži hibrīddraudu veidi, ir izstrādāti atsevišḳi sistēmu elementi, kā pretstāvēt šiem draudiem. Darbỉbas daļēji izriet secīgi cita no citas. Hibrīddraudi nav iekḷauti kā in all policies pieeja, un redzējums, kā pret tiem cīnīties vairāku gadu perspektīvā, ir daḷēji identificējams politikas plānošanas dokumentos. Aizkraukles novada ilgtspējīgas attīstības stratēgijā 2014.-2025. gadam ir identificēti kritiskās infrastruktūras objekti, izceltas to izmantošanas priekšrocíbas. Tomēr stratēgija neapskata ne iespējamos riskus un apdraudējumus, kas saistìti ar šiem objektiem, ne arī ietekmi uz vidi un sabiedrību. Piemēram, vadlīnijās par transporta sistēmas attīstību netiek apskatīti nekādi drošības aspekti.

Aizkraukles novada pašvaldība ir pieņēmusi Energeētikas rīcības plānu 2018.-2025. gadam. Tajā identificēts viens no energétikas sektora vārīgajiem punktiem Latvijā kopumā - atkarība no viena ārējā piegādātāja. Tāpēc energéētikas sektora neatkarības veicināšana, dažādojot enerğijas avotus, dokumentā iekḷauta kā viens no stratēǵiskās plānošanas vadmotīviem. Dokumentā arī norādìta stingra sasaiste ar valsts stratēgiskās plānošanas dokumentiem.

2018. gada pašvaldības darbības pārskatā ir uzskaitīts pašvaldības paveiktais 2018. gadā, raksturotas attīstības tendences, noteikti nākotnes darbības virzieni atbilstoši ilgtspējīgas attīstības stratēǵijai, tomēr nav iekḷauta tādu risku un draudu analīze, kas skartu hibrīddraudus, vai aprakstīti soḷi, kas veicinātu drošîbu pret kādu no hibrīdajiem apdraudējumiem. Lìdzīga situācija ir arī ar ziņojumiem par 2016. un 2017. gadu.

Pašvaldības pārstāvja ieskatā, šobrīd būtiskākā ir administratīvi teritoriàlā reforma, kuras paredzamo sagatavošanu un ieviešanu var raksturot kā salīdzinoši efektīvu, jo vairākas iesaistītās puses no citām pašvaldībām piedalās dialogā. Turpmākajam dialogam veidojoties konstruktīvi, varētu nostiprināt Aizkraukles kā reǵionāla, ekonomiska un sociāla centra lomu, kuru faktiski pilsēta jau pildījusi vairākas desmitgades. 
Lēmumu pieņemšanas process kopumā vērtējams kā visai caurskatāms. Domes sēdes ir atklātas, ir publiski pieejami sēžu audioieraksti. Notiek iedzīvotāju sapulces. Daudzi lēmumi tiek plaši skaidroti un diskutēti arī publiski, domes pārstāvjiem jautājot viedokli, argumentējot un diskutējot arī sociālajos tīklos un nodrošinot iedzīvotājiem un uzņēmējiem vieglu pieeju pie domes pārstāvjiem un speciālistiem. Dažādās mūsdienīgās formās ir publiski pieejama informācija par pašvaldības darbu. Sabiedrïbas informēšanai tiek izmantots vietējais preses izdevums, mājaslapa, sociālie tīkli. Tomēr mājaslapā nav paredzēta meklēšanas funkcija, kas rada izaicinājumus, meklējot nepieciešamo informāciju.

Pašvaldỉbas pārstāvis pasvītroja, ka ir pieredzējis parādības, kuras var vērtēt kā iespējamas hibrīddraudu izpausmes. Piemēram, vairākkārt notikusi negatīvu, tendenciozu ziṇu izplatīšana sociālajos tīklos, un dažos gadijumos šķitis, ka tā ir mērḳtiecīgi organizēta, lai mazinātu iedzìvotāju uzticēšanos. Tas, saskaṇā ar pašvaldības pārstāvja sniegto informāciju, ir licis pašvaldībai apzināt informatīvos draudus. Tāpēc tā stiprina pašvaldības komunikāciju kapacitāti, pastiprina domes aktivitātes, daudzos gadījumos uzṇemoties arī proaktīvu rīcību, kas pret viltus un tendenciozām ziṇām ḷauj darboties apsteidzoši un novērst to iespējamās negatīvās sekas sabiedrībā.

Intervējamais stāstija, ka domes komunikācijas speciālisti cenšas biežāk izmantot sociālo tīklu sniegtās komunikācijas iespējas, aktīvāk koordinējot savas darbības, apmainoties ar pieredzi un viedokḷiem, personiski uzrunājot viltus vai tendenciozu ziņu izplatītājus un atspēkojot viṇu teikto. Šo darbu atvieglo tas, ka nelielā pašvaldībā dezinformācijas avotu ir vieglāk identificēt un noskaidrot nepatiesi sniegtas informācijas iemeslus, kā arī to atspēkot.

Attiecībā uz pašvaldības informētību par rīcību X stundā, secināms, ka pašvaldībā ir daḷēji izstrādāti atbilstošie reageēšanas mehānismi, neskatoties uz kavēšanos ar civilās aizsardzības regulējumu nacionālajā līmenī. Pašvaldība izprot, kādi iespējamie hibrīddraudu riski var būt šādos krīzes apstākļos. Tajā ir daḷēji izstrādāti ieteikumi, kā operatīvi rīkoties X stundā. Ir nodibināta Aizkraukles sadarbības teritorijas civilās aizsardzības komisija, 2018. gadā ir apstiprināts tās darbības nolikums. Nolikumā atrunāts komisijas sastāvs, funkcijas un apziņošanas kārtība krīzes situācijās. Saskaņā ar to divas reizes gadā notiek apziņošanas kārtības pārbaude.

Pašvaldības darbinieks intervijā norādija, ka, pateicoties sadarbībai ar citām iesaistītajām pusēm, tai skaitā ar Nacionālajiem bruṇotajiem spēkiem, Valsts ugunsdzēšanas un glābšanas dienestu (VUGD) un uzñēmumiem, pašvaldība ir gan pastāvīgi ieguvusi papildu informāciju par dažāda veida iespējamajiem draudiem, ieskaitot hibrīddraudus, gan arī veicinājusi šìs informācijas nonākšanu līdz iedzīvotājiem. Lielā mērā tas ir saistìts ar tiešo sadarbības 
partneru, VUGD un armijas pārstāvju, kuri strādā Aizkrauklē, augsto profesionalitāti un ieinteresētību. Tomēr pašvaldības rīcībā pietrūkst aptverošākas informācijas par kopējo valsts līmeņa politiku un pasākumiem, lai ar tiem saskaņotu pašvaldības aktivitātes.

Apskatot starpiestāžu koordināciju vietējā līmenī, intervijas laikā pašvaldỉbas darbinieks norādijja, ka līdz šim nav īstenoti pasākumi pakḷauto iestāžu darbinieku sagatavošanai darbībai X stundā. Ikdienas darbā pakḷautības iestādes nav saskārušās ar tiešu nepieciešamību reagêèt uz hibrīddraudiem, kas varētu rasties X stundā. Pārstāvis uzsvēra, ka, viṇa ieskatā, ṇemot vērā pašvaldības darbinieku zināšanas un attīstîtos algoritmus darbam ar šādiem izaicinājumiem, zināšanu pārnesi uz apakšstruktūrām un darbību koordināciju, visticamāk, hibrīddraudus būs iespējams novērst operatīvi un mērkstiecīgi. ${ }^{34}$

Rezultātā secināms, ka pašvaldības normatīvais regulējums, kā arī cita publiski pieejamā informācija un intervija ar pašvaldības pārstāvi liecina par Aizkraukles pašvaldības informētību un zināmu izpratni par hibrīddraudiem. Tomēr plašākas zināšanas par to, kā atpazìt hibrīddraudus un attiecīgi reageēt uz tiem, iespējams, celtu pašvaldības drošỉbas stratēgijijas kvalitāti.

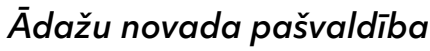

Intervija ar Ādažu pašvaldības amatpersonu atklāja, ka iedzīvotāju identificētos hibrīddraudus tā uzskata par būtiskiem un saskata nepieciešamību rast risinājumus kā vietējā, tā arī valstiskā līmenī. Ādažu pašvaldỉba ir veikusi vairākas aktivitātes hibrīddraudu apkarošanai un novēršanai. Pašvaldība hibrīddraudus uzskata par nozīmīgiem. Ir izstrādātas atsevišķas sistēmas, kā pretstāvēt tiem, un konstatējama darbību pēctecība, secība un savstarpējā pamatotība hibrīddraudu ietekmes mazināšanai. To nodrošina atbilstošs plānošanas ietvars, ieviešanas monitorings un rezultātu izvērtējuma mehānismi.

Pašvaldības plānošanas dokumentos, piemēram, Ādažu pašvaldības Attīstības programmas (2016-2022) sadaḷā, kurā tiek izvērtēti draudi sabiedriskajai kārtībai un drošībai, norādīts, ka drošība tajā ir pietiekama. 2016. gadā pieņemtajā dokumentā gan minēti divi izaicinājumi kritiskajai infrastruktūrai - valsts un pašvaldību ceḷu sliktais stāvoklis un ugunsdzēsēju depo trūkums pašvaldībā. Izcelta arī jaunu tehnologiju lietojuma nepietiekamība drošỉbas jomā. Atbilstoši identificētajiem trūkumiem ir izstrādāts rīcības plāns, lai šos trūkumus novērstu. Dokuments iezīmē arī riska teritorijas un objektus.

Analizējot normatīvo aktu izstrādes procesu kopumā, secināms, ka trūkst dinamisku pašvaldības aktivitāšu hibrīddraudu identificēšanai, novēršanai un

34 Fokusa grupu intervijas Ādažos, L̦audonā. 
apkarošanai. Pašvaldības pārstāvis intervijā norādīja, ka viens no būtiskiem izaicinājumiem šobrīd ir tas, ka kavējas visaptverošas valsts aizsardzības plāna (jumta likuma) ieviešana ar skaidru metodologiju par resursu nodrošināšanu un kompetenču sadali dažādu krīzes un kara scenāriju gadījumos. Viņš atzīmēja, ka nepieciešamas regulāras valsts mēroga civilās aizsardzības mācības, kurās ir iesaistītas arī pašvaldības.

Ādažu domes mājaslapā atrodams 2013. gadā apstiprinātais Ādažu novada civilās aizsardzības plāns. Plānā ir identificēti dažādi draudu veidi, tai skaitā vairākas hibrīddraudu kategorijas. Iedzīvotājiem ir nodrošināta informācija par Civilās aizsardzības komisijas locekḷiem, kā arī to kontaktinformācija. Plāns apraksta, kādi ir rīcības modeḷi dažādu veidu krīzēs un kas ir atbildīgās institūcijas. Plānā nav paredzēts individuālo aizsardzības līdzekḷ̣u (gāzmasku un respiratoru) nodrošinājums. Konkrētas instrukcijas par to, kā iedzīvotājiem jārīkojas krīzes situācijā, plānā pievienotas tikai attiecībā uz plūdiem. Turklāt, kā liecina Ādažu Attīstības programmas (2016-2022) rādītāji, laika posmā līdz 2019. gada beigām Ādažu pašvaldības teritorijā nav bijis neviena civilās trauksmes objekta. Saskaṇā ar intervijā sniegto informāciju lēmumu pieṇēmēji pašvaldībā apzinās nepieciešamību aktualizēt informāciju iedzīvotājiem. Tiek plānots atkārtoti ar vietējā drukātā izdevuma "Ādažu Vēstis" starpniecību informēt iedzīvotājus par pakalpojumu pieejamību un rīcību X stundā. Iepriekšèjā reize, kad šāda komunikācija tikusi ĩstenota, ir bijusi 2014. gadā (tūlìt pēc Krimas aneksijas).

Apskatot starpiestāžu komunikāciju, secināms, ka pašvaldības iestādes formāli informētas un izglìtotas par to, kā atpazìt hibrīddraudus un attiecīgi reagèt uz tiem. Tomēr intervētais pašvaldības darbinieks norādīja, ka pašvaldība saredz komunikācijas problēmas, gan komunicējot ar Aizsardzības ministriju (mežu ugunsgrēku, ārkārtas situāciju laikā; ugunsgrēku izcelšanos veicina militārās aktivitātes poligonā), gan informējot iedzīvotājus par iespējamo rīcību X stundā. Tāpat arī intervētā amatpersona norādīja, ka ir nepieciešams atkārtoti rīkot tādas civilās aizsardzības mācības pašvaldības darbiniekiem, kurās varētu simulēt krīzes situāciju un trenēties lēmumu pieņemšanā, izspēlējot scenārijus hibrīddraudu seku likvidēšanai. Pašvaldības pārstāvis apzinājās, ka pašvaldībai nepieciešams darboties kā starpniekam, nododot informāciju valsts pārvaldes iestādēm, ìpaši Aizsardzības ministrijai, un iedzīvotājiem. Šādu situāciju nosaka militāro spēku klātbūtne novadā. Viņš arī uzsvēra, ka savlaicīga informācijas apmaiṇa un plānveidīga un koordinēta komunikācija krīzes laikā, ja poligonā vai tā tuvumā noticis negadījums vai kḷūda, varētu atrisināt daudzas komunikācijas problēmas. Pašvaldības pārstāvja vērtējumā šobrīd ad hoc komunikācija notiek visai haotiski, ja noticis negadījums. 
Lēmumu pieņemšanas process kopumā vērtējams kā caurskatāms. Pašvaldībā ir pieejama informācija par lēmumu pieņēmēju darbību un pašvaldības kompetencē esošo hibrīddraudu novēršanu un apkarošanu. Pašvaldỉba ilgtermiņa plānu izstrādē iesaista sabiedrības pārstāvjus. Tomēr, spriežot pēc attīstības programmas uzraudzības pārskata, Sabiedrisko attiecību nodaļa 2019. gadā padziḷinātas iedzīvotāju viedokḷa aptaujas laikā aptaujājusi vien 5 respondentus. Lai gan intervijas laikā Ādažu novada domes amatpersona norādīja, ka atsevišķu būtisku ar drošību saistītu dokumentu un lēmumu caurskatāmībai ir ierobežojumi, jo šai informācijai ir ar likumu noteikts slepenais statuss, tomēr attīstîbas programmas un līdzīgu dokumentu izstrādē iespējams nodrošināt plašāku ieinteresēto pušu piesaisti. Pretējā gadījumā vien dažu sabiedrības pārstāvju viedokḷu uzklausǐšana drīzāk ir formalitāte.

Kopumā secināms, ka Ādažu pašvaldībā hibrīddraudiem tiek pievērsta lielāka uzmanība nekā citās pašvaldībās galvenokārt tāpēc, ka tās teritorijā ir izvietotas militārās bāzes. Tomēr, lai arī Ādažu novada pašvaldībā ir izveidots veiksmīgs politikas plānošanas mehānisms, vairāki hibrīddraudi tajā netiek identificēti kā nozīmīgi izaicinājumi pašvaldības iedzīvotājiem un to novēršanas instrumenti nav formāli paredzēti.

\section{Daugavpils novada pašvaldība}

Pašvaldībā ir identificēti atsevišķi hibrīddraudi un izstrādātas sistēmas, kā pretstāvēt šiem draudiem. Tomēr ir konstatējami trūkumi pēctecības, secỉbas un savstarpējās pamatotības ievērošanā hibrīddraudu ietekmes mazināšanai. Intervijas laikā pašvaldības pārstāvis norādīja, ka atsevišķu hibrīddraudu novēršanas pasākumi netiek realizēti politisko un ekonomisko apsvērumu dēḷ. Netiek identificēti tie iespējamie riski, kas saistīti ar pārrobežu sadarbības projektiem.

Intervijā Daugavpils pilsētas pašvaldības pārstāvis pauda izpratni par Daugavpils iedzīvotāju drošības izaicinājumiem saistībā ar vairākiem nozīmīgiem draudu veidiem, tai skaitā hibrīddraudiem. ${ }^{35}$ İpaša nozìme tika piešķirta hibrīddraudiem informatīvajā telpā.

Daugavpils novada domes pārstāvis: Ja kāds domā, ka šeit, Latgales pusē, nav problèmas un ka tas ir objektìvs un precizes situācijas novērtējums, tad viņš kḷ̆udās. Informatīvā telpa, kurā cilvēki dzīivo, ir tāda, kāda tā ir. Un, ja kādreiz ticēja, ka nomainīsies paaudzes, kaut kas mainīsies, tad nekas nav mainījies. Jaunie turpina dzīvot citā informācijas telpā. Tomēr domāju, ka kopumā riski ir minimāli, 
jo Latvija ir NATO valsts. Bet šì drošǐba nenāk no iekšienes, tā nāk tieši tāpēc, ka tā ir NATO valsts.

Kā vienu no nozīmīgākajiem aktuālajiem izaicinājumiem saistībā ar hibrīddraudiem informatīvajā telpā domes pārstāvis minēja iedzìvotāju protestus pret Meža Mackeviču militārā poligona paplašināšanu. ${ }^{36}$ Lìdzīgs viedoklis izskanēja arī par "Ukrainas scenārija" iespējamu atkārtošanos. Viṇa ieskatā, līdzīga situācija kā Doṇeckā varētu rasties Latgalē, ja vien Latvija nebūtu NATO dalībvalsts. Vienlaikus domes pārstāvis norādīja, ka par valsts ārējiem apdraudējumiem ir atbildīgas valsts pārvaldes iestādes, tāpēc to pārstāvjiem jādomā par šiem jautājumiem. Viṇa ieskatā, pašvaldībai nav ne tādu funkciju, ne resursu, lai iesaistītos hibrīddraudu novēršanā. Pārstāvis nesaskatīia arī pašvaldības lomu iedzīvotāju datu aizsardzības stiprināšanā interneta vidē.

Šì brīža plānošanas dokumenti liecina par visai vāju ilgtermiņa pieeju hibrīddraudu apkarošanai un novēršanai vai drošības stiprināšanai pašvaldībā kopumā. Plānošanas dokumenti koncentrējas galvenokārt uz ekonomisko attīstību, maz uzmanības veltot drošỉbai. Piemēram, Daugavpils novada ilgtspējīgas attīstības stratēóijā 2015.-2030. gadam nav iekḷauti plāni drošỉbas stiprināšanai regionā. Neskatoties to, ka novads ir pierobežu reǵions, iespējamie riski analizēti ierobežotā apjomā, to novēršana netiek apskatīta. Novadā izvietots maǵistrālais gāzesvads un naftas produktu vadi, ar tiem saistītās energètikas attīstības analīze stratēgijā ir iekḷauta, kamēr pie riskiem vien minēts tas, ka infrastruktūras nākotne būs atkarīga no Krievijas naftas tranzìta politikas. Novada vārīgumu hibrīddraudu kontekstā varētu mazināt kritiskās infrastruktūras elementu - veselības aprūpes sistēmas, gaisa, ūdens, dzelzceḷu un autocel̦u sistēmas un transporta infrastruktūras - pilnveide un attīstība. Tomēr pašvaldība plānā nav iekḷāvusi nekādu potenciālo risku novērtējumu šajā sakarā. Piemēram, nav izvērtēti Daugavas hidroelektrostaciju riski.

Lēmumu pieņemšanas process kopumā ir caurskatāms. Novada domes mājaslapā ir pieejami plānošanas dokumenti, normatīvie akti, informācija par sabiedrības līdzdalību, darbības pašvērtējumi, kā arī citi nozīmīgi dokumenti un iedzīvotāijiem aktuālā informācija par notikumiem pašvaldībā.

Daugavpils domes mājaslapā atrodams Valsts ugunsdzēsības un glābšanas dienesta (VUGD) izstrādātais civilās aizsardzības plāns, kas pēdējo reizi

36 Daugavpils novada domes pārstāvis: "Meža Mackeviču poligona apspriešanas jautājums - ne jau par zaḷo mežu tur rūpējas. Jautājums ir par to, ka, kā daudzi te uzskata, sev nedraudzīga NATO bruṇoto spēku izvietošana būs. Kāpēc tik liela rezonanse un ir mēginājumi viḷṇot sabiedrību. [..] Pretnostatijums ir liels. Iedomājieties, pat pašvaldība vāca parakstus, kaut gan iniciē viens politisks spēks. Un jautājums ir tikai par to, kura armija, viņuprāt, šeit nav vajadzīga. Nepievērst tam uzmanību ir l̦oti tuvredzīgi!" 
atjaunots 2013. gadā. Lai arī formāli tas vairs nav spēkā, tomēr demonstrē pašvaldības pieeju krīzes situācijām. Daugavpils novada pašvaldības civilās aizsardzības plāns ir izvērsts 88 lappušu garš dokuments, kas iekḷauj detalizētu novada aprakstu. Pozitīvi vērtējama Daugavpils novada un Ilūkstes novada teritorijā identificēto iespējamo apdraudējumu (tai skaitā ar pārrobežu iedarbību) analīze. Ir apskatīti arī daži aspekti par ievainojamību attiecībā uz atsevišķiem hibrīddraudiem, kā arī šo draudu iespējamās sekas. Tie ir: tehnogēno katastrofu riski (piemēram, vides radioaktīvais piesārņojums, ko rada Ignalinas atomelektrostacija Lietuvā, bīstamo vielu noplūde regionā un ārpus tā robežām, piemēram, Baltkrievijā); sabiedriskās nekārtības, terorakti, bruṇotas nekārtības; epidēmijas, epizootijas, epifitotijas. Dokuments nosaka, kas ir atbildīgie par civilās aizsardzības izpildi, un nosaka pašvaldības atbildības robežas. Ir aprakstīts sakaru nodrošinājums, apziņošana, sabiedrības informēšana krīzes situācijā, kā arī aprakstītas pulcēšanās vietas, evakuācijas maršruti un citi organizatoriski jautājumi, galvenokārt tos saistot ar iespējamu katastrofu Ignalinas atomelektrostacijā. Plāns paredz iedzīvotāju izglītošanas pasākumus civilajā aizsardzībā. Plānam pievienota valsts materiālo rezervju resursu nomenklatūra un daudzums pēc stāvokḷa līdz 2007. gadam VUGD Daugavpils brigādes noliktavā.

Informācija par to, kā rīkoties X stundā, civilās aizsardzības plānā iedzīvotājiem instrukcijas veidā nav sniegta. Bet ir atrodama informācija par atbildīgajām amatpersonām un šo amatpersonu kontaktinformācija. Tomēr neskaidrs ir jautājums par informācijas aktualizēšanas biežumu.

Intervijas laikā domes pārstāvis norādīja uz veiksmīgu pārrobežu sadarbību, kā arī visai veiksmīgu sadarbību ar valsts iestādēm civilās aizsardzības nodrošināšanai, tomēr vairākkārt uzsvēra valsts galveno lomu hibrīddraudu novēršanā. Viṇš uzskatijja, ka viena no problēmām, viṇaprāt, ir spēcīgas koordinējošas, ar resursiem apveltìtas institūcijas neesamība, izṇemot VUGD.

Secināms, ka pašvaldības normatīvais regulējums, kā arī cita publiski pieejamā informācija un intervija ar pašvaldības pārstāvi liecina par Daugavpils novada pašvaldības informētību un zināmu izpratni par atsevišķiem hibrīddraudiem. Tomēr plašākas zināšanas par to, kā tos atpazìt un attiecīgi reagèet uz tiem, iespējams, uzlabotu pašvaldības drošỉbas stratēǵijas kvalitāti un veicinātu preventīvu pasākumu ieviešanu.

\section{Talsu novada pašvaldība}

Talsu novada pašvaldības dokumenti, kā arī intervijas rezultāti rāda, ka pašvaldības darbinieki izprot to, ka hibrīddraudi ir aktuāls drošības izaicinājums. Tomēr šìs izpratnes pamatā galvenokārt ir viedoklis par kiberdraudiem un 
draudiem informācijas vidē kā nozīmīgiem un aktuāliem. Citu hibrīddraudu veidu aktualitāte identificēta ievērojami mazākā apjomā. Intervijas laikā Talsu novada pašvaldības pārstāvis atzina, ka hibrīddraudi ir aktuāls izaicinājums. Kā nozīmīgākais tika izcelts kiberdrošỉbas jautājums. Respondents norādīja uz nepieciešamību pievērst stingrāku vērību tam, ko pašvaldības darbinieki publicè par sevi interneta vidē.

Talsu novada pašvaldības darbinieks: Te ir jāapzinās, ka drošība ir pirmajā vietā un, ja tu savus datus publicēe, tev ir jādomā par riskiem un sekām. ${ }^{37}$

Intervijas laikā pašvaldības pārstāvis norādīja, ka kiberdrošības jomā Talsu novadā tiek veikti nepieciešamie preventīvie pasākumi, kā arī tiek nodrošināts nepieciešamais finansējums pašvaldības iespēju robežās. Ir izstrādāti saistošie noteikumi par datu drošǐbu. Apskatot iespējamos rīcības modelıus katastrofu gadījumā, respondents uzskatīja, ka, visticamāk, sagatavotības pakāpe vērtējama kā zema un "katrs skrietu savā virzienā"38. Citi hibrīddraudu veidi intervijas laikā netika identificēti kā nozīmīgi šim reǵionam.

Apskatot plānošanas dokumentus un normatīvos aktus, secināms, ka pašvaldība ir pievērsusies arī drošības problemātikai kopumā, tiesa, atsevišķi neizcel̦ot hibrīddraudus. Interesanti, ka Talsu novada ilgtspējīgas attīstîbas stratēgijiā 2030, minot lietotos "apdzīvojuma struktūras telpiskos aspektus ilgtspējīgai attīstībai”, drošîbas jēdziens minēts tikai pie "sociālajiem aspektiem”. Tiek arī paskaidrots, ka "Sociālie aspekti ir cilvēka vajadzībām radīta vide, kas skar veselību, izglīīibu, kultūru, aktīvu dzīvesveidu, sociālo darbu un pakalpojumus, un drošību" ${ }^{39}$. Drošība novadā citu "sociālo aspektu" vidū tiek raksturota šādi:

Talsu novadā darbojas Valsts policijas Kurzemes regiiona pārvaldes Talsu iecirknis, kas apkalpo arī Dundagas, Rojas un Mērsraga novadu teritorijas. Talsu novadā atrodas Valsts probācijas dienesta teritoriālā struktūrvienība. 2011. gadā jūnijā apstiprināts apvienotais Dundagas, Mērsraga, Rojas un Talsu novadu civilās aizsardzības plāns. Talsu novadā ir optimāls pašvaldības policistu skaits, lai gādātu par sabiedrisko kārtību visa novada teritorijā. Laucienē, Valdgalē, Virbos tiek finansēta ugunsdzēsības dienesta uzturēšana, lai nepieciešamības gadījumā varētu iedzīvotājiem sniegt operatìvu palīdzību. ${ }^{40}$

37 Intervija ar Talsu novada pašvaldības pārstāvi.

38 Turpat.

39 Talsu novada dome. Talsu novada ilgtspējīgas attīstības stratēgija 2030, 8. lpp. Pieejams: https://talsunovads.lv/wp-content/uploads/2019/07/stategija_apstiprinats_2030.pdf

40 Turpat, 10. lpp. 
No šì citāta redzams, ka drošība būtībā tiek skatīta personiskās drošǐbas nodrošināšanas aspektā. Savukārt "ekonomisko aspektu" un "vides aspektu" uzskaitījumā, kur minēti arī kritiskās infrastruktūras objekti un citi drošības nodrošināšanai būtiski elementi, drošîbas problemātika tiek apskatīta pastarpināti. Piemēram, analizējot ceḷu infrastruktūras kvalitāti, situācija tiek raksturota kā neapmierinoša. ${ }^{41}$

Talsu novada pašvaldības pārstāvis intervijas laikā norādīja, ka par nozīmīgu sasniegumu drošības stiprināšanā novadā uzskatāmi pašvaldības izdotie noteikumi par datu drošību. Katrs pašvaldības uzṇēmums un iestāde par to ir informēti. Tāpat tika atzīmēts, ka pēc 2008. gada notikumiem (vētras dēḷ nedēḷu novadā nebija elektrības) un 2014. gada notikumiem tika aktualizēti ārkārtas situācijas plāni. Tomēr vienlaikus respondents norādīja, ka, viṇaprāt, būtu nepieciešams rīkot praktiskās mācības, lai pašvaldības darbiniekiem un iedzīvotājiem atgādinātu, kā rīkoties ārkārtas situācijā.

Saskaņā ar publiski pieejamo informāciju Talsu novada pašvaldība iedzīvotāju informēšanai par novada aktualitātēm izmanto visai plašu un dažādu komunikācijas kanālu klāstu, sākot ar lokāliem medijiem - informatīvo izdevumu "Talsu Novada Ziņas” un "Kurzemes Radio" - līdz pat nacionālajiem medijiem, piemēram, ziṇu aǵentūrai "LETA" vai interneta portālam "Delfi". Saskaņā ar ilgtspējīgas attīstỉbas stratēgijā norādīto "pašvaldỉba sagatavo un plašsaziṇas līdzekḷiem nosūta 30 preses relīzes vidēji katru mēnesi”. Tāpat arī "pašvaldība regulāri rīko iedzīvotāju sapulces visa novada teritorijā" ${ }^{2}$. Tiesa, intervijas laikā pašvaldības pārstāvis norādīja, ka bieži vien lēmumu pieṇemšanas process nav vis tik caurskatāms, kā varētu likties. Īpaši tad, kad pašvaldība lemj par finanšu plūsmas jautājumiem.

Secināms, ka Talsu novada pašvaldības normatīvais regulējums, kā arī cita publiski pieejamā informācija un intervija ar pašvaldības pārstāvi liecina par Talsu novada pašvaldības informètību un dal̦ejju izpratni par atseviškiem hibrīddraudiem. Tomēr plašākas zināšanas par to, kā tos atpazìt un attiecīgi reag̣êt uz tiem, kā arī labāka izpratne par drošības problemātikas aktualizāciju stratēgíiskās plānošanas dokumentos, iespējams, uzlabotu pašvaldības drošības stratēgijas kvalitāti un veicinātu preventīvu pasākumu ieviešanu.

Intervijas ar vietējo pašvaldību pārstāvjiem apliecināja, ka tie identificē hibrīddraudus, tomēr reagêe uz tiem bieži vien salīdzinoši visai niecīgi vairāku iemeslu dẹl. Pirmkārt, hibrīddraudu specifika nosaka grūtības lēmumu

41 Talsu novada dome. Talsu novada ilgtspējīgas attīstības stratēéija 2030, 8. lpp. Pieejams: https://talsunovads.lv/wp-content/uploads/2019/07/stategija_apstiprinats_2030.pdf, 44. lpp.

42 Turpat, 10. lpp. 
pieņēmējiem tos atpazīt un atbilstoši reageèt. Pašvaldību plānošanas dokumentu un interviju analīze liecina par to, ka atsevišḳos gadijjumos pašvaldību darbinieku un amatpersonu zināšanas par hibrīddraudiem ir fragmentētas. Rezultātā tie ne tikai neatpazīst hibrīddraudus, bet arī bieži vien neapzinās savas darbības vārīgumu un rezultātā - pašvaldību ievainojamību šajā ziṇā.

Vadoša pašvaldïbas amatpersona: Es, piemēram, apzinos, ka man nav ko atņemt, man tà ìsti nekā nav, un diezin vai kādam mani vajag fiziski kā personu, tādèl tā loti neiespringstu, mani profili ir atvērti [..] man nekā nav, pazaudēt nav ko, tādēl [neko] īpašu nedaru drošǐbas vairošanai. ${ }^{43}$

Iespējams, ka situāciju varētu risināt ar specializētām atbalsta programmām, kuras pašvaldību darbiniekiem sniegtu iespēju papildināt savas zināšanas un palīdzētu atpazìt dažādus iespējamo apdraudējumu veidus un uzzināt, kā tie ietekmē pašvaldības darbu un kopienas dzīvi. Otrkārt, pašvaldības bauda salīdzinoši lielāku iedzìvotāju uzticēšanos nekā nacionālā līmeṇa valsts pārvaldes institūcijas. No pašvaldībām visbiežāk tiek sagaidīti praktisku jautājumu tūlītēji risinājumi. Tāpēc vairāku citu iedzīvotājiem būtisku draudu, piemēram, sociālu izaicinājumu, novēršana vai apkarošana pašvaldību darbībā tiek prioritizēta. Turklāt, pateicoties iedzīvotāju uzticēšanās apjomam, pašvaldībām rodas iespējas kādas neveiksmīgas rīcībpolitikas raksturot kā nacionāla līmeṇa valsts pārvaldes institūciju neizdarību. Tāpēc pašvaldības neizjūt iedzīvotāju pieprasījumu risināt jautājumus par hibrīddraudu novēršanu un apkarošanu. Treškārt, pašvaldību plānošanas dokumentos plašāk varētu tikt apskatīti potenciālie riski un apdraudējumi, kas ḷautu ilgtermiṇā iespējot pašvaldību iesaistīties hibrīddraudu novēršanā un veicināt kopienu izturētspēju pret dažāda rakstura draudiem, tai skaitā arī pret hibrīddraudiem. Tomēr jāṇem vērā, ka šāda veida dokumentos nav detalizēti jāapskata visi drošības riski vai to novēršanas mehānismi. Vairumā gadījumu apskatītie pašvaldību stratēgiskās plānošanas dokumenti un normatīvie akti atbilst labām pārvaldības praksēm un tajos iespējamie ieviešamie papildinājumi par lokāla mēroga drošỉbas stiprināšanu drīzāk skatāmi kā salīdzinoši nelieli papildinājumi, nevis būtiska trūkumu novēršanas prakse. Ceturtkārt, atsevišķ vietējo pašvaldību pārstāvji apzināti norobežojas no, viṇuprāt, sarežğîtām, nacionāla mēroga problēmām, kuru risinājumu mēgeinājumi lokālā mērogā nenestu vietējiem iedzīvotājiem skaidrus pozitīvus rezultātus vai pat būtu nepopulāri un mazinātu pašvaldību amatpersonu politisko kapitālu. 
Pašvaldības administrācija nodala pašvaldības kompetencē esošos jautājumus no nacionālā līmeņa un saredz, ka iedzìvotāju informēšana un izglītošana par vairākiem hibrīddraudu veidiem valdībai ir jārisina centralizēti nacionālā mērogā. Pašvaldību pārstāvju intervijas liecina, ka, pašvaldību amatpersonu un darbinieku ieskatā, tas panākams pārsvarā ar izglìtošanas, pieredzes apmaiṇas, redzesloka paplašināšanas metodēm un ka tā nav pašvaldības atbildība un neietilpst tās kompetencēe ${ }^{-44}$ Tomēr situācija nav tik viennozīmīga, ņemot vērā Pašvaldību likumā noteiktās pašvaldību funkcijas.

Pašvaldību darbinieki intervijās apliecināja, ka apzinās to, ka iedzīvotāji nezinātu, ko darìt X stundā. Turklāt ne visu pašvaldību dienestiem ir plāni rīcībai X stundai. Lai šo jautājumu risinātu koordinēti visā Latvijā, ir nepieciešama veiksmīga civilās aizsardzības plāna likuma ieviešana valsts mērogā, un tad katra pašvaldība izdarītu savu "mājasdarbu" un izstrādātu savus civilās aizsardzības plānus savam novadam vai pilsētai ar konkrētām lokācijām un rīcības nolikumiem ${ }^{45}$.

\section{Secinājumi}

Pētījumā gūtie rezultāti liecina, ka Latvijas iedzīvotāji identificē atsevišķas hibrīddraudu grupas un atzīst tos kā būtiskus izaicinājumus savai drošìbai. Visplašāk atpazìtie hibrīddraudi saistīti ar informatīvajiem draudiem un kiberdraudiem, kā arī ar iejaukšanos valsts iekšējās lietās tādā slēptā militārā veidā, kā tas notika Ukrainā 2014. gadā. Arī pašvaldību darbiniekiem un amatpersonām ir izpratne par to, ka šādi draudu veidi pastāv un potenciāli var radīt kaitējumu. Tomēr kopumā gan iedzīvotāji, gan pašvaldību pārstāvji neatpazina vairākus hibrīddraudu veidus kā būtiskus un aktuālus. Atsevišķu draudu iespējamība, piemēram, tehnogēno katastrofu iespējamība, tika vērtēta zemu.

Kā nozīmīgāko hibrīddraudu ārējo avotu iedzīvotāji atpazina Krievijas Federāciju. Dažkārt minēta arī Ķinnas Tautas Republika. Runājot par Krieviju, aptaujātie iedzīvotāji nosauca tūlitēejus drošības izaicinājumus, ar kuriem viṇi paši vai, viņu ieskatā, Latvijas sabiedrība sastopas savā ikdienā vai ar kuriem potenciāli varētu saskarties, iezīmējot visai skaidrus potenciālos scenārijus. Savukārt Ḳinas radītos potenciālos apdraudējumus aptaujātie raksturojuši kā neskaidrus, grūti izprotamus un tādus, ar ko Latvija saskarsies nākotnē. 
Starp hibrīddraudiem informācijas telpā visplašāk identificētie draudi ir propaganda un dezinformācija, īpaši viltus ziņas. Pašvērtējumā respondenti kopumā ir optimistiski par savām spējām atškirt patiesu informāciju no nepatiesības vai manipulācijām, kamēr savu līdzcilvēku - citu paaudžu, citu reǵionu, citu sociālo grupu pārstāvju - medijpratību un kritiskās domāšanas spējas vērtē kā drīzāk vājas. Padziḷinātās intervijās ar pašvaldību pārstāvjiem rāda, ka galvenokārt tie arī atpazīst draudus informācijas vidē, tomēr nesaredz pašvaldības lomu drošîbas stiprināšanā šajā jomā, jo uzskata to par valsts centrālo pārvaldes institūciju pienākumu. Tāpēc pašvaldības maz iesaistās cīnā pret Krievijas informācijas un cita veida ietekmes kampaņām, neskatoties uz to potenciālu, ko piedāvā vietējo kopienu komunikācijas kanāli, lokālo līderu politiskais kapitāls un sadarbības ar nevalstisko sektoru, kā arī publisko un privāto partnerību un citu pašvaldībām pieejamo instrumentu potenciāls.

Līdzīga situācija ir ar kiberdraudiem. Pašvaldības pamatā ir izveidojušas atbilstošus mehānismus kiberdrošỉbas nodrošināšanai pakḷautībā esošajām iestādēm. Bet iedzīvotāju, kuru kompetenci kibertelpas lietošanā vērtē kā zemu, izglïtošanu uzskata par valsts pienākumu un pašvaldības lomu īsti nesaredz. Interesanti, ka atsevišķu aptaujāto pašvaldības amatpersonu izteikumi par viņu personiskajiem preventīvajiem pasākumiem datu drošǐbas nodrošināšanai sakrīt ar iedzīvotāju izvēlēm nepievērst pietiekamu vērību drošu interneta izmantošanas stratēgiju lietojumam, lai gan viņi apzinās iespējamos riskus un apdraudējumus. Tas norāda uz sabiedrības nepietiekamu informētỉbu ne tik daudz par pašiem draudiem, cik drīzāk par tām sekām, kādas potenciāli var būt.

Gan iedzīvotāji, gan pašvaldību pārstāvji atzīst dažādu veidu iejaukšanos valsts iekšējās lietās kā vienu no nozīmīgiem potenciāliem apdraudējumiem. Gan aptaujātie iedzīvotāji, gan pašvaldību pārstāvji pirmkārt un galvenokārt ir minējuši slēptu militāru agresiju pēc līdzīga scenārija, kādu Krievijas Federācija realizēja Ukrainā, anektējot Krimu un eskalējot konfliktu Ukrainas austrumu reǵionos. Kopumā visi aptaujātie šo scenāriju izskata kā maz iespējamu, norādot uz NATO spēku klātbūtni kā nozīmīgāko atturēšanas faktoru. Kā otrs biežāk identificētais šis grupas draudu veids minēta ekonomisko un finansiālo spiedienu vai manipulāciju realizācija. Savu lomu šo draudu tipa novēršanai un apkarošanai ne iedzīvotāji, ne pašvaldības nesaskata.

Hibrīddraudu potenciālu radīt ievainojamību kritiskās infrastruktūras objektiem gan iedzīvotāji, gan lokālā līmeņa lēmumu pieņēmēji kā nopietnu draudu apsver vismazāk. Tas ir rezultējies ne tikai iedzīvotāju vājās zināšanās par kritiskās infrastruktūras objektu radītajiem riskiem un to nozīmi gadījumos, ja iestātos krīzes situācija, bet arī vāji izstrādātos saistìtajos plānošanas 
dokumentos, l̦oti vispārinātos regulējumos, kas sniegti publiskai lietošanai. Ar ierobežotas lietošanas informāciju autores šajā kontekstā neiepazinās, tādēl to nevērtē.

Viens no šobrīd vājākajiem regulējumiem attiecas uz civilo aizsardzību. Lai gan vairāku pašvaldību darbinieki norādīja, ka nopietni domā par civilās aizsardzības plāniem un strādā pie tiem, tomēr šobrīd nekāds vērā ṇemams progress vēl nav panākts vairāku iemeslu dēḷ. Viens no nozīmīgākajiem iemesliem ir kavēšanās visaptverošas valsts aizsardzības plāna ieviešanā. Lìdz ar to šobrīd publiski pieejami ir veci, formāli spēkā neesoši civilās aizsardzības plāni, kas visbiežāk neatspoguḷo pašvaldības faktisko stāvokli. Nav publiski pieejamas informācijas vai instrukcijas, kā iedzīvotājiem rīkoties krīzes situācijās, tai skaitā gadījumos, ja notiek kādas dabas vai tehnogēnās katastrofas. Fokusa grupu interviju laikā respondenti atzina, ka nezina, kas īsti notiktu un kā būtu jārīkojas šādās situācijās, kā arī to, kas ir tās atbildīgās institūcijas, pie kurām būtu jāvēršas pēc informācijas vai palīdzības. Zīmīgi, ka līdzīgi izteicās arī atsevišķu pašvaldību pārstāvji. Tas nozīmē, ka būtībā ne pašvaldības, ne iedzīvotāji nav gatavi krīzes situācijām.

Iedzīvotājiem ir interese par to, kādai ir jābūt katra indivīda rīcībai $\mathrm{X}$ stundā (piemēram, kiberuzbrukuma, elektronisko maksājumu apstāšanās gadījumā, elektriskas strāvas pārtraukuma dēl, dabas katastrofu, tai skaitā kīimisku vielu noplūdes, slēpta vai atklāta militāra iebrukuma gadījumā). Lielākā daḷa aptaujāto iedzīvotāju arī atzina, ka iesaistītos valsts aizsardzībā X stundā atbilstoši savām spējām, iespējām un zināšanām. Tāpēc šādas iedzīvotāju atziņas varētu tikt izmantotas, lai nevis apmierinātu pausto interesi, bet pilnveidotu Latvijas drošỉbas arhitektūru.

Nozīmīgs instruments ir pašvaldības darbinieku civilās aizsardzības mācības, kuru laikā tiek simulētas krīzes situācijas un trenēta lēmumu pieṇemšana sarežgìtos apstākḷos. Viens no šādu mācību virzieniem varētu būt saistīts arī ar hibrīddraudiem. Tādèjādi varētu iegūt nozīmīgas zināšanas par patieso situāciju reǵionos un apzināt nepieciešamos rīcības plānus sistēmas uzlabošanai, kā arī pilnveidot iesaistīto pušu kompetences. 


\title{
Militārā drošība
}

\author{
RUTA CEPLE, VALDIS OTZULIS
}

Raksta mērḳis ir identificēt tos militārās drošības sektora draudu veidus, kurus Latvijas iedzīvotāji uzskata par aktuālākajiem, un tādus mainīgos lielumus kā ārējais apdraudējums, Nacionālie bruṇotie spēki un sabiedroto spēku klātbūtne.

Veiktā analīze ḷauj secināt, ka, iedzīvotāju ieskatā, ārējais apdraudējums pastāv un ka vairums aptaujāto uzskata Krieviju par galveno draudu, un tikai atsevišķos gadījumos sabiedroto spēku klātbūtne (NATO) būtu atzīstama par apdraudējumu. Arī Nacionālo bruṇoto spēku veidotās infrastruktūras tuvums daḷai iedzīvotāju raisa nedrošîbas sajūtu, galvenokārt tādēḷ, ka pastāv potenciāli Krievijas uzbrukuma draudi šiem objektiem. Kopumā iedzīvotājiem militārā drošība nav prioritāra, svarīgākie draudu veidi, viṇuprāt, ir labklājības un ekonomiskā sektora draudi.

No pašvaldỉbas darbinieku viedokḷa galvenais nedrošības avots ir Krievija, savukārt sabiedroto spēku klātbūtne ir drošību veicinošs faktors. Analizējot pašvaldību veidotos civilās aizsardzības plānus, tikai vienā pašvaldībā bija iezīmēta vispārēja rīcība militāras krīzes gadījumā, un tas liek secināt, ka pašvaldības nav gatavas šādas krīzes pārvarēšanai un paḷaujas uz valdības rīcību.

Atslēgvārdi: militārā drošiba, subjektīvā drošības uztvere, draudi, ārējais apdraudējums, sabiedroto spēku klātbūtne.

The goal of this study is to identify and characterise military threats in the defence domain. The study focuses on the threats that have been identified by the Latvian population as important and significant within such changing environments as external threats to the State, the National Armed Forces, and the Allied presence in Latvia. Based on the data collected in interviews with people in the focus groups and in-depth interviews with representatives in local government, conclusions can be drawn that the majority consider Russia to be the main threat and single source of external threat to Latvia. Only on rare occasions do people consider the deployment of NATO 
forces and the Allied presence in Latvia to be a threat. The expanding infrastructure and regional presence of the Latvian National Armed Forces (NAF) is a source for insecurity in some people, which is based on the opinion that NAF infrastructure could be a target of a military offensive by Russia. In general, military security is not the leading security threat as perceived by the people of Latvia. The priorities are welfare and economic security. Therefore, the State's defence policy is communicated successfully, and military threats are addressed; consequently, the population is not worried about military threats in general, but non-military threats prevail in the population's individual threat perception.

Russia is the cause for the main insecurity, but NATO presence enhances the sense of security in the opinion of local government representatives. The Civil Emergency Plans in various local counties were analysed. Only one county's Emergency Plan includes a real plan for action in case of military conflict or crisis. All other local governments and municipalities were unprepared for a military crisis and relied on action plans issued by the central government.

Keywords: military security, subjective security, threats, external threat, Allied presence.

\section{levads}

Militārā drošība, kas ir nacionālās drošỉbas viens no būtiskākajiem elementiem, nozīmē valsts spēju aizsargāt tās iedzīvotājus un nacionālās intereses, kā arī spēju atturēt no ārējiem draudiem. Tradicionāli militārā drošība asocièjas ar starpvalstu attiecībām, taču tā ietver arī indivīda personīgo drošību nacionāla, reg̣ionāla un starptautiska apdraudējuma apstākḷos. Militārā drošība kḷūst aktuāla apstākḷıs, kad notiek pārmaiņas starptautiskajā drošības vidē un aktualizējas sabiedroto un starptautisko organizāciju atbalsts. NATO loma šādu apdraudējumu mazināšanā savienojumā ar nacionāla līmeņa bruņoto spēku attīstību un sabiedrības iesaisti valsts aizsardzībā kḷūst izškiriroša. Līdz ar izmaiņām starptautiskajā drošỉbas vidē, ko radījusi Krievijas revizionistiskā politika pret Ukrainu, militārie draudi tiešā veidā ietekmē arī Baltijas valstis kopumā un katru no tām individuāli. Krievijas radītais apdraudējums Latvijai ir veicinājis finansējuma pieaugumu aizsardzībai, sabiedroto spēku klātbūtni un Nacionālo bruṇoto spēku (turpmāk - NBS) militāro spēju attīstību, lai nodrošinātu pietiekamu Krievijas atturēšanu. Tāpat tas ir veicinājis sabiedrībā diskusiju par ciešāku sadarbību starp NBS un iedzīvotājiem visaptverošā valsts aizsardzībā un valsts aizsardzības mācības ieviešanu skolās.

Militārā drošība Latvijas nacionālās drošības kontekstā ir bijusi klātesoša kā politiskajā, tā arī akadēmiskajā diskusijā kopš Latvijas neatkarības 
atjaunošanas 1991. gadā. Tomēr, ņemot vērā militārās drošības aktualitāti, ir bijuši vien atsevišḳi kvalitatīvi pētijumi par Latvijas iedzīvotāju militārās drošības uztveri, kas sniedz ieskatu par to, kā iedzīvotāji dažādās kopienās uztver iespējamo militāro apdraudējumu un kā veidojas sadarbība ar pašvaldībām. Tādēḷ nodaļas mērḳis ir identificēt tos militārās drošỉbas sektora draudu veidus, kurus Latvijas iedzīvotāji uzskata par aktuālākajiem. Nodaļas sākumā tiks apskatīti līdz šim veiktie pētījumi par militāro drošības sektoru Latvijā, kam sekos drošības sektora definējums, veidojot šì pētijuma teorētisko ietvaru. Pēc tam tiks izklāstīti pētijuma rezultāti un apkopoti būtiskākie secinājumi.

\section{Kas paveikts militārās drošības izpētē?}

N̦emot vērā vēsturisko pieredzi un Latvijas geeogrāfisko novietojumu, militārā drošība ir bijis viens no aktuālākajiem jautājumiem pētniecībā. Lai gan pētỉjumos militārā drošỉba netiek skaidri definēta, tā tiek saprasta kā nacionālā drošiba (national security) vai drošỉba (security) kopumā, kuras ietvaros tiek atsevišķi skatīta militārā sadaļa. Pirmie akadēmiskie darbi par Latvijas militāro drošību tiek publicēti līdz ar Latvijas Ārpolitikas institūta dibināšanu, pievēršoties Latvijas aktuālajām drošības problēmām tūlīt pēc neatkarības atgūšanas. ${ }^{1}$

Militārās drošības pētniecỉbu Latvijā var iedalìt vairākos posmos, un pirmais posms iezīmē periodu no neatkarības atgūšanas līdz brīdim, kad Latvija iestājās NATO. Šajā posmā būtiskākās akadēmiskās diskusijas ir par militārās

1 Grāmatā "Baltijas valstis: drošibas meklējumi” (Lejiņš, A., Bleiere, D. (eds.) (1996). The Baltic States: search for security. Riga: Latvian Institute of International Affairs, pp. 31-34) tiek apskatīts drošības koncepts un tā veidošanās Baltijas valstīs. Tajā tiek norādīts, ka Latvijā pēc neatkarības atgūšanas bija citāds uzskats par drošības konceptu nekā tolaik Rietumos pastāvošais. Šì drošỉbas koncepta citādā izpratne tiek skaidrota ar to, ka visi ar aizsardzību saistītie jautājumi tika risināti Maskavā, tādējādi neveicinot Latvijas akadēmiskajā vidē izpratni par to, kas ir drošỉba. Tāpat tiek pausts, ka Latvijas politiskās aprindās ar drošibu bieži vien saprata tikai un vienīgi militāro drošỉbu, kas ietvēra tādus terminus kā aizsardzība, aizsardzības koncepcija, bruṇotie spēki vai militārie draudi. 1998. gadā Latvijas Ārpolitikas institūts publicēja Roberta Dalsjē (Roberts Dalsjö) rakstu "Vai Baltijas valstis sevi spēj aizsargāt? Par pašaizsardzības spēju kvalitāti un perspektīvām”, kur viņš asi kritizē Latvijas pētniekus par to, ka militārajai drošỉbai gan akadēmiskajās, gan arī politiskajās aprindās netiek pievērsta pietiekami liela uzmanība. Šì situācija tiek raksturota kā intereses trūkums pret drošības aizsardzības jautājumiem (Dalsjö, R. (1998). Vai Baltijas valstis sevi spēj aizsargāt? Par pašaizsardzības spēju kvalitāti un perspektīvām. Rīga: Latvijas Ārpolitikas institūts, 14.-15. lpp.). Grāmatā Small States in a Turbulent environment: the Baltic perspective tiek uzsvērts, ka Baltijas valstis, tuvojoties modernākai uztverei par drošības konceptu savā dienaskārtībā, arvien biežāk iekḷauj tādus aspektus kā sociālā un individuālā drošỉba, un norādīts, ka kompromisus par nepieciešamajiem mēriem ir vieglāk panākt sabiedrības drošības sektorā nekā militārās drošibas sektorā (Lejiņš, A., Ozoliṇa, Ž. (1997). Small States in a Turbulent Environment: The Baltic perspective. Riga: Latvian Institute of International Affairs, p. 137). 
drošības jēdziena izpratni un tā lietojumu kā šaurākā (Nacionālie bruņotie spēki, militārās spējas, militārie draudi), tā arī plašākā kontekstā, runājot par jauno drošîbas arhitektūru Baltijas valstīs, Ziemel̦eiropas reǵionā un NATO kopumā. 1999. gadā Latvijas Ārpolitikas institūta organizētajā konferencē par Baltijas valstu drošỉbas aspektiem tiek norādīts, ka Latvijas militārā drošība var tikt garantēta tikai ar pilnasinīgu dalību NATO. Papildus dalībai kolektīvajā drošības sistēmā tiek uzsvērti arī tie militārās drošības elementi, kuri būtiski ietekmē Latvijas drošību, kā, piemēram, ārējie draudi (Krievijas faktors), militārās spējas, finansējums aizsardzībai un sabiedrības izpratne par drošības jautājumiem. ${ }^{2}$

Militārās drošības otrais posms sākās pēc iestāšanās Eiropas Savienībā un NATO un turpinājās līdz Ukrainas krīzei 2014. gadā. Šì posma raksturīgākās iezīmes ir diskusijas par starptautiskās drošības aktualitātēm, kuru centrā tiek izvirzīta Latvijas militārā drošība Eiropas Savienības un NATO kontekstā. Tā, piemēram, rakstu krājumā "Latvijas ārpolitika un "robežu paplašināšana"” tiek secināts, ka nacionālā drošîbas politika vairs nevar tikt atrauta no plašāka reǵionāla un starptautiska drošības konteksta. ${ }^{3}$ Turklāt pati svarīgākā pārmaiņu izpausme ir tā, ka dalība ES un NATO Latvijai piedāvā papildu instrumentus nacionālās drošības stiprināšanai. ${ }^{4}$ Papildus empīriskajiem pētỉjumiem tiek veiktas arī kvantitatīvās aptaujas, lai noskaidrotu, kāda ir iedzīvotāju attieksme pret valsts dalību NATO. Lai gan iedzīvotāju viedoklis ir mainīgs, pētījumu aǵentūras "Latvijas Fakti" veiktajās aptaujās tiek secināts, ka iedzīvotājiem ir bažas par potenciālajām izmaksām, kas Latvijai kā dalībvalstij jāmaksā par dalību NATO, tajā pašā laikā kopumā viṇi atbalsta dalỉbu šajā organizācijā. ${ }^{5}$

Savukārt trešais posms iezīmē akadēmiskās diskusijas par Latvijas militāro drošỉbu pēc Ukrainas krīzes. Tā, piemēram, Toms Rostoks un Nora Vanaga, diskutējot par Latvijas drošības aspektiem, norāda, ka Ukrainas krīze ir mainijusi militārās drošības uztveri Latvijā, to argumentējot ar trijām pazīmēm, kas saistītas ar Krievijas maigās varas izpausmēm, - NATO spēku klātbūtne Latvijā, militāro spēju attīstība un iekšējā drošība. ${ }^{6}$ Turklāt viņi norāda, ka debatēs par militāro drošību netiek apskatīts jautājums par obligāto militāro dienestu Latvijā, to pamatojot ar Lietuvas un Igaunijas piemēru, kur abās valstīs

2 Apinis, P., Lejiņš, A. (red.) (1999). How Secure Are the Baltic States? Conference Proceedings (Cik drošas ir Baltijas valstis? Konferences materiāli). Rīga: Konrad Adenauer Stiftung, Latvian Institute of International Affairs, pp. 12-13.

3 Ozoliņa, Ž. (zin. red.) (2006). Latvijas ārpolitika un “robežu paplašināšana”. Rīga: Zinātne, 32. lpp. Turpat.

5 Latvijas Fakti (2007. marts). Sabiedriskās domas aptauja par Latvijas dalību NATO, 4. lpp.

6 Rostoks, T., Vanaga, N. (2016). Latvia's security defence post-2014. Journal on Baltic Security, 2(2), pp. 71-109. 
obligātais militārais dienests ir saglabāts. Tāpat arī, pievēršoties sabiedrības izpratnes noskaidrošanai par drošības jautājumiem, Rostoks un Vanaga secina, ka militārās drošības jautājumos, kas skar Krieviju un NATO, pastāv atškirīibas starp latviešu valodā un krievu valodā runājošo respondentu viedokḷiem, t. i., latvieši biežāk nosoda Krievijas politiku un uzskata, ka jāstiprina nacionālās aizsardzības spējas un jāpanāk aizsardzības budžeta pieaugums.?

Žaneta Ozoliņa un Valdis Otzulis, diskutējot par Baltijas valstu drošības stratēgiijām, pievēršas uzn̦emošās valsts atbalstam un secina, ka Latvijas militārās drošības pamatā ir pašaizsardzības spēju attīstība un spēja uzṇemt sabiedroto spēkus. ${ }^{8}$ 2020. gadā publicētajā pētỉjumā par Latvijas sabiedrības gribu aizstāvēt valsti U. Zupa un I. Bērziṇa secina, ka visaptverošas valsts aizsardzības koncepts ietver ne tikai militārus risinājumus, bet arī nemilitārus valsts aizsardzības pasākumus. Pētijuma laikā tika aptaujāti iedzīvotāji un izkristalizējās atziņa, ka grupās, kurās respondenti ir gatavi aizstāvēt valsti, ir lielāka uzticēšanās valsts un pašvaldību institūcijām, bet mazākumtautību iedzīvotājiem ir izteiktāka atsvešinātība no militārās drošības jautājumiem, proti, viņi mazāk uzticas NBS un Zemessardzei. ${ }^{9}$

Militārās drošības jautājumi ir tikuši pētīti arī dažādās sabiedriskās domas aptaujās. Pētījumu centrs SKDS kopš 2014. gada pēc Aizsardzības ministrijas pasūtijuma regulāri veic sabiedrības aptauju par NBS tēlu, uzticēšanos tiem un NBS attīstības jautājumiem. Tā, piemēram, 2014. gadā veiktās aptaujas kvantitatīvie dati liecināja, ka 64\% iedzivotāju paļaujas uz NBS un to îstenotajiem pasākumiem drošības stiprināšanā, ${ }^{10} 2015$. gadā tie bija $60 \%,{ }^{11}$ bet, saskaņā ar Eirobarometra aptaujām par sabiedrības viedokli, 2016. gadā NBS uzticējās 70\% iedzīvotāju, ${ }^{12} 2017$. gadā $-66 \%,{ }^{13} 2018$. gadā $-66 \%,{ }^{14} 2019$. gadā $69 \%$ iedzìvotāju ${ }^{15}$.

7 Rostoks, T., Vanaga, N. (2016). Latvia's security defence post-2014. Journal on Baltic Security, 2(2), p. 101.

8 Ozolin̦a, Ž., Otzulis. V. (2016). Shaping Baltic States defence strategies: host nation support. Lithuanian Annual Strategic Review, 2016-2017, Vol. 15, p. 98.

9 Bērzin̦a, I., Zupa, U. (2020). Latvijas sabiedrības griba aizstāvēt valsti: veicinošie un kavējošie faktori. Rīga: Drošỉbas un stratēǵiskās pētniecības centrs, 28. lpp.

10 SKDS (2014. gada novembris). Latvijas iedzīvotāju viedoklis par valsts aizsardzības jautājumiem, 23. lpp. Pieejams: https://www.mod.gov.lv/lv/dokumenti

11 Turpat, 2015. gada novembris, 24. lpp.

12 European Commission (2016). Public opinion in the European Union. Standard Eurobarometer 86, Autumn 2016, p. 52.

13 Ibid., Standard Eurobarometer 88, Autumn 2017, p. 53.

14 Ibid., Standard Eurobarometer 90, Autumn 2018, p. T39.

15 Ibid., Standard Eurobarometer 92, Autumn 2019. Pieejams: T39https://ec.europa.eu/commfrontoffice/ publicopinionmobile/index.cfm/Chart/getChart/themeKy/18/groupKy/82 [skatits 20.04.2020.] 
Saskaņā ar SKDS veikto aptauju 41\% iedzīvotāju 2016. gadā norādījuši, ka drošības situācija Latvijā ir uzlabojusies, pateicoties dalībai NATO un aktīvai divpusējai sadarbībai ar citām valstīm, piemēram, ASV.$^{16}$ Taču tikai $26 \%$ aptaujāto iedzīvotāju uzskatījuši, ka NATO situāciju ir pasliktinājusi un ka tā nedarbojas kā drošîbas garants. ${ }^{17}$ 2019. gadā SKDS veiktās aptaujas dati par militāro drošību Latvijā nav publiski pieejami, tāpēc jaunākās tendences iedzīvotāju militārās drošības uztverē nav iespējams izzināt un salīdzināt.

\section{Militārās drošības jēdziens}

Militārā drošība tiek definēta kā valsts spēja sevi aizsargāt, pieņemot politiskus lēmumus un izmantojot militāru spēku. ${ }^{18}$ Polijas Nacionālās aizsardzības universitātes profesors Rišards Špira (Ryszard Szpyra) militāro drošību definē kā procesu, kura laikā norisinās nepārtrauktas izmaiṇas militārajā sfērā un kopējā valsts politiskajā vidēe. ${ }^{19}$

Viņš min šādas raksturīgas pazīmes: militāro drošību veido tādi divi galveni elementi kā valsts un tās starptautiskās vides ietvars, kas ir saistīts ar bruņoto spēku esamību. Šajā ietvarā militārais spēks ir viens no galvenajiem valsts instrumentiem, lai mazinātu potenciālo apdraudējumu. ${ }^{20}$

Buzans, Vēvers un de Vilde uzskata, ${ }^{21}$ ka militārajā sektorā valsts ir noteicošais, taču ne vienīgais elements, kam pieder militārie resursi. Būtiska loma ir politiskajai elitei, kurai ir dotas leǵitīmas tiesības izmantot militāro spēku kā iekšēju krīžu, tā arī ārēju interešu aizstāvībai. ${ }^{22}$ Militārais sektors un tā dienaskārtība ir atkarīga no valdības noturības gan pret iekšējiem, gan arī pret ārējiem draudiem, taču tas nozīmē ne tikai militārus, bet arī nemilitārus risinājumus, piemēram, migrantu krīzes, dabas katastrofas un citos gadījumos. ${ }^{23}$

16 SKDS (2016. gada novembris). Latvijas iedzīvotāju viedoklis par valsts aizsardzības jautājumiem: Latvijas iedzīvotāju aptauja, 12. lpp. Pieejams: https://www.mod.gov.lv/sites/mod/files/document/ SKDS_aptauja_2016\%20\%281\%29.pdf.

17 Turpat, 16. lpp.

18 Militārās drošỉbas definīcija. Pieejams: https://www.yourdictionary.com/military-security [skatīts 31.08.2020.]

19 Szpyra, R. (2014). Military Security within the Framework of Security Studies: Research Results. Partnership for Peace Consortium of Defense Academies and Security Studies Institutes, 13(3), p. 65.

20 Ibid., p. 66.

21 Grāmatā Security: a new framework for analysis (p. 70) tiek secināts, ka valsts teritoriālā integritāte ir tradicionāls militārās drošības mērḳis, kur reǵionālā un iekšējā drošības vide ir galvenā šī sektora problēma.

22 Buzan, B., Wæver, O., de Wilde J. Security: a new framework for analysis. London: Lynne Rienner Publisher, p. 49.

23 Ibid., p. 50. 
Kā vienu no militārās drošìbas galvenajiem elementiem Buzans, Vēvers un de Vilde min valsts militārās spējas, kas papildināmas ar tādiem mainīgajiem kā geogrāfiskais novietojums, vēsturiskā pieredze un politiskie lēmumi. ${ }^{24}$

Zoltāns Senešs (Zoltán Szenes), raksturojot militāro drošību 21. gadsimtā iepretim jaunajiem draudiem, uzskata, ka aizsardzības stratēgijas, militārā politika un bruṇoto spēku attīstîba ir jābalsta uz tādiem faktoriem kā ārējās un iekšējas drošības attiecības, jāspēj noteikt, kas tiek apdraudēts (tā ir valsts vai kāda sociālā grupa), jābūt spēkam, kas spēj sniegt drošību (bruņotie spēki, policija, drošības dienesti), un jāapzinās valsts vājie punkti. ${ }^{25}$ Senešs uzskata, ka šie faktori ir būtiski, jo 21. gadsimta mainīgā drošības vide ir veicinājusi nemitīgas izmaiņas militārās drošības sektorā, kur starpvalstu kari tās klasiskā izpratnē ir papildināti ar terorisma draudiem, kā arī konflikta eskalāciju, kam grūti noteikt robežas. ${ }^{26}$

Pamatojoties uz akadēmiskajā literatūra paustajiem viedokḷiem par militāro drošību, ir iespējams izšķirt šādus ar militāro sektoru saistìtus elementus: ārējais apdraudējums, militāro spēju attīstība jeb nacionālie bruṇotie spēki. Papildus tam arī tādus faktorus kā aizsardzības budžets, sabiedrības iesaiste valsts aizsardzībā (visaptveroša valsts aizsardzība), sabiedroto spēku klātbūtne (NATO), kas pastiprina iepriekš minēto elementu spēju nodrošināt valsts militāro drošību. Tie veido šīs nodaļas analīitisko rāmi, kurš izmantots, lai pētītu, kā sabiedrība uztver Latvijas militārās drošības sektoru.

Identificētie elementi ir integrēti fokusa grupu interviju jautājumos par iedzīvotāju subjektīvo drošību, lai izzinātu, kas militārajā sektorā ir vislielākais apdraudējums, ko izjūt noteiktas indivīdu grupas un identificē pašvaldỉbu darbinieki.

\section{Latvijas iedzīvotāji par militāro drošību}

Fokusa grupu interviju rezultātus var sadalīt vairākās tematiskās grupās atbilstoši šajā apakšnodạ̣ā definētajam zinātniskajam ietvaram par militāro drošìbu - ārējais apdraudējums, sabiedroto spēku klātbūtne (ietverot arī NATO kā drošības garantu) un NBS (ietverot aizsardzības finansējumu, spēju attīstību, visaptverošu valsts aizsardzību).

24 Buzan, B., Wæver, O., de Wilde, J. Security: a new framework for analysis. London: Lynne Rienner Publisher, p. 59.

25 Szenes, Z. (2018). Military Security Today. New Threats, New Wars, New Theories. In: Finszter, G., Sabjanics, I. (Eds.) Security Challenges in the $21^{\text {st }}$ Century. NUPS, Dialog Campus, p. 72.

26 Ibid., p. 99. 


\section{Ārējais apdraudējums}

Interviju izvērtējuma rezultātā ir iespējams secināt, ka Krieviju kā ārējo draudu Latvijas iedzīvotāji uztver neviennozīmīgi. Lai gan Latvijas geogrāfiskajam novietojumam un Krievijai kā kaimiṇvalstij ir būtiska nozīme militārās drošības uztverē, tomēr viena daļa iedzīvotāju uzskata, ka Krievija rada nenozīmīgus draudus vai nerada tos vispār, turpretī otra daļa Krieviju dēvē par galveno ārējo apdraudējumu. Kopumā Krievija kā ārējais drauds prevalē pār tādiem ārējiem draudu veidiem kā starptautiskais terorisms vai uzbrukumi kibertelpā.

Ārējā apdraudējuma uztveres dažādību vislabāk atspoguḷo Âdažu un Liepājas pašvaldību iedzīvotāji, kuru teritorijās ir izvietota ievērojama militārā infrastruktūra. Tā, piemēram, Ādažu iedzīvotāju ieskatā, Krievija ir galvenais drauds, jo NBS militārās bāzes ir izvietotas viṇu pašvaldības teritorijā.

Pensionārs, Ādažu iedzìvotājs: L̦oti liels apdraudējums. Ja runā par raķešu uzbrukumu, tad tas ir viens no mērkiem, turklāt, ja netrāpa, tad Ādaži ir apdraudēti. ${ }^{27}$

Lai gan militārās bāzes klātesamība rada ārējus draudus, tomēr iedzīvotāji ir gatavi samierināties ar to, ja šie draudi tiek kompensēti ar finansiālajiem ieguvumiem, ko sniedz militārās infrastruktūras un sabiedroto spēku klātbūtne.

Sieviete darbspējas vecumā, Ādaži: .. armijas bāzes attīstība silda pašvaldības budžetu un tās ekonomiku. ${ }^{28}$

Pretēji domā iedzīvotāji Liepājā, kur arī ir militārā bāze. Viṇi nav tik kategoriski, taču uzskata, ka Krievija ir Latvijas apdraudējums, bet bāzes klātbūtne vairo drošỉbas sajūtu.

Pensionāre, Liepāja: Militārā zinnā viss ir kārtībāa, jo par militārajām lietām nav jādomā, primāri [par ko jādomā] tã ir sociālā un ekonomiskā drošǐba. ${ }^{29}$

Jaunietis, Liepāja: Pie mājām ir militārā šautuve, kad norisinās militārās mācības, tad aizdomājos par drošǐbu. ${ }^{30}$

Pašvaldībās, kurās nav būtiska militārā infrastruktūra (Talsi, Madona, Ļaudona, Rīga, Aizkraukle, Rēzekne, Gulbene), uzskata Krieviju par lielāku vai mazāku draudu. 
Jauniete, L,audona: Starptautiskā sistēma ir saprātīga, lìdz ar to Krievijas drauds ir maz ticams. ${ }^{31}$

Sieviete darbspējas vecumā, Talsi: Krievija kā kaimiṇi ir bīstama, taču to mēs izvèlēties nevaram. ${ }^{32}$

Jaunietis, Aizkraukle: Ja Krievija izdomātu sagraut NATO, tad Latvija būtu pir$m \bar{a}$... Krievijai nav nepieciešamas konvencionālas metodes, ar lienošu okupāciju tā varètu būt sekmīgākā. ${ }^{33}$

Savukārt Jaunjelgavas, Valmieras un Daugavpils pašvaldībās Krieviju redz kā sadarbības partneri, ar ko būtu jāīsteno kopēji attīstības projekti, kā kaimiṇu, ar kuru jāsaglabā labas attiecības. Latvija esot pārāk maza, tādēl Krievijai tā neesot vajadzīga.

Studente, Daugavpils: Latvija Krievijai nav vajadzīga, bet, ja vajadzēs, tad pañems ne tikai Latviju, bet visas Baltijas valstis. Kāpēe mums būtu jābaidās no Krievijas? Es nesaprotu, kāpēc tas mūs satrauc. Mēs esam Eiropas Savienībā, un viss. Jūs tur, Rīgā, varat no viņas baidīties, mums nav jābaidās. ${ }^{34}$

Sieviete darbspējas vecumā, Valmiera: Krievija var iejaukties, taču tai Latvija nav vajadzīga. ${ }^{35}$

Pensionāre, Jaunjelgava: Nezinu, vai būtu jāfokusējas uz Krieviju kā lielāko ienaidnieku, kā nekā kaimiņs. ${ }^{36}$

\section{Sabiedroto spēku klātbūtne}

Kopš 2004. gada, kad Latvija kḷuva par NATO dalïbvalsti, sadarbība ar sabiedrotajām valstīm kolektīvās drošibas jomā ir kḷuvusi par vienu no Latvijas aizsardzības pamatelementiem. Šì sadarbība īpaši cieša izvērtās pēc Krievijas agresijas Ukrainā, kad 2015. gadā Latvijā tika izveidota NATO spēku integrācijas vienība, kas ir pirmā NATO struktūra un komandḳēdes sastāvdaḷa. 2016. gadā NATO samitā Varšavā tika pieņemts lēmums izvietot Latvijā kaujas grupu Kanādas vadībā. Saskaṇā ar 2016. gada Valsts aizsardzības koncepciju NATO ir Latvijas drošỉbas un aizsardzības garants un ar sabiedroto spēku klātbūtni tiek nodrošināta atturēšana, turklāt "Latvijas interesēs ir panākt ilgtermiṇa risinājumu sabiedroto nozīmīgai militārajai klātbūtnei Latvijā"37.

31 Fokusa grupas intervija ar L̦audonas iedzīvotājiem 2019. gadā.

32 Fokusa grupas intervija ar Talsu iedzīvotājiem 2019. gada 2. novembrī.

33 Fokusa grupas intervija ar Aizkraukles iedzīvotājiem 2020. gada 18. janvārī.

34 Fokusa grupas intervija ar Daugavpils iedzīvotāiiem 2019. gada 27. septembrī.

35 Fokusa grupas intervija ar Valmieras iedzīvotājiem 2019. gada 23. novembrī.

36 Fokusa grupas intervija ar Jaunjelgavas iedzīvotājiem 2019. gada 19. oktobrī.

37 Saeimas paziņojums (2020). Par Valsts aizsardzības koncepcijas apstiprināšanu. Pieejams: https:// likumi.lv/ta/id/282964-par-valsts-aizsardzibas-koncepcijas-apstiprinasanu [skatīts 16.04.2020.] 
Fokusa grupu interviju izvērtējuma rezultātā var secināt, ka vairums iedzīvotāju atbalsta sabiedroto spēku klātbūtni un redz NATO kā Latvija drošības garantu. Iedzīvotāji Liepājas, Rīgas, Ādažu, Valmieras, Jaunjelgavas, Aizkraukles un Madonas pašvaldībās uzsver nepieciešamību pēc sabiedroto spēku klātbūtnes Latvijā un vērtē to kā drošìbu veicinošu faktoru.

Vīrietis darbspējas vecumā, Liepāja: Latvijas armija un NATO rada drošǐbas sajūtu, jo vecākais dēls ir karavīrs. Svarīgi, ka esam NATO un mums ir 5. pants. ${ }^{38}$ Pensionārs, Valmiera: Ja būtu vairāk sabiedroto spēku klätbūtne, bütu lielāka drošǐba, tikai vai mēs spējam uzturēt vinus. ${ }^{39}$

Vīrietis darbspējas vecumā, Rīga: Dalība NATO un ES sniedz mums priekšrocības un kalpo par atturēšanas mehānismu. NATO, cerams, varētu aizstāvēt, mēs neesam vieni paši. ${ }^{40}$

Students, Aizkraukle: Mēs esam pasargātāki, jo Latvija ir NATO. Spēku klātbūtne šeit ir pozitìva, ja nav saasinājuma, savukārt negatìvā puse ir tāda, ka abās robežas pusēs tiek pumpēti resursi. Krievi pievelk pie robežas karaspēku un atstäj, un tas nav droši. ${ }^{41}$

Apkopojot interviju rezultātus, ir iespējams arī uzzināt viedokḷus un iedzīvotāju nostāju - NATO klātbūtne tiek uztverta gan pozitīvi, gan kā drauds.

Pensionārs, Talsi: Sabiedroto spēku klātbūtne ir ilūzija, lai nomierinātu sabiedrību, un bütisks pienesums no to klätbütnes nav. ${ }^{42}$

Studente, Gulbene: Karadarbība nav prioritāri, par ko domāt, tāpēc ir ES un NATO. Tas ir bieds, ka krievi nāk. Šo izmanto, lai biedētu iedzìvotājus, un to izmanto kāds cits. ${ }^{43}$

Sieviete darbspējas vecumā, Daugavpils: Nē, viņi [sabiedroto karavīii] te staigāja $k a ̄$ saimnieki. Viṇi Daugavpilì nav vajadzīgi. ${ }^{44}$

Studente, Daugavpils: Mums ir kaut kāda mānija ar NATO. Labāk naudu iedot bērniem un veciem cilvēkiem. Priekš kam tērēt naudu NATO. Manuprāt, Latvi$j a ̄$ ir stabili. Ar to NATO nauda ir izmesta vējā. Varbüt var pieredzes apmaiņai, ik divos gados, bet pastāvīgi tas nav vajadzīgs. Latvijai nav ienaidnieku. ${ }^{45}$

Fokusa grupas intervija ar Liepājas iedzīvotājiem 2019. gada 20. augustā.

Fokusa grupas intervija ar Valmieras iedzīvotājiem 2019. gada 23. novembrī.

Fokusa grupas intervija ar Rīgas iedzīvotājiem 2019. gada 28. oktobrī.

Fokusa grupas intervija ar Aizkraukles iedzīvotājiem 2020. gada 18. janvārī.

Fokusa grupas intervija ar Talsu iedzīvotājiem 2019. gada 2. novembrī.

Fokusa grupas intervija ar Gulbenes iedzīvotājiem 2019. gada 21. septembrī.

Fokusa grupas intervija ar Daugavpils iedzīvotājiem 2019. gada 27. septembrī.

Turpat. 
Jauniete, Rēzekne: NATO drīzāk ir drauds, nevis drošības garants. Jābaidās no ASV karavīiem, jo nav zināms iemesls, kädēl tie atrodas pilsētā, nevis no Krievijas. ${ }^{46}$

\section{Nacionālie bruṇotie spēki}

Sabiedriskās domas aptaujas Latvijā rāda nemainīgu uzticību Nacionālajiem bruṇotajiem spēkiem un to veiktajām iniciatīvām drošìbas stiprināšanai. Fokusa grupas intervijās tika iegūti kvalitatīvi dati par NBS vērtējumu un noskaidrots, kā NBS attīstîba un klātbūtne spēj ietekmēt iedzīvotāju subjektīvo drošibas uztveri.

Līdzīgi kā sabiedroto spēku klātbūtni, arī Latvijas armiju vairums iedzīvotāju vērtē kā drošību veicinošu faktoru. Tā, piemēram, Liepājā, Rỉgā, Aizkrauklē, Gulbenē, Madonā un Valmierā iedzīvotāji pozitīvi vērtē gan NBS attīstību, gan arī to, ka aizsardzības budžetam ir atvēlēti $2 \%$ no valsts iekšzemes kopprodukta.

Jauniete, Gulbene: Valstī ir armija un robežsargi, tādēl par drošǐbu neuztraucos.

Turklāt Alūksnē ir bāze un Gulbenē ir robežsardze. Tagad ir žogs. ${ }^{47}$

Vīrietis darbspējas vecumā, Liepāja: Jāpilda savas saistības un $2 \%$ no budžeta ir jāmaksā, taču reāliem draudiem nacionālās spējas ir par maz. ${ }^{48}$

Pensionārs, Valmiera: Procentuāli pildām, un tas ir pilnīgi pietiekami, bet nav pārliecības par to, ko mēs varētu izdarìt pret Krievijas militāro pārspēku. ${ }^{49}$

Pensionāre, Rīga: Armija ir sakārtojusies, armijas prestižs ir audzis, un tas ir nopelns, ka par ārpolitiku tiek domāts. Liela drošǐbas sajūta, jo kā bijušajam padomju cilvēkam, kurš dzìvojis apspiestībā un stresā, ir jütamas bütiskas izmainas. ${ }^{50}$

Intervijās ir iespējams identificèt arī tās iedzīvotāju grupas, kuras uzskata, ka NBS veicina drošỉbu, bet tajā pašā laikā aizsardzībai atvēlētie 2\% ir pārāk daudz. Talsu Rēzeknes, Daugavpils un Gulbenes iedzīvotāji uzskata, ka aizsardzībai nevajadzētu tērēt vairāk, tā vietā finansējums būtu jānovirza citām jomām, piemēram, sociālajai aizsardzībai vai izglìtībai.

Pensionārs, Rēzekne: Ir laiks samazināt izdevumus apbruṇošanai. Mūsu paaudzei to nesaprast. Latvijā aizvien vairāk un vairāk ir armija. ${ }^{51}$

46 Fokusa grupas intervija ar Rēzeknes iedzīvotājiem 2019. gada 12. oktobrī.

47 Fokusa grupas intervija ar Gulbenes iedzīvotājiem 2019. gada 21. septembrī.

48 Fokusa grupas intervija ar Liepājas iedzīvotājiem 2019. gada 20. augustā.

49 Fokusa grupas intervija ar Valmieras iedzīvotājiem 2019. gada 23. novembrī.

50 Fokusa grupas intervija ar Rīgas iedzīvotājiem 2019. gada 28. oktobrī.

51 Fokusa grupas intervija ar Rēzeknes iedzīvotājiem 2019. gada 12. oktobrī. 
Vīrietis darbspējas vecumā, Daugavpils: Lìdz Gruzijai un Ukrainai tas miers bija daudz vairāk. Reāli, kad ir precedenti uz militārām intervencēm, domāšana bišķit mainās. Kad mēs noturam $2 \%$ militārām vajadzībām, bet nevaram atrast skolotājiem, pērkot vecus tankus, tad tā bilde nesaliekas nedaudz..$^{52}$

Students, Talsi: Satrauc, ka liela daḷa budžeta aiziet aizsardzībai un iepērk vecu tehniku. ${ }^{53}$

Fokusa grupas intervijās varēja arī uzzināt, ka Talsu, Ādažu, Jaunjelgavas, Rēzeknes un Daugavpils iedzīvotāji jūtas nedroši tieši NBS klātesamības dēl vai arī uzskata, ka iztērētajam aizsardzības finansējumam militārajām spējām vajadzēja būt jēgpilnākam.

Sieviete darbspējas vecumā, Daugavpils: Militäro budžetu plānojot, tajā jāparedz arī investīijas reǵiona iedzīvotājos vai, piemēram, reǵgiona.$^{54}$

Vīrietis darbspējas vecumā, Jaunjelgava: Izskatās, ka nauda tiek tèrēta neadekvāti, un to nevajadzētu uztvert kā pašmērkịi. Brīžiem izskatās, ka tiek plānots, ko vēl var nopirkt. Jāsaved kārtībā to mazumiņu, lai nauda aiziet reğioniem, piemēram, ZS. Helikopteru pirkšana nav adekvāta..$^{55}$

Sieviete darbspējas vecumā, Talsi: Man kā sievietei drošǐbu nerada, jo dabūsim pirmo triecienu, kur atrodas militārās bāzes. ${ }^{56}$

No fokusa grupas intervijās iegūtajiem kvalitatīvajiem datiem var secināt, ka iedzīvotāji atbalsta NBS klātbūtni, bet atsevišķos gadỉjumos militārās infrastruktūras tuvums rada viņos diskomfortu, tāpēc viṇi NBS klātbūtni uztver negatīvi. Apdraudējums izriet no uzskata, ka potenciāla kara gadījumā militārā infrastruktūra tiktu iznīcināta vispirms un tā, kura atrodas apdzīvotu vietu tuvumā, tiešã veidā ietekmētu iedzīvotājus. Taču tajā pašā laikā tā veicina apdzīvoto vietu ekonomisko izaugsmi, kas mazina apdraudējuma negatīvo uztveri, kā to pierāda arī Ādažu gadījums. Līdz ar to subjektīvajā drošỉbas uztverē militārās infrastruktūras klātbūtne ir drauds, bet tās sniegtais ekonomiskais ieguvums mīkstina draudu uztveri.

Runājot par visaptverošas valsts aizsardzības sistēmu, iedzīvotāji visās pašvaldībās, kurās tika veiktas fokusa grupu intervijas, uzsvēra, ka šĩ sistēma līdz galam nav skaidra vai arī trūkst būtiskas informācijas par to, kā plānots šo sistēmu ieviest un kas būtu jādara iedzìvotājiem.

\footnotetext{
52 Fokusa grupas intervija ar Daugavpils iedzīvotājiem 2019. gada 27. septembrī.

53 Fokusa grupas intervija ar Talsu iedzīvotājiem 2019. gada 2. novembrī.

54 Fokusa grupas intervija ar Daugavpils iedzīvotājiem 2019. gada 27. septembrī.

55 Fokusa grupas intervija ar Jaunjelgavas iedzīvotājiem 2019. gada 19. oktobrī.

56 Fokusa grupas intervija ar Talsu iedzīvotājiem 2019. gada 2. novembrī.
} 
Vīrietis darbspējas vecumā, Liepāja: Mēs kā sabiedrība neesam gatava mazākām krīzèm, vai mēs būtu gatavi kaut kam lielākam? Šeit ir l̦oti daudz darāmā, turklāt jaunai paaudzei nav sajēgas, ko un kā darīt. ${ }^{57}$

Vīrietis darbspējas vecumā, Jaunjelgava: Cilvēki sāk nogurt no drošības saistīšanas ar armiju. Vajag attīstìt skautismu. ${ }^{58}$

Sieviete bezdarbniece, Valmiera: Visaptverošas valsts aizsardzības iniciatīva ir atbalstāma. Jautājums, kā to stāsta, jo ne visi būs šāvēji. Lìdz ar to pirmā medicìniskā palìdzìba obligāti būtu ieviešama skolā. Vajag cilvēkiem šo iniciatìvu izskaidrot vairāk. ${ }^{59}$

Vīrietis darbspējas vecumā, Rīga: Trūkst informācijas, ko darīt, iet uz tuvāko Zemessardzes punktu vai armijas daḷu. Krimas scenārijs varētu būt reāls Daugavpilī vai Rīgā dēl krievvalodīgajiem, viegli būtu iefiltrēt citus elementus. Mums pašiem arī kaut kas jādara, lai vienkārši nepārietu pāri. ${ }^{60}$

Interviju laikā iegūtās informācijas analīze liek secināt, ka iedzīvotāju informētības līmenis par visaptverošu valsts aizsardzību ir samērā zems. Pamatā tiek norādīts, ka trūkst informācijas par civilās aizsardzības plāniem, par kuriem tieši atbild Iekšlietu ministrija, bet pastarpināti - Aizsardzības ministrija. Taču saskaṇā ar 2019. gada 8. janvārī valdības apstiprināto Aizsardzības ministrijas informatīvo ziņojumu "Par visaptverošas valsts aizsardzības sistēmas ieviešanu Latvijā" ${ }^{61}$ civilā aizsardzība tiek definēta kā viena no jomām, kuru būtu nepieciešams pilnveidot, lai attīstītu visaptverošas valsts aizsardzības konceptu. Turklāt jebkurš militārais konflikts ietekmē sabiedrību un tās aizsardzības plānus, tādējādi padarot Aizsardzības ministriju par līdzatbildīgu sabiedrības izglītošanā.

Kopumā visās pašvaldībās, kurās tika veiktas fokusa grupas intervijas, tika pausts atbalsts valsts visaptverošas aizsardzības sistēmai, jo tā ietvertu norādījumus par iedzīvotāju uzdevumiem atkarībā no viṇu spējām, zināšanām un profesijas un par viṇu rīcību krīzes situācijā, dabas katastrofā vai militāra apdraudējuma gadījumā. Atsevišḳās pašvaldībās (piemēram, Valmierā) iedzīvotāji uzskatīja, ka nepieciešams informatīvs izdevums (kā Lietuvā vai Zviedrijā), kur īsumā būtu aprakstīta jebkura vispārēja rīcība krīzes situācijā.

57 Fokusa grupas intervija ar Liepājas iedzīvotājiem 2019. gada 20. augustā.

58 Fokusa grupas intervija ar Jaunjelgavas iedzīvotājiem 2019. gada 19. oktobrī.

59 Fokusa grupas intervija ar Valmieras iedzīvotājiem 2019. gada 23. novembrī.

60 Fokusa grupas intervija ar Rīgas iedzīvotājiem 2019. gada 28. oktobrī.

61 Ministru kabinets (08.01.2019.). Informatīvais ziņojums "Par visaptverošas valsts aizsardzības sistēmas ieviešanu Latvijä”, 2. lpp. Pieejams: http://tap.mk.gov.lv/mk/tap/?pid=40462120 


\section{Militārā drošība pašvaldībās}

Šajā apakšnodaļā ir analizēti militārās drošỉbas sektora pārvaldības rādītāji tajās Latvijas pašvaldībās, kur militārie draudi tika uzskatīit par prioritāriem. Tā kā tikai Ādažu iedzīvotāju skatījumā militārie draudi ir visbūtiskākie, tad šajā apakšnodạ̦ā papildus ir apskatītas arī citas pašvaldības (Jaunjelgava, Rēzekne un Liepāja), kurās militārie draudi netika uzskatīti par prioritāriem draudiem. Tika analizēts pašvaldības darbinieku viedoklis par drošības jautājumiem, kā arī pètījumā iesaistīto pašvaldību civilās aizsardzības plāni. ${ }^{62}$

\section{Ādažu novada pašvaldība}

Intervijā ar Ādažu pašvaldības darbinieku militārā sektora draudi tika uzskatīti par būtiskiem tieši militāāās infrastruktūras dēḷ.

Bāze pievilina gan huligānus, gan reālus Krievijas aǵentus, gan kaut ko pa vidudronu lidinātājus virs bāzes utt. ${ }^{63}$

N̦emot vērā tuvumā esošo militāro infrastruktūru, pašvaldība saredz komunikācijas problēmas gan ar Aizsardzības ministriju meža ugunsgrēku gadījumā, kurš izcel̦as militārās aktivitātes poligonā, gan ar vietējiem iedzīvotājiem, informējot viņus par iespējamo rīcību krīzes situācijā. Iedzīvotāju informētîbai par pakalpojumu pieejamību krīzes situācijā pašvaldība plāno izmantot "Ādažu Vēstis", taču šobrīd tas netiek darīts, lai gan pēc Ukrainas krīzes ticis praktizēts.

Iepriekš, kad izpilddirektors bija zemessargs, tas ticis isstenots tūlìt pēc 2014. gada notikumiem Ukraina..$^{64}$

Civilās aizsardzības scenāriju praktizēšana tiek uzskatīta par nepieciešamu, jo pašvaldības darbinieku civilās aizsardzības atkārtotās apmācībās tiktu simulēta krīzes situācija un trenēta lēmumu pien̦emšana.

Civilās aizsardzības sistēmas mācības ir bijušas dānu ekspertu vadībā. ${ }^{65}$

62 Saskaṇā ar Valsts ugunsdzēsības un glābšanas dienesta mājaslapā pieejamo informāciju civilā aizsardzība ir pasākumu kopums, kurus īsteno valsts un pašvaldību institūcijas un sabiedrība, lai nodrošinātu cilvēku, vides un īpašuma drošību, kā arī īstenotu atbilstošu rīcību katastrofas un katastrofas draudu gadījumā. Viens no civilās aizsardzības uzdevumiem ir saistīts arī ar militāro drošỉbu, proti, nodrošināt atbalstu valsts aizsardzības sistēmai, ja noticis militārs iebrukums vai sācies karš. VUGD. Civilā aizsardzība. Pieejams: https://vugd.gov.lv/lat/par_vugd/darbibas_sferas/ civila_aizsardziba [skatīts 06.09.2020.]

63 Padziḷinātās intervijas ar Ādažu novada pašvaldības darbinieku 2020. gada 13. janvārī.

64 Turpat.

65 Turpat. 
Apskatot Ādažu civilās aizsardzības plānu, var secināt, ka pašvaldība ir ņēmusi vērā militārās infrastruktūras klātesamību, uzsverot, ka tās teritorijā ir izvietota viena no lielākajām militārajām bāzēm Baltijas valstīs. Kā tiek norādìts plānā, tās klātesamība tiek saistīta ar meža ugunsgrēka bīstamību tieši militārā poligona dệ̣. ${ }^{66}$ Tāpat plānā tiek runāts par bruṇotu konfliktu vai militāru iebrukumu.

Bruñots konflikts var izraisìties pierobežā vai iekšzemē. Tajā var tikt iesaistìtas bruņotas grupas, lai izraisītu konfliktsituāciju starp valstīm vai vienas valsts iekšienē, kas skar valsts teritoriju vai tās valdību. ${ }^{67}$

Civilās aizsardzības plānā nav detalizēti norādīts, kāda būtu pašvaldības rīcība militārās krīzes situācijās, vien uzsvērts, ka tā izṇēmuma ${ }^{68}$ vai mobilizācijas gadījumā apziņotu mobilizējamās personas, valsts institūciju darbiniekus un iedzīvotājus. ${ }^{69}$ Militāras krīzes situācijā pašvaldības rīcība tiktu noteikta ar atsevišķiem Ministru kabineta rīkojumiem.

Saskaņā ar Ministru kabineta noteikumiem par civilās aizsardzības plānu struktūru un tajos iekḷaujamo informāciju Ādažu pašvaldības civilās aizsardzības plānā nav aprakstìta pašvaldības rīcība militāra iebrukuma vai kara gadijjumā. ${ }^{70}$ Saskaņā ar pētijuma laikā izveidoto labas pārvaldības matricu, kur normatīvo aktu izmaiṇas ir viens no labas pārvaldības kritērijiem, Ādažu pašvaldība neizpilda kritēriju par esošo plānu aktualizāciju vai jaunu izstrādi, jo pēdējais apstiprinātais civilās aizsardzības plāns ir ticis aktualizēts vien 2013. gadā.

\section{Jaunjelgavas novada pašvaldība}

Jaunjelgavas pašvaldība analīzei tika izvēlēta tāpēc, ka šajā pētījumā iedzīvotāju ziṇā tā ir viena no mazākajām pašvaldībām, turklāt tās iedzīvotāju subjektīvajai drošîbas uztverei raksturīgs tas, ka viṇi ārējo apdraudējumu nesaskatīja.

66 Ādažu pašvaldība (2013). Civilās aizsardzības plāns. Pieejams: https://www.adazi.lv/pasvaldiba/ dokumenti/civilas-aizsardzibas-plans/ [skatīts 07.09.2020.]

67 Turpat, 32. lpp.

68 Saskaṇā ar likumu “Par Ārkārtas situāciju un izṇēmuma stāvokli” izṇēmuma stāvoklis ir īpašs tiesiskais režīms, kas izsludināms, ja valsti apdraud ārējais ienaidnieks vai valstī vai tās daḷā ir izcēlušies vai draud izcelties iekšējie nemieri, kas apdraud demokrātisko iekārtu. Skatīt: Saeima (2013). Par ārkārtējo situāciju un izṇēmuma stāvokli. Pieejams: https://likumi.lv/ta/id/255713-par-arkartejo-situaciju-un-iznemuma-stavokli [skatīts 07.09.2020.]

69 Ādažu pašvaldība (2013). Civilās aizsardzības plāns, 39. lpp. Pieejams: https://www.adazi.lv/pasvaldiba/dokumenti/civilas-aizsardzibas-plans/ [skatīts 07.09.2020.]

70 Ministru kabineta noteikumi Nr. 658 "Noteikumi par civilās aizsardzības plānu struktūru un tajos ieklıujamo informāciju”. Pieejams: https://likumi.lv/ta/id/294938-noteikumi-par-civilas-aizsardzibasplanu-strukturu-un-tajos-ieklaujamo-informaciju [skatits 07.09.2020.] 
Turpretim pašvaldības darbinieks domā, ka no ārējā apdraudējuma viedokḷa būtiskākos draudus rada Krievija, jo:

Jāapzinās starptautiskās drošības situācija, kur savu lomu vēsturiski spēlē agresīvās Krievijas faktors. ${ }^{71}$

No drošības viedokḷa tiek akcentēta zemessargu loma, taču, tā kā Aizkraukles bataljona struktūras ir mainīta, tiek norādīts, ka arī to aktivitāte pašvaldībā ir samazinājusies.

[Zemessargi] piedalās svinīgos pasākumos, ir jaunsargi, bet reti kad kaut kas [militāras mācības] notiek. ${ }^{72}$

Pašvaldības darbiniekam nav skaidrs, kā būtu jārīkojas krīzes situācijā. Tā, piemēram, pārskatot Jaunjelgavas mājaslapu, tajā neizdevās atrast apstiprinātu civilās aizsardzības plānu, kas saskaņā ar Civilās aizsardzības un katastrofas pārvaldīšanas likumu ir viens no pašvaldības domes uzdevumiem. ${ }^{73}$ Lìdz ar to arī šajā pašvaldībā, izmantojot labās pārvaldības matricu, nav iespējams konstatēt normatīvo aktu (pašvaldības gadījumā - saistošo noteikumu) izmaiṇas, nemaz jau nerunājot par to izstrādi rīcībai ārkārtas gadījumos. Runājot par pašvaldības rīcību krīzes situācijā, tika norādīts:

Pašvaldība pati nezina, kā rīkotos. Ja iedzīvotājiem trūkst informācijas, tad tā ir pašu vaina, jo cilvēki paši neinteresējas. Pēc Ukrainas 2014. gadā uzdevu šo jautājumu Pašvaldības savienībai, kā arī Zemessardzes bataljoni organizēja mācības, $k \bar{a}$ rìkoties. Nav speciālu instrukciju, kā rīkoties ärējas agresijas gadījumāa Nav skaidrs, iespējams, valdība pieņems kädus likumus. Pastāv divas iespējas - vai visu iznīcināt, vai saglabāt un nodrošināt visu nepieciešamo - ūdens, apkure utt. Jautājums, kas notiek ar vietējo varu? Gaida ienākošo karaspēku vai pamet šo teritoriju, cilvēkiem nav skaidrs. ${ }^{74}$

\section{Liepājas valstspilsētas pašvaldība}

Liepājas pašvaldība analīzei tika izvēlēta tāpēc, ka, līdzīgi kā Ādažos, arī šīs pašvaldības teritorijā ir izvietota NBS Jūras spēku militārā infrastruktūra. Intervijā ar Liepājas pilsētas pašvaldības darbinieku uzzinām, ka arī šeit pastāv

Padziḷinātās intervijas ar Jaunjelgavas pašvaldības darbinieku 2020. gada 31. janvārī

Turpat.

73 Saeima (2016). Civilās aizsardzības un katastrofu pārvaldīšanas likums, 11. pants. Pieejams: https://likumi.lv/ta/id/282333-civilas-aizsardzibas-un-katastrofas-parvaldisanas-likums [skatīts 07.09.2020.]

74 Padzị̣inātās intervijas ar Jaunjelgavas pašvaldības darbinieku 2020. gada 31. janvārī. 
potenciāli Krievijas draudi. Taču militāro vienību un sabiedroto spēku klātesamība Latvijā vairo drošǐbu.

Liepāja šajā zinnā ir jūtīga vieta, jo jānnem vērā, ka Krievijas vēstniecībai Latvijā ir divi ǵenerālkonsulāti - Daugavpilī un Liepājā. Tas nozīmēe, ka kaimiņi Krievijā redz savu interešu zonu arī Liepājāa. Tas mums jāatceras, un to nevar par zemu novērtēt. Tädēl es nekad neuzdrošinātos spēelèties ar drošības jautäjumiem, kā to darīja mani kolēgi Ventspilī. NATO klātbūtne ievieš drošību. Jāatceras, ka Liepāja vienmēr ir bijusi stratēgisks objekts un mès esam kaimiņu [Krievijas] interešu lok $\bar{a}^{75}$

Pašvaldības darbinieka ieskatā, ņemot vērā vēsturisko pieredzi - notikumus, kas norisinājās Liepājā 90. gados, kad Zemessardze spēja ieviest kārtību, arī mūsdienās zemessargi ir tie, kuri veicina drošỉbu reǵionā.

Man prieks, ka zemessargiem tieši Liepāja ir epicentrs, kas pārklāj visu Kurzemi. Zemessargi lielā mērā dod drošību liepājniekiem un visiem kurzemniekiem, jo, redzot militāro klātbūtni, mazinās nedrošība, ko rada Krievijas aktivitāšu klātbütne. Ja nav šo acìmredzamo struktüru, kuras mūs varētu aizsargāt, tad ir liela nedrošìba, bet ir klät spēki, kuri ir auguši profesionālās prasmēs, apgādē un zināšanās, tad palaušanās pieaug. ${ }^{76}$

Liepājas pašvaldības darbinieks uzskata, ka Liepāja ir stratēgiski svarīga pilsētu un ka militārā drošîba ir viens no tās aktuālajiem jautājumiem, tāpēc ir būtiski analizēt Liepājas civilās aizsardzības plānu, lai noskaidrotu pašvaldības rīcības algoritmus, kā pašvaldība rīkotos militāra apdraudējuma gadījumā. Līdzšinējo civilās aizsardzības plānu Liepājas pilsētas dome ir apstiprinājusi 2013. gadā, bet atjaunojusi 2019. gada 25. aprīlī. Pārskatot šo plānu, jāsecina, ka tas neietver ārējos normatīvajos aktos noteikto rīcības aprakstu par civilās aizsardzības sistēmas darbību militāra iebrukuma vai kara gadījumā. Līdz ar to no labas pārvaldības viedokḷa Liepājas pašvaldība nav ievērojusi valsts normatīvos aktus un nav veikusi labojumus pilsētas saistošajos noteikumos, papildinot civilās aizsardzības plānu ar rīcības aprakstu.

\section{Rēzeknes novada pašvaldība}

Fokusa grupas intervijās Rēzeknes pašvaldības iedzīvotāji nenorādīja, ka viens no galvenajiem apdraudējumiem ir militārās drošības draudi, un uzskatīja, ka NBS, sabiedroto bruṇotie spēki un NATO neveicina drošību un ka aizsardzībai 
nebūtu jāatvēl 2\% no IKP. Šì iemesla dēḷ Rēzeknes pašvaldība no visām projektā iesaistītajām pašvaldībām tika izvēlēta, lai noskaidrotu, vai iedzīvotājiem aktuālie draudi ir attiecināmi arī uz pašvaldību.

Analizējot datus, kas iegūti intervijā ar Rēzeknes pašvaldības darbinieku, var secināt, ka Krievija tiek uztverta kā apdraudējums, bet tiek uzsvērts, ka iedzīvotājiem ir arī otrs viedoklis - Krievija nav drauds.

Manuprāt, jā, ir, protams, viedokḷi. Ir cilvēki, kuri uzskata, ka tas [Krievijas tuvums] var apdraudēt vinun personīgo drošību. Sāksies tā rezultātā kāds konflikts. Vairāk es domāju, ka tādus viedokḷus iespaido tas, ko mès lasām presē, skatāmies TV, jo tiešā saskarsmē vai personīgas pieredzes nav cilvēkiem šajā saistībā. ${ }^{77}$

Runājot par Nacionālajiem bruṇotajiem spēkiem, pašvaldības darbinieks uzsver, ka to klātbūtne palielina drošību, jo tiek attīstīta militārā infrastruktūra. Turklāt vietējo iedzīvotāju iesaiste vai nu Zemessardzē, vai arī NBS profesionālajā dienestā tikai vairo drošỉbu. Bet tiek paustas arī bažas par to, ka drošỉba var tikt ietekmēta, ja karavīrs neizskatās atbilstoši, ar to domājot neatbilstošu ekipējumu vai apgēerbu.

Praktiski uz ielas ir tie paši vietējie iedzīvotāji, virsnieki, un tāpēc mēs vinuus nevaram uztvert kā draudu. Vairāk tas var dot lielāku drošǐbu, jo, ja kaut kas notiks, tad mès esam aizsargāti. Bet, protams, tā drošìbas sajūta var büt apdraudēta, ja karavīri neizskatās, pēc cilvēku uzskatiem, atbilstoši, piemēram, ir korpulents nu kā viņš var aizstāvēt, vai neatbilstoši géerrbies cilvēks, mētelis militārais, bet bikses citas. ${ }^{78}$

Arī aizsardzībai atvēlētos $2 \%$ no IKP pašvaldības darbinieks vērtē pozitīvi, uzsverot to, ka norisinās acīmredzama attīstība, kas vairo militāro drošību un veicina kopējo drošîbu pilsētā.

Tas, ko es personīgi redzu, - vieta, kura atvēlēta militärajai vienībai, un tur nemitīgi notiek darbi - vini sakārto savas teritorijas. Manī tas palielina drošības sajūtu. Es redzu, ka tur ir investīicijas un tās investīiijas ir pareizas. Tas palīdz arī sakārtot pilsētas vidi, un tās arī dod lielāku drošības sajūtu. ${ }^{79}$

Rēzeknes iedzìvotāju un Rēzeknes pašvaldības darbinieku viedokḷli ir atšķirīgi. Pašvaldībā NBS, sabiedroto spēku klātbūtne un aizsardzības finansējums tiek vērtēts kā drošību veicinošs faktors, savukārt iedzīvotājiem tas šķiet

\footnotetext{
77 Padziḷinātās intervijas ar Rēzeknes pašvaldības darbinieku 2020. gadā.

78 Turpat.

79 Turpat.
} 
kā apdraudējums. Izmantojot labas pārvaldības matricu, tika skatīts arī Rēzeknes pašvaldības sagatavotais civilās aizsardzības plāns, lai noskaidrotu tās rīcību potenciāla militāra iebrukumu gadījumā. Apvienotais Rēzeknes un Vị̣ānu novadu civilās aizsardzības plāns neparedz šo pašvaldību rīcỉbu militāra iebrukuma gadījumā. Plānā ir iekḷauts jautājums par mobilizējamiem resursiem, kas varētu tikt attiecināti uz militāru krīzi, bet tas plašāk netiek izvērsts, vien norādot, ka Rēzeknes un Viḷānu novadā nav izveidoti mobilizējamie civilās aizsardzības formējumi. ${ }^{80}$

Analizējot iegūtos datus par pašvaldībām, var secināt, ka pašvaldību darbiniekiem ārējais apdraudējumus ir viens no faktoriem, kas ietekmē subjektīvo drošības uztveri. Iegūtos datus salīdzinot ar iedzīvotāju draudu uztveri, secināms, ka ārējā apdraudējuma uztvere šajās pašvaldībās ir līdzvērtīga, izṇemot Rēzekni, kur iedzīvotājiem nebija viennozīmīgs viedoklis par Krieviju kā ārējo draudu.

Līdzīgi ir ar sabiedroto spēku klātbūtni, kas tiek uztverta kā drošību veicinošs faktors. Taču NBS klātesamība un ar to saistītie drošības aspekti ir atšķirīgi, to īpaši akcentē Ādažu pašvaldība, savukārt citās pašvaldībās NBS klātbūtne rada drošîu.

Tā kā no labas pārvaldības matricas militārā sektora analīzei tika izmantots tikai normatīvo aktu izmaiņu rādītājs, ar kura palīdzību tika mērìtas izmaiṇas pašvaldību civilās aizsardzības plānā, tad visaptverošus secinājums izdarīt nav iespējams. Taču var iezīmēt kopēju tendenci militārās drošỉbas sektorā, piemēram, pašvaldības reti pārskata un aktualizē civilās aizsardzības plānus, tajos nav iekḷautas ārējos normatīvajos aktos noteiktās izmaiṇas, kas attiecas uz pašvaldības rīcību militāra apdraudējuma gadījumā.

Tikai Ādažu pašvaldība ir nedaudz iezīmējusi tās rīcību militārās krīzes gadījumā, bet arī vien tādēḷ, ka novadā atrodas lielākais militārais poligons Baltijas valstīs. Jaunjelgavas pašvaldībā vispār nav pieejams civilās aizsardzības plāns un pašvaldības darbiniekiem nav informācijas, kā rīkoties. Lai gan Liepājai un Rēzeknei ir šādi plāni, tie nenosaka pašvaldības rīcību militāras krīzes situācijā. Pamatojoties uz iegūtajiem datiem, jāsecina, ka pašvaldības nav pievērsušas īpašu vērību militārās drošības sektora apdraudējuma mazināšanai.

80 Viḷānu novads (2018). Rēzeknes novada un Viḷānu novada pašvaldību civilās aizsardzības plāns, 24. lpp. Pieejams: https://www.vilanunovads.lv/lv/civilas-aizsardzibas-plans/ [skatīts 08.09.2020.] 


\section{Secinājumi}

Fokusa grupu interviju laika posmā (2019. gada rudens/ziema) militārais sektors iedzīvotājiem neškịiet aktuāls, prioritāri viņiem šķiet veselības, sociālās labklājỉbas un ekonomikas sektora draudi. Militārie draudi iedzīvotāju drošības uztverē nav tik nozīmīgi kā tie, kuri skar pamatvajadzību nodrošināšanu. Vienīgi retais aptaujātais kā galveno draudu uzsver militāro apdraudējumu sev un gimenei.

Pētijumu centra SKDS veiktajās aptaujās kā nozīmīgāko draudu iedzīvotāji minējuši ekonomisko un personīgo apdraudējumu (noziedzību), bet militārais drauds tika nosaukts kā trešais nozīmīgākais draudu veids. ${ }^{81}$ Arī šajā pētījumā militārie draudi iedzīvotājiem nav aktuāli un par tiem ikdienā netiek domāts. Šādai situācijai var būt vairāki iemesli, ko atzīst arī paši iedzīvotāji, ka valsts ìsteno sekmīgu aizsardzības politiku un iedzīvotājiem par militārās drošības jautājumiem nav jāsatraucas, tādējādi subjektīvajā drošỉbas uztverē prevalē nemilitāra rakstura draudi. Lai gan vairākos nacionāla līmeṇa un starptautiskos analīzes dokumentos tiek norādīts, ka Baltijas valstu, tātad arī Latvijas drošību apdraud Krievija, tomēr iedzīvotāju vairumam tas nav iemesls subjektīvās drošības uztveres maiņai, ja vien draudi nav izteikti reāli.

Interesants škita fakts par draudu atšķirīgo uztveri, salīdzinot Ādažu un Liepājas fokusa grupu interviju rezultātus. Lai gan abās pašvaldībās ir izvietota ievērojama militāra infrastruktūra, tomēr tās dēḷ izteiktāku militāro apdraudējumu izjūt Ādažu iedzīvotāji. Tas skaidrojams ar militāās infrastruktūras intensīvāku izmantošanu, piemēram, Ādažos ir izvietota NATO paplašinātās klātbūtnes kaujas grupa un atrodas lielākais militārais poligons Baltijā. Tur uz mācībām ik gadus ierodas sabiedroto valstu bruņotie spēki. Savukārt Liepājāa sabiedroto spēku klātbūtne nav tik intensīva, turklāt Jūras spēku apmācības notiek galvenokārt jūrā, tāpēc militāro aktivitāšu radītās sekas (troksnis, karavīru klātbūtne ielās) iedzīvotāji ikdienā neizjūt.

Pētijuma gaitā iezīmējās atšķirīga subjektīvā draudu uztvere Daugavpilī un Rēzeknē, kur par galveno draudu tiek uzskatīta sabiedroto spēku klātbūtne. Tajā pašā laikā iedzīvotāju subjektīvajā drošības uztverē NATO un ES tiek skatīts kā drošības garants, ìpaši izceḷot tieši ES nozīmi. To varētu skaidrot ar ES finanšu instrumentu investīcijām pašvaldību infrastruktūras objektos, kas iedzīvotājos rada pārliecību par sava veida drošību. Kā intervijā uzsver

81 SKDS (2016. gada novembris). Latvijas iedzīvotāju viedoklis par valsts aizsardzības jautājumiem: Latvijas iedzīvotāju aptauja. Pieejams: https://www.mod.gov.lv/sites/mod/files/document/SKDS_ aptauja_2016\%20\%281\%29.pdf [skatīts 07.04.2020.] 
Rēzeknes pašvaldības darbinieks, personīgo drošǐbu rada fakts, ka ir redzama, piemēram, militārās infrastruktūras attīstîba reg̣ionā vai notiek kāda cita rīcība, kas veicinātu vietējo iedzīvotāju atbalstu NATO. Lai mazinātu iedzīvotāju uztraukumu par NATO kā draudu, ìpaši svarīga ir ne tikai komunikācija ar sabiedrību šajās pašvaldībās, bet arī redzamāka NBS klātbūtne militāro mācību, publisko pasākumu laikā vai īstenojot citas sadarbības programmas, kā tas ir Ādažu pašvaldībā. ${ }^{82}$ Būtiski ir uzsvērt, ka tieši šajās pašvaldībās ir nepieciešama aktīvāka rīcība. Svarīga ir šo pasākumu intensitāte, lai sabiedrība pierastu, ka ne tikai NBS, bet arī sabiedrotie sniedz drošǐbu.

Salīdzinot iedzīvotāju draudu uztveres rādītājus ar pašvaldību darbinieku viedokḷiem, var secināt, ka iegūtais rezultāts ir visnotaḷ atšķirīgs. Spilgtākais piemērs ir Jaunjelgava, kur iedzivotājus neuztrauc ārējais apdraudējums, kamēr pašvaldības darbinieks uzskata Krieviju par ārējo apdraudējumu. Arī savstarpējā komunikācija Jaunjelgavā ir sarežğìta, jo iedzīvotājus uztrauc tas, ka pašvaldība nekomunicē ar viniem par to, kā būtu jārīkojas krīzes situācijā. Pašvaldība norāda, ka tā ir pašu iedzīvotāju vaina, ka viṇi neinteresējas, kas būtu darāms šādās situācijās. Arī pati pašvaldība nezina, kā būtu jārīkojas, jo nav civilās aizsardzības plāna, uz kura pamata būtu izstrādāti iedzīvotāju apziņošanas algoritmi.

Pētijumā gaitā tika noskaidrots, ka vairumā apskatīto pašvaldỉbu civilās aizsardzības plāni nav aktualizēti un tajos nav aprakstīta pašvaldību rīcība militārās agresijas gadījumā. Lai gan ārējie normatīvie akti nosaka šādu sadaḷu iekḷaušanu katras pašvaldības plānā, civilās aizsardzības plāni joprojām pamatā balstās uz dabas katastrofu un tehnogēno katastrofu pārvarēšanas algoritmiem. Caurskatot plānus, nākas secināt, ka militāras krīzes gadījumā pašvaldïbas paḷautos uz valdỉbas pien̦emtajiem lēmumiem, tādējādi, iespējams, apgrūtinot krīzes radīto seku pārvarēšanu, nevis ar saviem izstrādātajiem algoritmiem veicinātu iedzīvotāju drošību un ātrāk neitralizētu krīzes sekas.

Tika arī noskaidrots, ka ar valsts aizsardzību saistītie dokumenti atspoguḷo iedzīvotāju bažas par ārējo apdraudējumu. Tā, piemēram, Krievija kā viena no būtiskākajiem ārējiem draudiem tiek minēta Valsts aizsardzības koncepcijā, kas apstiprināta 2020. gada 24. septembrī. Koncepcija ir viens no pamatdokumentiem, kurā tiek iezīmēti galvenie draudi un turpmākā rīcība šo draudu mazināšanai četru gadu periodā. Atšḳirīibā no iedzīvotājiem, kas atsevišķās pašvaldībās min tādus draudus kā NBS militārās infrastruktūras klātesamība, sabiedroto spēku vai NATO klātbūtne, Valsts aizsardzības

82 Ādažos tiek minēts, ka sadarbība ar armiju izpaužas kā, piemēram, žoga uzlikšana vai kā Kanādas karavīru dāvinājums - ponijs - "Dzīvo sapṇu dārzam". 
koncepcija uzsver pretējo - Latvijas aizsardzība ir balstīta kolektīvās drošības sistēmā, kas izpaužas caur sabiedroto spēku klātbūtni un NBS militāro spēju attīstību. ${ }^{83}$ Tajā pašā laikā šajā koncepcijā tiek uzsvērts, ka būtiskākie draudi ir NATO valstu nepietiekamais finansējums, teroristiskie grupējumi, klimata pārmaiņas, tehnologiju attīstība u. c. ${ }^{84}$

83 Skatīt: Aizsardzības ministrija (2020). Valsts aizsardzības koncepcija, 3-27. lpp. Pieejams: AiMVAK_2020.pdf (mod.gov.lv) [skatīts 14.09.2020.]

84 Turpat, 5.-6. lpp. 


\section{Krīzes komunikācija: sabiedrības iespējošana vai drauds subjektīvai drošības uztverei}

KRISTAPS CELMIN,Š, ROVENA BERGA

Covid-19 izplatība Latvijā radīja daudzas pārdomas par valsts spēju operatīvi risināt krīzi, tai skaitā īstenot krīzes komunikāciju tādā veidā, lai sabiedrība kḷūtu par partneri un mazinātu pieaugošās bailes par efektīvu tās pārvaldīšanu. Šìs nodaḷas mērḳis ir noskaidrot, kā valdība nodod sabiedrībai vēstījumus par Covid-19 vīrusu un ieviestajiem ierobežojumiem, kādas ziṇas publicējuši galvenie sabiedriskie publiskie mediji, kā arī kāda ir bijusi sabiedrības reakcija un vai tā ir ietekmējusi iedzìvotāju subjektīvo drošības uztveri. Pētījuma gaitā tika identificēts, kas ir krīze, krīzes komunikācijas dzìves cikla posmi un tos raksturojošās pazīmes, bet pēc tam tika atspoguḷoti rezultāti, kas iegūti empīiskā pētījumā, monitorējot ziņas, sākot ar 1. martu līdz 12. maijam, un izmantojot kvalitatīvo kontentanalīzes metodi. Covid-19 krīzes pirmā posma analīze pierāda arī to, ka pirmās rokas darbības stratēgija ir visefektīvākā komunikācijas stratēgija krīzes komunikācijā, lai sniegtu skaidru, faktologiisku informāciju, bet ofensīvo atbilžu stratēgiju vai stratēgisko bezdarbību nebūtu ieteicams izmantot. Balstoties uz Covid-19 pirmā viḷna krīzes komunikācijas analīzi, iespējams secināt: lai informācija tiktu skaidri uztverta, pēc tās būtu jāseko arī attiecīgām darbībām, kas ir skaidras un konkrētas, nevis vairākas reizes uzlabotas, pielāgotas vai pat pilnībā mainītas, jo tas var veicināt sabiedrības neizpratni un nedrošỉbu. Lai izvairītos no kḷūdu piel̦aušanas potenciālajā Covid-19 trešajā viln̄i, lielāka uzmanība būtu jāpievērš jaunas krīzes komunikācijas stratēgijas attīstǐšanai, kurā tiktu ņemta vērā arī sabiedrības subjektīvā drošības uztvere.

Atslēgvārdi: krīzes dzīves cikli, krīzes vadība, personiskā drošība, valdības krīzes komunikācija, vēstījumu skaidrība.

The spread of Covid-19 in Latvia provided the opportunity to reflect on the country's ability to deal with the crisis promptly, implementing crisis communication in such a way that the public becomes a partner and the growing fears about its effective management are reduced. The purpose 
of this chapter is to find out how the government communicates the messages about the Covid-19 virus and the imposed restrictions, what news has been published in the main public media, how the public has reacted and whether it has affected the subjective perception of security. The study identified the crisis, including the stages and characteristics of the lifecycle of crisis communication, and reflected the results of an empirical study that monitored data from March 1 to May 12, using a qualitative content analysis method. The analysis of the first phase of Covid-19 shows that first-hand action is the most effective communication strategy to use in crisis communication to provide clear, factually accurate information and that offensive response strategies or strategic inaction is not advisable. Based on the analysis of the first Covid-19 crisis communication, it can be concluded that, in order to be clearly understood, information should also be followed by relevant actions that are clear and specific rather than repeatedly modified, adapted or even completely altered, as this can contribute to public misunderstanding and insecurity. To avoid making mistakes in the potential third wave of Covid-19, more attention should be paid to developing a new crisis communication strategy that also takes into account the public's subjective perception of security.

Keywords: clarity of messages, crisis life cycles, crisis management, government crisis communication, personal security.

\section{levads}

Krīzes situācijās ìpaša loma ir komunikācijai ar sabiedrību, kas var vairot un vienlaicīgi vājināt cilvēku drošības izjūtu. Strauji progresējošā mediju un sociālo platformu vide, kura piedāvā plašu informācijas un viedokḷu spektru, ietekmē publiskā sektora ziṇu un vēstījumu veidošanu un izplatību. Tomēr jaunu un globālu pārmaiṇu sākumā sabiedrības uzmanība un spēja analizēt notiekošo ir ierobežota - pārmērīgais ziṇu daudzums pazemina indivīda spēju apstrādāt informāciju, kā arī mazina tā subjektīvo drošības uztveri. Jo sarežǵitāka, abstraktāka vai svešāka informācija tiek izplatīta, jo grūtāk cilvēkiem to apzināt, izprast, pieņemt un rīkoties, lai mazinātu nedrošỉbu. Krīzes apstākḷos, ko pierāda arī Covid-19 gadījums, strauji izplatās dezinformācija par vīrusu, kas padara situāciju daudz bīstamāku, apšaubot pieņemto lēmumu legitimitāti. Covid-19 apstākḷ̆os publiskā sektora krīzes komunikācija digitālajā platformā ir kḷuvusi par nepieciešamību un vienu no iedzīvotāju iespējošanas nosacỉjumiem.

Valdības pieeja, stratēóija un krīzes pārvarēšanas un ārējās saziṇas mehānismi ārkārtas situācijās var palīdzēt valstīm sasniegt labākus rezultātus. Ja publiskais sektors balstās uz krīzes komunikācijas stratēgiiju vai vismaz vadlīnijām, kas nosaka, kādā formātā konkrētā ziṇa tiek pausta, ir radīti 
priekšnoteikumi sistēmiskai un uz partnerību balstìtai pieejai. ${ }^{1}$ Valdības vadītājs krīzes apstākḷos vada ārējo komunikāciju, kas galvenokārt ietver preses konferences un uzrunas televīzijā, kuras var pārraidìt arī sociālajos medijos. Sociālos medijus var izmantot par instrumentu, kas palīdz paātrināt saziṇu krīzes situācijās, bet tie var radīt arī jaunus izaicinājumus un riskus, ja tiem uzticas, piemēram, tie var manipulēt ar datiem tiešsaistē.

Covid-19 globālās pandēmijas krīzes pirmsākumi meklējami 2019. gada 31. decembrī, kad Pasaules Veselības organizācijas birojs Ķinnas Tautas Republikā publicēja tīmekḷa vietnē ierakstu par "vīrusu - pneimoniju” Uhaņā. ${ }^{2}$ Latvijā par pandēmijas sākuma datumu var uzskatìt 2020. gada 2. martu, kad diagnosticēja pirmo inficēto pacienti. ${ }^{3}$ Pāris dienu laikā saslimušo skaits sāka pieaugt un nācās pieṇemt straujus un atbildīgus lēmumus par turpmāko sabiedrības mobilizēšanu. Tāpēc 2020. gada 12. martā, pamatojoties uz Civilās aizsardzības un katastrofu pārvaldīšanas likumu, kā arī uz likumu "Par ārkārtējo situāciju un izṇēmuma stāvokli” un Epidemioloǵiskās drošības likumu, Latvijas Republikas Ministru prezidents A. K. Kariņš visā valsts teritorijā izsludināja ārkārtējo situāciju. ${ }^{4}$

Covid-19 izplatība Latvijā radīja daudzas pārdomas par valsts spēju operatīvi risināt krīzi, tai skaitā îstenot krīzes komunikāciju tādā veidā, lai sabiedrība kḷūtu par partneri un mazinātu pieaugošās bailes par efektīvu tās pārvaldīšanu. Pētijumā krīzes komunikācija analizēta no dažādiem valsts iestāžu darbības skatpunktiem, pievēršoties ziņu izplatǐšanai, nevis organizacionāliem jautājumiem. Šìs grāmatas nodaļas mērḳis ir noskaidrot, kā valdība nodod sabiedrībai vēstijjumus par Covid-19 vīrusu un ieviestajiem ierobežojumiem, kādas ziņas publicējuši galvenie mediji, kā arī kāda ir bijusi sabiedrības reakcija un vai tā ir ietekmējusi iedzīvotāju subjektīvo drošības uztveri. Rakstā iekḷautās atziṇas balstās uz sabiedriskās domas aptaujas datiem, kurus ieguvuši Latvijas Universitātes Sociālo zinātṇu fakultātes Politikas zinātnes nodaļas 1. kursa studenti, apzinot 1015 respondentu (947 latviešu un 68 krievu tautības respondentus, no šiem respondentiem ceturtā daḷa bija vīrieši) viedokli par

1 SIGMA (2020). Public Administration: Responding to the COVID-19 Pandemic. Pieejams: http:// www.sigmaweb.org/publications/SIGMA-mapping-public-administration-response-EU-members-coronavirus-COVID19.pdf [skatits 08.01.2021.]

2 ProMed International Society for Infectious Diseases (31.12.2019.). Pieejams: https://promedmail. org/promed-post/?id=6864153\%20\#COVID19 [skatìts 19.09.2020.]

3 LSM (02.03.2020.). Latvijā apstiprināts pirmais koronavīrusa "Covid-19" gadījums. Pieejams: https:// www.lsm.lv/raksts/zinas/latvija/latvija-apstiprinats-pirmais-koronavirusa-covid-19-gadijums. a349768/ [skatìts 19.09.2020.]

4 Veselības ministrija (14.05.2020.). Par ārkārtējās situācijas izsludināšanu-aktualizēts 14. maijā. Pieejams: https://www.vm.gov.lv/lv/jaunums/par-arkartejas-situacijas-izsludinasanu-aktualizets14-maija [skatits 19.09.2020.] 
stāvokli Latvijā Covid-19 krīzes laikā pavasara periodā. Respondenti pārstāvēja vecumgrupas no $18 \mathrm{līdz}$ 65+ gadiem un reprezentēja katru Latvijas reǵionu (Rīga, Kurzeme, Latgale, Sēlija, Vidzeme un Zemgale).

Lai sasniegtu pētījuma mērḳi, pirmajā raksta daḷā noskaidrots krīzes definējums, krīzes komunikācijas dzīves cikla posmi un tos raksturojošās pazīmes. Otrajā un trešajā dạ̧ā atspoguloti empīiskā pētỉjumā iegūtie rezultāti, monitorējot ziņas, izmantojot kvalitatīvo kontentanalīzes metodi, lai noskaidrotu vēstījumu skaidrību un izmantotās komunikācijas stratēgijas.

Krīzes komunikācijas monitorēšana ietvēra apjomīgu laika posmu, sākot ar 1. martu (sākusies testēšana, visi testi negatīvi) un beidzot ar 12. maiju (valdība pieņem lēmumu par ierobežojumu samazināšanu). Monitorēšanas procesa laikā apskatītas tādas komunikāciju īstenojošas institūcijas kā Slimību profilakses un kontroles centrs (turpmāk - SPKC), Neatliekamās medicīniskās palīdzības dienests (turpmāk - NMPD), Veselības ministrija, Ministru kabinets, Ārlietu ministrija, Izglìtibas ministrija, kā arī mediji: DELFI, "Panorāma" un Latvijas Radio 1 (LR1). Konkrētie mediji tika izvēlēti tāpēc, ka tie regulāri informēja sabiedrību par jautājumiem saistībā ar Covid-19 (ministrijas un SPKC, NMPD kā ziṇu pirmavots), kā arī tāpēc, ka Latvijā tie ir visbiežāk izmantotie mediji (it īpaši DELFI un "Panorāma"). Monitorēšanas sākumā tika iekḷautas visas ziṇas, kurās tika minēts Covid-19 vai tā ietekme uz konkrētām nozarēm, taču, sākot ar 19. martu, lielā ziṇu apjoma dēl tās tika skaitliski ierobežotas - 10 līdz 20 ziņas dienā.

Pirmkārt, fiksēts, kāds ir ziņas nosaukums, medijs un informācijas sniedzējs. Pirmais rādītājs bija komunikācijas stratēgijas (pirmās rokas darbības stratēgija, ofensīvās atbildes stratēgija, aizsardzības atbildes stratēgija, novēršanas atbildes stratēóija, daiḷrunīgās līdzjūtības stratēǵija, korigeéjošas darbības stratēǵija vai stratēgiska bezdarbība). ${ }^{5}$ Otrkārt, fiksēti draudi, kas iekḷauti ziņā, - tie var būt primāri, sekundāri vai terciāri. Krīzes komunikācijas monitorēšana paredzēja arī konkrētu atslēgvārdu - krīze, pabalsts, dỉkstāve, iepirkšanās, preces, sejas maskas, dezinfekcija, slimie, izveseḷojušies, ierobežojumi, distance, rokas, mediḳi, valdība, budžets, nāve, repatriācija, ārkārtas stāvoklis, atbildība, grūtības, pašvaldības - meklēšanu ziņās. Vēlāk tika pievienoti arī tādi atslēgvārdi kā vakcīna, aizsarglīdzekḷi un eksperimentālā ārstniecība. Kopējā pētỉjuma metodologija atspoguḷota 1. tabulā.

5 Smith, R. D. (2016). 25 Strategies for Crisis Communication. Pieejams: www.ron-smith.com. [skatīts 19.09.2020.] 
1. tabula. Pētijjuma metodoloǵija

\begin{tabular}{|c|c|c|c|c|c|}
\hline Medijs & $\begin{array}{c}\text { Komunikācijas } \\
\text { stratēǵija }\end{array}$ & $\begin{array}{c}\text { Draudi } \\
\text { (primāri, } \\
\text { sekundāri, } \\
\text { terciāri) }\end{array}$ & \multicolumn{2}{|c|}{ Atslēgvārdi } \\
\hline SPKC & $\begin{array}{c}\text { Pirmās rokas } \\
\text { darbības } \\
\text { stratēǵija }\end{array}$ & Ekonomiskie & Krīze & lerobežojumi & Atbildība \\
\hline DELFI & $\begin{array}{c}\text { Ofensīōs } \\
\text { atbildes } \\
\text { stratēǵgija }\end{array}$ & Politiskie & Pabalsts & Distance & Grūtības \\
\hline "Panorāma" & $\begin{array}{c}\text { Aizsardzības } \\
\text { atbildes } \\
\text { stratēǵija }\end{array}$ & Militārie & Dīkstāve & Rokas & Pašvaldības \\
\hline $\begin{array}{c}\text { mk.gov.lv } \\
\text { (Ministru } \\
\text { kabinets) }\end{array}$ & $\begin{array}{c}\text { Novēršanas } \\
\text { atbildes } \\
\text { stratēǵija }\end{array}$ & Sabiedrības & lepirkšanās & Mediki & Vakcīna \\
\hline NMPD & $\begin{array}{c}\text { Dail̦unīgās } \\
\text { lídzjūtības } \\
\text { stratēǵgija }\end{array}$ & Personiskie & Preces & Valdība & Aizsarglīdzekli \\
\hline
\end{tabular}

\section{Krīze un krīzes komunikācija}

Krīzes un krīzes komunikācijas analīzei piemērotās teorijas ir iespējams aplūkot politoloǵijas, komunikācijas, socioloǵijas un psihologiijas disciplīnā. Tās ir saistītas ar informācijas nodošanu auditorijai, lai palīdzētu izvairīties no krīzes vai novērst to, lai saglabātu sabiedrisko mieru, atgūtos no krīzes, kā arī saglabātu vai uzlabotu uzticību informācijas paudējam, šajā gadījumā - Latvijas valdībai un tās pārstāvjiem. Šajā rakstā izmantosim tās teorētiskās atziṇas, kuras spēj piedāvāt skaidrojumu Latvijas krīzes komunikācijas gadījuma analīzei.

Krīze ir incidents vai notikums, ko nav iespējams kontrolēt ar jau esošajiem kontroles mehānismiem, ${ }^{6}$ vai arī, atsaucoties uz Oksfordas angḷu valodas vārdnīcu, krīze ir "ārkārtīgi svarīgs vai izšķirošs posms, lai kaut kas notiktu; pagrieziena punkts; stāvoklis, kurā izškirirošas pārmaiņas uz labu vai sliktāku pusi ir nenovēršamas...” ${ }^{\prime}$. Kā raksta Arjens Boins (Arjen Boin) un Pauls Thārts

6 Jones, R. W. (2000) Critical Incident Protocol. Michigan State University, p. 37. Pieejams: https:// www.michigan.gov/documents/msp-critical__incident_Protocal_8735_7.pdf

7 Blanchard, B. W. (2008). Guide to Emergency Management and Related Terms, Definitions, Concepts, Acronyms, Organizations, Programs, Guidance, Executive Orders \& Legislation. A Tutorial on Emergency Management, Broadly Defined, Past and Present, p. 180. Pieejams: http://training.fema. gov/EMIWeb/edu/docs/terms\%20and\%20definitions/Terms\%20and\%20Definitions.pdf 
(Paul 'THart), "krīzē nākas sastapties ar notikumiem, kuri pieder pie "ne" kategorijas: negaidītas, nevēlamas, neiedomājamas un bieži nevadāmas situācijas"s. Krīzes gadijumos ir ierobežots laika limits lēmumu pieņemšanai un to skaidrošanai; intensīva informācijas plūsma, kura jāanalizēe, vai tās trūkums; sabiedrības un valdības emocijas ir sakāpinātas, veidojoties sistēmas pārslodzei; un notikumi notiek tik strauji, ka konstruktīva plāna izstrāde ir sarežğìta. Šādās situācijās organizācijas līmenī ir nepieciešama jau iepriekš apzināti veidota stratēǵija, kas iekḷautu galvenos krīzes risināšanas pasākumus un kompetenču sadalījumu. Krīzes vadība ir negatīva pagrieziena punkta stratēgiskās plānošanas process, kas novērš daḷu riska un nenoteiktības no negatīvās situācijas, tādējādi ḷaujot organizācijai vairāk kontrolēt savu likteni. ${ }^{9}$ Krīzes vadība ir veids, kā apzināti novērst krīzes eskalāciju un tās sekas, tomēr ir skaidrs, ka ar pastiprinātas uzmanības pievēršanu pašai krīzei nepietiek, jo tās rezultātā sabiedrībā var veidoties negatīvas emocijas, kuru ignorēšana var novest pie jauniem, iepriekš neparedzētiem nemieriem. Tieši šis apstāklis ir nozīmīgs krīzes komunikācijas izstrādāšanā un īstenošanā.

Krīzes komunikāciju pētnieks Timotijs Kūmbs (Timothy Coombs) definē kā "tādas informācijas vākšanu, apstrādi un izplatīšanu, kas vajadzīga krīzes situācijas risināšanai" ${ }^{10}$. Vienkārša krīzes komunikācijas definīcija attiecas uz iesaistīto pušu faktisko saziṇu ar ieinteresētajām personām un sabiedrību noteikta mērḳa sasniegšanai. Tie varētu būt valdības centieni informēt sabiedrību par to, ka, piemēram, saskaṇā ar likumu viņiem ir jālieto sejas maskas sabiedriskās vietās. Tā kā organizācija piedzīvo negaidītu situāciju un ir nepieciešama reakcija, var izrādīties, ka iesaistītajai organizācijai nav pilnīgas kontroles pār krīzi tās laikā, tāpēc nepieciešams veikt krīzes komunikāciju, lai saglabātu kontroli pār sabiedrības uzvedību un mazinātu potenciālās sekas. Latvijas gadījumā Covid-19 krīzes kontekstā komunikāciju uzsāka jau pirms pašas krīzes sākuma. Analizējot krīzes komunikāciju, svarīgi to aplūkot kā dialogu starp organizāciju un sabiedrību pirms krīzes, tās laikā un pēc tās, kā arī pēc pašas organizācijas izvēlētā vadības modeḷa, kas pielāgots attiecīgajam mērḳim.

Krīzes vadība ir process, kurā identificē potenciālo krīžu cēloṇus un veic darbības, kas sagatavo organizāciju reaǵēšanai uz krīzi un atlabšanai no tās. ${ }^{11}$

8 Boins, A., 'T Hart, P. (2007). The Crisis Approach. In: Havidán, R., Quarantelli, E. L., Dynes, R. R. (eds). Handbook of Disaster Research. Springer, pp. 42-54.

9 Banks, K. (2007). Crisis communications: a casebook approach. Mahwah, NJ: Lawrence Erlbaum Associates, p. 7.

10 Coombs, W. \& Holladay, S. (2010). The handbook of crisis communication. Chichester, U.K., Malden, MA: Wiley-Blackwell, p. 20.

11 Blanchard, B. W. (2008). Guide to Emergency Management and Related Terms, Definitions, Concepts, Acronyms, Organizations, Programs, Guidance, Executive Orders \& Legislation. A Tutorial on 
Krīzes pārvarēšana ir stratēgiska un visaptveroša programma, kas izstrādāta, lai novērstu krīzes cēloṇus un tās sekas, kā arī aizsargātu pašu organizāciju. Svarīga un būtiska sastāvdaḷa krīzes vadībā ir sabiedrības attiecības ar valdību un tās dialogs ar sabiedrību. Krīzes komunikācijā regulāri tiek izmantoti plašsaziņas līdzekḷi, lai izplatìtu vēstijumu sabiedrībai. Tas jo īpaši attiecas uz akūti svarīgu ziṇu paušanu, kad plašsaziṇas līdzekḷi kḷūst par galveno, ja ne vienīgo saziņas avotu, veidojot tiešu saikni starp valdības pārstāvjiem un sabiedrību. Efektīva krīzes komunikācija neapšaubāmi tiek uzlabota ar valsts valdības oficiālo atbalstu, pat ja šis atbalsts ir neliels un simbolisks. Šì darbība ir nozīmīga, ja valdíbas runas personai, kas komunicē ar sabiedrību, ir liela uzticība. Valdība var paust šo atbalstu, sākot ar publiski attēlotu un oficiālu atbalstu krīzes novēršanai un beidzot ar tādu tiesību aktu pieņemšanu, kas nosaka ierobežojumus un konkrētas veicamās darbības. Efektīiva krīzes vadība ietver krīzes komunikāciju, kas ne tikai var mazināt vai pat likvidēt krīzi, bet arī nodrošināt organizācijai pozitīvāku reputāciju nekā pirms krīzes.

Krīzes komunikācija aptver un iekḷauj trīs dalībniekus: publisko sektoru, privāto sektoru un masu medijus. Publiskais sektors monitorē krīzi, gatavo prognozes un izplata aktuālos brīdinājumus. Šis sektors ir faktiskais krīzes informācijas avots - privātā sektora un masu mediju paustā informācija balstās uz publiskā sektora sniegto informāciju. Lai arī šis sektors pamatā veido aktuālo krīzes informāciju, tā informācijas paušanas kanāliem ir salīdzinoši neliela mērķauditorija, tāpēc šis sektors nav spējīgs veidot individuālu un veiksmīgu krīzes komunikāciju vienlaicīgi. Kaut gan salīdzinoši mazāk, tomēr tikpat būtiski krīzes komunikācijas veidošanu ietekmē arī privātais sektors - tas ir tendēts motivēt cilvēkus ieguldīt savas nākotnes drošībā. Privātais sektors, kam kopumā ir lielāka mērķauditorija un vairāk informācijas kanālu nekā publiskajam sektoram, salīdzinoši nelielā daudzumā veido savu krīzes informāciju. Šis sektors kopèjā krīzes komunikācijā ir nozīmīgs - tas nodrošina nosacīti svaigu skatījumu uz krīzes informāciju un izplata tādu informāciju, ko neizplatītu publiskais sektors, piemēram, par publiskā sektora darbỉbas kompetenci vai nekompetenci. Masu mediji ir ietekmīgākais krīzes komunikācijas informācijas izplatītājs, jo, lai arī publiskais un privātais sektors veido saturu (to dara arī masu mediji), tieši masu mediji nosaka, kāds ir krīzes vadības atspoguḷojums, līdz ar to radot plašāku komunikācijas kontekstu. Masu medijiem ir nesalīdzināmi lielāka mērḳauditorija un vairāk informācijas paušanas kanālu, kas nodrošina gandrīz tūlìtēju ziṇas izplatîbu un ietekmi. Jāuzsver, ka masu mediju

Emergency Management, Broadly Defined, Past and Present, p. 182. Pieejams: http://training.fema. gov/EMIWeb/edu/docs/terms\%20and\%20definitions/Terms\%20and\%20Definitions.pdf 
kanāli ir radīti komerciālu apsvērumu dēḷ - to prioritāte ir iegūt pēc iespējas vairāk finansiālo līdzekḷu, tāpēc pretrunīgas informācijas izplatîba nereti ir primārāka par būtiskas informācijas izplatību; bieži vien tas pats attiecas arī uz negatīvas-pozitīvas informācijas izplatību. Labai krī̌̌u vadībai un novēršanai faktiski netiek veltīta liela masu mediju uzmanība, turpretim sliktai vadỉbai un novēršanai tiek pievērsta pastiprināta masu mediju uzmanība. Apzinoties šo tendenci, ir skaidrs: lai valdības krīzes komunikācija izdotos un kḷutu pēc iespējas veiksmīgāka, valdībai prioritāri ir jāpanāk, ka starp valdību un masu platformām valda abpusēja uzticība.

Mediju publicitātes pamatvērtība ir, ka tā sniedz trešās puses apstiprinājumu organizācijas vēstijumam. ${ }^{12}$ Auditorija uzskata, ka no televīzijas, radio un laikrakstiem iegūtās ziņas ir ticamākas nekā informācija, ko viṇi saņem tieši no organizācijas, izmantojot reklāmu, vietnes, brošūras u. c. Tas ir tāpēc, ka ziņu mediju informācija ir izturējusi noteiktu atlasi. Auditorija zina, ka ne viss tiek publicēts, tāpēc intuitīvi apjauš, ka profesionāli žurnālisti ir izvēlējušies, kuru informatīvu materiālu pasniegt kā ziṇu, - reportieris vai redaktors apsver ziņas saturu un nolemj, ka tas ir pietiekami aktuāls, lai to nodotu sabiedrībai. Masu mediju un informācijas tehnolog̣iju attīstība dod iespēju uzzināt par katastrofām ne tikai reǵionālā, bet arī globālā mērogā, tādējādi pastiprinot iespaidus, ko gūst pārējā pasaule, ${ }^{13}$ kas ir būtiski valsts prestiža celšanai vai zaudēšanai internacionālās vides kontekstā. Tomēr krīzes situācijā prioritāra nozīme ir tieši krīzes komunikācijas īstenošanai.

Krīzes komunikācijas informācijas sniegšana riskam pakḷautām personām un kopienām ir viens no gatavības un noturības veidošanas pamatiem. N̦emot vērā krīzes komunikācijas nozīmi un efektivitāti, pasaules, reǵionālā un vietējā līmenī iesaistîtie aktori pastiprināti iegulda resursus krīzes komunikācijas īstenošanā. ${ }^{14}$ N̦ūkāslas Universitātē veiktā pētỉjuma rezultāti liecina, ka vēstījuma skaidrība (nodoms izveidot attiecības) palielinās, ja ir skaidra un ticama informācija par notikumu (krīzi). ${ }^{15}$ Tas nozīmē, ka politikas veidotājiem un komunikācijas veicējiem ir kritiski jāizvērtē krīzes informācijas satura skaidrība un avota ticamība informācijas izplatīšanā komunikācijas procesa laikā. Tas arī palīdz labāk izprast faktorus, kas ietekmē situācijas uztveri

12 Smith, R. (2005). Strategic planning for public relations. Mahwah, NJ: Lawrence Erlbaum Associates, p. 94.

13 Beinaroviča, I. (2014). Katastrofu vadība: Latvijas gadijums. Rīga: Latvijas Universitātes Sociālo zinātṇu fakultāte, 7. lpp. Pieejams: https://dspace.lu.lv/dspace/handle/7/28132

14 Ballantyne, M. (2000). Information on Volcanic and Earthquake Hazards: The Impact on Awareness and Preparation. Institute of Geological and Nuclear Sciences.

15 Abunyewah, M. et al. (2019). Linking information provision to behavioural intentions. International Journal of Disaster Resilience in the Built Environment, 11(1), pp. 100-118. 
sabiedrībā. Šajā pašā pētījumā arī pierādīts, ka informācijas apmaiņa starp tās sūtitājiem un uztvēēejiem un atbildes uz jautājumiem mazina vēstījuma neskaidrību ${ }^{16}$ Tiek secināts, ka krīzes komunikācijas pieaugošā loma rada nepieciešamību pēc iespējas skaidrāk un saprotamāk nodot vēstījumu. Krīzes komunikācijā, lai būtu pēc iespējas lielāka vēstījuma skaidrība, būtiska ir atgriezeniskā saite, ko sniedz informācijas paudējs, piemēram, valdība.

Lai krīzes komunikācija būtu konsekventa un vēstījums skaidrs, tiek lietotas dažādas komunikācijas stratēǵijas. Valdība var izmantot virkni verbālu un uzvedības stratēgiju, pārvaldot savu reakciju uz opozīciju un atgūšanos no kritikas. Ar opozīciju tiek saprasts jebkurš centiens vai process, kas apšaubītu valdības rīcību un reputāciju, tai skaitā ne tikai politisko oponentu, bet arī mediju, organizāciju un sabiedrības pārstāvju darbība. Iegūto datu tipologíja, kuru izmantosim raksta gaitā, ir balstīta uz Ronalda Smita (Ronald Smith) definētajām komunikācijas stratēgijām. ${ }^{17}$ Pirmā veida stratēégija faktiski ietver pirmskrīzes rīcỉbu, kas notiek, pirms opozīcija sāk darboties pret valdību. Šì ir pirmās rokas darbības stratēgija, kuras pamatā ir ideja un tās ievirze, kuru nosaka sarunas uzsācējs un ar kuru jākonkurē visām alternatīvām versijām. Šìs stratēégijas pamatā ir pirmskrīzes uzbrukumi, kad sliktas ziņas ir neizbēgamas un primāri izmantotas pirmajos divos krīzes vadības posmos jeb riska un seku mazināšanas posmos, tāpēc krīzes sekas rada aizvien jaunus saspīlèjumus. Veiksmīga krīzes komunikācija rada aizvien jaunas pirmās rokas ziņas un aktualitātes. Šì stratēǵija ir jālieto, ja sabiedrība ir dzirdējusi apsūdzības vai citas sliktas ziṇas par organizāciju un tai ir nepieciešams piedāvāt spēcīgus pierādījumus, lai pamatotu, kāpēc ṇemts vērā konkrētais vēstījums.

Krīzes komunikācijas veicēji, reaǵējot uz kritiku, dažkārt izmanto tādas ofensivās atbildes stratēgijas kā uzbrukums, apmulsums vai draudi. To pamatā ir pieṇēmums, ka organizācija darbojas no spēka pozīcijas un, saskaroties ar opozīciju un izrādot spēku, novērš to, kas viṇu apdraud. Kā norāda R. Smits, bieži šìs stratēégijas mērḳis ir mudināt pretinieku atkāpties vai vismaz atturēties no turpmākas kritikas. ${ }^{18}$ Autors iesaka izmantot šo pieeju tikai tad, ja var pierādīt, ka apsūdzētāji ir lielā mērā pārspīlējuši organizācijas iesaistī̌sanos problēmas radīšanā. Cita stratēgíiskās komunikācijas pieeja ir aizsardzības atbildes stratēǵija, piemēram, noliegšana vai attaisnošana, kas nozīmē, ka organizācija mazāk agresīvi reaǵē uz kritiku nekā tad, ja tiek izmantota ofensīvās

16 Abunyewah, M. et al. (2019). Linking information provision to behavioural intentions. International Journal of Disaster Resilience in the Built Environment, 11(1), pp. 100-118.

17 Smith, R. (2005). Strategic planning for public relations. Mahwah, NJ: Lawrence Erlbaum Associates, p. 101.

18 Ibid., p. 103. 
atbildes stratēgija. Lietojot šo stratēgiju, organizācija var censties mazināt atbildību par kaitējumu, izvairīties no tās, neuzņemties to, var pat novelt atbildỉbu uz citiem un pati palikt cietējas lomā. Vēl ir daiļrunīgās lìdzjūtības stratēếija, kuru lietojot organizācija pauž empātiju un sapratni par neveiksmēm, kuras cietusi tās publika (valsts gadījumā tã ir sabiedrība). Tās ir bažas - organizācija pauž, ka nav vienaldzīga pret problēmu, bet neatzīst savu vainu; līdzjūtība - organizācija izsaka bēdas par kāda zaudējumu vai nelaimi, taču neatzīst savu vainu; nožēla - organizācija atzīst skumjas un sēras par situāciju.

Šajā rakstā apkopotas tās teorētiskās atziṇas, kas ir īpaši svarīgas empīriskā pētījuma veikšanā, lai noskaidrotu, vai valdības komunikācijas vēstījumi ir bijuši skaidri un vairojuši sabiedrības drošības sajūtu vai, tieši pretēji, to mazinājuši. Kā arī izpētītas valdības izmantotās komunikācijas stratēǵijas, kuras ietekmē iedzìvotāju uzticēšanos pieņemtajiem lēmumiem un līdzdalību drošỉbas vairošanā vai arī kuras var radìt negatīvas sekas lēmumu ieviešanā un krīzes stabilizēšanā.

\section{Krīzes komunikācija pandēmijas pirmā viḷna laikā: vēstījumu skaidrība}

Covid-19 krīzes laikā tika veikti daudzi pētījumi, kas liecina par sabiedrības subjektīvo drošības uztveri. Kā vienu no piemēriem var minēt Latvijas Universitātes Sociālo zinātṇu fakultātes Politikas zinātnes nodaḷas 1. kursa studentu veikto aptauju "Latvijas sabiedrības reakcija uz pandēmiju Covid-19". Tajā no 18. maija līdz 31. maijam tika noskaidrots Latvijas iedzīvotāju vērtējums par valdības rīcību krīzes laikā. Aptaujā uz jautājumu "Ko Jūs ieteiktu valdībai darìt Covid-19 krīzes laikā?” lielākā daļa respondentu atbildējuši, ka valdība labi pārvaldījusi situāciju un ka ir jāturpina iesāktais - 66\% aptaujāto latviešu un 51\% krievvalodīgo pozitīvi vērtējuši valsts pārvaldes iestāžu komunikāciju un izmaiņas pakalpojumu pieejamībā, ${ }_{19}^{19}$ taču respondenti norādijjuši arī to, ka liela nozīme ir bijusi tieši valsts komunikācijai ar sabiedrību un šai komunikācijai nepieciešama virkne uzlabojumu. Viens no ieteikumiem: ir nepieciešams vairāk strādāt pie izskaidrošanas pasākumiem dažādās sabiedrības grupās, jo daudzas grupas joprojām uzskata, ka Covid-19 neeksistē un neuztver valdības noteiktos ierobežojumus nopietni. Cits respondents norādijis, ka nepieciešams vairāk informācijas, jo informācijas vakuumā un nezin̄ā rodas konspirācijas

19 Politikas zinātnes studenti izstrādājuši pētījumu par Latvijas sabiedrības skatījumu uz Covid-19 pandēmiju (02.07.2020.). Pieejams: https://www.szf.lu.lv/par-mums/zinas/zina/t/59998/ [skatïs 25.01.2021.] 
teorijas. Lai arī kopumā aptaujātie atzīmē, ka informācija ir bijusi pietiekama, tomēr viṇi norāda, ka pietrūcis argumentācijas un plašāka skaidrojuma, kas padarītu vēstījumu saprotamāku dažādām sabiedrības grupām un vairotu viṇu drošibu.

Lai detalizētāk noskaidrotu, cik veiksmīgi valdība nodevusi sabiedrībai vēstījumus par Covid-19 vīrusu un ieviestajiem ierobežojumiem tā izplatības samazināšanai, ir jāapskata, kādas ziņas publicējuši galvenie sabiedrībā izmantotie mediji un organizācijas un kas ir padarījis to paustos vēstijjumus skaidrus vai neskaidrus. Lai vēstijjums būtu skaidrs un informāciju uztvertu ātri un precìzi, svarīgi ir tas, kā tiek veidots saturs, proti, vai izklāstījuma secība ir log̣iska, izteiksmes veids un forma ir sabiedrībai saprotama. Par neskaidru vēstijumu var runāt tad, ja tajā iekḷautā informācija ir pārāk apjomīga (vai, tieši pretēji, nepietiekama vai neadekvāti izskaidrota, un tas ir iemesls subjektīvai interpretācijai), minētie apgalvojumi ir nepamatoti vai pārāk sarežgíti un nesaprotami, kā arī nelog̣iski izklāstīti un izteiksme ir neprecīza. Būtiski ņemt vērā, kāda ir sabiedrības subjektīvā ziṇu uztvere, tāpēc katram nodotajam vēstỉjumam ir jābūt pēc iespējas skaidrāk saprotamam jebkurai auditorijai. Krīzes komunikācijā ir svarīgi arī apzināties, ka informatīvā vide ir fragmentēta un vēstījumam ir jābūt skaidram jebkuram indivīdam neatkarīgi no viņa kompetences, vietas hierarhijā, vecuma, izglīî̉bas, personīgās pieredzes vai citiem ietekmējošiem faktoriem.

Lai izprastu auditoriju un nodrošinātu tās uzticību paustajam vēstijjumam, svarīgi ir nepiepildìt informācijas telpu ar liekām ziṇām un publicēt to, kas lasîtājam šķiet būtisks, kā arī respektēt viedokḷu dažādību (ja kāds viedoklis varētu būt kaitējošs, censties to argumentēti izskaidrot, neizmantojot apvainojumus), izdarìt objektīvus secinājumus un censties pēc iespējas pārliecinošāk izskaidrot situācijas apstākḷus. Ja tiek lietoti konkrēti un jebkuram sabiedrības loceklim saprotami apgalvojumi, ziṇas ir grūtāk pārprast vai subjektīvi interpretēt. Visbiežāk viegli lasāmas ziṇas var publicēt tieši masu mediji.

Pētijumā ziṇu ar skaidru vēstỉjumu definējām kā tādu, kurā paustās informācijas saturs ir balstīts pierādījumos, tas ir informatīus, kā arī pilnīgs, proti, tas nerada neskaidrības vai papildu jautājumus. Tā ir arī būtiska krīzes komunikācijas sastāvdaļa, lai veidotu skaidru un argumentētu komunikāciju ar sabiedrību. Cilvēki jutīsies drošāk, ja vēstījums, ko organizācijas cenšas nodot sabiedrībai, tai būs skaidrs un saprotams. Sākoties Covid-19 pandēmijai, vēstījumu skaidrībai svarīgi bija definēt, kas ir šis vīruss, kādi ir saslimšanas simptomi, kā no šĩ vīrusa izvairīties, kā arī kādi ierobežojumi jāievēro. Pēc Latvijas Televīzijas Ziṇu dienesta pasūtijuma pētījumu centrs SKDS Covid-19 krīzes laikā veica aptauju, analizējot sabiedrības viedokli par vēstījumu skaidrību un 
informētību par pandēmijas ierobežojumiem. Vairāk nekā 85\% aptaujāto atzinuši, ka par vīrusa izplatību, tā radītajiem riskiem un noteiktajiem ierobežojumiem ir stāstīts un skaidrots pietiekami. ${ }^{20}$ Divas trešdaļas aptaujāto par vīrusa ierobežošanas pasākumiem izteikušies pozitīvi, un gandrīz puse aptaujāto pozitīvi vērtējuši saslimušo ārstēšanu. Analizējot ierobežojumu uzraudzību, aptuveni puse aptaujāto to vērtējuši pozitīvi. Divas trešdaḷas norādījušas, ka oficiālajai informācijai uzticas, it īpaši infektologa Uga Dumpja (21,6\%), epidemiologa Jurija Perevoščikova (8,4\%), mediķu un zinātnieku $(6,8 \%)$, Ilzes Viņķeles $(3,6 \%)$ un Ministru prezidenta Krišjāņa Kariņa $(2,8 \%)$ paustajam (daži respondenti minēja arī Vladimiru Putinu un Aleksandru Lukašenko $(0,8 \%)$ vai Aldi Gobzemu $(0,6 \%)) .{ }^{21}$ Noteicošs faktors cilvēku uzticībā bijusi arī valoda (krievvalodīgie iedzīvotāji biežāk norādījuši, ka neuzticas publicētajiem datiem). Iespējams secināt, ka skaidrība par vēstỉjumiem atšķ̌īās starp auditorijām.

Par ietekmi uz subjektīvo drošības uztveri liecina arī sabiedriskās domas aptauja, kuru no 9. līdz 20. aprīlim veica RSU doktoranti, lai uzzinātu, kāda ir sabiedrības izpratne par Covid-19 Latvijā, un kurā atklājās, ka iedzīvotājus visvairāk uztrauc ekonomikas stāvoklis Latvijā un pasaulē, vīrusa globālā izplatība un izplatība Eiropā. Viṇi pauda bažas par Latvijas medicīnas iestāžu kapacitāti un ārkārtas stāvokḷa izsludināšanu, slēgtajām izglīīibas iestādēm, un viṇus satrauca neziṇa par pandēmijas beigām un Latvijas institūciju gatavību, kā arī valsts robežu slēgšanu. ${ }^{22}$ Vismazāk satrauca pārtikas produktu pieejamība veikalos. Respondenti visbiežāk izjutuši ekonomikas sektora apdraudējumu, baidoties gan par saviem ienākumiem un pirktspēju, gan arī par valsts ekonomikas un uzṇēmējdarbības vides stabilitāti. Tā kā arī sabiedriskās domas aptaujās visvairāk iezīmējušās bažas par drošību tieši ekonomikas jomā, var secināt, ka neskaidrais vēstījums par atbalsta pasākumiem šìs bažas ir tikai veicinājis. Līdzīgs neskaidrs vēstījums novērojams arī komunikācijā par Covid-19 vakcinēšanās plānu, kas ietekmē sabiedrības subjektīvo drošības uztveri personiskās drošības sektorā.

Rožukalne, A. (2020). Aptauja: sabiedrïbas izpratne par COVID-19 Latvijā. 9.-20. aprïlis. Aptaujas rezultāti. Pieejams: https://www.rsu.lv/sites/default/files/imce/Zinas/Zinu\%20pielikumi/covid_19_ results_infographics_05_08_2020.pdf [skatits 26.01.2021.]

21 Bērtule, A. (08.05.2020.) Iedzīvotāji uzteic informētību par Covid-19, bet nopel ekonomikas glābšanu. Pieejams: https://www.lsm.lv/raksts/zinas/latvija/iedzivotaji-uzteic-informetibu-par-covid-19-betnopel-ekonomikas-glabsanu.a359086/ [skatits 26.01.2021.]

22 Bērtule, A. (12.05.2020.) 28\% iedzīvotāju netic oficiālajai informācijai par Covid-19. Pieejams: https://www.lsm.lv/raksts/zinas/latvija/28-iedzivotaju-netic-oficialajai-informacijai-par-covid-19. a359519/ [skatits 26.01.2021.] 
Pēc krīzes komunikācijas monitoringa ir iespējams iezīmēt, vai vēstījums visās apskatītajās platformās ir bijis vienāds un vai nav ticis izmainīts tā saturs vai formulējums. Kā piemēru var apskatît vēstỉjumu par sejas masku lietojumu un tā atspoguḷojumu dažādās informatīvajās vietnēs laika posmā no 2020. gada 1. marta līdz 31. martam (skatìt 2. tabulu). Analizējot iegūtos datus, iespējams secināt, ka ziṇa, ko publicējis SPKC vai Veselības ministrija, pēc tam tika ievietota medijos DELFI, LETA un LSM, lielākoties saglabājot sākotnējo vēstijumu (visbiežāk to papildināja kāds viedoklis vai intervija ar konkrētās nozares pārstāvi). Toties sabiedrībā neskaidrību varēja veicināt tas, ka konkrētā ziṇa tika pārpublicēta dažādos informācijas kanālos vai iekḷauta citos atsevišķos rakstos, vai publicēta citā dienā, nedaudz to pārformulējot. Covid-19 krīzes sākumā plašsaziņas līdzekḷos par konkrēto tēmu rakstu skaits dienā sasniedza līdz pat 50 rakstiem, kas liecina par l̦oti masīvu informācijas apjomu. Lai gan masu medijs DELFI spēja laicīgi un visai uztveramā veidā informēt sabiedrību par notiekošo Covid-19 krīzes kontekstā, monitorēšanas laikā tika secināts, ka vienā dienā tiek publicēts tik liels ziṇu apjoms par kādu konkrētu tēmu, ka tas varētu arī negatīvi ietekmēt sabiedrības uztveri, piemēram, ieviest bažas vai pat radīt paniku. Konkrētajā piemērā galvenais vēstijjums, ko centās nodot martā par sejas maskām, ir tas, ka iespējams inficēties, ja neievēro divu metru distanci, bet sejas maska jāliek tikai saslimušajiem, lai neinficētu citus, veselos maska nepasargās (teiktais neattiecas uz maskām, ko lieto mediḳi). Atslēgvārds "sejas maska" popularitāti ieguva vēlāk, kad sejas aizsargmasku lietošana 2020. gada otrajā pusē kḷuva par vienu no būtiskākajiem ierobežojumiem, lai pasargātos no Covid-19. Šāds vēstijums sabiedrībai var likties neskaidrs un veicināt nedrošību personiskajā sektorā, n̦emot vērā, ka Covid-19 krīzes sākumā maskas tika uzskatìtas par neefektīvām veselajiem cilvēkiem.

Lai komunikācija un vēstījums būtu skaidri, svarīga ir pareiza un precīza vārdu izvēle, secība un pareizs pieturzīmju lietojums. Uzrunājot plašu auditoriju, jāizvēlas emocionāli neitrāli valodas izteiksmes līdzekḷi, terminiem ir jābūt saprotamiem, vai arī tie ir jāskaidro. Lai ieinteresētu sabiedrību, var izmantot arī personīgās pieredzes stāstus un paust personīgos viedokḷus. Covid-19 pandēmijas sākumā informatīvajā telpā visbiežāk tika izmantoti tādi vārdi kā "rokas" un "distance": "bieži/regulāri un rūpīgi mazgā rokas" vai "ievēro divu metru distanci no cilvēkiem ar akūtas elpceļu infekcijas simptomiem”. Bieži tika lietoti arī vārdi "dezinfekcija": "spirtu saturoši dezinfekcijas līdzekḷi / sadzìvē lietojami dezinfekcijas līdzekḷi / roku dezinfekcijas līdzeklis uz alkohola bāzes" utt., "ierobežojumi” un "ārkārtas situācija/stāvoklis", kuri tika minēti gandrīz katrā vēstī. Var secināt, ka sabiedrības informēšana par ierobežojumiem un nepieciešamība nodrošināt, lai tie tiktu ievēroti ārkārtas situācijas 
2. tabula. Vēstījumu skaidrība/neskaidrība

\begin{tabular}{|c|c|c|c|}
\hline $\begin{array}{c}\text { Medijs, } \\
\text { organi- } \\
\text { zăcija }\end{array}$ & Ziṇas nosaukums & Datums & Vēstijjums \\
\hline SPKC & $\begin{array}{l}\text { 1. Farmaceitiem } \\
\text { 2. Sabiedriskā } \\
\text { transporta } \\
\text { organizatoriem }\end{array}$ & $\begin{array}{l}\text { 01.03.2020.- } \\
\text { 03.03.2020. }\end{array}$ & $\begin{array}{l}\text { Veseliem cilvēkiem nav jālieto medicīniskā } \\
\text { maska, lai sevi pasargātu no inficēšanās ar } \\
\text { Covid-19 infekciju izraisošo koronavīrusu. } \\
\text { Sejas maskas sabiedriskā transporta } \\
\text { vadītāju aizsardzībai pret iespējamo } \\
\text { Covid-19 infekciju nav efektīvas. } \\
\text { Medicīniskās maskas lietošana profilaktiskos } \\
\text { nolūkos rada viltus ilūziju par aizsardzību } \\
\text { no inficēšanās, tāpēc cilvēki nereti aizmirst } \\
\text { par pareizas roku un respiratorās higiēnas } \\
\text { ievērošanu }\end{array}$ \\
\hline DELFI & $\begin{array}{l}\text { 1. Kā Covid-19 } \\
\text { laikā uzvesties } \\
\text { autobusos? } \\
\text { leteikumi } \\
\text { sabiedriskāa } \\
\text { transporta } \\
\text { organizatoriem } \\
\text { un pasažieriem } \\
\text { 2. Lidostā "Rīga" } \\
\text { uzstādīti roku } \\
\text { dezinfekcijas } \\
\text { līdzekḷi un norit } \\
\text { pastiprināta } \\
\text { telpu uzkopšana } \\
\text { 3. Viedoklis: } \\
\text { Covid-19 no } \\
\text { imūnsupresīva } \\
\text { pacienta redzes } \\
\text { punkta } \\
\text { 4. Covid-19: } \\
\text { farmaceiti bijuši } \\
\text { apdraudēti; } \\
\text { situācija } \\
\text { aptiekās } \\
\text { uzlabojas }\end{array}$ & $\begin{array}{l}\text { 01.03.2020.- } \\
\text { 20.03.2020. }\end{array}$ & $\begin{array}{l}\text { Sejas maskas sabiedriskā transporta } \\
\text { vadītāju aizsardzībai pret iespējamo } \\
\text { Covid-19 infekciju nav efektīvas, jo tās } \\
\text { nepasargā no inficēšanās, bet rada maldīgu } \\
\text { drošības sajūtu. SPKC uzsver, ka veseliem } \\
\text { cilvēkiem nav jālieto medicīniskā maska, lai } \\
\text { sevi pasargātu no inficēšanās ar Covid-19 } \\
\text { infekciju izraisošo koronavīrusu. } \\
\text { Viedoklis: Negribu žēloties par to, ka nekur } \\
\text { nevaru nopirkt kirurǵiskās maskas, kas man ir } \\
\text { nepieciešamas ikdienā, lai vispār apmeklētu } \\
\text { jelkādu sabiedrisku vietu, -ja preces vēl var } \\
\text { pasūtīt internetā, tad nodot analīzes vai } \\
\text { izklausīt plaušas gan ne. Esmu gana labi } \\
\text { adaptējusies dzīvei karantīnas režīmā- } \\
\text { maskas var uzšūt no marles, dezinfekcijas } \\
\text { līdzekli pagatavot mājōs, un jebkurā } \\
\text { gadījumā nekas labāks par ziepēm un ūdeni } \\
\text { nav izgudrots. } \\
\text { Līdz ar pandēmijas izzinošanu klientu } \\
\text { skaits strauji pieaudzis, cilvēki pastiprināti } \\
\text { iepērk medikamentus un interesējas par } \\
\text { dezinfekcijas līdzekḷ un sejas masku } \\
\text { pieejamību }\end{array}$ \\
\hline
\end{tabular}




\begin{tabular}{|c|c|c|c|}
\hline $\begin{array}{l}\text { "Pano- } \\
\text { rāma" }\end{array}$ & $\begin{array}{l}\text { 1. Pastiprināti veic } \\
\text { dezinfekciju } \\
\text { 2. Liepājas } \\
\text { tekstiluzñēmumi } \\
\text { ražos sejas } \\
\text { aizsargmaskas } \\
\text { 3. Gatavi ražot } \\
\text { sejas vairogus } \\
\text { 4. Ar maskām } \\
\text { sargās visus } \\
\text { mediḳus }\end{array}$ & $\begin{array}{l}\text { 07.03.2020.- } \\
\text { 30.03.2020. }\end{array}$ & $\begin{array}{l}\text { Tas, vai viṇi lieto izdalītās sejas maskas, } \\
\text { esot darbinieku ziñā. Vairāki Liepājas } \\
\text { tekstiluzñēmumi jau sākuši ražot sejas } \\
\text { maskas, taču pagaidām nespēj apmierināt } \\
\text { pēc tām esošo pieprasījumu pat pilsētas } \\
\text { mērogā (dienas laikā iespējams izveidot } \\
\text { tikai } 1000 \text { masku). Hakatonā uzvarējusi } \\
\text { komanda, kas izveidojuši sejas vairogus. } \\
\text { Mediḳi tos grib saṇemt jau šodien. Primārais } \\
\text { uzdevums - apgrūtināt iespēju pieskarties } \\
\text { sejai ar netīrām rokām. Viss vairogs ir } \\
\text { dezinficējams - maskas un citi individuālās } \\
\text { aizsardzības līdzekli jālieto visiem medikiem. } \\
\text { RAKS piegādāta krava - } 48 \text { tūkstoši sejas } \\
\text { masku; maskas un respiratorus ieveda no } \\
\text { K̦īnas, pirms tam tās tiks pārbaudītas }\end{array}$ \\
\hline LR1 & $\begin{array}{l}\text { 1. Linkaits aicina } \\
\text { informēt } \\
\text { lidsabiedrību, ja } \\
\text { kādu iemeslu dē! } \\
\text { izvēlas nelidot uz } \\
\text { Latviju } \\
\text { 2. Karantīna vai } \\
\text { pašizolācija? }\end{array}$ & $\begin{array}{l}\text { 16.03.2020.- } \\
\text { 18.03.2020. }\end{array}$ & $\begin{array}{l}\text { Maskas nepasargā no iespējamas } \\
\text { saslimšanas. Tāpat, dodoties pēc } \\
\text { iepirkumiem, šiem cilvēkiem (slimajiem) } \\
\text { iesaka izmantot sejas masku un arī ievērot } \\
\text { divu metru distanci }\end{array}$ \\
\hline MK & $\begin{array}{l}\text { Valdība lemj } \\
\text { par atbalstu } \\
\text { uzñēmējiem } \\
\text { un paplašina } \\
\text { piesardzības } \\
\text { pasākumus } \\
\text { Covid-19 izplatības } \\
\text { ierobežošanai }\end{array}$ & 19.03.2020. & $\begin{array}{l}\text { Ja nav citu risinājumu, veikals jāapmeklē } \\
\text { stundās, kad veikalā mazāk cilvēku, lietojot } \\
\text { sejas masku un ievērojot } 2 \text { metru distanci no } \\
\text { citiem veikalā esošajiem }\end{array}$ \\
\hline NMPD & $\begin{array}{l}\text { NMPD pastiprina } \\
\text { aizsardzības } \\
\text { pasākumus } \\
\text { brigādēs un } \\
\text { ārkārtas tālruṇa } \\
113 \text { zvanu centrā }\end{array}$ & 31.03.2020. & $\begin{array}{l}\text { Jau vairākas dienas NMPD brigādes uz } \\
\text { katru izsaukumu dodas, lietojot individuālos } \\
\text { aizsardzības līdzeklus. Ja izsaukums ir pie } \\
\text { pacienta, kuram nav akūtas elpcelu slimības } \\
\text { pazīmes, bet ir cita saslimšana vai kurš ir } \\
\text { guvis traumu, brigādes personālam vienmēr } \\
\text { jālieto sejas maska un cimdi; dežūras laikā } \\
\text { personāls lieto sejas aizsargmaskas un } \\
\text { darbiniekiem ir arī papildu pārbaudes }\end{array}$ \\
\hline
\end{tabular}


laikā, bija vieni no svarīgākajiem jautājumiem, ko valdība centās nodot sabiedrības zināšanai. Salīdzinot SKDS veiktos pētijumus par sabiedrības attieksmi pret Covid-19, pirmajā pētījumā (no 2020. gada 2. aprị̣̄a līdz 5. aprīlim) $56 \%$ aptaujāto norādīja, ka ieviestie ierobežojumi ir atbilstoši situācijai un ka visvairāk jāizvairās no liela Covid-19 slimnieku un mirušo skaita (56\%) un no smagas ekonomiskās lejupslīdes (44\%). ${ }^{23}$ Ierobežojumu atcelšanu vin̨i uzskatīja par risku, kas veicinās saslimšanu un nāves gadījumus. Skalā no 1 līdz 10 vērtējot valdības rīcību, respondenti norādījuši, ka visveiksmīgāk veicies ar sabiedrības informēšanu $(7,6)$, ierobežojumu ieviešanu $(7,0)$ un palīdzības/atbalsta sniegšanu $(6,1)$. Maijā saglabājās pozitīvais valdības rīcỉbas vērtējums par sabiedrības informēšanu (62\% rīcību uzskata par atbilstošu), kā arī par ierobežojumu stingrību (70\%). ${ }^{24}$ Lielākās bažas bija radījusi valsts ekonomiskā stabilitāte. Novembrī veiktajā pētījumā tika secināts, ka sabiedrība, vērtējot valdības darbu, atzinīgi izteikusies par sabiedrības informēšanu (45\%) un ierobežojumu ieviešanu (30\%). ${ }^{25}$ Turpretim decembrī, vērtējot valdības darbu, tikai 32\% respondentu atzinīgi vērtējuši sabiedrības informēšanu un $24 \%$ - ierobežojumu ieviešanu. ${ }^{26}$ Tātad valdības darba vērtējums turpinājis pasliktināties. 2021. gada janvāri veiktajā pētījumā jau $61 \%$ aptaujāto piekrita tam, ka valdība pati nezina, ko darìt, lai ierobežotu Covid-19 izplatību, 50\% atzina, ka valdība akli seko starptautisko organizāciju rīkojumiem, nevis rīkojas tautas labā, bet $48 \%$ domāja, ka lēmumi tiek pieņemti šauras grupas, nevis tautas labā. ${ }^{27}$ Tikai $24 \%$ respondentu norādīja, ka valdība dara visu, lai mazinātu sabiedrības problēmas. Aptaujas dati korelē ar secinājumu par politikas drošības sektora apdraudējumu, ņemot vērā to, ka liela dạ̧a sabiedrības ir zaudējusi uzticību vai turpina neuzticēties politiskajiem institūtiem. Jāuzsver, ka aptaujā, ko 2021. gadā veikusi SKDS pēc LSM.lv pasūtijuma, tikai trešdaḷa (34\%) respondentu kopumā pozitīivi novērtējuši valdības darbu pandēmijas iegrožošanā, bet gandrīz divām trešdaḷām (59\%) viedoklis ir negatīvs. ${ }^{28}$ Iedzīvotāju vērtējums

23 Bērtule, A. (12.05.2020.) 28\% iedzīvotāju netic oficiālajai informācijai par Covid-19. Pieejams: https://www.lsm.lv/raksts/zinas/latvija/28-iedzivotaju-netic-oficialajai-informacijai-par-covid-19. a359519/ [skatìts 26.01.2021.]

24 SKDS (2020). Pētījums par sabiedrības attieksmi par Covid-19 (2020, aprīlis). Pieejams: https:// www.mk.gov.lv/sites/mk/files/media_file/apr_covid_krize_online_04.20.pdf [skatīts 26.01.2021.]

25 SKDS (2020). Pētījums par sabiedrības attieksmi pret Covid-19 (2020, maijs). Pieejams: https://www. $\mathrm{mk} . g o v . l v / s i t e s / \mathrm{mk} / \mathrm{files} / \mathrm{media}$ _file/maijs_covid_online_05.20.pdf [skatïts 26.01.2021.]

26 SKDS (2020). Pētījums par sabiedrības attieksmi pret Covid-19 (2020, novembris). Pieejams: https:// www.mk.gov.lv/sites/mk/files/media_file/nov_skds_vk_covid_20.20.pdf [skatīts 26.01.2021.]

27 SKDS (2020). Pētījums par sabiedrības attieksmi pret Covid-19 (2020, decembris). Pieejams: https:// www.mk.gov.lv/sites/mk/files/media_file/dec_skds_covid_12_2020.pdf [skatīts 26.01.2021.]

28 SKDS (2020). Pētījums par sabiedrības attieksmi par Covid-19 (2021, janvāris). Pieejams: https:// www.mk.gov.lv/sites/mk/files/media_file/janv_skds_covid_01_2021.pdf [skatīts 26.01.2021.] 
kopš Covid-19 otrā viḷnna ir kḷuvis negatīvāks - liela daļa sabiedrības neredz, ka valdības darbības būtu plānotas ilgtermiṇā, secīgi vai jēgpilni, tātad sniegtais vēstījums ir kḷuvis neskaidrāks.

Savukārt, analizējot vēstijumus, kuru atslēgvārdi ir "mediķi”" un "valdība", redzams, ka mediķi slavēti kā profesionāļi, kas ikdienā dara savu darbu un pašaizliedzīgi pilda savus pienākumus. Izskanējuši arī aicinājumi taupìt mediķu resursus un veselību. Valdība ir vērtēta kritiski, piemēram, ziņās izskanējuši aicinājumi valdībai lielākus resursus novirzìt saslimušo cilvēku ārstēšanai, nevis tādu pasākumu ieviešanā, kas kavē ekonomikas attīstību. Iedzīvotājos bija radušãs šaubas, vai valdība un dienesti spēs tikt galā ar vīrusa izplatību. Vienlaikus vēstijjumos parādijās arī izpratne, ka valdībai ir nopietni jāizšşiras par lēmumiem, kā arī lielākajā dậa ziṇu, lai skaidrotu valdības pieņemtos ierobežojumus, atslēgvārds lietots neitrālā nozīmē. Interesanti, ka bieži tika izmantots arī vārds "atbildība" un uzsvērts tas, ka svarīgi ir indivīdu personīgie lēmumi, atbildīga rīcība pret sevi un citiem, svarīgi ir pārbaudìt faktus un uzticēties oficiāliem avotiem, kā arī sekot atbildīgo iestāžu norādījumiem.

Izmantojot atslēgvārdu "krīze", bija centieni mierināt sabiedrību, ka "pēc iepriekšējās krīzes esam daudz mācỉjušies un kḷuvuši stiprāki” un ka "krīze ir arī iespēju laiks", kas "attīsta un maina mūsu paradumus, domāšanas paradigmu un kultūru”. Covid-19 izraisītā krīze neesot salīdzināma ar savulaik piedzīvoto finanšu krīzi.

Vārds "budžets" tika minēts gan kontekstā ar valsts budžetu un tā deficītu, uzsverot, ka tas nav un nebūs šḳērslis, gan runājot par individuālo budžetu, kurš cilvēkiem, kas atrodas pašizolācijā vai dīkstāvē, var būt ierobežots. Savukārt vārds "pabalsts" visbiežāk tika izmantots vārdkopā "dīkstāves pabalsts". Arī vārds "dīkstāve” izskanēja bieži, jo krīzes ekonomisko seku pārvarēšanai dīkstāves reglaments bija kas nebijis Latvijā, tāpēc bija nepieciešams sabiedrību izglìtot par dīkstāves pabalsta piešķiršanas nosacỉjumiem.

Vēl tika analizēts atslēgvārds "grūtības", kas vēstījumos tika lietots, runājot par atbalstu uzņēmumiem, kas nonākuši grūtībās; par tiem, kas vēlējās atgriezties valstī, bet saskārās ar šķērṣ̌liem; par mediju nozari, kurai bija kritušies ien̦ēmumi; par studentiem, kuriem ir grūtības apmaksāt studējošo kredītu; par gimenēm (it īpaši daudzbērnu giimenēm), kurās radušās problēmas ar attālinātajām mācībām. Atslēgvārds "grūtības" galvenokārt tika lietots vārdkopā "finansiālās grūtības". Zīmīgi, ka pirmo reizi vārds “izveseḷojies” tika minēts tikai 18. martā, kad tika paziṇots: lai noteiktu, ka persona ir izveseḷojusies, pacientam tiks veikti vēl divi testi, lai apstiprinātu vīrusa neesamību organismā. Salīdzinājumā ar vārdiem "slimie/saslimuši” šis vārds tika izmantots daudz retāk. 
Analizējot vēstījuma skaidrību drošìbas sektoru kontekstā, iespējams secināt, ka vēstījumu skaidrība lielākoties attiecas uz politiskās un personiskās drošības sektoru, kā arī ekonomisko sektoru. Personiskās drošības sektors iekḷauj arī draudus veselïbai, tāpēc tieši personiskās drošibas sektors bija primārais, kas tika minēts ziṇu vēstījumos (no kopumā minētajām vairāk nekā 700 reizēm personiskās drošības sektors ziṇās visbiežāk ir minēts kā primārais vai sekundārais drauds sabiedrībai). Visbiežāk ziņās par šo sektoru dominēja atslēgvārdi, kas saistīti ar personu veselību (to skaitā "dezinfekcija", "slimie/ izveseḷojušies”, "distance”, "rokas”, "sejas maskas” u. c.), kā arī atslēgvārdi (piemēram, "atbildība"), kas motivē sabiedrību rīkoties, lai uzlabotu savu drošîbu un labklājỉbu. Tātad vēstijjuma skaidrībai vairākkārt tika izmantoti šie atslēgvārdi, lai veicinātu sabiedrības izpratni par to, kā rīkoties drošỉbu draudu situàcijā, un lai pasargātu sevi un līdzcilvēkus.

Politiskās drošības sektors ziṇās saistīts ar vēlmi nodrošināt politisko atbalstu drošības situācijas uzlabošanai valstī, kā arī uzticības veicināšanai politiskajiem institūtiem. Ziņās politiskās drošỉbas sektors kopumā minēts biežāk nekā simts reižu un parasti asociēts ar terciārajiem draudiem (kā primārie un sekundārie visbiežāk tika uzsvērti ekonomiskie vai personiskie draudi). Parasti politikas sektoru asociēja ar atslēgvārdiem "valdība", "ārkārtas stāvoklis”, "ierobežojumi” un "repatriācija”, kā arī bieži vien šis sektors tika pieminēts ziṇās, kurās tika paustas bažas par drošîbas situāciju un tās pietiekoši labu kontroli. Vēstījumi tika saistīti arī ar diskusiju par pieņemto lēmumu legitimitāti un valdības stabilitātes vērtējumu, to skaitā arī ar diskusiju par vienotību starp politiķu vēstijjumiem. Jāuzsver, ka tas ir svarīgs uzticības veicināšanas faktors, jo vairākās ziṇās bija vērojama kritika, ko kāds parlamenta deputāts vai ministrs vērsa pret kādu no saviem politiskajiem pretiniekiem, par pausto viedokli vai pieņemtajiem lēmumiem, kas varēja veicināt neskaidrību vai sabiedrïbas neuzticību.

Ekonomikas drošibas sektors ziṇās ticis izmantots, lai informētu sabiedrību par to, kā rīkoties konkrētajā situācijā (piemēram, kā pieteikties pabalstu saņemšanai), kā arī diskutētu par valdības pieņemtajiem lēmumiem Covid-19 izraisītās krīzes risināšanā. Atslēgvārdi "krīze", "pabalsts", "dīkstāve”, "iepirkšanās", "preces”, "budžets” un citi var tikt asociēti ar ekonomikas drošỉbas sektoru - tie visbiežāk tika lietoti ziņās, lai ieviestu skaidrību par to, kā iedzīvotājiem saṇemt finansiālo atbalstu (plašsaziṇas līdzekḷos tika izmantoti arī ekonomistu viedokḷu raksti ar ieteikumiem krīzes skartajiem uzņēmējiem vai prognozēm par globālās ekonomikas svārstībām un tendencēm tuvākajā nākotnē). Sabiedriskās domas aptaujās parādījās daudzi ieteikumi valdībai finansiāli atbalstīt sevišķi tos sektorus, kas visvairāk izjūt pandēmijas 
ietekmi, piemēram, mazos un jaunos uzņēmumus, studentus un veselïbas aprūpes speciālistus. Arī SKDS veiktajās aptaujās tika secināts, ka Covid-19 pandēmijas sākumā sabiedrība visnegatīvāk vērtējusi valsts atbalstu tieši krīzē nonākušajiem uzņēmumiem un viņu darbiniekiem. Latvijas Tirdzniecỉbas un rūpniecỉbas kameras Ekonomikas indeksa vērtỉba krīzes sākumā bija nokritusi līdz 38,50 punktiem, "kas liecina par vidēju uzņēmēju pesimismu" - negatīvām nākotnes prognozēm par uzn̦ēmuma apgrozījuma kritumu, investīciju samazināšanos vai finansiālā stāvokḷa pasliktināšanos. ${ }^{29} 42 \%$ aptaujāto paredzēja darbinieku skaita samazināšanos turpmāko sešu mēnešu laikā, bet tikai 1\% uzñēmēju cerēja, ka vispārējā ekonomiskā aktivitāte valstī palielināsies (94\% bija pārliecināti, ka tā samazināsies). ${ }^{30}$ No reǵioniem vispesimistiskāk noskaņoti bija uzņēmumi Latgalē. SKDS veiktajā pētỉjumā pēc Latvijas Televīzijas Ziṇu dienesta pasūtijuma no 30. aprịḷa līdz 5. maijam internetā tika apjautāti vairāk nekā 1000 iedzīvotāju un secināts, ka krīzes iespaidā 44\% respondentu ekonomiskā situācija ir pasliktinājusies, $29 \%$ satrauc iespēja zaudēt darbu, 22\% bažījas par nokḷūšana parādos, bet $9 \%$ uztraucas, ka zaudēs ỉpašumus, jo, piemēram, nespēs samaksāt kredītus. ${ }^{31}$ Bažas par savu ekonomisko drošību spēcīgi izjutuši ne tikai darba devēji, bet arī darba ņēmēji, kas raizējas par savu ienākumu stabilitāti, pirktspēju un spēju veidot uzkrājumus, ko, visticamāk, ir ietekmējis neskaidrais vēstījums par ekonomikas sektoru.

Pētijumā iezīmējās, ka ir bijušas problēmas nodot skaidru vēstījumu par mainīgajiem valdības rīcības plāniem un problēmas ar dažādu avotu informācijas masīvu. Izpratnes problēmas radīja un veicināja arī apjomīgais viltus ziṇu apjoms sociālajos medijos, kas ietekmēja to, kā sabiedrība uztver valdības rīcību. Lai gan bija novērojama starpiestāžu koordinācija un informācija bija pieejama vienā vietnē (piemēram, SPKC vai Veselības ministrijas mājaslapā), tomēr informētība par to, kā rìkoties, atškīīās konkrētās sabiedrības grupās (tika ņemts vērā adresāta vecums, profesija, dzimtā valoda). Tas liecina arī par to, ka vēstījums nav pietiekami skaidrs un ka netika ņemtas vērā dažādās informācijas uztveres attīstības perspektīvas. Veiksmes stāsti krīzes komunikācijā Covid-19 pirmā viḷ̣a laikā ir saistîti ar tūlìtēju rīcību un neatliekamu komunicēšanu (piemēram, preses konferencēs uzreiz pēc valdības sēdēm), izmantojot

29 SKDS (2020. gada marts-aprīlis). LTRK Ekonomikas indekss. Latvijas uzṇēmēju aptaujas rezultāti. Pieejams: https://t.co/QZM8QxqGwn?amp=1 [skatīts 25.01.2021.]

30 Turpat.

31 Krenberga, O. (23.05.2020.) 51\% iedzīvotāju uzskata, ka Covid-19 krīze būs smagāka par iepriekšējo. Pieejams: https://www.lsm.lv/raksts/zinas/ekonomika/51-iedzivotaju-uzskata-ka-covid-19-krizebus-smagaka-par-ieprieksejo.a361013/ [skatīts 25.01.2021.] 
konkrētas runas personas. Pozitīvi jāvērtē arī tas, ka atkārtoti tika lietoti dažādi atslēgvārdi, lai veicinātu sabiedrības izpratni par notiekošo.

Apkopotie sabiedriskās domas aptaujas dati liecina: lai gan sabiedrība Covid-19 krīzes sākumā lielākoties ir pozitīvi vērtējusi valdības darbību un tās komunikāciju ar sabiedrību par ierobežojumiem un rīcības plāniem, tomēr tika sniegtas rekomendācijas par nepieciešamību novērst lielo dezinformācijas apjomu, kā arī tika aicināts rīkoties, lai valdības informāciju sasniegtu visas sabiedrības grupas. Subjektīvajā drošības uztverē kritiska bijusi arī informatīvā telpa un tajā pausto vēstījumu skaidrība un patiesība. Pandēmijas laikā visvairāk iezīmējušās bažas par drošību ekonomikas un personiskās drošības sektoros - lielākā dạ̦a sabiedrības baidījusies par savu pirktspēju, spēju veidot uzkrājumus, ienākumu stabilitāti, pieeju finansiālajam atbalstam nepieciešamības gadījumā, kā arī par savu veselību, sociālo aizsardzību, labklājību un pat emocionālo drošỉbu.

\section{Komunikācijas stratēǵijas Covid-19 pirmā viḷna atspogulojumā}

Katrā krīzes vadības ciklā ${ }^{32}$ ir nepieciešama tai atbilstoša specifiska komunikācijas stratēgija. Riska mazināšanas jeb mīkstināšanas posma laikā organizācija dara visu iespējamo, lai mazinātu potenciālos apdraudējumus. Vienlaicīgi notiek informācijas kanālu apzināšana un komunikācijā iesaistīto organizāciju identificēšana. Latvijas gadijumā tie ir Latvijas Republikas Veselības ministrija, SPKC un NMPD, kuri ir atbildīgi par sekošanu epidemiolog̣iskās situācijas attīstībai un informē sabiedrību par pasaulē veiktajiem pasākumiem, apmainās ar informāciju un zināšanām, lai tiktu galā ar vīrusa izraisìto uzliesmojumu. Iestādes veica arī agrīnu saslimušo uzraudzību, lai pēc iespējas ātrāk varētu atklāt un diagnosticēt saslimšanas gadījumus, kā arī spētu indivīdus laicīgi izolēt. Šajā laikā īpaši svarīgi bija izmantot pirmās rokas darbības stratēgiju, lai ievirzìtu sarunas diskursu publiskajā telpā un tiktu galā ar potenciālajām negatīvajām opozīcijas ziṇām. Otrajā krīzes dzīves cikla posmā (seku mazināšanas pasākumi) bija nepieciešams testēt vīrusa klātesamību, tāpēc SPKC ārstniecības iestādēm un ārstiem izplatīja

32 Saskaņā ar Kopolas iedalījumu (Coppola, D. (2007). Introduction to international disaster management. Amsterdam Boston: Butterworth Heinemann) krīzes vadībā tiek izškirti 4 dzīves cikli - pirmais jeb riska mazināšanas/mīkstināšanas posms, otrais - seku mazināšanas pasākumi, trešais atbildes posms, ceturtais - atgūšanās posms. Pirmais un otrais posms ietver laiku pirms krīzes, pēdējie divi - pēc tās. 
rekomendācijas, kurās bija noteikts, ka viṇiem ir nekavējoties jāziṇo, ja ir atklāti saslimšanas gadījumi personām, kuras 14 dienu laikā pirms saslimšanas apmeklējušas Uhaṇu vai bijušas kontaktā ar slimnieku, kas saslimis pēc cel̦ojuma uz to. Vienlaikus arì paši pacienti tika aicināti ziņot ārstniecības personālam par novērotajiem simptomiem un informēt savu gimenes ārstu vai Neatliekamās medicīniskās palīdzības dienestu, kam šādiem gadījumiem ir izstrādāts rīcības algoritms. Arī šajā posmā tika izmantota tieši pirmās rokas darbības stratēgija. Lai gan Latvijā ir novērojami pirmie divi krīzes cikli, tie ir ļoti īsi un nepilnīgi krīzes straujās attīstības dēḷ, par to liecina îsais laika posms un limitētais pieņemto lēmumu daudzums.

Šiem diviem krīzes dzīves cikla posmiem sekoja Covid-19 krīze, kas iezīmēja trešo krīzes cikla posmu, kurš konkrētā pētījumā skatāms no 1. marta un turpinājās tik ilgi, līdz valdība bija tikusi galā ar akūtajām problēmām. Informatīvā telpa bija piesātināta ar materiālu, kura vēstījumu iespējams klasificēt kā pirmās rokas darbību un korigêejošo darbību saturošu. Straujā krīzes komunikācija liecināja par īso un nepilnīgo krīzes vadību pirmā un otrā krīzes dzīves cikla laikā. Ja pirmajā krīzes dzīves ciklā būtu veikta pilnvērtīga krīzes komunikācija, nebūtu novērojams tik straujš krīzes komunikācijas pieaugums. Monitorēšanas procesā aprị̣̂a beigas (20. aprīîi) varētu uzskatìt par ceturtā posma sākumpunktu, jo pēc šì perioda sāka samazināties gan rakstu skaits, gan nepieciešamība pēc akūtās krīzes komunikācijas. Ceturtajā posmā Latvijas valdība bija tikusi galā ar akūtajām krīzes radītajām problēmām un sāka iziet no ārkārtas stāvokḷa, bet joprojām tika izmantota pirmās rokas darbības stratēgija un koriǵējošās darbības. Lai gan Latvijā ārkārtas stāvokḷa beigas tika pasludinātas 10. jūnijā, pētījumā monitorēšana beidzās 12. maijā, kad sāka mīkstināt noteiktos ierobežojumus. Posms var turpināties mēnešiem vai gadiem ilgi pēc pašas krīzes, taču Latvijas gadījumā tas beidzās līdz ar Covid-19 otrā viḷna sākšanos. Svarīgi norādīt, ka viens krīzes dzīves cikls neizslēdz citu. Krīzes komunikācijas monitorēěanā tika konstatēts arī otrā Covid-19 viḷna krīzes sākums un krīzes komunikācijas pirmie posmi.

Pētijumā tika analizētas komunikācijas stratēgijas, kas iekḷautas ziṇās, un secināts, ka laika posmā no 1. marta līdz 12. maijam vēstijjumos pirmās rokas darbības tika izmantotas vairāk nekā pusē no apskatītajām ziṇām (apmēram 60\%). Pētỉjumā pirmās rokas darbỉbas tiek uzskatītas par veiksmīgām, jo tās tika lietotas vēstijjumos, kur sabiedrība tika iepazīstināta ar kādu jaunu ierobežojumu vai informāciju, tādā veidā palīdzot ieviest skaidrību, pirms opozīcija bija paspējusi izteikt kritiku paustajam saturam.

Otra biežāk izmantotā stratēgija bija korigéēošās darbības (aptuveni 20\%). Bija novērojams, ka valdība korigêeja sabiedrības izpratni un kritiku par tās 
iepriekš paustajiem vēstījumiem, kā arī pati savus iepriekš paustos vēstījumus, lai mazinātu kaitējumu, kas bija radies iepriekš veikto neveiksmīgo lēmumu vai kḷūdaino izteicienu dēḷ. Kā piemēru var minēt NMPD un Veselïbas ministrijas ziṇu par pirmo mirušo pacientu 2020. gada 3. aprīì, kad atbildīgās iestādes lūdza sabiedrību ievērot speciālistu rekomendācijas, vēlreiz uzsverot visus nepieciešamos ierobežojumus - sekot ārstu un epidemiologu norādījumiem, sabiedrībā ievērot divu metru fizisko distanci un regulāri mazgāt vai dezinficēt rokas, it īpaši akcentējot, cik svarīgi ir būt atklātākiem pret mediķiem. Korigêejošās darbības var palīdzēt veidot skaidrāku vēstījumu, jo tiek mazināta spriedze sabiedrībā un apliecināta individuālās vai kolektīvās atbildības uzṇemšanās.

Trešā komunikācijas stratēǵija, kas tika izmantota visbiežāk, bija aizsardzības atbildes stratēǵija (aptuveni 10\%). Ar šīs stratēgijas palīdzību tika identificētas tās ziṇas, kurās valdības pārstāvji aizstāvēja sevi pret saṇemto kritiku (jāuzsver, ka tas netika darīts agresīvi, kā varētu būt novērojams ofensīvās atbildes stratēgijā. Lielākoties tas nozīmē, ka organizācija vai nu noliedza kādu vēstījumu un centās ieviest skaidrību, vai arī atvainojās, centās attaisnoties, ja kritika bijusi pamatota. Viens no aizsardzības atbildes stratēgijas piemēriem parādijāa 2020. gada 16. martā, kad daudzi šoferi bija iestrēguši pie VācijasPolijas robežas un bija neapmierināti par informācijas trūkumu. Ziņās tika izmantota arī daiḷunīgās līdzjūtības stratēgija, kas lielākoties tika lietota reti un tādos brī̌os, kad vēstijums pauda vai nu nožēlu par notiekošo, piemēram, saslimušajiem, vai līdzjūtību tuviniekiem sakarā ar Covid-19 izraisitajiem pirmajiem nāves gadījumiem. Organizācijas centās parādīt, ka izjūt līdzjūtību un nožēlu (piemēram, 2020. gada 2. martā medijos parādījās ziṇas, ka premjerministrs saslimušajai rīdziniecei novēl ātru atvesel̦ošanos).

Novēršanas atbildes stratēgija tika izmantota reti - gadijumos, kad bija nepieciešams novērst sabiedrības skatienu no organizācijas problēmām, piemēram, šo stratēgiju lietoja 2020. gada 23. martā, kad bija radušies skolēnu mācỉbu portālu darbības traucējumi, bet to pārstāvji ieteica vietnes, kas procesus nodrošina tiešsaistē, iztur jau iepriekš paredzēto pieslēgumu un lietojamības slodzi. Stratēgiska bezdarbība, kad valdība apzināti pieņemtu lēmumu nekomentēt vai nerīkoties, netika konstatēta.

Vēstỉjuma skaidrību ietekmēja arī tādi faktori kā valdības spēja skaidri komunicèt ar sabiedrību par īstenoto rīcības plānu, to skaitā ieviestajiem ierobežojumiem, kā arī to, vai rīcības plānam sekojušas arī iepriekš definētas skaidras un konkrētas darbỉbas. Ja iepriekš minētās rīcības un plāni tiek vairākas reizes uzlaboti, pielāgoti vai pat mainīti, sabiedrībā var rasties apjukums, kas var ietekmēt tās drošības uztveri. Krīzes komunikācijā varēja novērot, 
kādas sekas uz sabiedrības subjektīvo drošības uztveri atstāj neskaidrs vēstījums par valstī pieņemtajiem lēmumiem par atbalsta pasākumu ieviešanu uzņēmējiem un krīzē cietušajiem darba n̦ēmējiem. Atbalsta pasākumi tika mainīti daudz reižu - sākumā atbalsts bija plānots visvairāk cietušām nozarēm, bet pèc tam tika nolemts atbalstīt visus uzņēmumus, kuriem ir bijis apgrozījuma kritums. Arī šie regulējumi neiekḷāva visus strādājošos (piemēram, pašnodarbinātos), tāpēc vēlreiz bija jāmaina regulējums, lai iekḷautu arī pārējos strādājošos, taču tad sākās citas problēmas - darba devēju nodokḷu parādi, kuru dēl nebija iespējams saṇemt cerēto atbalstu un bija jāpanāk vienošanās ar Valsts ieņēmumu dienestu par parāda atmaksu. Tā kā grozijumi notika îsā laikā un bija grūti izsekojami lielajā informācijas plūsmā, tie veicināja sabiedrības neizpratni par valdības darbību Covid-19 laikā.

Krīzes komunikācijas kontentanalīze liecina, ka visbiežāk izmantotā komunikācijas stratēgija šajā laikā bija pirmās rokas darbības stratēẹija, taču valdībai nācās izmantot arī korigêejošās darbības, lai noraidītu kritiku, kas tikusi vērsta pret tās darbību. Pirmās rokas darbības stratēǵiju var saistìt arī ar vēstījumu skaidrību, jo tā visbiežāk nozīmēja tieši faktologisku informāciju, kuru pauž ziņas pirmavots. Komunikācijas stratēgijas ietekmē vēstījumu skaidrību arī tāpēc, ka mulsinoša uzvedība var iespaidot sabiedrības subjektīvo drošības uztveri, - ja vēstījums ir skaidrs, bet uzvedība bijusi mulsinoša, tad sabiedrības drošības uztvere var vājināties.

\section{Secinājumi}

Covid-19 situāciju var dēvēt par krīzi, jo valsts saskārās ar pēkšņām, grūti pārvaramām problēmām, kuru risināšana pārsniedza ierasto sarežğỉjumu pārvarēšanas mehānismu iespējas. Vīrusa izplatība pasaulē un citu valstu reakcija, un īstenotie krīzes vadības mehānismi palīdzēja Latvijas valdībai un citām iesaistītajām organizācijām izstrādāt krīzes vadības un arī komunikācijas stratēǵiju. Būtiska bija arī skaidru vēstijjumu veidošana, jo neskaidrība un neziņa veicina šaubas sabiedrībā, apdraudot gan cilvēku personiskās drošības (it īpaši veselības vai emocionālās drošības), gan politiskās drošîbas sektorus (dezinformācija var veicināt tādu ideju rašanos, kas apšauba valdības stabilitāti un pieņemto lēmumu leg̣itimitāti).

Centrālo lomu krīzes vadībā, konkrēti, krīzes komunikācijā, ieṇem sabiedrïbas attiecības ar valdỉbu un valdības dialogs ar sabiedrïbu - veicot krīzes komunikāciju un cenšoties sasniegt pēc iespējas efektīvāku vēstījuma skaidrību, ir būtiski saṇemt atgriezenisko saiti no informācijas paudēja, piemēram, no 
valdības. Krīzes komunikācijā regulāri tiek izmantoti plašsaziṇas līdzekḷi, lai izplatītu vēstijjumu sabiedrībai. Tas jo īpaši attiecas uz akūti svarīgu ziṇu paušanu, kad plašsaziņas līdzekḷi kḷūst par galveno, ja ne vienīgo saziņas avotu, veidojot tiešu saikni starp valdības pārstāvjiem un sabiedrību. Krīzes komunikācijas pieaugošā loma rada nepieciešamību pēc iespējas skaidrāka vēstījuma, kas balstītos uz pirmās rokas darbības stratēgiju.

Skaidri ir tādi vēstījumi, kuros iekḷauti patiesi fakti. Oficiālajos valsts ziṇu portālos un visbiežāk lietotajos plašsaziņas medijos lielākoties ir bijusi skaidra un faktos balstīta informācija, taču bija diezgan daudz arī tādu ziṇu, kuru autori centās korig̣ēt citus iepriekš paustos vētỉjumus vai izteikt emocionālu viedokli par notiekošo. Vienlaikus publiskajā telpā (it īpaši sociālajos medijos) bija sastopamas arī daudzas viltus ziṇas, kuru mērḳis bija apzināti mulsināt sabiedrību, veicinot iedzīvotāju neuzticību valdībai un apgalvojot, ka tā ir neizdevusies un destruktīva, kā arī radìt apjukumu par informācijas patiesumu. Pretrunīgā un mainīgā informācija sociālajos tìklos un plašsaziņas līdzekḷos ir veicinājusi neizpratni par to, kādu valsts atbalstu sabiedrība varētu saņemt krīzes situācijā.

Informācija lielākoties bija vienota (gan saturiski, gan dažādās vietnēs). Tas liecina par starpiestāžu komunikāciju krīzes laikā. Par vēstījuma skaidrību liecina arī ir tas, vai ziṇa sasniedz visas sabiedrības grupas neatkarīgi no tās valodas vai izglîtîbas līmeṇa (vēstijjumam jābūt vairākās valodās un viegli saprotamam). Par to sabiedriskās domas aptaujās respondenti norādīja kā uz problēmu. Savukārt vēstījuma sniedzējiem svarīga ir bijusi vēstījuma vienotība, jo konstanta savstarpējā kritika var radīt apjukumu un veicināt sabiedrības neuzticību. Izvēlēta konkrēta uzticības/runas persona no iestādes, kura veic krīzes komunikāciju un pārstāv tās viedokli, ir labs veids, kā radìt uzticību un nodrošināt vēstijumu skaidrību un vienotību. Covid-19 krīzes gadỉjumā Latvijā šo lomu veiksmīgi pildīja Uga Dumpis, Jurijs Perevoščikovs un Ilze Viṇķele.

Covid-19 izraisītās krīzes pirmā posma analīze pierāda arī to, ka pirmās rokas darbības stratēgija ir visefektīvākā komunikācijas stratēgija, ko izmantot krīzes komunikācijā, lai sniegtu skaidru, faktolog̣isku informāciju, bet ofensīvo atbilžu stratēgiju vai stratēgisko bezdarbību nebūtu ieteicams izmantot. Balstoties uz Covid-19 pirmā viḷna krīzes komunikācijas analīzi, iespējams secināt: lai informācija (piemēram, rīcỉbas plāni) tiktu skaidri uztverta, pèc tās būtu jāseko arī attiecīgām darbībām, kas ir skaidras un konkrētas, nevis vairākas reizes uzlabotas, pielāgotas vai pat pilnībā mainìtas (stratēégijas), citādi sabiedrībā radīsies neizpratne un nedrošỉba. Pozitīvi vērtējams tas, ka informācija netika noklusēta vai slēpta no sabiedrības, ņemot vērā, ka krīzes komunikācijas panākumu atslēga ir godīgums un atklātība. Komunikācija tika 
uzsākta, tiklīdz notika straujas izmaiņas vai tika pieņemti jauni lēmumi (piemēram, preses konferences norisinājās uzreiz pēc valdības sēdēm).

Arī sabiedriskās domas aptaujas pierāda, ka veiktais pētījums par krīzes komunikāciju atspogulo vēstījumu skaidrības nozīmīgumu. To pierāda arī fakts, ka Covid-19 pirmā viḷna laikā iedzìvotāji visvairāk uzticējušies NMPD, SPKC un Veselības ministrijai, kas bija galvenie informācijas paudēji. Taču Covid-19 otrajā vilnī iepriekš lietotā krīzes komunikācijas stratēgija vairs nesniedza tik pozitīvus rezultātus. Tas ir pierādījums tam, ka katra krīzes situācija ir unikāla, lìdz ar to ir iespējams secināt, ka krīzes komunikācijas stratēgijām būtu jābūt atš̌kirīgām un piemērotām atbilstoši konkrētajām situācijām. Ar vienu krīzes risināšanas modeli nav iespējams nodrošināt veiksmīgu krīzes komunikāciju citos gadījumos. Lai izvairītos no kḷūdu piel̦aušanas potenciālajā Covid-19 trešajā vilnī, lielāka uzmanība būtu jāpievērš jaunas krīzes komunikācijas stratēgijas attīstî̌anai, kurā tiktu ņemta vērā arī sabiedrības subjektīvā drošibas uztvere. 


\section{Secinājumi}

Pētījums "Latvijas iedzīvotāju subjektīvā drošỉbas uztvere: ietekme uz drošibas politikas veidošanu” ir tapis laikā, pirms Latviju un pasauli skāra pandēmija. Tieši šis notikums neplānoti ir kḷuvis par savdabīgu atskaites punktu, kas paver iespējas salīdzināt to, kā Latvijas sabiedrība uzlūko drošỉbu un uztver draudus parastos vai "normālos" apstākḷos, kuros valsti neapdraud krīze, un kā sabiedrība reagēe krīzes situācijās, kad indivīdi un grupas sastopas ar reāliem dzīvības un izdzīvošanas draudiem un nenoteiktību. Pētijuma mērḳis bija nevis sniegt gatavus politiskus risinājumus un atbildes uz visiem jautājumiem par Latvijas iedzīvotāju drošības izjūtas stiprināšanu vai valdības rīcíbspēju risku un apdraudējumu novēršanā, bet gan analizēt Latvijas iedzīvotāju subjektīvo draudu uztveri, lai varētu konstatēt, kurus draudus viṇi uzskata par nozīmīgiem un kurus - par mazsvarīgiem. Šāda subjektīvās draudu uztveres analīze nepieciešama ne tikai tāpēc, lai zinātu sabiedrības viedokli un noskaņojumu, bet arī tāpēc, lai konstatētu, vai uz iedzīvotāju satraukumu reaǵējuši vietējo pašvaldību lēmumu pien̦ēmēji.

Pētijuma autori, konstruējot analītisko ietvaru, balstijās uz teorētisko literatūru par drošības uztveres veidošanas psiholoǵiskajiem, sociālajiem un politiskajiem aspektiem, secinot, ka īpaša nozīme ir konkrētam sociālpolitiskajam kontekstam, indivīda pieredzei un vēsturiskajai atmiņai un ka lēmumu pieņēmēji un plašāka sabiedrība atšķirīgi definē drošību un atšķirīgi interpretē iespējamos apdraudējumus. Turklāt var atšḳirties arī dažādu sabiedrības grupu skatỉjums uz drošîbas politiku un šo grupu izvēlētās rīcības stratēgijas.

Izpratnei par iedzivotāju bažām piemìt nozīmīgs potenciāls ne tikai veiksmīgu drošības un aizsardzības rīcībpolitiku veidošanai to tradicionālajā izpratnē, bet arī to piemērošanai visdažādākajām 
sabiedrības dzīves jomām. Jo īpaši svarīgs šis aspekts kḷūst, paplašinoties publiskajai telpai un tajā esošajiem informācijas avotiem, kas tieši vai netieši ietekmē iedzīvotāju subjektīvās drošības uztveres tālāko attīstību. Līdz ar to vienlīdz nozīmīga ir pašvaldību un nacionālā līmeņa atbilstošu politiskās komunikācijas stratēgiju veidošana, kas mazinātu nepamatotas bažas un skaidrotu pieņemto lēmumu nozīmi krīzes situācijās vai to novēršanā. Izprotot iedzīvotāju bažu veidošanās mehānismu un analizējot stratēgijas bažu un draudu pārvarēšanai, ir iespējams izmantot apsteidzošas inovatīvas rīcībpolitikas, kas piedāvātu lēmumu pieņēmējiem veidot mērḳètas un precīzas rīcíbpolitikas. Šāda pieeja drošỉbas politikai ne tikai rada nosacijumus savlaicīgai reakcijai uz pastāvošajiem dažāda veida izaicinājumiem, ar ko sastopas iedzīvotāji, bet arī stiprina uzticēšanos valsts pārvaldei, kas apzinās iedzīvotāju bažas un spēj uz tām savlaicīgi un efektīvi reagèèt. Šāda sinergiija savukārt veicina valsts kopējo drošumspējas potenciālu, kas ir nozīmīgs nacionālās drošỉbas garantēšanā.

N̦emot vērā pētījuma nacionālās drošǐbas stiprināšanas nepieciešamības kontekstu, autori kā nozīmīgākās analīzes vienības izvēlējušies šādus faktorus: baiḷu līmeni dažādos drošíbas sektoros, kas var rezultēties pasīvā reakcijā uz notiekošo un attiecīgi arī mazināt līdzdalību visaptverošas aizsardzības sistēmas veidošanā; dusmas sabiedrības grupās, kas potenciāli var radīt priekšnoteikumus agresijai un pat radikalizācijai; pārliecību par nākotni (dzīvi, karjeras attīstību, prognozējamību) kā drošumspējas/noturīguma rādītāju; uzticēšanos institūcijām/valdỉbai, kas veicina sadarbību starp drošỉbas politikas veidotājiem un sabiedrības pārstāvjiem.

Lai operacionalizētu izvirzìtās teorētiskās vienības atbilstoši pētỉjuma vajadzībām, autori izveidoja aktuālāko drošības sektoru sarakstu Latvijā un piemēroja tam atbilstošus indikatorus. Pētijumā tika apskatīti šādi drošǐbas sektori: ekonomiskās drošības, politiskās drošîbas, vides jeb ekolog̣iskās drošības, sabiedriskās jeb identitātes drošības, militārās drošỉbas, hibrīddraudu un personiskās drošības sektors. Atbilstoši drošỉbas sektoru specifikai tika piemeklēti arī labas pārvaldības indikatori: pārvaldības sistēmas stabilitāte, prognozējamība, pēctecỉba; plānošanas ilgtermiṇa pieeja; reformu jēgpilnums - ieviešanas efektivitāte; caurskatāmība; normatīvo aktu izmaiṇas un to biežums; ierēdṇu profesionalitāte; informētība, kā rīkoties X stundā, preventīvās rīcībpolitikas veidošana; iestāžu darbïbas koordinācija. Tiesa, labas pārvaldības elementi pētījumā tika uzlūkoti par netiešiem/fona indikatoriem, kas ir saistīti ar drošỉbas vidi un var ietekmēt iedzìvotāju neapmierinātību un radīt diskomfortu. Tādẹl labas pārvaldỉbas indikatori kā fona indikatori caurvij visus drošības sektorus, jo, piemēram, normatīvo aktu izmaiņu biežums vai reformu jēga ietekmē gan ekonomiku, gan politiku, gan arī vidi. Savukārt šķietami universālais 
un caurviju pārvaldības indikators "preventīvo rīcībpolitiku veidošana" parāda katrā drošības sektorā esošās pārvaldības problēmas.

Drošïbas sektori un indikatori kḷuva par pamatu empīriskajai izpētei - fokusa grupu jautājumu formulēšanai, padzị̣ināto interviju izstrādei, kā arī tālākai datu apstrādei un analīzei. Rezultātā grāmatas nodaļas ir izveidotas, nevis apskatot katru analizēto pašvaldību atsevišķi, bet gan sniedzot ieskatu, kādas ir iedzīvotāju subjektīvās uztveres īpatnības, kā uz tām reaǵē vietējo pašvaldību pārstāvji un kas ir tie izaicinājumi, ar ko sastopas abas iesaistītās puses.

Dažādās nodaḷās iezīmētie aspekti norāda uz vairākām būtiskām tendencēm, ar ko lēmumu pieņēmējiem nāksies sastapties gan šobrīd Covid-19 pandēmijas radītās krīzes apstākḷ̆os, gan arī pēc tās pārvarēšanas. Pirmais ir dalījuma "iedomātās kopienās" pārvarēšana, jo ierastā pieeja, nodalot latviešu un krievvalodīgo kopienu, vairs nav vienīgā, kas nosaka regionu attieksmi pret drošību. Pastiprināta uzmanība jāpievērš citam dalījumam. Tā ir viena kopiena, kas dzīvo Rīgā, un cita, kas apdzīvo pārējo Latvijas teritoriju. Pēdējās pārstāvji uzsvēruši savu sociālo un politisko nošķirtību no nacionālā līmeņa dienaskārtības, kas tiek asociēta ne tikai ar Saeimā vai valdībā pieṇemtajiem lēmumiem, bet arī ar dzìvi galvaspilsētā kopumā. Šis aspekts ir iezīmējies visos drošības sektoros un negatīvi ietekmējis reǵionu iedzivotāju uzticēšanos nacionālā līmeņa pārvaldes iestādēm neatkarīgi no to kompetences vai darbības efektivitātes.

Ekonomisko drošîbu Latvijas iedzīvotāji uzskata par vienu no nozīmīgākajām viṇu dzīvē. Apkopojot fokusa grupu interviju rezultātus, autori secinājuši, ka ekonomiskā drošība vērtēta augstāk nekā tādi drošības izaicinājumi kā, piemēram, militārie draudi vai hibrīddraudi. Pētỉjuma rezultāti liecina, ka kopumā ekonomiskās drošības uztveres atšḳirības iedzīvotāju vidū dažādās pašvaldībās un reǵionos ir nebūtiskas. Respektīvi, visi Latvijas iedzīvotāji lūkojās uz ekonomisko drošǐbu kā faktoru, kas ietekmē to dzīves kvalitāti un stabilitāti. Savukārt no šajā sektorā pastāvošajiem riskiem iedzīvotāji minējuši stabilas nodokḷu sistēmas trūkumu un ne tik daudz nodokḷu apjomu vai kopējo nodokḷu slogu, cik kopējās nodokḷu sistēmas nestabilitāti un neprognozējamību, ko demonstrē nemitīgās nodokḷu regulējošo normatīvo aktu izmaiņas, kurām seko nepieciešamība pielāgot jau iedibināto uzṇēmējdarbības modeli. Nodokḷu apjoms šajā gadījuma skatīts kā sekundārs drauds. Aptaujātie iedzīvotāji norādīja arī uz atklāto korupcijas gadījumu negatīvo ietekmi uz motivāciju godīgi maksāt nodokḷus. Kā vēl viens demotivējošs faktors un iespējams apdraudējums minēts nesamērīgi augsts administratīvais slogs, liels un dārgs birokrātiskais aparāts. Aptaujāto iedzīvotāju vērtējumā tā uzturēšana liedz novirzìt ievērojamu finanšu līdzekḷu apjomu tādām vajadzībām kā, piemēram, 
infrastruktūras attīstība vai veselības aprūpe. Tiesa, neskatoties uz pieprasījumu pēc zemākiem nodokḷiem un mazāku valsts pārvaldes iestāžu darbinieku skaitu, vienlaikus izskanējusi vēlme, lai tiktu nodrošināts liels ekonomiskā un sociālā atbalsta pakalpojumu klāsts.

Iegūtie dati l̦auj secināt, ka iedzīvotāju uztverē pašvaldību loma ekonomiskās drošības veicināšanā ir mazāka, nekā to vērtē paši pašvaldību pārstāvji. Fokusa grupu intervijās sniegtās atbildes, no vienas puses, liecina par to, ka iedzīvotāji ekonomiku stimulējošu instrumentu klāstu, kas ir pašvaldību rīcỉbā, uzskata par nelielu, lai gan demonstrē galvenokārt tām (izņemot Rìgu) augstāku uzticēšanos nekā nacionālā līmeņa lēmumu pieṇēmējiem. Iedzīvotāji ekonomiski vājākās pašvaldībās vairāk akcentējuši valsts un pašvaldību uzdevumu garantēt noteiktu sociālās un ekonomiskās labklājības līmeni iedzīvotājiem, kamēr ekonomiski spēcīgākās pašvaldībās uzsvērts pašvaldības pienākums nodrošināt uzṇēmējdarbībai un iedzīvotāju ekonomiskajai aktivitātei stimulējošus apstākḷus. Savukārt pašvaldību pārstāvju vidū dominē viedoklis, ka būtiskākais faktors, kas veicina ekonomisko drošîbu un izaugsmi, ir iedzīvotāju ekonomiskā aktivitāte. Savu lomu ekonomikas stimulēšanā tie ir novērtējuši tādās jomās kā ceļu infrastruktūra, ūdensapgāde, izglītības sistēma, sabiedriskā kārtība un kultūras pasākumu nodrošināšana. Tādējādi viens no būtiskākajiem Latvijas publiskās pārvaldes rīcibpolitikas uzdevumiem ir konkurētspējīgas uzṇēmējdarbības vides un iedzīvotāju ekonomiskās aktivitātes veicināšana, kur vismaz termiņa stabilitāte normatīvo aktu izmaiņās būtu apsveicama. Ceḷot kopējo labklājības līmeni, iespējams mazināt iedzìvotāju subjektīvo draudu izjūtu ekonomiskajā sektorā, kā arī veicināt iedzīvotāju lojalitāti pret valsts pārvaldes un drošỉbas institūcijām.

Politiskais sektors ir otrs prioritārais sektors, kurā Latvijas iedzīvotāju subjektīvās drošības uztveres kontekstā saskatāmi vairāki nozīmīgi apdraudējumi. Aptaujātie Latvijas iedzīvotāji kā būtiskāko draudu minējuši valdības mainīgos lēmumus, kā arī to, ka valdībai trūkst ilgtermiņa redzējuma par valsts attīstību. Aptaujātie sabiedrības pārstāvji valdības stabilitāti un tās pieņemto lēmumu ietekmi skata caur indivīda labklājỉbas veicināšanas prizmu, respektīvi, vai lēmumu rezultātā uzlabojas individuālā labklājība. Tomēr diskusijās izkristalizējās, ka iedzīvotājiem trūkst izpratnes par saikni starp individuālajām vajadzībām un valdības stabilitāti. Iegūtie dati l̦auj secināt, ka reg̣ionu iedzīvotāju un arī pašvaldību pārstāvji neuzticas nacionālā līmeṇa valsts pārvaldes institūcijām, jo tās neizprotot vietējo situāciju, un tas noved pie atbalsta trūkuma. Aptaujātie iedzīvotāji ḷoti bieži pauduši pārliecību, ka nesaredz jēgu piedalīties Saeimas vēlēšanās un ka viṇi nevar ietekmēt valsts politisko norisi. Fokusa grupās apgalvots, ka nacionālā līmeņa valsts pārvaldes institūciju 
lēmumi dažkārt tiek uzskatīti par apdraudējuma avotu, jo pastāv atšķirīgas dienaskārtības regionos un Rịgā. Šāda veida apdraudējuma sajūta raksturīga kā sabiedrības, tā arī lokāla mēroga lēmumu pieņēmēju pārstāvjiem. Šāds reǵionu skatījums uz politiskajiem procesiem valstī uzskatāms par nozīmīgu draudu pilnvērtīga demokrātiskā procesa funkcionēšanai un valsts integritātei. Bažas par regionu un Rīgas pretnostatỉjumu nedrīkst uzskatìt par nezināšanas vai informācijas trūkuma rezultātu. Bažas par reǵionu un Rỉgas pretnostatijumu nozīmē, ka rīcībpolitikas veidotājiem reǵionālās attīstības jomā, klasteru attīstībā un uzņēmējdarbības vides atbalsta mehānisma pilnveidē jārisina plašs uzdevumu klāsts.

Runājot par politiskās drošîbas sektoru, vietējā līmeṇa lēmumu pien̦ēmēji bauda ievērojami lielāku uzticēšanos, kas balstās iedzivotāju ticībā par to efektivitāti un par spēju reagèt uz lokāliem izaicinājumiem. Vairāku pašvaldību iedzīvotāji norādījuši, ka politiskās drošības stiprināšanai vietējo pašvaldību līmenī nepieciešams pilnveidot komunikāciju starp lēmumu pieñēmējiem un vietējās kopienas pārstāvjiem. Tiesa, pašvaldības sagaida no iedzīvotājiem lielāku aktivitāti un iesaisti lēmumu pieņemšanas procesā. Rezultātā iespējama spriedzes palielināšanās, vietējās kopienas neapmierinātības un neuzticēšanās pieaugums, ko var pārvarēt, atbalstot gan iedzīvotāju lielāku iesaisti un līdzdalības aktivitāti, gan arī mūsdienīgus informēšanas paṇēmienus.

Viens no pētījuma vērtīgākajiem secinājumiem ir par Latvijas iedzīvotāju attieksmi pret izaicinājumiem apkārtējai videi. Tos aptaujātie uztver kā maznozīmīgus draudus. Pētỉjuma rezultātā iegūtie dati liecina, ka bieži vien Latvijas sabiedrības pārstāvji apšauba klimata pārmaiņu negatīvo ietekmi uz Latvijas teritoriju, tas savukārt var negatīvi iespaidot nacionālā līmeņa mērķu sasniegšanu. Latvijai kā ES dalībvalstij ir jāievieš tās starptautiskās saistības, ko tā uzņēmusies, bet bez sabiedrības atbalsta un iesaistes šie ambiciozie mērḳi ir apdraudēti. Regionos vides problēmas tiek biežāk uztvertas no tautsaimniecības skatpunkta. Gaisa, iekšzemes un jūras ūdens piesārṇojums vai biodaudzveidības saglabāšana pētījuma gaitā netika identificēta kā nozīmīgs aspekts iedzīvotāju subjektīvajā drošības uztverē, turpretim vietējo pašvaldību dokumentu analīze norāda, ka, neskatoties uz sociālā un politiskā spiediena trūkumu no sabiedrības puses, pašvaldībās šie draudu veidi tiek skatīti kā aktuāli un tiek meklēti risinājumi to novēršanai. Tātad pastāv dalīta attieksmi pret vides jautājumiem rīcībpolitikas un sabiedrības līdzdalības līmenī.

Apdraudējumus sabiedrības drošỉbai Latvijas iedzīvotāji skata kā būtiskus neatkarīgi no to reǵionālās, etniskās piederības un sociālā statusa. Kā vienu no vislielākajiem apdraudējumiem aptaujātie sabiedrības pārstāvji minējuši imigrāciju. Lai gan realitātē tā nav uzskatāma par būtisku izaicinājumu, ar ko 
šobrīd sastopas valsts, tomēr iedzīvotāju bailes no svešā, lai kas tas arī nebūtu, ir lielas, bieži vien iracionālas un nosaka iedzīvotāju attieksmi pret virkni valsts veidoto politiku (piem., imigrācijas politiku). Kā citu nozīmīgu aspektu iedomātu kopienu dalījumā un savstarpējās neuzticēšanās sēšanā iedzīvotāji min reǵionu iedzīvotāju atsvešinātību no valsts. Vietējās kopienas identitāte, kas ir dominējošā, šajos apstākḷ̆os nosaka arī bailes par šīs kopienas pastāvēšanu nacionālā līmeņa rīcībpolitikas dēḷ. Lìdzīgi kā iepriekš, arī šajā gadījumā pašvaldību pārstāvju viedokḷi bieži sakrìt ar iedzīvotāju paustajām bažām. Šāda pozīcija tiem ir zināmā mērā izdevīga, jo pašiem nav tūlīt proaktīvi jārīkojas.

Cits nozīmīgs draudu avots, uz kuru intervijās norāda iedzīvotāji, ir patriotisma trūkums. Bažas par patriotisma trūkumu apliecina šīs problēmas nozīmīgumu valsts drošîbas ilgtspējas nodrošināšanā. Patriotisma uzturēšanā un attīstībā pašvaldībām ir svarīga loma, ņemot vērā lokālās identitātes nozīmi un uzticēšanās kredītu, ko tam piešķīruši iedzīvotāji. Lai gan pašvaldības îsti nesaskata savu lomu sabiedrības drošības stiprināšanā, tomēr ikdienā tās pilda šo funkciju, veicot dažādu sociālo grupu atbalsta pasākumus lokālā patriotisma stiprināšanai un citas līdzvērtīgas aktivitātes. Raugoties no nacionālās drošìbas perspektīvas, nozīmīga būtu arī valstiskuma stiprināšana ar iekļaujošām un savstarpēji nekonkurējošām pašvaldību rīcībpolitikām, atbilstoša nacionālā diskursa izvēlēm komunikācijas stratēéijās. Savukārt dažādības izcelšana vietējo kopienu mērogā un atšķirīgā pieņemšanas un integrācijas spēcināšana ar atbilstošu naratīvu palīdzību ir veids, kā pašvaldỉbas potenciāli var iespējot Latvijas sabiedrību, lai nostiprinātu valsts vietu Eiropas kultūras un vērtību telpā.

Personiskās drošības sektorā Latvijas iedzīvotāji identificējuši četras nozìmīgākās draudu jomas: indivīdu fiziskā drošība; izglīîibas sistēmas pakalpojumu pieejamība, tai skaitā fiziskā pieejamība un kvalitāte; veselības aprūpes sistēmas pakalpojumu pieejamība un kvalitāte; sociālā aizsardzība. Iedzīvotāji izjūt ievērojamas bažas par veselības aprūpes pakalpojumu un sociālās aizsardzības mehānismu pieejamību. Veselības pakalpojumu pieejamības jautājumā draudu intensitātes atšķirības ir atkarīgas no pašvaldības statusa un infrastruktūras pieejamības, bet, runājot par sociālās drošības draudiem, nav ievērojamu atšķirību subjektīvajā draudu uztverē atkarībā no pašvaldības lieluma un statusa. To var izskaidrot ar faktu, ka pilnīgi visas pašvaldības piedāvā plašu sociālo pakalpojumu klāstu, savukārt veselības aprūpē pašvaldības iesaistās tikai tad, kad vienīgi tā var nodrošināt primārās veselības aprūpes pakalpojumu klāstu iedzīvotājiem. Visās pašvaldībās ir izveidoti sociālie dienesti, kamēr krietni mazāk ir feldšeru punktu.

Izglìiības pakalpojumu pieejamība skatīta galvenokārt skolu reformas kontekstā. Tāpēc nav pārsteidzoši, ka gan iedzīvotāji, gan pašvaldību pārstāvji 
uzskatījuši nacionālā līmeņa lēmumu pieņēmēju darbỉbu par apdraudējumu iedzīvotāju dzīves kvalitātes nodrošināšanai un jaunākās paaudzes zināšanu kapitāla uzkrāšanai, kas ilgtermiņā radītu pamatu drošai un ilgtspējīgai kopienai.

Veiktās intervijas l̦auj secināt, ka pašvaldību darbinieku skatijums uz šo draudu formu aktualitāti ir bijis līdzīgs, tomēr atšķīiries viedoklis par pašvaldības lomu to novēršanā un tiek uzsvērta nacionālā līmeņa lēmumu pieñēmēju nozīme. Svarīgi norādīt, ka bieži vien iedzīvotājiem ir grūti nošķirt nacionālā lìmeņa un lokālā līmeņa lēmumu pien̦ēmēju kompetences. Tāpēc vietējā līmeņa lēmumu pien̦ēmēji, kas iedzīvotājiem ir labi zināmi, bauda lielāku uzticỉbu un izmanto viṇu neziṇu, un novirza atbildíbu no saviem pleciem, aizbildinoties, ka "valsts prasa".

Personisko draudu novēršana pašvaldībās kopumā vērtējama pozitīvi, pašvaldību pārstāvji iedzīvotāju subjektīvi uztvertos draudus atpazīst, ir iekḷāvuši to novēršanu savās vietējās rīcībpolitikās, mēgina meklēt lokālus risinājumus - veidot feldšeru punktus, apgaismot ielas, stiprināt pašvaldỉbas policiju. Aptaujātie respondenti norādījuši uz nepieciešamību uzlabot pašvaldības darbinieku komunikāciju ar vietējās kopienas pārstāvjiem, kam var būt izškịīịa nozīme subjektīvās nedrošỉbas mazināšanā.

Veiktais pētijums l̦auj secināt, ka Latvijas iedzīvotāji atpazīst vairākus hibrīddraudu veidus, tai skaitā informatīvos draudus, kiberdraudus, kā arī citas valsts iejaukšanos valsts iekšèjās lietās, kā tas notika Ukrainā 2014. gadā, tomēr diemžēl viṇi neasociē to ar jēdzienu "hibrīddraudi", kā arī neizvērtē šo draudu iespējamās ietekmes dziļumu un plašumu. Arī pašvaldību darbinieki un amatpersonas izprot to, ka šādi draudu veidi pastāv un potenciāli var radīt personisku kaitējumu. Lai gan tikuši atpazìti vairāki hibrīddraudu veidi, tomēr gan sabiedrība, gan lokālā līmeņa lēmumu pieņēmēji demonstrējuši salīdzinoši bezrūpīgu attieksmi, neapzinoties savu lomu to novēršanā. Tāda attieksme bija, piemēram, pret kiberdrošības vai informācijas drošības jautājumiem. Kopumā gan iedzīvotāji un pašvaldību pārstāvji nav atpazinuši vairākus hibrīddraudu veidus kā būtiskus un aktuālus un savas zināšanas un prasmes sevi pasargāt no tiem subjektīvi vērtējuši augstāk, nekā ir patiesībā. Visos analizētajos gadījumos atsevišķu draudu, piemēram, tehnogēno katastrofu, iespējamība vai nopietni apdraudējumi kritiskajai infrastruktūrai kopumā tikuši vērtēti zemu. Kā nozīmīgākie hibrīddraudu avoti tiek atpazìtas galvenokārt Krievijas Federācija un retāk - Ķīnas Tautas Republika. Pēdējā drīzāk tiek uzskatīta par potenciāla apdraudējuma avotu nākotnē ar neskaidriem nodomiem un neskaidrām ietekmes sekām uz Latvijas valsts un sabiedrības drošǐbu.

Analizējot civilās aizsardzības plānu ieviešanu, secināts, ka gan iedzīvotāji, gan pašvaldības izrādījušas interesi par to, tomēr abu pušu sniegtās atbildes 
liecina par nepietiekamu informāciju un nepietiekamu savas lomas apzināšanos krīzes un ārkārtējās situācijās. Vairums aptaujāto iedzīvotāju atzinuši: lai gan viņi saprot, ka par sevi un tuvākajiem būtu nepieciešams parūpēties un ka valstij un pašvaldībai ir atbalsta mehānismi, tomēr viņiem nav tādu zināšanu un iemaņu, kas būtu nepieciešamas $X$ stundā. Iedzīvotāju interese par aizsardzību pret hibrīdajiem apdraudējumiem ir liela. Tas rada labvēlīgu augsni valsts atbildīgajām institūcijām gan visaptverošās valsts aizsardzības ieviešanas plāna īstenošanai, gan vienlaicīgi cita veida sabiedrības iesaistes un izglìtošanas pasākumu veikšanai, lai nostiprinātu valsts izturētspēju. Faktiski hibrīddraudu neapzināšanās un to diezgan vieglprātīgā uztvere nozīmē, ka kopienu reakcija uz draudiem ir nenobriedusi un ka kopiena reaǵē pārlieku vāji vai arī pārlieku saasināti.

Militāro draudu sektora izpēte liecina, ka iedzīvotāji saskata potenciālo militāro apdraudējumu no Krievijas, tomēr šie draudi netiek uzskatīti par prioritāriem salīdzinājumā ar ekonomiskajiem, sociālajiem vai politiskajiem draudiem. Arī pašvaldību darbinieki atpazīst iespējamus ārējus militārus draudus, tomēr kopumā nav gatavi krīzes situācijām un drīzāk paḷaujas uz nacionālā līmeņa institūtiem un to ieteikumiem šajā jautājumā.

Pētỉjumā īpaša uzmanība pievērsta divām pašvaldībām, kurās atrodas militārā infrastruktūra, - Ādažiem un Liepājai. Autori konstatējuši, ka Ādažu un Liepājas iedzīvotāji un pašvaldības atšķirīgi uztver militārās infrastruktūras izvietojumu. Ādažos iedzīvotāji jūtas nedrošāk nekā Liepājā. To var skaidrot ar atškịirīām iedzīvotāju saskarsmē ar militārā personāla aktivitātēm ikdienas situācijās. Lai gan Latvijas iedzīvotāji atškiringi uztver militāro draudu intensitāti, tomēr NATO viņi vērtē kā Latvijas militārās drošības garantu visās pašvaldībās, kurās tika veikts pētijums. NATO spēku klātbūtne kā iespējamais apdraudējums minēts tikai ļoti retos gadījumos un arī tad galvenokārt saistîbā ar eventuālo Krievijas reakciju.

Valdības krīzes komunikācijas izpēte Covid-19 pandēmijas izplatības laikā papildina kopējās atziņas un secinājumus ar vērtējumu par spēju skaidri formulēt un nodot vēstījumus, kas ir svarīgi izdzīvošanai, tādējādi mazinot bailes un bažas par subjektīvās drošības līmeni. Šāda veida analīze ir būtiska tālākā diskusijā par to, kā valdības vēstījumi caur dažādiem komunikācijas kanāliem, tai skaitā mūsdienās aktuālajiem interneta portāliem un sociālajiem tìkliem, potenciāli var gan mazināt, gan vairot subjektīvo drošības izjūtu un iespējot iedzīvotājus krīzes pārvarēěanai proaktīvā veidā.

Covid-19 pandēmijas pirmā viḷna laikā valdība salīdzinoši veiksmīgi realizējusi saziṇu ar sabiedrību. Tāpēc sabiedrība rỉkojās atbilstoši norādēm un pieauga tās uzticēšanās valdības lēmumiem. Tomēr krīzes tālākās attīstības 
apstākḷos situācija pasliktinājās, jo valdības komunikācija kḷuva birokrātiska. Jāsecina, ka informācija, kas tika raidīta sabiedrībai (piem., rīcības plāni), piedzīvojot vairākas korekcijas un precizējumus un neizskaidrot tās, mazināja sabiedrības izpratni par notiekošo. Neuzticēšanos vairojis arī informatīvais fons, dezinformācija un dažāda rakstura viltus ziņu izplatība. Kombinējot sekundāros datus un veikto kontentanalīzes datu apkopojumu, iespējams secināt, ka precīzāka, skaidrāka valdības komunikācija, kuru papildina konsekventa darbība, veicinātu sabiedrības izpratni un drošības izjūtas pieaugumu.

Iedzīvotāji pozitīvi novērtējuši godīgumu un atklātību, kas bijusi raksturīga valdības krīzes komunikācijai, kā arī nepārtrauktu sabiedrības informēšanas procesa nodrošinājumu, kas sākotnējā posmā piesaistijis mediju un plašākas sabiedrības uzmanību.

Sabiedrības noguruma un citu apstākḷu dẹl sākotnēji izvēelētā veiksmīgā krīzes komunikācijas stratēgija nav darbojusies ilgtermiņā, tāpēc stratēgiskajai komunikācijai vajadzēja adaptēties atbilstoši izmaiņām epidemioloğiskajā situācijā. Atbilstoša, vienkārša un skaidra vēstījuma veidošana, institūciju savstarpējā koordinācija, izplatot vienotu vēstījumu, godīguma un atklātības princips lauj veidot tādas stratēǵiskās komunikācijas stratēgeijas, kuras veicina drošîbas izjūtu un vairo uzticēšanos lēmumu pien̦ēmējiem, un paātrina efektīvas rīcībpolitikas ìstenošanu.

Pētijums par Latvijas iedzīvotāju subjektīvo drošības uztveri un tās ietekmi uz drošības politikas veidošanu ir papildinājis jau esošo pētỉjumu klāstu ar vairākām inovatīvām idejām, pieejām un datu kopām, kuru apspriešana un publicēšana sniegs papildu informāciju kvalitatīvākai lēmumu pieņemšanai nacionālā un pašvaldību līmenī. 


\section{Pielikums}

\section{Latvijas iedzīvotāju identificētie nozīmīgākie draudi (hierarhiskais izkārtojums) ${ }^{1}$}

\begin{tabular}{|c|c|c|}
\hline $\begin{array}{l}\text { Fokusa } \\
\text { grupas } \\
\text { norises } \\
\text { vieta }\end{array}$ & $\begin{array}{l}\text { Trīs nozīmīgākie } \\
\text { apdraudējumi }\end{array}$ & Draudu hierarhiskais izkārtojums \\
\hline Liepāja & $\begin{array}{l}\text { - Personiskie } \\
\text { draudi } \\
\text { - Politiskie draudi } \\
\text { - Sabiedrības } \\
\text { drošība }\end{array}$ & $\begin{array}{l}\text { 1. Sociālā aizsardzība (apdraudējumi, kas saistīti ar } \\
\text { darba zaudēšanu un atbalstu no pašvaldības) } \\
\text { 2. Veselības aprūpe (apdraudējumi, kas saistīti ar } \\
\text { iespējām tikt uz pieneménšanu pie speciālista) } \\
\text { 3. Izglītība (apdraudējumi, kas saistīti ar skolu reformu) } \\
\text { 4. Fiziskā drošība (pašvaldības policija kā drošības } \\
\text { garants) }\end{array}$ \\
\hline Talsi & $\begin{array}{l}\text { - Personiskie } \\
\text { draudi } \\
\text { - Hibrīddraudi } \\
\text { - Ekonomiskie } \\
\text { draudi }\end{array}$ & $\begin{array}{l}\text { 1. Sociālā aizsardzība (apdraudējumi, kas saistīiti ar savu } \\
\text { un savas ǵimenes sociālo nodrošinājumi) } \\
\text { 2. Veselības aprūpe (apdraudējumi, kas saistīti ar } \\
\text { izmaksām un slimnīcu tuvumu) } \\
\text { 3. Izglītība (apdraudējumi, kas saistīti ar izglītības } \\
\text { kvalitāti) } \\
\text { 4. Fiziskā drošība (neizjūt apdraudējumu, darbojas } \\
\text { videonovērošanas sistēmas, kas pasargās) }\end{array}$ \\
\hline Daugavpils & $\begin{array}{l}\text { - Personiskie } \\
\text { draudi } \\
\text { - Politiskie draudi } \\
\text { - Hibrīddraudi }\end{array}$ & $\begin{array}{l}\text { 1. Sociālā aizsardzība (apdraudējumi, kas saistīti ar savu } \\
\text { un savas ǵimenes sociālo nodrošinājumi / darbu) } \\
\text { 2. Veselības aprūpe (apdraudējumi, kas saistīti ar } \\
\text { izmaksām un korupciju slimnīcās) } \\
\text { 3. Izglīīība (apdraudējumi, kas saistīti ar izglīiības } \\
\text { kvalitāti) } \\
\text { 4. Fiziskā drošība (pašvaldības ielās jūtas droši) }\end{array}$ \\
\hline Rēzekne & $\begin{array}{l}\text { - Personiskie } \\
\text { draudi } \\
\text { - Ekonomiskie } \\
\text { draudi } \\
\text { - Sabiedrības } \\
\text { drošǐba }\end{array}$ & $\begin{array}{l}\text { 1. Sociālā aizsardzība (apdraudējumi, kas saistīti ar } \\
\text { savas ǵimenes sociālo nodrošinājumi, bažas par valsts/ } \\
\text { pašvaldības pabalstu izškēērdētību) } \\
\text { 2. Veselības aprūpe (apdraudējumi, kas saistīti ar } \\
\text { izmaksām un iespēju tikt uz pieṇemšanu pie kvalificēta } \\
\text { speciālista) } \\
\text { 3. Izglīīiba (neizjūt apdraudējumu) } \\
\text { 4. Fiziskā drošība (pašvaldības ielās jūtas droši, } \\
\text { neskatoties uz to, ka pašvaldības policija ir likvidēta) }\end{array}$ \\
\hline Jaunjelgava & $\begin{array}{l}\text { - Personiskie } \\
\text { draudi } \\
\text { - Politiskie draudi } \\
\text { - Sabiedrības } \\
\text { drošība }\end{array}$ & $\begin{array}{l}\text { 1. Sociālā aizsardzība (apdraudējumi, kas saistīti ar } \\
\text { materiālo nodrošinājumu) } \\
\text { 2. Veselības aprūpe (apdraudējumi, kas saistīti ar } \\
\text { pakalpojumu izmaksām) } \\
\text { 3. Izglīīība (apdraudējumi, kas saistīti ar skolas } \\
\text { reformām) } \\
\text { 4. Fiziskā drošība (privātīpašuma aizsargāšana) }\end{array}$ \\
\hline
\end{tabular}

1 Draudu intensitāte fokusa grupu diskusiju laikā tika noteikta, pamatojoties uz to nosaukšanas biežumu respondentu vidū. 


\begin{tabular}{|c|c|c|}
\hline Valmiera & $\begin{array}{l}\text { - Personiskie } \\
\text { draudi } \\
\text { - Ekonomiskie } \\
\text { draudi } \\
\text { - Hibrīddraudi }\end{array}$ & $\begin{array}{l}\text { 1. Sociālā aizsardzība (apdraudējumi, kas saistīti ar } \\
\text { darbu un pabalstiem, ko maksā pašvaldība krīzē } \\
\text { nonākušiem iedzīvotājiem) } \\
\text { 2. Veselības aprūpe (apdraudējumi, kas saistīti ar } \\
\text { pakalpojumu kvalitāti) } \\
\text { 3. Izglītība (apdraudējumi, kas saistīti ar izglīīības } \\
\text { kvalitāti, realizētām mācību programmām) } \\
\text { 4. Fiziskā drošība (neizjūt apdraudējumu) }\end{array}$ \\
\hline Laudona & $\begin{array}{l}\text { - Politiskie draudi } \\
\text { - Personiskie } \\
\text { draudi } \\
\text { - Ekonomiskie } \\
\text { draudi }\end{array}$ & $\begin{array}{l}\text { 1. Sociālā aizsardzība (apdraudējumi, kas saistīti ar } \\
\text { iztikas pelnīšanu) } \\
\text { 2. Veselības aprūpe (apdraudējumi, kas saistīti ar } \\
\text { pakalpojumu izmaksām un to pieejamību) } \\
\text { 3. Izglīīība (apdraudējumi, kas saistīti ar skolu reformu un } \\
\text { izglīīibas pakalpojumu kvalitāti) } \\
\text { 4. Fiziskā drošība (apdraudējumi, kas saistīti ar ikdienas } \\
\text { fizisko drošību, piemēram, kas pasargās, ja uzbrūk } \\
\text { kaimiṇu suns) }\end{array}$ \\
\hline Gulbene & $\begin{array}{l}\text { - Ekonomiskie } \\
\text { draudi } \\
\text { - Personiskie } \\
\text { draudi } \\
\text { - Sabiedrības } \\
\text { drošība }\end{array}$ & $\begin{array}{l}\text { 1. Sociālā aizsardzība (apdraudējumi, kas saistīti ar savu } \\
\text { un savas ǵimenes sociālo nodrošinājumi) } \\
\text { 2. Veselības aprūpe (apdraudējumi, kas saistīti ar } \\
\text { izmaksām un slimnīcu tuvumu) } \\
\text { 3. Izglīīība (apdraudējumi, kas saistīti izglīīības kvalitāti). } \\
\text { 4. Fiziskā drošība (neizjūt apdraudējumu, pašvaldībā } \\
\text { jūtas droši) }\end{array}$ \\
\hline Madona & $\begin{array}{l}\text { - Ekonomiskie } \\
\text { draudi } \\
\text { - Personiskie } \\
\text { draudi } \\
\text { - Hibrīddraudi }\end{array}$ & $\begin{array}{l}\text { 1. Sociālā aizsardzība (apdraudējumi, kas saistīti ar } \\
\text { pašvaldības atbalstu krīzes situācijās) } \\
\text { 2. Veselības aprūpe (apdraudējumi, kas saistīti } \\
\text { ar izmaksām un slimnīcu tuvumu, slimnīcu tīkla } \\
\text { reorganizāciju) } \\
\text { 3. Izglīīība (apdraudējumi, kas saistīti ar izglītības } \\
\text { kvalitāti) } \\
\text { 4. Fiziskā drošība (neizjūt apdraudējumu, darbojas } \\
\text { videonovērošanas sistēmas, kas pasargās) }\end{array}$ \\
\hline Aizkraukle & $\begin{array}{l}\text { - Personiskie } \\
\text { draudi } \\
\text { - Sabiedrības } \\
\text { drošiba } \\
\text { - Ekonomiskie } \\
\text { draudi }\end{array}$ & $\begin{array}{l}\text { 1. Sociālā aizsardzība (apdraudējumi, kas saistīti ar savu } \\
\text { un savas ǵimenes sociālo nodrošinājumu, pašvaldības } \\
\text { atbalsta mehānismu) } \\
\text { 2. Veselības aprūpe (apdraudējumi, kas saistīti ar } \\
\text { izmaksām, medicīniskā personāla nepietiekamību) } \\
\text { 3. Izglītība (apdraudējumi, kas saistīti ar izglītības } \\
\text { kvalitāti un pakalpojumu pieejamību) } \\
\text { 4. Fiziskā drošība (neizjūt apdraudējumu, darbojas } \\
\text { videonovērošanas sistēmas, kas pasargās) }\end{array}$ \\
\hline
\end{tabular}




\section{Rekomendācijas}

Grāmatā izcelto drošỉbas sektoru analīze dod iespēju sniegt vairākas rekomendācijas politikas veidotājiem kā lokālā, tā arī nacionālā līmenī. 1. Vērtējot sabiedriskās domas aptaujas, kas analizē iedzīvotāju attieksmes pret drošỉbas jautājumiem, ir svarīgi ņemt vērā vairākus aspektus. Pirmkārt, tā ir "nepiemērotā uztvere" (misperception), kas tipiski piemīt sabiedrības pārstāvjiem attiecībā uz drošības un politikas jomu. Respektīvi, cilvēki savā prātā konstruē realitāti tā, lai tā atbilstu viņu personīgajam pien̦ēmumam, kādai realitātei ir jābūt vai vajadzētu būt. Otrkārt, no atbildēm, kādas sniegtas uz jautājumiem par gatavību iesaistīties valsts aizsardzībā un uz lìdzìgiem jautājumiem, nav iespējams vienkāršoti secināt, kā iedzìvotāji rīkosies nozīmīga apdraudējuma situācijā, jo draudu uztvere un attiecīgi lēmumu pieņemšana krīzes situācijā potenciāli var būtiski atšķirties no iepriekš deklarētā. Draudu identifikācijā, prioritizācijā un reakcijā svarīga ir gan sociālā pieredze, gan sociālā atmiņa, piel̦aujot, ka cilvēki ir tendēti izvēlēties tādas draudu pārvarēšanas stratēgijas, kuras jau ir izmantojuši un kuras ir darbojušās. Turklāt draudu uztvere un sekojoša reakcija netiek mantota un katra paaudze vienus un tos pašus draudus mēgina pārvarēt ar citām stratēgijām. Treškārt, pozitīvs vērtējums par kādu drošības aktoru, kas iesaistīts drošîbas nodrošināšanā, vēl nenozīmē, ka iedzivotāji paļaujas uz to un tic, ka tas spēs realizēt šo funkciju. Piemēram, šajā pētijumā veiktā analīze norāda: lai arī Latvijas iedzīvotāji kopumā salīdzinoši loti pozitīivi vērtē Latvijas Nacionālos bruṇotos spēkus, tie nepaḷaujas uz to, ka šie spēki varētu aizstāvēt Latviju no ārēja iebrukuma vai sniegt būtisku atbalstu krīzes situācijā. Tāpat arī kopumā Latvijas iedzīvotāji, piemēram, ievērojami pozitīvāk vērtē 
vietējās pašvaldības nekā nacionālā līmeṇa valsts pārvaldes iestādes, tomēr vienlaikus reti saredz lokālā līmeṇa lēmumu pieṇēmēju lomu savas drošības stiprināšanā, neskatoties uz to, ka vairākos aspektos tas būtu iespējams. Tas ḷauj secināt, ka turpmākā draudu izpētē ir nepieciešams dalījums pa vecumgrupām, lai precīzāk izzinātu katras vecumgrupas skatījumu uz draudu pārvarēšanas stratēgijām. Pētnieki iesaka detalizēt visaptverošās sabiedrības rīcībpolitikas, skatot tās sabiedrības grupu griezumā, tā iegūstot daudz precīzāku informāciju un datus.

2. Vērtējot sabiedrības pārstāvju pašu iesaisti daudzu iespējamo vājību (vulnerabilities) novēršanā, kas būtu salīdzinoši viegli izdarāms, nav vēlams pārvērtēt šādas proaktīvas rīcỉbas iespējamību kā tādu. Šāda optimistiska neobjektivitāte, kas visai plaši aprakstìta kognitīvos pētijumos, šajā pētỉjumā tika visai spilgti iezīmēta kiberdrošības jomā. Kā liecināja gan fokusa grupu intervijas ar iedzīvotājiem, gan arī padzị̣̂nātās intervijas ar pašvaldību pārstāvjiem, diemžēl šāda nepamatoti optimistiska un bezrūpīga domāšana un nepietiekama risku novērtēšana ir raksturīga abos gadījumos. Ir nepieciešams stiprināt gan iedzīvotāju, gan arī pašvaldības pārstāvju izpratni par viņu lomu un atbildību drošības stiprināšanā dažādos sektoros. Optimistisko neobjektivitāti, kas izraisa nenobriedušu krīzes reakciju (inmature crises response), var pārvarēt, skaidrojot potenciālo draudu izpausmes indivīda līmenī, piemēram, ko nozìmē datu noplūde.

3. Latvijas politiskajā komunikācijā trūkst vienkāršas, viegli saprotamas komunikācijas, kas iekḷauj viegli uztveramus, skaidrus vēstijumus no valsts pārvaldes institūcijām. Īpaši asi šì problēma ir izgaismojusies Covid-19 izraisītās pandēmijas kontekstā, tomēr arī pirms tās aptaujāto iedzīvotāju fokusa grupu intervijas liecina par to, ka sabiedrỉbai ir grūtības izprast gan valsts pārvaldes pārstāvju pieņemtos lēmumus, gan arī rīcībpolitiku virzienus, iespējamās sekas un to nozīmi tās ikdienas dzīvē un tās uzlabošanā, tai skaitā drošības stiprināšanā. Tādēl iesakām gan lēmumus, gan rīcībpolitikas virzienus skaidrot, izmantojot individuālos piemērus.

4. Nav iespējams veidot veiksmīgu visaptverošo valsts aizsardzības sistēmu situācijā, kad valstī novērojama sabiedrības uzticēšanās krīze - tā neuzticas nacionālā līmeņa lēmumu pieṇēmējiem. Šādi neveselīgi apstākḷi rada labvēlīgu augsni valstij naidīgiem spēkiem gan miera apstākḷos, gan, kas jo īpaši bīstami, krīzes situācijā izmantot neuzticēšanos un šaubas par nacionālā līmeņa institūciju vēlmi un spēju atbalstīt iedzìvotājus.

5. Laba pārvaldība ir tikai drošỉbas uztveres fons, taču, ilgstoši nerisinot fona jautājumus, pieaug iedzīvotāju neapmierinātība un diskomforts. Valdībai un politikas veidotājiem apņemoties uzlabot kaut vienu fona indikatoru, 
var panākt uzticēěanās kāpumu. Piemēram, rīcībpolitikas veidotājiem, rūpīgāk izstrādājot normatīvos aktus un samazinot kaut uz pusi normatīvo aktu grozījumu skaitu, varētu panākt pozitīvu ietekmi uz drošības uztveri.

6. Lai politiskajā diskursā izskaustu Rīgas un reǵionu pretnostatījumu, ir nepieciešams laiks. Taču rīcībpolitikas veidošanas procesā šo pretnostatījumu var mēǵināt mazināt ar mērḳētiem regiionālās attīstības instrumentiem, reǵionālo attīstību veicinošām atbalsta programmām cilvēkresursu un infrastruktūras attīstībai. 


\section{Bibliogrāfija}

Aatola, M. et al. (2018). Societal Security in the Baltic Sea Region: Expertise Mapping and Raising Policy Relevance. Rīga: Latvijas Ārpolitikas institūts.

Āboltiņš, R. u. c. (2020). Klimata inženierija un politika. Rīga: RTU Izdevniecība.

Abunyewah, M. et al. (2019). Linking information provision to behavioural intentions. International Journal of Disaster Resilience in the Built Environment, 11(1).

AC/UNU Millennium Project - United Nations Doctrine for Managing Environmental Security (2000). Pieejams: https://apps.dtic.mil/dtic/tr/fulltext/u2/a572501.pdf

Aigars, J. (red.) (2018). Latvijas ekosistēmu dinamika klimata ietekmēe. Rīga: LU Akadēmiskais apgāds.

Apine, L. (2011). Residents' attitude towards possible adaptation measures to the sea coast erosion in Latvia. International Journal of Climate Change Strategies and Management, 3(3), 238-249. Pieejams: https://doi.org/10.1108/17568691111153393

Apinis, P., Lejiņš, A. (red.) (1999). How Secure Are the Baltic States? Conference Proceedings. Riga: Konrad Adenauer Stiftung, Latvian Institute of International Affairs.

Arklone, I. (2017). Labas pārvaldības ievērošanas valsts un pašvaldības iestādēs. Rīga: Latvijas Republikas Tiesībsarga birojs.

Arnold, W. (1962). Discord and Collaboration: Baltimore: Johns Hopkins University, p. 150.

Arteus, G., Lejiňš, A. (1997). The Baltic Security. Looking towrds the 21st Century. Stockholm: Forsvarhogskolan/Riga: Latvian Institute of International Affairs.

Auers, D., Bukovskis, K. (2006). Eiropas Parlaments un Eiropas kopējā ārējā un drošības politika. No: Ozoliņa, Ž. (red.) Eiropas Parlaments: ārējās un drošǐbas politikas īstenotājs. Rīga: Zinātne.

Axworthy, L. (1997). Canada and Human Security: The Need for Leadership. International Journal, 52(2), 183-196, Doi: 10.2307/40203196. Pieejams: https://www.jstor.org/ stable/ 40203196?seq $=1$

Bajarūnas, E., Keršanskas, V. (2017). Hybrid Threats: Analysis of Content, Challanges Posed and Measures to Overcome. Lithuanian Annual Strategic Review, Vol. 16. Vilnius: Military Academy of Lithuania. Pieejams: https://content.sciendo.com/view/ journals/lasr/16/1/article-p123.xml?language $=$ en

Ballantyne, M. (2000). Information on Volcanic and Earthquake Hazards: The Impact on Awareness. Institute of Geological \& Nuclear Sciences.

Baltijas sociālo zinātṇu institūts (2006). Pētījums par cilvēktiesībām Latvijā. Rīga: Providus.

Banks, K. (2007). Crisis communications: a casebook approach. Mahwah, N. J.: Lawrence Erlbaum Associates. 
Beckwe, M. (ed.) (2013). Worrying and Rumination are Both Associated with Reduced Cognitive Control. Psychological Research, 9, DOI: 10.1007/s00426-013-0517-5

Beinaroviča, I (2014). Katastrofu vadība: Latvijas gadījums. Rīga: Latvijas Universitāte. Sociālo zinātņu fakultāte. Pieejams: https://dspace.lu.lv/dspace/handle/7/28132

Berry, Ch. (Ed.) (1993). The Search for Peace in Europe. Institute for National Strategic Studies and the George C. Marshall European Center for Strategic Studies, Garmisch-Partenkirchen.

Bērziña, I. (red.) u. c. (2015). Sabiedrības destabilizācijas iespējamība Latvijā: potenciālie nacionālās drošǐbas apdraudējumi. Rīga: Latvijas Aizsardzības akadēmijas Drošības un stratēgiskās pētniecības centrs.

Bērziña, I. (red.) (2016). Sabiedrības destabilizācijas iespējamība Latvijā: potenciālie nacionālās drošìbas apdraudējumi. Rīga: Latvijas Nacionālā aizsardzības akadēmija.

Bērziña, I. (2020). From 'total' to 'comprehensive' national defence: the development of the concept in Europe. Journal of Baltic Security, 6(2).

Bērzin̦a, I., Zupa, U. (2020). Latvijas sabiedrības griba aizstāvēt valsti: veicinošie un kavējošie faktori. Rīga: Latvijas Nacionālā aizsardzības akadēmija.

Blanchard, B. W. (2008). Guide to Emergency Management and Related Terms, Definitions, Concepts, Acronyms, Organizations, Programs, Guidance, Executive Orders \& Legislation. A Tutorial on Emergency Management, Broadly Defined, Past and Present. Pieejams: http://training.fema. gov/EMIWeb/edu/docs/terms\%20and\%20definitions/Terms\%20and\%20Definitions.pdf

Blavatnik school of Government, Oxford University (2019). International Civil Service Effectiveness Index. Pieejams: https://www.bsg.ox.ac.uk/about/partnerships/international-civil-service-effectiveness-index-2019

Bleijere, D. et al. (1999). The Impact of European Integration Processes on Baltic Security. NATO Fellowship Programme.

Bleiere, D., Stranga, A. (2000). The Latvian Russian Crisis of 1998. In: Stern K. E., Hansen, D. (eds.) Crisis Management in a Transitional Society: The Latvian Experience. Stockholm: CRISMART.

Boins, A., 'T Hart, P. (2007). The Crisis Approach. Handbook of Disaster Research. Springer.

Booth, K. (2005). Critical Security Studies and World Politics. Boulder Co: Lynne Rienner.

Bull, H. (1977). The Anarchical Society: A Study of Orderi $n$ World Politics. New York: Columbia University Press.

Bungs, Dz. u. c. (2007). Eiropas Savienības Kopējā ārējā un drošības politika vērtību un interešu krustugunīs (bet ne krustcelēs). No: Ozoliṇa, Ž. (red.) Latvijas skatījums uz Eiropas Savienības nākotni. Rīga: Zinātne.

Buttedahl, P. (1994). Viewpoint: True Measures of Human Security. IDRC Reports, 22(3), 1-5. Pieejams: http://www.nzdl.org/

Buzan, B. (1991). New Patterns of Global Security in the Twenty-First Century. International Affairs (Royal Institute of International Affairs 1944-), 67(3), 431-451.

Buzan, B. (1991). People, States and Fear. An Agenda for International Security Studies in the PostCold War Era. London: Harvester Wheatsheaf.

Buzan, B. et al. (1993). The European Security Order Recast. Scenarios for the Post-Cold War Era. London, New York: Pinter Publisher.

Buzan, B., Waever, O., de Wilde, J. (1998). Security: A New Framework for Analysis. Boulder Co: Lynne Rienner Publishers, Inc, Boulder, Colorado.

Buzan, B. (2007). People, states \& fear: an agenda for international security in the post-cold war era. Colchester. England: European Consortium for Political Research Press.

Buzan, B., Hansen, L. (2009). The Evolution of International Security Studies. Cambridge: Cambridge University Press.

Cederberg, A., Eronen, P. (2015). How Can Societies be Defended Against Hybrid Threats? Strategic Security Analysis, No. 9. Geneva Centre for Security Policy. 
Chifu, I. (n. d.). Societal Security. An Agenda for Eastern Europe. Pieejams: http://www.cpc-ew.ro/ pdfs/societal_security.pdf

Chivvis, S. C. (2017). Understanding Russian "Hybrid Warfare" and What Can be Done About It. Santa Monica, CA: RAND Corporation. Pieejams: https://www.rand.org/pubs/testimonies/ CT468.html

Coan, Travis G. et al. (2012). Emotional Responses to Human Security Threats: Evidence from a National Experiment. Pieejams: www.travisgcoan.com/replication-materials.html.

Cole, G. A. (1997). Personnel Management: Theory and Practice. London: Greener Books.

Commission on Human Security (CHS) (2003). Human Security Now. New York: CHS.

Coombs, W. \& Holladay, S. (2010). The handbook of crisis communication. Chichester, U. K. Malden, MA: Wiley-Blackwell.

Coppola, D. (2007). Introduction to international disaster management. Amsterdam Boston: Butterworth Heinemann.

Coppola, D. P. (2011). Introduction to international diasaster management. Elsevier, p. 178.

Costa, T. G. (2008). Political Security, an Uncertain Concept with Expanding Concerns. Pieejams: https://link.springer.com/chapter/10.1007/978-3-540-75977-5_42

Curiel, R. P., Bishop, St. R. (2016). A metric of the diference between perception of security and victimisation rates. Crime Science, 5(12).

Dalsjö, R. (1998). Vai Baltijas valstis sevi spēj aizsargāt? Par pašaizsardzības spēju kvalitāti un perspektīvām. Rìga: LIA, 14.-15. lpp.

Diamant, J. (2017). Ethnic Russians in Some Former Soviet Republics Feel a Close Connection to Russia. 24.07.2017. Webpage of Pew Research Center. Pieejams: https://www.pewresearch. org/fact-tank/2017/07/24/ethnic-russians-in-some-former-soviet-republics-feel-a-closeconnection-to-russia/

Duffy, B. (2018). The Perils of Perceptions. Why We're Wrong About Nearly Everything. Atlantic Books.

Escriba-Folch, A. (2013). Repression, Political Threats, and Survival under Autocracy. International Political Science Review, 34(5).

Farnham, B. (2003). The Theory of Democratic Peace and Threat Perception. International Studies Quarterly, 47(3).

Feldmanis, I., Stranga, A., Virsis, M. (1993). Latvijas ärpolitika un starptautiskais stāvoklis: 30 . gadu otrā puse. Rīga: Latvijas Ārpolitikas institūts.

Filimon, L. M. (2016). An Overview of the Copenhagen School's Approach to Security Studies: Constructing (In)Security through Performative Power. Pieejams: https://www.academia. edu/38227272/An_Overview_of_the_Copenhagen_School_s_Approach_to_Security_Studies_ Constructing_In_Security_Through_Performative_Power

Global Commission on Elections, Democracy \& Security (22.06.2014.) Pieejams: https://www.kofiannanfoundation.org/supporting-democracy-and-elections-with-integrity/global-commission-onelections-democracy-security-2/

Graeger, N. (1996). Environmental Security? Journal of Peace Research, 33, 109-116.

Gun, N. (2014). Maslows Hierarchy of Needs. Pieejams: https://www.incentivesolutions.com/ employee-engagement-hierarchy-needs/

Hassan, O. (2015). Political security: from the 1990s to the Arab Spring. Contemporary Politics, 21(1), 86-99.

Hoffman, F. (2007). Conflict in the 21st Century: The Ryse of Hybrid Wars. Arlington: Potomac Institute for Policy Students.

Hogg, M., Abrams, D. (1988). Social Identifications: A Social Psychology of Intergroup Relations and Group Processes. London: Routledge. 
Huddy, L. et al. (2002). The Consequences of Terrorism: Disentanglingthe Effects of Personal and National Threat. Political Psychology, 23(3). Pieejams: https://cpb-us-el.wpmucdn.com/you. stonybrook.edu/dist/f/1052/files/2018/03/Huddy-Feldman-Capelos-and-Provost-2002-TheConsequences-of-Terrorism-rpyn7l.pdf

Human Development Report (1994). Oxford: Oxford University Press.

Hybrid CoE. Brief Introduction to Hybrid Threats. Pieejams: https://www.hybridcoe.fi/whatis-hybridcoe/;

Hybrid CoE. Countering Hybrid Threats. The webpage of Hybrid CoE. Pieejams: https://www. hybridcoe.fi/hybrid-threats/

International Civil Service Effectiveness Index (2019). Latvija gan centrālā pārvaldes lìmenī, gan pašvaldïbu lìmenī tiek atzinīgi novērtēta un ierindota 23. vietā. Pieejams: Blavatnik school of Government, Oxford University.

Jervis, R. (1976). Perception and Misperception in International Politics. Princeton, New Jersey: Princeton University Press.

Jone, R. W. (1999). Security, Strategy and Critical Theory. Boulder Co: Lynne Rienner.

Jones, R. W. (2000). Critical Incident Protocol. Michigan State University, p. 37. Pieejams: https:// www.michigan.gov/documents/msp-critical__incident_Protocal_8735_7.pdf

Jundzis, T. (1995). Latvijas drošỉba un aizsardzība. Rīga: Junda.

Jundzis, T. (1996). Defence Models and Strategies in the Baltic States. The International Spectator, 31(1), DOI: $10.1080 / 03932729608456728$

Kažoka, I. (29.01.2021.) Latvija - joprojām zemas uzticēšanās sabiedrība; iedzīvotāji vēlētos plašākas iesaistes iespējas. Pieejams: https://www.lsm.lv/raksts/zinas/latvija/latvija--joprojam-zemasuzticesanas-sabiedriba-iedzivotaji-veletos-plasakas-iesaistes-iespejas.a390701/

Khagram, S., Clark, W., \& Raad, D. F. (2003). From the environment and human security to sustainable security and development. Journal of Human Development, 4(2), 289-313. Pieejams: https://www.researchgate.net/profile/William_Clark3/publication/44836193_From_ the_Environment_and_Human_Security_to_Sustainable_Security_and_Development/ links/09e4150ac0da26c23b000000.pdf

Klimats un ilgtspējīga attīstība (2016). M. Kḷaviṇa un J. Zaḷokšṇa redakcijā. Rīga: LU Akadēmiskais apgāds.

Kḷaviņš, M. (2010). Klimata pārmaiṇas un to iespējamās ietekmes Latvijā. Akadēmiskā Dzīve, Nr. 47 (2010/2011), 33.-42., 153. lpp.

Kḷaviņš, M., Briede A. (ed.) (2011). Climate Change in Latvia and Adaptation to it. Riga: University of Latvia Press. Pieejams: https://edu.lu.lv/pluginfile.php/150753/mod_resource/content/1/ Climat_Change-makets\%5B1\%5D.pdf

Koṇušveskis, R. u.c. (2019). Nodokḷu reforma neapliekamā minimuma, atvieglojumu un attaisnoto izdevumu piemērošanas problēmu, efektivitātes un risinājumu izvērtējumā. Rīga: Latvijas Republikas Tiesībsarga birojs.

Krause, K. (2007). Towards a Practical Human Security Agenda'. Geneva Centre for the Democratic Control of Armed Forces, Policy Paper № 26.

Krenberga, O. (23.05.2020.) 51\% iedzīvotāju uzskata, ka Covid-19 krīze būs smagāka par iepriekšējo. Pieejams: https://www.lsm.lv/raksts/zinas/ekonomika/51-iedzivotaju-uzskata-ka-covid-19-krizebus-smagaka-par-ieprieksejo.a361013/.

Kriviņš, A. (2015). Korupcijas novēršana un apkarošana publisko iepirkumu jomā. Drukātava.

Krumm, R. et al. (2019). Security Radar 2019. Wake -up Call for Europe. 2019. Vienna: FES Regional Office for Cooperationand Peace in Europe.

Kudors, A. (red.) (2014). Krievijas publiskā diplomātija Latvijā: mediji un nevalstiskais sektors. Rīga: LU Akadēmiskais apgāds. 
Laegried, P., Rykkja, L. H. (ed.) (2019). Societal Security and Crisis Management. Governance Capacity and Legitimacy. London: Palgrave Macmillian.

Lašas, A., Matonite, I., Jankauskaite, M. (2020). Facing past, present and future: the role of historical beliefs and experiences in the Lithuanian public perception of military threats. Journal of Baltic Studies, 51(2).

Latvija. Pārskats par tautas attīstību. Cilvēkdrošība (2002-2003). Rīga: UNDP.

Latvijas Aizsardzības ministrija (2019). Par visaptverošas valsts aizsardzības sistēmas ieviešanu Latvijä. Pieejams: https://www.mod.gov.lv/sites/mod/files/document/Informativais\%20zinojums_ VVA\%20ieviesana_2018.pdf

Latvijas Fakti (2007. g. marts). Sabiedriskās domas aptauja par Latvijas dalību NATO.

Latvijas Fakti (2017). Latvijas Iedzīvotāju medijpratība. Pieejams: https://www.km.gov.lv/uploads/ ckeditor/files/mediju_politika/petijumi/Medijpratiba_petijuma\%20rezultati_Latvijas\%20 Fakti_18_07_2017.pdf

Latvijas Fakti (2020). Sabiedriskās domas aptauja Liepājā. Pieejams: https://faili.liepaja.lv/Dokumenti/Dokumentu-biblioteka/Pārskati-publikācijas-ziņojumi/Iedzivotaju_telefonaptauja_ 2020_Latvijas_Fakti.pdf

Latvijas Republikas Nacionālās drošības likums. 22. pants, 2. daḷa. Pieejams: http://m.likumi.lv/doc. php?id=14011

Latvijas Republikas Saeima (1994). Likums "Par pašvaldībām". Piennemts 19.05.1994. Stājies spēkā 09.06.1994. Pieejams: https://likumi.lv/ta/id/57255-par-pasvaldibam

Lejiņš, A. (1993). The Baltic Security Dilemma: How to Secure Independence. In: Barry, Charles L. (ed.) The Search for Peace in Europe. Institute for National Strategic Studies and the George C. Marshall European Center for Strategic Studies, Garmisch-Partenkirchen.

Lejiňš, A., Apinis, P. (Ed.) (1995). The Baltic States on Their Way to the European Union/Security Aspects. Riga: Latvian Institute of Foreign Affairs.

Lejiņš, A., Bleiere, D. (red.) (1996). The Baltic States: search for security. Riga: LIIA.

Lejiňš, A., Ozolina, Ž. (1997). Small States in a Turbulent environment: the Baltic perspective. Riga: LIIA.

Lejiňš, A. (1999). Baltic Security Prospects at the Turns of the 21st Century. Helsinki: Kikimora Publications.

Lejiņš, A. (red.) (2003). NATO un Eiropas Savienības sadarbība drošības jomā: atšķirīgi viedokḷi un kopēji risinājumi. Rīga: Latvijas Ārpolitikas institūts.

Lejin̄š, A. (red.) (2007). Pastiprināta Eiropas Savienības austrumu kaiminnu politika: jautājumi un izaicinājumi. Rīga: Latvijas Ārpolitikas institūts.

Lisabonas ligums. Pieejams: https://www.mfa.gov.lv/arpolitika/eiropas-savieniba-arpolitika/tiesibu-akti-un-dokumenti/lisabonas-ligums

McCulloh, T., Johnson, R. (2013). Hybrid Warfare. Pieejams: https://www.socom.mil/JSOU/JSOUPublications/JSOU\%2013-4_McCulloh\%2CJohnson_Hybrid\%20Warfare_final.pdf

McSweeney, B. (1999). Security, Identity and Interests. Sociology of International Relations. Cambridge: Cambridge University Press.

Mearsheimer, J. (2001). The Tragedy of Great Power Politics. New York: Norton.

Metrium (2017). Rēzeknes pilsētas teritorijas plānojums 2018.-2030. gadam. Pieejams: https:// rezekne.lv/wp-content/uploads/2018/04/paskaidrojuma_raksts.pdf

Moller, B. (2000). The Concept of Security: the Pros and Cons of Expansion and Contraction. International Peace Research Association.

Morgenthau, H. J. (1967). Politics Among Nations. New York: Knopf.

Nacionālā Aizsardzības akadēmija (2015). Aktuālās drošības problēmas Latvijā. Rīga: Nacionālā Aizsardzības akadēmija. 
Nacionālā Aizsardzības akadēmija (2016). Sabiedrības destabilizācijas iespējamība Latvijā: potenciālie nacionālās drošỉbas apdraudējumi. Rīga: Nacionālā Aizsardzības akadēmija.

NATO StratCom Riga (2016). Internet trolling as a hybrid warfare tool: the case of Latvia. Riga: NATO Strategic Communications Centre of Excellence.

NATO StratCom Riga (2016). Redefining Euro-Atlantic values and Russia's strategic communication in the Euro-Atlantic space. Riga: NATO Strategic Communications Centre of Excellence.

NATO StratCom Riga (2017). StratCom Laughs: In search of an analytical framework. Riga: NATO Strategic Communications Centre of Excellence.

Nef, J. (1999). Human Security and Mutual Vulnerability: The Global Political Economy of Development and Underdevelopment. IDRC.

Norstat (2020). Diskriminācijas izplatība nodarbinātības vidē Latvijā. Rīga: Latvijas Republikas Tiesībsarga birojs.

Ozolina, Ž. (1998). Latvia. In: Mpouritzen, H. (ed.) Bordering Russia. Theory and Prospects for Europe's Baltic Rim. London: Ashgate.

Ozoliņa, Ž. (2000). Latvijas drošỉbas politikas reǵionālie aspekti. Rīga: Izglītība.

Ozoliṇa, Ž. (2006). Latvijas ārpolitikas un robežu paplašināšăana. Rīga: Zinātne.

Ozolina, Ž., Rostoks, T. (2006). Latvian Outlook on the European Union Common Foreign and Security Policy. In: Tiirma-Klaar, H., Marques, T. (eds.) Global and Regional Security Challenges: A Baltic Outlook. Tallinn: Tallinn University Press.

Ozolina, Ž. (2007). European Security and Defence Policy: the Latvian perspective. In: Archer, Cl. (ed.) New Security Issues in Northern Europe. The Nordic and Baltic states and the ESDP. London: Routledge.

Ozoliņa, Ž. (Ed.) (2010). Rethinking Security. Rīga: Zinātne.

Ozoliṇa, Ž. (red.) (2012). Cilvēkdrošìba Latvijā un pasaulē: no idejas līdz praksei. Rīga: Zinātne.

Ozoliṇa, Ž. (2014). Ziņojums par cilvēkdrošǐbas koncepcijas ieviešanu kopienu lìmenī. Pieejams: https://www.sif.gov.lv/nodevumi/nodevumi/5985/Nodevums1_Cilvekdrosibas_koncepcija.pdf

Ozoliṇa, Ž., Reinholde, I., Rudzīte, L. (2014). Praktiskās vadlīnijas cilvēkdrošības koncepcijas ieviešanai kopienu līmenī, tajā skaitā nevalstiskajās organizācijās. Pieejams: https://www.sif.gov.lv/ nodevumi/nodevumi/5985/Nodevums3_Vadlinijas.pdf

Ozolina, Ž. (Ed.) (2015). Gender and Human Security. A view from the Baltic Sea Region. Rìga: Zinātne.

Ozoliņa, Ž. (red.) (2016). Societal Security. Inclusion-Exclusion Dilemma. A Portrait of the Russian Speaking Community in Latvia. Rìga: Zinātne.

Ozoliņa, Ž., Otzulis. V. (2016). Shaping Baltic States defence strategies: host nation support. Lithuanian Annual Strategic Review, 2016-2017, Vol. 15.

Pew Research Centre (2017). Ethnic Russians in some former Soviet republics feel a close connection to Russia. Pieejams: http://www.pewresearch.org/fact-tank/2017/07/24/ethnic-russians-in-someformer-soviet-republics-feel-a-close-connection-to-russia/

Pew Research Centre (2018). Eastern and Western Europeans Differ on Importance of Religion, Views of Minorities, and Key Social Issues. Pieejams: https://www.pewforum.org/ 2018/ 10/29/eastern-and-western-europeans-differ-on-importance-of-religion-views-of-minorities-and-keysocial-issues/?fbclid=IwAR0Af1zqir6iRYBAYd_dZ1hsDOoMOhMJUc4qxgpqD6Q6XdDF4Z ulqXUlLp4\#fn-30843-1

Raedt, R. de, Koster, E. H. W. (2010). Understanding vulnerability for depression from a cognitive neuroscience perspective: Areappraisal of attentional factors and a new conceptual model. Cognitive, Affective, \& Behavioral Neuroscience, 10.

Rostoks, T., Vanaga, N. (2016). Latvia's security defence post-2014. Journal on Baltic Security, 2(2).

Rostoks, T., Vanaga, N. (eds.) (2018). Dettering Russia in Europe. Defence Strategies for Neighbouring States. London and New York: Routledge and New York, p. 29. 
Rostoks, T. Vanaga, N. (eds). (2019). Deterring Russia in Europe. Defence Strategies for Neighbouring States. London: Routledge.

Rousseau, D., Garcia-Retamero, R. (2007). Identity, Power, and Threat Perception: A Cross-National Experimental Study. Journal of Conflict Resolution, 51(5).

Rožukalne, A. (2020). Aptauja: sabiedrības izpratne par COVID-19 Latvijā. 9.-20. aprīlis Aptaujas rezultāti. Pieejams: https://www.rsu.lv/sites/default/files/imce/Zinas/Zinu\%20pielikumi/ covid_19_results_infographics_05_08_2020.pdf

Saeima (2013). Par ārkārtējo situāciju un izṇēmuma stāvokli. Pieejams: https://likumi.lv/ta/ id/255713-par-arkartejo-situaciju-un-iznemuma-stavokli

Saeima (2016). Civilās aizsardzības un katastrofas pārvaldīšanas likums. Pieejams: https://likumi.lv/ $\mathrm{ta} / \mathrm{id} / 282333$-civilas-aizsardzibas-un-katastrofas-parvaldisanas-likums

Sauka, A., Rivža, B. (red.) (2014). Latvijas ekonomikas un uzṇēmējdarbības izaicinājumi. Ventspils: Ventspils augstskolas Uzṇēmējdarbības, inovāciju un reǵionālās attīstības centrs.

Siegrist, M., Gustcher, H., Earle, T. C. (2005). Perception of Risk: The Influence of General Trust, and General Confidence. Journal of Risk Research, 8(2).

SIGMA (2020). Public Administration: Responding to the COVID-19 Pandemic. Pieejams: http:// www.sigmaweb.org/publications/SIGMA-mapping-public-administration-response-EUmembers-coronavirus-COVID19.pdf.

Sīmane, M. (ed.) (2003). Latvija: pārskats par tautas attīstību 2002/2003. Pieejams: http://providus. lv/article_files/920/original/UNDP2003_ful_lv.pdf?1326366357

SKDS (2011). Pētījums par korupciju valsts iestādēs. Pieejams: https://www.mercell.com/ lv-lv/31549912/skds_petijums_par_korupciju_valsts_iestades.aspx

SKDS (2014). Latvijas iedzīvotāju viedoklis par valsts aizsardzības jautājumiem. 2014. gada novembris. Pieejams: https://www.mod.gov.lv/lv/dokumenti

SKDS (2016). Latvijas Barometrs.

SKDS (2016). Latvijas iedzīvotāju viedoklis par valsts aizsardzības jautājumiem: Latvijas iedzìvotāju aptauja. 2016. gada novembris. Pieejams: https://www.mod.gov.lv/sites/mod/files/document/ SKDS_aptauja_2016\%20\%281\%29.pdf.

SKDS (2017). Latvijas Barometra aptauja. Latvijas iedzīvotāju noskaṇojuma novērtējums (jūnijs). Pieejams: https://www.skds.lv/jaunumi?gads=2019\&pp=

SKDS (2017). Latvijas Barometra aptauja. Latvijas iedzīvotāju noskaņojuma novērtējums (jūlijs). Pieejams: https://www.skds.lv/jaunumi?gads=2019\&pp=

SKDS (2018). Latvijas Barometra aptauja. Latvijas iedzīvotāju noskaņojuma novērtējums. Pieejams: https://www.skds.lv/docs/1414/2016-2017/Latvijas_barometrs_120__092018_.pdf

SKDS (2018). Latvijas Barometrs.

SKDS (2020). Turības Biznesa indekss. Pieejams: https://www.turiba.lv/lv/augstskola/turibas-biznesa-indekss

SKDS (2020. gada marts-aprīlis). LTRK Ekonomikas indekss. Latvijas uzṇēmēju aptaujas rezultāti. Pieejams: https://t.co/QZM8QxqGwn?amp=1

SKDS (2020). Pētījums par sabiedrības attieksmi par Covid-19 (2020, aprīlis). Pieejams: https://www. mk.gov.lv/sites/mk/files/media_file/apr_covid_krize_online_04.20.pdf

SKDS (2020). Pētījums par sabiedrības attieksmi par Covid-19 (2020, maijs). Pieejams: https://www. mk.gov.lv/sites/mk/files/media_file/maijs_covid_online_05.20.pdf

SKDS (2020). Pētījums par sabiedrības attieksmi par Covid-19 (2020, novembris). Pieejams: https:// www.mk.gov.lv/sites/mk/files/media_file/nov_skds_vk_covid_20.20.pdf

SKDS (2020). Pētījums par sabiedrības attieksmi par Covid-19 (2020, decembris). Pieejams: https:// www.mk.gov.lv/sites/mk/files/media_file/dec_skds_covid_12_2020.pdf_

SKDS (2020). Pētījums par sabiedrības attieksmi par Covid-19 (2021, janvāris). Pieejams: https:// www.mk.gov.lv/sites/mk/files/media_file/janv_skds_covid_01_2021.pdf 
Smith, R. (2005). Strategic planning for public relations. Mahwah, N. J.: Lawrence Erlbaum Associates.

Smith, R. D. (2016). 25 Strategies for Crisis Communication. Pieejams: www.ron-smith.com.

Stein, J. G. (2013). Threat Perception in International Relations. In: Huddy, L., Sear, D. O., Levy, J. S. (eds.) The Oxford Handbook Political Psychology. Oxford: Oxford University Press.

Stevens, D., Vaughan-Williams, N. (2014). Citizens and Security Threats: Issues, Perceptions and Consequences Beyond the National Frame. British Journal of Political Science, 46.

Stranga, A. (1996). Russia and security of the Baltic States 1991-1996. In: Lejiņš, A., Bleiere, D. (eds.) The Baltic States: Search for Security. Riga: LIIA.

Stranga, A. (1997). Baltic-Russian relations: 1995 - beginning of 1997. In: Lejiñš, A., Ozoliṇa, Ž. (eds.) Small States in Turbulent Environement: The Baltic Perspective. Riga: LIIA.

Stranga, A. (2010). Vēsturnieki par Latvijas drošības problēmas risinājumiem starpkaru periodā. Latvijas Vēsture. Jaunie un Jaunākie laiki, Nr. 2.

Szenes, Z. (2018). Military Security Today. New Threats, New Wars, New Theories. In: G. Finszter, I. Sabjanics (Eds.) Security Challenges of the 21th Century. NUPS, Dialog Campus.

Szpyra, R. (2014). Military Security within the framework of security studies: research results. Connections, 13(3).

Šumilo, E., Baumane, I. (2007). Some Negative Aspects of Social Capital: The Case of Undeclared Work in Latvia. Humanities and Social Science in Latvia, 2(51). Riga: Institute of Economics.

Tadjbakshs, Sh., Tomescu-Hatto, O. (2007). Promoting human secuirty: ethical, normative and educational frameworks in Eastern Europe. Pieejams: https://unesdoc.unesco.org/ark:/48223/ pf0000151145? posInSet=1\&queryId=e7e86a89-64bc-4890-8737-d7985bb43043

Thomas, C. (2001). Global Governance, Security and Development: exploring the links. Third World Quarterly, 22(2), 159-175.

Treverton, G. et al. (2018). Addressing Hybrid Threats. Swedish Defence University; European Centre of Excellence for Countering Hybrid Threats, Countering Hybrid Threats. Pieejams: https:// www.hybridcoe.fi/hybrid-threat;

Tsereteli, M. (2008). Economic and Energy Security: Connecting Europe and the Black Sea-Caspian Region. Central Asia-Caucasus Institute and Silk Road Studies Program, Singapore. Pieejams: http://www.silkroadstudies.org/resources/pdf/SilkRoadPapers/2008_03_SRP_Tsereteli_EnergyBlack-Sea.pdf

Ullman, R. H. (1983). Redifining Security. International Security, 8(1).

Human Development Report 1994. Pieejams: http://hdr.undp.org/sites/default/files/reports/255/ hdr_1994_en_complete_nostats.pdf

Vedantam, S. (2015). How Emotional Responses To Terrorism Shape Attitudes Toward Policies. Radio NPR. Pieejams: https://www.npr.org/2015/12/22/460656763/how-emotional-responses-to-terrorism-shape-attitudes-toward-policies

Waltz, K. N. (1979). Theory of International Politics. New York: Random House.

Weiss, T. G. (2004). The Sunset of Humanitarian Intervention? The Responsibility to Protect in a Unipolar Era. Security Dialogue, 35(2), 135-153.

Weldes, J. et al. (1999). Cultures of Insecurity: States, Communities, and the Production of Danger. Minneapolis: University of Minnesota Press.

Wells II, L. (2017). Cognitive-Emotional Conflict - Adversary Will and Social Resilience. PRISM, 7(2). Pieejams: https://cco.ndu.edu/News/Article/1401814/cognitive-emotional-conflict-adversary-will-and-social-resilience/.

Wæver, O. et al. (1993). Identity, Migration and the New Security Agenda in Europe. London: Pinter.

Wæver, O. (2008). The Changing Agenda of Societal Security. In: Brauch H. G. et al. Globalization and Environmental Challenges. Hexagon Series on Human and Environmental Security and Peace, Vol 3. Springer, Berlin, Heidelberg. 
Wolfer, A. (1962). Discord and Collaboration: Esseys on International Politics. Baltimore: John Hopkins University.

World Health Organization (2012). Governance for health in the 21st century.

Zelče, V. (zin. red.) (2018). Latvijas mediju vides daudzveidība. Rīga: LU Akadēmiskais apgāds.

Ziemele, I. (2004). Latvijas loma drošības un miera tiesiskā nostiprināšanā. Vai starptautiskām tiesībām un organizācijām ir nozīme? No: Jundzis, T. (red.) Latvija Eiropā: nākotnes vīzijas. Rīga: LZA Baltijas stratēgisko pētijumu centrs.

Zobena, A. (red.) (2006). Latvijas pārskats par tautas attīstību. Rīga: Sociālo un politisko pētījumu institūts.

Zurlini, G., Muller, F. (2006). Environmental Security. Pieejams: https://www.sciencedirect.com/ topics/earth-and-planetary-sciences/environmental-security

Герасимов, В. (2013) Ценность науки в предвидении. Новые вызовы требуют переосмыслить формы и способы ведения боевых действий. Pieejams: https://www.vpk-news.ru/articles/14632 


\section{Par autoriem}

Berga Rovena ir Latvijas Universitātes Sociālo zinātṇu fakultātes politikas zinātnes bakalaura studiju programmas 3. kursa studente, bet vidējo izglìīibu ieguvusi Rīgas Valsts 2. ǵimnāzijā humanitārā un sociālā virziena programmā, padziḷināti apgūstot latviešu valodu, literatūru, vēsturi un politiku. Studiju laikā Rovena ir bijusi praktikante arī Pārresoru koordinācijas centrā, palīdzot "Latvijas Nacionālā attīstības plāna 2021.-2027. gadam” izstrādē, bijusi brīvprātīgais palīgs dažādu konferenču, kā arī simpoziju organizēšanā, aktīva studējošo interešu pārstāve pašpārvaldē, kā arī profesionāli darbojusies starptautiskās politikas jomā. Akadēmiskās intereses iekḷauj tādas tēmas kā publiskā diplomātija, Baltijas valstu savstarpējā sadarbība un krīzes komunikācija.

Celmiņš Kristaps ir Latvijas Universitātes Sociālo zinātṇu fakultātes politikas zinātnes bakalaura studiju programmas 2. kursa students, vidējo izglītîbu ieguvis Rīgas Valsts 2. gimnāzijā humanitārā un sociālā virziena programmā, padziḷināti apgūstot latviešu valodu, literatūru, vēsturi, filozofiju un politiku. Studiju laikā Kristaps Celmiṇš ir darbojies kā Nacionālo bruņoto spēku rezerves dienesta karavīrs, pārstāvējis studējošo intereses fakultātes pašpārvaldē, kā arī iesaistījies vairāku nevalstisko organizāciju darbībā gan kā brīvprātīgais, gan kā praktikants, kā arī kā projektu vadītājs. Izstrādājis un organizējis plaša spektra projektus par sabiedríbas izglïtošanu drošỉbas politikas un starptautiskās politikas jautājumos. Akadēmiskās intereses iekḷauj tādas tēmas kā Latvijas drošības politika, Arktikas reǵiona drošības politika un krīzes komunikācija. 
Ceple Ruta ir Latvijas Universitātes Sociālo zinātņu fakultātes politikas programmas doktorantūras studente. Galvenās pētniecības intereses ir saistītas ar stratēǵisko komunikāciju aizsardzības jomā, hibrīdo draudu pētniecību Baltijas valstīs un Ziemelvalstīs.

Kārkliņš Harijs ir Latvijas Universitātes Sociālo zinātņu fakultātes doktorantūras studiju programmas "Politikas zinātne" students. Iepriekšējo izglìtību ieguvis arī Latvijas Universitātē - 2015. gadā pabeidzis 2. līmeņa profesionālo bakalaura programmu "Matemātiķis-statistiķis", 2017. gadā - maǵistratūras studiju programmu "Politikas zinātne". Četru gadu pieredze darbā Latvijas Republikas Finanšu ministrijā saistībā ar ES fondu ieviešanas uzraudzību, pirms tam divu gadu pieredze darbā vienā no vadošajām ieguldījumu pārvaldīšanas sabiedrībām Baltijas valstīs.

Kjakste Aleksandra ir pasniedzēja Latvijas Universitātē, Sociālo zinātṇu fakultātē. Savu akadēmisko amatu apvieno ar zinātniskā asistenta amatu Sociālo un politisko pētījumu institūtā. Aleksandra Kjakste ir zinātniskā grāda pretendente politikas zinātnes jomā, publiskās pārvaldes apakšnozarē, 2014. gadā ieguvusi maǵistra grādu ar izcilību, aizstāvot darbu par tēmu "Publiskās pārvaldes transformācijas problēmas: Latvijas un Kazahstānas gadījums". Doktorantūras studiju laikā ir publicējusi vairākas zinātniskās publikācijas un piedalījusies vairākās starptautiskās konferencēs un semināros. Pētnieciskās intereses ir saistītas ar publiskās pārvaldes modernizācijas, transformācijas jautājumiem postpadomju telpā, politiskiem procesiem Āzijas valstīs, izglìtības problēmām un krievvalodīgo minoritāšu jautājumiem Latvijā.

Otzulis Valdis ir Latvijas Universitātes Sociālo zinātṇu fakultātes politikas programmas doktorantūras students. Galvenās pētniecības intereses ir saistītas ar uzņemošās valsts atbalstu, atturēšanas politikas koncepta pētniecỉbu un Baltijas valstu drošîbu.

Ozoliṇa Žaneta ir Latvijas Universitātes Politikas zinātnes nodaḷas profesore, vairāk nekā 100 publikāciju autore un grāmatu zinātniskā redaktore. Piedalās akadēmisku žurnālu - Journal of Baltic Studies, Defence Strategic Communications, Lithuanian Annual Strategic Review - redkolēgijās un ir žurnāla "Latvijas intereses Eiropas Savienībā" zinātniskā redaktore. Viṇa lasa lekcijas Baltijas Aizsardzības koledžā, Lietuvas Militārajā akadēmijā, Pekinas Starptautisko studiju universitātē un daudzās citu valstu augstskolās. Bijusi Stratēǵiskās analīzes komisijas priekšsēdētāja (2004-2008) un Eiropas Pētniecības 
telpas padomes biedre (2008-2012). Vadïjusi vairākus pētnieciskus projektus Eiropas Parlamentam, Eiropas Komisijai, NATO Stratēgiskās komunikācijas izcilības centram un Baltijas jūras valstu padomei. Piedalās Latvijas Ārpolitikas ekspertu padomes, Eiropas Padomes darbā un vada Latvijas Transatlantisko organizāciju.

Reinholde Iveta ir Latvijas Universitātes Politikas zinātnes nodaļas profesore pārvaldes un administrācijas jomā ar lielu pieredzi rīcībpolitikas un pārvaldes reformu novērtēšanā, kā arī iekšèjā audita jomā. Iveta Reinholde ir vairāk nekā 30 publikāciju autore par cilvēkdrošības, publiskās pārvaldes reformu, labas pārvaldības un vietējo pašvaldību jautājumiem. Profesore regulāri lasa lekcijas ārvalstu augstskolās un universitātēs Eiropā un Āzijā, kā arī piedalās pārvaldes ekspertu darba grupās. Kopš 2014. gada viņa ir Eiropas Padomes Vietējo un regionālo pašvaldību kongresa neatkarīgā eksperte. 2019. gadā Iveta Reinholde saṇēma prestižo Alenas Brunovskas balvu par izcilību publiskās pārvaldes studiju kursu docēšanā (Alena Brunovska Award for Teaching Excellence in Public Administration), ko pieškīra NISPAcee (Network of Institutes and Schools of Public Administration in Central and Eastern Europe) organizācija, kas apvieno augstākās izglītības iestāžu politikas zinātnes apakšnozares pārvaldes un administrācijas jomā Centrāleiropā un Austrumeiropā.

Struberga Sigita ieguvusi maǵistra grādu politikas zinātnē ar specializāciju starptautiskajās attiecībās. Viṇas pētniecības interešu laukā ir tādas tēmas kā Krievijas politika un tās ietekme tuvējās pierobežas valstīs, drošỉbas globālie un reǵionālie aspekti, stratēégiskā komunikācija un publiskā diplomātija. Sigita Struberga ir noslēgusi doktorantūras studijas un turpina darbu pie promocijas darba par Krievijas publisko diplomātiju Latvijā un Moldovā. Pilda Latvijas Transatlantiskās organizācijas generālsekretāres pienākumus, kā arī nodarbojas ar pētniecību Latvijas Universitātes Sociālo un politisko pētījumu institūtā, lasa lekcijas LU Politikas zinātnes nodal̦ā. Vairāk nekā 15 zinātnisko rakstu autore un līdzautore atbilstošā zinātṇu nozarē. Viṇa ir iesaistīta vairākos nacionāla un starptautiska līmeņa zinātnes projektos, tīklojumos, konsorcijos un starptautiskās domnīcās.

Stučka Malvīne ir doktorantūras studente Latvijas Universitātes Sociālo zinātṇu fakultātes Politikas zinātnes nodạ̦ā, kur pirms tam ieguva arī bakalaura un maǵistra grādu. Izpētes intereses saistītas ar pašvaldībām, urbanizāciju, publisko administrāciju un politisko līderību, ko pēta arī promocijas darbā. Ir piedalījusies zinātniskajās konferencēs, kur uzstājās par politisko līderību 
un arī par drošības aspektiem pašvaldībās. Pasniegusi lekcijas politikas zinātnes bakalaura studentiem kursā "Politikas terminologiija", kā arī par stratēǵisko plānošanu un pašvaldību pārvaldību. Savas kompetences ietvaros piedalās kā eksperte arī citos projektos. Papildus studijām doktorantūrā strādā Latvijas Republikas Saeimā.

Valdmanis Gunārs ir ieguvis mağistra grādu politikas zinātnē Latvijas Universitātes Sociālo zinātṇu fakultātē un maǵistra grādu vides zinātnē Rīgas Tehniskās universitātes Enerğêtikas un elektrotehnikas fakultātē (šobrīd - Elektroenergeetikas un vides inženierzinātṇu fakultāte). G. Valdmaṇa iepriekšējā profesionālā pieredze ir saistīta ar žurnālista darbu vairākos medijos (Latvijas Radio, "Diena”, “Dienas Bizness"), privāto uzṇēmējdarbību, darbu valsts pārvaldē - Ekonomikas ministrijas Enerǵijas tirgus un infrastruktūras departamentā. Šobrīd viņš pilda Latvijas Elektroenergêetiķu un Energobūvnieku asociācijas izpilddirektora pienākumus. G. Valdmanis ir arī vairāku drošības un energètikas politikai veltītu publikāciju un grāmatu līdzautors. 
Latvijas iedzīvotāju subjektīvā drošības uztvere: ietekme uz drošības politikas veidošanu

Latvijas Universitātes Akadēmiskais apgāds Aspazijas bulvāris 5, Rīga, LV-1050, Latvija www.apgads.lu.lv 